


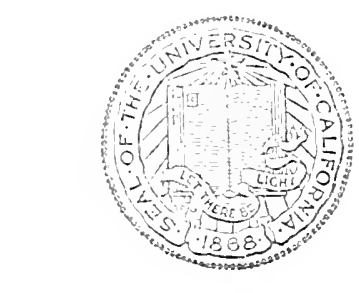

\section{UNIVERSITY OF CALIFORNIA LOS ANGELES}

SCHOOL OF LAW

LIBRARY 






\title{
THE LAW
}

OF

\section{INTERSTATE COMMERCE}

AND ITS

\section{FEDERAL REGULATION}

\author{
$\mathrm{BY}$ \\ FREDERICK N. JUDSON \\ Of the St, Lovis Bar
}

CHIC.AGO

T. II. FL()()I \& CO. 


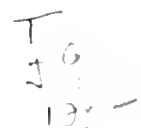

COPYRIIHT, 1:10.5,

(:)

T. II. FLOOD AND COMP.NY 
To Hoxorable

WILIIAM HOWARD TAFT, LL. D.

One time Judge of the Circuit Court of the United States whose name is written large upon the pages of the judicial history of Interstate Commerce. 



\section{PREFACE.}

The purpose of this book is to present in a compact form the law of interstate commerce as declared by the courts since the adoption of the Constitution, and also as enacted by Congress and applied by the Interstate Commerce Commission in the direct exercise of the power of federal regulation. The book has been written under the conviction that the direct federal regulation of interstate commerce, though it only dates since the close of the Civil War, has come to stay.

The rules declared by the Interstate Commerce Commission in the eighteen years of its existence, though its powers have been in some respeets eurtailed by the judicial construction of the Interstate Commerce Act, have made a body of administrative railroad law which seems properly included in a treatise of this character. Every phase of the eomplex adjustment of railway rates has been considered by the Commission, and their rulings in this infinite variety of eases have a permanent value in the solution of the transportation problems of the future.

In the annotation of the Interstate Commeree Act it has been the aim to cite such only of the rulings of the Commission. as are illustrative of the practical enforcement of the Act under the limititions of their powers as declared by the Supreme Court.

The limits of the unexercised power of fecleral regulation can be intelligently consiclered, only with a clear apprehension of what the Supreme Court has declared in determining the line between fecleral and State authority, as with few exceptions the decisions of the Court in interstate commerce have declared what the States can and cannot do, and not what Congress can or cannot do.

In view of the present agitation for the amendment of the Interstate Commeree Act, as well as for other new legislation in the regulation of interstate commerce, it is well to ascertain what has been done under federal regulation in the past and what can be done under existing laws in the future. It is 
the aim of this book to state withont neclless amplification or iteration the existing law. als its rules have been jullicially formulated, and the interesting puestions of public policy connected with this subject have therefore not been discrussed. The obvions difliculty of applyin these rules of law the judicially declared to the complex concrete questions arising moler our dual form of govermment is illustrated in the close divisions of the supmene fourt in such cases, and they must be determined in the future, as they have been in the past, by the judicial process of inclusion amel exchusion.

In view of the informal chatrater of many of the proceedins be bore the commission, as well at for convenience and in the interest of bevity, the eitations of ('ommission cases have

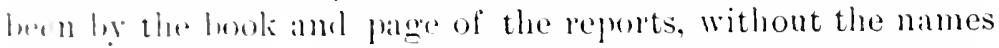
of the fitrties. A table in the appendix however gives all the calses deaderl by the commission, with the names of the parties in alphabetical order. and also with the date of the decisiom, the name of the commissimer writing the opinion, the volumr and patae of the report as well as the page of the citation. licepence is marle in the eitation of Commission cases hoth to the Interstate ('ommerce Commission Reports (I. C. C. L., and the Intristilte ('ommerce Reports (Int. ('om. Rep.) The suphome ('nurt of the I'nited states is cited as "Supreme cimrt." linefrence is madre to the law wers annotited edition :s Well as to the oflicial oflition, and in the Cirenit Court of Alpurals eatses the the lederil lieporter as well as to the C. C. 1. lingerts.

I talk pleasure in acknowledging my great indebtedness to the very alliciont sirvices of Mr. Iohn 11. (Merall, Ir., of the -t. I.mis bar, not wnly in the compilation and verification of "asu, and in revision, lut in the important and tedions work of preprating the index. - and also the eflicient assistance of

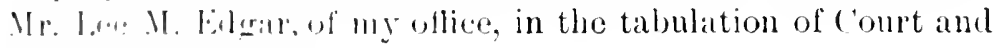
('immunisitull ("istes.

Fremeliok $\mathrm{N}$. Jlenon.

ST. I.111- .1, Hil, R.t1. 


\section{TABLE OF CONTENTS.}

\section{PAR'T I.}

\section{CIIA P'TER I.}

INTERSTATE COMMERCE UNDER THE FEDERAL CONSTITUTION.

$\S 1$. The commerce clause in the Constitution ........... 2

2. Power of Congress in foreign commerce and with the In-

dian tribes distinguished $\ldots \ldots \ldots \ldots \ldots \ldots \ldots \ldots \ldots$

3. The preference clause in the Constitution $\ldots \ldots \ldots \ldots \ldots 6$

4. Federal sovereignty in interstate commerce ......... 7

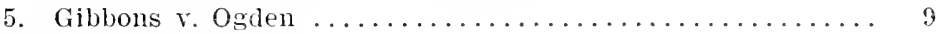

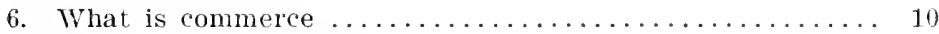

7. What is not commerce ..................

S. Insurance is not commerce ................... 14

9. What are the subjects of commerce ............. 15

10. Wild game and fish as subjects of commerre ......... 17

11. Natural oil and gas as subjects of commere ........... 19

12. The commerce clause and the admiralty juristiction..... 20

13. Erie Canal subject to admiralty jurisdiction $\ldots \ldots \ldots \ldots .21$

14. Jurisdiction of Federal courts in admiralty cases ....... 22

15. State corporations in interstate commerce .......... 22

16. The original package in interstate commerce ......... 24

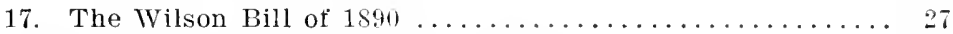

18. A State cannot tax interstate commerce ............ 27

19. But a State can tax the property employed in interstate commerce .......................... 2 s

20. State power of taxation of colporations engaged in inter-

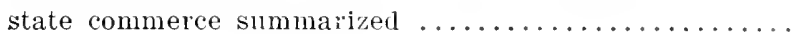

\section{CHAPTER II.}

\section{THE CONCURRENT AND EXCLUSIVE POWERS.}

$\S 21$. The concurrent and exclnsive powers distinguished..... 31 22. The Supreme Court on the three classes of commerce cases 32 23. The concurrent State power ................. $3:$

24. The State power as to interstate telegraph companies..... 34

25. Concurrent power in interstate railroad transportation... 35

26. State Sunday laws and interstate traffic ............ 36 
s: . State laws as to qualifiations of employees and safety of

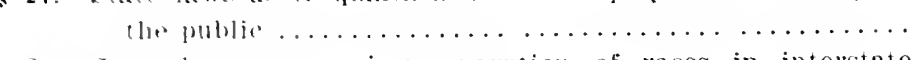
Pagre

24. State laws concerning separation of races in interstate

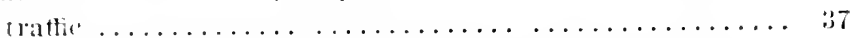

29 . Jimitation of state power in stoppage of through trains...

:in. Srate resulation of contractual relations of interstate rail.

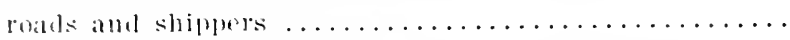

:1. Satr resulation under rules of common law in State courts

:i-. The conturent julisdiction in live stock inspection laws.

:.:. Fifmel of conglessional lesislation upon concurrent power

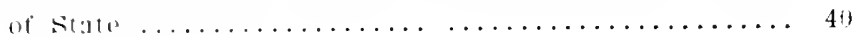

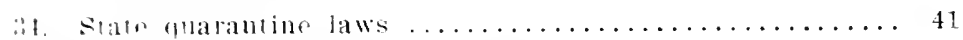

a.i. Frentom of interstate commere .............. 42

ati. condressional inarion in foreign and interstate commerce

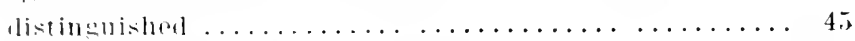

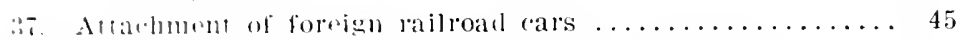

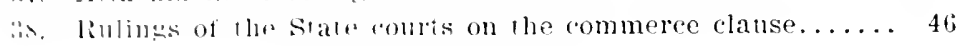

\section{('IIATTER III.}

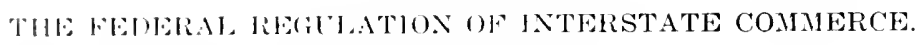

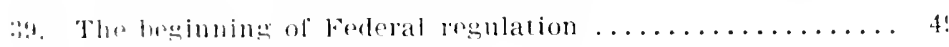

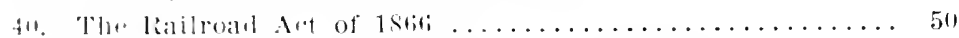

41. Sial. renulation of railways in the fonited States ...... 52

$4:$ rovernmental renulation of railways in England ....... 5:3

4:3. Thr atmmon law in interstate commere ............ 54

4. Fontrial and State compts in the Ferleral regulation of in.

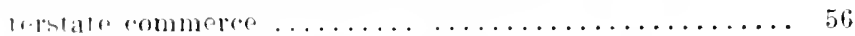

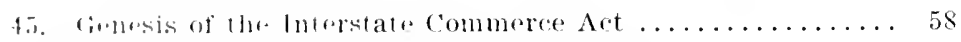

th. Patsale of the Interstate commere Art . . . . . . . . 59

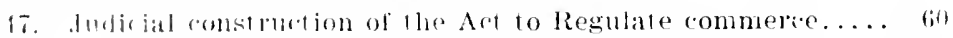

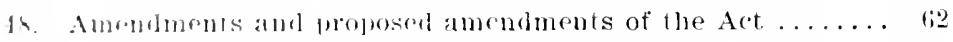

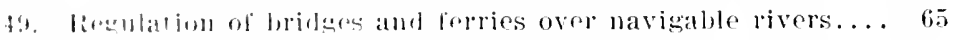

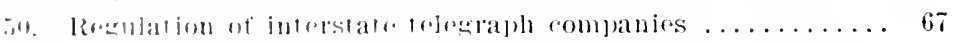

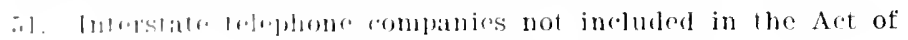

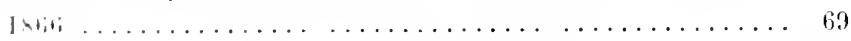

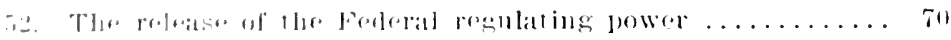

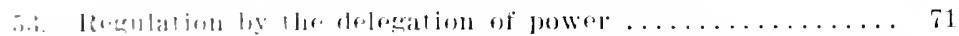

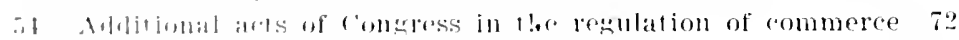

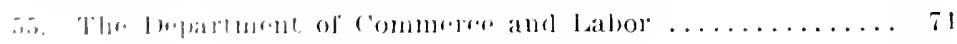

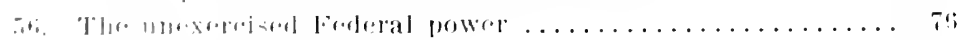

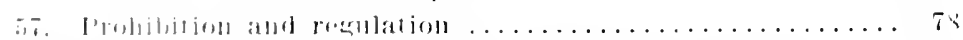

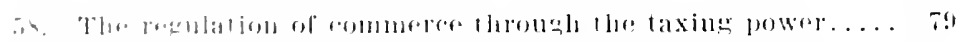

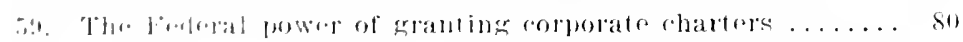

fol. Nitefonal inererporation as a means in the exereise of the

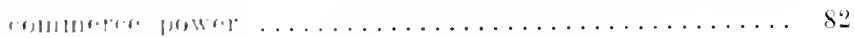

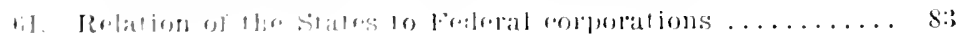


Page

$\S 62$. The requirement of Federal franchise for business corpora-

tions in interstate commerce ............... 84

63. The developing construction of the Federal power in the

regulation of commerce $\ldots \ldots \ldots \ldots \ldots \ldots \ldots \ldots \ldots . .66$

\section{CIIAPTER IV.}

BUSINESS AND LABOR COMBINATIONS IN INTERSTATE CONIMERCE.

64. Demand for Federal regulation of business combinations.. 88

65. The Anti-Trust Act of $1890 \ldots \ldots \ldots \ldots \ldots \ldots \ldots \ldots$

66. Relation of Act to common law of interstate commerce... 91)

67. Constitutionality of the Act.................. 91

6S. Construction of the Act by the supreme Court........ 91

69. Reasonable and unreasonable restraints of trade........ $9: 3$

70. Contracts in restraint of trade under the Act......... 95

71. Contracts restraining sales by rebates not within the Act 96

72. Monopoly within the meaning of the Act........... 99

73. Monopoly in law and in fact distinguished........... 99

74. No distinction in the Act between necessaries of life and other articles......................... 100

75. No application to commerce within a State.......... 102

76. Application to State "holding companies" ............ 10 3

77. The labor legislation of Congress................ 104

78. Regulation of interstate commerce in relation to lahor.... 10.5

79. The courts on labor combinations in relation to interstate

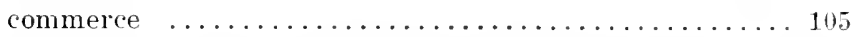

80. The Federal judicial power and labor combinations...... 1116

81. Sympathetic strilies and boycotts by interstate employees.. 108

82. The law of conspiracy in interstate commerce......... 110

83. Distinguished trom common law conspiracy........... 113

84. Interstate commerce in relation to employees therein.... 114

85. "Picketing" and "soliciting" in interstate commerce..... 116

86. The relation of interstate railroad employees is that of free

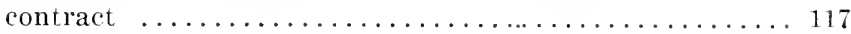

87. The right of labor organization includes the right of repre-

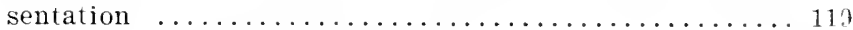

88. Injunction in interstate commerce.............. 12

89. Contempt in Uniter States Courts............... 123

90. Mandatory injunctions in interstate commerce ........ 127

\section{CIIAPTER T.}

THE FEDERAL CONTROL OF STATE REGULATION.

91. State regulation of railroads under State Commissions... 128

92. The power of regulation independent of State or Federal incorporation 
5.?. The limitations of the State authority in clomestic traffir.. 130

!4. The aldention of the Fourteenth Amendment......... 131

4.. Fental review of slate regulation of carriers......... 131

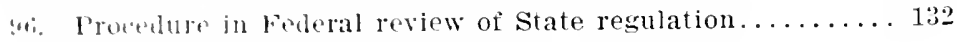

$\because 7 . \quad$ Limitation hy Foleral authority of the States power in reg-

ulating interstate rates................. $13: 3$

!) What is leasonableness in the limitation of State authority 135

!n. No lotinite standard of roasonableness in railroad rates... 137

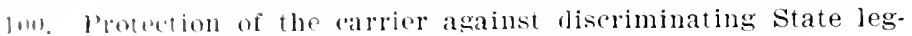

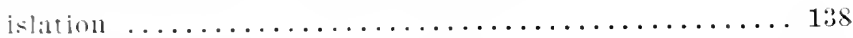

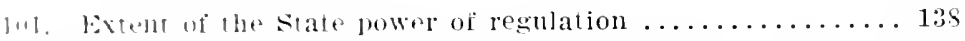

111. Whe state. Anti-Trust laws and the Fourteenth Amendment 140

113. Classitioation in state railroad legislation........... 142

\section{PARTII.}

\section{INTERTATE COMUERCE ACT.}

\section{Fictox 1.}

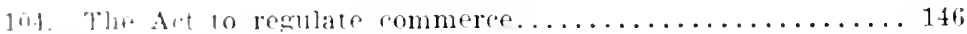

111. All of interstate commerce not included........... 1tb;

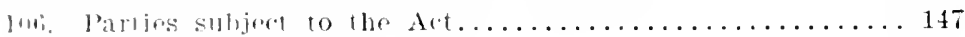

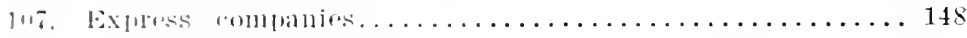

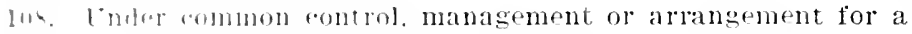

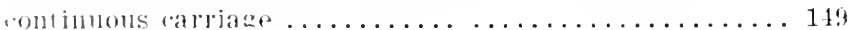

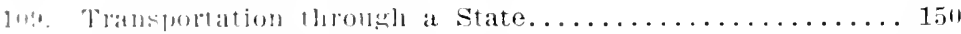

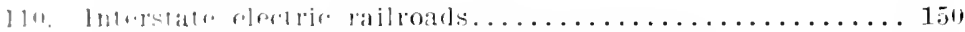

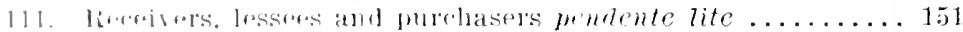

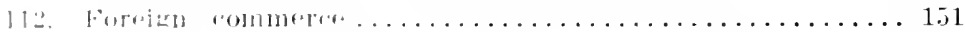

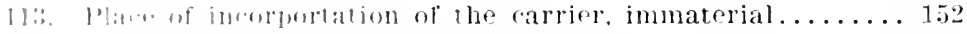

11. Th. infolim of infrestate shipnent is not suffeient.... 152

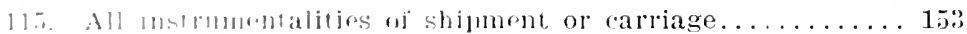

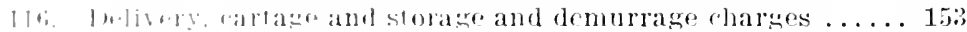

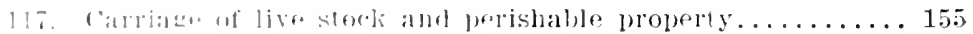

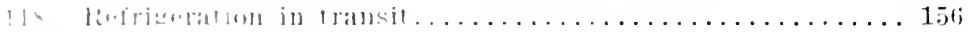

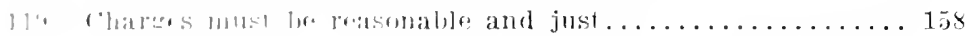

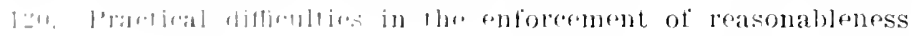

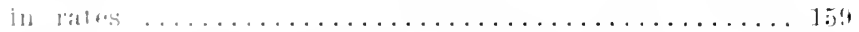

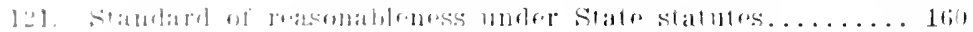

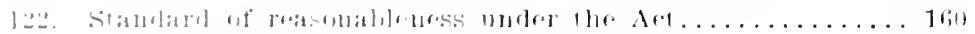

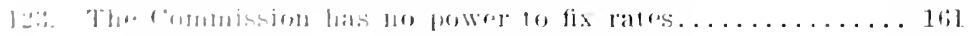

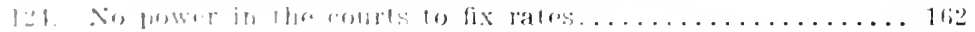

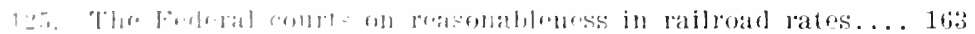

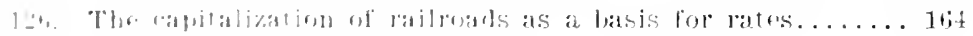

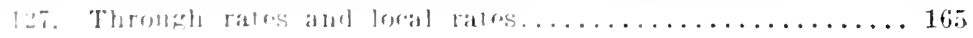


$\$ 128$. The Commission on through and local rates .......... 167

129. Responsibility for through rates............... 169

130. Reasonableness under sections 1 and $3 \ldots \ldots \ldots \ldots \ldots \ldots 170$

131. Consideration of reasonableness in the courts........ 170

132. Rulings of the Commission upon the reasonableness of rates 171

133. The burden of proof before the Commission......... 172

134. Presumption of reasonableness from established rates... 172

135. The Commission on cost of service and needs of the

shipper ............................

136. The Commission on the character of the traffic.......... $17 t$

137. The Commission on distance as a factor in rates........ 17

13s. The Commission on comparison of rates............ 175

139. Relation to State local rates.................. 17 ;

140. Reasonableness and proportion.................. 176

141. The Commission on rate wars and reasonableness of rates. 177

14\%. Illustrative cases upon specific rates............ 178

\section{SECTION 2 .}

143. Unjust discrimination defined and forbidden.......... 1s

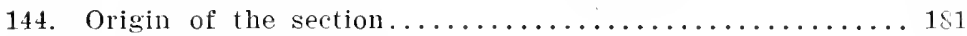

145. Purpose of the section.....................

146. Effectiveness of the section. Act of Feb. 19, 1903....... 18?

147. Common law as to discriminations.............. 184

148. Just and unjust discriminations at common law ........ 1st;

149. Difference in charge based upon difference in service..... 189

150. Circumstances and conditions of through traffic and local

traffic are dissimilar ..................... 1911

151. Competition of carriers does not malie eircumstances dis-

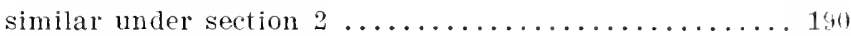

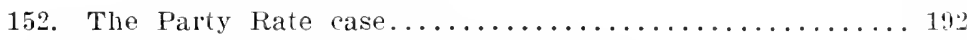

153. Wholesale and retail rates in freight trafic.......... 192

154. Wholesale rates in freight and passenger traffic distin-

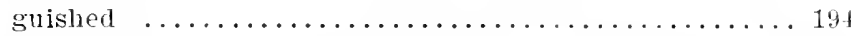

155. Discrimination not unjust when based on special service.. 195

156. Carload and less than carload rates.............. 195

157. Discrimination in application of carload rates......... 197

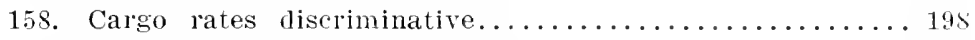

159. Different forms of discrimination................ 19

160. Discrimination through interest in connecting company....

161. Discrimination by carrier in favor of itself as a shipper... 200

162. Discrimination in the storage of goods, etc.......... 202

163. Stoppage in transit privileges.................. 203

164. Unlawful discrimination through abuse of stoppage in tran-

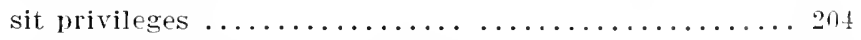

165. Unjust discrimination in passenger service.......... 205

166. Giving passes to shippers prohibited.............. 206;

167. Application of the section...................... 


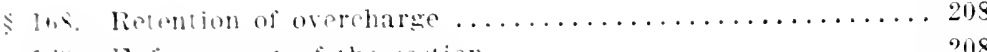

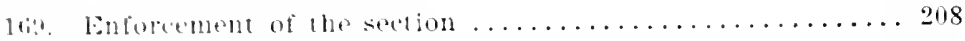

17. Entorement by injunetion . . . . . . . . . . . . . . 209

17. Fifect of rebates upon contracts of affeightment........210

lila. Discrimination in allowance to private transfer companies. 210

\section{Sictur 3.}

1:2. Indur or mn rasonahle preference or advantage forbidden 212

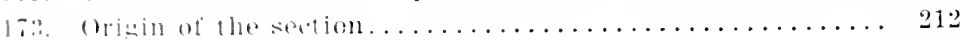

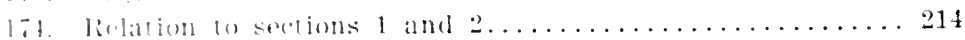

17. Preformens of lowities enfored by competition are not

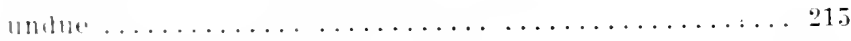

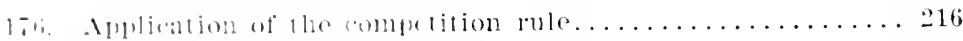

17. Wholur ompertion is controlling is a question of fact... 216

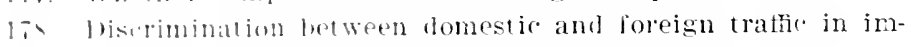
purt and aport rates not undue preference .......... 217

17:4. Alpliation of the import rule to intermediate points on the

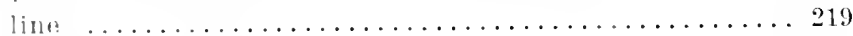

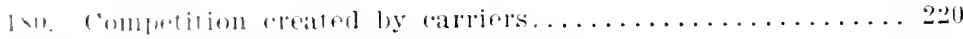

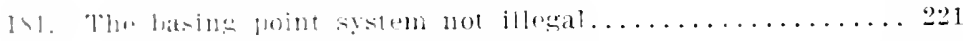

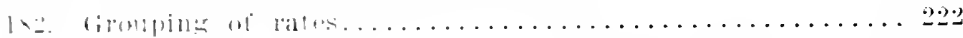

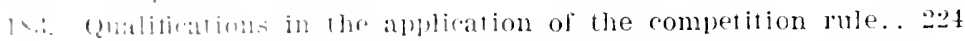

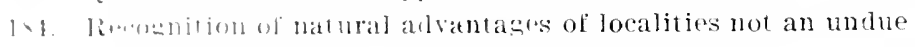

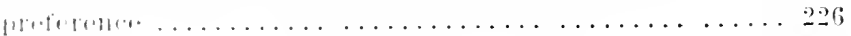

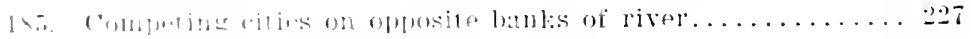

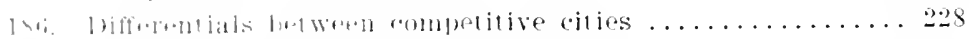

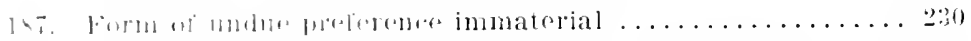

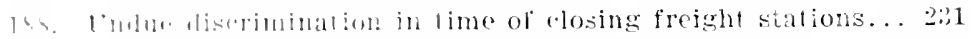

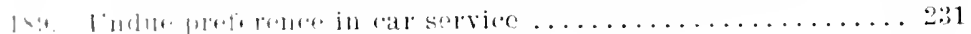

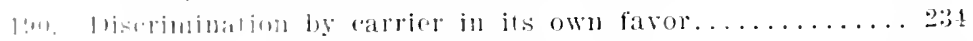

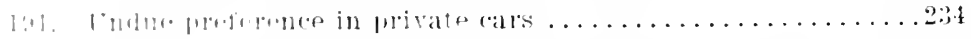

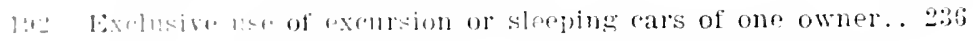

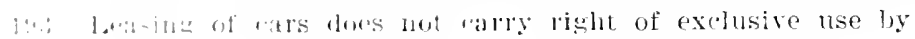

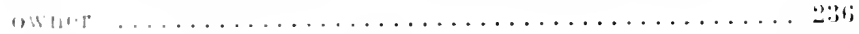

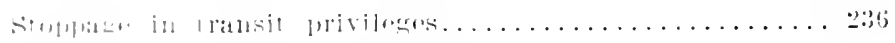

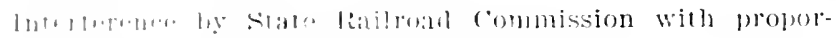

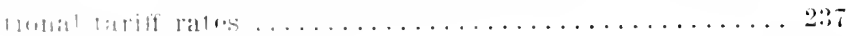

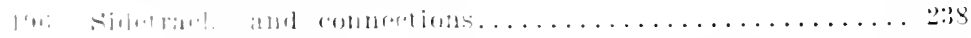

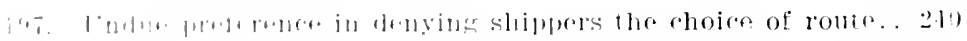

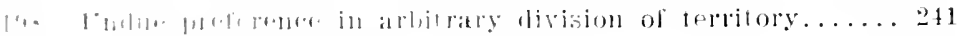

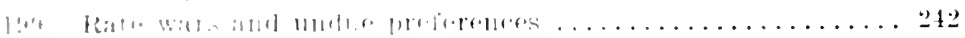

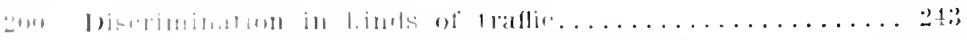

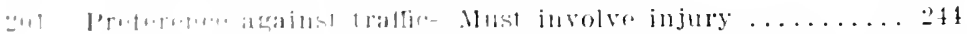

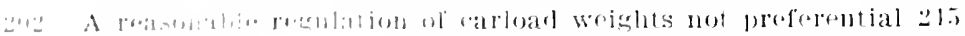

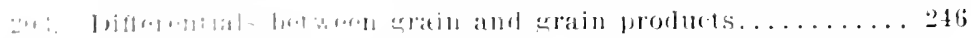

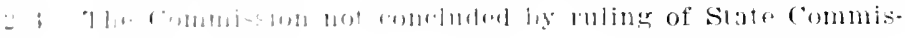


$\$ 205$. Discrimination in mode of shipment ..............

206. Classification ............................ . 48

207. Consultation of carriers in classification not illegal combina-

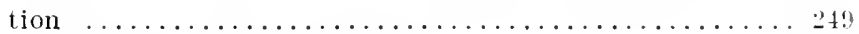

208. Undue preference in classification.................24?

209. Power of Commission in correcting classification........ 251

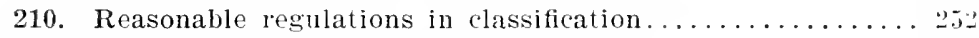

211. Facilities for interchange of traffic...............

212. Exacting prepayment not undue discrimination ........ 2.;

213. State control of interchange of interstate traffic....... 25t

214. State and municipal control of terminals........... 25..

215. The charging of local rates an undue discrimination...... 235;

216. The rights of exclusive through routing............. 257

217. Contract rights of trackage................... 55

218. Rights of connecting carriers as to milling in transit privi-

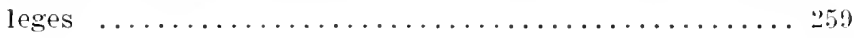

\section{Secrion 4.}

219. Long and short haul provisions................ 26,

220. History of the section . . . . . . . . . . . . . . . 260)

221. "Under similar circumstances and conditions" ........ 261

222. Competition under section 4 and under section 2...........

223. "Over the same line" ..................... 26:"

224. The proviso of the section ..................

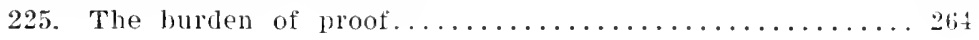

\section{SECTIOS 5 .}

226. Pooling of fleights and division of earning forbidlen.... 26f;

227. Construction of section.........................

22s. Controlling through routing to comections by initial a 'ar. rier ........................ 267

229. Agreements not witbin the prohibition............. 268

230. The relation of the section to the Anti-Trust Law of 1896. . 269

231. Pooling as a defense to action of the carrier........... 27)

\section{SECTION 6.}

232. Printing and posting of schedules of rates, fares and charges, etc. ......................

233. Amendments .......................... 27

234. Effect of publication.....................

235. Enforcibility of unpublished rate against the carrier.... 275

236. What is included in scherlules................

237. What is sufficient publication and filing............

238. Joint tariffs and through rates................. 27?

239. Published joint rates must be duly authorized.......... 280)

240. Application to export and import rates.............. 281 


\section{Sientex}

Page.

s. 2+1. Continuous arriage of freights from place of shipment to

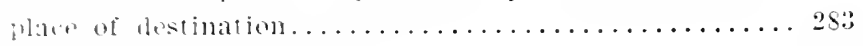

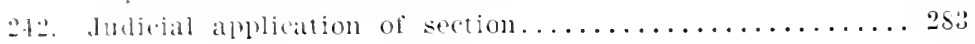

\section{SHorox}

$\because 2:$ tiahility of common arriens for damages .......... 284

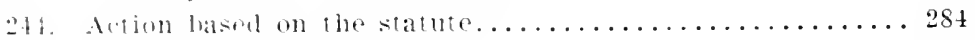

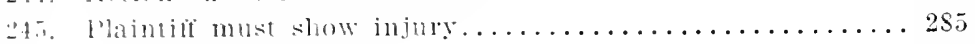

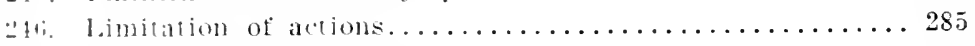

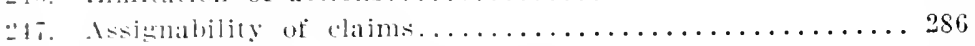

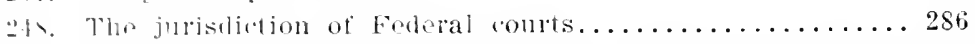

"2t!. Inristiction of the Federal courts in equity under the Act. 287

25 . Jurisliction in equity for protection of interstate commerce 290

\section{secriox 9.}

251. lersons claiming to be damagen may elect whether to comnlain to the Commission or bring suit in a Enited States

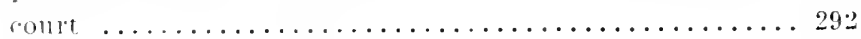

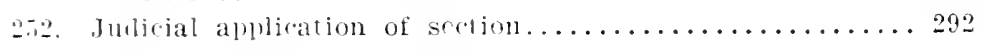

\section{SiETOX 111.}

2.:.). Penalias for violalions of Act by calriers ........... 294

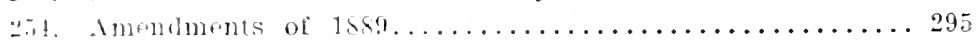

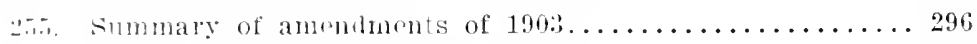

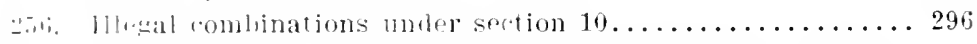

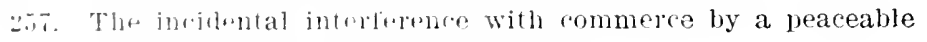

strilin not a violation of the section ............. 297

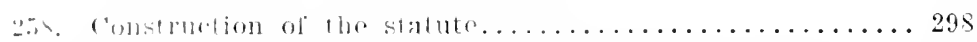

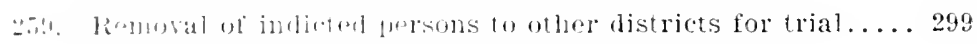

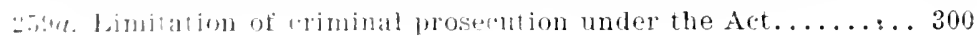

SICINA 11.

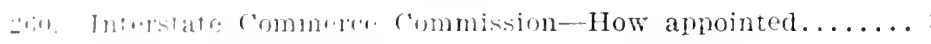

$$
\text { - } 1: \min 12
$$

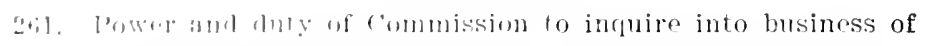

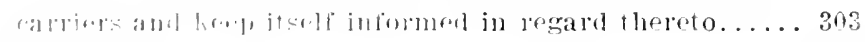

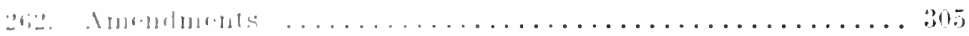

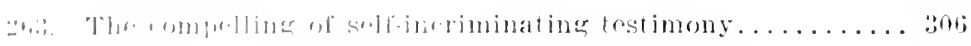

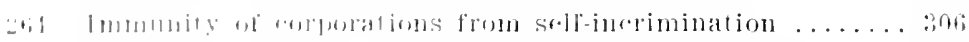

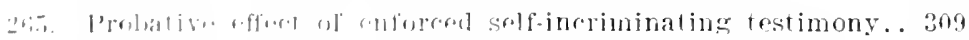

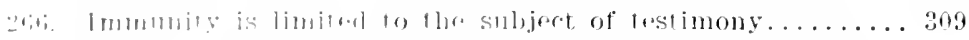

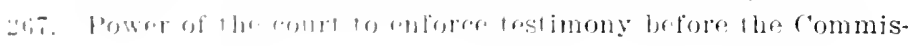

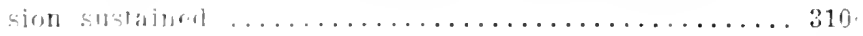


$\S 268$. Relevancy of testimony before the Commission ......... 311

269. General powers of the Commission ................311

\section{Section 1:.}

270. Complaints to Commission-How and by whom made-How

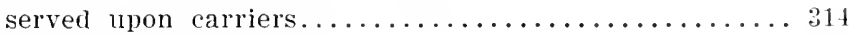

271. Procedure before Commission-Parties.............. 314

272. Pleadings and proofs..............

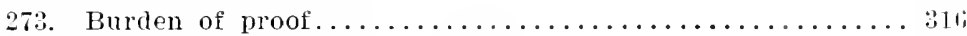

274. Production of books and papers.................. 817

275. The rulings of the Commission as precedents......... 318

\section{SECTION 14.}

276. Commission must make report of investigation........ 314 277. The report of findings of fact made wima facie evidence. . 319 278 . The Commission as a general referee............ 320 279. Claims for reparation before the Commission......... 321

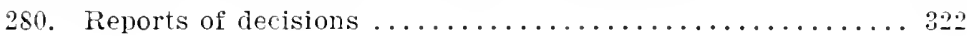

\section{SECTION 15.}

281. Notice to common carrier to cease from violation of Act... 32 ? 282. Notice to the carrier is jurisdictional............ 323

\section{SETION 16.}

283. Peition to United States courts in cases of disobedience to order of Commission.......................

284. The saving of the right of trial by jury ............ 326

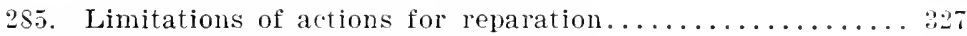

286. Jurisdiction of the Circuit Court............... 328

287. Proper and necessary parties to procedure........... 328

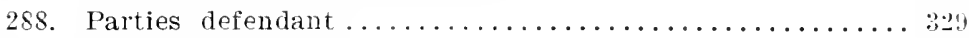

289. Prima facie effect of the report................ 829

290. The revisory power of the court ................ 390

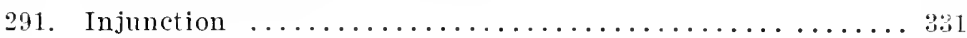

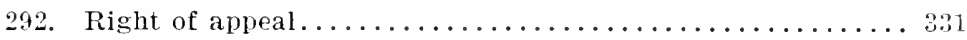

293. Supersedeas on appeal............................ 331

294. The provision as to supersedcas applies only to appeals from Circuit Courts ....................... $3: 2$

\section{SECTION 17.}

295. Interstate Commerce Commission-Form of procedure... 393

\section{Section 15.}

296. Salaries of Commissioners, Secretary, etc............ 334

297. Expenses of the Commission.................. 394 


\section{SECTION 19.}

$\$ 29 s$. Principal office of the Commission, ete.............

294. Practice of the Commission in hearings............ 395

\section{SECTIOX 21.}

:300. Carriers subject to the Act must render full annul reports to Conmission ............................ $3: 6$

:31. Railroals which are not subject to section 20 of the Act... 336

\section{Sictux 21 .}

: Annual reports of the Commission to Congress on or before

December 1 st each year .........................

\section{SECION}

31:3. Persons and property that may be carried free or at re-

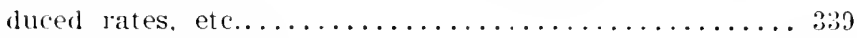

304. Amendments to section........................ 840

305 . The section illustrative and not exclusive........... 340

:nit. The section permissive only.................. $3+1$

307. Withdrawal of commutation tickets............. 341

\section{SECTION 23.}

30S. Jurisdiction of Uniled States Courts to issue writs.......

:31\%. Application of section to car shortage..............

\section{INTELSTATE COMIMERCE ACT AMENIMUNT.}

Amendatory Act of February 19, 190: (Elkins Act).

:110. Section 1. Carrier corporation as well as officer or agent

liable to conviction for misdemeanor...........

;11. Sertion 2. Parties interested subject to orders or decrees. : \$46

$\because 12$. Sextion $:$ Proceedings to enjoin departure from pullished

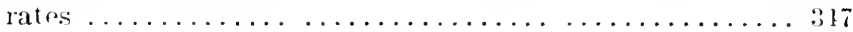

:3:: Section 4. Conllicine laws repealed.............. 345

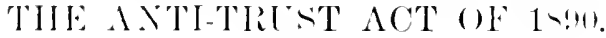

\section{SigTun 1.}

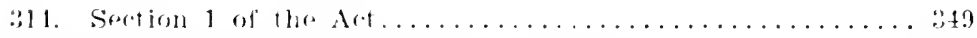

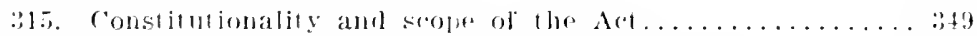

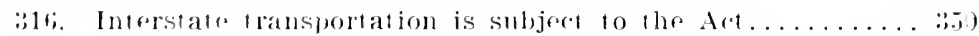

:37. Inlawtul rombinalions in rommere of her than thansporta-

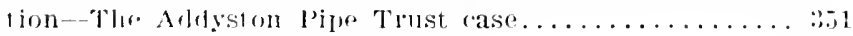

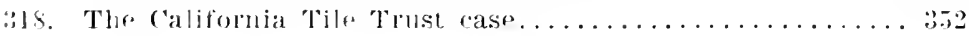


819. The Tennessee Cabifornia aud Ohio Coal (asos liar.

320. The Chicago Neat Trust case....................

321. The Washington Shingle Trust case............. 3..

322. Incidental restraint of trade not viclative of the Act..... $3: 51$

323. The Kansas City Live Stock Exchange cases. . . . . . . . . . . 35.

324. Agreements not within the Act...................

325. Certain agreements not to enter into competition not within

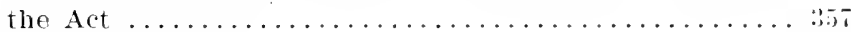

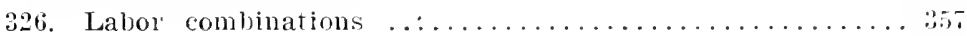

\section{SEUTON 2.}

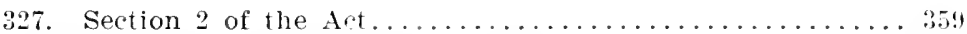

328. Criminal procedure unier the Act..................

\section{SECTION :;.}

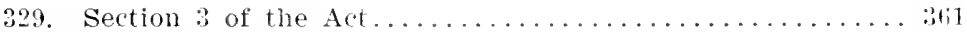

330. Territories and District of Columbia included......... 351

\section{SECTION 1 .}

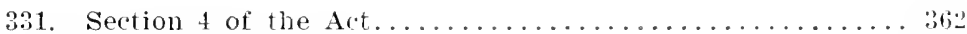

3:2. Procedure in equity under the Art . . . . . . . . . . . $36:$

333. Right to statutory injunction limiter to the government. . :31:3

3:4. A State cannot enjoin under the Act...............

\section{SECTION 5 .}

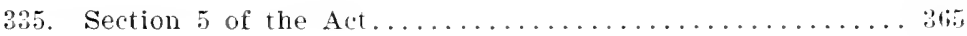

\section{SETITIN T.}

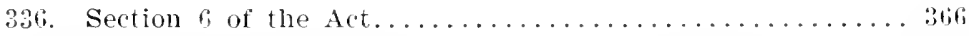

397. Enforcement of seizure of gools under section ij........2 2titi

\section{SECTHX 7.}

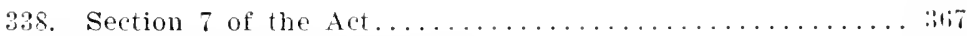

3:59. Private actions under sertion $7 \ldots \ldots \ldots \ldots \ldots \ldots \ldots \ldots$;

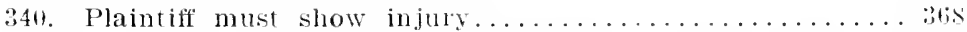

341. A State is not a "person or corporation" under section 7 . . 36?

842. Pleadings under section $7 \ldots \ldots \ldots \ldots \ldots \ldots \ldots \ldots \ldots \ldots$. 364

343. Measure of damages moler section $7 \ldots \ldots \ldots \ldots \ldots \ldots \ldots$ ithet

344. Limitation in private actions.................

345. The Act as a detense in suits by allesed illegal combina-

tions ...............................

346. The Act as a defense in patent litigation...........

347. Self-incriminating testinony $\ldots \ldots \ldots \ldots \ldots \ldots \ldots \ldots \ldots \ldots \ldots$ 


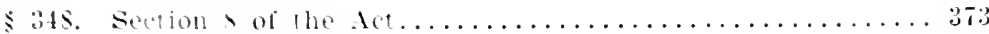

\section{TIIE FATEITION A('T.}

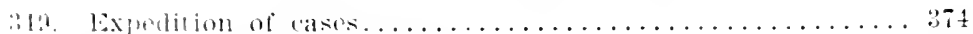

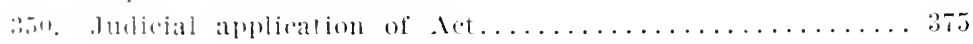

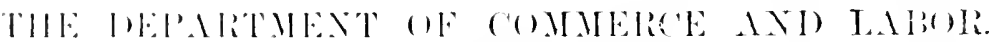

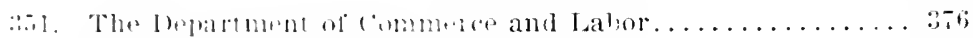

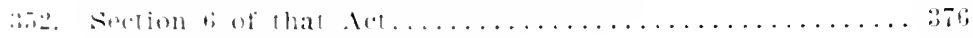

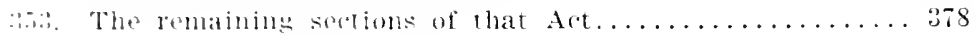

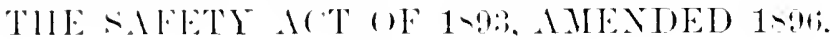

$$
\text { SI:THax } 1 .
$$

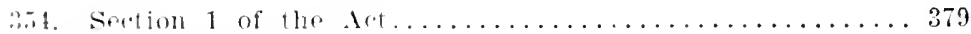

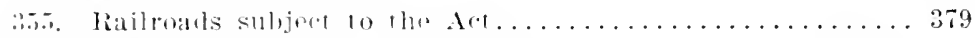

anti. The communtaw duty of the rarrel in relation to safet:

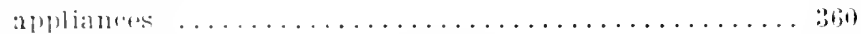

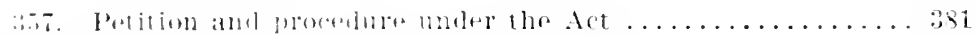

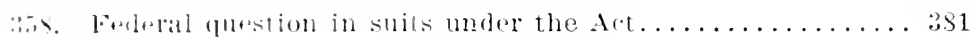

$$
\text { SHCTOS } 2 .
$$

:34. Shet

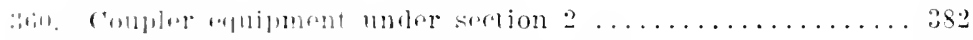

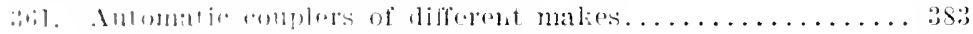

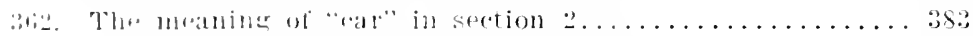

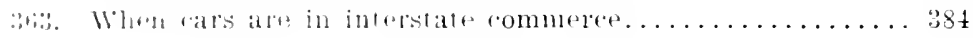

$$
\text { Mren: : }
$$

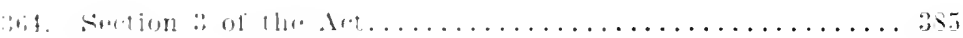

\section{Sienorist.}

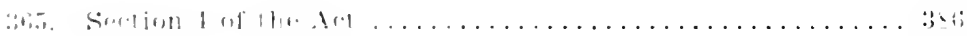

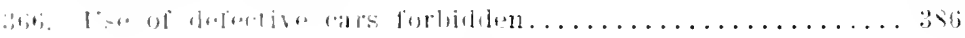

$$
\sin 1 \pi N \%
$$

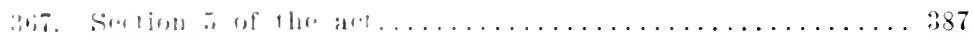

$$
-1,111 \cdots \infty \text { i: }
$$

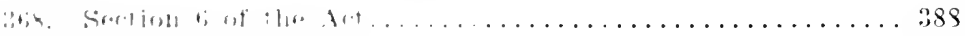

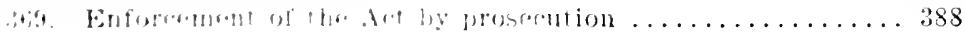




\section{Section 7.}

$\$ 370$. Section 7 of the Act......................... 889

371. Discretion of the Commission in delaying enforcement of

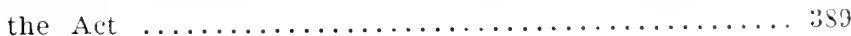

\section{SECTIUN $\checkmark$.}

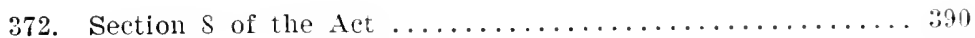

373. Contributory negligence under the Act.............

AMENDMENT OF 1908 TO SAFETY ACT.

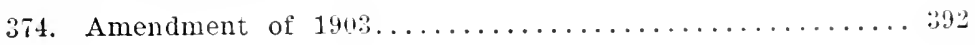

\section{TIIE ACCIDENT LAII OF MAlicll 3, 1911.}

375. Monthly reports of railway accidents............ 394

\section{FEDERAL LABOR STMTLTES.}

376. The National Trade Union Incorporation Act........ 395

\section{NATIONAL ARPITRATION ACT.}

377. Act of June 1, 1898, 3 Compiled Statutes, $8205 \ldots \ldots \ldots \ldots 396$

\section{PROCEDURE BEFORE INTERTTATE COMMERCE COMMISTHON.}

378. Rules of practice before the Commission in cases and proceedings under the Act to regulate commerce....... 402

Forms in Proceedngs Before the Comminion.... . ......... 411

Table of Court Cases.............................. 41.

Table of Commission Rulings....................... $4: 8$

Table of Conmssion on Reasundereses of Rates and Dispusi-

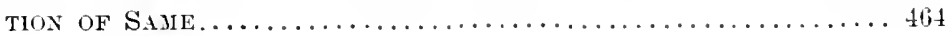





\section{THE LAIV OF \\ INTERST ITE COMMERCE.}

\section{PAR'T I.}

CHAPTER I.

interstate COMNER'E CNIER THE FEDERAL CONSTITUTION.

CHAPTER $1 \mathrm{I}$.

THE CONCURRENT AND EXCLLSIVE POWERS IN INTERSTATE CONNERCE.

CHAPTER III.

THE FEDERAL LEGISLATIVE REMCLATION OF INTERSTATE COMNERCE.

CHAPTER IV.

BLSINESS AND LABOR (OMHINATHNS IN INTERSTATE COMMBRCE.

CHAPTER I.

THE FEDERAL CONTR'L OF STATE REGLLATION OF COMAEICE,

\section{('IIPTER I.}

INTERSTATE COMMERCE UNDER THE FEDERAL CONSTITUTION.

$\$ 1$. The commerce clause in the constitution............... 1

2. Power of congress in foreign commerce and with the lnolian tribes distingmshed . . . . . . . . .

3. The Preference clause in the constitution...............

4. Federal sovereignity in interstate commerce.............

5. (ibbons . Orden...........................

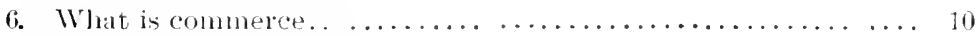

i. What is not commerce.........................

8. Insurance is not commerce....................... 11

9. What are the subjects of commere.................

10. Will game and tish as subjects of commerce............. 17

11. Natmat oil aml gas as subjects of commerce.............. 1!

1?. The commerce clanse and the admiralty jurisdiction.........

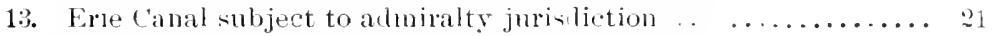

14. Juridiction of ferleral conts in almiralty cares.............

15. State corporations in interstate commerce. . ...........

16. When transit ends: the original packige in interstate commerce 24

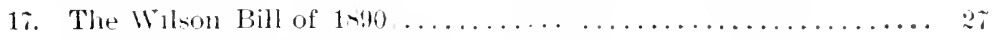

18. A state camnot tax interstate commerce ............... ?

19. But a state can tax the property employed in interstate commeree os

20. State power of taxation of corporations engaged in interntate commerce summarizerl. .................... 99 
"The congress shall have power . . . to regulate commerce with foreign nations, among the several states, and with the Indian tribes." Constitution of the United States, art. I, see. - par. 3.

.. The congress shall have power to make all laws which shall be necessiury and proper for carrying into effect the foregoing powers, and all other powers vested by this constitution in the government of the Enited states, or in any department, or any ollicer thereof." Art. 1, sec. s, par. 1 .

" No tax or duty shall be laid on articles exported from any state. No preference shall be given by any regulation of conmerce or revenue to the ports of one state over those of another: nor shall ressels bonnd to or from one state be obliged to enter, clear, or pay duties in anotlser." Art. I, sec. 9, par. 5.

"The citizens of each state shall be entitled to all the prisileges and immunities of the citizens of the several states." Ait. IV, sec. 2 .

"This constitution and the laws of the Cnited States which shall be made in pursuance thereof, and all treaties made or which shall be marle under the authority of the United States shall be the supreme law of the land; and the judges in every state shall be hound therely, anything in the constitution or laws of any state to the contrary notwithstanding." Art. YI, par. 2.

"The powers not rlelegated to the Inited States by the constitution, nor prohibited by it to the states, are reserved to the states respectirely, or to the people." Amendment X (declated ratified January, 1795$)$.

. All persons born or naturalized in the Lnited States and subject to the juriscliction thereof are citizens of the United states and of the state wherein ther reside. No stite shall make or enforce any law which shall abridge the privileges or immunities of citizens of the Lniterl states, nor shall any state deprive any person of life, liberty or property without due process of law. nor deny to any person within jts juriscliction the equal protretion of the laws." Article XIV, Section 1 (declared ratified July 2s, 1-ris).

1. The commerce clanse in the constitution.-The commerce clause in the federal constitution illustrates more pointally that any other the circumstinces which forced the adoption of the constitution and the formation of the government 
of the Union, and its julicial history is the clearest example of the adaptation of a written constitution by construction to conditions and emergencies never contemplated by its framers. It was the necessity for national control over foreign commerce which was the immediate occasion for calling the convention of 1757 , as the defect of the articles of confecleration in failing to provide for the control of this commerce was universally recognized.

Under the articles of confederation arlopted during the revolutionary war congress had power to regulate trade with the Indians, but the control of foreign and interstate commerce remained with the states. The compact between Virginia and Maryland relative to the navigation of the P'otonac river and the Chesapeake Bay, and the report of the commissioners thereon led the Tirginia legislature to call a conference at Annapolis in 1786 to take in to consideration the "trade of the United States, to examine the relative situation in the trade of the states, to consicter how far a miform system in their commercial relations may be necessary to the common interests and their permanent harmony." From the Annapolis conference came the call for the Philatelphia convention of 1757 , which framed the constitution.

Commerce among the states howerer was in 175 rery simple, and other than that carried on in teams and wagons was carried on by navigation. There was comparatively little discussion in the debates of the convention or in the Federalist concerning the federal control over interstate commerce, and no consideration seems to have been given to the question of the effect of this grant of the federal power upon the police or taxing power of the states. It was regarded as essentially silpplemental to the control over foreign commerce, and was granted so as to make the control over foreign commerce effective. It was said by Mr. Madison, ${ }^{1}$ that without this supplemental provision the great and essential power of resulating foreign commerce would have been incomplete and ineffectual,

${ }^{1}$ Federalist No. 4?. It was suggested in the convention though not alopted, and atso in some of the state conventions as a condition of ratitication, that no navigation law or law regulating commerce should be passed without the consent of twothirds of the members present in both houses. 
and that with state control of interstate commerce, ways would be fomnd to load the articles of import and export during the passige through their jurisolictions with duties, which womld fall on the makers of the latter and the consumers of the former.

The far-reaching importance of this federal control over commerce among the states was not and could not be foresecn. It only came to be realized in the course of years, as the commercial derelopment of the country demanded a jadicial construction of the federal power in barmony with the requirements of such commerce. ${ }^{\prime}$ The basis of this construction for all time was made by the far-sighted and masterful reasoning in the hroad and comprehensive opinions of Chief Justice Marshall:"

The supreme ('ourt in 159.5 in affirming the supremacy of the ferleral porer in interstate commerce, saill: ${ }^{3}$

- ( onstitutional provisions do not change, but their operation extends to new matters, as the modes of husiness and the bithits of life of the people vary with each succeeding generation. 'The law of the common carrier is the same to-dar as when transportation on hand was hy coach and wagon, and on water by canal hoat and saling ressel. vet in its actual operation it tonches and resmates transportation by moles then anlinwwn, the ralpoal trans and steamships. Just so it is with the watnt to the mational govermment of power orer interstate connmeree. The anstitution has not changed. The power is the sime. lint it operates to-klay mpon morles of interstate commorece maknown to the fathers. and it will operate with repal forec mpon any new moles of such commeree which the fllume may develop."

I (1)ly tire anses in wolving the consraction of the clature were deculed

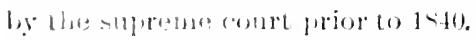

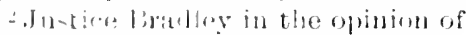
the compt in letoup r. Port of Mobile.

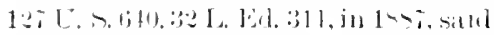

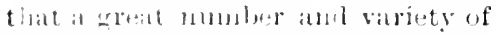

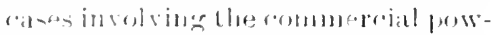

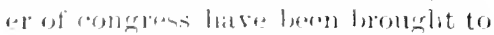

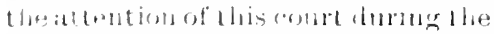
fiat fifteren years, which have fre-

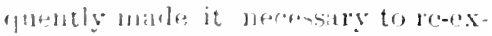
aluines the; wholes sub,jecel with ("atres

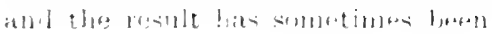

that in orler to give full and fair effert to the different clauses of the comstitution, the cont has been constramed to reles to the fundamental principlesstated and illustrated with so much clearness and force by Chief Justice Marsall and other members of the court in former times, and to modily to some degren. cortain dirta and decisions which have occationally been mate in the intervening periorl.

"In re llabs, 1.is L. S. l. c. p. jyl, :31. 1. W. 10.?. 


\section{S. Power of consress in foreign commerce and with} the Indian tribes distinguished.-In the commerce clanse, congress is empowered to regulate commerce with foreign nations among the several states and with the Indian tribes. Mlthough the three classes of commerce are thus grouped in the same clause and in the same terms, there is a distinction which has been frequently liscussed between interstate commerce on the one hand, and that with foreign nations and with the Indian trib: s on the other, and this distinction is mportant not only in the construction of the legislation heretolore enacted by congress, but in determining the power of congress in what maly be termed its mexercised power over interstate commerce.

In its control over foreign commerce, congress exercises the power of an independent sovereign dealing with other independent sovereign powers, and there is no implied or reserved power in the states in relation to such commerce. Congress may exercise the sorereign power of placing an embargo upon foreign commerce or it may exclude aliens. Commerce with the Indian tribes is also distinct from that between the states, in that congress in such regulation exereises the power of a sovereign over a dependent people or tribal communities subject to the parmount authority of the Lnited states." The power of controlling commercial relations with foreign nations and with the Indian tribes is therefore an essential sorereign power, which might have been inferred as an attribute of an independent sovereign nition created by the constitution without express grant of such power in the constitution.

The power to regulate commerce among the states was expressly given to congress in order to secure equility and freelom in conmerelal intereourse between the states as sorereign political communities, subject only to the paramount authority of the Lnited States in national concerns. Althongh the three classes of commerce are thus included in the same clause and in the same terms in the enumeration of powers,

11 Story on the Constitution. sec. 289: United States v. Brigantine William, Dist. of Mass, 2 Hall's Am. Law. J. 25.5.

2 Cherolse Nation v. Georgia, 5 Peters 1(1831), S L. Ed. 35: Worcester v. Georria, 6 Peters 515 (1s32) 8 L.
Ed. 183: United States r. Kagama, 118 U. S. 375.90 L. Ed. 228 (1 346$)$ : United States v. Forty-three frallons of Whiskey, 93 U. S. 188, : L. Ed. 846 (1s.6): Cherokee Nation r. Kansas Ry. Co. 135 C. S. 641 (1890) 34 L Ed. :?!s. 
they are clearly distinguished in their historic setting and constitutional import, and the laws, which are necessary and proper in regulating commercial intercourse with foreign nations and with the Indian tribes, may not be necessary and proper in regulating such commercial intercourse between the states. ${ }^{1}$

:3. The preference clause in the constitution.-The socalled preferential clause of the constitution (article I, section 9. paragraph 5. $x^{\prime \prime \prime \prime \prime}(t)$ illustrates this differentiation of the feleral control of commerce among the states from that over. foreign commerce and with the Indian tribes.

As already observed, at the time of the adoption of the constitution, commerce among the states, all of which were connected by sea and navigable waters, was conducted wholly by narigation except what was conducted by stage or wagon. The prohibition therefore of any preference of the ports of one state orer those of another, or of any luties in interstate traffic. harl an inportance at that time as a restraint upon the powers of the general government which can hardly be appreciated at the present time. The section is deroted exclusively to defining the powers conferred upon congress, and is a distinct limitation of the powers of congress in the regulation of commerce between the states.'

The prohibition of a tax or duty upon articles of export from any state was assumed in Almy $v$. California ${ }^{3}$ to apply to exports from one state to another. It has since been held that this prohibition has noapplication to interstate traffic, but applies to foreign exports only.

This clause was discussed in one of the Insular cases, ${ }^{5}$ where a bare majority of the court held that a tariff upon merchandise going into Porto Rico from the Cnited States was not a duty upon an article exported from the Cnited States, as it was not exporterl to a foreign country.

Mr. Justice brown in delivering the opinion of the court said it was not intended to intimate that congress could lay a tariff mon merchandise carried from one state to the other, while

S See opinion of Justice McLean in Groves v. Slatughter, 15 Peters l. c.

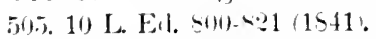

"Morgan v. Jouiniana, 119 U.S.

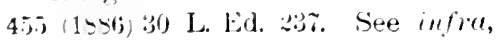
s.tis.
3.4 Howard 169 (1860) 16 L. Ed. (it4.

4 Woolruff v. Parham, 8 Wallace 123 (1s65) 19 L. Ed. 382.

5 Dorley v. United States, $18: 3$ U.S. $151(1901) 46$ L. Ed. 125. 
in the dissenting opinion ${ }^{1}$ it was insisted that this clause was intended to prevent the exercise through the taxing power of congress or its power to regulate commerce so as to discriminate between one part of the country and another, and the power to regulate interstate commerce was granted in order that trade between the states might be left free from discriminating legislation, and not to impart the power of creating antagonistic commercial relations between them.

$\S$ 4. Federal sovereignty in interstate commerce.-The federal authority in interstate commerce is enforced not only by the power of regulation granted to congress by the constitution, but also by the exercise of other expressly enumerated powers of congress, more or less directly relating to interstate commercial intercourse. Thus the power to establish postoffices and post roads, to coin money, to establish uniform systems of bankruptcy, to grant patents for discoveries, and most important of all the taxing power, are closely associated with commercial relations and aetivities. There is also what has been termed the "co-efficient power," the power to make all laws necessary and proper to carry into effect the foregroing porvers, and all other powers rested by the constitution, in the government of the United States or in any department or officer thereof.

The broad and comprehensive construction given to this coefficient power, of selecting measures for carrying in to execution the constitutional powers of the grorernment has made academic rather than practical the long debated distinction between the express and implied powers of congress. ${ }^{2}$ The words "necessary and proper" are not limited to such measures as are absolutely and indispensably necessary, without which the powers grinted must fail of execution, but they include all proper means which are conducive or adapted to the end to be accomplished, and which in the judgment of congress will most advantageously effeet such enct. ${ }^{3}$

The federal authority in interstate comnerce, as in other matters, does not rest on a mere aggregation of the enumerated

\footnotetext{
1 Justices Fuller, Brewer, Harlan and Peckliam.

${ }^{3}$ Legal Tender Cases, 110 U. S. 421

2 McCulloch $v$. Maryland, 4 Wheat. 316, 438, 4 L. Ed. 579.
} 
powers. Althom the goremment of the Inited States is one of entumerated powers, and under the tenth amendment the powers not delenated to the Inited stites by the constitution, nor prohibited by it to the states. alre reserved to the states respectively or to the people, it is also true that there is a national sorereignty - at national federal state - within the scope of the enmmerated powers, and the constitution and latws of the l'nited states are the supreme latw of the land. Coron this boal principle of the sorepeignty growing ont of the angerention of anmerated powers was based the power to chater a national bank, the power to exercise the right of aninent romatn," the power to issme legal tender motes." and the power to excluke aliens." The power to issne lenal temder notes. Which was strongly controverted, was based upon two emmurlated purers. that of coining money and thereby estahlishing a nationil currency, and also upon the commere poller. It was also lechand to he a power inferent in sovereronty as exercised hy rother sorepeignties at the time of the aloption of the constitution, ame not expessly with held by the eonstitution from conceress.

As a political solereingty the goremment of the Inited states may by phesteal force. through its oflicial agents, in thes enforcement of its pollers, exereise complete sovereignty orer cery part of American soil which helongs to it. There is a "Peatere of the lonited states." and this Peace can be enforeed he the exerative" in the protection of the jualicial biicers of thr. lonited citatris throughont the lnited states and whtion the limits of any state. These fundamental prineiples

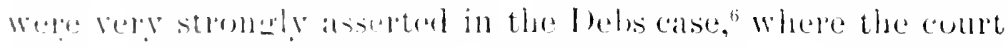
salir that the enermuent of the l'nited states, in the exereise of its power over the mails and in protecting interstate commerer. ban juriseliction orer every fout of soil in its territory and areted directly mon erepre itum. The decision was expressly based upen the sorereing power of the Inited states

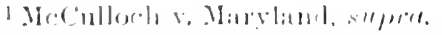

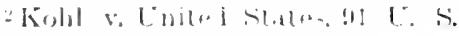

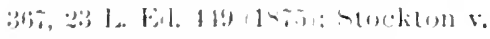

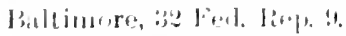

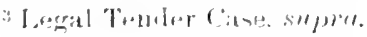

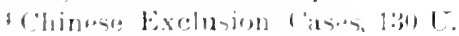

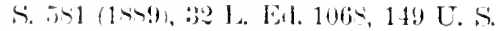

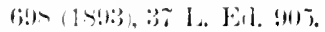

s. In re Nagel. 135) U. S. $1(1490)$, : $) 4$

I. Fi.1. .5.

"Silpw. $\leqslant 1$. 
within the limits of its enmmerated powers, and on the power of the government to enforce that sovereignty through the executive or through the courts, acting directly through the citizens and not through the agencies of a state, when the feder:al anthority is resisted.

The complexity of our feleral governmental system inclules this distinct sovereign power in the feleral government with sovereign powers in the states. In the language of Chief Justice Marshall, ${ }^{1}$ the powers of a sovereign are divided betweet: the government oflicers of the Union and those of the states. They are each sovereign with respect to the rights committed to it, and neither sovereign with respect to the rights committed to the other. The supreme Conrt of Massachusetts" said that it was a bold, wise and successful attempt to place the people under two distinct govermments, each sovereign and independent within its own sphere of action, diviling the jurisoliction between them, not by territorial limits nor by the relation of superior or subordinate, but classifying the subjects of juriscliction and designating those over which each had entire and independent jurisdiction.

The federal government therefore, thongh sovereign within the sphere of its enumerated powers, has not what has been termed inherent sovereignty, nor has it any general police powers; but with its wide scope of selection of the means for the execution of its enumerated powers the distinction is hardly a pratetical one in the actual working of our clual political system.

5. (tibbons r. Ooden.- The judicial construction of the commerce clause begins in $182+$ with the great opinion of Chief Justice Marsball in Gibbons r. ()gden, "wherein a grint of the state of New York for the exclusive right to navigate the waters of New York with boats propelled by fire or steam was held roid as repagnant to the commerce clause of the constitution, so far as the act prohibited ressels licensed by the laws of the United States for carrying on the coast trale from nat rigating the said waters by tire or steam.

1 McCulloch r. Maryland, 4 Wheat. 17 Johns. 488 (1890), and Kent, J., 316 (1819), 4 L. Ed. 579. in 4 Johns. Ch. $1.50(1819)$. and alio in

2 Opinion of Justices. 14 Gray, 615. Livingston $\mathrm{s}$. Van Ingen, 9 Johns. 50\%

39 Wheat. 1. 6 L. El. 23 , reversing (1812.) 
The broal and comprehensire construction of the term "commerce" in this opinion is the basis of all subsequent decisions construing the commerce clause, and is the recognized source of aluthority. Commerce is more than traffic: it includes intercourse. The power to regulate is the power to prescribe the rules by which commerce is to be governed. This power like all other's rested in congress is complete in itself, and may be exereised to its utmost extent, and acknowledges no limitations other than as prescribed in the constitution. The power over commerce with foreign nations and among the several stiltes. said the court, is rested in congress as absolutely as it would be in a single government having in its constitution the salme restrictions on the exercise of the power as is found in the constitution of the Lnited States. The power comprehended narigation within the limits of every state, so far as navigation may be in any manner eonnected with commerce with foreign nations or among the several states, or with the Inclian tribes, and therefore it passed beyond the jurisdictional line of New Tork and incluled the public waters of the state which were connected with such foreign or interstate commerce.

The most important and far-reaching declaration in the opinion was that of the supremacy of the federal power, so that in any case of conflict the act of congress was supreme, and state laws must yield thereto, though enacted in the exercise of powers which are not controverted.

(i. What is commerce. - The term "commerce" is not defined in the constitution, but its meaning has been determined by the process of jullicial inclusion and exclusion on the broad and comprehensive basis laid down in Gibbons v. Ogden. Commerce, it was there salid, is not traffic alone, it is intercourse. "It described the commercial intercourse between nations, and parts of nations in all its branches, and is regulated by prescribing rules for carrying on that intercourse."

In the P'assenger Cases ${ }^{1}$ the rule declared in Cibbons v. Ogden wis applied in holding invalid certain state statutes imposing taxes upon alien passengers. It was said that cominerce includer navigation and intercourse and the transportation of passengel's. 
In the Pensacola Telegraph Company case ${ }^{1}$ the court said that since the case of Gibbons v. Ogrden it had never been doubted that commercial intercourse was an element which comes within the power of regulation by congress, and that the power thus granted was not confined to the instrumentalities of commerce known or in use when the constitution was adlopted, but kept pace with the progress of the country, adilpting themselves to the new developments of time and circumstances. In the language of the court :

"They extend from the horse with its ricler to the stage coach, from the sailing ressel to the steamboat, from the coach and steamboat to the railroal, and from the railroad to the telegraph, as these new agencies are successively brought in to use to meet the demands of increasing population and wealth. They were intended for the government of the business to which they relate at all times and uniler all circumstances."

In a later case it was said ${ }^{2}$ that the commerce which congress could regulate included not only the interchange and transportation of commodities or visible and tangible things, but the carriage of persons and the transmission by telegraph of ideas, orders and intelligence.

The electrically transmitting of articulate speech by telephone between states is interstate commerce. This was assumed by the Supreme Court in holding that the act of July 24,1866 did not apply to the telephone business, telephone communication being unknown at the time of the passage of that act. The court therefore said that when the act of 1806 spoke of telegraph companies it coukl have meant only such companies as employed the means then in use or embraced by existing inventions for the purposes of trunsmitting messages merely by sounds of instruments or by signs and writing. ${ }^{3}$

While a bridge is not a common carrier, it affords a highway for such carriage, and a state enactment prescribing the rate of toll on an interstate bridge is an unauthorized regulation of interstate commerce. Commerce among the states, therefore,

196 U. S. 1 (18\%7), 24 L. Ed. 708. 711. Construing act of July :4, 1866. as a prohibition of all state monopolies in interstate telegraph business.

2 W. U. Tel. Co. v. Pendleton, 122 U. S. 347 (188\%), 30 L. Ed. $118 \%$.
${ }^{3}$ Richmond v. Southern Bell Telephone Co., 174 U. S. 761 (1899), 43 L. Eu. 1162.

${ }^{4}$ Covington, etc. Bridge Co. v. Kentucky, 154 U. S. 204 (1894), 38 L. Ed. 962. As to taxation of an interstate 
embraces navigation, transportation, of passengers and freight traffic and the communication of messages by telegraph ${ }^{1}$ and by telephone."

The carring of lottery tickets from one state to another by corporations or companies whose business it is to carry tangible property from one state to another, constitutes interstate commerce which mal be properly prohibited by congress under its power of remalation."

Interstate commeree, as distinguished from domestic commeree, incinles trattic between points in the same state, but which in transit is carried through another state. It follows that the railroad commission of a state cannot, without violatint the commerce clause, fix and enforce rates for the continuolls transportation of goods between such terminal points. A talx on an interstate railroad can be apportioned according to mileage in a state (see $\$ 19$, intia), but when a freight rate is established it must be established as a whole. (See $\$ 109$, infmo)

commerce inclules narigation, and the power to regulate commerce comprehends the control, for that purpose, and to the extent necessiry, of all the rivers of the Inited states which are accessible from a state other than those in which they lie.' The right to regulate navigation carries with it the right to regulate and improve narigable rivers and the ports on such rivers, and the power to close one of sereral channets in a navigable stream, if in the judgument of congress the narigation of the river will be thereby improved. Thus the frower of congress over the Sarannah river was not affected

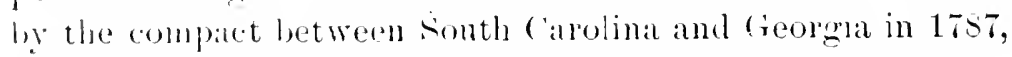
lielore the adoption of the constitution." (As to concurrent puwer of state in river improrements, see chap. 2 , intim.)

To constitute interstate commerce, it must be so in fact and not only in intention. The intention to ship manufactured goods

bridge see Henderen Tiriline co. v. Kentucky 16iti L. S. 150) (159\%) 41 I.

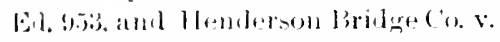
Hemderton, 10; L. S. 5is, 45 L. Ed. (5:3): 1 $15 \div 19$.

1 Pensanda Pelegraph co case. su. man.

a intral Lnion Tel. Co. r. State. 11- Ind 1:1, and In re I'enn. Tel. Co. . ㅈ. . E. E. 191 .
"Hottery cases. 1ss U. S. $3: 1$ (1!):3), four Judges dissenting, $47 \mathrm{~L}$. E+1. $4 ! 3 \%$.

llianley v. K. C. So. R. Co.. 18 U. S. 1:1\% (1!19:3), 4\% L. Eol. :333.

scilman v. Philadedphia, :3 Wallace T.2. 1s L. Eul. 99.

SSouth Cirolina $v$ Georgia, $93 \mathrm{U}$. S. 1. 2:3 L. Ell. $692(1 \times-69)$ As to the almiralty jurislictionsee infra, $\$ 12$. 
to other states does not make a contract for the operation of a factory for their manufacture relate to interstate commerce in a constitutional sense so as to exempt it from the operation of state laws, ${ }^{1}$ nor does such intention to export property from the state constitute a ground for the exemption from the power of State taxation. (see $\leqslant 15$, intiuc.)

$\$ \tau$. What is not commerce. - While commerce is more than traffic and includes commercial intercourse and the transmission of intelligence, it loes not inclucle the contractual relations between citizens of different states, which are incidental or even in one sense are essential to interstate commercial intercourse. 'The distinction may be illustrated by a bill of leding and a bill of exchrnese. I bill of lading upon an interstate or foreign shipment represents the property shipped, and in the case of an interstate shipment is beyond the taxing power of a state, ${ }^{2}$ and in the case of a foreign shipment a tax upon a bill of lading is a tax upon exports, and therefore beyond the taxing power of either the state or fecleral government." in the other hand, a bill of exchange, whether drawn on an interstate shipment or a foreign shipment, is an incielent of such commerce and not a part of it. It follows, therefore, that a broker dealing in foreign bills of exchange is not engaged in commerce, but in smplying the instrumentalities of commerce, and a state tax npon mony and exchange brokers is not roid as a regulation of commerce.

The business of a monefintming company, although the manufactured product is sold by the company in other states and in foreign countries, is not interstate commerce." ('ommerce succeds manufacture and is not a part of it, and the relation

1 Diamond Glue Co. s. United States Glue Co., E. D. of Wis. (190)", 10:3 Fed. Rep. s:s'.

2 Almy r. California, it How. 169, 16 L. Eil. 64t (1s60): Woodnutf r. Parhatu, \& Wall. 12:3 (15i9), 19 L. El. 28.?

"Fairbanks r. United States, 181 U. s. $28: 3(1901)$, 4.) L. Ed. $86 ;$.

4 Nathan s. Loniriana. \& How. 7.) (15iso), 12 L. Eu. 9.9?. The lend. ing of money by a citizen of one state to a citizen of another is not interstate commerce. Helms r. Mort gage Co. 92 Ala. 15\% Mr. Inamilton, in bisargument on the prore to charter a national bank.:3 Hamil-

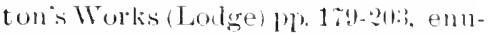
merates. among the subjects orer which he had little doubt the national power extended, the regnlation of policies of insurance aum bills of exchange drawn by a merehant of one state upon a merchant of another.

"Kidle r. Pierson. 12s L. S. 1 (1)m.

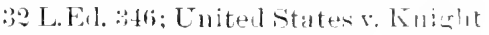

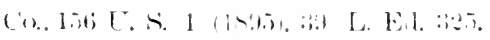


of the manufacturer, in such a case, to interstate and foreign commerce is incilental and indirect, and the business therefore is subject only to state control.

Tidelemarks, though useful and raluable aids of commerce, are not subject to congressional regulation, unless limited to their use in commerce with foreign nations and among the several states and with Indian tribes. ${ }^{1}$

S. Insurance is not commerce.-An important application of this principle, that the contractual relations incilental to commerce are not inclucled in the commerce clanse, has been matle in relation to the business of insurance. The business of lire and marine insurance is intimately related to interstate and foreign commerce, and is indeed an essential feature of such commerce, while life insurance involves an associated relation for the averaging of human lives, extending not only through the states of this country but foreign countries. ${ }^{2}$ It was first held in the case of a foreign fire insuranee company which claimed exemption from state control, that a policy of insurance was not an instrument of commerce, but was a mere contract for indemnity against loss by fire, and that the fact that the panties were domiciled in different states did not make such contracts interstate transactions within the meaning of the commerce clause. ${ }^{3}$ Later this ruling was applied to a contract of marine insurance, and the court said, if the power to regulate interstate commeree applied to all the incidents to which commere might gire rise, and to all the contracts which minht be made in the comrse of its transaction, the power would cubrace the entire sphere of mereantile activity in any way connected with trale between the states. Finally, in 1900 , the ruling was extended to the case of mutnal life insurance, althongh here it was contended that the policies were not mere

1 Trade llatk Cases, 100 C. S. S2,

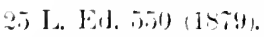

"I resident finwerelt, in his mes-

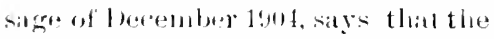
businens of msurabere ritilly allects lhe great mass of the people of the Enitral Statese am! i- national and not locad in its appliantion, and that it involves a mulatule of trancare tions anonir the perple of the lifferent states and betwern Ameriat: comntries and foreign governments. Ile ureges concress to consider "hetirer the prower of the Burean of Cinprations, infin. \$3.50, coukl not constitutionally be extended to cover interstate transactions in msurance.

"Panl r. Virginia, s Wall.16s (1>69),

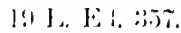

H

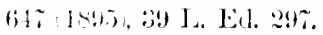


contracts of indemnity, but represented an associated relation based on the comparative certainty of the arerage life and the uncertainty of the inclividual life, thus necessitating a uniform law controlling this associated relation of parties resident in different states and countries. The court, however, refused to distinguish the business of mutual life insurance from that of fire and marine insurance.' The business of insurance therefore, in all its branches is subject to the legishation of the different states ${ }^{2}$ wherein the companies are locited.

It was strongly contended by the dissenting jurlges in the lottery cases, supre, that lottery ticliets, unler the ruling in the insurance cases, were mere evidences of contractual relations, furnishing the means of enforcing contract rights, and were not instruments of commerce in any sense. It was ruled in the prevailing opinion, however, that lottery ticliets are subjects of traffic, and are therefore subjects of commerce.

9. What are the sulpjects of commerce.-Commerce between the states includes only the subjects, which are properly and lawfully articles of commerce. The regulating power of congress does not deprive the states of their inherent police power in protecting the lives and property of their citizens, although the line is oftentimes diflicult to draw, as the dissents in the supreme court show, between reasomble police regulation which oniy indirectly or inciclentally effects interstate commerce, and legislation which invades the prerogatives of congress.

Thus the states may legislate to prevent the spread of crime, and may exclude from their limits paupers, convicts, persons likely to become a public charge, and persons aftlicted with contagious diseases. ${ }^{3}$ A state may protect the moral as well as the physical health of its people. A corpse is not the subject of commerce. This power of the state inclules the right to protect the people against fraud and deception in the sale of food products. The principle was applied by the court in sus-

1 New York Life Ins. Co. ₹. Cravens, 178 U. S. 389 (1890), 44 L. Ed. 1116.

2 As to the exercise of their power by the states and its effect upon the business of insurance, see infru, $\leq 1 \%$.
${ }^{3}$ But as to right of excluding foreign immigrants, see Henderson v. New York, 92 U. S. 259 (1)7j, 93 L. Ed. 543, Chy Lung v. Freeman,

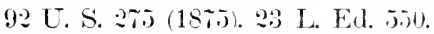

${ }^{4}$ In re llong lung Guy. 6 Saw. 442. 
taining a Massachusetts statute, which prohibited the manufacture and sale of imitation hutter, oleomargarine, artificially colored so as to caluse it to look like butter.

This principle does not extend to the exclusion of any commodity which is generally recognized as a legitimate article of commerce, though condemned and sought to be excluded hy the loushation of a particular state. I state camnot determine for itselt mpon its own standards of public opinion what are and what are not law ful subjects of commerce, amainst the crenerally aceepted opinion of the commercial world. This distinction wis illustrated in another oleomargarine case ${ }^{2}$ where the comet held invalul a statute of Pennsylvania which absolutely prohibited the manufacture or sale of oleomargarine, so lar as that statute prohibited the introduction of oleomarwarine from another state and its sile in the orignal package.

The court distinguished the I'lumley (Massichusetts) case on the ground that it was based upon the right of the state to prevent leception and framd, and that the right of a state in relituon to the administration of its internal affatis wats one thine, and its right to prevent the introduction within its limits of an article of commerce was another and totally different thina. The court in its opinion referred to the fact that oteomansulne had been treated by congress as a propep subject of taxation." that this was in eflect an allimative declaration in hy enmess that it was a proper subject of commeree, and that it Was establisherl by competent testimong that it was at Wholesome human fool and a legitimate subject of commerce.

This anflict between local and general public opinion as to What ald proper subjects of commeree was illustrated in the case

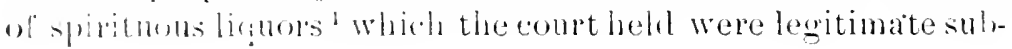

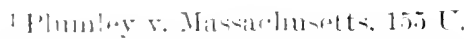

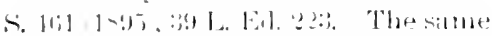

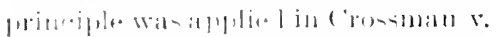

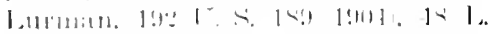

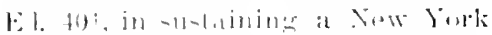

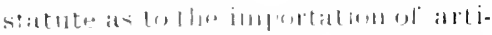

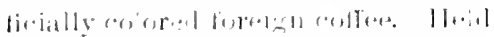

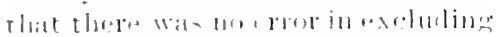

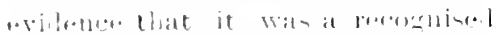

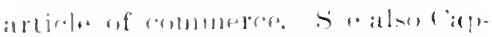

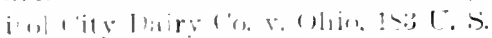

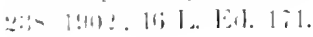

"Schollenhererer r. Pennylvania, 1i1 L. S. 1 , 1-tos, 4:3 J. Eil. 4!r: In collins s. New Hampehire $171 \mathrm{C}$.s. :3 (1:54), 4:3 L. Ed. 40. the comt held invalid. as being in necessiry efrect drohilitory,astatute prohilitingsate of oleomalgarine as a subatitute for butter muless rolored pink.

:Aret of Allatust ?. is 66 ; c. 40.24 statlutes at latroge. 30!.

tsiest infore. 21. 
jects of commerce, the introluction and sale whereof in the original packilge could not be prohibited by the state. The right of the state in its control of its domestic commerce to enforce its own views of public policy in prohibiting the manufacture and sale of both liquors ' and oleomirgarine' laal been sustained ly the comt.

Tobaceo is also a lewitimate article of commerce and the supreme court said that it could not take judicial notice of the fact that it was more noxions in the form of cigarettes than in other forms." It was therefore subject to the same extent as intoxicating lipuors to the police power of the state, that is, the state conk declare how far cigarectes shoukl bs sold or prohibit their sale entipely after they had heen tiken from the original packages or hat left the han ls of the importer, providing no discrimination was used as against those imported from other states, ${ }^{+}$but conh not prohilsit their importition.

The lawinl pulice porer of the stilte also extencls to the reasonable inspection of articles brouth in from the other states, this right of inspection being expressly recomized by the constitution in the case of foreign importations.' lut this inspection must be reasonable, and is invalid if burdened with such conditions as would wholly prevent the introduction of the sound article from other states."

810. Mill gane and fish as subjects of commeree.- Law ful subjects of commerce must be capable of prirate ownershinl, and while this is not snbject to the determination of a state in relation to reconnized subjects of commere, it is sul,ject to the state control wiere the natter is not a subject of pribate owner.

1 Murcer v, Kancas, 12: U. S. 62:3. 31 L. E1l. 20.5) (1s:i).

"Puwell v. Penmylrania, 12r U. S.

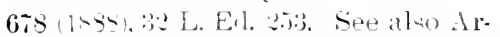
buckle r. Bhakbarn. bth circuit, is c. C. A. 12:2,11:3 Fed. Rep. 619, 6.5 L. R. A. stot, wher the court refuned to enjoin the enforcement of a state stattute f rohibitug coloring, coating or polishing an article mitender for food. whereigy damaze or interiority is concealed. The court sail this was not in conflict with the power of congress to regulate commere. though nuplied to articles sold in orizinal backages importel from otlerestiete-

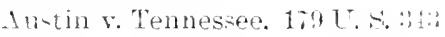
(1909). 4.5 L. E1. 2.)4.

4 As to size of the original Inackat. see infire, $\$ 10$.

3. Ait. I. sec. 10. par. ?: J'atapiron Guano Cor. Xoth Carolina Isand

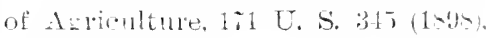
1:3 L. Li. 191.

"See Minnesota r. Barp"er, 13\% L. S. 31:312:\%, :3+ L. E1. 15\%. 
ship except as permitted by state law. Thus the wild game within a state at common law belongs to the sorereign, and in this country to the people in their collective capacity, and the state therefore has a right to say that it shall not become the sabject of commerce. I pon this principle the supreme Court sustained a Connecticut ${ }^{1}$ statute prohibiting the killing of certain game in the state, with the intent of transporting the sime ont of the state.

Culer the same principle the state determines on what conditions the prolucts of orster berls and fisheries may become subieetsof commerce, as each state, subject to the paramount control of navigation in the federal government, owns the beds of all tile water's and public waters in its jurisdiction.?

In the case cited from Massachusetts the courts held ralid an act of that state prohibiting fisheries in the waters of Buzramlis liay, except under the rewalions prescribed by the act, and held that it applied to a ressel which hat a license to fish under the laws of the Tnited states. There has been no grant to congress of power over fisheries, and these remain under the exchusire control of the states. The extent of the territorial juristiction of the state of Minsachusetts over the sea adjacent to its coast was held to be that of an independent nation, and cxcept so firr as the right of control over this territory had been crinter to the "nited states, the control remained with the state. sulject of course to the almiralty and maritime jurisdiction of the Cnited states. Within what are generally recognized as the territorial limits of stites by the law of nations, a state can define its boundaries on the sea and the boundaries of

I (ieter vonnecticnt, 181 L. S. itg (149i), 40 1. lid. ro:\% After this atecinion it was hell in the catse of $1 n$

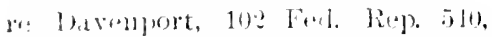

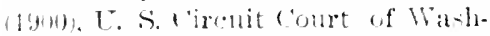
metou, that it state haw no power to

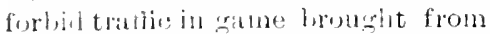
anchlies state where it hiw heen law. fully lillent: bnt the L. S. Circuit

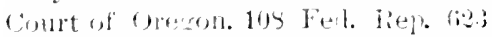

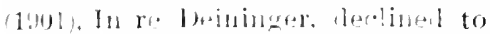

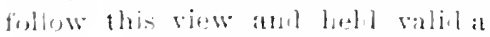
strtig law making it a penal oflense to have trout in possesion for sate although brought from anotherstate where it was lawfully caught. Some of the state rourts had held that such laws were invalid as reunlative of interstite commerce. Seestate r. Sinders. 19 Kan. 12\%, and Territory v. Evans. 2 Iraho gist.

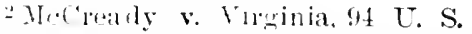
:91 (1-ir). 24 J. bil. "It: Hanchester v. Nituachusetts. 1:39 U. S. $210(1890)$, 3.5 1. E. .1. 15y. 
its counties; and by this test Massachusetts can properly include Buzzard's Bay within the limits of its counties.

\$1. Natural oil and gas as subjects of commerce.- Natural oil and gas are not subject to absolute ownership while in the confines of the earth, and from their tendency to more from one place to another have been called in some of the decisions minerals fere nuture. They become however lawlul subjects of commerce when brought to the surface and secured in pipes. A statute of Indiana prohibiting the piping of natural gas from the state was held by the supreme court of that state to be an attempted regulation of interstate commerce, and violative of the natural right of dealing with property and therefore void. The court said that the natural gas in the earth cannot be a commercial commodity, but when brought to the surface and placed in pipes for trinsportation, it assumed that character as completely as coal in cars or petroleum in tanks.

While this position seems to be conceded in all the courts as to the commercial character of oil and gas when brought to the surface and secured in possession, it is also recognized that owing to the peculiar character of these substances the property right of the owner of the land in such mineral oil and gas while contined in the earth is necessarily subject to qualifications. Thus an act of Indiana making it unlawful for the owner of a natural gas or oil well to allow or permit the flow of gas or oil from any such well to escape into the air, without being confined within the well or proper pipes, for a longer period than two days after the gas or oil shall have been struck in such well, was not a riolation of the constitution of the United States, nor taking of private property withont conpensation, nor a denial of due process of law, but was a lawilul regulation by a state within its discretion of a subject which especially comes within its lawful authority.2

\footnotetext{
I State ex rel r. Indiana \& Ohio Gas and Mining Co. 120 In l. inj.

Indiana Consumers \& T. R. Co. v. Horlass, 131 Ind. 4t6: Hazue $r$. 2 Ohio Oil Co. v. Indianat, 1ri C.S. Wheeler, 15r Pa. St. 324: Jamison v. 190. 44 L. Ed. 729. See also Brown Indiana Natural Gas \& Fuel Co., 1:8 v. Spillman, 15, U. S. 65.5, 39 L. Ed. Ind. 5.5. 12 L. R. A. 65\%: Benedict r. :314: Westmoreland \& Cambria Nat- Construction Co., 49 N. J. Eq. 4:9: ural Gas Co. v. Dewitt. 1B0 Pa. St. Manufacturer Gas Co. v. Ind. Nat.

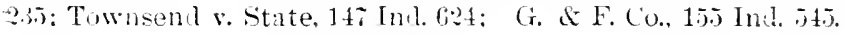


The supleme comrt said in this ease that there is a distinction between animals fire metere and gas and oil, in that in the case of the former there was no individual proprictorship until the actual retuction of the property to possession, the property right until then being in the public. In the case of natural gas and oil no such right exists in the public: and in the case of the former every one may be prohibited from seeking to reduce to possession. In the case of natural gas and oil however the surface proprietors within the gas lieht have the right to reduce to possession the gats and oil beneath. and they cannot be absolntely deprived of this right without the taking of private property. The legislative power lowerer, from the peculiar natmre of the right and the objects upon which it is to be exerted, can be manifested for the purpose of protecting all the collective owners in the gals field and preventing waste.

It was ured in this case that it was necessiry to waste the gas in ondre to force $n p$ the oil: but the cont sail this was a matter which ahltessed itself to the wistom of the legislature and died not atfect the power to malie the regulation.

$\$ 1 \%$. The eommerce clanse and the almiralty jurisliction.- The felleral power wer interstate and foreign commepere is reinforced ats to the commerce on water, as distinEnshen from land transpertiation. by seetion -2, articte IlI, of the constitution, "xtending the jullicial power of the courts of the I nited states to all cass of almiralty and maritime furis liretion. It is not within the seopen of this work to consider

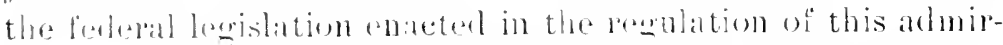
alty and martine juristiction. Further than to show the proEpessive developunent of this jursistiction. which has more than

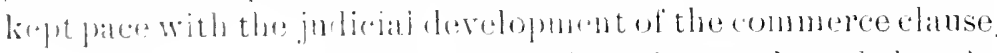

It was lirst rold, following the Enelish precedents, ${ }^{1}$ that the

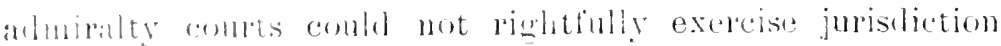
"Xerent in cases where the service was substantially performed

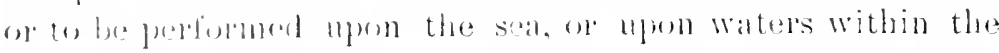

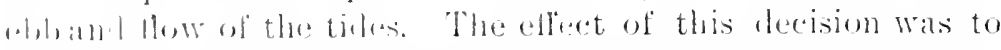

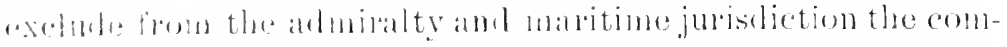

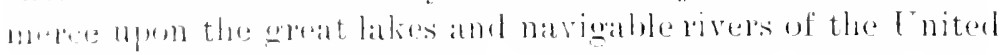
states. It wats not wntil 1-il that the earlier decision was 
overruled, and it was definitely decided that the admiralty and maritime juriscliction granted to the feleral government by the constitution of the Cnited Stat was not limited to tirle waters, but extended to all public navigable lakes and pivers where commerce was carried on between different states or with foreign nations. ${ }^{1}$ This case arose "pon the great lakes, but the rule was subsequently extended to cases arising upon the nargable ricers of the Inited states where there was no ebb and flow of the tide. ${ }^{2}$

Later it was held that a stream lying wholly within a state and forming by its junction with Lake Michigan a continuous highway for commerce, both with other states and with foreign nations, was a narigable water of the [nited states." In this case the rule was annonnced, that those rivers must be regarded as public navigable rivers in law, which are navigable in fact, and that they constitute navigable waters of the [nited states within the meaning of the acts of congress in contradistinction between the navigable waters of the states, when they form in their orlinary condition by themselves, or by uniting with other waters, a continued highway over which commerce is or can be carried on with other states or foreign conntries, in the customary moles in which such commerce is conducted by water. It is immaterial that the navigahility of such a river may be interrupted by rapids and lalls over which portages are required to be made.

13. Erie callal suligect to almiralty jurisdiction.-In a recent case the admiralty and maritime juristiction has been extended to the Erie canal, which lies wholly within the state of New York, on the ground that it connects narigable waters and is a great highway of commerce between ports of different states and foreign countries, and is, therefore, a navigable water of the United states within the legitimate scope of the admiralty jurisdiction of the courts of the L'nitel States. In

1 The Genesee Chief, 12 How. 443 (15.51), 13 L. Ed. 1055.

2 The Magnolia, 20 How. 296 (185\%), 15 L. Ed. 909: Fretz v. Bull. 12 How. 466, 13 L. Ed. 1068 (19:51).

${ }^{3}$ The Daniel Ball, 10 Wall. 5ji (18;0), 19 L. Ed. 999.
4 The Montello, 20 Wall. 430 (1584), 22 L. E⿺. 391; Escanaba Co. v. Chi. cago, 10 í U. S. 6 is (1582), 2i L. Eal. 44: Miller v. The Mayor, 109 C. S. $355(1-83)$. $9 \%$ L. Ed. 9\%1; In re (rarnett, 141 C.S. 1 (1s91), 35 L. Ed. 6:31. 
this case it was adjulged that the enforcement of a lien in rim for pepairs to a canal boat engaged in traftic on the Erie canal and the lludson river, and at a port in the state, was within the almiralty jurisdiction, and could not he enforced by any proceeding in the courts of the state of Xew Jork.

\$14. Jurislicaliction of fuleral comets in admiralty cases.- The admiralty and maritime jurisliction is conferred by the constitution upon the juclicial power, and not in expross tems upon the legislative power of the federal government. The sinpeme court howerer has held that the power of legislation on the same subject must necessinily be in the national legislatmre, and not in the state legislatures. The feleral lecrislative power is not eonlined to the boundaries or class of subjects which limit and characterize the power to regulate commerce; but in maritime matters it extends to all matters and places to which the maritime law extends. The boundaries and limits of the almiralty and maritime juriseliction are matters of jullicial cornizance, and they cannot be affected or controlled by legislation, whether state or national. The jurisliction of the fulcral courts in maritinc cases, therefore, is broaler than that under the commeree clanse, as it includes maritime cases, where the royage or contract, if marime in character, is male to be performedwholly within a single state. ${ }^{2}$ Ender the juliciary act of 17 st the jurisdiction of the courts of the l nited states is exclusive in all cases of admiralty and matritine jurisliction, saving to suitors a common law remedy, where the common law is competent to give it. ${ }^{3}$

\section{i.j. State corporations in interatate commerce.- The} right of a state corporation to engage in business in another state by locating therein, whthout the permission of that state, must depend upon whether the corporation is encraged in carrying ron interstate conmeree. In this connection the term " carrying on intrerstate commerce" is limited to the corporations actually engaged in carrying on interstate comberce, that is, com-

1 The Perhere IV. Parsons, $191 \mathrm{U}$. S. 17. 190:3, 4- 1. Fid. 73. Justices Brewer, Fuller. leerkham and Harlatu dissontel on the grounil that the asntract wats not a marition rontrillt and that the admiralty jurisdiction did not extend to contracts for re- fairs to vessels which were incapacitated for foreinn commerce and designed and used exchusicely for mere local traffic within the state.

2 Th re diarnctt, 141 C. S. 1 , and cates citerl, 35 I. Ed. 6331.

"Sec. rll R. S., L. S. 
mon carriers and others who afford the facilities whereby commerce is carried on among the states or actually carry on such commerce and does not include manufacturing and trading companies making interstate shipments. Thus all public carriers, railroads, steamboats, telegraph or telephone companies, bridge and ferry companies operating in different states, are carrying on interstate commerce in this sense. The state can neither exclude corporations of this class actually engaged in interstate commerce, nor can it impose conclitions upon the transaction of their business in the state, though it may tax their property employed in the state.

In one sense, all commercial business between citizens of different states is interstate commerce, and the manufacturer who ships his goods to the purchasers in another state is engaged in interstate commerce. This commerce is protected by the fecleral power against discriminating or interfering state legislation, and in such protection, there is no distinction between non-resident individuals and corporations. Corporations, it is true, are not citizens within the meaning of the constitution, ${ }^{1}$ providing that citizens of each state shall be entitled to all the privileges and immunities of the citizens of the several states, though they are persons within the meaning of the fourteenth amendment and are therefore entitled to due pro. cess of law and the equal protection of the laws. The right to engage in interstate commerce loes not depend upon citizenship, and the capacity of the foreign corporation to carry on such business must be determined by its own charter, granted by the state of its creation, and by the law of the state in which it is carrying on husiness. The manufacturing or trading company incorporated and doing business under the laws of one state can send its commercial travelers soliciting sales through other states, and may ship its goods to the purchascrs, and such business cannot be interfered with by the states in the exercise of either their taxing or police powers. Such interstate commerce does not constitute a "loing of business" within the state. But while the foreign manufacturing or trading corporation may sell its goods in the state, or solicit sales in the transaction of interstate commerce, it cannot es-

1 Constitution, art. IV, sec. 2; Crutcher v. Kentucky, 141 U. S. 4 (1 (1901), 35 L. Ed. 649. 
tablish a business oflice in the state withont the consent of the state. As a state has the right to exclule foreign corporations, it necessurily has inrolved therein the right to impose conditions upon their admission into the state.

The state powes of prohibiting. absolutely or conditionally, the forejun corporations, not engaged in interstate comnerce in the constitutional sense from doing business in the state is illustrated ly the ruling of the supreme court atrealy referred to snstaining state statutes regulative of the insurance business. seres sonfy. Than, the provisions of state statutes prescribinte terms and conlitions of insurance contracts have been held tole written m to the policy contracts made by the parties, overriding the will of the parties and makmg contracts for them (contriry io their expressed intent." These statutes were sustained on the theory that the state had the power to determine the conditions under which the insurance business should be conducterl. to the extent of writing these conditions in the prolicies for the parties and controlling the terms of their contracts, and in the case of foreign corporations such conditions would be enforced as conlitions imposed upon their being permitted to do business in the state and to which the comfanies are presumeal to assent by doing businesss in the state under its laws:

\section{When transit cuds: the orignal packawe in interstate} commerere- The original package" rule, which has been the subject of extended julicial discussion both in relation to the taxing power as well as the police power of the state, was first

I Wilters Pierce (bil co. ve Texil,

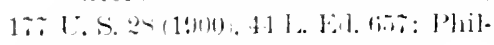

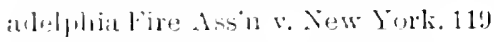

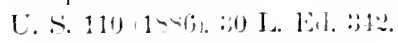

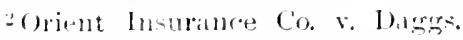

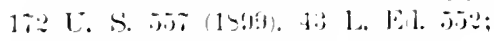
lopuitable life Asomature sine $\mathrm{x}$

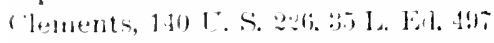
(1490): New York Lilo Ins. (a. v.

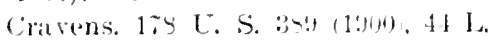
E]. 1116 .

In mutual life insuramre it is ol vious that the writing of ditferent state statutes into the folicy contracts is necessarily destructive of the insuranre scheme. which is based upon the uncertainty of the intivid. nal life and the comparative certainty of the average life ancertained from human experience aml whieh therefure contemplates the minon of the interests of a large number of jeroms resilent in wifferent states and countries and the administration of a fund for the mutual benefit umier a single applicatory law. In. surance Co. v. Statham, 9:3 L. S. 21. 2:; 1. Eal. 249: Bogardus vo lnsurance Co., 101 న. Y. 329 . 
declared in 1827, in Lrown v. Maryland. ${ }^{2}$ This case involved the validity of a statute of Maryland, requiring every importer of foreign merchanlise to take out a license, paying therefor tifty dollars. The court admitted the difficulty of setting a time when the taxing power of the state should begin, but fixed it as beginning when the original package in which the goorls had been imported was broken up or sold, and thu; was first latid down the "original package" pule. While the court has arthered to this rule in respect to state taxation of foreign importations. it has not been extended to intersta te commerce, so that goods brought from one state into another are subject to the taxing power of the state, whether they are in the original packiage or not: ${ }^{2}$ that is to say, such grools which hare reached then destination in the state may be taxel as property in common with other property in the state, when the tax is levied without discrimination as between domestic and non-domestic goods."

There is a distinction, however, between the taxing power of a state and its police power with reference to the original packages in interstate stipments. In the absence of legislattion by congress, commerce between the stites must be free, and the right to sell goods imported is an inseparable incident of the right to import. Congress alone can act as to the almission of goods from one state to another, and its non-action means that the commerce must be free. ${ }^{+}$This freelom of trins-

112 Wheat.419. 6 L.E. 6. 6.9. Twenty years later Chief Justice Taney said in his opinion in the License Cases, 5-How. I. c. 505, 12 L. Ed. 250, that he argued this case for the state of Maryland, but that since then matured reflection had convincel him that the rule laid down by the supreme court was a just and safe one. It was a very difficult question for the judicial mind. but he did not see how the line could be drawn more accurately.

2 Woodruff v. Parham. 8 Wall. 193 (1868), 19 L. Ell. 383; Brown v. Hou:ton, 114 U. S. 622 (185.5). 29 L. Ed. 2ir: Pittsburgh, etc. Coal Co. v. Bates, 156 U. S. 57 (1595), 39 L. Ed. $5: 38$.
"American Steel \& Wire Co. v. sileed, 19: U. S. 500, 45 L. El. 539 (1931)

4 Buwman v. Railway Co., 12. U.S. 46.5 (1555), 31 L. Ed. 700; Leiny r.

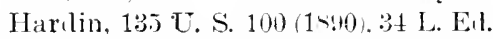
128, overruling the License Cases, is How. 504 (1847), 1? L. Eil. 256. The distinction between the state police power and the state taxing power in relation to "original packages" imported from other states is illustrated in two lowa cases (January, 1905). decided by the supreme court. In Am. Exp. Co. v. Coffin the police interference with a lifuor importation was denied: while in Cook r. County of Marshall tax on a cigarette importation was sustained. 
portation and of sale extends to gools in their original packages, when imported in packages. Thus, the original package first introduced in lirown v. Marylanl, in reference to foreign importations, becomes material in interstate commerce in liniting the police power of the state. In original pacliage in interstate conmeree means the box or calse in which the groods were shipped, and not the paciage in which they were placed by the manuficturer when manufactured and before they were placed in the larger boxes for shipment. The importation howerer must be matle in the usual manner prevalent among honest lealer's. and in a bonu filc packige usual for shipment."

The original package rule was one of conrenience, is not detined in anr stiltute of the Cnited states. and is of course only applicable where property is imported in packages. As to other property, such as live stock, the commercial transit ends when it is rlelivered to the consignee. Thus a flock of sheep dricen throwh a state is a subject of interstate commerce and protected by the federal power against state taxation. although the sheep were permitted to graze during their journey. ${ }^{3}$ Property in commereial transit, however transported, through a state or into a state, is not subject to the taxing power of a state. and this immunity extends until the termination of the shipment by the delivery to the consignee. Goods, to be exempt. howerer, must be actually in commercial transit, that is, the transit must have commenced by the delirery to the carrier for ship!nent.j It loes not follow however that this immunity lrom the state taxing power would prevent the property from being subject of an illegal agreement or combination in violation of the anti-trust act (See infin, \$69.) The termination of the transit means that the property is subject to taxiltion in common with other property; but it cannot be subjected to any discriminating regulations on account of its foreign origin.

1 Iay v. Niw Orleans. 17s C. S. 490 (1599. H4. El. 116j, athirming 51 Lal. Ann. lorit, four justicesdisenting;

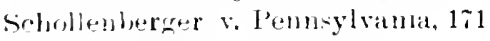
L.S. 1 1タ9, 4:3 L. Fil. 4!)

2Austin r. Temn tset 179 C. S. 34:; (19001. 45 L. Eal. 22:2t. Tee aloo Cook r. County of Marshall, supra.
${ }^{3}$ Kelley r. Rhoades Diamond Match Co. x. Ontonogon, 158 C.S. \$ (1909), 4 L. Lul. 394, 188 C. S. 1 (1903) . $4 \tau$ L. Eil. :3!4.

tRholes v. Iowa 170 U. S. 412 (1<!s. 4: L. Fil. 1058.

sCoe v. Errol, 116 C. S. 517 (1S86, 29) L. Eil. 715. 
$\$ 1 \%$. The Wilson bill of 1 s.90.- The judicial application of the original paekage rule in interstate commerce to the police power of the state and the conserquent inability of the state to exclude the importation of liquors resulted in the passage by congress in 1890 of the so-called Wilson bill, - providing that liquors transportel into any state or territory should, upon arriving in such state or territory, be subject to the operation and effect of its laws enacted in the exercise of its police powers to the same extent and in the same manner as though such liquors had been there produced, and shouk not be exempt therefrom by reason of being introlueed in the original packiges or otherwise. This aet was in effect a prohibition by congress through stite action of interstate liquop traffie. Its constitutionality was contested on the ground that congress could not delegate its control over interstate commerce to the states. It was sustained, howerer, by the supreme Court." The court said that in surrenlering their own power orer interstate commerce the states did not secure alisolute freedom in such commerce, but only the protection from eneroachment afforded by conforming its execution to congress. The term "arrival" in this statute, it was hetd in a later calse, means the completion of the shipment by delivery to the consignee in the state, and not the arrival at the station," (see $\$ 52$, infial).

\$ 1s I state cannot tax interstate commerce.-Although the necessity for the regulation of commerce was the great moving force in the adoption of the constitution, and wis thoroughly discussed in the proceedings of the convention an! in the Federalist, there is in neither any reference to any possible interference with the tilsing power of the stite growing out of such regruation. The law of foleral restraints upon state taxition has been developed upon the fundamental principle of the supremacy of the federal authority. The exemption from state taxation of the means employed by the fecteral

1 Act of August, 1890, and $: 6$ Stats. 313 c. 228 . The same principle was also applied in 1900 , in mating effective the game laws of the states. Act of May 25, 1900, 3 Comp. Stats. U.S. p. 31s1, and in Aet of May 9.
1902. in making effective state laws as to "oleomarnarine," "butterine" and other imitations of butter.

"In Rabrer, 140 U. S. 545 (1891), 35

L. E], 5\%2.

${ }^{3}$ Rhodes r. Iowa, supra. 
goremment lor carrying on its functions was first declared in 1-1:4, in Hed ulloch v. Maryland. and the principle was later

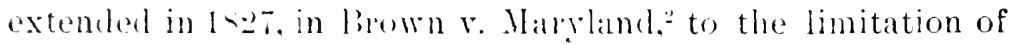
the state taxing authority by reason of the national control orer foreing commeree.

Inder the rule deelared by the supreme Court for the first time in Iur;," which has since heen consistently achered to by the enut. the husiness of calrying on interstate commeree cammot be taxial at all, and as the right to bring goods from oflerstatesinclules the right to sell them and to solicit soles therefor.as well as to deliver the property sold, the state cinnot tax the piuht to sell or leliver, or to sulicit sales, whether in the form of license tax or otherwise. It is immaterial that the tix a withont riscrimination, as between domstic and forcinn drummers. as interstate commerce cannot be tixed at al!.4

\section{\$19. lint a state (an tax the property employed in inter-} state commeree. - While a state cannot tax interstate commerce, that is, the privilege of carryng on such commerce, jt can tax the property in its jurisdiction employed in carrying on such commere. The dilliculty of defining the line where the state and federal powers meet in such cases is illustrated by the not inleepuent dissents of members of the supreme collt in arses involring these questrons of conflict between the state and loderal power. No puestion is male as to the power of a state to tax the tangible property within its juriseliction of a rabromb telowaph or other company engaged in interstatc commolece, but the dilliculty has been found m letermining what portion of the intangible poperty of such comporatinns ran be located within a state so as to be subject to its taxing war. Thus, has been formulated the so-called "unit ruls:" wheremder the entire ralue of an interstate railpoad, iangible as well as intangible, may be apportioned mpon a

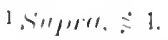

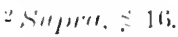

Rebhin- L Shelly County Taxing

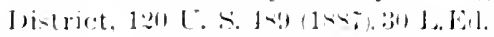
6:4. 4.

1 Asherer ro Jexat. 120 C. S. 129

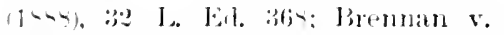

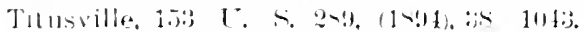

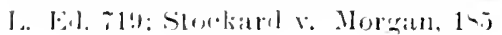

L. S. 2. (1902) 46 J. EAl. Os. Caldwoll r. North Car. 1s: L. S. 6:2 $(16,1)$. 4; L. EAl. :336: N. A W. R. R. (a. r. sims. 191 T. S. 411 (190\%) 48 l. Eil. :it.

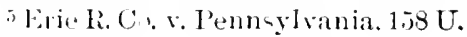
S. $4: 31$ l.c. 43\%. (1895), 39 L. Ed. 
mileagre basis as a means, prime, findi, of arriving at the rahe of the property within the stite, that is, the state's proportion. ate part of the valne of the entire property.

The rule of the "average habitual use" has also been formulated in the taxation of railroad cars, so that a state may tax its proportionate part of the property actually employed in its jurisdiction."

Thus, also, while the receipts from interstate commerce can. not be taxed as such, the tax may be levied upon the corperal. tion, as an excise or franchise tax. which may be apportioned on the basis of the proportion of the mileage within the state to the total mileage. ${ }^{3}$

These rules, howerer, are only admissible in determining the actual value of the property in the state lor the purposer of taxation, and will not allhorize the taxing by a state of the privilege of carrying on in terstate commerce among the states, nor the taxation of property permanently outside of its jurislicetion. ${ }^{*}$

\$20. State power of taxation of compurations enganed in

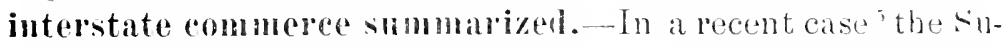
preme Court, in holding that a city conk recover from an inter-

1 State Railroal Tay Cases. go C. . .

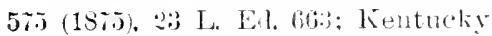
Railroad Tax Cases, 115 L. S. 301 (1s8.j), 29 L. Ed. 414: Pittsburgh etc: R. Co. v. Backus, 1.j [. S. $4: 1$ (1st) 35 L. Ed. 10:1; C. C. C. \& st. L. R.

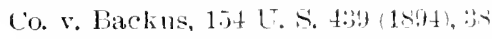
L. Ed. 1041; Western Union Tel. Co. v. Massachusett $-1: 5$ L.s. $530(185 \%)$. 31 L. Ed. r90: Massialinsetts r. Telegraph Co., 141 U. S. fl) (1 L) 3), 3.) L. Ed. 62s; Western Union Tel. Co. r. Tagrgard. $160 ;$ U. S. 1 (15:46), 41 L. Ed. 49; Adams v. Ohio, 16ij C. S. 194 (18.76) 41 L. Ed. 64:3; Adams Express Co. v. Kentucky, 166 U. S. 1 .1 (14!)i). 41 L. Ell. 960: Henderson Firilge Co.

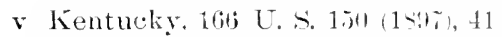
L. Eu. 9.): W. U. Tel. Co. v. liottlieb, 190 U. S. 412 (1943) tr L. Ed. i116.

¿Pullman Palace Car Co. r. Penn.

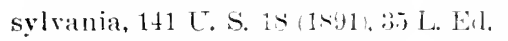
613: Marye v. B. \& O. R. Co., 12: U.

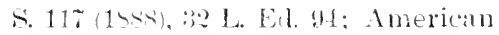
Refrigerator Tansit Co. r. Hall. lat

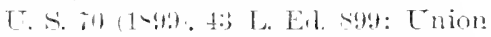
Felriperator Transit co. r. Lynch,

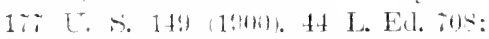
Winconsin \& M. R. (i) r. l'owers, 191

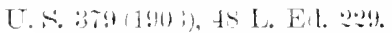

"The State Freight Tax Catses, 1i

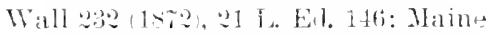
r. Gland Tromk R. Co. 14: L. S. ?tr

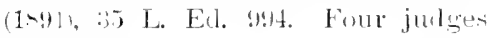
dismenting:

* Fargo r. Hart. 198 U. S. 490 (190) L. 4 L. El. 261. Fol consiileration of the many questions arising on the adjustment of the taxing fwrer of the state to the patamomat authority of congress in interatate commeres. see anthors " Power of Taxation." chapters. 111 and VIll.

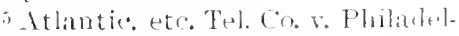
phia, 194 U. S. $160(1-94 i)$ ti L. Eil. $9 \%$ 
state telegraph company a reasonable license fee for the occupation of its streets by telegraph poles, subject however to the determination by a jury of the reasonalideness of the charge, sidil that there were few questions more important or more cmbarrissing than those arising from the efforts of the states or municipalitics to increase their revenues by collections from coppolations engaged in interstate commerce, but that the folforing propositions had been so often adjulicated as to be no longer open to discussion: Fist. The constitution of the lnited citates haring given to congress the power to regulate commerce not only with foreign nations but among the ser"ral states. that power is necessirily axelusive whenever the subjects of it alre national in their character or admit of only one unilorm system or plan of regulation. Secont. To state can compel a paty, individnal or corporation, to pay for the mirilege of engaging in interstate commerce. Third. This immunity does not prevent a state from imposing ordinary moperty taxes upon property having a situs in its terpitory and employed in interstate commere. Fompth. The franchise of a copporation, although that lianchise is the business of interstate commerce, is, as a part of its property, subject to state taxilion. provided the franchise is not derived from the Lnited states. Fith. Xo colporation, even though enraged in interstate commerce, (an apmopriate to its own use moperty, public or private, without liability to charge therefor.

The soliciting of traftic for an inturtate ratroad is axempt from taxation. YcCall s. Cal.. 1:36 U.S. 1:3t (1-90) 34 L. Fd. 391. In 1sis hefore the arloption of the fourteenth a'sendment il was heid in crambal

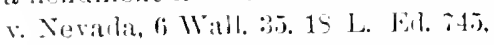
lhat a state tix lyon through pitssengers was voll as inconsistent with the rights of citizens of the Enited states, in free tratrel throngh the states, and not merely as an at tempteil resulation of commerce among the states. The opinion of Justice Miller quotes from the dissenting opinion of Chief Justice Taney of the Pascenger Cases, infict. $\$ 21$, where he conceles that the state tax inposed on for wigners wonhl be invalid, if inposed on citizens. 


\section{CHAPTER II.}

\section{THE CONCURRENT AND EXCLUSIVE POWERS.}

621. The concurrent and exclusive powers distinguishe.l. . . . . . 81

22. The supreme cont on the three classes of commerce cases.... 32

2:3. The concurrent state power. . . . . . . . . . . . . . . .

21. The state power as to interstate telegraph companies.. . . . . 34

25. Coneurrent power in interstate railroad transportation....... 3.5

26. State Sunday laws ant interstate traftic. .............. 36

2\% State laws as to qualifications of employees and safety of public : $3 ;$

28. State laws concerning separation of races in interstute trafic... :

29. Limitation of state power in stoppage of through trains....... 37

30. State regulation of contractual relations of interstate railroad and shippers............................. 38

31. State regulation under rules of common law in stite courts... 39

32. The coneurrent jurisiliction in live stock inspection law...... 40

33. Effect of congressional legislation upon concurrent power of

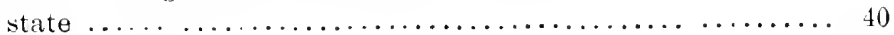

31. State quarantine laws . . . . . . . . . . . . . . . . . . 41

$35 . \quad$ Freedom of interstate commeree................. 42

36. Congressional ination in foreign and interstite commerce dis.

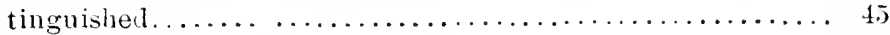

3\%. Attachment of foreign railroad cars . . . . . . . . . . 4j

38. Rulings of the state courts on the commerce clanse......... 46

\section{$\$: 1$. The concurent and exchisive powers distinguished.} The supremacy of the feleral power in interstate commeres

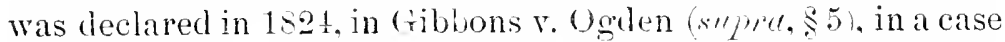
wherein congress had exercised its power by anthorizing the granting of coasting licenses, and the decision of the conrt therefore was based upon the claim of an exclusive grant by the state as aginst this right, under anthority of congress, in the navigation of the public waters of the state. The yrestion of the power of the state to legislate affecting interstate commerce, when congress had not legislated upon the subject, was not directly involved or decided; and this remained a eerata questio, and widely different riews were expressed by members of the court, until a definite rule was declared in 1551.' Thus it was contended on the one hand that the power

1 Wilson r. Black Pirl Creek Cases, 5 How 504 (1847), 12 L. Ed. Marsh Co., 2 Peters. 245 (18.9). I L. 256: Passenger Cases, 7 How. :8:3 Eul. 112; New Fork r. Miln, 11 Peters. (1849). 12 L. Eul. ‘( 12. 102 (18:3\%) 9 L. Eil. 648: License. 
to recrulate interstate commelee was itself a mit, and the grant to congress was necessuriby exelusire, and no part of this regulation could be expreisul by a state: and on the other hand that the want to conness was not itself a prohibition to the states, and that this authority of the states in the exercise of their sovereign police powers was complete and exclusive.

The uncelatinty produced by these differing opinions was shown in sustaminer a Kew Jork statute - requiringmasters of pasenener rescels to leport to the state anthorities as to arriring gassenetes: while a lew vears later statutes of New York

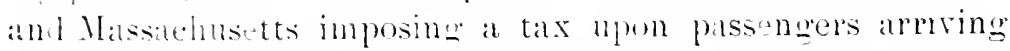
from other states or foregen conntries, for defraging expenses of prolice baws exelurling pampers and remviets. the surplus to

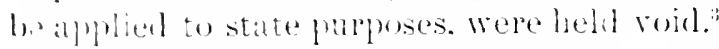

In Lthi the laws of certain of the New England states, prohibiting or lestraning the introfuction of spirituns liquors

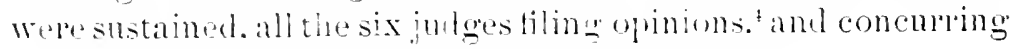

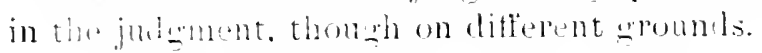

Iinally. in 1-in, the rule was lectared, which has been the batsis of subequent aljulrcations, that the power to regulate commeree is one which includes many subjects. valions and quite unlise in their nature and that whenerer thes subjects ape in theil nature national, or admit only of one aniform systum or flat of regulation, they may be justly helel to belonge to that clatsone which congress has exclusive power of regulation: but that houl and linited matters. not national in their nature. mat be resulated by the states duringe the non-action of conzless. The action of coneress however renders roid sus lendutions of the states asconflict with it."

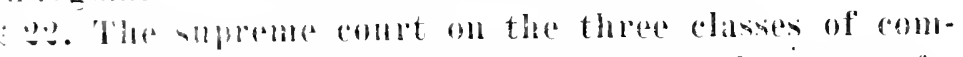
meree rans. The suppene cont in lenging the power of a

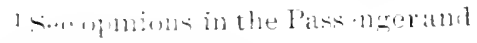

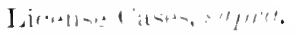

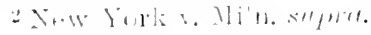

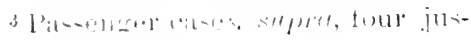

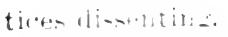

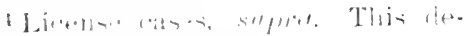

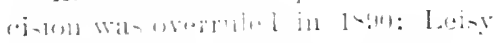

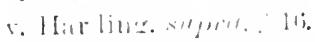

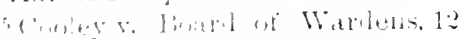

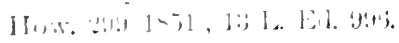

The ruie hak been stated in subse-

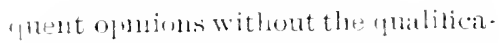
bon of the word "only." so als to rusl " anlmit of mur unitoms system "1 phin of rezulation." see state Wreght Tax, 1, Wall, :4:3, 21 L. Eil.

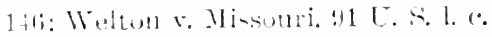

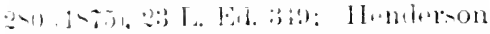

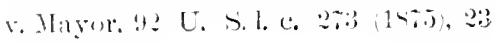
1. E.l. - : : 
state to regulate tolls upon an interstate bridge without the assent of congress, reviewed its decisions upon the construction and application of the commerce claluse of the constitution, and said they were divisible in to three distinct classes. ${ }^{1}$ The trixt, where the power of the state was exclusive, inclurling the construction of highways, turnpikes, railroads and canals, between points in the same state, and their regulation for public use, the operating of bridges over navigable streams and reg'tlating navigation over internal waters which did not by themselves or in connection with other waters form a continuous highway for interstate or foreign commerce. In the secomil class were included the cases of concurrent juriscliction of the states, and wherein it is not the existence, but the curcerse of the power of congress which is incompatible with the exercise of the same power by the states. In the third class the court included those cases where the power of congress was exclusive, and it was not the exercise but the caistence of the power in congress which excluded the power of the state. The first class requires no distinct consideration. The dividing line between the second and third class has, however, been questioned in a number of calses, as will be seen in the succeeding sections.

\$ :3. The concurent state power.- The concurent jurisdiction of the states, as it is called, may be exercised in the second of the classes of cases mentioned in the preceding section, where it is not the existence but the exercise of the power of congress which is incompatible with the excrise of the state power.

Thus, the regulation of pilots has an intimate connection with commerce, and discriminating state laws might be enacted on the subject, yet the nature of the power is such that it is likely to be best provilled for by the legislative discretion of the sereral states, adapted to local needs."

In this essentially local class are the state inspection laws," state quarantine laws, ${ }^{4}$ and laws regulating the improvement of navigable waters within the jurisdiction of a state, or the

1 Corington, etc. Bridge Co. $\mathbf{x}$. Ken. tucky, 154 U. S. 204 (1894), 38 L. Ed. 96 ?.

${ }^{2}$ Cooley v. Port Wardens, supre.
${ }^{3}$ See 59. supre.

* Steamship Co. v. Louisiana, 119 U. S. $45.5(1886), 30$ L. Ed. 23. Infir, ?34. 
use of brilges over such waters which have been sustained. In the Mobile har hor case cited, ${ }^{1}$ the court said that perhaps some of the diverwent riews noticed upon this question of state power among former judges, may have arisen lrom not always bearing in mint the clistinction between com nerce as strictly defincd and its lo:al aids or instrumentalities, or measures taken for its improvement. In the Chicago case" the court sustained the state control of the construction, repair and regulation, and use of the brilges over the Chicago river, saying that until congress acted, the power of the state over the bridges was blenily.

In the same class are state laws regulating whroves, piers

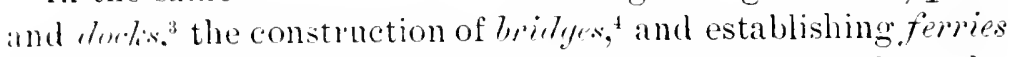
over navigable rivers within state juristiction. Local regulations, howerer, cannot impose a tax or charge upon interstate commerce. Thus, while a state can exact a toll or compensation for a specific improvement of a narigable water within its jurisliction," it cannot exact a license for the use of navigable waters. which is not a charge for any specific improrement. ${ }^{6}$

: 24 . The state power as to interstate telegraph companies.- A telegraph company doing an interstate business is rngaged in interstate commerce, and is recognized by act of congress.' It cinnct, therefore, be excluded by a state, nor can its interstate messages be taxed by the state. ${ }^{8}$ The state may, howerer, make regulations with respect to building poles, location of wires, and all necessiry appliances, which the conrenience of the community may require. It can tax intra state messages, and municipalities may charge a reasonable rental for occupation of streets with poles." The state can

1 County of llobile $\mathrm{s}$ Kimball, $10^{\circ}$

[5. S. $691(1 s=0) .26$ L. E1]. 2:3s.

2Excanaba Co. r. Chicago, $10 \pi$ U.S.

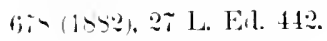

${ }_{3}$ Packet Co. v. Aiken, 121 U.S. 444 (1357), :39) L. Eal. 9rit).

4 Cirtwell v. Am. Brilge Co.. 11:3 U. S. 20.T (1585, 2.S L. E.1. 9.5\% As to interstate brifges and ferries and cares citerl see lilonce-ter l'erry Co.

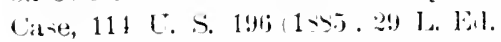
15s; St. Clair County r. Interntate

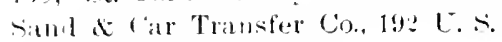

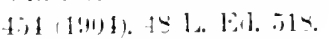

${ }^{5}$ Huse r. Glover, 119 U. S. 543 (18+6), :30 L. Ed. 4si; Samls r. Manistee Riror Imp. Co., 123 U. S. 285 (158\%), 31 L. El. 14:3.

${ }^{6}$ Harman v. Chicago, $14 \tau$ U. S. 396 (1S93), 3 L. Ea. 216.

T A c of July 24, 1860 , Comp. Stats. 52)(i: Ponsacola Tel. Co. r. W. U. Tel. Co.. sumpro.

"Telegrapli Co. v. Texas. 105 U. S. 460) (1>4i), 26 L. El. 166ĩ.

"Telegraph Co. v. Philatelphia, 190 C. S. 160 (19903, 4\% L. Eu. 995. 
prescribe how messiges shall be delivered within the state, whether received from within or without the state. ${ }^{1}$ as this is the exercise of the police authority of the state in its jurisdiction; but on the contriry, the state cann t prescribe how messages received within, but delivered without the stilte, shall be delivered."

\$ 95. Concurent powers in interstate railroal transportation. - Not only is the rule established that the state, in the absence of congressional action, may regulate local matters which relate to interstate or foreign commerce, but the state power of regulation has been further extended and held to include a wide field in the exercise of its lawful power over the relations of persons and property in its jurisdiction. The federal power of regulation ma be exercised wathout legislation, as well as with it, and by inaction, congress in effect adopts the local law. State laws regulating the relative rights and duties of persons within the jurisdiction of the state are therefore effective upon interstate carriers." The court said in the case cited that it is to this law that persons within the scope of its operation look for the definition of their rights and for the redress of wrongs. "The failure of congress can be construed only as an intention not to disturb what exists, and is the mode by which it adopts, for cases within its power, the rule of the statelaw, which, until displaced, covers the subject."

The effect of the enactment of congress upon the police power of the state is ilhstrited by the ruling of the supreme Court prior to the enactment of the interstate commerce act, ${ }^{5}$ holding valid a statute of Iowa requiring each railroad company annually, in the month of September, to establish passenger and freight rates, and on the first day of October following to put up at all the stations on its roal a printed copy of such riates and cause it to remain posted during the year, notwithstanding the act of congress of $1560^{\circ}$ anthorizing the interstate car-

1 W. U. Tel. Co. v. James. $16 \geq$ U.S. $99(15 \% 6)$ 2: L. Ed. 819; Chicago. etc. R. $650(1896)$. 40 L. Ed. 110.j.

2 W. U. Tel. Co. v. Pendleton, 122

U. S. $34 \tau$ (158\%), 30 L. Ed. 115 . Co. v. Solan. 169 U. S. 133 (1598), 42

3 Smith r. Alabama, 124 U.S. 465 31 L. Ed. 5ı). L. Eal. 688.

5 Railroad Co v. Fuller, 17 Wall. $560(18 \div 3), 21$ L. Ed. $\% 10$.

4 Sheriock et al v. Alling, 93 U. S.

"Infica, s 40 . 
riage of freight. The state statute was held to be simply a police rewalition. and that even though it did effect commerce, the question would arise whether it did not fall within that class of eases where state legislation was sustained in the absence of congressional legislation. I similar statute came hefore the court from Texis after the passige of the interstate commerce act, although the statute had been enacted before. ${ }^{2}$ The court sail that the stale law and the national law operater upon the same subjectmatter and prescribed different rules, and that the state statute must therefore give way.

\section{s: St. State sumbly law and interstate transporation.-} Included in this range of the concurrent state power regulating persons within the juriscliction and affecting interstate commerce are sunclay laws, prohibiting the running of freight trains on sumlay. The court said such a law merely established a rule of ciril conduct applicable to all freight trains, domestic as well as interstate, and to all similar traflic.

The court in this case sustained a reorgia statute and quoted from the opinion of the supreme court of that state which said that the legislature had the right to enforce a day of rest as a crvil duty. although men might difter as to the religious duty.

5 . S. State laws as to qualifications of employees and safuty of the public.- The principle has been extended to inclucle laws which establish a standard of qualitications for railroald employees ${ }^{3}$ on in terstate as well as local trains, for example, color hlindness of engincer's. The court sail in the latter case that it was a principle fully recognizerl that wherever there is clanger to the public in the conduct of a business, it was not cmly within the power, but the plain duty of a state to make provision against accidents likely to follow. State laws requirinc the leating of passenger cars. requiring guard posts on railroul brilges and trestles, ${ }^{t}$ the protection of surface crossings in citis. and the regulation of speed in municipal limits, are sustained upon the same prineiple. The court said that trat-

1 Gulf. Colo. etc. R. Co. v. Helfley,

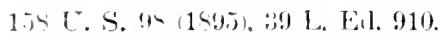

zH+muingun $\mathrm{r}$ (ieorria, 10;: U. S. geg9 1):36), (Fuller, C. J. and White, J., dikenting), 11 L. Eit. 16 fo.

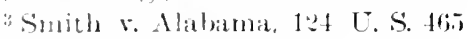

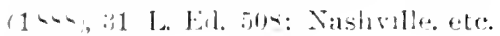

R. Co. v. Alabama, 128 U. S. 96 (18ss). 32 L. Eul. 3.5:2.

4 N. Y., N. H. \& H. R. Co. v. New York, 165 U. S. $628(189 \pi), 41$ L. Ed. 5.5:3.

5 Erb v. Morasch, 177 U. S. 584 (1900). 44 I. Ed. $89 \%$. 
elers on interstate trains are as much entitled, while within a state, to the protection of that state as those who travel on domestic trains.

Congress has also enacted legislation, as will be seen hereafter, for the safety of employees and the prevention of aecilents in interstate commerce. These acts, as the Aceilent Act, infra, $\$ 33$, and the Safety Act, infra, $s 35 t$, are by their terms applicable to all railroals engaged in interstate commeree. From the nature of the subject it is difficult to say when the enactment of such legishation by congress so covers the gronnd as to make inoperative state legislation bearing upon the same subject. Under the ruling laid down by the supreme court in the live stock cases (see infio, $3: 4$, the state statute enacted for the protection of employees and travelers within its jurisdiction, must be taken as valid, unless the same subject is taken under direct national supervision in the exercise of the lawful power of congress over interstate commerce.

\$ D. State laws concerning separation of races in interstate traffic. - A state can regulate the separation of races in railroad transportation on trains within the state, ${ }^{1}$ but it cannot determine whether interstate passenger's shall be compelled to share their cabin accommodations, as that is a question of interstate commerce to be determined by congress alone. A statute of Lonisiana enacted in 1869 , prohibiting discrimination on account of race, was held inapplicable to a Hississippi steanboat engaged in commerce between the states; ${ }^{2}$ while the state laws providing for separate cars within the state, were sustained.

\$29. Limitation of state power in stoppage of through trains.- The limitation of the state's power of regulation in relation to interstate commerce is illustrated by the rulings of the supreme court upon state laws requiring the stopp:ige of trains at certiin stations.

A statute of Minnesota requiring every railroad company to stop all regular trains at county seats, but provicting that it should not apply to other railroad trains entering the state

I L., N. O. \& T. R. Co. v. Mississippi, tucky, 179 U. S. 388,45 L. Ed. 244; 133 U. S. 557) 1s90), 33L. Ed. 784, distin- Plessy r. Ferguson, 163 U. S. $53 \%$ (1896), guishing Hall v. De Cuir, 95 U. S. 455,41 L. Ed. 256.

24 I. Ed. 547; C. \& O. R. Co. v. Ken- 2Hall v. De Cuir. supra. 
from another state. or to transcontinental trains from another state, was sustained as to a train connecting with an interstate train and carrying mails and some interstate passengers for that train. ${ }^{1}$ This case, however, was decided upon its special facts. as the train was run wholly within the state. A statute of Illinois wils held in ralid which refuired all regular passengrel trains to stop a sulficient length of time at county seats to receive and let off passengers with safety, as a direct interference with interstate traffic. This statute was held invalid both as to a comty seat station which wils three and one-half miles from the direct roul ${ }^{2}$ and also as to a connty seat station which was on the direct line." In the case last cited the court reviewed the previous decisions and said that none of them were opposed to the principle that, after all local conditions had been alequitely male, railways had the legal right to adopt special provisions for through traffic, and that legislative interference therewith was unreasonable and an infringement upon the constitutional guaranty of the freedom of interstate commerce.

\section{State recrulation of contractual relations of inter-} state railroal and shippers. - The contract relations of interstate railroads with their shippers must be determmed. in the absence of congressional legislation, by the local law of the place where the contract is made. State statutes regulating the contractual relations and changing the common law rules controlling such relations are within the scope of the state's regulating power. Thus, statutes permitting the carrier to limit his common law liability to a stipulated valuation, regulating the effect of an agreement limiting liability to the carrier"s own line in a shipment to be made over other lines, and also prohibiting contractual exemption from any common law liability of the carrier, have been sustained. In the Iughes cilse ${ }^{4}$ it was said by the supreme court, in allowing a judgment against an interstate carrier in excess of the amount limited in the bill of lading on the ground that no federal right was denied, that although congress had made it obligatory to

1 (iladson r. Munnesota. $16 \%$ U.S. $42 \pi(1 \leq 95) .41$ L. Ed. 1069 .

2Illinois Central li. Co. v. Illinois, 16:3 U. S. $14 \%$ (1896), 41 L. Ed. 11\%.
3 Cleveland, etc. R. Co. r. Illinois, 17 U. S. 514 (1900), 44 L. Ed. \$68.

${ }^{4}$ I'ennsylvania R. Co. v. Hughes, 191 U. S. 47\% (190:3), 4S L. Ed. 265. 
provide proper facilities for the interstate carriage of freight and had prevented carriers from obstructing continuous shipments on interstate lines, there was no sanction of agreements limiting liability by stipulation, and until congress had legislated upon it there was no valid objection to the states enforcing their own regulations upon the subject, although they may to that extent affect interstate contracts of carriage. ${ }^{1}$

\$31. State regulation unler rules of common law in state courts. - It is immaterial, in this exercise of the state's lawful power over persons and property within its jurisdiction, whether the enforcement by the state of its power in the regulation of relative rights and duties of persons and corporations within its limits is enacted into a statute or results from the rules of law enforcel in the state courts. The state, said the court, has a right to promote the welfare and safety of those within its jurisliction by requiring carriers to be responsible to the full measure of the loss resulting from their negligence, a contract to the contrary notwithstanding.

The state regulations in all of these cases were sustained upon the theory that they are not in themselves regulations of interstate commerce, though they control in some degree the conduct and liability of those engaged in the commerce, and as long as congress had not legislated upon the particular subject, they are to be regarded as legislation in aid of such commerce and as a rightful exercise of the police power of the state to regulate the relative rights and duties of persons and corporations within its limits."

This lawful exercise of the police power of the state over persons and things within its juristiction is illustrated by the ralings of the supreme court sustaining the power of the state to regulate the sale of patent rights, or articles covered by letters-patent of the Cnited states. The court said that congress never intended that the patent laws should displace the

1 Richmond, etc. R. Co. v. Tobacco Co., 169 U.S. 311 (1895), 4 L. Ed. 5.59.

While congress has not legislated upon the forms of bills of lading in interstate commerce, it has, by the enactment of the Harter Act, U. S. Compiled Statutes, 1901, p. 2946 , legislated concerning the forms of maritime bills of lading and controlling the insertion of stipulations therein limiting the responsibility of carriers. See case of The Delaware, 161 U. S. 4 r (1S96), 40 L. Ed. iob.

" Chicago, M. \& St. P. R. Co. v. SoIan, 169 U.S. 1333 (18.4', 42 L.El. 6s's. 
police powers of the state. that is, those powers by which the health, good order, peace and general welfare of the community are promoted, provided such laws do not discriminate agilinst non-resilents. ${ }^{1}$

s:2. The concurrent jurisdictlon in live stock inspection laws. - The concurrent jurislietion of the state and federal governments in interstate commerce is well illustrated in the matter of state laws regulating the exclusion of diseased eattle. The danger of the communication of disease in driving or otherwis's trinsporting eattle from state to state, has been recognized hoth in the legrislation of the western states as well as in that of the federal government. The right of the state to protect its people and property atgainst such dangers by reasonable enactments, not going beyond the necessities of the case, has been attirmed in several cases," but this right of protection against diseased cattle did not justify the absolute prohibition against certain cattle within certain seasons. ${ }^{3}$ The right of inspection of animals or of anything intended for human fool brought into the state from another state is conceded, but such inspection must be reasonable, and a state law is invalid which is burdened with such conditions, as would prevent the introluction into the state of sound meats, the proluct of animals slaughtered in other states. ${ }^{4}$ In this case the act reguired inspection twenty-four hours before slaughtering, and this necessarily incluled all meats from animals slaughterer in other states.

3:3. Eiffect of congresional legislation npon concurrent power of state. - Congress hats legislated on this subject of the transportation of live stock, ${ }^{5}$ and has authorized the secretary of agriculture to make investigation and inspect cattle intended for interstate commerce, and male unlawful the transportation of cattle known to be diseased. It was argued that this exercise of the federal power of regulation had the effect of nullifying or suspending the state statutes on the same sub-

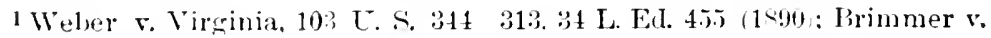
$(1851) .26$ L. Ed. ijti.

: Kimminli v. Ball, 129 L. S. 21; Ed. s(i2. (15y9). :3) L. Eil. 699.;.

5 Act of May 29, 18s4, c. 60 , and act

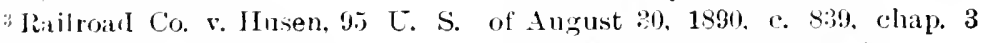
$46.5(15 i 9), 24$ L. Fil. j:5i Comp. Stits. pp. 3182 to 3193.

4 Minnesota v. Barber, 1:30 U. S. 
ject. The Supreme Court held, howerer, ${ }^{1}$ that the act of congress known as the Animal Industry Act did not cover the whole subject of the transportation of live stock from one state to another, and that the statutes of Kansas and Colorado related to matters not covered by such act. The statute of Kansas imposed a civil liability upon the railroad company bringing diseased cattle in to the state, and that of Colorallo made it a misdemeanor to bring into the state cattle which had been herded within ninety days prior to their importation with cattle having a contageous disease. ${ }^{2}$ The court said that the state, not Laving assumed charge of the matter as in rolved in interstate commeree, conld protect its people and their property against such dangers. When the entire subject of the transportation of live stock from one state to another is taken under direct national jurisdiction and a system devised by which diseased stock may be excluded from interstate commerce, all local or state regulations in respect of such matters and covering the same ground woull cease to have any force, whether formally abrogated or not, and such rules and regulations as congress may lawfully prescribe or authorize woulel alone control. The power, said the court, may thus be suspended until national control is abandoned and the subject thereby left under the police power of the state.

The constitutionality of the statute of August 30,1890 , in so far as it provided for the inspection of the slaughtering and packing within a state, of eattle intended for exportation, was denied by the United States circuit court, ${ }^{3}$ and a party inclicted for bribing an inspector was discharged on the ground that congress had no power to provide for the inspection of a manufacturing business within the limits of a state.

\$34. State quarantine laws. - The quarantine law established by the state of Louisiana ${ }^{4}$ was also sustained, the court saying that those state quarantine laws were a rightful exercise of the police power of the state for the protection of health, and although some of the rules of this system amounted to

I Missouri, Kansas \& Texas R. Co. v. Haber, 169 U. S. $613(1 \triangleleft 9 \varsigma), 42 \mathrm{~L}$. Ed. 578; Reid v. Colorado, 1s: U. S. 13 (1902), 4\% L. Eil. 108.

2 Rasmussen v. Idaho, 181 U. S. 198 (1901), 45 L. Ed. 8:0.
3 United States v. Boyer, 85 Fed. Rep. 4:5 (W. Dist. of Mo.) (1898).

4 Morgan v. Louisiana, 118 U. S. 455 (1S86), 30 L. Ed. $\$ 3 \%$. 
regulation of commeree with foreign nations, they belonged to the cliss which the state could establish until congress acted in the matter by covering the same ground or by forbickling state laws, and congress had in effeet alopted the laws of the state and forbidlen interference with their enforcement. ${ }^{1}$

: :5. Freedom of interstate commerce. - The right of interstate commeree, that is, the right of conducting tralfic and commereial intercourse between the states, is independent of state control, and where freedom of commerce between the states is directly involved, the non-action of congress indieates its will that the commeree should be free and untrammeled, and the states cannot interfere therewith either through their police power or their taxing power.

This freetom of interstate commeree from state control was definitely established as to the taxing power of the state in the case of the state Freight Tax, ${ }^{2}$ in 1873 , and later, in 1887, in the case of Robibins $v$. Shelby County Taxing District." The freeciom of interstate commerce with respect to the police power of the state was also declared in the cases relating to the liquor traffic. Finally, in 1ssf, in the Wabash Railway case." the supreme Court held that a statute of a state, intended to regulate or to tax or to impose any other restrictions upon the transmission of persons and property or telegraph messages from one state to another, was not within that class of legislation which the states could enact in the absence of legislation by congress, and that such statutes are rojul even as to that part of such transmission which may he within the state. The statute of Illinois, therefore, regulating railroad chares was held to have no application as to an interstate shipment even as to that part of the distance which lay within the state of Ilinois, and this regulation of interstate commerce from the beginning to the end of the shipment was confided to congress exclusively under the power to regulate commeree aunong the states.

In $15: 4$ this prineiple was extended to an interstate bridge, and it was held that the bridge was an instrument of interstate commeree whereon congress alone possessed the power

1 Chapter 5:3. Rev. Stat. Act of $18 \pi$, 20 Stats. at Large. 1. :3i.

2See 15 Wall. 2:32. s See sum $: \leq 1 \div$

4 see silp'r, $\div 9$.

5 Wabash R. Co. v. Illinois, 118 U.S.

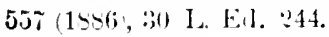


to enact a uniform schedule of charges, and that the authority of the state was limited to fixing tolls of such channels of commerce as were exclusively within its territory.' The court, in reviewing the cases, said that in none of the subsequent cases had any disposition been shown to limit or qualify the doctrine laid down in the Wabash case.

The same principle was later applied in holding invalid the dispensiry laws of South Carolina regulating the sale of intoxicating licuors and prohibiting their importation, ${ }^{2}$ the court holding that as the state recognized the sale, manuficture and use of intoxicating liquors as lawful, it could not discriminate against their being imported from other states.

The right to carry on commerce among the states is subject only to the regulation of congress, and as to this fumlamental right to conduct such commerce, it is not the exercise but the existence of the power in congress which excludes all state control and interference whether under the taxing or the police power.

This freelon from state control in the carrying on of interstate commerce must however be reconciled with the general police power of the state in regulating persons, corporations and property within its juristiction, and in determining their relative rights and obligations. Thus while a state cannot impose any tax upon interstate commerce as such, nor restrict the persons or thing's to be carried therein, nor regnlate the rate of tolls, fares or freight, or interfere with through trains, or exclude any lawful subjects of commerce, it can prescribe rules for the construction of railroads and their management and operation for the protection of persons and property. Such rules are not in themselves regulations of interstate commerce, althongh they may control in some degree the conduct and hiability of those engaged in such commerce. ${ }^{3}$ While the line of distinction is not always clear between what is a lawful regulation of persons and property within the jurisdiction

1 Covington. etc., Bridge Co. v. cook, 170 U.S. 438 (1898), 42 L. Edl. Kentucky, 154 U. S. 204 (1S94). 38 L. 110 ).

Ed. 962.

'Scott v. Donald, 165 U. S. 58: 41

L. Ed, 632 (1897); Vance $\nabla$. Vander-
${ }^{3}$ Chicago, etc., R. Co. v. Solan, 169 U. S. $13: 3$ (1895), 42 L. Ed. 688: Pennsylvania R. Co. v. Hughes, 191 U. S. $4 \pi$ (1903), 4s L. Ed. 268 . 
and what is a regulation of interstate commerce conducted by such persons or with such property, the rule remains as declared in the Wabash case, that it is not the exercise but the existence of the power in congress which makes roid any aetion by the states regulating such commerce.

The distinction between the lawful exercise of the power of the state in regulating the relative rights and duties of those subject to its jurisdiction and the unlawful regulation of interstate commerce was illustrated in two recent cases where state legislation undertuok to deal with the liability of carriers in interstate shipments of goods damaged on connecting lines. A Virwinia statute, providing that a carrier might make any limitation as to its liability on an interstate shipment beyond its own line which it deemed proper, providing only the evidence was a contract in writing and signed hy the shipper, ${ }^{1}$ and that the carrier shonld be liable unless within a reasomable time he gave satisfactory proof to the consignor that the loss or injury diel not occur while the thing was in his cinarge, was sustained by the supreme court. Such a provision, the court said, was a reasonabic one and not a regulation of interstate commerce. ()n the other hand, a Georgia statnte, which, as construed by the supreme Court of that state, applied to interstate shipments and imposed upon the carrier, as a condition of availing itself of a ralid contract of exemption from liability beyond its own line, the duty of tracing the freight and informing the shipper when, where, and how, and by which carrier, the freight was lost. lamaged or destroyed, and of giving the names of the parties and their oflicial position, if any, by whom the truth of the fact set out in the information could be established, was, when applied to an interstate shipment, in violation of the constitution." The court clistinguished this case from the Virgrinia case in that the carricer was marle liable for the negligence of another carrier over whose track it had no control, unless it obtained information which it had no means of compelling another carrier to give. The court sail this was not a reasonable reguation in ald of interstate commerce but a direct and immerliate burden upon it.

1 Richmond \& A. R. Co. v. Patterson Tobarero Co., 169) C. S. 311, 4: L. Fil. T., (149)
2Central of Georgia R. Co. r. Murphey, 25 Sup. Ct. Rep. 218 (Feb. 15, $190.5)$. 190 C. S. 194. 


\section{Congressional inaction in foreign and interstate} commerce distingnished.- In one of the "original package" cases, Bowman v. Railroal Company, ${ }^{1}$ where the Supreme Court first laid down the rule that in interstate commerce the inaction of congress meant freedom of commercial intercours" as to any lawlul subject of commerce in the "original package," 2 it was suggested that while the two powers over interstate and foreign commerce are contained in the same clause and in the same term, the same inference was not always to be drawn from the absence of legislation by congress. Laws which concern the exterior relations of the United States with other nations and governments are general in their nature, and the people of the several states can have no relation with foreign powers in respect to commerce or any other subject except through the government of the United States, its laws and treaties. The question was therefore to be considered in cach case, as it arises, whether the fact that congress his failed in the particular instance to provide by law a regulation of commerce among the states is conclusive of the intention that the subject shall be free from all positive regulation, or that until it positively interferes, such commerce may be left free to be dealt with by the respective states.

33\%. Attachment of foreign railroad cars.- - An interesting question has been mate in cases in the state courts, though it does not appear to have been directly presented in the federal courts in any reported cases, as to the right to attach cars of a foreign railroad company while in a state in the custorly of another company which has received them under an arrangement whereby they are to be $m$ loaded and returned loaded to their owner. Thus, it was deciled by the supreme court of West Virginia in a recent case ${ }^{3}$ that a railroal car belonging to a railroad company of another state and sent from that state loaded with freight, to be returned loaded to the former state in the transaction of interstate commerce, could not be levied upon under a state attachment, nor would another railroad company having in its possession such cars in the process of carrying on such commerce be liable to garnishment by reason

1 Bowman v, Chi. \& N. W. R. Co., 12.5 U. S. 465 (1888), 31 L. Ed. 700.

2 Supra, sito.

${ }^{3}$ Wall v. Norfolk \& Western R. Co.. 52 W. Va. 485 , and 64 L. R. A. 5111 (Anmotated). 
of its possession of such cars. The constitution of the state provided that the rolling stock should be subject to levy under execution, but the court based its ruling upon the suplemacy of the federal power in interstate commerce. There was no act of congress prohibiting state process against such cars. but the court based its decision mpon the paramount force of the commerce clatuse of the constituon, and the act of 1 sifi, ${ }^{1}$ anthorizing interstate connections for the transaction of interstate commerter

The same luling mas made in Minnesota in a recent case. 'The conrt malde the same ruling in regard to an unloaded car belonging to a foreign carrier which had been sent into the state to be muloarled and reluaded and sent back without unleasonible delay. The court said if there was unreasonable delar, or if the car was direrted to other uses, a different mule might apply. lint where the car was practically in transit, the litigants womld be compelled to test theil camse of action in the tribmals where the property lad its undoubted legal situs."

These lecisions, it will be seen, are based not upon the exemption of the rolling steck or other property of ratilnads or other public camiers from legal process, but mpon considerations of public policy in the enforcement of the process of state courts against proputy which had its legal situs in other jurisdictions.

This attachmont of foreign cars, or the gamishment of a local company on account of its possession of such cars of a foreign carrier, is to be distinguished from gamishment of carricrs on aceount of consigmment of merchandise for debts of shippers. such garnishment his been sustamed.

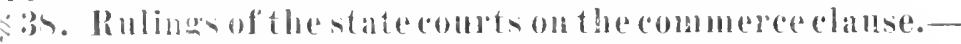
While the simpreme comt of the Cniterl sitates is the final arbitre of all guestions in the construction and application of the federal constitution and the validity of state legrislation in

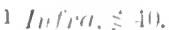

z(omnery v. \%, ). \& K. ( . R. ( o.. S1 Yinn. - and 6; J. R. A. 6i2): Bahll. winv, lirut Northern h. R., \l ilinn. $21 \%$.

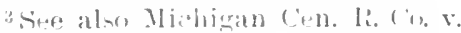

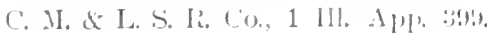

The same ruling is reported to have heen matle ly certain of the U. S. (orroit court, but cases have not been oftirelially reporter.

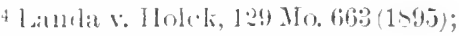
Alame v, scott. 10 I Mass. 164. 
the exercise of the police or taxing power of the state with reference to the same, it is also true that uncler our dual form of government the state courts may, in the exercise of their jurisdiction, be called upon to determine such questions, and their juclgment may be final as to the parties to the cause when their decision is in favor of the federal right set up in the case. Thus, if a federal right or immunity is chained in a case in a state court. and the judgment of the highest court having jurisdiction in the state is in faror of the party making. such claim of federal right, the decision of the state court thereon is final in that cause, and cannot be reviewed on writ of error by the supreme court. This is because the judiciary act of 17 s limits the appellate juristiction of the supreme Compt in reviewing decisions of the highest courts of the state to cases where the decision is against the federal right, privilege or exemption claimed. In a number of cases decisions of state courts have been rendered sustaining the claim of federal right of exemption and adjudging such statutes to be invalis, and such judgments, for the reasons stated, are final as to the parties to the cause. In the cases cited in the preceling section the decisions of the state courts were final, as they were rendered in favor of the feleral claim set "p in the case by the defendant carriers. ${ }^{1}$

1 In the following cases state statutes have been lield roid by state courts:

Requiring a railway company to transfer its freights, passencers. etc., at a given point. Council Btufts s. Railway Co., 4.j Iowa. 3:35. Insp $\lrcorner$. tion before slaughtering of certain animals in so far as it provides that fresh meats camnot be shipped into the state except that the animils shall be inspected forty-eight hours before being slanghtered. Schmidt v. Peop!e, 18 Colo. is. Imponing a penalty of $\$, 00$ for shipping freight other than as designated by the ship. per. Lowe v. Railway Co.. 63 S. C. 218. Making a railway ticket binding on the railway company for six years. La Farier v. Railway Co., 84 Me. 286. Goods made by convict labor in another state to be labeled as such when exposed for sale. People r. Hawkens. 15\% N. Y. 1. Or to be -o'd under special license. Arnold v. Yanders (Ohiol, 4: N. E. 50. Fiail. roals to remore free of charge paupers bronglit into the state by it. Bangors.smith. 83 15e. 4?. Imposing a tax on bills or lating. Garrison $r$. Tillinghast, 1s Cal. 404. Inspectins cattle driven into a state and impon. ing a fee therefor. Faris $r$ Henderson, 1 Okl. 384. Proviling for the inspection of lime imported in to the statte. Higrins v. Casks of Lime, 130 Mass. 1. Requiring all persons other than photographers of the state who shall solicit pictures to be enlarged ontside of the state to pay tax. State v. Scott.95 Tenn. 2it. City ordinance prohibiting a street railroad, engaged 
in interstate commerce, to discriminate in rates in farol of resilents of city. State r. Omaha li. Co. (lowa), st $x$. W. ly. loriding that no stone shall be usel on any municipal work except the stone was dressed or cut or carved within the state. leople $x$. Coler, 166 N. Y. 144.

statestatutes have been held ralid by the courts of their respective ctates in the following cases:

Ifohling a lailroal company liable for damares done by sparks from its engine. Smith r. Railway Co., 63 X. H. 2.j. Requiring railroad leases to be recorder. Commonwealth $v$. Railway Co. (Ky). $40 \mathrm{~s}$. W. Rep. 250. Prohiliting the sale of tickets by any one not anthorized to do so by the ritway company. State s. Corbett, ii 1linn. 345: Commonwealth r. Wilson, 14 Phila. 384 ; State r. Fry, 63 In!. 5is: buriliek s. llinois, 149 Ill. 600. lmpo-ing a penalty on the railwar company for rofusing to deliver freight upon temier of payment of chares shown in the bill of lading. Railway Co. v. Dwyer, is Tex, jis. Prohbiting a railway company from churving for the freight any greater sum that specilied in the bill of lating. Ratilwa Co. v. Carden (Tex.). if S. W. liep. 145. Prohibiting railroal from increasing freight rates for a certain class of freight after freight has been tendered for shipment. Railway Co. v. Wolcott. 111 Ind. 36i. Compelling a railway to post nutices as to whether a train is on time or not. State r. Ind. Ry. Co.,
133 Ind. 69. Prescribing the hours during which a railroad ticket office shall be open. Hall v. Railway Co. 25 S. C. 564 . Regulating the speed of boats on navigable rivers. People r. Jenkins, 1 Hill (N. Y.), 469. Requiring owners of vessels narigated through a canal within a state to furnish l.sts of numbers of tons of freight. Canal v. Lockes Co., 6 Oreg. 21!. Prescribing how many lights a boat siall carry, provided number is not less than the number prescribed by con ress. Fitch v. Livingston, 6 N. Y. Superior Ct. 49:. Compelling railway company to ship freight. whthin iive days after its receipt. Bags v. Railway Co., 109 N. C. 279. Reifuiring license of commercial agency. Statev. Morgan. 2 So. Dak. 3:. A Texas statute imposing a penalty on railroals for not furnishing ears within six lays after notice. onequarter of the freight being tendered. was held valid in the case of a shipment to a point outsile of the state. Hunston dTexas C. R. Co. v. Mayes, Texas Court of Appeals. $83 \mathrm{~S}$. W. Rep. in. In Atlantic Coast Line R. Co. v. (ommonwealth (Va.), 46 S. E. Rep. 910, the rules prescribed by the new Virinia constitution with reference to storage. demurrage, car service, and car letention, charges were not roul as regulations inci. dentally affecting interstate commerce. but this ruling was withont prejudice to the right of any carrier to raise and determine the validity of any rule in any specific case. 


\section{CHAPTER III.}

\section{THE FEDERAL REGULATION OF INTERSTATE COMMERCE.}

\$ 39. The beginning of federal regulation ................. 49

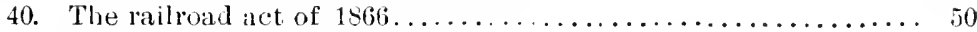

41. State regulation of railways in the United States........... 52

42. Governmental regulation of railways in England.......... 53

43. The common law in interstate commerce............. 54

44. Federal and state courts in the fe leral regulation of interstate commerce ............................... is

45. Genesis of the interstate commerce act.............. 5

46. Pasrage of the interstate commerce act . . . . . . . . . . .9

47. Julicial construction of the act to regulate commerce....... 60

48. Amendments and proposed amendments of the act ....... (i)

49. Reguation of bridges and ferries over navigable rivers....... (5.5

50. Regulation of interstate telegraph companies............. 67

51. Interstate telephone companies not incluled in the act of 1866 . 69

52. The release of the federal regulating power ............ in

53. Regulation by the delegation of power............... in $_{1}$

54. Additional acts of congress in the regulation of commerce.... i i

55. The department of commerce and labor.............. it

56. The mexercined federal power in regulation of commerce.... 76

5\%. Prohibition and regulation $\ldots \ldots \ldots \ldots \ldots \ldots \ldots \ldots$ is

58. The regulation of commerce throunh the taxing power... . . . ig

59. The federal power in granting corporate charters........... st

60. National incorporation as a means in the exercise of the com-

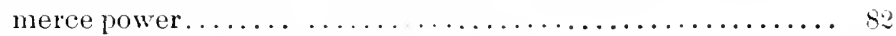

61. Relation of the states to federal corporations............ 83

62. The requirement of federal franchise for business corporations in interstate commerce........................ 84

63. The developing construction of the federal power in the regulation of commerce........................ 86

839. The beginning of federal regulation.-Although the recognized necessity for the national control of interstate commerce was the immediate occasion and moring purpose in the adoption of the constitution and the formation of the federal union, and the broad and comprehensive construction of the commerce clause by the supreme court under chief justice Marshall has laid the foundation of all subsequent decisions; the direct federal regulation of such commerce, at least as to land 
transportation, did not begin until the close of the first century of the republic's existence. The far-reaching importance of national control over interstate as well as orer foreign commerce was not and could not be foreseen at the time of the aloption of the constitution. It was not until twenty years after the close of the ciril war that changed economic conditions of the country male intolerable the hiscriminating legislation of the states and led to the julieial declaration isy the supreme court in 1-sif. that in the matter of interstate commeree the Inited States were but one country and are and must be subject to but one system of regulations, and not to a multitude of systems. Soon after this, in 1 sss and in 1590,2 the court extemed the sane principle of the freelom of interstate commerce to the police power of the states in the liquor tratlic decisions. In $1-56$ it was also detinitely decided ${ }^{3}$ that the state power of regulation of ralway traffic did not and could not extend to interstite traffic in any form, and that such shipments were national in their character, and their regulation confined to congress exclusively. Thus it was for the first time deciled that this right of interstilte commerce was so essentially national in its character that the inaction of congress was equivalent to its letermination that the commerce must be free, and that therefore, any state regulation of the right to carry on such commerce was inoperative and void. The principle of concurrent state powers luring the inaction of congress and the in validation of state action by reason, not of the existence, but of the exercise of the feleril power had no application to the regulation of the right to carry on commerce between the states.

Thus the close of the first one hundred years of the government was marked by the distinct judicial declaration of the freedom of inter-tate commerce from any control or regulation be the states, either by police or taxing power. and the way was logically opened for the direct exercise by congress of the power of regulation conferred by the constitution.

40. The railroad act of 1566 . - Nhthough congress had

1 Robbins v. Shelly County Taxing District, supro.

Wabash, St. L. \& P. R. Co. v. Illinois, sipria.

¿Bowman s. Railway Co., smma;

Ieisy s. Hardin, stpren. 
frequently legislated on the subject of water transportation $(x " 1)$ ' $(12)$, its first legislation in regard to railroal transportation, other than the incorporation of the land grant and government aided Pacific railroads in $1 S 62$, was the act of June $1 ., 1566$, since incorporated in the revised statutes as section i.js. This act was entitled in its preamble,

"Whereas the constitution of the I'nited States confers upon congress in express terms, the power to regulate commerce among the several states, to establish post-roads, and to raise and support armies," and it provided as follows:

"Every railroad company in the T'nited States, whose road is operated by steam, its successors and assigns, is hereby authorized to carry upon and over its road, boats, bridges and ferries, all passengers, troops, government supplies, mails, freight and property on their way from any state to another state, and to receive compensition therefor, and to connect with roads of other states, so as to form continuous lines for the transportation of the same to the place of destination.

"This section shall not be construed to authorize any railroad company to build any new roal, or any connection with another road, without authority from the state in which such railroal or connection shall be proposed."

The purpose of this act, as declared by the supreme Court, was to remove trammels upon transportation which had previously existed, and to prevent the creation of such trammels in the future, ${ }^{1}$ and also to be a declaration by congress in faror of the great policy of continuous lines, and, therefore, as farroring such business arrangements between companies as woukd malie such connections effective, ${ }^{2}$ and as indicating an intent that interstate commercial intercourse should be free. ${ }^{3}$

The statute, however, imposes no duties upon carriers so as to compel through routing of interstate traffic, and merely permits or anthorizes the carriage of freight or traffic from one state to another and the formation of continuous lines by mutual agreement. ${ }^{4}$ The act was only intended to remove trammels upon transportation between different states imposed by state enactments or the then existing laws of congress, and did

1 Railroad Co. v. Richmond, 19 Wall. 584 (1873), 22 L. Ed. 173.

-Union Pacific R. Co. v. Chicago, etc. K. Co., 163 U. S. 589 (1896), 41 L. El. :68, 2\%4.
${ }^{3}$ Bowman v. C. \& N. W. R. R., 19,j U. S. 46.5 (1888), 31 L. E.l. 700 .

4 Kentucky \& Indiana Bridge Co. v. L. \& N. R. Co., 37 Fed. Rep. 56r, l. c. 1. 63:3 (1839). 
not prevent the operation of police laws of the states affecting interstate railways. ${ }^{1}$

The statute did not interfere with the laws of the states hiving for their object the personal security of passenger's, nor did it interfere with such state enactments as the regulating of the running of trains on Sunday, ${ }^{2}$ or exchuding diseased catthe." This statute, howerer, in its declaration of the national public poliey in faroring continuous interstate transportation, wals inrolied by certain state courts in holding that railroad cars employed in interstate transportation are not subject to lery under attachment process against the owning company when in the possession of a connecting company in another state. ${ }^{+}$

\section{State regulation of railways in the Cnited states.} With this julicial decluration of the freedom of interstate commeree from stite control, also came the distinct judicial reconnition of the grovernmental power of regulation over public earriers. This principle had been alrealy established both in the states of this country and in Engrand.

Thus, in this country, prior to the aloption of the interstate commerce act, railway tommissions had been established in sereral states, some with powers of regulation, and others only with powers of investigation, and recommendation. It was established in the (ranger eases, ${ }^{5}$ that railroad companies were calriers for hire and as such were engaged in the publie employment affecting the public interests and were subject to legishative control as to their rates of fare and freight, unless protected by their own charters therefrom. As carriers they unst carry when called upon to do so, and can charge snly a reasonable sum for the carriage. The principle was also distinetly declared that when property had been clothed with a public interest, the legislature may fix a limit to that which in law shall be reasonable for its use, and that this limit binds the courts as well as the people. It was mrged in these cases that the statutes of the states regulating rates amounted to a

${ }^{1}$ R. R. Co. v. Fuller, 17 Wall. 560 (15\%). 21 L. Ed. 710 .

5 Munn v. Illinois, 94 U. S. 118 (15i6), 24 L. Ed. ir: Railroad Co. ฯ.

"Hennington v. Gieorgia, supret.

M. K. \& T. R. Co. v. HJaber, 169

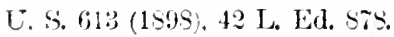
Iowa, 94 U. S. 155 (1876), 24 1. Ed. 94 : 4 see sur Peik v. Railway Co., 94 U. S. 164 (1si6), 24 L. Ed. 97. 
regulation of commerce among the states; but it was held that where the railroad was employed in state as well as in interstate commerce, and until congress acted, the state must be permitted to establish such rules and regulations as may be necessary for the promotion of the general welfare of the people within its own jurisdiction, even though in doing so those without may be indirectly affected.

While there has been some difference of judicial opinion as to what classes of business were affected with a public use su as to warrant state regulation of charges, there has been no such difference as to the application of the principle to common carriers, and their subjection to public regulation has been uniformly conceded. ${ }^{1}$

- 4. (dovernmental regulation of railways in England.The principle of governmental regulation of railways was allopted in England soon after the first introduction of railways in that country. Thus, the Railways Clauses Consolidation Act of 1545 , in granting the power to vary tolls upon railways so as to accommolate them to the circumstances of the traffic, provided that tolls should be at all times charged equally to all persons, and that the power of rarying should not be used for the purpose of prejulicing or faroring particular parties, or for the purpose of collusively or unfairly creating a monopoly either in the hands of the company or of particular parties. The Railway and Canal Traffic Act of 18.542 specifically provided that the railway company should make arrangements for receiving and forwarding freight, and prohibiting any undue or unreasonible preference or advantage, using substantially the language adopted in the third section of the Interstate commerce Act, and authorized summary proceedings in the courts for the enforcement of its provisions.

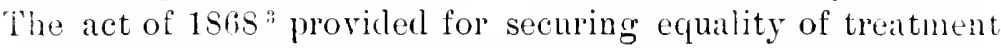
where the railway company operates its steam ressels; and, linally, the Regulation of Railways Act of $1873^{4}$ authorized the appointment of not more than three commissioners, one

1 Budd v. New York, 143 U. S. $51 \%$ (1892), 36 L. Ed. 24r: Brass v. North Dakota. 153 U. S. 391 (1894), 38 L. Ed. iji: State ex rel v. Associated Press. 159 Mo. 410 (1901), Minneapolis \& St.
Louis R Co. v. Minnesota. 186 U. S. $25 \%$ (1902). 46 L. Ed. 1151.

21 and 18 Vic., c. 31.

331 and $3 \%$ Vic., c. 119.

436 and $3 i$ Vic.. c. 48. 
of whom should be experienced in the law and one of experience in the railway business, and not more than two assistant commissioners, and this commission was granted very comprehensice power's, including the power of making through routes and apportioning through rates thereon. As will be hereafter seen. some of the provisions of the Interstate Commerce Act are based upon the English statutes, and the English decisions construing those statutes have been frequently cited in the ferlerial courts. ${ }^{1}$ English precedents however in the matter of public regulation of railways are of limited value in this country in view of the vast lifference in the conditions of railroad service. In the one there is compact population in a limitel area; in the other a great continent, with immense tracts of sparsely settled and newly opened territory, corered with a great network of railroads and with numerous competing communities.

4:3. The common law in interstate commerce.- There is no felteral common law in the sense of a national customary law distinct from the common law of England, as adopted by the several states, each for itself, applied to its local law and subject to such alterations as may be provided by its own statutes." There are therefore no crimes of the United States, and no pains and penalties are enforced by its courts, except as enacted in the statutes of the United States.

Inder section 721 of the Judiciary Act the laws of the reveral states are enforcel in the courts of the United States." In this section, by the "laws of the states" is meant the statute laws of the states as construed by the local tribunals, and not the rules of law declared by the decisions of the states in matters of general jurisprudence. ${ }^{4}$ The federal courts are not bound to follow the rulings of the state courts on questions of general commercial law or of equity jurisprudence,

IIIfir. Interstate Commerce Act, secs. 2 and 3.

:Wheaton v. Donaldson, 8 Pet. l. c. 6.5. S L. Ed. $10 \pi 9$ (1834): Smith v. Alabama, 124 U. S. 46.5 (1858), 31 1. Edi. jos.

3"Sec. 721. Laus of the states; rules of decision. The laws of the sveral states, except where the con- stitution, treaties, or statutes of the United States otherwise require or provide, shall be regarded as rules of decision in trials at common law, in the courts of the United States, in cases where they apply." (Act Sept. 24, 1789, c. 20, 34,1 Stat. 92.)

4 Railroad Co. v. Baugh, 149 U. S. 368 (189:3), 3\% L. Ed. 722. 
but they declare their own views of the law, irrespective of the courts of the state, ${ }^{1}$ and the same ruling has been made as to the legal principles controlling the liability of railroad com. panies to employees.

There was no federal statutory regulation of interstate commerce prior to the enactment of the interstate commerce law in 1ss7. It was ruled in some of the circuit courts, that in the absence of a distinct federal, common law or statute, there was no law prior to 1857 controlling the regulations of carriers and shippers in interstate commerce and warranting a recovery on accounc of discriminating charges therein, and that this was a matter of exclusive federal juriscliction, which was not exercised prior to the enactment of the Interstate Commerce Act." It was therefore held that the state courts had no jurisdiction in such cases, and as the courts of the Uniterl States in removed cases had no willer juristiction than the courts from which they were removed, the federal courts had no jurisdiction therein.

This question of the common law in interstate commerce was presented to the Supreme Court in 1901 in a case from Nebraska, ${ }^{3}$ where the Supreme Court of that state had sustained a recovery against an interstate telegraph company, for alleged discrimination in charges. The company claimed that as there was no federal regulation of interstate telegraph rates, there could be no recovery, as there was no controlling statute or common law for such recovery. The supreme Court, however, sustained the recovery, holding that there was a common law in force generally throughout the United States, and that the countless multitude of interstate commercial transactions were subject to the rules of common law except so far as they were modified by congressional enactment. The jurisclietion of the state court to enforce these principles

1 swift v. Tyson, 16 Pet. 1 and 18 Railroad Co., 62 Fed. Rep. 24, 35 C. C. (1842), 10 L. El. s6.), 871; Oats v. A. 62 (1899), 92 Fed. Rep. s68; Adams, Bank, 100 U. S. 299 (18.9), 25 L. Ed. J., in Kinnaey v. Terninal Associa580; Railroad Co. v. National Bank, 102 U. S. $14(1880), 26$ L. Ed. 61.

2 Swift v. Railroad Co., 58 Fed. Rep. 858; Sheldon r. Railroad Co., 105 tion, 81 Feu. Rep. 802.

3 Western Union Tel. Co. v. Call Pub. Co., 181 U. S. 92 (1901), 45 L. Ed. 765.

Fed. Rep. 78.j. See contra, Murry v. 
of the common law in interstate commercial transactions was therefore sustained.

The court in its opinion in these cases refers approvingly to an opinion of fulge shiras in the Iowa circuit, ${ }^{1}$ where the subject hat been exhaustirely discussed in a suit for damages atgainst a railroad carrier on accomnt of alleged liscrimination in interstate shipments prior to the enactment of the Interstalte commeree Act. 'This ase had been filed in the state comrt and remosed to the Lnited states circuit court, and it was held that the state court had jurisdiction of the subjectmatter, and therefore the I'nited states comrt had jurisiction orer the removed case, as congress had not declared any exelusire jurisdiction in such cases for the federal courts.

Inder the law as declared in these cases, the principles of the common ha were enforced as to matters of national eontrol as well as to matters of state control, and in this sense there is a common law of the Lnited states controlling the relations of interstate carriers and the public, and the enactments of congress in the regulation of those relations are to be construed in the light of the principles of the common law.

This applies to interstate commerce on land. Interstate commerce carriel on by watel, whether on the seas or on the inland narigable waters of the United states, is subject to the rules of the maritime law where applicable.

\section{4t. Federal and state courts in the federal regulation} of interstate commerce. - Under the constitution of the Inited states the judicial power of the Inited States is ext:nded to cases arising under the constitution and laws of the Inited states, and this juristiction may be made exclusive in the federal courts by Congress either by express enactment or by necessary implication therein." It was at one time questioned whether the state courts could exercise concurrent juris. dition with the ferleral courts in cases arising under the constitution, laws and treaties of the I'nited states; but it was salid by the Supreme ('ourt in the case cited that the laws of the Inited ctates were laws in the several states, and just as much binding therein on the citizens and courts thereof as were the laws of the states. Rights, whether legal or equit-

M Murray v. Railmall Co.. suprom.

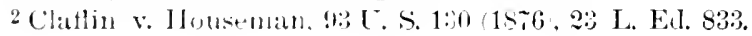


able, acquired under the laws of the United states may be prosecuted in the courts of the Cnited States, or in the state courts competent to decide questions of like character and class, subject however to the qualification that when a right arises under a law of the United States, Congress may give to the courts of the United States exclusive jurishiction. ${ }^{1}$

Under the act of $1857^{2}$, the Circuit Courts of the Lnited states were given original cognizance, concurrent with the courts of the several states, of ali suits of a civil nature in common law or equity, not only in cases of diverse citizenship, but also in cases arising under the constitution and laws of the United states, or treaties made, or which shall be made, under their authority. This is subject to the reservation of the exclusive juriseliction of the Enited States courts under section 711 R. s., U. s.," in criminal, patent, admiralty cases, and suits for penalties and forfeitures under the laws of the United States. Not only such suits brought to enforce the provisions of specific acts of congress, but also all suits based upon and asserting federal rights in interstate commerce, are suits arising under the constitution and laws of the United States, and the circuit courts of the Enited States have jurisdiction thereof irrespective of diverse citizenship. The supreme Court held in an application for habeas corpus by a party committed for contempt for violating an injunction granted to an interstate railroad to prevent in terference with its interstate trattice, that the circuit court had juriseliction irrespective of citizenship, and that a cise arose under the constitution and laws of the United States, whenerer the plaintiff sets up a right to which be is entitled under such laws, and the correct decision of the case depends upon the construction of such laws.

In suits bronght for the enforcement of rights in interstate commerce and not for the specific enforcement of the provisions of the Interstate Commerce Act or the Anti-Trust Act, the state courts have concurrent jurisliction with the federal courts, and such suits may be brought in the United States cireuit courts irrespective of citizenship." The fact that inter-

ISee Mr. Hamilton in S2d Federalist.

2 See Act of March 3, 1887. and Aurgust 13, 1888. 1 Compiled Stats.. .508.
${ }^{3} 1$ Compiled Statutes, p. 5\%.

${ }^{4}$ In re Lennon, 166 C. S. 545. I. c. 5i) 41 L. Eil. 1110.

S. See section $s$ of Interstite Commerce Act, infru. s: $: 4 t$ et siry. 
stite commerce is beyond state legislative control does not ipwe filcto prevent the courts of the state from exercising jurisiliction orer cases growing ont of that commerce, ${ }^{+}$but the state juristiction is excluded, if congress has made exclusive the juriscliction of the federal courts.

botls in the Interstate Commerce Act and the Anti-Trust Aet of 1 - -40 there is an express resting of jurisliction in the United states conrts, of suits brought to enforce the provisions of the ate. Is to such suits brought to enforee the provisions of the Interstate commerce Act, it has been held, both in the federal and in the state courts, that the jurisdiction is exelusive in the [nited states eourts." The same ruling would doubtless be mille as to suits brought to enforce the Anti-Trust Aet of 1590.6

4.). Genesis of the Interstate Commerce Act.- The reeownition of the gorernmental power in controlling interstate commerce immediately preceded the judicial decharation that interstate railway trinsportation was beyond state control. The question of interference with interstate commerce had been raised in the (iranger eases, and the court had held ${ }^{7}$ that the act regulating fares was ralid in the absence of regulation by congress. and that until congress undertook to legislate for those who were without the state, the state could provicle for those within, even though those without might be indirectly aflecterl.

The supreme court of Illinois ${ }^{9}$ cited these eases in sustaining a state statute as to so mueh of interstate transportation as. Wils within the limits of the state of Illinois. Put the Supreme Court in the same case ( $(m),(1,35)$, said that in the Granger cilses the importince of the question of the governmental power of regulation and of the company's contract right of exemption therefrom overshadowed all others, so that the question of

4 Iuray v, chicago \& N. W. R. 12 L. R. A. 725; Charles v. Mo. Pac. R. Co..ti? Pel. liep. 25, l. c. 43.

iser sections s anıl ! of Interstate Comm+ce Ict, infra: Van Patten v. Rathoall Co. it Fed. Rep. 9s1: Swift v. Ritilroul (Co. 5s Ferl Rep. S.j9; Edmuncls s. Ill. Central R. R. Co.. so Fell. liep. ig: Shehlon v. Wabatsh R. Co.. 11.; Fed. Rep. 18.; Ordway v. (entral Nat'l. Bank, 4\% M(l. 21.); Copp $\therefore$ Ritilway Co., 43 La. Ann. 511, R. Co., $16 \$$ Mo. 65:; Gulf. C. \& S. F. R. R. Co. v. Moore, (Texas). $83 \mathrm{~S} . \mathrm{W}$. Rep. 362.

6 See sections 4 and 7 of the act of 1890. infra.

i Pilse v. Chicago, etc. R. Co., $9+$ U.

S. l. c. $177(1876), 24$ L. Ed. 98.

s Wabash, St. L. \& P. R. Co. v. IIlinois, 104 Ill. $4 \% 6$. 
freelom of interstate commerce received but little attention at the hands of the court. This decision of the Supreme court reversing the Supreme Court of Illinois, was rendered in $18 s+$, in the same year that the freedom of interstate commerce from the state taxing power was declared in the Tennesee drummer ease, and broally allirmed that the statute of a state enacted to regulate and tax, or to impose any other restriction upon the transmission of persons or property or telegraph messages from one state to another, was not within the class of legislation which the state, in the absence of legislation by congress, conkl enact, and that the state statute was roid as to all interstate shipments, including that part of the transmission of such shipments which was within the state.

46. Passage of the Interstate Commence Act. - The decision in the Wabash case demonstrated the lack of power in the states to regulate interstate shipments, ${ }^{1}$ and the demand for the exercise of this power by congress becoming irresistible, the interstate commerce bill which had been pending for several years in congress became a law February $4,1586^{2}$.

The discussion in the two houses of congress and in the public press was mainly directed to the long and short hanl clause contained in the fourth section, and the prohibition of pooling contained in the fifth section of the act. Infferences of opinion developed between the house and the senate, the former insisting on the prohibition of pooling and on a qualified long. and short haul clauso. The bill was finally enacted in the form reported by the enference committee of the two houses of congress. Frequent references were made in the debates to the then recent decision of the supreme court in the Wabash case denying to the states any power for the regulation of interstate traffic. A very widle difference of opinion was developed in the discussion as to the proper construction of the act, particularly as to what were the "substantially similar circumstances and conditions" in the fourth section, and one of the members of the house in the final debate described the bill as

1 This case was decided October $25,188 \%$, but the terms of the commis1856.

2 The interstate commerce commission was established March 2:, erals, p. 47, 1887. sioners were computed from January 1st. See 19 Opinion of Attorney Gen- 
"one which nobody understands, nobody wants, and everyboly is going to vote for."

$4 i$. Julicial construction of the act to regulate commeree. - The act to regulate commerce was so clearly within the powers of congress, that no serious question was raised as to its constitutionality. Tery grave questions, however, have been male as to what powers were conferred upon the conmission by the terms of the act, and as to the construction of the lifferent sections of the act in relation thereto.

As will be seen from the cases infir, grouped under the diflerent sections of the act, the powers of the commission have been construed by the supreme Court to be materially ditlerent from the powers claimed and exercised by the commission during the first rears of its existence. Thus, the commission has no power to make maximum and minimum rates for the future, and the judicial construction of the long and short haul clause in section four of the act, so that the competition between the carricrs creates substantially different circunstances and conditions within the meaning of this section and has materially curtailed the jurisdiction of the commission

1 For a comprelsensive and accurate statement of the condition of the state regulation of rialroads at and prior to the adoption of the interititle commerce act, see Hidley's " Ratilroall Transportation. its History and its latws," first published in 1-s.j. Siee also report of Windom to $\mathrm{U}$. S. Senate, 15it, (Senate Report No. 30\%. toril Congress, 1st Session). Cullom Report (senate lieport No. 46, 45th ('ongre-s, 1st Session). Hepburn Report. New York Legislature of 1sig.

In the Import Rate case. 102 U. S. $\because 11$, 41 L. Fil. 941, the supreme court in referring to the causes for the enactment sail:

"They chiefly grew out of the use of railroads as the principal modern instrumentalities of commerce. While shppers of merchandise were under 111) lemal necessity to use railroads. fractically they were. . . From the very nature of the case, there. fore, railroads were monopolies, and the evils that usually accompany monopolies soon hegan to show them. selves, and were the cause of lond complaints. The companies owning the railroals were charged, and sometimestruthfully, with making unjust discrimmations betweenshippersand localities, with making secret agreements with some to the detriment of other patrons, and with making pools or combinations with each other, leading to oppression of entire communities. . . . As the powers of states were restricted to their own territories and did not enable tluem eficiently to control the management of great corporations whose roads extesd throughout the entire country. there was a genelal clemand that congress. in the exercise of its plenary power over the subject of foreign and interstate commerce, should deal with the evils complait. ed of by a grenerial enactment. amd the statute in question was the result.' 
under the act. The commission can dechre, subject to the approval of the court, a specific rate unleasonable, but it can not leclare and enforce any substituted rate as reasonable.

The supreme court has approved the language of Mr. Jus. tice Jackson, who said in one of the early cises under the act:"

"Subject to the two leading prohibitions that their charges shall not be unjust or unpeasomalle, and that they shall not unjustly discriminate, so as to give undue preference or disadvantage to persons or traftic similarly circumstanced, the act to regulate commerce leares common carriers as they were at the common law, free to make special contracts looking to the increase of their business, to classify their traffic, to adjust and apportion their rates so as to meet the necessities of commerce, and generally to manage their important interests upon the same principles which are regarded as sound, and adopted in other trades and pursuits."

This judicial construction of the act has led to agitation for its amendment, so as to give the commission a more effective control in the enforcement of reasonable rates, and also in expediting procedure in the enforcement of the act." The conmission hats also contended in its successive annual reports thit the evils which are sought to be remedied by the act, included not only the discriminations between shippers and localities in the enforcement of established rates, but also the establishment and maintenance of rates which in themselves, or as between localities and kinds of trattic, were unreasonable. ${ }^{3}$

It has developed also in the ribilmoul history of the country since the enactment of the Interstate ('ommerce let and in the discussions before the commission and in the comrts, as well as before the committees of congless, that what the public gool really requires is not only reasonibleness, but also stability in

I Interstate Commerce Commission $\therefore$ B. \& O. R. Co., 43 Fed. Rep. $4 i$ $(1590)$.

2 The delays of the law were for. cibly illustrated in the fact that it was not until $18: \%$, ten yeirs alter the passage of the act, that the juclicial construction was definitely established as to the short and long haul and the powers of the commis. sion in making rates. At this time the cases only reached the supreme court through the circuit court of appeals. since that time the procelure has been materially expedited, especially since the so-called Expedition Act, injor, \$:349.

$\because$ See anuual report of the commission recommenting amendments; also final report of industrial commission, 190:, rol. 19, pl. 259, 419, t\$1. 
railroad rates. The prohibition of pooling in section 5 (infin, $\leqslant$ (is) of the act has been a powerful influence in promoting the effectual elimination of competition through consolidations and practical control of competitors throngh community of interest. The device of a holding corporation as a means of effecting this control was condemned in the Northern Securities case, but the tendency toward a practical elimination of competition is none the less clear. It has, therefore, been suguested with force that as unregulated competition with recurring rate wars is detrimental to the public as well as to the raibrads, conferences and agreements as to rates, and especially in the adjustment of the complicated relation of rates, under the regulating supervision of some pubic authority such as the lnterstate Commerce Commission, would greatly contribute to the maintenance of stable and reasonable rates and thus to the permanent solution of the pending difficulties of the transportation problems between the railroads and the public.

\section{Amendments and proposed amendments of the act.} Ameniatory acts have been passed by congress in 1589,1593 and 1903. The first of these was that of 1859 and gave a shipper an additional summary and effective remedy by writ of mudumu, to compel the carrier to furnish equal facilities finfia, $\$ 30-$ ). That of 159 :) remedied the difficulty growing ont of the inability to enforce self-incriminating testimony lintir, $: 263)$. In 1 ! $10 ;$ was enacted the so-called Expedition let lintin. $: 49 \%$, which materially expedited the procedure in suits bronght by the Inited States, or suits prosecuted by direction of the attorney-general in the name of the Interstate commerce ('ommission.

The anemelatory act of Fehruary 19, 1!148, known as the Elkins law, made very important changes and materialiy enfored the provisions against liscriminations, in that it made the publisherl rates conclusive against the carrier, every deviation therefom being punishable. The scope of the act was atso materially extended as to the parties subject to its provisions. line was substituterl for imprisomment in the penal provisions of the act (intion. : : 110 ).

Sone of these amendments have affected the rate-making fower of the commission. A strong agitation has been made 
for such an amendment to the act as would enable the tommission to determine after hearing, not only what was an unjust and unreasonable rate, regulation or practice, but at the same time to determine what was just and reasonable, and that such determination should become operative without an appeal to the court as under the present law, and subject only to be set aside by a judicial review at the instance of the carrier. $^{1}$ A special court of transportation has also been proposed to review the orders of the commission in case of appeats.

Under the act as it now stands, the commission is an inves. tigating and prosecuting administrative body, whose findings are griven a frima force force in juclicial proceedings. Tnder the proposed amentment, its finling would become self-en forcing, in that it woukl be binding upon the carrier unless the court shoukl, upon hearing, restrain its operation. As will be hereafter seen, questions of reasonableness in the adjustment of rates are, in the main, questions of fact and often involve very complicated circumstances, especially in determining the relation or interdependence of rates in our vast territory. The analogies of ordinary litigation are not applicable, in that every auestion of rates is adjusted to the then existing cireumstances, which may be, and ordinarily will be, materially changed before the court of tinal review can act. The doctrine of julieial precelent, therefore, has a very lim. ited application. It is also true that a bond giren by the carrier as a condition of maintaining a rate found unreasonable by the commission or a court, may be a very inadefuate remelly to the parties or industries really injured by such rate, and on the other hand, it is also true that the carrier wonld be practically withont remedy, if compelled to reduce a rate $\mathrm{un}$ der an opder of the commission which was afterwarls set aside on the review in court. ${ }^{2}$

1 President Roosevelt, in his message of December, 1904 , recommends the amendment of the Interstate Commerce Act by conferring on the InterstateCommerceCommission the power to revise rates and regulations, subject to juilicial review, the ruling of the commission to go into effect and remain in elfect, unless and until reversed by a court of review; and also that steamship companies engaged in interstate commerce, protected in the coitstwise trade, should be held to the obserrance of the act. The act now includes only railroads and water transportation comected with railroads.

2 The house of representatises of the jsth congress. on February 9 , 1905. passed what was known as the 
The funlamental powers of government are necessarily inrolvel in the public regulation of railway charges through the orlers of rilway commissions. The supreme court said in the Naximum Rate case, ${ }^{1}$ that the power to preseribe a tariff of rates is a legislative, and not an administrative or judicial funetion.-' The power to letermine whether an existing rate is or is mot reasonable is julicial. Inder the present law the commission is charged with the administrative or executive function of "nforeing the law, and also with quesi judicial powers in investimating and letermining, subject to the approval of the court. the risonableness of the rates. If to these powers now exercisel is allded the legrislative power of making rates, the reviewing power of the conrt should extend to the reasonableness of the rates, found unreasonable by the commission in the exercise of its judiclal power, as the necessary basis for the exercise of its legislative power. "Ine process of law" would require this power in the court, whether in interlocutory or on final hraring. As the question in rates is ordinarily one of fact

Twmmentlesch bill (H. R. 1ః, j8s). which hall been reported by the majority of the juidiciry committee (renor Xo. 4093$)$ as al substitute for sunhy bills. The bill was not reached in the stuate, and therefore failed of parsiage. This bill conferred upon the commision the power to name "ar rate, practice or regulation" in piace of one found to be moreasonalike the same to take silpet in thirty days from date of servee upon the carrier, the latter having the right whthin sixty days to appeal to the connt of tratsplortation, provided in the act for a review of the "lawhlness. justice or reasonableness ol the late." If the late is a joint one, the (onmission was empowered to approtion the same if the parties to lla joint rate failed to arree within twenty lays. The comnuission womlal las increatsol to seven mambers. with sitaries of tou thonsand rollars each 1." annmm, only four lom the same politioal party A romet of transJurtation was providerl of live are

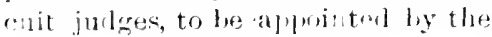

Presilent from the circuit judges of the United States, five arlditional circuit judges being apmointed, no two from the same circuit. such court to have exclusive jurisdiction of all cases miler the at, its juldyments to be final. except with appeal to the smpreme court " in cases wheremule the laws theretofore in force, an appeal or wit of error lay from the final order jurlument or decree of thecircuit conrt."

$116 \pi$ U. S. 1. c. 50,5, 42 L. Ed. 25.5 (159\%)

? The general rule, that courts will not intorfere with the exeroise of the leris'ative power, but only with the attempted enforcement of such legislation by the executive power when prisate rights are invaled, has bern alphlied in the case of the making of rallroal rates by state commissions, the courts leclining to interfere with the rate-making power hefore it was exercised. See Mcchord v. I. \& N. R. Co., $15: 3$ U. S. $459.46 \mathrm{~L}$. ill. 289 (1902), reversing 103 Fed. Liep. 216. 
only, the prima firie elfect of the finding of fact mate by the commission extends to the evidentiary faets, and not to the ultimate conclusion of reasonableness. I ()ther questions may be sugrested by this blending of the distinct powers of grovermment in one tribunal, which are prematme now to liscuss.:

\$ 49. Rexulation of bridges and ferries over uniquhls rivers.- The broadened conception of the federal power over interstate commeree in this direct regulation of such eommerec is illustrated in the mulings of the supreme cout with reference to the building of bridges and establishment of ferries over navigable pivers, as also in the exereise of the legrishative power in authorizing improventents, alterations and obstructions in public navigable waters. The power of the state to establish hridges over navigable and tide waters was admitted, subject, however, to the paramount authority of congress to declare a bridge an obstruetion to navigation, the paramount anthority of regulating briclges that afrect the navigation of the navigable waters of the I nited States being admittedly in congress." Thus in the case cited the Wheeling bridge constructed across the ohio river under an act of Virginia, had, by decree of the supreme court at the suit of the state of l'ennsylrania, been dechred in its then condition an unlawtul obstruetion of the navgation of the rivel and in conllict with the acts of congress regulating such narigation. and therefore ordered to be elevated or abated. ('ongress therempon passed an act deciaring the bridge to b a law ful strueture in its then condition and elevation, and this act was sustained as giving

I There is a blending of the judicial legislative and alministratise power's in the powers of railroad conmissioners in several of the states. The constitutionality of such acts hats been sustained both in the state :ml felleral courts. See Express Co. r. Ritilroal Co., 111 N. C. 46:3; Burlington, etc. R. Co. v. Dey, 82 Iowa 312; Chicago, etc. R. Co. v. Jones, 149 Ill. 361 ; ( ieorgia, etc. R. Co. v. Snith, 70 Ga. 694. See also the Railroal Commission Cases, 116 U. S. $30 \%, 29 \mathrm{~L}$. E. 6:36, and infra. \$91. In these and other cases, the prima facie effect given to the findings of the commis- sion has been sustained. Such a frima farie effect, however. might be far more serious where the case is heard in court only upon the record marle before the commiscion. particularly in its possible bearing upon the question of interlocutory relie: if the court is concluied by the tini ings of fact made by the commission.

"As to the constitutional limitations of the rate-making fower of congress, see infra, $\leqslant 56$.

"Pennsylvania v. Wheeling, etc. Bridge Co., 18 How. 121 (15.5.5), 1.5 L. E!l. 45.5. 
full authority to maintain the bridge. The practice thereupon grew up of building bridges by state corporations - where the rivers constituted the boundary of states, securing the concurrent action of both states, - and at the same time obtaining an act of congress that the bridge, when constructed accordinc to its provisions, should be a lawful structure and not an ohstruction to narigation.

In 1 so't however it was held ${ }^{1}$ that congress had full anthority to incorporate a bridge company for the construction of a bridge across a navigable river, and sustained the validity of the North liver lirilge (ompany for the construction of a bridge across the Ifulson river between the states of New lork and Tew lersey. The court said that it was not necessary lor congress to reconize and approve bridges erected by authority of two states across navigable waters between them, but could, at its discretion, use its sovereign power, directly or through a corporation created for that object, to construct bridges for the accommodation of interstate traffic by land,2 as it undoubtedly may do to improve the narigation of rivers for the convenience of such traffic by water. In the case of this Corth River Brilge Company the act mate provision for the condemnation of lands, for the construction and maintenance of the bridge and its approaches, and for just compensition to the owners.

In the case of ferries there is no such necessity of securing the sanction of congress, as there is no such obstruction to narigation." But ferries as well as bridges are instrumentalithes of interstate commeree when they cross rivers which are the boundaries of states, and as such are exempt from state control.

In al recent case ${ }^{5}$ the court held that an unconstitutional lumen was imposed on interstate commerce by an Illinois

1 Luxton v: Nortl River Tirilge

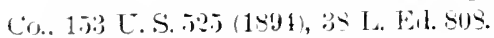

"Willinette Bridge Co. v. Hatch.

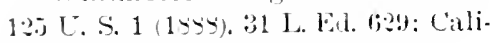
Pornia v. Pacific Ry. Cu. 1:2 L. S. 1 (1sbs), 32 L. Ed. 1,io.

"Covington \& Cincinnati Brilge Co. x. Kentucky, 151 L.s. 201 (1s99), us 1. Ed. $96 \%$.
4 Covington, etc. Bridge Co. v. Ken. tucky, 1 ist U. S. 204 , 1. c, 219, ;s L, El. 962 (1s99); Gloucester Ferry (Co. v. Pennsylmania, 114 U. S. 196 (IS85), 29 L. Ld. 15 s.

sst. Clair County v. Interstate Transfer Co., 192 U. S. 454 (1901), 48 L. El. j1s. 
statute penalizing the carrying on of a fery without a license, when applied to the transportation of loaled or unloarled railroat cars across the Mississippi river from the Illinois to the Missouri side. The court said that there was an essential distinction between a ferry in the restricted and legal sense of the term, and the transportation of railroal cars across a boundary river between two states, constituting interstate commerce, and that sach trinsportation could not be subjerted to burdens imposed by a state, which were direct burdens upon interstate commerce. In this case the power to grant the license was made discretionary; citizens of Illinois were to be preferred and the licensee conld be required to conduct a general ferry business. The court therefore found it unnecessary to consider whether the broal declarations of the power of the state to regulate ferries orer navigable rivers constituting boundaries between states, supported in the earlier cases, had not been modified by the rule laid down in the Gloucester Ferry case' and the Corington Iridge case.

so. liegulation of interstate telegraph companies.-Although congress has not provided for a national regulation of interstate telegraph and telephone as it has for that of interstate carriers, the interstate business of such companies is controlled by the rules of the common law." which are operative upon all interstate commercial transactions, except so far as they are modified by congressional enactment, and such common law rights, as protection against unjust discrimination, may be enlorced in the state as well as in the federal courts.

Congress has legislated from time to time in relation to telegraph lines in interstate commerce, but more particularly with reference to the grant of telegraph privileges to the government-aided Pacific raiiroads. Thus, in 18ti2," congress included the right to construct, maintain and operate telegraph lines in its grant of the charters to build Pacific railroads.

subsequently, in $1866,{ }^{4}$ congress granted to any telegraph company organized under the laws of any state the right to construct, maintain and operate lines of telegraph through and

1 Conway v. Taylor, Executor, 1 Black, 60:3, 17 L. El. 191 (1861); Fanning r. Gregoire, 16 How. 5:4, $14 \mathrm{~L}$. Ed. $104:$ (18.j3).
2 Western Union Tel Co. s. Call Puib. Co., supra.

${ }^{3}$ Aet of July 1, 186 ?

$\$ 3$ Compiled Statutes, p. 35:9, Title 6.5. 
over any portion of the public domain of the Cnited States, orel and along any of the military or post roads of the L'nited states which have been or may lierealter be declared such by lat and orer. along and across any of the navigable waters of the lnited states.'

This act of 1-riti was construed by the supreme court ${ }^{2}$ as. in afrect amountine to a prohibition of all state monopolies in the telegraph husiness between the states. The court said that it Wils a legitimate regulation of commercial intercourse between the states and wats proper legislation to carry into execution the pwers of concress over the postal serrice. The statute did nut extend only to such militiry and post roads as were upon the public domain. The state law of Florida conferping exchusive privileges upon a state telegraph company was dechared to be in conflict with the legislation of congress.

This act of 1 riti was permissire only The privilege conferrel carred with it no exemption from the ordinary burdens of taxition in a state where the companies owned or operated lines of telegraph," nor dirl it carry with it any unrestricted right to appropriate public property of a state or city, but it was like any other franchise, to be exercised in subordination to puhlie as well as private rights. ${ }^{4}$

The act of lyitio does not ariant to telegriph companies accentury its provisions the power of eminent domain over the privite property of railroal companies. A railroal right of Way is not public property though often called a highway and subiect to a certain extent to state and federal control. A tele. grilfit company camnot, therefore, under the act of 1 refi, occupy a milmal right of way except by the consent of the railroal

1 The art also provided for the $11, \mathrm{~s}$ uf materials from the public lamls,

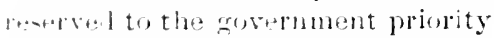
wor other business and turther proviled for l he purchane by the Cnited States for pontal, military or other furpwes. all the froperty and efrects rf cumpanies acting under the act at an alpraised value to be ascertainel ly five competent, disinterrited frerons. two of whom were to

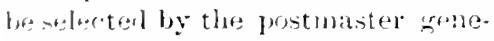
ral, twr by the company interester and one by the four previously selecterl.

2 Pensacola Telegraph Co. v. Western Union Telegraph Co. 96 C.S. 1 (15ri). 24 L. Edl. 70s. ill.

3 Westan Union Tel. (o. v. Masis-

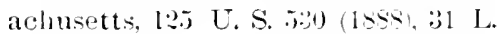
E(I. 790.

${ }^{4}$ St. Louis r. Western Union Tel.

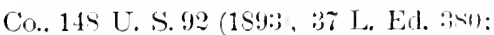
Westem Union Tel. Co. v. Ann Arbor R. R. Co. 1is U. S. 239, 44 L. Ed. 10.j\} $(1961)$. 
or under the power of eminent domain; and in the absence of federal or state prorision for the exercise of such right of eminent domain, the railroal right of way can be oceupied with telegraph poles only with the consent of the railroad company. ${ }^{1}$

The Interstate Commerce Commission is rested with jurisdiction over the government-aided telegraph lines constructed under the l'acific Railroad Act by the act of $18 x-, 2$ whereunder the commission is required to ascertain the facts and determine and order what arrangement should be male for the interehange of business required by the act, and it was made the duty of the railroad and telegraph companies to file with the Interstate Commerce C'ommission all contracts relating to the control and use of their telegraph lines and to file amnual reports with the commission as to their condition and business. The Supreme Court, construing this act, held that it was a lawful exereise of the powers of congress and that a contrict between the Cnion Pacilic Riallway and the Western Lnion Telegraph Company, giving the latter company control of all telegraph business on its roals, was void. 'The act in this case required that the railroats should exereise by themselves alone all the telegraph franchises conferred upon them, and to allow equal facilities to connecting lines on terms just anl equitable; the right of connection with equal facilities being given to any railroad which had accepterl the provisions of the act of $1-60.3$

\section{Interstate telephone companies not included in the} act of $1866 .-$ The provisions of the Telegraph Act of July 24 , 1866 , did not apply to interstite telephone companies whose business is that of transmitting articulate speech between different points. ${ }^{+}$The telephone company in this case claimed

I Western Union Tel. Co. v. Pennsylvania R. Co. 25 Sup. Ct. Rep. 151$1 \pi \%(1904)$.

$\because$ The Act of August 7.1885, p. 3582.

"See also United States v. North"rn Pacific R. Co. 120 Fed. Rep. 546. where the circuit court held that a contract of the Northern Pacific R. jo. with the Western Union Telegraph Company was not violative of the act, as it provided for the exclusive use of one or two wires by the railroad company, for which the rail. roud company agreed to pay one. third the cost of construction and to transport the property and employees of the telegraph company in constructing and maintaining the line, free of charge. This case wat therefore distinguished from the Union Pacific case.

${ }^{4}$ Richmond v. Southern Bell Tele. graph \& Telephone Co., 1it U. S. r61, $43 \mathrm{~L}$. El. 116? (1s99), reversing the circuit court, is Fell. Rep. 8.5, and the circuit court of appeals, s.j Fed. Rep. 19, and 28 C. C. A. 659 
that it was entitled, under the act of 1866 , to occupy the streets of Richmond with its lines without the consent and against the will of the municipal authorities of the city.

This claim was sustained by the circuit court, but the Circuit Court of Appeals, while holding that the plaintiff was entitled to avail itself of the provisions of the act of 1860 , adjulged that the rights and privileges granted by that act are to be enjoyed and subject to any lawful exercise of the police power belonging to the state, or one of its mnnicipalities. The supreme Court held that the Circuit Court of Appeals was correct in this view as to the scope and effect of the act of 1866 , but that conrt, as well as the circuit court, was in error in holding that the act of 1866 was applicable to telephone companies. The court said it was immaterial that the business charter described it as a telephone and telegraph company. It might be true, said the court, that if the telephone had been known and in use when the act was passed, congress would have expressed in its provisions, companies employing instruments for electrically transmitting articulate speech, but that nothing in 1860 was known of the telephone, as Bell's invention was not made public until 1876 . When, therefore, the act of 1566 speaks of telegraph companies, it only meant such companies as employed the means thus used or embraced by existing inventions for transmitting by sounds or by signs and writing.

There is no federal statute regnlating interstate communicatıon by telephone, ${ }^{1}$ thongh it is clearly includer in interstate commerce, as defined by the courts.

\section{S.: The release of the federal regulating power.- In-} terstate commerce may be regulated not only by the action of concress, but also by its inaction, as where the subjects require unilorm regulation, the inaction is equivalent to a declaration that the commerce must be free. There is also a form of regulation, already referred to, where congress divests particular subjects of their commercial character, thus subjecting them, when delivered to their consignees in the original packagres, to the police power of the state (supra, $\$ 9)$. It was contender in the Rahrer Case ${ }^{2}$ that the Wilson Act of 1890 was

1 The act of February 28, 1902, 3 Comp. Stats. 226. grants the right of wity for the railroal and telegraph and telephone lines through Oklahoma and Indian Territories.

2 sumra, $1 \pi$. 
void, as the power of regulation vested in Congress could not be delegated to the states. The court held that this was not a delegation of the federal power, but was merely a designation that certain subjects of interstate commerce should be governed by a rule which divested them of that character at an earlicr period of time than would otherwise be the case. ('ongress, said the court, did not use terms of permission to the states to act, but simply removed an impediment to the enforeement of the state laws created by an absence of speeific utterance on its part in respect to imported pacliages in their original condition. It imparted no power to the state not then possessed, but allowed imported property to fall at once upon arrival within the local jurisdiction.

In the later Iowa case, ${ }^{1}$ May, 1898 , the compt, in holding that the term "arrival" meant lelivery to the consignee, said that the act of 1590 was not to be construed as authorizing states or state laws to forbid the bringing in to the state at all. In other works, the power of the State did not attach to the acts until the termination of the interstate commerce shipment, and that did not occur until the actual delivery of the shipment to the consignee. The court said this construction of the act of 1890 renclered it unnecessary to consider whether, if the act of Congress had submitted the right to make interstate commerce shipments to state control, it would be repugnant to the constitution.

The right of Congress, therefore, as aljuclged in these cases, to surrender its regulating power only extends to the limitation of the original package rule as to a certain class of commodities, so that they should lose their interstate character and become subject to the police power of the state when delivered to the consignee, and not when, as is the case with other shipments, the original package is broken up or sold and thus hecomes merged in the general mass of property in the state.

\section{53. Regulation by the delegation of power.-Congress} in its legislation upon interstate commerce has vested in the Interstate Commeree Commission certain discretionary power in the enforeement of the statutes. Thus, in the Interstate Commerce Act in section 4 , the commission is authorized in

${ }^{1}$ Rhodes $v$. Iowa, supra, page 26 , note 4 , page $2 \pi$, note 3. 
special cases, alter investigation, to grant an exemption to the carriers from the requirement of the section, that no greater rate shall be chalrged uncier substantially similar circumstances and conditions for a shorter than for a longer distance over the same line, and the commission is authorized from time to time to prescribe the exteat to which such carrier may be refieved from the operation of salid statute. Also in the socalled safety Appliance Aet, the commission is, under section 7 , authorized to grant an extension of time within which the common carriel may comply with the requirement of equipment with automatic car couplings prescribed by the act.

Inder the act of Warch 3,1 s.9., concerning the construction of bridges over navigable livers, the secretary of war is not only vested with the duty of approving plans for the construction of brideres, but is, moler section 11, given the porrer to establish harbor lines, and under section :; to permit in his discretion temporary deposits in the rivers.

These cases seem to be within the rule declared by the Supeme Court ${ }^{1}$ in sustaining the powers conferped upon the President by section :3 of the act of 1890 to suspend hy proclamation the free introduction of certain articles when satisfied that the contry prolucing them imposes duties upon the products of the inited states. The court said this was not a delegation of legislative power, bnt merely made the presiclent the agent of the law-making department to ascertain and dechare the event upon which its expresserl will was to take ellect. He had no discretion in the premises except in respect to the duration of the suspension order, and that related only to the enforcement of the policy established by congress.

\section{Adlitional acts of congress in the regulation of} commeree.- congress in recent years has enacted several laws in the regulation of interstate commerce. The act establishing a Bureau of Animal Industry, for preventing the Exportation of liseased (attle, and for the extirpation of disease among domestic animals, enacted May 2!), 1954," was held by the supreme court "not to corer the subject of transporta-

1 Field v. Clatk, $14: 3$ C.S. 649 (159?), 30 1. Fil. 294. Sine isloo Buttield v.

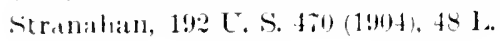
E.i. i.j.
21 Compiled Statutes. 1. 299; see also Act of Aurrust $30,1890,: 3 \mathrm{Com}-$ piled statutes, 3182.

3 Reill s. Co'oraldo, supra, p. 41, n. 1. 
tion of live stock from state to state, so as to preclude the enactment of state legislation for the protection of the property of the state.

In 18.13 congress exereised its power of regulation in another class of cases by the passing of the act to promote the safety of the employees and travelers upon the railroads, and eompelling common carriers who engarged in interstate commerce to equip their cars with antomatic couplers and brakes, and ther locomotives with driving wheel brakes. See intires sint it sy.

In 1901 was passed the act requiring common carriers engaged in interstate commere to make full reports of all ace:dents to the Interstate Commerce Commission. (Act of March:? 1901, infial, 87201 This act in its requirement of reports is not lmited to aceidents to trains engaged in interstate commerce, but includes all accidents on the railroals "engaged in interstate commerce;" and a ralload is so engaged within the regulating power of congress when it makes through shipments by through routing in interstate commeree. This act does not seem to have been judicially construed.

Recent legislation by Congress in the regulation of interstate commerce includes the prohibition of interstate carriage of obscene literature," of game lilled in violation of state laws,3 condemned careasses of animals, ${ }^{4}$ lottery tickets, ${ }^{3}$ dairy products falsely labeled or brandel as to the state or territory in which produced."

Congress has also empowered the Secretary of Agriculture to establish rules concerning exportation and transportation of live stock and issue certificate of freedom from diseas, and providing for admission of cattle so certified into any state without further inspection or fees.'

1 The Interstate Commerce Com. mision in its annual reprort for 1904 discusses at length the subject of the increasing number of railroal accidents and strongly recommends legislation by congress requiring the aloption of the block system and the block signal. Also recommends that the reports of accidents in the annual reports of the commission be abolisherl and that the law should be male to require monthly reports to rover all classes of accidents.
Act of February 2, 1s97, 3 Comp. Stat. 3181 .

3 Act of May 25. 1900, \& Conup. Stat. 3181.

${ }^{4}$ Act of May 2, 1s95, 3 Comp. Stat. 319.

s.sinde, 5 .

"Act of July 1, 1902. Supp. Comp. Stat. p. $3 \pi 1$.

Act of February 2, 1903, Supp. Comp. Stat. p. 3\%2. 
The police power of the state was extended to oleomargarine, untterine, ete., as it had theretofore been extended to liynor's in the "original packige." 1

As to the anti-trust legislation of congress and also legislation in relation to the relations of labor and capital in interstate commerce, see chapter IV, intide," Business and Labor combinations in Interstate commerce."

concress has also legislated extensively in regard to transportition by water in the navigation acts. The Interstate commeree det only regulates water transportation, when the trinsportation is partly by railroal and partly by water under a common control or management.

.j. The Department of Commerce and Labor. - In 1903 congress established the department of commerce and labor, the secretury at the heal being male one of the executive officer's of the grovernment and as such one of the President's adrusers known as the Cabinet."

This department ineluded several of the bureaus theretofore included in other lepartments. and among others the Department of Iabor, which had been established by congress in $1 \cdots$

Section : of this act establishes a Bureau of Manufactures, and section is a liureau of Corporations, which is rested with the same power and authority of investigation in respect to corporations and combinations engaged in interstate commerce as is conferred on the Interstate Commerce Commission in respect to railroals. The commissioner of corporations is given pwers of investigation, with the right to summon witnesses and call for the production of books and papers, subject to the same immunities against the enforcement of self-incriminating trstimony, as is contained in the act of 1893 concerning the Interstate ('ommerce Act.'

This act inchules in section 4 , as subject to the in restigation of the commissioner of corporations, corporations engalged in insurince. It has been adjudged, supha, 8 , in successire opin-

1. Act of May 9, 1902, Supp. Comp. Sitit. 1.:2,190.

2. Act of Feliruary 18, 190:3, Supp. Comp. Stats. 1. 41 .

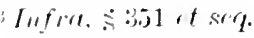

4. Ar to the construction of this act, see infira, $\leq 4$ : also Interstate Commerce Commission v. Brimson, 1it U. S $44 \pi, 38$ L. Ed. 104\%; Interstate Commission v. Baird, 194 U. S. 25, 45 L. Ed. $s 60$, inf $r a, \leqslant 36$ s. 
ions of the Supreme Court, that insurance is not commerce in any of its forms. ${ }^{1}$

This act has not been judicially construed. The ferleral government has obriously no visitorial power over corporations which it does not create, and the power of the commissioner to make investigations or to compel reports would be clearly limited to transactions in interstate commerce, to the same extent as the powers of the interstate commerce commission are limited to transactions in interstate as distinguished from domestic commerce.

While the powers of the Burean of Corporations are described mainly by reference to those contained in the Interstate Commerce Act, the latter is a quasi judicial body, in the sense that it is empowered to hear complaints and make charges and findings for judicial investigation and determination, while the Commissioner of Corporations is at the head of an administrative department of the government. The powers of investigation rested in this bureau are to be used for the purpose of assisting the legislative department in making laws, and the executive department in enforeing them. The commissioner has no judicial powers, and within the scope of his duties must appeal to the courts for the enforcement of his orders. ${ }^{2}$ The

1 The Commissioner of Corporiltionsin his first annual report. December 1904 , says that if this prurpose is irrerocably settled. the powers of the commissioner relative thereto are of purely a statistical, voluntary, non-compulsory nature. He sug. gests however, that in view of the lapid developement of the insurance business, its extent, the enormous amount of money and the diversity of interests inrolved and the present business methods, that under existing conditions, that insurance is commerce and may be subject to federal regulation through affirmative action by congress.

It is difficult to see, however, if the supreme court adheres to its present rulings, how the jurisdiction of Congress can be enlarged by its own declarations of the extent of its porrers.
2 It is said in the very exhanstive first annual report of the comminsioner. Hon. James R. Garfield, "that miny of the specific powers of the Interstate Commerce Commission are clearly inapplicable to the purpose of the Burean of Corporations. He cannot make investigations or procure and enforce information by means of his compulsory powers for the purpose of enforcing the penal provisions other than those contained in the organic act of the burean, nor can he furnish information so procurerl to private individuals for their personal use. His compulsory investigatory powers are further limited by the rights of prisacy of the citizen which may not be invided by inquiry except for a definite, constitutional and legal object, and only such matters may be investigated as relate to and give information upon 
statute has not been judicially construed, nor has any appeal been made to the courts to enforce its powers of investigation by compulsory testimony or production of books. ${ }^{1}$

siti. The umexercised federal power.- - In determining the possible limits of the unexercised federal power in the regulation of commerce, there is comparatively little in the way of direct julicial anthority. The supreme Court has frequently been called mon to decide, and has decided, what the states camnot do. and it is from the expressions in these negative opinions that we are compelled to rely in determining what congress can do, that is, what are the limits of the regulating power of concress. The law of interstate commerce is essentially judge malle law. supplemented in comparatively recent rears by the exercise of the regulating power of congress. The supreme ('ourt has repeatedly declined to formulate a general rute as to the precise line where the power of congress begins and the power of the state ends." It was on this question of the conflict between the admitted powers of the state and of the federal government, that Chief Justice Marshall said that the power and the restriction on it, though quite distinguishable when they did not approach each other, may well, like the intervening colors between white and black, approach so neariy as to perplex the unlerstanding, as colors perpox the vision in malking the distinction bet ween them."

In the recent lottery case the extent of the federal regulating power was directly presented and exbanstively discussed, and by a bare majority of the court the feleral power to prohibit interstate traflic in lottery ticliets was sustained, but it was sitil in tlie previliling opinion that the whole subject was too

the objects of the bureau and its (urk:."

1 ( 'ommissioner farfield says in his report of Iecember 1904, "In lsrief, the policy of the bureau in the ac(omplishment of the purposes of its rreation is to co-operate, and not an. tagonise, the business worlu. The mmerliate object of its inyuiries is the suggestion of constructive legislistion, not the institution of criminal lecrislation. It proposes through exhaustive mrentigations of law and fact to secure conserrative action, to avoid ill considered attack upon corporations which will aroid unfair and dishonest practices. Legitimate business law respecting persons and corporations have nothing to fear from the proposed exercise of this govermmental power of inquiry:"

2Welton v. Missouri, 91 U. S. 275 (1875), 2:3 L. Ed. 347: Hall v. De Cuir, 9.5 C. S. 4रं, 24 L. El. 54\%.

"Brown v. Maryland, 12 Wheat. $419(1$ s) 6 , 6 L. Eil. 6is. 
important and the question sugrested by its consideration too dilficult for solution, to justify any attempt to lay down a rule for determining in alvance what could be enacted by congress unler the commerce clause. See Lottery case, supre.

The power of congress in the regulation of interstate commerce has been impliedly declared by the supreme court with reference to the Interstate Commeree Act in several cases lecirled, involving the construetion of that act. Thus the comrt has pointed ont the possble limits of the power which congress could have delegated to the railway commission, saying that congress could itself have prescribed the rates, or could have committed to some subordinate tribunal this duty; but it helel as a matter of construction of this act that congress had not taken either of these permissible comrses in the commerce act.'

This unexercised federal power has been discussed $(\Leftrightarrow u p m$. $\$ 45$ ) in connection with the proposed anendment of the Interstate Commerce let. While it seems to be conceded that con gress has the power to regulate rates or to delegate that legislative power to a commission, this power must he excereised subject to the guarantees of the "due proeess of law," and against the taking of private property for public use withous compensation. In the exercise of this power, congress, or any commission under the authority of coneress, is restrained by the provision that " no preference shall be wiven to any regulattion of commerce or revenue to the ports of one state orer those ol another." "Ports "of entry are now not only on the seaboarl, but are seattered through the interior, and the application of this prorision to the federal reculation of carrier"s charges in the recognition of "diflerentials" between compet-

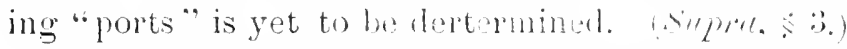

A wille field for the possible exercise of the feleral power of regulation is fonnt in the chass of cases wherein the court has adjulged that thestates have a concurrent power of legishat. tion in the non-action of congress. In other words, congress can act in cases wherein it has heretofore exereised its power of regulation by its non-action. Thus, in cases where congress has heretofore allowed local regulations to control, and also in the cliss of cases where the court has suntained state statutes

${ }^{3}$ Interstate Commerce Commission v. Railway Co, 16\% U. S. Fia, l. c $494(189 \%), 42$ L. El. 24:3, 251. 
or state laws regulating the relations of interstate carriers to their patrons. In such cases the court has said that as long as congress has not legislated in aid of interstate commerce, they are to be revidrided ats a rightful exereise of the police power of the state in regulating the lawful duties of persons and corporations within their limitations. ${ }^{1}$

There is therefore a wide legishtive ascretion in congress to determine when a subject is capable of uniform regulation in interstate comnerce, aml when it is so determined. all locil or state legislation in respect to such matters and covering the same gromul cease to hare the same force whether formally abro rated or not, and the regulations prescribed by congress will then alone control. It is for the supreme court to determine, when al question arises, as to whether a state law is thus abrogated by the exercise of the power by congress. The pwer which the states can thus exercise will in this way be suspended until the national control is abolished and the subject thereby again left under the control of the states. ${ }^{2}$

s. Prohibition and regulation.- The most important and indeed the fundament 1 question in rolved in the extension of the federal regulation of commeree was discussed, but not definitely decided, in the Lottery Cases. It was there strongly contended that the power to regulate commerce did not inchule the power to prohibit. as the power delegated to conaress was for the purpose of securing the freedom of interstate commerce and preventing the hostile or discriminating ation of the states. and was thereby distinguished from the wrereign control over foreign commerce. and that congress hawl no ganeral police powers such as are reserved to the states. This riew was strongly maintained by the four dissenting junleres.

The prevailing opinion did not directly dispute or disclin the pesition of the dissenting judges. and declined to formu late any greneral rule as to the powers of congress, but based the position of the majority upon what was essentially the molial view, that the lottery business hat grown into such dis-

Pennsylvania R. Co. v. llughes. 191 C. S. 477, l. c. $49(1+199 \%), 45$ L. Ed. aj).
'Rejal s. Colorallo, $15 \%$ U. S. 137 (1903), 4\% L. Ed. 108.

${ }^{3}$ Justices Fuller, Brewer, Shiras and Peckham. 
repute and had become offensive to the people of the country, and was a kind of traflic that no one was entitled to pursus as of right, and that under the circumstances of the particular case prohibition was an appropriate method of regulation. The decision was therefore limited to the single point that lot. tery tickets were subjects of traflic and that congress could lawfully prohibit such traftic. ${ }^{1}$

The power to prohibit is necessarily in rolverl in any effective federal control of the corporate agencies engaged in the conduct of commerce, whether throngh federal incorporation or any form of fecleral franchise, that is, to make the fecleral srstem effective its adoption must be mate compulsory. The lottery decision related to the suljects of commerce and did not involve the power of congress in controlling the corporate relations of parties engaged in commeree. The presailing opinion rests, in the final analysis, upon the broad ground that it is for congress to determine when the publie good requires the use of prohibition as a form of regulation of interstate commerce.

\section{Regulation of commeree throngh the taxing power.} Interstate commerce may also be regulated through the exercise of the taxing power by congress. While congress bas not an unlimited power as to the purpose of taxation, and can lery taxes only in order to pay the debts and provide for the common defense and general welfare of the United States. ${ }^{2}$ it is also true that under the permanent revenue system of the gorernment, taxes are levied, not for specific purposes, but by continuing laws establishing the rate of customs duties and internal revenue taxes, and questions relating to the lawful purposes of taxation do not arise in levying revenue taxes but in the appropriation of public funds for public needs.

It is well recomized that the power of tixation is sometimes invoked with no purpose of revenue in view, but solely to destroy the interest or business upon which the tax is levied by

1 The court had sustained a statute excluding lottery tickets from the mails. See In re Jackson, 96 U. S. 72\%. 24 L. Ed. 8\%, and In re Rapier. 143 U. S. 110,36 L. Ed. 93 . This was on the ground that as congress furnished postal facilities it had the right to say what should be carried therein. But it was said that congress could not prevent the carriage of such tickets by other means, though they were excluded from the mails.

$\because$ Story on the Constitution, sec. $90 \%$. 
taxing it out of existence. Thus the notes of the state banlis. were taxed out of existence in order to open the means for circulating the notes of the national banks. This act was sustained by the supreme conrt. ${ }^{1}$ The court said that it was immaterial that the tax destroyed the business or franchise exercised under state anthority While the only lawlul purpose of taxiltion is revenue, the amount of the tax on any subject within the scope of the taxing power is for the legislative diswetion to determme. In the words of chief justice Marshall in Mcculoch v. Maryland," "it is a perplexing inguiry unfit for the julicial department, what degree of taxation is a legitinate use and what degree may amount to an abuse of the power." A tax on oleomargarine, as is well known, was imposed for the arowed purpose of destroying the business. It therefore follows that congress, subject to the constitutional requirement of geographical uniformity ${ }^{3}$ and to the limitations of direct taxition, ${ }^{+}$could impose indirect taxes and excises on subjects and facilities of commerce or upon the privilege of cirrying on such commerce, whether by individuals or corporations, and that the amount of such taxes would be determined by the discretion of congress.

\subsection{The federal power of granting corporate charters.-}

Th. mesereised or undereloped power of congress in interstite commerce is now discussed more particularly with reference to the power of congress in federal incorporation of business or trading companies. Interstate and foreign commerce unter modern business conditions are almost wholly carried on ly corporations chartered by the sereral states. The states therefore have the sole visitorial control of the organization of the business associations, through and by which the interstate and foreign business, subject to the exclusive jurisdiction of contress, is carried on. The diflieulty of effectual governmental resulation of such commerce is apparent.

The power to charter a corporation is not among the enumerited powers of congress, but in the great case of Mc('ul-

1 Veazie Bink v. Fenno, s Wall.

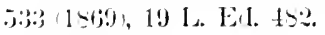

$\therefore$.

"Heal IIoney Casns. 11: U. S. j>0, 2) L. Ed. igs: Knowllon v. Moore, 1is C.S. 41, 44 I. Ed. 969 \%.
4 Income Tax Cases, 15s U. S. 601. 39 L. Eil. 108: Nicol v. Ames. 1 i3 U. s. .00, 43 L. Ed. is6; Knowlton $v$. Moore, suprat. 
loch v. Maryland ${ }^{1}$ the court based the power to charter a national bank upon the right of congress to adopt incorporation as a reasonable means of carrying into effect its enumerated powers. "Incorporation," said the court, "is never marle the end for which their powers are exercised, but a means by which their objects are accomplished." . . "The power of creating a corporation is never used for its own sake, but for the purpose of affecting something else." The bank, therefore, was lawfully incorporated as a means of managing the great fiscal concerns of the government. The constitutionality of the national banking act of $156 t$ was based on the same principle. The national banks organized nnder the act, said the court, were the instruments lesigned to be used to aid the government in the administration of an important branch of the public service. They are means appropriate to that end. ${ }^{2}$

Congress also has the power to incorporate railroad companies to carry on interstate commerce, ${ }^{3}$ and to charter a corporation for constructing a bridge over a narigable stream forming the boundary of two states and condemn the property for approaches thereto. ${ }^{4}$ The power to incorporate was sustained as a reasonable and proper means of regulating commerce between the states, since corporations were direct instrumentalities for carrying on interstate commerce.

A corporate franchise involves the power to be, and also the power to do. Congress has the power to grant a corporate franchise for the construction of national highways. The supreme conrt in the Pacitic Railroad Tax cases," said that in former times this power was exercised very little, as commerce was then conducted wholly by water, and many of our statesmen had entertained donbts as to the existence of the power to establish ways of communication over land. But since the expansion of the commerce of the country, the multiplication of its products and the invention of railroals and locomotion by steam, land transportation has so vastly increased, that a sounder con-

14 Wheat. 316, supra.

2 Farmers, etc., National Bank v. Dearung, 91 U. S. 29 (18ij), 23 L. Ed. 196.

${ }^{3}$ Pacific R. Cases, 115 U. S. 2, 29 L. Ed. 319 (185.5); California v. Pacific
Railroads, 127 U. S. 1, 32 L. Ed. 150:

Decker v. R. R. Co., 30 Fed. Rep. 723.

4 Luxton v. North River Bridge Co., 153 U. S. 525, 38 L. Ed. S0\%.

5127 U. S. 1, supra, note 3. 
sideration of the subject has prevailed and led to the conclusion that congress had plenary power over the whole subject.

Congress has granted charters of incorporation with franchises to be exercised in the I)istrict of ('olumbia, as insurance companies. ${ }^{1}$ and savings banks and trust companies. ${ }^{2}$ A federal charter was also granted to the Maritime Nicaraugua Canal Company for facilitating intercourse between the Atlantic and Pacific oceans. ${ }^{3}$ The National Trades Lnion incorporition act, infin, $\$ 3 r$, contains no reference to interstate commerce except that the members must be resident in two or more states. To incorporation had been formed under this act up to Jinuary 1,1005 .

(5). Xational incorporation as a means in the exercise of the commerce power.... Is congress can exercise this power of incorporation as a means and not as an end. its power of incorporation under the commerce clause would necessarily therefore be limited in its grant to the carrying on of interstate and foreign commerce, with such corporate powers as would be fairly inciciental to such general grant. Congress las no power orel the business of manufacturing, mining or other local productive industries contucted in the states, ${ }^{4}$ and therefore such powers could not be granted by congress, nor exercised under a congressional grant.

It has been suggested" that a "franchise to proiluce," as by manufacturing. would be an incidental and essential franchise to sell, and, therefore, congress would have the power to grant prolucing franchises as essential to the carrying on of interstate commerce. This position seems clearly untenable in riew of the distinct declaration of the supreme court in the Knight case, that commerce is incidental to manufactmre and succeeds to it, but is not a part of it, and that the jurisdiction of congress relates to commerce alone. As said in that case and in an earlier case, ${ }^{6}$ the result of a contrary ruling would be that congress would be invested to the exclusion of the states with the power to regulate every branch of human industry.

1 Act of February $14,156, j, 13$ Stats. 125.

2. 1 ct of March $8,1 \mathrm{~s}, 5,13$ Stats. .i19.

3 . Act of February $: 0,1899$, 25 Stats. 6i.j.
4 United States v. Kuight Co., silpmo.

ispendix A to Report of Commissioner of Corporations, Dec. 1904.

"Kind s. Pearson, 128 C.S. 1. 3: L. Eil. :;il. 
A corporation or ranized to engage in interstate and foreign commerce would necessirily buy in order to sell, and such purchases and sales, both domestic as well as interstate and foreign, conk be held incilental, as essential to the exereise of the federal grant. The power "to produce," howerer, woukl involve manufacturing, minng and the whole range of locil productive industries, and their regulation and control by federal authority, under the commeree power would essentially revolutionize the whole frime-work of our government, with its distinct divisions of the powers of sovereignty between the state and federal governments.

The difliculty does not lie merely in the conflict with the sovereignty of the state, which has exclusive juriscliction over the business of manufacturing and producing within its borders, but in the limitation of the feleral government to the powers expressly granted and to those which are fairly and reasonably incidental to those expressly granted.

\$61. Relation of the states to fesleral corporations.-Assuming that corporations are chartered by congress for the carrying on of interstate and foreign commerce, their status in relation to the state government can be determined by analogy from the relation now held by national banks, which are organized under federal law, and by interstate railroud corporations organized under federal litw, and corporations, as railroat companies, transacting interstate business, though chartered under state law.

National banks are not chartered under the commerce clause, but as banks of deposit and discount their ordinary business does not differ in any wise from that of the state banks in the same communities.' The Pacific railroads were incorporated by Congress, and though chartered by the federal power, they transact local as well as through business, and as to the former are subject to the laws of the states where they operate." It would seem, however, from expressions in the opinions cited, that this subjection to state control in the regulation of local

1 The Secretary of the Treasury. December 1904, recommends that congress should make prorision for the incorporation and regulation of trust companies.
2 Reagan r. Mercantile Trust Co., 154 U. S. 413 (1894), 38 L. El. 1028; Smyth v. Ames, 169 U.S. 466 (1:95), 42 L. Ed. $\$ 19$. 
rates results from a failure of congress to cxpress any intention in the acts of incorporation that the company should be exempt from state control.

Assuming, therefore, that congress should incorporate companies for the purpose of carrying on interstate and foreign commerce, such companies could make domestic as well as interstate and foreign sales. Congress would have visitorial power over such corporations, as it has over national banks, but its domestic business would be subject to state regulation and control, as the domestic business of interstate carriers is subject to such state control. The state power of taxation of property within its jurisdiction could be subjected to the state taxing power as that of national banks is now so subjecterl. The franchise "to do," that is, the franchise to transact interstate and foreign commerce, which would be held by such corporation uncler the feleral grant, would not be subject to state taxition, and neither the right to transact such business, nor such interstate and foreign business conducted by state corporations would be subject to state taxation; but the "business" so exempt is to be distinguished from the property employed in the juristiction in the transaction of the business.

It has been suggested that federal incorporation of business companies would be ineffective without a "franchise to produce," as states could pass discriminating laws prohibiting sales to such corporations. It is obvious, however, that any state statutes interfering with or discriminating against federal corporations in the excreise of their ferleral frinchise, would be clearly riolative of the federal supremacy in the regulation of interstate commerce. ${ }^{1}$

\section{$6 \%$. The requirement of feleral franchise for business} corporations in interstate commerce.- Another method of proposed regulation of interstate commerce is through the requirement of a federal franchise for state corporations to transact interstate commerce. This is the method recommended

1 See barton v. Iowa, 1s U.S. 220:

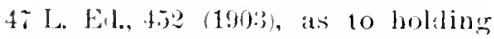
void attempted state regulation of national banks.

On this general subject of the in corporation power of congress. see adlress of J. B. Dill before Harvard university, March, 190:', Yale Law Journal, 1909, on A National Incorporation Law for Trusts: Professor IIorace L. Wilgas, Michigan State University.Law School, in Michigan 
by the commissioner of corporations. ${ }^{1}$ Assuming that sueh a system was adopted, its effectiveness would of course depend upon its exclusireness. Thus, colporations not having such federal license would be concluded from the transaction of interstate commerce. It is true also that if a system of ferleral incorporation was alopted, it would not be effective if its aloption was voluntary, as under the present system corporate charters are sought from the states which are the most liberal in their incorporation laws. The adoption of federal eharters could doubtless be made effective through the exercise of the federal power of taxation, as the same power was effective in the establishment of the national banking system.

The requirement of either method, therefore, would mean the exercise of the power of prohibition by congress by means of regulation, in that corporations not having the necessary franchise would be precluded from transacting interstate commeree. Such a policy as to the parties transacting interstate commerce would be essentially novel, as the power of prohibition has been heretofore exercises only as to the suljects of commerce, as in the lottery cases.

Law Review, February and April, 1904; report of Industrial Commission, Vol. 19 , pp. 644 et seq.; also report of Committee on Commerce of American Bar Association of 1904 ; W. S. Logan in thirty-seren Law Review, March and April, 1903; Carmon F. Rantolph in Columbia Lhw Review for March, April an! Nay. 1903; bill of H. W. Palmer, 5sth congress, H. R. 66. See also address of Professor Wilgus before State Board of Commissioners for Promoting Uniform Lergislation, September 29, 1904, published by George Wahr, Ann Arbor. Mich., "Should there be a Federal Incorporation Law for Commercial Operaations?"

$1 \mathrm{Mr}$. Garfield, the commissioner of corporations, in his first annual report. December, 1904, recommends that congress consider the advisability of enacting a law for the regulation of interstate and foreign cor- porations, under license or franchise. which should provide a federal franchise or license to those engagerl in interstate commerce and a prohibition of all corporations or corporate agencies from engaging in interstate or foreign commerce without such federal franchise or license, and to include the imposition of all necessary requirements, as to corporate organization and management, as a condition precedent to the granting of such federal franchise or license, with the right. to refuse or withdraw such franchise or license in case of violation of law. with the proper right of judicial appeal to prevent abuse of power.

See reciew of this report in the Michigan Law Review of February, 1905, by Professor H. L. Wilgus, "Federal License or National Incorporation." 
The supreme court held ${ }^{1}$ that a state statute providing that an agent of an interstate express company should take out a license showing that the company he represented was possessed of a capital of $\$ 150,000$, was invalid. The court said that to earry on interstate commeree was not a franchise or a privilege granted by the stite, but a right which every eitizen of the Cnited States was entitled to exercise under the constitution and laws of the United States, and the accession of mere corporate facilities in earrying on their business could not have the effect of depriving them of such right unless congress should see fit to interpose some contrary regulation on the subject. Nlthough this decision was renlered with reference to the power of a state over an interstate express company, it would seem to follow, as the only regulating power is that of congress, that it ean determine what, if any, regulation is required for the conduct of interstate commerce with corporate facilities.

But assuming that congress may have the power to determine on what conditions commerce may be conducted under corporate organizations, or by corporations, it does not follow that it wouk have an nnlimited power in prescribing the terms and conditions of eorporate organization to be exacterl as a condition of such licenses. These requirements, it would seem, should have a reasonable relation to the business of interstate commerce, over which alone congress has the regulating power.

63. 'The developing construction of the federal power in the regulation of commerce.- The developing power of public opinion growing out of changed economic conditions may lonbtless affect in the future, as it certainly has in the past, the construction of the federal constitution as to the federal power over interstate commerce. The commerce clanse, written for the lays of the stage-coach and sailing ressel, has been alapted by judicial construction to the age of steam and electricity. The public opinion of one age or generation, even the thonghtful and judicial opinion, is not that of another. It was the changed economic conditions, the tremendous development of commerce between the states, which forced the way to the judicial recognition of the latent federal powers in the com-

${ }^{1}$ Crutcher v. Kentucky, 141 C. S., 47, 35 L. Ed. 649 (1891). 
merce clause of the constitution, and it cannot be doubted that these influenees will be felt in the future, as they have been in the past. The questions of the present day growing out of the new business conditions, the development ol great combinations both of commerce and of labor, which are diseussed in the succeeding chapter, will doubtless influence the judicial construction of the eommerce elause in the future.

The inherent and fundamental difliculty of construing a written constitution to meet altered economie and social conditions never eontemplated by its framers is illustrated in the close divisions of the supreme court in the Insular cases, the Anti-Trust Railroad cases and the Lottery case, which are in striking contrast with the unanimity of the court in the great constitutional decisions of our early history. In reading these opinions, wherein learned jurists find themselves compelled to reach radically different conclusions, we realize that we are between the "Mighty Opposites," representing irreconcilable forces in our national constitutional and economic development.

It was wisely said by Mr. Lowell that our written constitutions are an obstacle to the whim, but not to the will of the people.

The change in public opinion influencing constitutional judicial construction may result not only from economic or social changes, but from changes in the moral standards of public opinion. This was forcibly illustrited in the lottery cases, where the decision was based on a distinctly moral ground, that lotteries were recognized public nuisances; while at the time of the adoption of the constitution lotteries were a reeognized means of raising money for public, educational and charitable purposes. It would have appeared strange indeed to the framers of the constitution that the federal power could ever be successfully exerted to prohibit interstate traffic in lottery tickets. ${ }^{1}$

I See Waite, C. J., in Stone v. Mississippi, 101 U. S. 814, 818, 25 L. Ed. 1079 (1979). In Cohens v. Virginia, 6 Wheat. 264 (1821), 5 L. El. 25\%, wherein Marshall, C. J., delivered his great opinion on the supremacy of the federal judicial power, the case was that of a party claiming the right to sell lottery tickets in Virginia for a lottery in the District of Columbia. established under a charter granted by Congress in 1812 . 


\section{CHAPTER IV.}

\section{BUSINESS AND LABOR COMBINATIONS IN INTERSTATE COM-}

MERCE.

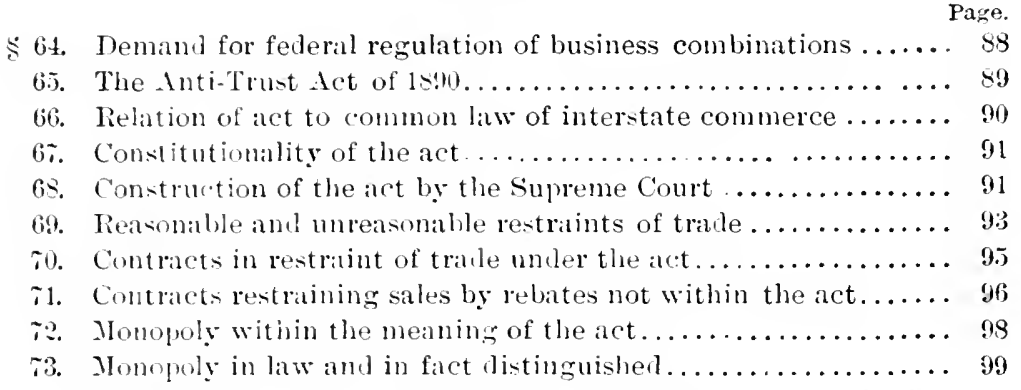

74. No distinction in the act between necessatries of life and other

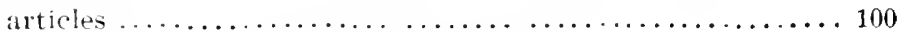

75. No ipplication to commerce within a state............ 102

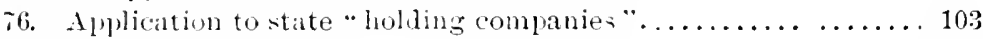

$\approx \approx$ The labo: legrislation of Congress .................... 104

78. Regulation of interstate commerce in relation to labor....... 10.

79. The courts on habor combiuations in relation to interstate com-

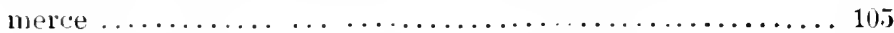

80. The feleral julicial power and labor combinations ......... 106

81. Sympathetic strikes and boycotts by interstate employees . . . 108

s. The law of conspiracy in interstate commerce ............ 11)

83. Distinguished from common-law conspiracy ............. 113

84. Interstate commerce in relation to employees therein ........ 114

5.j. "Pitketing" and "Soliciting" in interstate commerce ........ 116

s6. The relation of interstate railroad employees is that of free con-

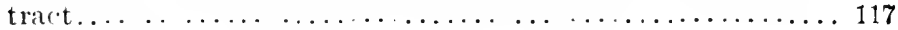

8\%. The right of labor organization includes the right of representation ..................................... 119

s. Injunction in interstate commerce................. 120

89. Contemit in Cnited States courts . .................. 123

90. Manlatory injunctions in interstate commerce .......... 127

6t. The demand for federal regulation of business combinations.- As the demonstrated incapacity of the states to regrulate interstate commerce was the direct occasion for the enactment of the Interstate Commerce Law in $15: \bar{r}$, so the antitrust agritation following thereafter caused the demand for the exercise of the ferleral power in dealing with business combinations in commerce which the states were powerless to control. The distinct economic trend in industrial development, which 
was then manifested in the efforts to save economic waste in the protection and distribution by the concentration of capital in business enterprises, resulted in different forms of combinations for the restriction of competition in business, which aroused public hostility and led to the enactment by many states of anti-trust laws more or less drastic, prohibiting all combinations in restraint of competition. Such laws, however, proved inadequate, as they could have no extra-territorial operation beyond state lines, and the freedom of commerce secured under the constitution of the United States precluded the states from excluding "trust-made" goods imported from other states. Public opinion, which has found frequent expression in judicial opinions, was firmly convinced that the repression of competition tended to monopoly, and that the control of production and prices by the elimmation of competition in any industry was dangerous to the public welfare. It was recognized that the control of prices could be cxercised not merely in raising, but also at certain times in certain localities in unduly depressing them so as to crush competitors by underselling. The evil aimed at was the unregulated power of control over industries resulting from the successful elimination of competition through the extension of the principle of business association.

This agitation in congress and out of it resulted in the passage of the so-called Sherman Anti-Trust Act, which was approved July 2, 1890. While the occasion of the act was clearly the popular outcry against business combinations, it will be seen that in its judicial construction and practical working its main effectiveness has been in its application to interstate railroads and labor combinations.

865. The Anti-Trust Act of $\mathbf{1 5 9 0 . - T h i s ~ a c t ~ w h i c h ~ w a s ~}$ entitled "An Act to protect trade and commerce against unlawful restraints and monopolies," declared illegal and criminal, punishable by fine or imprisonment or both, every contract or combination in the form of trust or otherwise, or conspiracy in restraint of trade or commerce among the sereral states or with foreign nations. ${ }^{1} \quad$ The act prorided penalties for its violation, included contracts made in any territory or the district

1 The Tariff Act of 1894 contained the same prohibition of combinations in the import trade, and this was continued in force by the Tariff Act of $189 \pi, 3$ Comp. Stats. p. 3202. 
of Columbia, and provided for seizure and condemnation of property in the comrse of transportation owned under any contrict made in volation of the act, gave an action to private persons injured by such combinations with threefold damages, and a summary procelure in equity at the suit of the United sitates to prevent and restrain violations of the act. ${ }^{1}$

\section{sib. Relation of act to common law of interstate com-} meree.-Contracts in interstate commerce, and subject as such to the regulating power of congress, in the absence of congressional regulation are controlled by the rules of the common law." There are no common law crimes in the United States, and at common law contracts in restraint of trade, that is in seneral restraint of trade, are not illegal except in the sense that the law will not enforee them. "It does not prohibit the making of such contracts, it merely declines after they have been made, to recognize their validity." ${ }^{3}$ This statite therefore changes the common law, in that it makes contracts in restraint of trate in interstate commerce both illegal and criminal.

It was declared by the supreme court howerer in the Debs case, that the power of the national government over interstate commerce and its right to invoke the power of the courts to renove any obstructions to such commerce, did not depend upon the statute, but on the broader ground of the attributes of sorereignty possessed by the govermment within the limit of its enmmerated powers. It seems also that there is a jurisdietion in equity which may be invoked by private citizens irrespective of the statute, on general principles of equitable jurisprudence, to afford preventive relief against threatened injury about to result to an individual from any unlawful agreement, combination or conspiracy in restraint of trade irrespective of the statute." It would follow, therefore, that without the statute, or if the statute was repealed, the public

1 See infra. s314 et sery. for act in full. with the julicial construction and applieation of the sereral provisioms, and procedure for enforcement.

2 sinpres. 5 43.

"Lord Bowen in Mogul Steamship, (o. v. Mckregror, 23 Q. B. Liv, 59s (1589).
41,58 U. S. 564,39 L. Ed. 1092.

5 (iulf, Colo. \& S. F. R. Co. v. Miami S. S. Co., 5th Circuit Court of Appeals, 30 C. C. A. 142 , l. c. 156 , and 86 Fed. Rep. 407 (1898). See supra, s 43. 
interests and private property rights, could be protected by the civil courts against unlawful combinations in interstate commerce.

67. Comstitutionality of the act.- The constitutionality of the Anti-Trust Act has been sustained by the supreme conrt. Even as construed in the Trans- Missouri Freight Association cise and in the Joint Traftic Association case, that no contract or combination, whether reasonable or unreasonable, restraining trade or commerce in interstate commerce is legal, the act was alljudged not violative of the freelom of contract gnaranteed by the fifth amendment of the constitution of the United States. ${ }^{1}$ The court said that notwithstanding the general liberty of contract possessed by citizens under the constitution, there were many kinds of contracts which were not themselves immoral or mala in se, which may yet be prohibited by the legislatures in the states, or in certain cases by congress. The power existed in congress and the statute was the legitimate exercise of the power of congress to regulate interstate commerce, and the question lor the court was one of power only and not of policy, as the latter question was determined by congress.

8 65. Construction of the act hy the Supreme Court.-The construction of the act by the supreme court disappointed many of the anticipations of its effectireness, as it was held in the Sugar Trust Case ${ }^{2}$ that the statute did not reach a state manufacturing company which was acquiring by purchase of the stock of other refining companies through shares of its own stock, nearly complete control of the manuficture of refined sugar in the United States. The reasoning of the opinion went beyond the construction of the act, and inclicated that the power of congress was exhausted in its designation of the contracts and combinations which were made illegal. Manufacture preceles commeree but is not a part of it, and sale as an incilent to manufacture, therefore, was distinguished from commeree. The monopolies denounced by the act are those in interstate and foreign commerce, and not

1 United States v. Joint Traffic As- v. United States, 175 U. S. 211 (1899), sociation, 171 U. S. 505 (1898). 43 L. 44 L. Ed. 136.

Ed. 259; Addyston Pipe \& Steel Co. 2United States v. Knight Company, 1.56 U. S. 1 (1895), 39 L. Ed. 325. 
those in the manufacture of the necessuries of life or anything manufactured. The court said that if the term "commerce" were held to inclule the regulation of all such manufactures as were intended to be subject to commercial trinsictions in the future, the result would be that congress would be invested to the exchusion of the states with power to regulate, not only minufactures, but all domestic industries, as they all contemphated more or less clearly interstate or foreign marliets.

Combinations between interstate railroals for the suppression of competition are incluled in the act. ${ }^{1}$ In the last cited case it was held that the New Jersey corporation organized as a "holding corporation" for holding the shares of competing interstate railroals was an illegal combination and in restraint of interstate commerce. The Interstate Commerce A.t and the Inti-Trust let are not inconsistent and both statutes stand. P'rior to the passage of the Interstate Commice Act. combinations had some times endearored to regulate competition and rates by pooling, and that form of combination was specifically forbiduen by section 5 of the Intratate Commerce Act."

While the act has been construed to include combinations where the direct, immediate and intended effect is for the suppression of competition in interstate business, ${ }^{3}$ it does not include agreements and regulations which are nothing more than charges for local facilities provided for the transaction of commerce, or which only incidentally affect interstate commerce. It is not restraint of trade that is mate illegal by the statutes, as that may be the incidental effect of a valid agrement. or conduct, but it is the making of a contract which is, or is intended to be, in direct restraint of trade.5

1 Cnited states v. Freight Associ-

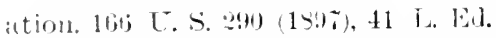
190i: United Stales v. Joint Traftic

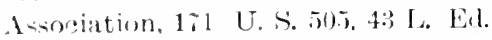
2.99(1s!); United States Northern Securities Co., 19.3 U. S. 19\% 1!19.3\% ts

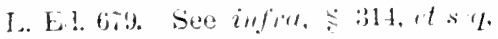
$f(1)$ fuller statement of these cases.

ZUnitel States $x$ Prans.llissouri Frelght Assin, 166 C.S. L. c. 314.41 1. E. 1. 10)\%.

3 Allyston Pipe and stuel Co. v.
United States, 175 U. S. 211 (1899), 4 L. Ed. 1:36; IIontague v. Lowry, 19:) U. S. $38(1904), 48$ L. Eil. 608.

+Hopkins v. United States, $1 \approx 1 \mathrm{U}$. S. 5is, 4:3 L. Ed. 290 (18:15); Anderson s. United States, 1:1 U. S. 604 (1\$98), 4:) L. Ed. 300.

sIn opinion of Attoruey General Griges to the Interstate Com. Com., of Dec. 30, 1899, 2l Annual Rep. of Com. for 1599 , p. 16 . it is sajd that the consultation by the representa- 
The distinetion is illustrated in the eases cited. In the Adryston Pipe case there was a direet agreement for the restraint of trale; in the Stockyards case there was a restraint of trade resulting indireetly from the exercise by the parties of their lawful rights in business associations. The former was therefore obnoxions to the act, while the latter was not.

A commodity may be the subject of an illegal agreement in restraint of trade, in violation of the act, although it is still subject to the taxing power of a state. ${ }^{1}$

A combination is subject to the act which ineludes the suppression of competition in the purchase of eattle in different states, and also the suppression of eompetition in the sale of meats in clifferent states, where all these acts were part of a single purpose to control and monopolize eommerce. Commerce between the states, the court said, was not a teehnica! legal conception, but a practical one drawn from the course of business. When cattle are sent for sale from a place in one state with the expectation that they will end their transit after purchase in another, and when in effect they do so with only the neeessary interruption to find a purchaser at the stockyards, and when this is the typieal and constintly recurring" course, the current thus existing is a eurrent of commerce among the states, and the purchase of the cattle is a pirt and incident of such commerce." The court could not orter the defendants to compete, but it could enjoin them from eombining not to compete.

$\$ 6$. Reasonable and moreasomable restraints of tralle.In the Trans-Missouri Freight Association case, supre, the ques-

tives of interstate railroads in con. mittee concerning the changes in classification, and subsequent independent action by the ralroad companies in the adoption of a new classification reccmmended by the committee where there is no evidence that any railroal company acted under compulsion of a combination, does not show a combination or conspiracy within the meaning of the act. See also In re Tyrrell, 51 Fed. Rep. 2î3.

1 Addyston Pipe \& S. Co. v. United
States, supra; United States v. Swift. 1:3 Fel. Rep. 5:9 (19):3).

¿swift v. United States (Beef Trust Case), 2j Sup. Ct. Rep. 256, deciled Jinuary $30,190.5$, by the Supreme Court of the United States. In this case the facts charged in the jetition were in effect confessed hy the demurrer whereon the in junction was granted. The practical difficulty of proving an agreement not to compete from the fact of non-competition was not presented. 
tion was directly raised whether the probibitory provisions of the act of 1890 applied to all contracts in respect to interstate or foreign trade or commerce, in respect to whether the restraints were reasonable or unreasonable. The majority of the court, (four julges dissenting, ) ruled that the act applied to all restraints, whether reasonable or unreasonable. There was no definite stanilud of reasomableness of rates, saill the previling opinion, and if only that kind of traffic which was an unreasonable restraint of trale was within the meaning of the statute, the result would be to leare the question of rates to the companies themselves. This ruling was reaffirmed in the Joint Tratlic Association case, supra.

In the Northern Securities case Justice Brewer, who had concurred in the prevalingr opinions in the Trans-Missouri Freight Association Case and the Joint Traffic Association case, filed a concurring opinion. ${ }^{1}$ wherein he said that while his conviction was not disturbed that the former cases were correctly decided he thought in some respects the reasons given for the judgment coukl not be sustained, and that instead of holding that the Inti-Trust act included all contracts, in restriant of interstate trale, reasonable or unreasonable, the ruling should have been that the contracts there presented were unreasonable contracts in restraint of trate, and as such within the scope of the act.

The act was leveled at only unlawful restraints and monopolies. Congress, he said, did not intend to reach and destroy those "minor contracts in partial restraint of trade which the long course of decisions at common law had affirmed were reasonable and ought to be upheld." The purpose rather was to place the statutory prohibition with prescribed penalties and remelies upon those contracts which were in direct restraint of trade, umeasonable and against public policy.

This concurring opinion however, when analyzer, substantially places the construction of the act where it had already been placed in the Stockyarls cases, where it was held that the act did not apply to arpeements among business men for the - better conduct of their own husiness which incidentally affect in terstate commerce. Is this concurring opinion holds that the restraint of competition in each of the railroal cases was unreasonable, it would seem to follow under this riew that any 
agreement for the restraint of competition by interstate carriers would be an unreasonable restraint of trade, and therefore obnoxious to the law.

so. Contracts in restraint of trade nuder the act.Judge Taft, then on the cireuit bench, in the opinion of the court of appeals of the sixth circuit, in the Aldyston Pipe $\mathrm{t}$ Steel Company case, ${ }^{1}$ in an exhaustive opinion, holding that the contract in guestion was violative of the act, and was also unenforcible at common law, laid down the rule that no contractual restraint of trade was enforeible at common law unless it was merely ancillary to some lawful contract involving some such relations as rendor and rendee, pirtnership, employer and employee, and necessary to protect the corenuntee in the enjoyment of the legitimate fruits of the contract, or to protect him from the dangers of those unjust acts by the other parties. The main purpose of the contract suggests the measure of protection neederl, and furnishes a sufliciently uniform standard for determining the reasonablen:ss and validity of the restraints. Iint where the sole object of both parties, in making the contract, is merely to restrain competition and enhance and maintain prices, the contract is roid and unenforcible at common law, and where made in interstate commerce is violative of the act of $15 ! 10$.

In this case there was an allotment of territory comprising a large part of the Cnited States among a number of companies engaged in the manulacture of iron pipe, and in that territory. competition was eliminated through this allotment of territory and through a system of pretended bids giving an appearance of active competition at public lettings when there was none.

Where the contract is thus for the direct suppression of competition, it is not necessary for trade in the commolity to be completely suppressed in order to render the combination one in restraint of trade. It is sufficient that the contract operates in restraint of trade. In determining whether an association of manufacturers or dealer's constitutes a combination in restraint of trade of interstate commerce, the court will consider the whole agreement in all its provisions. Thus, an agreement between manufacturers of tiles not to sell unset tiles to any one other than members for less than list prices, which

129 C. C. A. 111, and 8.j Fed. Rep. 271 (1898). 
were fifty per cent higher than the prices to members, and membership was dependent on conditions, one of which was the carrying of at least $\$ 3,000$ worth of stock, was held to constitute part of a scheme involving the enhancement of prices, and that the whole thing was so bound together that the transactions within the state were inseparable and became part of a scheme which, when carried out, amomted to and was a combination in restraint of interstate commerce. ${ }^{1}$

The eireuit court of appeals for the ninth circuit in a recent case" applied the decisions in the Knight and the Addyston cases to a combination which it said oceupied a ground intermediate between the other two. The combination was one of manufacturers of red shingles in the state of Washington and provided for the control of production and prices. But it appeared that more than four-fifths of the manufactured articles were produced for interstate trade, and that the purpose of the combination was to diminish competition in the production and to allance the price in that trade. The court said that the act did not reguire that the combination shoula by its terms refer to interstate commerce, and thit it was enough if its purposes anl ellect were neessarily to restrain such commerce. If it were otherwise, all combinations in the restraint of interstate trate may be so expressed in works as to aroid the statute. The combination was. therefore, held to be one in restraint of trade at eommon haw and violative of the statute of 1890 .

si. Contracts restrieting sales by rebates not within. the art.- The distinetion between contracts directly and substantially restrictmo free competition, and those which only incidentally and inflirectly restrict competition, was illustrated in at recent ilecision of the circuit court of appeals for the eighth circuit. composed of three of the four judges who rendered the opinion in the cirenit cont constrning the act in the Northern ricempities "ase." In this calse a tobaceo company sold its goods to jobbers by allotting to the intending purehaser an amount which he was refuired to buy during each succeding period

1 Montague r. Lowry, 19:3 U. S. :39 Co. 12.j Fel. Rep. 454 (November,

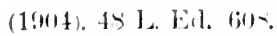
1:10:3). 60 C. C. A. 290; Phillips v. Iola

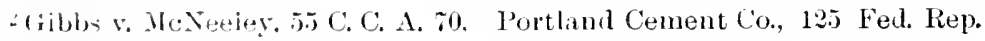
11s Fed. Rel. 1:0 (1!): 2 ) $593(1903), 61$ C. C. A. 19.

"Whitwell v. Continental Tobacco 
of four months, this allotment being in excess of the amount which he would be able to sell during that time. The price of the goods comprising the allotment was fixed so high that if the purchaser paid the price, he could not make any profit by buying and selling the goods. The requirement was marle that each purchaser should refrain from dealing with tobacco made by competitors. If the purchaser complied with the requirements, his allotment was reduced "to the amount he was able to sell and he was paid back such a percentage of the aggregate price of the groods he bought by way of rebate that the handling of the commodities was by this repayment alone made protitable to him. If the purchaser refused to comply with the requirement, the allotment and price was not reduced so that the purchase was necessarily unprofitable. The jobber who did deal with the plaintiffs on this basis refused to refrain from handling the goods of competitors, and plaintiff refused to roduce the allotment or prices and thereupon the plaintiff, being unable to purchase the gools elsewhere, brought suit for treble damages under 7 of the act. The court said that the parties were not dealing in articles of prime necessity, such as grain and coal, nor were they rendering public or quasi public services, like railroals and gas corporations. Each therefore had the right to sell its commodities at any price and to tix the prices and terms upon which it would sell them, and the persons with whom it made contracts of sale, and that they were deprived of none of these rights by the Anti-Trust Act. There was no competition between the plaintiff and defendant and therefore no restraint of competition by the contract. The court said that it had been settled by repeated decisions of the supreme Court whether the contract was in restraint of trade and in violation of the act must be tried not by the intent with which the combination was made, nor by its effect upon traders, purchases or consumers, but by the nec-essiry effect which it has in defeating the purpose of the law.' As the contract in question before the court did not defeat the purpose of the act, but only enabled the vendor to extend his own business and it was open to his competitiors to do the same, it was held not violative of the act.

1 See also decision of the circuit court (Judge Jackson, afterwards of the Supreme court), in the case of In re Greene, 52 Fed. Rep. 104. 
The reasoning of the opinion excludes from the act the socalled factor's' agreements or any form of agreements whereby the seller seeks to control, through rebates or otherwise, the trale of his own customer's. ${ }^{1}$ It is not restriant of trade in the ordinary use of the term, but restraint of competition tenting to monopolization of the market in interstate or foreign commerce which is condemmed by the act.

s. Honoply within the meaning of the act.- The second section of the act makes mlawful and punishable the monopolizing. or attempting to monopolize, or combining or conspiring to monopolize any part of tracle or commerce anong the sereral states. The meaning of the term "monopolize" in this connection was discussed by Mr. Justice Jackson,? then cirenit judge. afterwards of the supreme bench, in an early case under the act. Ile said it was not very clear what congress meant in this second section. but that it was very certain that congress could not and did not by this enactment attempt to prescribe limits to the acquisition either by a private eitizen or state corporation, of property which might become subject to interstate commerce, or to declare that when the accumulation or control of property by legitimate and lawful methods reached such magnitude or proportions as enabled the owner or owners to control the tratlic therein. or any part thereof among the states, criminal offence was committed by such owner or owners. In other worls, it is not the magnitule of a party"s business with the incidental or indirect powers thereby acquired. which constitutes the monoply or attempt to monopolize. Ifonopoly. in a legil sense therefore as it is intenched in the

1 The same court in Passaic Print frools ro. r. Ely \& Walker Dry (roous Co. 44 C. C. A. 496 , and 11).

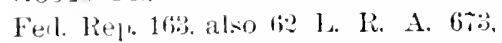
lielil that a merchant din not subject lumself to liability of an action for lamages to a manufucturer by sem indr circulars to the retail trade offering a small quantity of such manufacturer"s products, which he owned, at a cut price for the purpose of tle. stroying or injuring such manufacturer's tradeand depressing his gomls ju the market, and that mercluants (onlil not be helil liable for a con- spiracy by offering goods of a certain manufacturer. which they owned, at a cut price for the pur pose of injuring his trade or depressing the market price of his product. Sauborn, J., dissenting. The court in this case discussed and applied the rule of Allen v. Flood, 1 A. C. (1898), 1.

2 In re Greene, 52 Fed. Rep. 104 (1592). The court in this case cited approvingly llogul Steamship Co. v. MoGregor, Appeal Cases, part 1, p. $2 . ;$, decided by the house of lords in December, $15 \% 1$. 
act, means the engrossing trade to one's self by means which prevent other parties from engaging in fitir competition with him. As defined by Blackstone, "it is the grant of exclusire right from the sovereign power." There must be therefore an exclusive right or privilege on the one sicle and a restriction or restraint on the other, which operates to prevent the exercise of a right or liberty open to the public before the mo. nopoly is secured.

In the case cited the ownership of seventy distilleries in the country, constituting serenty-five per cent. of the distillery products of the country, did not make a monopoly because all other persons who saw fit to engage in the trale were at liberty to do so. Neither did paying of rebites to parties who lealt exclusirely with the company, constitute an attempt to monopolize, as the purchaser was left at liberty to buy where he pleased, and all other sellers of the alticle were left unrestrained in offering at greater inducements. The agrecment of rebate was wholly unilateral until there was compiance with the conditions by the purchaser.

The same construction of the term "monopolize" was made in the Continental Tobacco case, by the Circuit Court of Appeals of the eighth circuit." The court sail the purpose of the second section was the same as that of the first, to prevent the restriction of competition, and the second section ought to receive similar interpretation. It was not the purpose of the second section to prohibit or punish the customary and universal attempts of all manufacturers and traders engaged in interstate commerce to monopolize a fair share of it in the necessary conduct and desired enlargement of their business, while their attempts left their competitors free to make successful enleavors of the same kind.

5.3. Monopoly in law and in fact distinguished.- The construction in these cases is based upon the absence of an agreement for the restriction of competition between business competitors, and that the monopolizing is simply the effort of the trader to secure his own business, and that there is no monopoly in the legal sense without some exclusive privilege.

14 Blackstone Com.. 159; Case of Habite of Monopolies (1623), 21 Jas. Monopolies (1601), 11 Co. Rep. stb: J. c. :3.

2 Supra, p. 96 n. 3. 
Monopoly in this sense can in this country be based only upon rights under patent or copyright laws. Monopoly in fact, however. though not in law, may exist where a party is in possession of the only source of supply, as where the owners of all the coal available for the supply of a locality are combined in a single corporation. Other illustrations may be sugresested.

While this construction of the section seems the only admissible one, it is obrious, in view of the facility of eliminating competition by incorporating under state laws, that the eflectireness of the act is now mainly limited to the restraint of combinations between interstate railroals.

The supreme conrt remarked in the Freight Association Case, s"pr" that it was readily seen from the ruling in the Knight Company Case, supun, that if the act did not apply to the trinsportation of commodities by railroals from one state to anotler, or to foreign nations, its application was so greatly limited that the whole act might as well be held inoperative.

it. No distinction in the act between necessaries of life and other articles. - In the opinion of the circuit court of appeals in the Continental Tobacco Company Case, supra, it is sail that tobacco, the subject of the contract in question, was not an article of "prime necessity," such as grain or coal. This was doubtless said in view of the recognized principle that the subject of the contract will be considered in the determination of the reasonableness of contracts in restraint of trarle. The question in such cases is whether the public welfare is involved, and, if not, whether under the particular circumstances of the case the restraint upon one party is not rrater than the protection to the other requires. ${ }^{1}$ In cietermining the enforcibility at common law of a contract, it might be material that it related to a subject of "prime neces$\therefore$ it ${ }^{\prime}$ " in a restrictel territory, and this might be a circumstance affecting the reasonableness of the restraint." This fact has also been held material in determining whether combina-

1 Fowle v. Park, $1: 3$ U. S. 88, 1. c.

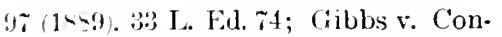
solirlaterl (ias Co. 130 U.S. 396 (1988), :2 I. El. 8.9. See also Oliver v. Gilnure, j2 Ferl. Rep. j63.

2It was said, however, by Taft, J. in the Addyston Pipe \& Steel C'o. case, supra, that the cases showed that the common law rule against restraint of trade extended to ali articles of merchandise, and that the introduction of the distinction (of 
tions are injurions to trade or commerce in the jurisdictions where the common law of conspiracy prevails. ${ }^{1}$

In the same connection the court referred to the fact that the contract in question was not that of a public service colporation, recognizing that in the case of such corporations there was a different standard of determining the reasonableness of contracts in alleged restraint of trade.

There is, however, nothing in the Anti-Trust Act of 1s90 warranting the limitation of its prohibitions according to what a court may adjudge are or are not necessaries of life. Tobacco and whiskey, and many other articles, may not be of such prime necessity as grain and coal, but in a complicated and progressive industrial civilization the standard of living of the masses is constantly advancing, and the comforts and even the luxuries of one generation are the necessities of another. At common law, contracts in general restraint of trade are unenforcible, irrespectire of the subjects of the contract, and it was only in the determination of the validity of contracts in partial restraint of trade that the subjects of the contracts were considered. Monopolies were first judicially pronounced illegal as against common right in a suit involving a royal grant of a monopoly in playing cards." The meliaeval statutes long since repealed in England have never been in force in the United States in the law of interstate commerce, nor is there any common law of conspiracy in the laws of the United States." The only federal law restraining freedom of interstate commerce is the Anti-Trust Act. Tuder this statute, therefore, there is no basis for any distinction between articles of prime necessity and other articles. The owners of both classes of property have the same rights under the law, and are subject to the same obligations. ${ }^{+}$

articles of prime necessity) only furnished another opportunity for courts to give effect to the varying economical views of its members. It might be difficult to say why it was any more important to prevent restraints of trade in beer, mineral water, leather, clotll, than of trade in certain shades of glue.

I In People v. Sheldon, 139 N. Y. 251 (1893), a combination of coal dealers was held an unlawful conspiracy under a statute making it a, misdemeanor to conspire to commit any act injurious to trade or com merce.

${ }^{2}$ See case of Monopolies, 11 Coke Reps. $84 b$ (1601).

${ }^{3}$ See infra, \$82 et seq.

${ }^{4}$ The Forestalling Statute, $25 \mathrm{Ed}$ ward III, enacted in 1350, mado criminal the forestalling of "wine 
A contract directly affecting interstate commerce, which would be unenforcible at common law as in restraint of trade, whaterer the subject, would be violative of the Anti-Trust Act. On the other hand, it would seem that a contract in prirate business relating to interstate commerce, whatever its subject, which would be valid and enforcible at common law as imposing only a reasonable restraint, and as ancillary to a valid contract, would not be violative of the federal act.

\section{5.). To application to commerce within a state. - Al-} though the jurisdiction of congress over commerce among the states and over foreign commerce is full and complete, it has none over that which is wholly within a state, and therefore none over combinations or agreements so far as they relate to a restraint of such trade or commerce; nor does it acquire any jurisdiction over that part of a combination or agreement which relates wholly to commerce within a state by reason of the fact that the combination also covers and regulates commerce which is interstate. This fundamental principle, which not only controls the construction of the act of July 2, 1590, but also the power of congress to enact any legislation concerning commercial combinations, was forcibly illustrated in the case of Addyston Pipe \& Steel Co., supra. The combination in that case included both state and interstate commerce. As to such of the defendants as might reside and carry on business in the same state where the pipe provided for in any particular contract was to be delivered, the sale, transportation and delivery of the pipe by them under that contract

and other rictuals, wares and other merchandise that came to the good towns of England by land or water." The stitute of Edward VI against "regrators, forestallers and grocers" includel in merchandise, victuals or any other thing whatsoever. "Cat. the. sheep. grain, butter, cheese. fish, or other deal rictual whatsoever," were $\cdot$ ialso included. These statutes were all repealed in $1 \% \pi 1$, Act of George III, $i 1$. The preamble to the repealing act is as follows: "Whereas, it has been found by ex. perience that the restraints laid by several statutes upon dealing in grain, meal, flour, cattle and sundry other sorts of victuals have a tendency to discourage the growth and to enhance the price of the same. which statutes if put into execution would bring great distress upon the inhabitants of many towns of this kingdom, and particularly upon the cities of London and Westminster."

In view of the ruling in Rex $r$. Waddington, 1 East. 16\%, that the offenses had existed at common law and the repeal of the statutes was insufficient, an act was passed, 7 and 8 Victoria, c. 24 , in 1844 , in express. terms abolishing the offenses. 
would be a transaction wholly within the state, and the supreme court said, modifying the judgment of the circuit court of appeals in that respect, that the statute would not be applicable to them in that case. They might make any combination they choose with reference to the contract, although it happened that some non-resident of the state finally obtained it. In the language of the court, in brief, their right to conbine in regard to a proposition for pipe, deliverable in their own state, could not be reached by the federal power derived from the commerce clause in the constitution. A combination violative of the act may, however, include a series of acts, concluded in different states, when they are part of purpose, as in the purchase and shipment of cattle to control and monopolize commerce between the states. ${ }^{1}$

§ f6. Application to state lolding companies.- The Northern Securities case, supra, was novel in that it decided that the corporation organized under the laws of a state and empowered under its charter to hold the stock of other corporations, was prohibited by this act from holding the stock of competing interstate railroad corporations. The illegal combination was founded upon the fact of control of competing railroads in a single authority and the resulting power of direct suppression of competition through such control. Thayer, J., in the circuit court, said that a state could not inrest a corporation organized under its laws to do acts in its name which operate in restraint of trade and commerce, and that the court woukd not consider whether a combination would be of benefit to the public; but that a holding corporation organized under the laws of the state was in violation of the Anti-Trust Act, since it destroyed any active form of competition between the two rouds, ${ }^{2}$ and it was immaterial that each company had its own boird of directors.

The holding corporation was condemned in this case, not becanse it was a "holding corporation ". merely, but because it held the stock of subsidiary corporations directly engaged in interstate commerce, and thus controlled competition as between those companies. The act, as such, has nothing to do with holding corporations where the subsidiary corporations

\footnotetext{
I See Chicago Meat Trust Case, 2120 Fed. Rep. 721. supra.
} 
are not engaged as competitors directly employed as public carriers in interstate commerce. 'The right of the holding corpolation in other cases depends upon the authorization of its own eharter and the laws of the states whereunder the subsiliary companies are organized and do business.

si. The labor logislation of congress. - The labor legislition of C'ongress has not been limited to the relations of labor in interstate commerce, but certain features of this legisiation ale distinctly related to the interstate commerce relations of lilbor, and the provisions of both the interstate commerce and the inti-Trust Acts relating to unlawful combinations in interstate commeree have been construed as applicable to labor as well as to business combinations. The general labor legislation of congress is therefore properly considered in this connection.

The liareau of Labor created moler the act of dune 27,1854 , Was made a lepartment of Labor under the act of June 13 , 1 S... The general design and duties of the ('ommissioner of Libur. "re dectired by the act "to acpuire and diffuse among the people of the Inited states usefut information on subjects connected with labor in general in the most comprehensire sense of the word, and especially upon its relation to capital, the hours of labor, the earnings of laboring men and women, and the general means of promoting their social, intellectual and moral prosperity."

The commissoner was charged to investigate conditions of labor, Wages, cost of living, effect of customs laws, what articles were controlled by trusts, combinations of capital, and Wlat effect trusts and other combinations of capital had on frenluction and prices. The commissioner was also charged to investigate the cases of disputes between employees and inployers.

liy the act of February 14, 1:108,3 the Department of Commerce and Labor was established, and the Department of Labor made a part of this department.

I The Supreme Court sail, in the Joint Traffic Association Case. sumper, 1. r. p. isfir, that "never to its knowlalde hall the formation of corporations for business or manuficturing purposes been regarded in the nat ure of a contract in restraint of trade." $\because 1$ Compiled statutes, 302.

"1 supp. to Comp. Stats., p. 41. 
5. Regulation of interstate commerce in relation to lahor.-Congress also exercised its power of regulation in the effort to harmonize the relations of capital and labor in interstate railroads. The first legislation of this character was the act of June 29, 1586. ${ }^{1}$ This act was not limited to the employees of carriers, but authorized the incorporation of any association of working people having two or more branches in the states or territories of the Union, and the incorporation was affected by filing articles in the office of the recorler for the District of Columbia. Provision was made for the establishing of branches and sub-unions in any territory of the Lnited States.

The act of June 1, 1898," was entitled "An act concerning carriers engaged in interstate commerce and their employees," and by its terms only applied to employees engaged in the railroad train service, excluding employees of street railroads Under section 2 of this act of 1598 , the chairman of the Interstate Commerce Commission and the Commissioner of Labor were reguired to put themselves in communication with the parties to the controversy between a carrier and its employees threatening to interrupt the business of the carrier, and to use their best efforts by mediation and conciliation to amicably adjust the same; and if these efforts were unsuccessful, to endearor to bring about a voluntary arbitration of the controversy in accordance with the provision of the act. Provision is made in the act for such voluntary arbitration. This act also amends the Yational Trade Lnion Incorporation Act, by providing that the articles of incorporation shall set forth that any member shall cease to be such by participating in or inciting force or violence against persons or property during strikes, lockouts or boycotts, or by seeking to prevent others from working through violence, threats or intimidation.

89. The conts on labor combinations in relation to interstate commerce. - As there has been no national incorporation of trade unions, there has been no judicial construction or practical application of the act. It was said, however, by

13 Com. Stats., p. 3204, infra, \& 376. arbitration for settling controversies

$23 \mathrm{Com}$. Stats., p. 3205. infra, $\$ 3 \%$. between interstate carriers and their This repealed the earlier statute of employees.

Oct. 1, 18s8, providing for boards of 
Justice Ilarlan. in an opinion rendered in $1894,{ }^{1}$ with reference to. the original act of 1 satilegalizing the incorporation of national trade unions. that it did not in any degree sanction illegal combinations. but that its purpose in authorizing worling people to better their own conditions by such combinations was most praiseworthy and should be sustained by the courts whenever their power to that end was properly in roked.

Neither has there been any arbitration under the act of Inne 1, 1s9. This act therefore, as the Tracle Cnion Incorpolation Act, has thus far been effective only as a declaration of national poliey." Judge Adams of the eastern district of Missouri called attention to this arbitration act in dissolving the injunction in the Wabash Raihroal Case, ${ }^{3}$ expressing a hope that the parties, if unable to adjust their differences, would submit the questions in dispute to the board of arbitration proricted by this act.

\section{so. The federal judicial power and labor combinations.} While the fecleral courts have been frequently called upon in cases involving trarle lisputes, particularly in cases of alleged intimilation and interference with non-union labor, where the juristiction is insoked on aceount of diverse citizenship and no. feleral question is involved, there have been comparatively few aljulications involving questions directly relating to in. terstate commerce, and these have usually been with relation to interstate carriers, and the interference with their interstate traflic growing out of contentions with their employees.

Railroal labor organizations have been considered in the

1 Arthur r. Oakes, infin.

$\because$ There seems to have been a similar experience in England. An at. trinjt was mate in $18 \% 4$ (5) Geo. IV,

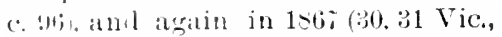
$\therefore 111.5$, and in $1922(35,31 ;$ Vic., c. 46$)$, (1) porite for settlements of trate di-putes. But the acts were never unchl and wrefe finally replaced by the conculiation Act of 1814 (5) 60 Vic., (.):30.

"Wabash Railroal Co. v. Hannalatn et al.. 1:1 Fed. Rep. 5j53.

thoutlern Ry. Co. v. Machinists laral Lnion, 111 Fed. Rirp. 49 (West. biet of Tenn ); Allis-Clahiners Co. v.
Reliable Lodge. 111 Fed. Pep. 264; Elder v. Whiteside, r2 Fed. Rep. 724 (La.): Consolidated Steel \& Wire Co. v. Murray, 80 Fed. Rep. \$11; Makall v. Rutchford, 82 Fed. Rep. 41 (w. Va.); Coeur dAlene Consolidated Mlining Co. v. Miners Union, 51 Feal. Rep. 260 (1dalıo): American Steel \& Wire Co. v. Wire Drawers, etc., 90 Fed. Rej. $60 \mathrm{~s}$ (No. Dist. of Temn.); United States v. Weber, 114 Fed. Rep. 950 (West. Dist. of Va.): Otis steel Co. v. Local Union No. 18. 110 led. Rep. 698: Hopkins v. Oxley Stave Co., 28 C. C. A. 99, and 83 Fed. Rep. 912, affirming 22 Ferl. Rep. 695. 
judicial construction and application of both the Interstate Commeree Act of 1887 and the Anti-Trust Aet of 1890 . In the industrial disturbances of 19,93 and 18.4 there were a number of injunctions sued out in the different circuit courts enjoining interference with interstate commerce, some of these by railroad companies enjoining interference with the interchinge of traffic with connecting rail roads; ${ }^{1}$ also applications by receivers of railroads for protection against interference with their possessions and operation, ${ }^{2}$ and also direct suits by the Eniterl States under the provisions of the Anti-Trust Act enjoining unlawful interference with interstate commerce and the mails. ${ }^{3}$

It was held in these cases that the Anti-Trust Act was applicable to any combinations restraining trade, whether of labor or of capital, ${ }^{4}$ and that the penalties prescribed by sec. 10 of the Interstale Commerce Act were applicable to the employees of an interstate railroad who, while continuing in their positions as employees, refused to handle the freight received from other roads. Such refusal, when made in consequence of a boycott declared by theip Lnion against such road. was an unlawful conspiracy and punishable as such under the laws of the Cnited States, and also punishable as a contempt when their employing road was under an injunction prohibiting it from refusing to exchange interstate tratfic with such boycotted road.

The Supreme Court, in the Debs case, ${ }^{5}$ while not dissenting from the conclusion of the circuit court in holding the AntiTrust Act applicable to a labor combination interfering with

1 Toledo, A. A. \& N. R. Co. v. Penn. Co., et al, jt Fed. Rep. 730 (Taft, J., in Northern Dist. of Ohio): see also 54 Fed. Rep. $7 \pm 6$; Southern Cal. R. Co. v. Rutherford, 6: Fed. Rep. 796 (So. Dist. of Cal.)

2 Thomas r. C.. N. O. \& T. P. R. Co., 62 Eed. Rep. 803, (Taft, J., in Sonthern District of Ohio.

${ }^{3}$ United States r. Workingmen's Amalgamated Council, 54 Fed. Rep. 994 (Dist. of La.); United States r. Eliot, $6 \pm$ Fed. Rep. $2 \pi$ (West. Dist. of Mo.): Unitel States v. Agler, 62 Fed. Rep. 826 (Dist. of Ind.); Charge to
Grand Jury, Grosscup, J., 62 Fed. Rep. S:S; Ross. J., 62 Fed. Rep. 834; Waterhouse v. Comer, 55 Fed. Rep. 149 (S. Dist. of Ga.), $189 \%$.

4 See authorities, supra, and In re Debs, 64 Fed. Rep. 724. In United States r. Carssiday, 6r Fed. Rep. 698, it was held that the provisions of the Anti-Trust Law were broad enough to reach the combination or conspiracy that would interrupt the transportation of property or persons from one state to another.

5158 U. S. 564 , l. c. 600. 
interstate commerce, affirmed the juriscliction of the federal court to grant an injunction against such interference on the broaler ground of the federal power orer interstate commerce, which included the power to remove anything put upon the highways. natural or artificial, to obstruct the passage of such commerce, and that this federal power was enforcible by injunction.

\section{s s. Sympathetic strikes and boycotts by interstate em-} ployees.- The right to strike, that is to enforce demands for the betterment of their own conditions by concerted ceasing from employment on the part of employees directly engaged in interstate commerce, has been uniformly affirmed, but has been broally distinguished from the right to boycott or encitre in a so-called sympathy strike. The incidental interference with commerce resulting from a strike when a boly of lathorers by concerted action leare their employment does not constitute an unlawful conspiracy, nor is it riolative of the Interstate Commerce Act or the Anti-trust Act. ${ }^{i}$ Laborers

1 lopkins $v$ United States. 1il L.

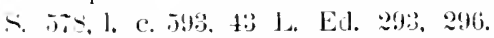
1. to the law fulness of a strike. $p e r$ w. by railroad employees, see opin. jon of I Ion. Richard Ohnes, then Attorney Cieneral of the Lnited states, in the case of the Philadelpha $\&$ Reading R. Co., in the proposed aloption of a rule by the receivers excluding members of raibroal brotherloods from employment. printel in p. 504 of Hearings on I Ionse bill No. 89 , before the Committee on the Judiciary of the isth Congress. The court in this case, (ii) Fed. Rep. 660, declined to direct the receivers to abrogate such a rule, which they beliered was adrantageous to the management of the property: but see Taft. J., in (i2) Fel. Rep. $80 \%$, in the Phelan Case, that "the employees of the receiver had the right to organize into or join a labor union which should take action as to the terms of their employment. It is a benefit to them ant to the fullic that laborers shonlil unite for their common interest anl for lawful purposes. They have liabor to sell. If they stand together they are often able. all of them, to command better prices for their labor than all dealing singly with ruch employers, because the necessities of the single employee may compel him to accept any prices that are offered. The accumulation of a fund for those who feel that the wages offered is below the legitimate market ralue of such labor is desirable. They have the right to appoint officers who shall advise them as to the course to be taken in their relations with their employers. They may unite with other unions. The ofticers they appoint, or any other person whom they choose to listen to, may advise them as to the proper course to be taken, both in regard to their com. mon employment, or if they choose to appoint any one. may order them, on pain of expuision from their union, pencefully to leare the employ of their employer because any of the terms of their employment are unsatisfactory." 
directly engaged in interstate commerce have the right, singly or in concert, to cease from them employment whenever they deem such action necessary for the betterment of their ow conditions, and it is immaterial, if their demands are made in good faith for the betterment of their own conditions, that is, as to wages or other conclitions of employment, whether such demands are reasonable or unreasonable, provided of course that they act within the limit of their law ful rights and do not interfere with those who continue in the employment or who are employed to take their places; that is, within these limits they have the same right with others to determine the reasonableness of their own demands for the betterment of their own conditions.

On the other hand, a boycott, or a sympathetic strike, that is the ceasing from employment, not for the purpose of bettering their own conditions, but for the purpose of en lorcing the employing company to refuse traffic from a connecting carrier, or to refuse to handle some boycotted tratlic, is unlawful. It was said by .Judge Taft, ${ }^{1}$ in speaking of the attempted boycott of the Pullman cars, that it was immaterial that such boycott was unaccompanied by violence or intimidation.

"The purpose, shortly stated, was to starve the railroal companies and the priblic into compelling I'ullman to do something which they har no lawful right to compel him to do; certainly the starvation of a nation camnot be the lawful purpose of a combination, and it is utterly immaterial whether the purpose be effected by means usually" lawful or otherwise."

The distinction was drawn in another case ${ }^{2}$ between a combination of the employees of the complainant railway company which was seeking an injunction from the combination of the employees of the defendant company. The court said the former was lawful, as the employees of that company were simply exercising their lawiful right to cease from employment, that is, to strike, while the latter combination for the refusal of the traftic of the former, was unlawful, as it inrolved a boycott for no grierances of their own, thus making a direct interference with interstate commerce, which was the intended result of their act, and not the incidental

1 Thomas v. C., N. O. \& T. P. R. -Toledo, A. A. \& M. R. Co. v. Co., 62 Fed. Rep., l. c., 803, suma. Penmsyania Co., 5 t Fed. Rep. $: 30$. 1. c., 235 
result of their exercise of a lawful right. It was also ruled that a combination to compel railroad companics to break their contracts with the owners of certain cars for the use thereof, was an actionable conspiracy and unlawful.

It will be observel that in these cases there wils not what is known as a simple or primary boycott, as in the case of an oromized withdrawal of patronage from a trader for the purpose of injuring the business, but it was a "sympathetic strike" of the employees of one interstate carrier for the purpose of foreing a refusal of business relations with another interstate carrice in violation of law.

\section{S 2 . The law of compiracy in interstate commerce.-} The lat of conspiracy hat been extensively discussed in relation to the combinations of both labor and capital in interstate commerce. Is there are no common law offenses in the Lnited states, criminal conspiracies are punishable only as such when they are distinctly declared in the laws of the Enited States. There are certain specific conspiracies made punishable by the statute, but the section involied in relation to interstate commerce is what is known as the general conspiracy statute, section $54 t 0$ R. S., U. S., which is as follows: ${ }^{1}$

"If two or more persons conspire either to commit any offense algainst the Eniterl states. or to defram the Euiter ctiltes in any manner or for any purpose, and one or more such parties do any act to affect the object of the conspiracy, all the parties to such conspiracy shall be liable to a penaity of not more than ten thousind dollars, or to an imprisonment of not more than two years. or to both fine and imprisonment, in the discretion of the court."

A conspiracy was defined by the Supreme Court as a combination of two or more persons by concerted action to accomflish a criminal or unlawful purpose, or some purposes not in itseli criminal or unlawluk, by criminal or unlawïul means.' This section has been held to include all conspiracies for allect-

1.Sertion 5140, R. S. C. S.. : Comp. stats. 1. 1960. This statute wals first enacterl in $186 \pi$ as a part of the in. trinal revenue act the penally there. in being not less than one linousind mor more than ten thousind dollars. and imprisonment for not more than (wi) years: subsequently incorpo- rated in the revised statutes and amended into its present form by act of May 1\%, 1sis. It bas been held to apply to all crimes miler the laws of the United States. See United States r. Sanch, ; Fed. Rep. r1j (W. Dist. of Tenn.).

2Pettibone v. United States, 148 
ing private rights and interests where they are under the protection of the criminal laws of the Lnited States as well to the rights and interests of the government itself. Whive the offense of conspiracy is an "infamous crime" within the meaning of the Fifth Amendment to the Constitution, requiring presentment or indictment of a grand jury, it is yet a mislemeanor and not a felony, and an indictment is not defective by reason of failing to arer that the conspiracy was "feloniously" entered into." As the offense is a misclemeanor, the doctrine of merger has been held not applicable, so that an acquittal of the offense of conspiracy is not a bar to the prosecution for the crime itself.

A conviction under this statute for conspracy to obstruct the United States mails was affirmed, and the conspiracy was held to be a separate offense for which congress had power to provide a greater punishment than for the offense itself for which the conspiracy was formed."

The law of conspiracy was involied in connection with the labor disturbances of 1593 and 1 1 94 , and a number of criminal prosecutions were instituted and indictments found for criminal conspiraey to commit offenses of riolation of the Interstate Commerce and Anti-Trust Acts. ${ }^{i}$ These statutes, as will be seen, prohibit and malie criminal interferences with or combinations in restraint of trade in interstate commerce.

U. S. $19 \%, 37$ L. El. 419, citing Shaw, C. J., in Commonwealth r. Hunt, 4 Ietcalf, 111. In this case the court quashed an indictment whereurder. a conviction hal been had for conspiring to obstruct the due administration of justice by intimidation and violence in a strilse. on the ground that the indictment failed to show that the defendants had notice of the pendency of proceedings in the United States courts which they were charged with combining to obstruct.

${ }^{1}$ United States 8 . Situch. $\%$ Fed. Rep. 715, supra.

2 Makin $\therefore$ United States. 117 U.S. 348, 29 L. Ed. 909 (1886); Callan v. Wilson, 12 U U. S. 540, 32 L. Ed. 223, where held that a conspilacy at common law for alleged boycott in the District of Columbia was not triable summarily before a police magistrate, but that jury trial was demanuable as a right.

${ }^{3}$ Bannon v. United States, $156 \mathrm{U}$. S. 464.39 L. Ed. 494 (1895).

4 Berkowitz $\mathrm{r}$. United states. Thir Crrcuit, 35 C. C. 1. 379.93 Fed. Rep. 452.

'Sec. 3995 R. S. of C. S., 3 Compl. Stat., 2i16.

${ }^{6}$ Clune v. United States, 159 U. S. 590, 40 L. Eu. 269 (159.5).

i See Charge to Grand Jury. Grosscup, J., 6: Fed. Rep. 8?8, and Ross, J., 62 Fed. Rep. 838; United States v. Cassiday, 67 Fed. Rep. 698. In re Debs, 63 Fed. Rep. 436. 
The subject was exhaustively discussed also in the injunction and contempt proceedings growing out of the same disturbances. The law of conspiracy has been applied in determining the responsibility of persons not parties to the record for contempt of court in riolation of an injunction nuler the rule, that when a conspiracy is shown, each conspirator is responsible for the acts of his co-conspirators. ${ }^{\mathrm{I}}$ It was held by Taft, .I. in the Toledo, A. A. I X. W. Railroad Case, supre, that threatening action to withhold labor from another, for the purpose of inducing, procuring or compelling the other to commit an unlawful aet was itself a criminal or mulawful act. Is the Interstate ('ommerce Aet, section :3, prohibited the carrier from refusing to interchange traffic with another carrier, the threatening to withhold labor for the purpose of compelling him to refuse such tratfic was itself a eriminal or unlawful act. The enforcement of a rule of the Brotherhood of Engineers, reyuring its members to refuse to hancle property of a railroal system with which the brotherhood was at issue, was held to constitute a criminal conspiracy uncler the laws of the Inited states, and that the officers and all members of the brotherhood engaged in enforeing the rule were equally guilty and subject to the penalties of the section.

The courts have allowed proof of the character and purposes of a conspiracy to be made by official proclamation, newspapers and reports, and other matters of public current history."

It was also held in these cases that the parties to a criminal conspiracy are liable for any actual loss to private parties inflicted in pursuance of their conspiracy. The gist of any such action, however, is not, as in criminal cases, in the combination, lut in the fact of injury, and no civil liability arises unless injury is done. Ordinarily the only difference between the civil liability for an injury from one person and from the same acts done by a conspiracy, is in the greater probability of injury in the latter case. The threat of such injury from which irroparable injury would flow warranted the relief by injunetiun to prevent the injury.

In re Bessette. 111 Fed. Rep. 417 gated Ass'n, 54 Fed. Rep. 994; Clune (Inl.) v. U.S., 159 U. S., 590, 40 L. Ed. 269

2 In re Debs, stura; C. S. v. Amal- (1595). 
It should be observed however that a conspiracy may consist in a combination to accomplish a lawful end by means which are unlawful, though not eriminal in the sense that they are made punishable by statute. All criminal acts are unlawful, but unlawful acts are not all criminal. As a concerted, peaceful cessation from labor is lawful, there can be no basis of a tharge of conspiracy in such cases unless unlawful means are employed in furtherance of the purposes of the strike. There can be no conspiracy in the exercise of a lawful right by lawful means, and it is immaterial in such a case what may be the motive in this exercise of a lawful right. As men may leave their employment at will, when not under contract, so the employer may exercise his right of terminating the relation, where there is no contract, whatever the motive, and no charese of conspiracy can be based upon such exercise of a lawful right. ${ }^{1}$

S: Distinguished from common law conspiracy. Conspiracy under the laws of the Cnited states as applie 1 in interstate commerce cases is to be distinguished from common law conspiracy, which is in force in some of the states. Thus, in England it was found necessary to legalize strikes of worlkingmen by the enactment of the "Conspiracy and Protection of Property Act" of 1875. " The law of the Lnited States requires an act to be done affecting the object of the conspiracy, that is, an overt act, and the conspiracy must relate to an offense against the Lnited Stites or the defrauding the Initerl States. Not only obstruction of the mails, but any direct and intended interference with interstate commerce, if committed by one person, is an offense against the Cnited States, and pun-

1 Boyer v. Western Union Tel. Co., 124 Fed. Rep. 246 (E. Dist. of 3 Io.).

$238,39 \mathrm{Vic}$ c. 86 . proviling that an agreement or combination by two or more prsons to do or to procure to be done any act m contemplation or furtherance of a trade dispute between employers and workingmen shall not be inilictableas a couspiracy, for such act, if committerl by obe prer. son. would not be punishable as a crime. Nothing in this section shall exempt from punishment any person guilty of a conspiracy for which a punishment is awarded by act of parliament.

It was held in Regina v. Bauld, 1:3 Cox C. C. 28: $(18 \% 6)$. that under this act neither master nor men had a right to take any proceerlings to compel other masters or men to adopt their views on any trade question. Witl this section were also enacted certain limitations and restrictions: upon the "besetting" by picketing and solicitation in case of strikes. 
isiable as such. ${ }^{2}$ The law of conspiracy, therefore, in such a aise is not the basis of the criminal action, as the offense is not made by the combination, but by the illegality of the end proposed, whether the means employed are lawful or unlawful. The enactment of the English statute by Congress would have no material bearing upon the law of eonspiracy as now applied in interstate commerce cases. As a concerted peaceable cessation from labor is lawful, in interstate employment as in any other, there is in such cases no illegality in the object sought, and no statute is required to legalize such action.

The English statute only applies to criminal prosecutions for conspiracies. and combinations for unlawful, though not criminal ends, as the destruction or injury of another's property or business, without justifiable reason, are still unlawful in England, and still constitute the basis of civil liability.

\section{st. Interstate commere in relation to emplogees therein.} There has been some diflerence of judicial opinion as to the illegality of boycotts when unattended with violence, intimilation or other illegal methods, that is, whether, in the absence of statute, the act which one might lawfully do, as the witholding of patronage from another, is made illegil by comhinations with other's to do the sameact. Thus it has been said that malice or the specific intent to injure the party may constitute a combination an illegal conspiracy, while other anthorities have based the legal right to relief upon the greater probability of injury in the case of a combination, and it has been denied that private malice can be an ingredient in making a ciril action." except in certain recognized exceptions where malice is essential, as in malicious prosecution.

1 Sec. 10 of Interstate Commerce Act. infru.

- See prevaling and dissenting opinions in Jopkins r. Oxley Stave Co., 28 C. C. A. 99, and s:3 Feil. Rep. 91:. and Vegellian v. Hunter, 16i Mass. 9: (1890); Taft, J., on the state bench of Ohio, in Moores r. Briclibayers Cnion, 23 Weekly Law Pul. 12, and r Railway \& Corp. Law Jomp-

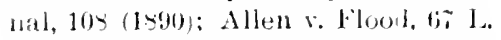
J. liep. Laper of L. C. Krauthofl on Nat ire as an Ingredient of Civil
Actions, American Bar Association of $18 \% 8$.

The weight of American authority is condemmatory of " boycotts, "that is of organized efforts to destroy another"s business. The cases are usu. ally complicated. however, with distinctly jilegal "means." See State v. Glidilen, jis Conn. 4 (is (1ssi): Crump v. Commonwealth, of Va. !1: (1<89);

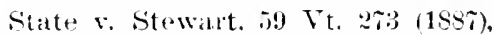
State v. Jonaldson, 32 N. J. Law, 151, where indictments for conspiracy in 
This distinction, howerer, is academic rather that practical in its relations to interstate commerce. There is an obvious distinction between the relations of quasi public corporations, such as carriers to their employees,-- which is emphasized by their connection with interstate commerce, and thus a matter of direct federal concern,--and that of private employers to their employees, which grows out of the peculiatr relations of such carriers to the public. The former cannot "lock out" their employees by suspending business for a time because of unsatisfactory labor conditions which prevent them from doing business profitably, and in such matter they have not the rights which may be exercised by private manufacturers. The cars must continue to more and traffic must continue to flow. Any interference with the traffic, therefore, except that which is the incilental result of the exercise of a lawful right, as the ceasing from employment for the betterment of one's own conditions, is unlawful.

This principle does not require the existence of through routing arrangements between carriers but rests on the broad deelaration of national policy which requires the interchange of traffic, whether through routing under contractual arrangements exists, or not.

This immunity of interstate commerce from direct interference not justified by the lawful exercise of rights, is not limited to railroads or other interstate carriers, but is applicable to any parties engagel in transporting or handling interstate traffic, such as teamsters, draymen, transfer employees, or others, that is, wherever the services are essential to the continued moring of interstate traffic from the point of shipment by the consignor in one state to the delivery to the consignee in another state. ${ }^{1}$ Thus, combinations in restraint of interstate commerce are obnoxious to the federal law, though the subjects of such contracts are within the juriscliction of the state."

boycott cases were sustained. See also Casey r. Central Trpo. Union. 45) Fed. Rep. 135; Old Dominion s. S. Co. v. McKenna, 30 Fed. Rep. 4! :So. Dist. of Ohio); Carew v. Rutherford, 106 Mass. 1 (So. Dist. of N. Y.); Walker v. Cronin, 107 Mass, 5is; Dore. mus s. Hennesy, 17t Ill. 60s; Lucke v. Clothing Cutters \& Trimmers Assembly, it Md. 396.

I See Rhodes $\mathrm{r}$. Iowa. 170 U. S. 412 , 42 I. Er. 1088.

Addyston Pipe \& Steel Co. r. United States, 175 U. S. 211, 1. c. 246 , and 44 L. Ed. 136: United States r. Swift, 122 Fel. Rep. 5:9 (N. Dist. of III.). 
A boycott involving any form of interference with interstate traffic at any stage would be unlawful.' Thus, a combination in New (orleans to enforce the employment of none bit union men in all departments of labor became a combination in restraint of interstate commerce within the meaning of the statute when, in order to grain its ends, it songht to bring about a diseontinnance of labor in all departments of business includin $y$ the transportation of goods from state to state and from for ign nations."

s. "Picketing " and "Soliciting" in interstate com. merce.- The same distinction is to be applied and the same distinction recognized in determining the rights of striking employees in picketing the approaches to stations or besetting, by soliciting or otherwise, their fellow-employees who do not strike, or those whoare employed to take their places. It is not within the seope of this work to consider what is the extent or what are the limitations of the right to picket or solicit in private employment. Such puestions are frequently presented to the state courts, and also in the federal courts in cases where their jurisdiction is involed on grounds of diverse citizenship, and no distinctly fedral question is in rolred. The public interest, which is not considered paramount in ordinary trade disputes, that is, the public convenience and even the public necessities, are often not given the weight that they should have. But wherever interstate or foreign commerce is involved, this public interest is made paramount by the laws of the Cnited States. All chasses of the community, workingmen as well as cippitilists, are interested in the prompt transmission of the mails and the uninterpuptel carriage of persons and freight.

Iny form of interference, therefore, with the free movement of interstate traffic, whether by pieketing or soliciting, or any lorm of ob-truction, would be a direct interference with interstate commerce and mnlawful as such, when it is not the incilental result of the rexercise of a lawful right, as the concerted cessation from employment. It is true that a concorterl cessation from employment, as in strikes, results also in an interference with interstate commerce, and may inrolve

Shee Knulson $\therefore$ Jenn (Dist. of Amalgamated Council of New Or-

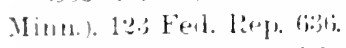
leans (Eantern Dist, of Lia.), ijt Fed.

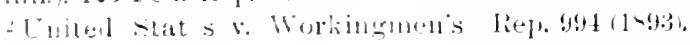


widespread public ineonvenience and suffering, but that is the incidental result of the exercise of a lawful right. After this right is exercised, the interference thereafter resulting from boycotting any interstate traffic, or soliciting or besetting employees in such commerce to leare their employment, is not incidental, but is caused by a direct interference with interstate commerce. This distinction is not based upon any faror to the carrier. or for any abridgment of the rights of employees, but beeause the public interest, which concerns all eitizens ailike, is paramount.'

S6. The relation of interstate railroad employees is that of free contract. - The relation of interstate carriers to their employees is that of free contract, terminable by either party, subject to the terms of the contract. This relation, therefore, is not analogous to that of seamen in the maritime service, who to a certain extent surrender their liberty in their employment and are punishable for an unlawful desertion." It was said in Arthur v. Gakes" that, in the absence of legislation to the contrary, the right of one in the service of a quaspublic corporation to withdraw himself at such time as he sees fit, and the right of the managers of the corporation to discharge an employee whenever they see fit, must be deemed so far absolute that no court could compel the continuance of the employment on the demand of either party.

It has been suggested that there are limits npon the right of the employees of a railroad to abandon their employment; that is, that it should not be exereised at a time or under circumstances indicating a purpose to obstruct commerce or to

1 United States v. Workingmen's intelligent responsibility for their Amalgamated Council. supra: acts which is accredited to ordinary Knudson r. Benn, suma (Minn.): adults, and as needing the protecUnion Pacific R. Co. r. Ruef (Dist. of tion of the law, in the same sense in Neb.), 120 Fed. Rep. 10\%.

2 The supreme court said, Pobertson v. Baldwin, 16, U. S. I. c, 28\%, $41 \mathrm{~L}$. Ed. 719 (1897), in sustaining the constitutionality of sections 4595 and 4.599, R. S. U. S., 3 Comp. Stat. p. $311 \%$, authorizing apprehension of deserting seamen, that "seamen are treated by congress, as well as by the parliament of Great Britain. as deficient in that full and which minors and wards are entitled to the protection of their parents and guardians." Harlan. J., dissented, saying that the holding of any person in custody for the purpose of compelling him to remler personal service in a private business was "in "oluntary servitude." prohibited by the constitution.

311 C. C. A. :09, and 63 Fed. Rep. 310 . 
prevent its operation, rather than to exercise the lawful right of withdrawal from employment." 'Thus, the supreme Court, in afirming the jurisliction of the circuit court in punishing an engineer for contempt of an injunction," said that it was not necessary to decide whether an engineer may suddenly and without notice quit the service of a railroal company at an intermediate station or between stations, though cases may be inatrined where the sudden abandonment of a trainload of passengers might imperil their safety or even their lives, as in this case the court below had found from the testimony that the petitioner did not quit in good faith, but intended to continne in the company's serrice, and that his conduct was a derice to aroid obeying the order of the court.

This subjeet of the exercise of the right to leare employment was discussed by the (irenit Court of Appeals for the seventh cirenit in an opinion by . Instice Iarlan "in a case wherein the court below hat made an order enjoining employees from so quitting the service of the receivers, "with ol" without notice, as to cripple the property or prevent the operation of the railroad."

The eourt saicl that the latter words, "as to cripple the property," etc., should be stricken ont. The fact that employees of raiboads may quit under circumstances which would show bad faith or reekless disregal of their contracts, or the convenience or interests of both the employer and the public, did not justify a departure from the general rule that equity woukl not require employees against their will to remain in the personal service of the employer. The court ruled, however, that the injunction properly prohibited the employees from combining

1 While there is no federal statute on the subject. there are special statutory provisions in the several states, Mlaine, Pennsylvania. Illinois, New Sersey. Kansas. Delaware and IIis-issippi, the purpose of which is to prevent surl sudden abandonment of employment as should endinger life or seriously obstruct the actual physical use of the railroad. In several of the states the provision is expecially that no locomotive engineer. and in some states conductors and trainmen. slatl abandon the locomolive and train at any other place than the regular scheduled end of the road. Illinois Revised Statutes, 109, 111 and 11t: Maine R. S. 190:3, p. 92\%, sec. 7 ; Penusylvania R. S. 1s94. p. 132s, sec. 60.): New Jersey R. S. 1895 , 1. 2696 , sec. 245; Kansas R. S. 1901, sec. 2:34: Delaware R. S., p. 928: Mississippi R. S. 189?, sec. 12\%0. See also Report of Industrial Commission, vol. 5, p. 132; vol. 17 , p. 601.

2In re Lennon, 166 U.S. 548 (189\%)。

41 L. Ed. 1110.

3 Arthur v. Oakes, supra. 
and conspiring to quit with or without notice the service of the receivers with the object and intent of crippling the property in their custody or embarrassing the operation of the railroal.

This case was not based upon either the Interstate Commerce Act or the Anti-Trust Act, but, as the court said, upon the general principles which controlled the exercise of jurisdiction by courts of equity.

$1 \quad \S \$ \%$. The right of labor organization includes the right of representatation. - The right of organization into unions or brotherhoods by the employees of interstate railroads is recognized both by the federal statutes ${ }^{1}$ and by the courts, and this right carries with it the recognition of the right of "collective bargaining" by employees through their organizations in the betterment of their own conditions of service. Incidental to this right thus recognized is the right of representation of employees by their own officials selected by them in the presentation of their demands for the betterment of their conditions of service. A distinction is properly made between such represenatives of employees who seek the redress of the grierances of those represented by them, and the status of those not connected with employees who seek to induce them to break their contracts of employment for other purposes than their own betterment. ${ }^{2}$ This right of representation was directly involved in the recent case decided by Judge Adams in the eastern district of Missouri. ${ }^{3}$ In this case an injunction was sought by the railroad company against the oficials of the railroad brotherhoods of trainmen and firemen enjoining them from calling a strike on an interstate rililroad on the ground, among others, that these officials were not employees of the railroad, and that their action in calling a strike would be a direct interference with interstate commerce. The court found from the evidence that there was an existing dispute about the conditions of employment and that the officers of the brotherhood had been directed by the employees on the road to call a strike and therefore held that the employees had a right to act by their representatives, and the injunction was dissolved.

1 See National statute of arbitration. supra.

2 Thomas v. C., N. O. \& T. P. R. Co, 62 Fed. Rep. 803, supra; see also charge of Judge Grosscup to grand jury, 62 Fed. Rep. 828.

${ }^{3}$ Wabash R. R. C. v. Hannahan et al, 1:1 Fer. Rep. 593. 
S.S. Injunctions in interstate commeree. - In a progressive industrial eivilization preventive remedies are frequently the only adequate remedies when business or property rights are invaleal, particulary when there is any question as to the pecuniary responsibility of the parties charged with the wrong. This is the case with labor disturbances which involve a direct interpuption of bnsiness and damages, which are in the nature of things irregirable, because they cannot be acemately ascertainerl, eren if the defendants were responsible. Where the fublic interest interrencs. as in the case of interstate commeree. Where the tralfic must continue to be moved and the cals continne to rum. some form of preventive relief, asually that of injunction. is orilinirily the only arailable remedy.

The influence upon our jurisprubence of the ancient historic jealousy of courts of chancery is illustrated in the contention that where the trespasses or other wrongs to business or other property involve a violation of criminal law, there is no jurisdiction in equity to enjoin the commission of the acts. This contention is obviously unsound. The injunction restrains not the crime, but the irreparable injury to property. 'The question was detinitely settled by the supreme court in the hels case, where the court held that while a chancellor had no criminal juristiction, and something more than the threatened commission of an olfense against the laws of the land was necussily to eall into excrcise the injunctive power of the court, that when interference with property, actual or threatenel, appreared, the jurisliction of the court of equity arises, and is not destroyed by the fact that the interferences are accompanied by or are themselves a violation of the criminat law. The juristiction of the ciril court is involied, not to

1 The use of preventive renterlies seems more firmly established in the English conts thin in our own. The listunction between the powers of courts of law and courts of equity has there now only historical interest. All divi-ions of the surreme Court of Julicature have jurisdiction to grant injunctions when it shall aljear to the conrt to be just or conventent that such shall be matte tsub. sec. \&, sec. 25. Jubluature A.l. 18.3), and to award damares in audution to or in substitution for such injunction.

On the general subject of the modern use of injunctions, see F. J. Stimson in Political science Quarteris. June, 1s95; Charles Clatlin Allen at American Bar Association, 1894: Hon. Wm. H. Taft, then circnit judge, in defense of the federal judiciary, American Bar Assuciation, 1s:3.

:1.5 U.S. l. c. p. 593, 39 L. Ed. 1106. sulpur. 
enforce the criminal law and to punish the wrong-loes, but to compensate the injured party for the damages which he or they have suffered, and it is no defense to the civil action that the same act by defendant exposes him also to indictment and punishment in a court of criminal jurisliction. In this case the injunction was sought by the government itself, and it is obvious that the right of any other litigant to preventive relief in the case of threatened irreparable injury to property by criminal trespasses would be also available.

The same remely of injunction was invoked by the government against the railroads of the country in the proceedings under the Anti-Trust $A$ et, ${ }^{1}$ and also against combinations of capitalists under the same statute. ${ }^{2}$ In a very recent opinion in the Beef*Trust case," the Supreme Court affirmed the decree of the circuit court of Illinois enjoining the defendants in a suit by the United States against certain specific acts in restraint of competition in interstate commeree.

In this latter case however the Court directed a modification of the injunction by striking out the general words "or by any other method or device, the purpose and effect of which is to restrain commerce as aforesaid," saying that the defendants onght to be informed as accurately as the case permitted what they were forbidden to do. The court said that while it was bound to enforce the act, it was also bound by the first principles of justice not to sanction a decree so vague as to put the whole conduct of defendants' basiness at the peril of a summons for contempt, and that it could not issue a general injunction against all possible breaches of the law.

There has been considerable discussion in the courts and also in the committees of congress as to the scope of injunctions rendered in trade disputes. Thus, in the Debs case the injunction order included all persons whatsoever, not named therein, from and after the time when they shall severally have notice of such order. The question as to the scope of the order was not definitely determined, as the order was issued and served upon the defendant, so that this feature of

1 See United States v. Trans-Missouri Freight Association; United States v. Joint Traficic Association, and United Stat es v. Northern Secur- ities Co., stopra: Swift v. United States (Jan. 30, 190.5).

2 See Anti-Trust Law, infre.

${ }^{3}$ Swift v. United States, 196 U. S. 375. 
the order was not discussed in the supreme Court, although the power of the court under such an order was sustained in the cireuit court. ${ }^{1}$

Persons who are in privity with the defendant as agents, servants or employees are to be distinguished from independent tort-feasors who are not shown to be in any wise allied with the lefendants." The supreme Court sustained the jurisdiction of the Circuit court in the case of In re Lennon," saying that it was sufticient that he had actual notice, although he wis not a palty to the suit, nor served with process; in that case however Ienmon was an employe of the defendant, which had been enjoined from refusing to interchange tratlie with the complainant, and he was shown, with full linowledge of the injunction, to have refused to obey it.

Uther fuestions have been raised as to the proper scope of injunctions in trale disputes, particularly with reference to the conduct of striking employees, but these have been in cases, where the juristiction of the federal courts was based on diverse eitizenship as in mining and other local industries where interstate commerce was in no wise in rolred."

1 Tohrib. etc. R. Co. v. Penn. R. Co., is Fel. Rep. it6; ln re beus, 64 Fed. Rep. $\sim 2$. As to the jurisiliction of the courts in issuing injunctions under the Interstate Commerce Act. see sec. S, infiru: and as to the AntiTrust det and the procedure thereunder, see Anti-Trust Act, infru, $\$ 314$.

$\because$ In re Reese, 9s Ferl. Rep. 954, 47 C. C. A. -i, and 10i Fed. Rep. 942.

"16tj L.S.5tS 41 L. Ed. 1110, supre.

1 See \$ so. sulun: see also discusfion before the Iuliciary Committot of the Honse of Representatives of the isth consress. The agitation over the increasel use of injunctions in trade disputes and the application of the law of conspiracy in the trial of contempts has been rxtensively discussed in congress in connertion with the so-called Anti( - mepirary and Anti-Injunction Bill. to linut the meaning of the word "conspiracy". in the uce of restrain. ing words and orders in certain cases. which has been introduced in sereral successive congresses, but has not been enacted into law. The proposed alet is as follows:

Be it enacted by the senate and Homse of Representutices of the United states of America in Congress assembled. That no arreement, combination or contract by or between two or more persons to do or procure to be clone. or not to do or procure not to be done, any act in contemplation or furtherance of any trade dispute between employer's and employees in the Dintrict of Columbia or in any territory of the United States, or between employers and employees who may be engaged in tralle or commerce between the several states, or between any territory and another. or between any territory or territories and any state or states or the District of Lolumbia. or with foreign nations, or between the District of Columbia and any state or states or foreign nations shall be deemed criminal. mor shall those engaged therein be indictable or otherwise punishable for the crim- 
89. Contempt in Inited States courts.-A contempt proceeding, said the Supreme Court in a recent case, ${ }^{1}$ is criminal in its nature in that the party is charged with doing some-

of conspiracy, if such act committed by one person would not be punish. able as a crime, nor shall such acreement. combination, or contract be considered as in restriant of triule or commerce, nor sluall any restraining order or injunction be issued with relation thereto. Nothing in this act shal exempt from punishment, otherwise than as herein excepteil, any persons guilty of conspiracy for which punishment is now provided by any act of congress, but such act of congress shall, as to the arree. ments, combinations, and contracts hereinbefore referred to, be construed as if this act were therein contained.

This bill was favorably reported by a majority of the house judiciary committee of the jith congress. The committee said in their reprort that no evil would come of the act as interference with the mails was a statutory crime, and that it would not legalize acts directly interfering with interstate commerce. The minority of the committee contended that the bill was ambiguon', and recommended two amendments, by striking out the words "nor shall such agreement, combination, or cons. tract be considered as 11 restraint of tride or commerce." and also by adding to the bill these words: "provided that the provision of this act shall not apply to threats to injure the person or projerty. business or occupation of any person. firm, as. suciation or corporation, to intimida. tion or coercion, or to any acts caus. ing, or tending to cause, illegal in. terference by overtacts with the richts of others."

The report of the majority conceded that there was possibly some danger in the use of the rord "thereto" in connection with "re- straining order or injunction," as it might be construed to forbid the use of any injunction to prevent the execution of acts done in further. ance of agreements not made criminal by statute, which if unrestrinined would result in irreparable injury to property, and that it might be wise to strike out the word anil insert "based solely thereon," or the words "based solely thereon if no unlawful act has been clone in execution thereof; "or to add the words "until some criminal or unlawful act has been done or threatened to to be done in execution thereof:" but it was said "this was hardly necestary, as such construction would be strained."

The house prassel the bill without amendment. but it was not renched in the senate. It was reintroduced in the isth congress, but was not reported to either fouse. At the hearing before the committee of the House of Representatives the bill was strongly opposed by representatives of business and manufac. turing astociations, on the ground that it was ambiguous, that it wis. not needed to validate strikes, but would ralilate boycotts and otler unlawful combinations.

This proposed act goes, as it will be seen, far beyond the scope of the English act of 1sio. That law related only to criminal prosecutions and was intended to legalize strilies. Unlesi this proposerl law should he construed to validate boycotts or sympathetic strikes, it is difficult to see what effect it would have upon interstate commerce.

The regulating power of Congress extends to the business of interstate 
thing forbidden, and if found guilty, is punished. Tet it may be resorted to in ciril as well as in criminal actions, and also independently of civil or criminal action. While the power to punish for contempts is inherent in all courts, the exercise of the power by the conrts of the Lnited states has been regugated by statute, as foliows: ${ }^{1}$

"Courts of the Inited states shall have power to impose and alminister all necessary oaths and to punish by fine or implisonment at the discretion of the courts contempt of their authority: provided that such power to punish for contempt shall not be construed to extend to any case except the misbethatrior of any person in their presence, or so near thereto as to obstruct the oflicers of said cont in their ofticial transactions, and the disobedience or resistence by such officer or by any party, juror, witness or other person to any lawful order, proeess, inte, lecree, or command of said conte."

Whether a particular act constitutes a contempt, as well as the mode of proceeding atrainst the offender, are left to be determined according to such established rules of the common law as are applicable to the situation. A fecleral court may pumsh for contempt in its presence. or so near as to obstruct justree, though the oflense is indictable."

The interference with the operation of a road by a receiver appointed by the federal court is itself a contempt, as the receiver is an officer of the court, and no specific injunction order in such cases is refuired.; The power of the court to punish disoberlience of an injunction orter by a party to the case as a contempt has been repeatedly adjudged. ${ }^{+}$The power to punish for contempt is inherent in all courts of record, and it has been held that in the case ol courts estiblished by the constitution this power cannot be abrilged by the legislature, as this is the inherent power of a co-oplinite branch of the government. ${ }^{3}$

It was intimated by the supreme Court howerer that the power of the circuit courts and listrict courts of the Cnited commerce, and relates to trale disputes therein only as directly affecting such commerce.

isec. T2., I. S. C. S., 1 Comp. Stats. p. is:s.

2 In re Savin. $1: 31$ U. S. 26\%. $3: 3 \mathrm{~L}$. E.1. 1.50 15-(1).

3 [nttel States v Kane. 2:3 Fed.

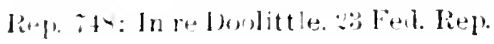

j44: In re Higgins, 27 Fed. Rep. 443; Thomas v. R. Co. 6: Ferl. Rep. s0:3.

4 Ex Parte Lennon, 166 C. S. ij48, 41 L. El. 1110: In re Debs. 1.js L.S. 564. 3! L. Ed. 1092.

5 Commonwealth v. Carter, 96 Va. 7.91 $(15 !) !)$.

"i Ex parte Robinson, 19 Wall, 505, 2.2 L. E.l. :05. 
States conld be regalated by Congress, and that their power is limited by the act of $14: 31$, cited above, and that the power to punish by fine and imprisonment is negative of all otiser forms of punishment. The Cireuit ('ourt said in the Dels ease ${ }^{1}$ that the power of the cont to make an onder carries with it the equal power to punish for disobedience of that order and the inquiry as to the question of disobedience has been from time immemorial within the discretion of the court. It was also held that a case of contempt was not triable by jury, nor is a judgment on such eharge a substitute for, or any defense to a criminal prosecution for the same aet.

The increasing use of in junctions, howerer, in trade disputes has lead to a discussion as to the inherent distinction between direct and indirect contempts, that is, between those committed in the presence of the court and properly subject as such to summary hearing and punishment, and those of alleged disobedience to the orders of the currt, not committed in its presence. It has been elaimed with foree thit as to this latter class, particulariy where parties are charged with a responsibility for acts of others under the law of conspiracy, that the hearing should not he summary, but should be regulated by law in atcordance with the constitutional guarantees in crininal hearings."

Another classification has been male of proceedings for contempts, between eriminal or punitire, where conducted to preserve the power and rindicate the dignity of the court and to punish for disobedience of their orders, and civil, remedial or coerive contempts instituted to protect and enforce the rights of

115 U. S., 1. c. 54.

2 In the jith conmress, 1896, a bill wis reported from the judiciary commit tee proviling that contempts be divided into two classes, direct and indirect, the former inchding contempts committed during the sitting of a comrt. or of a judge in chambers, or so near thereto as to obstruct the administration of justice. These were to be punislatble summarily, without written accusation: while the other, that is, indirect contempits, were to recunire an orler to show cause and a procedure upon testimony. as in criminal cases, and a jury trial, if applied for by the accused, with a preservation of the? testimony by bill of excejtions and stay of the judgment upon giring bond pending appeal.

The provisions of the act alpllier] to all proceerlings for contempt in al! conts except the supreme conrt. The bill passed the senate and was reported with amendments by the house judiciary committee set House Rejort No. 2ti1, jth con gress), but it was not reachel for passage. It has been introlucerl in substantially the same form in ditferent congreses since. 
prirate parties. $^{1}$ A criminal contempt, said the Court of Appeals in the case cited, in rolves no element of personal injury. It is directed against the power and dignity of the court, and private parties have little, if any, interest in the proceeding for its punishment. It was said by the supreme court in the Pessette case, which was a trade dispute not involving interstate commerce," that it may not be always easy to classify the particular act as belonging to either one of these two elasses, and that it may partake of the characteristics of both. Thus, in cases in rolving combinations interfering with interstate commeree, whether filed directly by the government or by public carriers, it would seem that the riolation of the injunction order, made for the promotion of public and not private ends, would properly fall into the class of eriminal rather than civil contempts.

The law of conspiracy has been applied in proceedings for contempt, and persons not parties to the record have been charged with contempt as co-conspirators with the defendants, and therefore in law responsible for their acts. ${ }^{3}$ The liability to punishment for contempt is not limitel to parties to the recond, but any person, who knowingly assists in defeating the older of a court, may be charged with contempt therefor. In such cases, however, where the injunction has been issued for the benefit of a private person with no public interest involved, the offense of the person not a party is solely that of resistance to the authority and dignity of the court and he should be proceeded against upon that theory, and not upon the theory of being hound by the injunction as a party thereto.

An oreler of a lederal Cireuit Court, adjudging a person not a party to a suit guilty of contempt for conspiring to riolate an injunction in a trade dispute, was held reviewable by writ of cror in the circuit court of Appeals, but in such a writ oniy matters of law can be considered, the decision of the trial tribunal being conclusive of the fiacts.

1 In re Teritt, Cir. Ct. Alle. eth

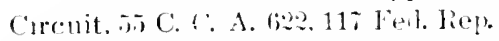
$4 \mathrm{Hs}$, guoted by the supreme court in lieriette r. W. IR. Comkey ro. 194 C. S. 3:4. I. c.. p. 320 to L. Eil. 95\%.

21. c., 1. $3: 9$ ?.

"See In re bessette 111 Fed. IRep. $41 \%$.
4 See In re Reese, 99 Fed. Rep. 984, silpirt.

SHessette r. Conkey Co.. supra (1!n1). See alio In re Christensen Enemerering Co. 194 L. S. 1.5. 45 L. Eil. war. holding reviewable by wrat of error : an onler of the circuit court a ijuiruing a defendiut in a patent 


\section{Mandatory injunctions in interstate commerce.-}

As a preventive remedy is the only aderpate remedy in the case of a threatening of commerce, the form of the preventive relief must be adapted to the emergency, and the injunction mandatory in its terms is therefore often the only remedy which meets the emergency. A mandatory injunction is one that compels the defendant to restore things to their former condition, and virtually directs him to perform the act. specific provision is made in the Interstate Commerce Let for a mandamus to compel the performance of the duties of a carrier. Section 23 of the Interstate Commerce Act, infiu.

Such an injunction may be issued as well upon a proper showing on a preliminary as on a final hearing. It was said by Taft, J., ${ }^{1}$ that the office of a preliminary injunction is to preserve the status que until upon final hearing the court may grant full relief, and generally this can be accomplished by an injunction probibitory in form. It may sometimes happen. however, that the stutus quo is not a condition of rest, but of action, and the condition of rest is exactly what will inflet an irreparable injury upon the complainant. In such cases, therefore, it is only a mandatory injunction, compelling the traffic to flow as it is wont to flow, which will protect the complainant from injury.

It was said by the Supreme Court ${ }^{2}$ that it is one of the most useful functions of a court of equity that its methods of procedure is capable of being made such as to accommodate themselves to the development of the interests of the public in the progress of trade and traffic by new methods of intercourse and transportation, and it may be added, in securing the uninterrupted morement of commeree. ${ }^{3}$

suit guilty of contempt in clisobeying the preliminary injunction and ordering him to pay a fine. one-half to the United States and on -half to the complainant on the ground that the fine payable to the United States was clearly punitive anu as such reviewable without waiting for final decree in the cause.

IToledo, A. A., etc. R. Co. Case. supra.

Joy v. St. Louis. 138 U. S. 1, l. c., p. 50. 34 L. E⿺辶. 8.3.
${ }^{3}$ In So. Cal. Co. v. Rutherford) So Dist. of Cal.), 62 Fed. Rep. 796 , the court granted an injunction to a railroad company against its employeer, compelling them to perform all their regular and accustomed duties as long as they remain in the employ- . ment of the complainant company. This was in a case where the employees, while continuing in the serrice, had boycotted the Pullman Car Co. 


\section{CHAPTER V.}

\section{THE FEDERAL CONTROL OF STATE REGULATION.}

\$91. State regulation of railroads under State Commissions.

92. The power of regulation independent of state or federal incorporation............................ 129

93. The limitations of the state authority in domestic traffic....... 130

94. The adoption of the Fourteenth smendment............. 131

9i. Federal review of state regulation of carriers. ............ 131

ati. Procedure in federal review of state regulation. . .......... 132

9. Limitation by federil authority of the state's power in regulatin interstate rates $\ldots \ldots \ldots \ldots \ldots \ldots \ldots \ldots \ldots \ldots \ldots \ldots \ldots \ldots$

9. What is reasonableness in the limitation of state authority . . . . 13;

99. To definite standard of reasonableness in ratilroud rates....... 137 1111. Frotection of the carrier aga inst discriminating state legislation.. 138 101. Fxtent of the state power of regulation............... 135 10:? The state anti-tru-t laws and the Fourteenth imendment..... 140 10:3. Classification in state ratroad legislation............. 142

\section{\$1. State regulation of railroads mader State commis-} sions.-The complexity of our dual form of government is nowhere more foreibly illustrated than in the administration of the railway system of the country under the statecommissions as to their state traffic, and uncler the Interstate commerce commission as to their interstate traffic. The power of the states to recrulate the rates of rail roads and other earriers had been definitrly established in the (iranger cases as al ready seen, prior to the adoption of the Interstate commeree Act. This power of the states conk be exereised either directly by the lewislature lixing the rates, or could be delegaterl to a comm ission acting for the state. Commissions had been established In many of the states prior to $15, \overline{6}$, some with advisory powers ancl other's with power's to tix maximum rates.'

It was hele by the supreme Court, that a railroad forming a continuolls line in two or more states, and owned and mananel by a copporation, whose corporate powers are derived from the legrislatures of each state in which the road is situated,

I See reviow of state commisson statutes in Maximum Rath Case. 169

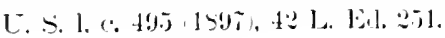

2 Railroat Commission Cases, 116

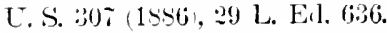


is as to the domestic traffic of each state a corporation of that state subject to the laws of the state not in conflict with the constitution of the United States. It was also established that an authorization of a commission by a state to fix a schedule of rates for a railroad was not an unconstitutional delegation of legislative power. ${ }^{1}$ Justice Brewer said in the case first cited that the line of demarcation between legislative and allministrative functions was not easily discernable and that the reasonableness of a rate was constantly changing with changing circumstances, and, therefore, was peculiarly a subject for an administrative board to determine.

The entire expense of a state railroad commission may be lawfully assessed upon railroads operating within a state in proportion to their operated mileage within the state. ${ }^{2}$ The court said that as the railroad commission was charged with special duties in the general supervision of the railroads of the state for the benefit of the public, it was reasonable that the expense should be so apportioned, and there was in this no violation of the state constitution providing for uniformity in taxation.

\$9. The power of regulation independent of state or fereral incorporation. - This power of regulation under state commissions, as that of the Interstate Commerce Commission, under the Interstate Commerce Act, is dependent upon the character of the traffic, whether intrastate or interstate, and not upon the state or federal incorporation of the carrier. The same railroad is subject as to these two classes of traffic to the state and federal authority, respectively. Thus the power of the interstate commerce commission extends to railroads organized under state and fecieral authority as well as to corporations organized under the laws of Canada and operating in the United States. In the Merger case a corporation organized under state authority, for the purpose of holding the stock of competing interstate railroads, was adjudged an unlawful combination under the Anti-Trust Act of Congress. ${ }^{3}$

1 Chicago \& N. W. R. Co. v. Dey, 3j Fed. Rep. S66; also Railroad Commission Cases, supra; Regan v. Farmers Loan \& Trust Co., supra.

2 See supra, 53 .
${ }^{3}$ Regan r. Mercantile Trust Co., supra: Ames r. Union Pacific R. Co., 64 Fed. Rep. 165; Smyth v. Ames, supia. 
On the other hand, as to state traffic, it is immaterial by what ageney it is performed, that is, whether by a state or a federal corporation. Railroals derising their franchises from Congress are subject to the control of the state in all matters of taxation, rates on domestic traffic, and to all reasonable police regulations. Such subjection of such corporations to the laws of the state is not based on the aceptance by the railroad company of state legislation, but results from the failure of Congress to express any intention in the at of incorporation that they shall be exempt from state control. ${ }^{1}$

sio The limitations of the state anthority in domestic tiallic.- It was held in the leading case of the Wabash Railway Company that a state commission had no regulating power over a through interstate rate, that is, orer eren that pirt of it which was within the state. The limitations of the state authority were further illustrated in the two Kentucky cases decided in 1901. In the first of these," the court affirmed the Fentucky court in sustaining a conviction of the railroad company for violation of the long and short haul elanse of the Kentucky statute in a rate on an intrastate shipment. The court below had excluded evidence that the rates were reasonable fier se, and held that it was immaterial that the less charge for the longer haul was induced by competition, on the ground that the state had authorized the state commission to give relief on application. In the other case at the same term, ${ }^{3}$ the supreme Court held the Kentucky statute unconstitutional as construed by the state court in its application to a long and short haul where the short haul was wholly within the state and the long haul was partly within and partly without the state. The court said that the direct effect of the statute so construed was to regulate the interstate rate, for it was impossible for the carrier to do any interstate business at the local rate, and so it must gire up its interstate business, or else reduce the local rate in proportion. The result therefore was a direct interference with commerce between tive states, ear. ried on though it may be by a single company.

1 C. C. \& A. R. Co. v. Gibbes, 142 U. S. 386,35 L. Ed. 10.51 (159\%).

2 L. \& X. R. Co. v. Kentucky, 193
U. S. $5(1) ;(199) ?)$, 46 L. Ed. 298 , reversincr 10:3 Fed. Rep. 216.

${ }^{3}$ L. \& N. I. Co. v. Eubank, 184 U. S. $: 2(190), 46$ L. El. 416. 
\$ 94. The adoption of the Fonrteenth Amendment.- Prior to the adoption of the Fonrteenth Amendment in 1868, there was no appeal to the federal courts against any riolation by state power of due process of law or of tre equal protection of the laws, which did not involve an interference with national anthority or a violation of some provision of the ferleral constitution. The federal courts administered the state laws and followed, as they still do, the decision given by the state courts as to the construction of the state statutes.

The fourteenth amendment provided in its first clause that no state should deprive any person of life, liberty or property without due process of law, nor deny to any person within its jurisdiction the equal protection of the laws. Corporations are persons under this amendment and are therefore entitled to clue process of law and to the equal protection of the laws, ${ }^{1}$ and a state has no more power to deny the equal protection of the laws to a corporation than it has to individual citizens."

This far-reaching change in our judicial system, wherein the fundamental rights of property are protected by the felleral power against state invasion, was adopted about the same time that the julicial declaration of the freedom of interstate commerce against state interference had opened the way for the direct exercise of the fecheral regulating power.

95. Felleral review of state regulation of carriers. - The comprehensive power of the state in the regulation of the intrastate traffic of carriers, whether exercised directly under legislative act of the state or throngh a commission of the state, is subject to the juristiction of the courts of the United States under the provisions of the Fourteenth Amendment guaranteeing due process of law and the equal protection of the laws to all persons against any invasion by state authority.

A suit against a state commission or state officials acting under the authority of a state in fixing rates of carriers is not a suit against the state within the meaning of the Eleventh Amendment of the Federal Constitution. ${ }^{3}$

I Santa Clara County v. Southern Pacific R. Co., 118 U. S. 394 (18s6), 30 L. Ed. 118.

2 Railroad Co. r. Ellis, 165 U. S. l. c. $1.7(189 \pi), 41$ L. Ed. $66 \%$.
${ }^{3}$ Chicago, Milwaukee \& St. Paul R. Co. v. Becker, 35 Fed. Rep. 8s:3 (1888): Reagan v. Farmers Loan \& Trust Co. 154 U. S. $362(1594), 38$ L. El. 1014. 1021: So. Ry. Co. v. Greensboro Ice \& Coal Co, $13+$ Fed. Rep. 8\%. 
The jurisdiction of the courts of the United States in such cases does not depend upon the unconstitutionality of the state statute, as a valid law may be wrongfully administered by the officers of the state. If the statute of the state, as construed by the highesi court of the state having jurisdiction, denies due process of law or equal protection of the laws, the federal jurisdiction under the Fourteenth Amendment may be in roked.

This power of the federal courts cannot be limited by state legislation. Une who is entitled to sue in the federal circuit court may in roke its jurisliction in equity whenerer the established principles and rules of equity permit such suit in that court, and he cannot be deprived of that right by reason of beingr allowed to sue at law in the state court or before a state board on the same cause of action. ${ }^{2}$

An act of a state providing that the rates charged, established by a commission, shall be final and conclusive as to what are reasonable charges, and which, as construed by the supreme court of the state, preclucles any judicial inquiry as to the reasonableness of the rates, deprives the company of its property withont due process of law and of the equal protection of the laws." The carrier is thus secured under the Fourteenth Amendment, not only in a judicial liearing upon the question of his intrustate rates, but also in his right to charge reasonable rates; and the reasonableness or unreasonableness of the rates established under state authority will be reviewed by the federal courts in determining whether or not the company is deprived of its property withont due process of law."

: 96. Procedure in federal review of state regulation.The question of reasonableness of rates may be raised by a carrier by way of defense by action at law for the penalties imposed by the act of a state legislature, ${ }^{5}$ and also, preferably, by a bill in equity directly challenging the validity of the rates.

The circuit courts of the United States have jurisliction of

1 Rearan v. Farmers Loin \& Trust supra; Chicago, Mil. \& St. Paul Co.s supurt.

- Sinyth v. Ames, supra.

3 Chicaro, etc. R. Co. s. Ilinnesota, 134 C. S. $418(1890)$, 33 L. Ed. 970.

Sinyth r. Ames, supra: Rearian

v. Farmers' Loin \& 'Prunt Co., R. Co. v. Tompkins, $1 ; 6$ U. S. $16 \pi, 44$ L. Ed. 417; Covington \& Lexington Turnpike Co. v. Sandford, 164 U. S. 578 (1S96), 41 L. Ed. 560.

5 St. Louis \& S. F. R. Co. v. Gill, $15(j$ U. S. (j(181695), 39 L. Ed. $56 \pi$. 
an action of the non-resident stockliolders of such companies against the companies and the state ofticials contesting stateimposed rates. As in the case where a suit can be maintained in the courts of a state, the United States circuit court will protect property rights of a citizen of another state who invokes the juristiction of the fecleral courts. ${ }^{1}$ But where the basis of the complaint is that the rates estahlished by the state are confiscatory and unreasonable ancl violative of due process of law under the Fourteenth Amendment, the federal courts would have jurisdiction irrespective of citizenship. This jurisdiction may be exercised through writ of error to the highest court of the state, where the ferleral right involied is deciderl adversely to the claimant by the state court, or the jurisuliction may be exercised in a direct proceeding in the assertion of the federal right in the United states Circnit Court. It was said by the supreme Court in a recent case " that it was a better practice in cases contestıng the reasonableness of carrier's' rates to refer the testimony to some competent master to make all needed computations and find fully the facts, and that, in view of the difficulties and importance of such a case, it was imperative that the most competent and reliable master, general or special, shonlel be selected, for it is not a light matter, said the court, to interfere with the legislation of a state in respect to prescribing rates, nor a light matter to permit such state legislation to wreck large property interests."

\section{\$9\%. Limitation by federal authority of thestate"s power in} regulating intrastate rates.-The regulation by the state of intrastate rates in the exercise of its authority over domestic commerce has been reviewed by the supreme Court in this juridiction under the Fourteenth Amendment in cases from Arkansas, ${ }^{+}$

1 Reagan v. Farmers' Loan \& Trust Railroad Commissioners, 90 Fed. Co., 154 U. S. 391 (1894), 38 L. Ed. Rep. $3: 3$. 1021 .

2 Chicago, Milwaukee \& St. Paul, R. Co. v. Tompkins, 176 U. S. $16 \%$, 44 L. Ed. 417 (1900), reversing 90 Fed. Rep. 36:3.

${ }^{3} \mathrm{As}$ to the proper allegations in the bill of complaint to restrain enforcement of an order of a state commission reducing rates, see Wulmington \& W. R. Co. v. Board of
4St. Lonis \& S. R. Co. จ. Gill, snpur: Dow v. Beirlelman, 125 U.S. 680 (1858); 31 L. Ed. 841 . In the latter, an Arliansas case, the court said that in the absence of evidence of the amount invested in an organized corporation the fact that the income of the road at the rate of fare fixed by the lerislature would only be one-half of one per cent. on the orig- 
Texas, ${ }^{1}$ Tebraska," Michigan, ${ }^{3}$ Sonth Dakota ${ }^{4}$ and Minnesotia. $^{3}$

In the Texas rate case the Supreme Court reversed the decree of the circuit court in so lar as it restrained the railroad commission from dischatring the duties imposed by the lerislative act and from proceeding to establish reasonable rates, but allirmed the decree in so far as it restrained the commission from enforcing the rates already established. The enfoleement of the state rates was also enjoined in the Nebraska ritte case, and in the Sonth Dakotal case the decree of the circuit court refusing to enjoin and dismissing the bill of the railruald company wats reversed with directions to the circuit conrt to determine the reasonableness of the rates. In the other calses it was ruled that the raitroal company failed to orercome the presumption of the reasonableness of the rates fixed by the state anthority.

In these cases in the fecleral courts, however, the standard of reasonableness considered by the court is not the same as that involved in the determination of what is reasonable between a carrier and its patrons, whether raised uncler the Interstate Commerce Act or otherwise. It is not what the carrier can charge under the common law rule of reasonableness, but what limit the state can lawfully impose upon his contractual power in making rates without violating the feleral constitutional guaranty against the taking of property without due process of law.

In all such cases where the federal power is involied to prevent the enforcement of rates imposed by the states, the presumption is that the rates thus imposed are reasonable, and it devolves upon the carrier to show that the enforcement of such rates would involve a confiscation of property rights, that is, the taking of property without due process of law. This involves the determination of what is a reasonable profit upon

inil cost of the roall did not show a taking of property without due process of law.

1 Rearan v. Farmers' Loan \& Trust Co.s supuet.

"Simyth s. Anes, supra. ${ }^{3}$ Chicago (irant frunk R. Co. v. 11.j1.

Wellman, 143 U. S. 3399 (1892), :36 I.

Ed. 1\% 6 .
${ }^{4}$ Chicago, M. \& St. P. R. Co. v. Tompkins, supra.

5 Chicago, etc. R. Co. v. Minnesota. 134 U.S. 418,33 L. Ed. 970; Minneapolis \& St. Louis R. Co. v. Minnesota, 186 U. S. 257 (1902), 46 L. Ed. 
his investment, to which a carrier is entitled. As to the different elements to be considered in determining the limits of this right to reasonable profits, see $\$ 126$, infra, "Capitalization of Railroads as a Basis for Pates."

On the other hand, in actions against the carrier, whether under the Interstate Commerce Act or otherwise, the party complaining must make proof of unreasonableness, as he is the

1 actor and is bound to prove his case. See $\$ 13:$, infra. ${ }^{1}$

Another distinction is to be observed between the two classes of cases wherein the federal authority is involed in the supervision of railway rates, in that in proceedings under the fourteenth amendment the entire schedule of maximum rates imposed by state authority is usually challengerl while in the cases under the Interstate Commerce Act, as will be hereafter seen, it is, as a rule, the reasonableness of the rates on specific commodities or to or from specified localities, or more usually the relation of rates as between competing communities or kinds of traffic which is brought under review.

$\$ 98$. What is reasonableness in the limitation of state anthority.- It was said by Justice Brewer in the Circuit Court in the Nebraska Rate case, subsequently affirmed by the Supreme Court, that the test to determine the reasonableness of rates was not well settled, and that it was doubtful whether any single rule conld be laid down applicable to all cases; and in another case it was said by the supreme Court that few if any questions were more difficult and perplexing than those in rolving the validity of the rates prescribed for carriers by a state legislature.

In the Texas Rate case the Court based its decision, enjoining the enforcement of the rates, on the facts established in the case as to the cost and present value of the railroad, the voluntary steady decrease of its rates and the proof adduced

1 The burden is upon the complaining shipper in proceedings before the Commission. But in judicial proceedings to enforce the ruling of the Commission, the findings of fact of the Commission are made primrifucie evidence as to every fact found. Under the proposed amendment of the Interstate Commerce Act see
\$ 48, supra), the rulings of the Com. mission. in the absence of judicial proceedings, would be self-enforcing. subject to review in the court of transportation. and in such judicial proceedings the findings of fact made by the Commission are to be received as prima facie evidence. 
that the proposed tariff would prevent the road paying interest on its bonds, nothing being shown to justify such a result.

In the Nebraska Rate case it was definitely ruled that the realsonableness of local rates must be determined without reference to interstate rates, over which the state had no control. The state, it was said, could not justify nureasonably low rates for domestic transportation on the ground that the carrier was earning large profits on its interstate business, nor, on the other hand, could the carrier justify unreasonably high rates on domestic business on the ground that only in that way conkl it meet the losses on its interstate business.

In the Sonth I)iliota liate case the Court said that the circuit court erred in making a comparison between the gross receipts from local business, under the existing and proposed rates, without consilering also the cost of doing the local business and ascertaining the net earnings and determining therefrom the true effect of the reduction. ${ }^{1}$

A definite rule has not been laid down in any of these cases as to what is the reasonible rate which a carrier will be protected by the federal anthority in charging within a state. The carrier is entitled to charece a reasonable profit in his domestic business as in its interstilte business, and the state cinnot enforce rates unreasonably low within the state because the carrier is charging unreasonable rates on its interstate business. In ascertaining the value of the property upon which income is to be earned, it is not the cost, but the present value, which is to be consilered. But in ascertaining value the original cost, the amount expended for permanent improvements, the present as compared with the original cost, are all facts to be considered. It has also been said that in deternining the reasonableness of rates, the betterments and replacements made necessary by the growth of traffic, and also the permanent estahlishment and good will should be considered, and that the mere valuation of the physical structure of a roal is too narrow a basis when a road is constructed and the property inrested with a view to the future, and the original investment is made at a time when the conditions of the country are such as to give no expectation of reasonably profitable earnings. ${ }^{1}$

1 For disposition of this case in cirroit rourt, after remamling, see 110

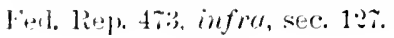

-S se cases, supra, and also Metropolitan Trust, ('o. v. Railroal Co., 90 Fel liep. (is:3. For further discus- 


\section{No definite standard of reasonableness in railroad} rates. - The subject of the reasonableness of railroad rates and the factors to be considered in the determination of such reasonableness have thus been considered by the federal courts in two classes of cases. That is, in cases arising under the Interstate Commerce Act, where the shipper complains that he is charged by the carrier more than a reasonable rate, and in cases arising under state laws, where the carrier complains that he is prohibited by the state law or order of a state eommission having the force of law from charging a reasonable rate.

While the Interstate Commerce Act rcaffirms the eommon law in the requirement of reasonableness, neither the statute nor the common law furnishes any definite standard for the determination of what is reasonable. In ordinary business transactions a reasonable charge for a personal service is the resultint of the free economic forces of supply and demand. It is obvious that under the complicated conditions of railway transportation this free play of the economic forces of supply and demand does not ordinarily exist. When eompetition does act in determining railway rates, it is only at certain points, as terminal centers, where the rate may be made unreasonable from the carrier's point of view, while at local points on the same line it may not exist at all. The standard of reasonableness, therefore, is one thing for the railroad manager who wishes to secure at all times a reasonable profit upon the cost of service, and a very different thing for the shipper who wishes to secure at all times a reasonable profit for his own business as against his competitors in other communities.

In the Trans-Missouri Freight Association case ${ }^{1}$ the court, referring to the argument that the Anti-Trust Act of 1890 should not be construed as applying to agreements resulting in only the reasonable regulation of rates, said: "What is a proper standard by which to judge the fact of reasonable rates?" And after commenting upon the different factors to be considered said: "That it it is quite apparent that it is exceedingly difficult to formulate even the terms of the rule itself which should govern in the matter of determining what would be reasonable rates for transportation, and that there was such sion of this subject see secs. 125 and 126, infra.

1166 U. S. 1, c. 331,41 L. Ed. 102\%. Sec. 1 of Interstate Commerce Act. 
an infinite variety of facts entering into the question of what is a reasonable rate, no matter what stanclard is adopted, that the individual shipper would be practically remedyiess. It is also true that the complexity of the problem requires for its solution the largest experience, and the fullest knowledge of the details of the cost of service, and ail the conditions of trathie." 1

\section{$\$ 100$. Protection of the carrier against discriminating} state leqislation.- The Fourteenth Amendment protects the carrier not only against unreasonable state limitation of rates, but aiso acainst any state legislation which unreasonably interferes with the carrier's right to carry on and manage its concerns. This federal guaranty may be involed irrespectivo of whether there is any contract between the state and the company exempting it in any measure from state control. While the carrier is subject to the general police power of the state in the greneral concluct of its affairs, the running of its trains and providing for the proper accommolation of the public, it cannot be subjected to discrininating or class legislation. Thus, a statute of Miehigan which provided that the railroarls should keep for sale one-thousand mile ticliets good for two years at a reluced rate, such ticket to be issued in the name of the purchaser's wife and children when desired, and redeemable by the company if not used, was held violative of due process of law and the equal protection of the laws. The Court said that such legislation was not included in the power to fix maximum rates and that the company had the right to insist that all persons should be compelled to pay alike and that no discrimination against it in favor of certain classes of married men with families, excursionists of others should be made by the legrislature. ${ }^{2}$

1."The rates of freight must be sufticiently low to result in the development of the largest anount of traftic, and at the same time they must be high enough to produce sulticient reveuue to pay for the eost of inainienance and operation of the roads and if posible. interest on the incestment. The rates must in no care exceel the value to the public of the services remleren, which is iletormined by the commercial laws by competition with all rail lines, whth rail and water lines, by competition between narkets, by competition of products with products, by the value of the articles of freight at the places of production and manufacture, and the places of consumption. by other circumstances and conditions." Fink on Railway Rates.

2 Lake Shore \& II. So. R. Co. v. smith, 17:3 U. S. 64t (1899), 43 L. Ed. 8.58. Three justices dissenting. 
\$ 101. Extent of the state power of regulation.-- The power of the stite in its control of domestic eommerce when unincumbered by contracts to fix maximum rates subject to the judicial determination of theip reasonableness, also includes the power to make any reasonable regulations for the conduct of the carriers' business subject to the judicial determination of what is reasonable. Thus discriminations may be prohibited, the requirement of facilities for the transler of freight by direct connection at the intersection of railroals may be required, ${ }^{1}$ and the reasonableness of contracts of the carriers, whether such contracts be made directly with the patrons of the roal or for a general arrangement between railroals in the transportation of persons and property, are properly subject to state control." The consoliclation of parallel or competing lines of railway may be prohibited."

While a charter contract not containing a reservation on the part of the state of the right to alter or amend is protected by the federal constitution against impairment by subsequent legislation, the right may be reserved by the state to alter, amend or repeal the charter contract. In such cases the rights vested in the corporation by the terms of the charter contract may be modified by subsequent legislation, though this right of impairment or annulment does not extend to vested rights in property or contract acquired by user of corporate powers and franchises. Thus, where by a railroad charter the general power is given to consolidate with, purchase. lease or acquire the stock of other roals, which had remained unexecuted, the legislature may declare by subsequent acts that this power shall not extend to the purchase, lease or consolidation with parallel or competing lines. ${ }^{*}$

Where a railroal corporation is organized under state law by the purchasers of the property of a railroad corporation at foreclosure sale, there is no contract right created protected by the feleral constitution against the enforeement of subseguent statutory regulations respecting railroal rates existing when

1 Atchison, etc R. Co. v. Denver, Minnesota, 196 U. S. $25 \pi$ (1909). 45 L。 etc. R. Co. 110 U. S. 667 (1584), 28 L. Ed. 2s1; Wisconsin. etc. R. Co. v. Jacobson, 179 U. S. $28 \pi(1900)$, $45 \mathrm{~L}$. Ed. 194.

2 Minneapolis \& St. Louis R. Co. r. Ed. 1151, snpre.

${ }^{3}$ Loulswille \& Nashville R. Co. r. Kentucky, 161 U. S. 677 (1896), 40 L. Ed. 849.

${ }^{4}$ Piersall v. Great Northern R. Co., 161 U. S. $646(1 \mathrm{~s} 96)$, to L. Ed. \$3s. 
the new company was incorporated, though not in force when the mortgage was executed, and the railroai company, by incorporating under a general law of the state, is estopped to contest the validity under the federal constitution of the prorisions of an act regulating railroad rates, which form one of the burlens imposed by the stite as a condition of becoming an incorporated boly.'

It is the proper duty of a railroad company to establish stations at proper places on its line, and it is therefore within the power of a state to make it the prime frecie duty of the company to establish stations at all villages and boroughs on their respective lines. A state statute recpuring such erection of stations hy railroad companies on the order of the state railway and warehouse commission, the burden being imposed upon the company of meeting the presumption that the order of the commission is correct, (toes not amount to an invasion of the rights of private property and is not repugnant to the constitution of the United States. ${ }^{2}$

\section{0\%. The state Anti-Trust Laws and the Fonrteenth} Imendment. - Many of the states have enacted anti-trust laws prohibiting contracts and combinations in restraint of competition, and such statutes are within the constitutional power of the state when not violative of the federal guarantees of due process of law and the equal protection of the laws, or other constitutional grnaranties.

The extent of the state power in the enactment of such statutes is illustrated in the recent decision of the supreme Court," holding that a statute of Wisconsin which punished combining for the purpose of wilfully or maliciously injuring another in his business, and construed by the supreme court of the state as requiring malicious, as distinguished from mere wilful injury, was not violative of the lawful right to contract protected by the Fourteenth Amendment. The court said that malicious mischiel was a proper subject for legislative repression, and still more were combinations for

1 Grand Rapids \& Indiana R. Co. v. Osborne, 193 U. S. 17, 48 L. Ed. jas (1904). See also People of New York v. Cook, 14s U. S. 39\%, 3i L. Ed. tay $(1592)$.
2 Minneapolis, etc. R. Co. v. Minnesota, 19:3 U. s. 5:3(1904), 48 L. El. 614.

3 Aikens v. Wisconsin, 25 Sup. Ct. Rep. 3; Smiley v. Kansas, U. S. Sup. Cit. Feb., 190is. 
the purpose of inflicting it, and that it would be impossible to hold that the liberty to combine to inflict such mischief, even upon such intangibles as business or reputation, was among the rights which the Fourteenth Amendment was intended to preserve. ${ }^{1}$ The court did not decide what would be the force of the eonstitutional objection if the statute was construed to embrace combining as to effeet wilful, as distinguished from malieious, in jury.

The Texas Anti-Trust Law, which provided that persons out of the state could be liable for indictment and eonviction for committing any of the offenses enumerated in the act, which did not in their commission necessarily require a personal presence in the stite, the object being to reach and punish all persons offending against the provisions of the act, whether within or without the state, was held by the United States Circuit Court to be an attempt to grive the laws of the state an extra-territorial foree, and therefore void."

Such a law is also invalid when it attempts to exempt a certain elass of the eommunity, such exemption bein' on no reasonable basis of classitication. Thus, the Anti-Trust Law of Illinois was held invalid on the ground that agriculturil products or live stock in the hands of the producer or raiser are exempted from the operation of the statute, which prohibited the recovery of the price of the article sold by any trust or combination if in restraint of trade or eommerce in violation of the act. The Supreme Court said that this discrimination was a denial of the equal protection of the laws. ${ }^{3}$ The Court said that such a statute was not a legitimate exertion of the power of taxation, rested upon no reasonable basis, was plainly arbitrary and clearly denied the equal protection of the laws to those against whom it discriminated, as this exemption was such a material feature of the law that presumably it would not have been enaeted without it, the whole law was held void.

1 The conviction affirmed in this case was that of certain newspaper managers who, it was alleged. had combined to maliciously injure at rival paper by agreeing to refuse space to advertisers who should pay the increased rates fixed by such rival, except at a corresponding in.

crease, but to permit those to advertise in their papers at the old rate who should refuse to pay their rival the new rate.

2 In re Grice, (No. Dist. of Texas), 79 Fed. Rej. 627 (1897).

"Connolly v. Union Sewer Pipe Co. 184 U. S. 540 (1902), 46 L. Ed. 629. 
The exemption in the Texis Anti-Trust Law of agricultural products and live stock in the hands of producers and raisers was also held roid. ${ }^{1}$

10:3. Classification of state railroad legislation.-Where classification is reasonable, that is. based upon legitimate considerations of public policy. it is ralid, as legislation must necessarily be specialized in its arlaptation to the subjects of legislation. The question is thus left open for letermination in every case of classification for legislation, whether the discrimination is natural and reasonable or apbitrary and oppressire. and therefore a denial of the equal protection of the laws guaranterl by the Fourteenth Amendment.

The dilliculty of determining these questions of classifieation was illustrated in the division of the Court in two recent cases. In one the Court held invalid a statute of Texas which required raitroad companies in all cases of claims under $\$ 50$ to pay an attorney's fee not exceeding $\$ 10$ to the party sueces-fully suing, provided the suit was brought thirty days after the refual of the company to pay the cham." The contr saicl that this was an arbitrary selection which could not be justified by calling it classilication. In the other case a Kinsas statute proviling that in all actions brought for damages caused by fire from the operation of the railroad the court should allow the plaintiff on recovery a reasonable attorn'y's fee, which should become part of the judgment, was snstained, the opinion of the court being rendered by the same juige, Instice Brewer, in both cases. It was said in the latter cise that while the principles of separation between the classes were not difficult, yet their application often became rery troublesome, especially when the case was near the dirid-

In re Grice, snpra.

In Niagaril Falls Fire Ins. Co. $\mathrm{s}$. Cornell, 110 Feil. Rep. 816 (1901), the rircuit court of Nehraska held the anti-tru-t law of that state void on account of its exemption of assemlies and ascociations "of worlsingmen" and reserving to them "all their rights and privileges now accorderl to them by law." This cane also held that foreign insurance companies doing business in the state by permission were entitled to envoke the protection of the federal law and challenge the valility of statutes which affected their busine-s, equally with state companies.

2 Ratroal Co. v. Ellis, 165 U. S. 151) +1 L. Ed. 156\%. three judges dissenting.

3. T. \& S. F. R. Co. s. Matthews, 12. C... ! $\%$. 43 L. Ed. 909, four judges dissenting. 
ing line. "It is easy to distinguish," said the Court, "between the full light of day and the darkness of milnight, but often very difficult to determine whether the riven moment in the twilight hour is before or after that in which the light predominates orer the dilriness."

The statute of Kansas regulating charres in public stockyards and applying only to one corporation and not to other companies or corporations engarged in like business, was held to deny the equal protection of the laws. ${ }^{1}$

A law of Texas directed solely against railroad companies and imposing a penalty for permitting . Johnson grass or liussian thistle upon their roallway was sustained, ${ }^{2}$ the Court saying: "Great constitutional provisions must be administered with caution. Some play must be allowed for the joints of the machine, and it must be remembered that the legislatures are the ultimate guardians of the liberties of the people in quite as great a degree is the courts."

A law of lowa excepting "sales by jobbers and wholesalers in doing an interstate business with customer's outside of the state" from a license tax iruposed upon dealers in cigarettes, was sustained, ${ }^{3}$ the Court saying that there was a clear listinction in occupations warranting the classification.

1 Cotting v. Kansas City Stock- cision of Supreme Court of United yarús Co., 183 U. S. 79,46 L. Ed. 9:. States on Wisconsin Anti-Trust Law,

2 Missouri, Kansas \& Texas R. Co. Novemher 4, 1904, 195 U. S. 194. v. May, 194 U. S. 26 ; $(1904)$, 4 L. Eil. 3 Cook v. County of Marshall, 971 , two judges dissenting. See de- U. S. Sup. Ct. Rep., January 16, 1905. 



\section{PART II.}

\section{INTERSTATE COMMERCE ACT.}

\section{SECTION 1.}

\$ 104. Sec. 1. The act to regulate commerce ................ 1tif

105. All of interstate commerce not included .............. 146;

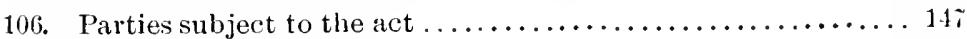

107. Express companies ........................ 14 s

108. Under common control, management or arrangement for a con-

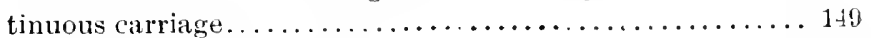

109. Transportation through a state..................... 1.50

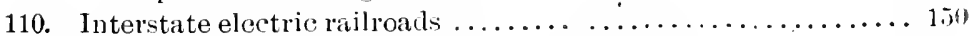

111. Receivers, lessees and purchasers, pendente lite......... 151

112. Foreign commerce...............................

113. Place of inco"poration of the carrier immaterial .......... 15:

114. The intention of interstate shipment not sufficient $\ldots \ldots \ldots \ldots$ 15:

115. All instrumentalities of shipment or carriage..... . . . . 15:

116. Delivery, cartage and storage charges............. 153

11\%. Carriage of live stock and perishable property.......... 15.5

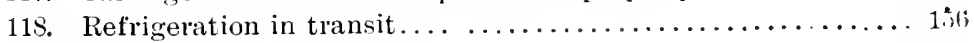

119. Charges must be reasonable and just. $\ldots \ldots \ldots \ldots \ldots \ldots \ldots$ 1is

120. Practical difficulties in the enforcement of reasonableness in

rates... ................................

121. Standard of reasonableness under state statutes.......... 160

122. Standard of reasonableness under the act $\ldots \ldots \ldots \ldots \ldots \ldots$ 160

123. The Conmission has no power to fix rates............. 161

124. No power in the courts to fix rates.................

125. The Federal Courts on reasonableness in railroad rates...... 16:3

126. The capitalization of railroals as a basis of rates......... $16 \mathrm{t}$

197. Through rates and local rates......................

128. The Commission on through and Jocal rates............ 167

129. Responsibility for through rates $\ldots \ldots \ldots \ldots \ldots \ldots \ldots \ldots$.

130. Reasonableness under sections 1 and $3 \ldots \ldots \ldots \ldots \ldots \ldots \ldots \ldots$

131. Consideration of reasonableness in the courts .......... 170

132. Rulings of the Commission upon the reasonableness of rates.. 171

1:3:. The burden of proof before the Commission . . . . . . . . 1 2 :

134. Presumption of reasonableness from established rates....... 17?

135. The Commission on cost of service and needs of the shipper... 1..3

136. The Commission on the character of the traffic......... . 1it

137. The Commission on distance as a factor in rates ......... . 1 if

138. The Commission on comparison of rates.............. 1it.

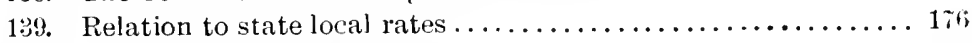

140. Reasonableness and proportion................. 1 iti

141. The Commission on rate wars and reasonableness of rates.... 1it

142. Illustrative cases upon specific rates................ 1is 
104. The act to regulate commerce.-Be it enseted by the Sencte and House of liepresentatives of the Inited states of Ameriad in Compress assmlded: see. 1. That the provisions of this act shall apply to any common carrier or carrier's engaged in the transportation of passengers or property wholly by railroad, or partly by railroad and partly by water when both are nsed, under a common control, management, or arrangement for a continuous carriage or shipment. from one state or territory of the Inited states, or the l istrict of Columbia, to any other state or territory of the ['nited States, or the L)istrict of ('olmmbia. or from any place in the Tnited States to an aljacent foraign country. or from any place in the Lnited states through a Foreign coinntry to any other place in the E'nited states. and also to the transportation in like manner of property shipped from any place in the Lnited states to a foreign country and carried from such place to a port of trans-shipment, or shipped from a forejgn country to any place in the [nited states and earried to such place from a port of entry either in the Cnited states or an aljacent foreign country: $l^{2}$ movidel. loweres. That the provisions of this act shall not apply to the transportation of passengers or property, or to the receiving, delivering. storage. or handiing of the property, wholly within one state, and not shipped to or from a foreign country from or to any state or territory as aforesaicl.

The term "raitroad" as used in this act shall inclirle all bridges and ferries used or operated in connection with any railroatl, and also all the road in use by any corporation operating a railroad. whether owned or operated under a contract, agreement, or lease: and the term "transportition" shall inclucle all instrumentalities of shipment or carriage.

All charges made for any service rendered or to be rendered in the transportation of passengers or property as a foresaid, or in connection therewith, or for the receiving, lelivering, storage, or handling of such property, shall be reasonable and just; and every unjust and unreasonable charge for such service is prohibited and declared to be unlaw ful.

\$105. All of interstate commerce not inchuled.- The definition in this section of the carriers subject to the act does not include all the carriers engaged in interstate commerce, but only those engaged in the transportation of persons or property wholig by ralload, or partly by railroud and partly by water, or ioth, are used. That is, it does not inclucle transportation wholly water, nor does it include transportation by team or wagon. sice $\because$ I. C. ('. R. 2sti). Congress had repeatedly legislated with reference to water transportation, but its attention in this enactment was directed only to the abuses in railroal transportation. 
A steamboat on a navigable river can only demand of a railroad connecting with river points that it receive and deliver freight at the published local rates, as an independent water

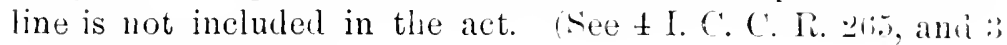
Int. Com. Rep. 27S).

The recisions of the courts on this question have been in accord with the rulings of the ('ommission. A raihoad lying wholly within a state which transports freight, whether coming from within or withont the state, solely on local litls of lacling on a special contract limited to its ow n lines, and without dividing eharges with any other carriers or assuming any obligations to or for them. does not come within the provisions of the act and is not bound to make any reports of its i,usiness to the Commission. Cnited states r. Railroal lo., 1 Fed. Rep.

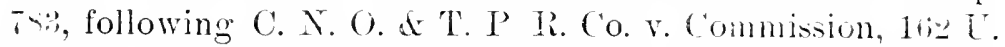
S. 18t, to L. El. 985, and Commission v. B. Z. d ( R. R. Co., 7t Fed. Rep. 942. See also U. S. v. Gedles rith Cir. C. C. A.), 131 Fed. Rep. 452, where the same ruling was male as to railroads subject to the Safiety Act.

106. Parties subject to the act.- The only parties subject to the act, that is, to the juriscliction of the fommission, are the common carriers described in this section, that is, those carriers engiged in the transportation of persons or property as described in the section. The Commission has no juristiction, under this section, over parties other than the carriers and those who invoke its jurisdiction against the carriers. Thus it had no jurisdiction under this section over the owners of private cars whose charges to the carriers may materially affect the rates charged to the shipper. In this connection, however, should be considered scction 2 of the amendatory act of February 19, 1903, infra, \$311, which specifieally provides that in any proceeding instituted before the Commission $O P$ in the courts, it shall be lawful to include as parties in ad. dition to the carrier all parties interested in or affected by the rale, regulation or pratice under consideration, and that inquiries, investigations, orders and decrees may be made with reference to and against such parties in the same manner, to the same effect and subject to the same conditions as are or shall be anthorized by law with respect to carriers. This amendatory act has not yet been judicially construed, though 
it has been considered by the commission in sereral cases, with reference to sections 2 and 6 of the act. See infred, $146-$ $16-233$. It would seem that under this amendatory act the owners of private cars or others whose charges lirectly affect the charge of the carrier to the shipper would be subject to the jurisdiction of the act.

This section in declaring who are subject to the act does not in express terms include carriers making shipments within" t. ritury, that is, from one point in a territory to another. The power of congress over the territories is general and plenary, combining the powers of the state and federal gorernments. under the express power to make all neelful rules and regulations respecting the territory of the United States. Constitution, article IV, section 3. See Hormon Church v. Enited states, 136 U. S. 1, 34 L. Ed. 451. This power over the commerce within a territory, it will be seen, was exercised in the Anti-Trust Act, infra, $\$ 329$. The question of the application of the Interstate Commerce Act to traffic shipments entirely within a territory was suggested in the recent report of the commission in the matter of the Atchison, T. \& S. F. R. Co., 10 I. C. C. R. 4 so.

$\$ 10 \%$. Express companies.-The Commission ruled soon after its organization that independent express companies were not included in the act. See 1 I. C. C. R. 349 and 1 Int. Com. Rep. 67\%. This ruling was adopted by the United States circuit court of Missouri in United States v. Morsman, 42 Fed. Rep. 44, where the court quashed an indictment against a party for alleged violation of the act in acting as agent for an express company, as the indictment did not allege that the express company was a mere adjunct of a rail road company or a combination of railroad companies. See also Southern Indiana Express ('o. v. Cnited States Express Co., 3.) C. C. A. 172 ind :2.2 Fed. Rep. 1022, affirming SS Fed. Rep. 659.

Before the passage of the Interstate Commerce Act of 1886 , the supreme Court in the Express Company cases, 117 U. S. 1, 29 1. Ed. 791, had decided that railroad companies were not reguired by usagre or the common law to transport express traffic for the independent companies over their lines, and that they were not obliged to do more as express carriers than to provide the public at large with reasonable accommodations, 
and in the absence of a statute, they were not obliged to furmish equal facilities to all express companies. The regulation of such matters, said the court, was legislative and not juclicial.

10S. Under common control, management or arrancement for a continuous carriage. - The rulings of the Commission as to what constitutes a common control, management or arrangement for a continuous carriage have been affirmed by the courts. The test of subjection to the act is through routing in interstate commerce. When a carrier unites with one or others in making a rate for interstate traffic and a through bill is issued therefor, it is subject to the act. In C., I. O. \& T. P. R. Co. v. Commission, 162 U. S. 154 , to L. Ed. 935, the Supreme Court held that a railroad company whose road was wholly within the bounds of a single state which had roluntarily engaged as a common carrier in in terstate commerce by making an arrangement for the continuous carraige of goois through another state, was subject as to such traffic to the provisions of the act. An express agreement for a through rate is not required, but the successive receipt and forwarding in the ordinary course of business by two or more carriers in interstate traffic under through bills, or any arrangement for a continuous carriage over their lines, constitutes assent to such common arrangement for the carriage with the meaning of the act.

When there is a through bill of lading for a continuous carriage, it is immaterial that one of the roads party to the through bill received the sole benefit of the rate on its own line. Such a case was presented to the Supreme Court in L. \& N. R. Co. v.Behlmer, 175 L. S. $648,4 t$ L. El. 309, where the court said that the contention under this state of facts that the carriers did not constitute a continuous line bringing them within the control of the act to regulate commerce was no longer open to controversy in that court. See also United States r. Seaboard Railway Co., S2 Fed. Rep. 563.

A local switching company is not subject to the act where it makes no contracts of through shipment, but imposes a separate trackage charge upon the other companies for the use of its tracks in local transportation. But where such a company does become a party to such a contract for through shipment, it becomes as to such business subject to the act. See C., M. 
it St. P. R. Co. v. Beeker, :32 Fed. Rep. S49. As to the evideneing of contrats for through shipments, see the ruling of the Commission in 2 I. C. C. R. 5.53 and 2 Int. Com. Rep. 393.

Through routing by arrangement for continuous interstate trattie is a matter of eontract between the carriers, and there is no provision for either the eourts or the Commission enforcing the making of such contracts; 3 I. C. C. R. 592 and 2 Int. Cont. Rep. Sor. See inf'r, section 3, "Interchange of Facilities."

(10) Transportation through a state.-Commerce between points in the same state, but which, in the being carried from one point to another is earried through another stite, is interstate commerce and subjeet to the act. This was definitely determined by the supreme court in IIanley v. Kansas City Southern Railway Co., 187 U. S. 617, t7 J. El. $3: 3$ deeided January 1903, where the eourt affirmed the judgment of the circuit eourt of Arliansas enjoining the railroad commissioners of Arkansas from fixing and enforcing rites upon that part of the route within the state of Arkansas of a shipment beginning and ending in the state of Arkansas.

The court held that there could be but one rate fixed by one aluthority and that the ease was analogous to that of narigation on the high seas between ports of the same state. The conrt distinguished this ease from that of a tax which was sustained in Lehigh Valley Ry. Co. Pennsylvania, 145 U. S. 192. if L. Ed. 672 which was in respeet of the receipts of the proportion of the transportation within the state. A tax may be thus apportioned according to mileage, but when a rate is established, it must be established as a whole. This was the view that hall been sustained by the Commission in several eases, 7 I. C. C. R. 92, and overrules United States v. Lehigh Valley R. Co., 11.5 Ferl. Rep. 372, and several state decisions which had been biscel upon the decision in the Lehigh Valley Case.

110. Interstate electric railroads. - It was ruled by the commission, 7 I. C. C. R. S:, though the question does not seem to have been adjudicated in the courts, that a line of eleetrie railroad lying partly in the District of Columbia and partly in the stite of Maryland, was subject to the act, although it was constructerl on publie high ways and was essentially a suburban road for the convenience of urban and suburban passengers.

'Two of the Commissioners dissented on the ground that the. 
terms of the act were not broad enough to include street railways.

\$111. Receivers, lessees and purchasers pendente lite.When railroad eorporations are subject to the act, their reeeivers are also subject to its prohibitions, requirements and regulations. 6 I. (.C. R. 1; 6 I. C.C. R. 37s; seo also E.b v. Morash, 17 U. S. 5st, 44 L. Ed. 897 . Lessees of such corporations and purchasers at foreelosure sales are bound by the orders of the Commission made pending such foreelosure. Interstate Commerce Commission v. W., N. Y. \& P. R. Co., W. I). of P'a. Sะ Fed. Rep. 19:.

It was ruled by the Commission in 6 I. C. C. R. 37 , that a railroad company subject to the Act, conld not by leasing its road, free itself from liability for praetices made illegal by the act, nor after resuming possession of its property, pending proceedings against it to enforce such statutory provisions, claim exemption from liability during the time of the lease.

\$11:. Foreign commerce.- The act includes traffie "from any place in the Lnited States to any idjacent foreign country," and "from any place in the Cnited States "through a foreign country to any other place in the United States," and also "from any place in the United States to a foreign country and carried from such place to a port of trans-shipment," or "from a foreign country to any place in the United States and carried to such place from a port of entry either in the United States, or an adjacent foreign country."

The Supreme Court said in the Import Rate case, 162 U. S. 197, to L. Ed. 94i, after quoting this part of the section.

"It would be difficult to use language more unmistakably signifying that congress had in view the whole field of commerce (excepting commeree wholly within a state) as well that between the states and territories as that going to or coning from foreign countries."

The juriseliction of the Commission extends to only that part of the through import or export rate which applies to the inland proportion received by the carrier. As to effect of competition in import and export rates making dissimilar cireumstances and conditions under sections 3 and $t$, see p. 217 . infra. As to publications of import and export rates, see S I. C. C. R. $214 ; 10$ I. C. C. R. 55 . 
It was contended in a recent case before the Commission (10 I. C. C. R. 0.2 ), that when traffic is transported from a point within the Lnited states to a point in a foreign country, not adjacent, upon a thomgh bill of lading, such transportation is not within the purriew of the act. It is true that the section does not include hy any complehensive langragre all transportation between points in the United states and points in forejon commerce, but states in detail what traflic is ineluded. This contention would exchude from the act the vast volume of commerce with countries not adjacent, and the commission sidi that the question was really deciled by the supreme ('ourt in the Import liate case in the language quoted above, though the exact point was not before the court, and therefore held that traffic transferred from a point within the Inited states to a point in a foreign comntry through a port of transhipment is within the first section.

\$ 113. Place of incorporation of the carrier immaterial. - The commission has ruled that a foreign railroad corporation such as the fiand Trunk Railroad Company carrying on its tratlic between the Cnited states and Canada, was subject as to its business in the Lnited states to the sime rules and conditions as domestic carriers. $:$ I. C. C. R. s9, and 2 Int. ('om. liep. 49\%: 4 I. C. C. R. 447 , and 3 Int. Com. Rep. 417. lint while a copporation engaged in interstate traftic in the states is subject to the act as to such traflic, the juristiction of the commission is necessarily limited to the United States and does not extend to a question of alleged local discrimination in a foreign country as Canada. 10 I. C. C. R. 217.

\section{4. 'The intention of interstate shipment is not suffi-}

cient. Transportation is not made interstate and subject to the jurisdiction of the Commission by the intention of the shipper that when the shipment is delivered by the carrier in the same state it shall be furthered transported by another. carrier into another state, 1 I. C. C. R. 31), and 1. Inter. 60\%. Thus, fruit delivered to a consignee at Jersey City under rates made to .Jersey City on trallic originating in New. Jersey thourh destined for the state of New lork, is not interstate traflic and the ('ommission had no authority over such freight. ¿ I. C. C. R. 14ะ, and $\triangleq$ Int. ('om. Rep. $8 t$.

This was the rule applied by the supreme Court of the 
United States in taxation cases, where it was held that the intent to export is insufficient to exempt from the taxing power of the state. Coe v. Errol, 116 U. S. 517, 29 L. Ed. 715 .

11.). All instrumentalities of shipment or carriage.The term "railroal" as used in the act expressly includes all bridges and ferries used and operated in connection with any railroad. It was held in the first important case arising under the act (Kentucliy of Intiana Bridge Co. v. L. \& X. R. Co. 37 Fed. Rep. 567, Circuit Court, Justice Jackson, alterwards of the supreme bench), that this inclusion of brirleces and ferries as subject to the act did not apply where a brilige was not operated by the bridge company, but by railroal companies under contract with the bridge company. In such cases the court said the bridge company was not, either in law or fact, a common carrier within the scope and meaning of the section. The railroad company using the bridge. and not the bridge company, was the common carrier.

It was ruled by the commission in 1 I. C. C. R. 495 , and 1 Int. Com. Rep. 75., that a railroul company chartered by the state of Tennessee, owning a short road wholly in that state, neither operating its road nor owning any rolling stock, but used and operated as a means of conducting interstate traffic in coal by the companies owning a connecting interstate road, was one of the instrumentalities of interstate commerce and subject to the act.

\& 116. Delivery, cartage, storage and demurage charges.-The inclusion in the reguirement of the reasonableness of charges for the services rendered in receiving, delirering, storing and handling property did not impose any additional duty upon the carrier in regard to the delivery or storage of property, and the carrier is not obliged under this section to deliver or store otherwise than is required by its common law duty as a carrier. These services, including any charges for demurrage and other terminal expenses, which have been included under the general term of accessorial services, are subject to the act, whenever rendered in connection with interstate traffic, as to the reasonableness of the charges under this section. It also follows that such services must be rendered without discrimination as between individuals in 
violation of section 2 , and without undue preference as be. treen localities or kinds of traflic under section 3.

It Was sild by the supreme Court in the Grand IIaven Cartage case. Commission v. Railroad Co. 167 T. S. 639, l. c. 6t5, t.2 L. El. 306 , that while cartige was not in general a terminal expense and not in general assumed by the carrier, the transportation as a rule being ended when the freight was. reecived at the warehouse, that it was a reasonable exereise of the (ommission's power to direct in a general order that the ratilnall companies should thereatter regird caltage as one of the terminal chargos to be published in their schedules, as required under section $f_{\text {(As }}$ to ruling of the commission theremeler, see infir, sec. 6, and note, and 7 I. C. (. R. 1. c. 591).

The Cirenit ('ourt of Appeals, in the same Grand IIaven Cart. age case, in their opinion, 21 C. C.A. $10: 3$ and it Fed. Rep. su:?, which was approvel by the supleme court, called attention to the distinction between the Anerican and Engish customs of delivery of goods by carriers. Free cartage had heen developed in the acts of the English railways from their competition with the carrier companies who used their lines. hut that no such conditions had been dereloped in the growth of our dmerican system of tramsportation, where it was rery exceptional for railroads to do the carting repuired for delivering and collecting the grools. The service was essentially a distinct and separate service from rail carriage and purely accossorial.

The fact that a railroad company for many years has paid the charge for hauling freight from wharves to its station does not hind it to continue that practice, and, if not bound by contrict. it may stop doing so at any time. (1 I. C. C. R. 111. 1. Int. ('om. Riep. :36:3).

It Was rulel by the ('ommission. S I. C. C. R. 5:1, that the makime ol demurare charges to commence before the expiraion of a reasonable time for loading or unloading was a violation of the provisions of this section.

Is to storage charges, it was ruler by the Commission, $10 \mathrm{I}$. ('. ('. IR. :,:-y, that a railroad freight depot and a public warehouse are not used for the same purposes, and a charge for striage in a railroad depot may properly be made higher than. a public warehouse chatrge, with the object of compelling the 
expeditious removal of the freight, without violation of this section.

As to storage of grain in elevators at points of stoplage under milling in transit privileges, see 10 I. C. C. R. 309.

\section{1\%. Carriage of live stock and perishable property.-} The character of the property may impose upon the carrier a distinct obligation in the matter of delivery. Thus in the case of live-stock, the company is under a legal obligation to provide suitable and necessary means and facilities for receiving live-stock offered for shipment, and this duty cannot be efficiently discharged, at least in a town or city, withont the aid of enclosed yards in which the stock offered for shipment may be handled with convenience and safety and without inconvenience to the public. The railroal company therefore cannot, in addition to the customary and legitimate charges for the transportation, make a special charge for merely receiving and delivering stock in and throngh the yards provided for the purpose. Corington Stockyarls Co. r. Keith, 139 U. S. 125, 3.5 L. Ed. 73. The court in this case applied the rule laid down in Northern Pennsylvania Railroad Co. v. Commercial National Bank of Chicago, 123 U. S. $727,31 \mathrm{~L}$. Ed. 257 , that the undertaking of a carriel to transport livestock differed in some respect from the responsibility assumed in the cartage of ordinary goods and included the delivery of such live-stock, the difference referred to growing out of the nature of the particular property transported.

A railroarl carrier conld make an exclusive contract with a stock yards for delivery of live-stock provided no charge was made for delivering when taken by consignee within reasonable time. Corington Stock Yards v. Keith, supra; Butchers \& Drovers Stock Yards Co. v. L. \& N. R. Co., 1t C. C. A. 290, 31 U. S. App. 252, 67 Fed. Rep. $35 ; 10$ I. C. C. R. 179; Central Stock Yards v. L. \& N. R. Co. 192 U. S. 568, ts L. Ed. 565. See, infira, section 3. In the case of the Union Stock Yards of Chicago (Commission v. C. B. \& Q. R. Co., 186 U. S. 320,46 I. El. 1182), the Supreme Court affirmed the Circuit Court of Appeals ( 43 C. C. A. 209, and 103 Fed. Rep. 249), in refusing to enforce an order of the Commission holding unreasonable the charge of $\$ 2$ for the delivery of the livestock to the stockyards. It seems that prior to $189+$ no separate 
terminal charge was made; and the through rate existing prior to $189+$ was presumed to have provided compensation for serviees for making deliveries to the stockyards. The court said that the defendants had the right to divide their rates, and that the terminal eharge must be separately considered as a distinct charge, and if it was reasonable as a separate charge, it did not follow that it should be reduced when the throngh rate was reduced. The court therefore affirmed the decree of the Court of Appeals without prejudice to the Commission's right therealter to commence proceedings to eorrect any unrealsonableness in the rate resulting from the additional terminal eharge as to any territory. As to reasonable charges for extra hazard to carrier in live-stock shipments, see 10 I. C. C: Li. : : $: 20$.

1 railroal company acenstomed to leliver ears of cattle at stockyards off its line by transporting them orer a line belonging to a stockyards company, for whieh it pays a fixed sum per car, was held in Walker v. Keenan, 19 C. C. A. 1565 and 73 Fed. liep. 755, by the Circuit Court of the Tnited States, seventh circuit, to be under no obligation to consignees whose husiness was located at the stockyarts to supply unloading facilities at its own stations in a different part of the state, and hence was not bound in default thereof to deliver at the stockrarls without a separate eharge. It conld on posting schedules to that effect, as required by seetion 6 of the Interstate commerce Act, make a charge for the freight to the station and a separate terminal charge of a fixed sum per ear for delivery to the stockyards. (Reversing it Fed. Rep. 992.)

11 . Refrigeration in transit. - When carriers undertake the transportation of perishable traffic requiring refrigeration in transit, the providing of ice and facilities for its transportation in connection with the traffic are ineidental to the transportation, and the charge therefor is a eharge in connection with the service and subject to the requirement of reasonableness contained in this section. This was ruled by the Commission in a case of a shipment of strawberries and regetables from Charleston to Jersey City. 6 I. C. C. R. 295. Arequate refrigeration was held to be an incident of sea worthiness under a bill of lading for ocean transportation of dressed beef. See Martin r. Southwarls, 1!r U. S. 1, to 1. Ed. (i) $(19+1+1)$. 
The Commission has consillered the question of the reasomableness of eharges for refrigerator car service in recent cases. Thus the eharges for refrigerator cars furnished by the Armour car line for freight traftic from points in Michigan were considered in 10 I. C. ( . R. 360, and the complaint of tho Georgla fruit growers for alleged un reasonableness of charges for refrigerator car service in the transportation of peaches from Georgia to the north was investigated in $10 \mathrm{I}$. ('. ('. IR. 2\%.5. The ('ommission ruled in these cases that the carrier was bound to furnish such ears by reason of their common law duty as carriers, but that they eould provide such ears by purchase or by lease, and if by lease the lease could be made with one complany. The Commission ruled, however, that the charges for refrigeration, however furnished, should be published as other charges and athered to as other charges for transportation, and in the transportation of the freight the carrier nust either furnish the ice for a reasonable price, or permit the slipper to do so.

In the Michigan ease the Commission fonnd that the charges for the leased cars were excessive and that the carriers by making these exclusive contracts with the owners of the car's. had in effeet imposed upon the shippers unreasonable eharges for the transportation, in violation of section 1 .

In the Georgia case the Commission considered the exceptional conditions of refrigerator ear service, such as the necessity for rapid transit, the expense of handling, the uncertainty. of the crop, absence of return loal, etc. Lnder these circumstances it was found that the minimum load rate in weight of eighty-one cents per one humbed pounds was not unreasonable, but that the regulation whereby the rate was increased to the valuation piaced by the shipper was unreasonable, as the difference in valuation was too slight to justify the diserepency. It was also ruled that the arbitrary charge made by the New York, New Ilaven and Ilartford railroad company for cars was un reasonable.

The Commission consideref this subject in connection with the general subject of private freight cars in its annual report for 1904 , and said that a practical monopoly had been created in the use of private cars for the morement of certain commolities, especially in the morement of freight, which had 
enormonsly increased to the public the cost of transportation. l'alctically the ieing challee, it was said, is a part of the shipper's cost of transportation, as every shipper must use the railroad and the refrigerator car, and the car must be iced. The ('ommission satil that the result of existing conditions was good service and an alequate car supply, and an enormons increase in the refrigeration charges, of which instances were given. The Commission contends that these exclusive contracts, when they result in unpeasonable icing charges, are unlawful and that the faimre of the carriers to publish such charges is also a riolation of the statute. On the contrary, it has been contended by the private car lines that icing is a private service over which the commission has no juristiction uncler the present law. The Commission, therefore, recommends that great grood will be accomplished by legislation which will leave no room for such contentions, and that the only complete remedy that could be afforded would be by inresting the Commission, or some other tribunal, with power to inguire whether these charges were reasonable, and to make them reasonable if found unreasunable. The Commission said this could be accomplished in two ways: First, either by maling the common carriers responsible in the matter of this special equipment and refrigerator service, if they were not now responsible: and sccond, by bringing the car line companies which provicle this refrigcration for interstate shipments under the jurisdiction of the Act to Regulate Commerce and maling their charges subject to the determination of the Commission.

As to the effect of the Elkins law of 190:3, infre, 810 , in bringing private cars under the jurisdiction of the Commission. see Parties subject to the act.surer so 106 .

is to liscrimination through charges for refrigeration, am other prisate car service, see infia, section 2 .

\$119. Charges must be reasonable and just. - The last paragraph of the first section, providing that all chareses for any scrvice rendered in the transportation of persons and property, shall be reasonable and just, and prohibiting and declaring unlawful crery unreasonable charge for such service, is only an aflirmance of the common law In England, a comurrin carrier was bound to cary for a reasonable remuneration as he was bound to carry for all such persons and property 
offered for transportation and suitable to be carried. though it was not uniformly held that the carrier was bound to carry for all at the same rate. In the Maximum liate case, 167 L. S. 511,42 L. Ed. 251 , the Supreme Court sail that this section was a simple enactment of the common law repuirement, and that for more than a hundred years it had been the aflirmative duty of the courts to exact and enforce the common law requirement that all charges should be reasonable and just. This requirement of reasonableness grew out of the relation of the carrier's' occupation to the public as was deckared in the (iranger cases, $9+\mathrm{U}$. \$. 11:, $2+\mathrm{L}$. Ed. T., where the court said that the carrier must carry when cal'ed upon to do so, and that he could charge only a reasonable sum for the carriage, and in the absence of any legislative regulation upon the subject, the courts must decide, as they did for private persons when controversies arose, what is reasonable.

120 . Practical difliculties in the enforcenent of reasonableness in rates. - There are few if any cases wherein recovery has been had at law upon the common law liability of the carrier for charging excess orer a reasonable rate. As said by the supreme court, in the Trans-Missouri case last cited, any individual shipper would in most cases be apt to abandon the efiort to show the unreasonable character of the charge, by the necessary expense of time and money to prore the fact and at the same time to incur the ill-will of the road itself in all its future dealings with him.

Furthermore, the question of what is reasonable is one of fact, dependent upon the special circumstances of each case, and as these circumstances are changing from time to time, a rate which is unreasonable when pail, may become reasonable, through changed conditions, before the case is determined in the court of last resort, or even in the trial court. See conclusion of opinion in Smyth v. Ames, 169 L. S. 1. c. 549, +2 L. Ed. \$19.

Another reason for the practical difficulty in the way of enforcement by shippers of this common law obligation of the carriers to charge only a "reasonable rate," lies not only in the delay and expense of litigation, and in the small amount involved in the payment of the charge for any one shipment, but in the fact that a party paying the unreasonable charge 
without protest, in the absence of any mistake or fraul, was denied any right of action. But see Cook v. C. R. I. \& P. R. Co., $\$ 1$ Iowa, 5i1, and 9 L. R. A. 764, where held that payments made by shippers in ignorance of discrimination and af ter the assertion of the carrier that no lower rates were given, are not voluntary payments within the rule that they could not be recovered back.

Even assuming that recovery was had, the enforcement by ditlerent juries of their own standarls of reasonableness,-- for it must be in each case a question of fact at last, - would be necessarily destructive of the uniformity which is essential in any permanent regulation of transportation for both shippers and carrier. See remarks of Phillips, J., in Windsor Coal Co. v. C. \& A. R. Co., 52 Fed. Rep. 716. It was suggested, however, by the I'nited States court of appeals in Sonthern Pacific R. Co. v. Colorado Fuel it Iron Co., 42 C. C. A. 12, 101 Fed. Rep. 799, that it was possible that a jury verdict would lead to a withdrawal of the rate adjudged unreasonable.

121 . Standard of reasonableness under state statutes.Inder state statutes re-asserting this common law requirment of reasonableness and providing for the publication of tarifís and charges and their submission to and approval by state commissions, it has been held that the common law right is superseded by the statute and that there can be no recovery for alleged unrcasonableness in the charges thus published and approred, as the published rates will be conclusively presumed to be reasonable. Young v. Kansas City, St. J. \& C. B. R. Co., 3: Ilo. App. 509; Windsor Coal Co. v. C. \& A. R. Co., 52 Fed. liep. Tlt; McGrew v. Missouri Pacific R. Co., 114 Mo. 210; Railroad Co. v. People, 77 Ill. 443 ; Sorrell v. Railroad Co., 75 (ia. 509; Burlington, C. R. \& N. R. Co. v. Dey, S2 Iowa 212. In the latter case, in answer to the claim that the Commissioners' rate would not secure the accused from conviction, if it was 'xcessive, the court said that the state would be precluded from denying that the rate was reasonable.

19. Standard of reasonableness under the act.-The principle on which these eases concerning state statutes were decided was applied to the Aet to Regulate ('ommerce in the case of Van P'atten v. ('., M. \& st. I'. R. Co., 81 Fed. Rep. 545, decided in the Circuit rourt for the northern district of Iowa 
in 1597. This was a suit to recorer damages on the ground that the plaintiff was charged an mmeasonable rate. The conrt ruled that the plaintiff in order to recover must show that the rate was unreasonable according to the provisions of the act, and that courts and juries could not resort to any other stanlard of reasonableness than that tixed by the standari rates published by the carrier, and that it was a good defense to an action for damages that the earrier had adopterl, printed and posted a properly proportioned scherlule of rates under section 6 , the only other standard in the act being that as to the long and short hani provided in section 4 , and as the charges complained of were in accordance with the published schedule and there was no violation of section 4 , there could be no recovery.

In the ('ireuit ('ourt for the eastern district of Missonri, Judge Adams, in Kinavey v. Terminal hailroad Association, 81 Ferl. Rep. soz, about the same time, in a similar action, said that the rates so published and filed were a prime fure criterion, and that to constitute a cause of action there must be an arelment either that the carrier failed to publish a schedule of rates, or that it charged in excess of the rates as published and then in force, and in either case that the charge in fact was unreasonable, or an averment of other facts suflicient to do away with the prma fucc eflect of the schedule rates.

In the cases above eited plaintiff's had elected to proceed in the courts under sections s and 9 , intra, without appealing to the Commission to adjudge the rate unreasonable and for reparation. As to the power of the Commission to allow reparation in damages for unreasonable rates, see infira, sections 14 and 16 .

12:3. The Commission has 110 power to fix rates. - During the first ten years of its existence, the Commission elaimed and exercised the power of fixing rates in futoro, that is, when a rate was adjudged unreasonable, to determine what rate was. reasonable and to direct the carrier by a given date to reduce the rate to the designated maximum. Illustrations of these decisions by the Commission will be found in their reports from 1887 to 1597 The Commission states in its annual report for 1857 , page 16 , that out of the one hundred and thirty fire formal orders made in suits actually heard from its institution 
down to that time, sixty eight had prescribed a change in the rate for the future.

This question of the powel' of the Commission did not come before the supreme Court until 1s96, when it was decided in what is known as the social circle case, 1ti2 L. S. 15t, to I. Ed. 9:5, and the following rear, in the ('incinnati Freight Bureau case, 167 L. S. $479.42 \mathrm{~L}$. El. 243 , that ('ongress hall not conferred upon the (ommission the power to prescribe rates, whether maximum, minimum, or absolute. The reasonableness of a rate in a given case, the court said, depended upon the facts, and the function of the ('ommission was to consider those facts and grive them their proper weight, saying in the case first cited. p. 196: "If the Commission instead of withholding judgment in such a matter until an issue has been made and the facts found, itself fixes a rate, that rate is prejudged by the ('ommission to be reasonable."

The court says in the Freight Bureau case, that Congress might have fixed the rate itself or committed to some subordinate tribunal the duty, but that it hal not done so.

In 7 I. C. C. P. 2st, the ('ommission says that the effect of these decisions was to give the carriers the power to exact charges and establish rates independent of the julgment of the Commission. See also Report of Commission of $159 \mathrm{~s}, \mathrm{pp}$. $2: 3$ to 2 .

$1: 4$. No power in the courts to fix rates.-As the power of the Commission is thus limited to determine that an existing rate is unreasonable, the power of the courts is also so limited. The fixing of rates for the future is a legislative and not a judicial duty. This was directly determined by the United States Court of Appeals for the eighth circuit in an opinion by Thayer. J., in Sonthern Pacific Ry. Co. v. Colo. Fuel \& Iron co., t.2 C. C. A. 1.2, and 101 Fed. Rep. 7.9. in 1900. In this case the ('ircuit court had made an order directing that the rates from P'ueblo to P'acific coast points should not exceed if per cent. of the rates contemporaneously in force from Chicago to the same points, the rates on steel rails and fastenings not to exceel ti; per cent., and on other iron products should not exced :3i- per cent. The court silil that as the supreme Court had decided that the ('ommission could not fix rates, because no such power was given by the Commerce 
Act, for much stronger reasons the power to fix a schedule of rates did not belong to the ferleral courts. because Congress had not attempted to delegate that power to the courts, even if it could divest itself of such a legislative function and impose it upon the judicial branch of the government.

A restraining order upon a carrier which neither forbids nor commands the doing of any specific act. but simply repeats the general admonition of the Interstate Commere Act, cannot be granted, since such an injunction does not give any sanction to the statute, but leaves all vital questions concerning violations of the law to be tried by proceedings for contempt, instead of in the usual manner before a court and jury. See Southern Pacitic Railroad Co. v. Colorado Fuel \& Iron Co. suruet.

Thus, an order that commodity rates must not be lower than necessary to meet competition, nor to be applied to articles not subject thereto, is a mere statement of what the law authorizes and prescribes, too indefinite to be the basis of a decree. Farmers Loan \& Trust Co. v. Northern Pacific R. Co., 83 Fel. Rep. 249.

1:5. The federal courts on reasonableness in railroar rates.-- The question of reasonableness in railroad rates las been construed by the Federal Courts in two distinct classes of cases. Thus in the judicial review of the state-imposed rates upon intrastate business, supra, $55-97$, the courts have been compelled to determine whether carriers have been deprived of the right to make reasonable charges; while in questions arising under the Act to Regulate Commerce the yuestion is raised whether the rates charged by the carrier exceed what is reasonable. In the first class of cases the burden of proof is upon the carrier to show that the state has fixed unreasonable limitation upon his rates; while in the other class of cases the burden is upon the party complaining to show that the carrier has exceeded a reasonable standard. The Supreme Court sail in the Maximum Rate case, 167 C.S. 1. c. 511, 4.2 L. El. 2.51, that a rate may be unreasonable because it is too low as well as because it is too high. In the former case it is unreasonable and unjust to the stochholder, and in the latter to the shippes.

In Covington \& Lexington Turnpike Road v. Sanford, $16 t$ 


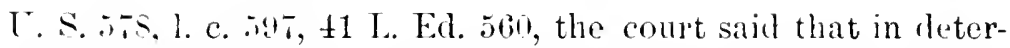
mining the question of reasonableness its duty was to take into consicleration the interests both of the public and of the owner of the property.

\section{1:6. The capitalization of railroark as hasis for rates.-} It wats claimed in the Nebraska Rate case, supro, that a railroal wais not entitled to charge excessive rates for the purpose of paring divilends upon excessive capitalization. The court silil that it was true that it was not the cost but the present value of railroal property which was to be considered, and that the apparent value as represented in the stock and bonds of the company was not alone to be considered; but that in ascertaining value the original cost of construction, the amount expeniled for permanent improvements, the amount and market value of its stock and bonls, the present as compared with the original cost of construction, the probable earning capacity of the property uncler the particular rates prescribed by the statute, and the sum required to meet operating expenses, were all matters for consideration and to be given such weight as might be just and right in each case, with due regard for the rights of the public as well as for the interests of the raitroad company. In this case the enforcement of the state rates was enjoined without prejudice to the right of the state commission to apply to the court for the discharge of the injunction thereafter if changed conditions would admit of the reluction without depriving the railroad of just compensation.

In the Minnesota Rate case, 186 U. S. 25\%, 46 L. Ed. 1151 , the court said that each case must be determined by its own considerations, and that while the rule stated in the Nebraska liate Case was undoubtedly sound as a general proposition, that railroads were entitled to have fair return upon the capital invested, it might not justify them in charging exhorbitant chareses in order to pay operating expenses if the conditions of the country did not permit it. It sometimes happened that for the purposes of ultimate profit and for the purposes of building up trade, railroads carried both property and passengers at an evident loss, and that while it might not be within the power of a state Commission to compel such a tariff, it might not, on the other hand, be claimed that the rail- 
roals would in all cases be allowed to charge grossly exorbitant rates as compared with rates charged by other roals, in order to pay dividends to stockiholders.

In the Kansas City Stockyards case, 183 U. S. 79, 46 I. Ed. 92 , the Kiansas statute regulating charges in public stockyards was held invalid, three of the judges concurring in an opinion by .Justice Brewer, holding that the statute deprived the company of its property without due process of law, while the other six judges held that it was discriminative in denying the equal protection of the laws. The opinion of - Justice Brewer said that a classification which was not based upon the character or value of the services rendered, but simply on the amount of the business done by the party, cutting down his profits because from the whole agreregate of his business he was enabled to make such profits, although he made the same charge that other's in the business got, and which was perfectly reasonable so far as the value of the services was concerned, was unsonnd and invalid.

In a case before the United States Circuit Court in Texas involving the Texals state rate, Metropolitan Trust Co. $r$. Railroad Co. et al, 90 Fed. Rep. 658 , the court took a more liberal view of the basis for estimating the value of property for the purpose of determining the reasonableness of rates. It said that the state anthorities should take into consideration the betterments and replacements made necessary by the growth of traffic, and also the permanent establishment and good will of the road should be considered and determined with reference to the value upon which a return would be realized. The court assumed that the cost of replacing the physical structure of a roal was too narrow a basis upon which to determine its value, as it may have been constructed at a time when the conditions of the country were such as to gire no immediate expectation of reasonably profitable earnings.

\&196. Through rates and local rates.- The distinction between the through and local services of a company and the reasonable right of the carrier to make the local rates greater than the proportionate part of a through rate orer the same distance has been distinctly recognized in the decisions of the supreme Court. The question was raised in the State Rate cases, as the intrastate rates subject to state rewulation are as 
a rule local rates, while the interstate rates not subject to state regulation are through rates.

Thus in the South Dakotal Rate case, 176 U. S. $167,4+\mathrm{L}$. Ed. 417 , the court said that it was erroneous to determine the reasonableness of local rates without finding the cost of doing local business, and said it was obvious on a little reflection that the cost of moring local freight is greater than the cost of moving through freight, and equally obvious that it is almost. if not quite, impossible to determine the difference with mathematical accuracy, and that upon such difference the opinions of experts familiar with the railroad business was competent testimony and could not be disregarded.

(In the rehearing of this case in the Circuit Court, 110 Fed. Rep. 13.3 , the master to whom the case was referred reporting that the business in the state was honestly, economically and elliciently conducted and the net earnings therefrom in the state did not realize enough to pay interest on the mortgage lebt, the court held that rates relucing such net earnings were unreasonable aud should be enjoined.

In the Xinnesota Rate Case, 186 U. S. 257, 46 L. Ed. 1151 it was claimed by the carrier that the sum of two admittedly reasonable local rates could not be unreasonable as a through rite between two designated points. But the court said that the practice of railroads in this country was almost unirersally to the contrary, and that a through tariff is almost always fixed at a sum less than the aggregate of local tariffs between nearby cities upon the same road, saving:

" Joubtless the fixing of a lower through tariff is dictated larcely by a desire of each road to get as much mileage as possible out of its patrons, as well as by the desire to meet competition of other lines doing business in the same territory: but in addition to this there is an increased cost of local businrss orer through business in the additional fuel consumed and the increased wear and tear of the machinery on each train in rolved in the stopping at every station."

The supreme Court also considered, before the passage of the Interstate ('ommerce Act, the question of the reasonableness of the charges made by the Union Pacific Railway Company to the frovernment for compensation in transporting the mail. troops and supplies. See Union Pacific Ry. Co. v. Inited States, 114 U. S. 66i2. 26 J. Ed. 854; Union Pacific 
Ry. Co. v. United States, 117 U. S. 355,29 L. Eal. 92\%. In the first of these the court held that the court or jury was authorized to look over the entire field of services in determining what was fair and reasonable charges, and that the compensation should be determined upon consideration of all the facts, and not exceeding the amount paid by private parties for the same lind of service, and in the other case that the comrt could not affirm as a matter of law that the service rendered in transporting a local passenger between two points was identical with that in transporting the same passenger for the same distance in passing orer the whole line.

In Augustal s. R. Co. v. Wightsrille of s. R. Co., it Fed. Rep. 522 (15:16, the United States Circuit Court for the nortl $r_{-}$ ern District of Georgia, discussed the distinction between through and local rates, holding that a carrier was not justified in exacting tocal rates where the service belonging to local rates was not offered, especially when this was done for the purpose of diverting traffic or stifling a competitor. It was held, therefore, that the rates charged were unreasonable for the service rendered. For discussion of through and local service and rates by the Commission, see 4 I. C. C. R. 251 and 3 Int. Com. Rep. 272.

19x. The Commission on through and local rates. - The Commission, in a number of cases, has discussed this essential distinction between through and local rates. Through rates and through billing are matters of agreement among carriers engagred in interstate commerce, but when they have been established and until finally abrogated or changed, they are required by the statute to be kept open to public use. See infir, section 6; : I. C. C. R. 152. The total rate for the through carriage over two or more lines, whether made up of different established locals or of through and local rates, or upon a less proportionate basis, it is the through rate that is subject to scrutiny by the regulating authority; how the rate is made is only material as bearing upon the legality of the aggregate charge, and how any reduction may be accomplished is a matter for the carriers to determine among themselves. 5 I. C. C. R. 32t, and 4 Int. Com. Rep. 121, 121. 'Through rates are not required to be made on a mileage basis, nor local rates corresponding with the divisions of a joint through rate over 
the same line. Nileage, howerer, is usually an element of importanee, and due regard to listanceand proportions are to be observed in connection with other eonsiderations; they are material in fixing transportation charges. :3 I. C. (. R. R. 2,

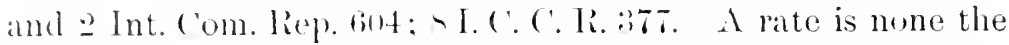
less a throngh rate in law becanse the initial carrier charges its lo all rate als part of the through rate and the remaining lines. charge an agreed rate made by pereentages. Thromgh rates alluit of a ereat rariety in the forms they assume, and when reasonable and farly adjusted in their relations to local business. are greatly faroped in law beause they fumish cheaper rates and greater facilities to the publie, while at the same time they give increased earnings to a large number of car-

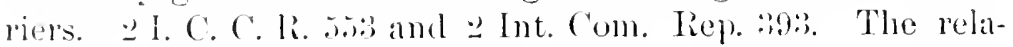
tion of the proportion of the through rate to the rate over the same distance along the same line must be reasonable and a roid unjust discrimination. See intial, section 3. See also 2 I. C. C. R. 2.: and Int. (om. Rep. 3.). (As to basing points in the adjustment of through rates, see infia, section: $:$.)

Divisions of joint rates are usnally less than the correspondinc locals, and almost without exeption are not greater. 9 I. C. ('R. 17. A local rate, which presumably includes terminal expenses is prime facic excessive as part of a through line composed of two or more carriers. if I. C. C. R. 1. While there is no mileage requipement in the act, other than what may be involved in the long and short haul rule in section $t$ and the general requirement of reasonableness, as a rule in the transportation of freight by railroals, while the aggregate charge is continually increasing the further the freight is carried, the rate per mile is constantly growingless, making the agrgregate charce less in proportion every lundred miles after the first, arising out of the character and nature of the service performed and the cost of the service, and thus staple commolities and merchandise are able to bear the charges from and to the most distant portions of the country. 1 I. C. C. R. tso and

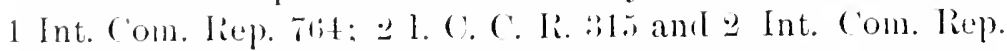
1!9. ()n this general rule as to local rates: $:$ I. C. C. R. 4.11. and 2 Int. ('om. Rep. T21: 1 l. C. C. R. lie and 1 Int.

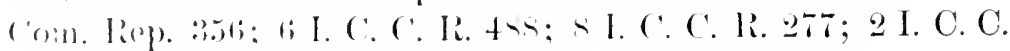

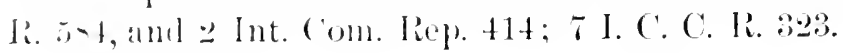


This admitted right of carriers to fix throngh rates on a dower relative basis than local rates, has led not only to the allowance of the through rate for commodities manufactured en route, as in milling in transit and compressing in transit privileges, but also to illegitimate devices to secure such lower through rate. See milling in transit, infru, sections 2 and :3.

1.99. Responsibility for through rates.- When railroad companies make a through and continuous line and offer it for the use of the public, the Commission has held that they cannot rid themselves of responsibility for unjust charges by break. ing the haul in two and calling themselves carrier of the separate ends of their through line. Through and continuous lines imply throngh rates, which must be reasonable rates, and suitable instrumentalities of shiperent and carriage. "f I. C. C. R. 3is. The Commission, in 2 1. C. C. R. 131 and 2 Int. Com. Rep. Tapplied this principle to the Pennsylrania railroad company, which operited a part of a through line and owns a controlling interest in the cappital stock of a connectingline, the l'ittsburgh, Cincinnati \& st. Lonis, and the commission held that the Pennsylvania Railroal Company could not free itself of the responsibility for the through rates by hiding behind the corporation of the other company as a separate carrier.

The carrier howerer cloes not assume responsibility for rites made by a connecting road because merely of its giving them in connection with its own rates by way of information to parties desiring to make through shipments. 1 I. C. C. R. 401, and 1 Int. Com. Rep. 703. In the absence of some agreenent or understanding with a connecting line, by which the joint tariff rates is authorized, the carrier cannot lawfully publisis or apply any other rates than those fixed for transportation between the points reached by its railroads, and it cannot publish the sum as a rate to points on the line of another carrier withont its consent. Such a through rate is not a joint rate, for joint rates can be made only by concurrence or assent, and it is not a combination rate, for one of its component parts is not a subject for a separate charge. There must be lawful rates for each of the roads before there can be a law ful combination of rates. See infra, section 6 .

It has been held that where the lines of sereral railroad corpolations are conducted as a single system for the purpose of 
tratfic between different points originating on either, and such corporations divicle the protits of such business on a mileage hasis, the sereral corporations as to such business are partners liable to third persons on the principles of the law of agency. see lehigh Valley li. ('o. r. Hupont, C. C. A. ond Circuit, $1 \geq 8$ fed. Rep. - to. lint the fact that a raihoart company owns stock and honds of another railroal does not show partnership or anperment to rum the roads on the katter of a common account. see l'ennsilvania R. (o. v. Jones, 1., L. S. 39:3,89 L. El. 176.

130. Reatsonableness muler sections 1 and :3.-The reasomableness of rates under section 1 must be distinguished from undue and unreasonable preferences of localities. which are frohibited by section 3. Thus it was held in ('ommission r. X. C. a St. L. R. Co., 120 Fed. Rep. 984, that a finding of umreasonableness under section 1 could not be established merely by a proof of a violation of section 3. That is, that a rate may be reasonable per se and still be unduly preferential of a locality, and thus be violative of section 3. A rate which is unreasonable, howover, jer se, may be shown by the same facts to be unduly preferential of the locality as comparel with other localities. See infirl, section 3.

\section{Comideration of reasonableness in the courts.-} In Commission r. Sonthern Railway Co., 117 Fed. Rep. it1, the Circuit ('ourt of the western district of Virginia said that in determining the issue as to whether rates to and from a city were unjust and unreasonable in themselves, the greatest weight should be giren to the opinions of expert witnesess, the effect of the rates charged upon the growth and prosperity of the city. the cost of transportation as compared with the rates chared and the rates in force to other cities where the circumstances are as nearly the same as may be. In this case the contref refused to enforee an order of the Commission directing reduction of rates to Danville, V'a.

In commission v. L. \& N. R. Co. 118 Fed. Rep. 613, the (w) found that the rates to Savanmah from eertain points on the l'ensacola division of the Lonisville \& Nashville road were unreasonable and said that they could not be justified by the contention that the railroal eompany had been building up a frort and thus securing a longer haul. The court said that mates unreasonable in themselves could not be justified by 
considerations of this character. In this case an arlvineed rate filed with the Interstate Commerce Commission and put into effect pendingr the hearing before the Commission on the legality of the rate previonsly in force, was held properly before the Commission on such hearing.

On the issue of reasonableness in rates, the sworn return of the officers of the roal made to stite authorities for the purposes of taxation is admissible but not conclusive. L. $\mathbb{E} X$. R. Co. v. Brown, 123 Fed. Rep. 946.

In Commission r. Lehigh Valley R. Co., it Fed. Rep. Tst, the court said that the fact that the cost of earriage of all the coal of an entire railroad system from all points of the shipment to all destinations was a certain per cent. of the gross receipts from all coal did not justify the conclusion that on a particular line of part of the system the cost of carriage bore the same relation to the gross receipts of the whole line, and that the commission erred in holding the contrary theory.

The carriage of expensive merchandise is entitled to greater compensation than that of eheap goods. Commission v. D. L. \& W. R. Co., 6t Fed. Rep. 723.

\section{\$13\%. Rulings of the Commission upon the reasonable-} ness of rates.--While the Commission has no power to determine what a railroul shall charge in the future, and its exercise of that jurisclietion during the first ten year's of its existence was unauthorized, it does not follow that its conclusions and opinions in considering and determining the reasonableness of rates are without value. The Commission is vesterl with a very important jurisliction in investigation and determination whether rates are reasonable or nnreasonable, and their conclusions are held prime fact correct in subsequent proceedings in the courts to enforce their orders. The Supreme Court has in several cases wherein it differed from the Commission in the conclusions of law as to the construction of the act, remandel the cases to the Commission for its own investigation upon the question of the reasonableness of the rates, or has entered julgment without prejuclice to the Commission's right of re-investigation of the question of reasonableness of the rates. Lombard v. West Chicago Park Com'rs, 1S1 U. S. 33, 45 L. El. 731 : L. \& N. R. R. Co. v. Behlmer, 175 U. S. (iti, +4 L. El. 409. 
In many cases the conclusions of the ('ommission have been acepted and acted upon by the railroad companies in the adjustment of their rates, and though its conclusions may be recommendations and not judgments, they none the less have a permanent value and constitute a body of the alministrative lat $w$ on this difficult question of railroad administration. The opinions and conclusions have the greater weight from the character of the membership since the organization of the commission and from the thoroughness of its inrestigation, as evidenced by the opinions.

1333. The inden of proof before the Commission.-The burlen of proof in complaints made before the Commission, of the unreasonableness of rates, is with the party complaining. The Commission has uniformly held that rates cannot be declared unreasonable without other testimony than that alforded by comparison. 1 I. C. C. R. 2.30, and 1 Int. Com. lip. 1.27. The long continuance of rates justities the inference of reasonableness where the rates were voluntarily establistrel. Parties complaining must therefore make proof of unrealsonableness. !I I. C. C. R. 1.

\section{1:34. Presumption of reasomableness from established} rates. - There may be a presumption of reasonableness or unpeasonableness in case of specific rates from the scale of chin wes theretofore establisher and maintained by the carrier. Thus where on shipments of strawberies and regetables from Charleston destined to New lork the expense of carriage over from Jersey ('ity had been incluled in computing the total cost of transportation to New York, and thereafter there was a change in the place of delivery to Jersey City instead of New York and the same scale of chirges was maintained to Jersey (ity, so that the carriers were charging for a less service a compensation which they had presumably deemed adequate for a greater, the rate so applied to Jersey City was primer fir.ir excessive. See 6 I. C. C. R. 29.5. There may be an inference of unreasonableness in a voluntary reduction of a rate by a carrier, though not conclusive. SI.C. C. R. bti. see also + I. C. C. R. 48, :3 Int. Com. Rep. 93, where the Commission discussed the alleged excessive freight rates on fool products. 
The Commission has refus do change rates reasonable in themselves to equalize commercial conditions or to enable cities to secure traffic from their own territory (6 I. C.C. R. R!1.i, as rates cannot be fixed to overcome natural advantages for the purpose of equalizing commercial eonditions. 6 I. C.C. R. r.t.

135. The Commission on cost of service and needs of the shipper.- The general eonsiderations of public policy relating to the cost of production of the commo lity and the needs of the shipper on the one hand, and the circumstances and financial condition of the carrier, such as are involved in the cass before courts relating to interstate traffic, have been eonsidered by the Commission in several cases, notably in the report to the Senate in 1590 in response to a resolution of the Senate calling for such report, on the alleged excessire freight rates and charges on food prolucts. 4 I. C. C. R. 4 , , Int. Com. Rep. 93-151, and in the opinion of April 1, 1918, on the proposed alvance in freight rates. 9 I. C. C. R. :3.). Thus the circumstances of the carrier, its operating expenses, cost of transportation, grades, density or sparseness of population, volume of business, book eharges, dividends, are all properly considered but are not controlling. See 2 I. C. C. R. 37 ant 2 Int. Com. Rep. $299 ; 3$ I. C. C. R. 473 , and 2 Int. Cons. Rep. $7 \pm 2 ; 6$ I. C. C. R. 601. See also 2 I. C. C. R. 227, and 2 Int. Com. Tep. 16?.

The eapitalization of a railroad, the Commission has said, to have consileration in cases involving the readjustment of rates, should be examined by the history of the capital account, the value of the stock and various secmrities and the actual cost and the value of the property itself, as the making of the capital account alone the basis of legitimate earnings would place, as a rule, railroals conservatively managed and capitalized at an enormous disad vantage. S I. C. C. R. 158. Isut the circumstances of the carrier and its financial interests are not alone to be considered. !I. C. C. R. 16\%. While the expense of operation, liability to damage from sand drifts, ete, and the requirement of a return upon the investment of the carrier, are considered, the financial necessities of the carrier do not justify excessive rates. Railroals are entitled to share in the general prosperity of the conntry, but the cost of replacement and of new eonstruction should not be charged to earnings and 
cost of operation so as to diminish net earnings and justify an adrance of rates. 9 I. C. C. R. 352.

1:36. The commission on character of the traflic.-- The Commission has uniformly recognized that the character of the trattic is material in determining the rates and that the riates must be raried according to the value of the commodities ats well as the cost of hamlling and the degree of risk to the carrier. Thus to malie the rites on metals, coal, and other low srade freights. yield per ton the a verage received on all freight woukl be myjust, and these considerations are the bisis of classitication. See inter, section 3. Thus coal is one of the most desirable kinds of traflic, with a small bazard of loss, and the eost of receiring and delivering is less than that of most other linds of lreight, and at the same time it is an article of miversal necessity in haily life and the basis of industries. see 10 l. C. C. R. :3:3. On the other hand, the increased hazard to the carrier in transporting live stock is properly taken into account in tixing the tariff. 10 I. C. C. R. 327 . See also I. C. C. R. $51+$ anil + Int. Com. Rep. 228 ; A I. C. C. R. 4 s.

In the circumstances to be considered are all questions bearing upon the cost of service by the carrier, including any special services rendered the shipper, such as ripicl transit and increased cost of handling. 2 I. C. C. R. 73 and 2 Int. Com. Rep. t.?.

137. The Commission on distance as a factor in rates.The Commission has uniformlly held that distance is an important factor in determining the reasonableness of rates and orlinarily the standard, but not always controlling. It lias been sail to be controiling in the absence of other influential conditions. TI. C.C.R. 1si. Distance by the shortest route has bern frequently considered in determining the rate on another and competing line and the distance ly the shortest available route has been taken as a basis of differentials in grain rates. TI. ('. C. R. ts.

When the Act to Regulate commerce was before Congress, the mileage bises for rates was suggesterl but not adopted. The ('ommission said in I. (. C. R. 6iz!), - Int. Com. Rep. 9, that the fact that the rates were not fixed on a mileage basis loes not necessatrily make them either illegal or unjust, and the comminsion has no power to malie an order requiring the 
adoption of such a basis. See also 2 I. C. C. R. .2, 2 Int. ('om. Rep. 41 .

Where rates seemingly reasonable are made by a number of carriers in a widely extended territory and ale relatively far so far as the evidence shows, the ('ommission wili not order these rates changed at one important point, thereby throwing the rates of the entire system into confusion for the purpose of conformine to the mileage basis. 2 I. C. C. li. 31. 2. Int. Com. Rep. 19!?.

The rule of increased aggregate rate and decreased rate per ton per mile as distimce inereases, while general, is subject to qualifications and exceptions. 9 I. C.C. R. 16. Chalges are not proportioned to distance where distances are considerable and the distances between the points relatively small. $\therefore$. I. C. C. R. $26 t$ and $t$ Int. Com. Rep. 6.). As to grouping of rates, see infire, section 3 .

\$135. The Commission on comparison of rates. - Rates reasonable in one section of the country may be unreasonible in another. 6 I. C. C. R. 121. There is no necessary comner. tion between rates on traflic of the same kind or class in one direction and rates in the opposite direction, als special cirentustances, such as flow of traftic, may justify higher rates in one direction than in the other' especially is this the case where the distance is of great length. 6 I. C. C. R. S5, 121,9 I. C. C. R. 64.2. The share of a through rate is not necessarily the measure of a reasonable rate, but is properly used as a basis of comparison in determining its legality. if I. C. C. R. 4.s: and the apportionment of through rates to the different parts of the through line may be significant of the question of the reasonableness of the through rate. 2 I. C. C. R. 1:3, and 2 Int. Com. Rep. 79. Local rates are not properly compared with through rates. 1 I. C. C. R. 401, 1 Int. Com. Rep. 719; 3 I. ( C. R. 534, 2 Int. Com. Rep. 77\%. Where a railroad owned two parallel lines, it was held that having aceepted low rates on one of them, it should have provided corresponding advantages to the patrons of its other lines, allowances being properly made for any differences in conditions. t I. C. C. R. T?. and 3 Int. Com. Rep. 115.

In comparison with rates in other loealities, dissimilar conditions and modifying circmmstances are to be considered. 
5 I. C. C. IR. 1ini, and : Int. Com. Rep. 794. Rates on the lines of rival compantes or different branches of the same company are properiy considered. i I. C. (. R. 121, I. C. C. R. 3:5, 1 lnt. Com. liep. titl. A I. C. C. R. 19.): as also rates to contiguous points on same line. 2 I. C. C. R. is, 2 Int. Com. Rep. $+12$.

(in the cutustion of reasonableness, it is immaterial whether the rilitroats combine or act separately. 2 I. C. C. R.:375, Int. (Com. Rep. 2a!), and an increase of rates for the purpose of securing certain lines of thatfic from territory set apart to railloals under an agreement is prima fucie unreasonable. 6 I. C. ( . R. R. 1!r.

\section{3:\%. Relation to state local rates. - The Act to Regra-} late (ommeree contains no provision under which the interstate fares must be reduced because the intrastate rates are lowered by the state commissions. The substantial dissimilarity between throngh and local rates is not effected by such exercise of state authority. F I. C. C. R. tiul.

140. Reasonableness and proportion.-- It was said by the commission in an opinion by its chaiman, Judge Cooley. in an cally case, ㄹ I. ('. C. I. 2:31, and 2 Int. Com. Rep. 137, that the phrise "rates reasonable in and of themselves" was rery likely to be misleading, and that it was not the theory of the let that reasonableness of rates could thus be separately aml independentiy determined.

in the contrary, it is assumed in the Act that persons, corporations and localities are interested not only in the rates charged them, bat in the rates whieh are charged to others also and that while the Act does not require all rates to be proportionate, it nevertheless makes an element of proportionment an important one when the rates to any locality are to be determined. No rates therefore can be reasomable in and of themselves, in contemplation of the Act, which are made rewirlless of proportionment. And in another case it was said (:) I. (C. ('. R. 5.84, and 2 Int. ('om. Rep. T76):

"The tems "reasonable and just" as used in the statute, as applied to pates are each relative terms. They do not mean to imply that the rates on crery railroarl emploved in interstate comineres shall he the same or aven about the same. The comblitions and circumstances of cach road surrounding the 
traftic, and which enter into and control the nature and character of the service performed by the carrier in the transportation of property, such as the cost of transportation, which includes volune or lightness of trattic, expense of construetion and operation, competition in some respects of carriers not subject to the law, rates made by shorter and competing lines to same points of destination, space occupred by freight, and risk of carriage,- all have to be consilered in determining whether a given rate is reasonable and just." Tested by these, a rate mity be very reasonable and just as to one road, and not as to another.

As to the complexity of the question of adjusting rates so as to make them at once reasonable $p^{\prime}$ se and in proportion, see Fink on railway freight rates, supre, $\$ 99, n$.

\section{$\$ 141$. The Commission on rate wars and reasonable-} ness of rates. - In the matter of the (hicago, St. Paul \& Kansas City Railway Co. 2 I. C. C. R. $2: 31,2$ Int. Com. Rep. 137), the Commission in an opinion by Julge Cooley, considered this subject under an applieation for alleged violation of the fourth section of the Act, and satid that the Act was not passed to protect railroad corporations against the misconduct or mistakes of their officers, or even primarily to protect such corporations against each other, and that the term "just and reasonable" is employed to establish a maximum limitation for the protection of the public, not in minimum limitation for the protection of reckless carriers against their own action. The Commission conceded that there was evidence that in many cases railroad companies temporarily establisherl rates which were not only below the fair compensation for their services, but if persisted in were destructive of their own interests as well as of the interests of its rivals; but carriers that made such unreasonably low rates were giving the public to understand that those rates were reasonable and remunerative and were doing very much to establish against themselves a low standarl of rates for all time. The Commission held that it had no power to order rates to be increased upon the ground that they were so low that persistence in them would be ruinous. This ruling was cited and approved by the Supreme Court in the Maximum Rate case, 105 U. S. 511, l. c., 42 L. Ed. $25 \%$, the court saying that the argment showing that the commission had no power to fix a minimum or establish 
an absolute rate went also to show that they had no power to prescribe any tariff or to fix any rate to control in the future.

14:. Illustrative cases upon specific rates.-Hllustrative cases discussing the question of reasonableness per se on different commolities and as to different localities: salt, i) I. C. (. R. 299 , and 4 Int. (com. Rep. 39 ; transcontinental shipments from New lork and lioston, I. C. C. R. 436, and 1 Int. ('om. Rep. 7it; coal rates, Lake Erie District, 21. C. C. R. 418, and 2 Int. Com. liep. 436; coal rates from south Mc.llister to Dennison, Tex., 10 I. C. C. R. 337; food prolucts from Mississippi Rirer to eastern cities, 4 1. ('. C. R. ts, and 3 Int. Com. Rep. 93, 1.)1; grain and grain products from East $\mathrm{t}$ t. Louis to Mississippi points, $10 \mathrm{I}$. C. C. R. $2 \triangleleft 9$; grain and grain products from northwestern Iowa to Chicago, S I. C. C. R. 15s, and from Chicago to New York, 9 I. C. C. R. 3s; from Ritzrille, Wash., to St. Paul, 5 I. C. C. R. 7 , and 3 Int. Com. Rep. 655; from Kentucky to Newport News, 7 I. C. C. R. 380 ; cotton from Florida to Savannah, S I. C. C. R. 377; Indian Territory to St. Lonis, 6 I. C. C. R. i, 1; roofing slag from Lcesport, Pa., to ITarlem River, S I. C. C. R. 59s; oranges from Floricla to New York, 5 I. C. C. R. 1:, and 3 Int. Com. Rep. 6ss; mclons from South Carolina to New York, S I. C. C. I. 1; strawberries and regetables from Floricla to New York, 6 I. C. C. R. 295 ; peaches from Delaware listrict to Boston, 4 I. C. C. R. 66t, and 3 Int. Com. Rep. 493; furniture from Lansing, Mich., to California, 5 I. C. C. R. 51t, ind 4 Int. Com. Rep. 223; lumber from southwest Tirginia to New York, 9 I. C. C. R. S7; lumber from Dalton to Lynchburg, I. C. C. R. 450, and 1 Int. Com. Rep. 76t; packing house products Chicago to New York, 9 I. C. C. R. 382; Savannah to Florida, 8 I. C. C. R. 37 ; oil from Oil City to New York and lioston, 5 I. C. C. R. 415, and 4 Int. Com. Rep. 162; milk grouping rates basis, to New York, 7 I. C. C. R. 92; live stock terminal charges in (hicago, 7 I. C. C. R. 519; butter from lincoln to Lenver, 5 I. C. C. R. 156 , and 3 Int. Com. Rep. 794; locality rates from st. Louis to Eureka Springs, 7 I. C. C. R. 69: St. Louis to lincoln, Neb., 2 I. C. C. R. 15.5, and 2 Int. Com. Rep. 95: Chicago and Iruluth to Norfolk, 9 I. C. C. R. $\because 2$; Wilmington to boston, 9 I. C. C. li. 17; Verona to 
E. St. Louis, 7 I. C. C. R. 43 ; milling in transit rates from south Minnesota to Chicago, S I. C. C. R. ti; Eureka spriness rates, 7 I. C. C. R. 69; electric street car line of I)istrict of Columbia and Maryland, 7 I. C. C. R. 58 ; Meridian and New Orleans, 2 I. C. C. R. 37., and 2 Int. Com. Rep. 259 ; Chicago and Cincinnati to southern territory, 6 I. C. C. R. 15.5; Pacitic Coast to Denver aud the Missouri River, 9 I. C. C. R. (ioti; sugar from New Orleans to Wichita, Kan., 10 I. C. C. R. tho. 


\section{SECTION 2.}

Page.

\$143. Sec. ?. Enjust discrimination detined and forbidden........ 180

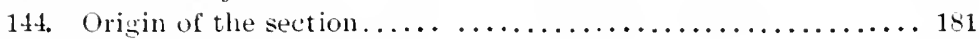

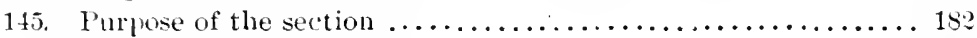

146. Erlectireness of the section $\ldots \ldots \ldots \ldots \ldots \ldots \ldots \ldots \ldots \ldots \ldots \ldots \ldots$

14\%. Common law as to discriminations................ 184

14s. Just and unjust discrimination .................. 186

149. I) ifference in charge based upon difference in service ...... 1sy

150. Circumstances and conditions of through traficic and local trafic are dissimilar ........................ 190

151. Competition of carriers does not make circumstances dissimilar

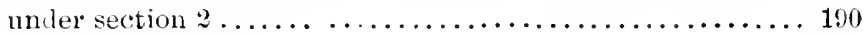

152. The Party Rate case............................. 192

153. Wholesale and retail rates in freight trafnic............ 192

154. Wholesale rates in freigint and passenger traflic distinguished. 194

15.5. Discrimination not unjust when based on special service.... 19.

156. Cirlond and less than carload rittes . . . . . . . . . . . . . 195

15\%. Discrinination in ipplication of carload rates........... 197

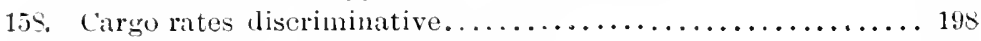

159. Different forms of discrimination...................... 198

160. Discrimination through interest in comnecting company..... 200

161. Discrimination by carrier in favor of itself as a shipper ..... 200

162. Discrimination in the storage of goods, etc $\ldots \ldots \ldots \ldots \ldots \ldots 20$

163. Stoppage in transit privileges ....................... 203

16. Unlaw ful discrimination through abuse of stoppage in transit

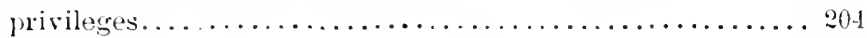

16.j. Enjust discrimination in passenger service............ 20 .

166. Giving passes to sinipters prohibited................ 206

16i. Application of the section........................ $201 ;$

16s. Letention of overcharge $\ldots \ldots \ldots \ldots \ldots \ldots \ldots \ldots \ldots \ldots \ldots \ldots . \ldots \ldots$

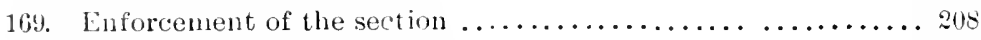

1\%0. Enforcement by injunction ...................... 20 9

1i1. Enfect of rebates upon cont racts of affreightment ......... 210

\section{4: Cujust discrimination defined and forbidden.-}

sia. 2. That il any common carrier subject to the provisions of this act shall, directly or indirectly, by any special rate. rebate. drawback, or other device, charge, demand, collect, or receive from any person or persoms a gleater or less compensition for any service rendered, or to be renclerel, in the transportation of passengers or property, subject to the provisions of this act, than it chares, demands, collects, or receives from any other person or persons for doing for him or them a like and contenporaneous service in the transportation of a like kind of traffic under substantially similar circumstances and conditions, such common carricr shall be deemed guilty of unjust discrimination, which is hereby prohibited and declabed to be mulawtul. 
144. Origin of the section.-This section was said by the Supreme Court in the Texas of Pacific Railway case, $162 \mathrm{I}$. S. $1: 17$, l. c. $219,40 \mathrm{~L}$. Ed. Stu, to have been modeled upon section 90 of the Railway Clauses Consolidation Act of 1st.r, $s$ \& 9 Vict. ch. 20, the first English statute regulating railways. This section is as follows:

"Sec. 90. And whereas it is expedient that the company should be enabled to vary the tolls upon the railways so as to accommodate them to the circumstances of the tralfic, but that such power of varying should not be used for the purpose of prejudicing or favoring particular parties, or for the purpose of collusively or unfairly creating a monopoly, either in the hands of the company or of particular parties; it shall be lawful, therefore, for the company, subject to the provisions and limitations herein and in the special act contained, from time to time to alter or vary the tolls by the special act authorized to be taken, either upon the whole or upon any particular portions of the railway, as they shall think fit; provided that all such tolls be at all times charged equally to all persons, and after the same rate, whether per ton, per mile, or otherwise, in respect to all passengers, and of all goods or carriages of the same description, and conreyed or propelled by a like carriage or engine, pussing only over the sume portion of the line of railuay under the sume circumstances; and no reduction or advance in any such tolls shall be made either directly or indirectly in favor of or against any particular company or person traveling upon or using the railway."

This section of the English law, known as the equality clause, differs from section 2 of the American Act in the worls "passing only over the same line of railway under the same circumstances," which impart a very different meaning as construed in the English courts from the words "under substantialiy similar circumstances and conditions" found in the American Act. The English section as construed by the English courts was confined in its operation to shipments passing only. over the same portion of the line between the same points of departure and the same points of arrival. See M. S. \& L. Ry. Co. v. Denaby Main Colliery Co., 4 Railway \& Canal Traffic Cases, p. 452; Murray v. G. \& S. W. Ry. Co., 4 Railway \& Canal Traffic Cases, p. 460; Denaby Main Colliery Co. v. ML. S. d L. Ry. Co., 6 Railway \& Canal Traflic Cases, p. 141; L. \& Y. Ry. Co. v. Greenwood, Law Reps. 21 Q. B. Div. pp. 217 and 215.

It appears from a statement made in the debate in Congress by Senator Sherman, on May 1t, 14si, that the words "and 
from the same original point of departure or from the sime point of arrial" were at one time contained in section 2 , but that these works were taken out by the conference committee. and the words " under substantially similar circumstances and conditions "alopted in lien thereof. So that discriminations are "unjust" and riolative of this section: first, when the service is like and contemporaneous; second, when it is rendered in the transportation of a like kind of traffic, and, third, when the service is renclered under substantially similar eircumstances and conditions. That is, all three of these conditions must concur.

145. Purpose of the section.--The purpose of this second section is the prevention of unjust discrimination between shippers by any form of device. It wats salil by the Commission in its report on its in restigation of the subject of "underbilling," 1 1. C... R. (38:, and 1 Int. Com. Rep. s1:, that the enmmeration in this section of special rates, rebates, drawbacks and other devices showed the methods of favoritism which were presented most distinctively to Congress in framing the act. and added: "The investigation which preceded the passage of the Act hat disclosed the fact that preferences were frequent, in fact were ahmost universal." The Commission quoted from the report of the senate committee to the effect that the prevailing policy of railway management is but an claborate system of special rates, rebates, drawbacks and concessions to foster monopoly, to enrich farored shippers and to prevent frec competition in the many lines of trale in which the item of transportation is an important factor. The Commission said that the Act was prepared accorlingly with these evils directly in view.

The section has been construed both by the Commission and by the comts, in recognition of these evils which Congress intended to remedy. The supreme Court said in Wight v. Inited States, 1675 C. S. 512 , 42 L. Ed. 258 , that the section was designed to compel every carrier to give equal rights to all shippers over its own roal and to forbid it by any derice to enforce higher charges against one than another.

In another case. Union P'acific Railway Co. v. Goodrich, 149 L. S. 651, 37 L. Ed. s.m, the court said in construing a Colorido statute similar in terms, that the purpose of the Colorado 
statute was to apply to intrastate traffic the same wholesome rules and regulations which Congress thereafter applied to conmerce among the states, and to cut up by the roots the entire system of rebates and discriminations in favor of particular localities, special enterprises an! farored corporations, and to put all shippers upon an ibsolnte equality.

This section 2, howerer, does not deal with discriminations 1 between and preferences in faror of or against locallies, or with discriminations between kimds of troffic, which are dealt with in the succeeding section, but only with discriminations between shippers of the same kind of tratfic, that is, where the service is in the transportation of a like kind of traflic "under substantially sinilar circumstances and conditions."

146. Effectiveness of the section. The act of Fehruary 19, 1903. - The main purposes of the Act are more distinctly expressed in the second section than in any other. The reasonableness of rates remains as complex and indefinite a problem as when the Act was passed, and as will be hereafter seen, the anticipated prevention of the building up of trade centers to the prejudice of smaller towns has proven impossible of realization in the face of controlling competition. On these subjects the powers of the Commission hare been materially curtailed by the juclicial construction of the Act, but on the question of discrimination between individuals, or classes of individuals in the same kind of traflic, the rulings of the court have been, with the exception of the Party Rate decision, in harmony with those of the Commission. It may be said further, that the evils prohibited in this section are recognized by railway managers, so that they have in the main co-operated with the Commission in their efforts for their suppression. Thus the Commission said in its first annual report, 1857, in reviewing the operation of the Act for the first eight months in which it was in force, that it was justified in saying that the Act had operated directly to increase railroad earnings by putting an end to rebates, drawbacks and special rates upon freight business, a result which was also fonnd to be eminently satisfactory to the general public; and the investigations of the Commission had not as yet disclosed the existence of unjust discriminations resulting from the use of those particular methods of preference in interstate tralfic. "()n the contrary, a 
vast number of instances have been fonnd where special rates, rebates and drawbacks have been discontinued, and where preferences and adrantages which were formerly thereby given, have been terminated."

In the intense competition of business, new devices for securing discriminating freight rates have been eagerly songht, and it appears from the subseguent reports of the fommission that while discriminations are less openly given, the evil is far from being suppressed, particularly in the use of private cars in freight traflic, in the division of rates with terminal railroals owned or controlled by shippers and in other devices. See report of 1944, pages 1.2 to 19 , and 10 I. C. C. R. $35.5,10$ I. C. C. R. tio. The act of February 19, 1908, commonly known as the Elkins bill, hats rery materially enforeed this section. This law, intire. s310, requires carriers in all cases to publish their tarifl's and prohibits "any practice on the part of the carriers whereby any such property shall by any device whatever bo transported at a less rate than that named in the tariff. . or whereby any other advantage is given or discrimination practiced." Cnder this amendment the practice of seeret rebates from pubtishal rates, thongh made to all "similarly circumstanced" is made unlaw wul.

$\$ 14$. Common law as to discriminations.--It was said of the first section, as to the obligation to charge retsonubly, that it was only a reallirmation of the common law. This can be said only in a qualified sense of the obligation to charge equally imposed by the second section. In the Party Rate case 145) U. S. 275,36 L. Ed. 708 , the Supreme Court said that at common law it was even doubted whether carriers were bound to make the same charge to all persons for the same serviee, although the weight of authority in this country was in faror of equality of charge to all persons for similar service. Several cases have held that while it was elementally that common carriers could charge no more than a reasonible compensation, the mere discrimination in rates was not illegal. If a rate charred one party was reasonable, be conld not complain if another was chargerl a less rate; though the fact that another was charged less might be material as evidence for the jury tending to prove that the reasonable charge was the smaller one. Mr. Justice lBa(kiburn in Great Western Rail- 
way Co. v. Sutton, L. R. 4 II. I. 235; Johnson v. Pensacola, etc. Co. 16 Fla. 623 . In Cowden r. Pacific Coast Steamship Co. 94 Cal. 470 and 15 L. R. A. 221 , the court intimated that it was because the common law was not clearly settled on this point that it was necessary for Parliament to enact the stringent equality clanses, and that there was a lack of direct authority in this country for the reason that common carriers, especially railway companies, had been placed entirely under the control of statute liaws.

On this question of the right of discrimination at common law, see Ex parte Benson, 1s S. C. 35: Raxendale v. Ratilway, 4 C. B., N.S. 63 . In the latter case, in 1558 , it was silid that though a carrier was limited to a reasonable charge, there was no common law obligation to charge equal rates to all customers. It followed that he could discriminate in the purpose of securing traffic which woukd otherwise go by another route. Ragan r. Aiken, 9 Lea (Tenn.), 609 (1892).

In Menacho v. Ward, 27 Fed. Rep. 52, ( S. D. of X. T.), decided in 1Ss6, the court, Wallace, J., conceded the right to discriminate, and said the courts had always recognized the rights of carriers to regulate their charges with reference to the quantities of merchandise carried for the shipper, either at a given shipment or in a given period of time, although. said the court, public sentiment in many communities had objected to such discrimination and had crystalized into condemnation of the practice. The court howerer relused to apply this principle to the case where the carrier, (a steamship company), sought to make a discriminating rate in order to prevent competition, that is, by charging a higher rate to those who refused to patronize it exclusively.

See also later cases deciled by the same court after the pas. sage of the Interstate Commerce Act. Thus in Lnited States v. D. L. \& W. R. Co., 40 Fed. Rep. 101 (1Sss), it was said that the Interstate Commerce Act had qualified materially common law rights and obligations of carriers. That at common law he was not obliged to treat all who patronized him with absolute equality and that discriminations were only unreasonable, when they inured to the undue alvantage of one person, or class of persons in consequence of some injustice inflicted on an other. 
See also the same court in Interstate Commerce Commission v. Texas i Pacific R. Co., 52 Fed. Rep. 157.

\section{Just and unjust diserimuation at common law.-} The right of discrimination at common law was not unlimited, and the general statement found in some of the opinions that the carrier hald the right at common law to consult its own interests. wals qualified by the distinct recognition, especially in the latter cases, that this discrimination must be exercised within the limits of farness and impartiality in view of the public duty owing by the carrier. See C. C. C. \& I. R. Co. v. Closser, 129; Ind. 34 and 9 L. R. A. 754, deciled in 1-:1!. There is an obrions difficulty in the application of this principle in cases where the discrimnation is sought to be justified on the ground of securing tratfie which would not otherwise be secured, and in thus making eoneessions to large shippers, thereby giving them a distinct advantage over their competitors.

The trend of the later cases, both in the Federal and State Courts, irrespective of the Interstate Commerce let, distinctly condemns discrimination based solely on the ground of the guantity of the freight shipped, as contrary to sound public policy and inconsistent with the obligations of the carriers to the public. Thus in B.C. R. \& N. R. Co. v. Northwestern Fuel Co., 31 Fed. Rep. (Iowa) 6.̈, the Cirenit Conrt, Brewer .J., held that at common law a contract whereby a railroad company made a rate of $\$ 1.60$ per ton to all shippers of $1+1$.11m tons per month or over, with a rate of not less than S.th per ton to those shipping less than 10 , ono tons per month, was so arbitrary and obviously in the interest of capital as to be contrary to public poliey and roid, though it was not distinctly decided that any discrimination based upon the amount of shipments was permissible.

In another case, IIandy v. C. \& M. R. Co., 31 Fed. Rep. 689, S. I), of (thio (1S5T), Baxter, J., removed the receiver of a railroal for making a discriminating rate in favor of the Stanclard (sil Company of ten cents a barrel while charging a rival shipper thirty-five cents a barrel and agreeing to pay the twenty-fivecents per barrel excess thus receivel over to the Standard ()il (ompany. This discrinination was solght to be justilied because the Standard ()il (ompany had threatened to 
store its oil until it could lay a line of pipes unless the receiver should give such rates. The court said this was such gross and wanton discrimination as to warrant the removal of the receiver, although he had acted under the advice of counsel for what he deemed the protection of the interests of the railroad, ani it did not appear that the money received from the rival shipper had been paid orer to the Standard Oil Company.

In IIayes v. Pennsylvania Co., 12 Fed. Rep. 309, decided in 1882 on common law principles before the enactment of the Interstate Commerce Act, (Dist. of Ohio), Judges Raxter and Walker, it was held that discriminations based solely on the amount of freight shipped without reference to any conditions tending to decrease the cost of transportation, were discriminations in favor of capital and were a wrong to the disfarored party, entitling him to recorer the difference between the amount pail by him and that paid by the favored competitor. The court in its opinion distinguished the case of Nicholson v. Great Western Railroad ('o., \pm C. B. S. 366 , as in that case there was an undertaking to furnish a specific quantity of freight within a stated period. The conrt said in the Hayes Case, however, that while this English case was clearly distinguishable, future experience might possibly call for a molification of the principle there announced. This decision was approved in Kinsley v. P. N. T. \& P. R. R. Co., 37 Ferl. Rep. 181, decided in 1sss, where the receiver of a railroad was directed to pay the claim for money exacted for freight, when a lower rate was charged to another shipper who shipped larger quantities of freight.

On the other hand, there is a class of cases where a reduced rate in consideration of the amount of shipment, where the shipment was attended with decreased expense to the carrier, was sustained, as was Hoorer v. Pennsylvania, 1.66 Pa. 2.2', and 22 L. R. A. 263 , and L. \& N. Consolidated R. Co. v. Wilson, 132 Ind. 517, and 18 L. R. A. 105. in the Pennsylvania case cited, the Pennsylvania Constitution prohibited discriminations in somewhat the same terms as section 2 of the Interstate Commerce Act, and the court held that the carrier had a right to discriminate in rates on coal in favor of a manufacturer, saying: 
"Differences in freight rates on coal to manufacturers and mere dealers are and have been for many years in universal practice, and not a single case other than this has reached the courts of last resort, either in England or in this comtry, fuestioning the entire propriet $y$ and legality of such differencess and that cireumstance is ample proof that both the professional and the lay mind recognize that the difference is legal." The court cited in this case the decision of the supreme Court of the Lnited states in the Party Rate Case, infia.

In Evershed v. London a Northwestern R. Co., L. R. 3 Q. B. 1). 185 , decided in 157 , the court conceded that a large business could be done at a cheaper rate than a small one, and that speaking generally, it was open to the railway company to make a bargain with a person provided they were willing to make that same bargain with another, although that other was not in a position to make it. In this case, however, it was held that a gratuitons carting, loading and unloading, by a railroad company for three firms of brewers in order to get their business, wasan unjust discrimination against another brewer in the same place, the three being connected with another railway while the complainant was not connected with either railway.

On the other hand, the right to make an!) discrimination in faror of a shipper, where the ground of discrimination is based solely on the amount furnished for shipment, eren when necessary to secure the traflic of the farored shipper, has been denied on the ground of public policy and the public duty of the carrier. See Scofield r. Lake Shore \& Michigan Southern R. Co., 43 (Ohio St. 571; State v. Railroad, 47 Ohio St. 130. In IIilton Lumber Co. v. Atlantic Coast Line R. R. Co., the Supreme Court of Torth Carolina, in a recent opinion, Norember $15,1904,60 \mathrm{C}$. L. .J. 30, in a reriew of the cases, held that a railroad carrying raw material to factories could not charge a factory, agreeing to ship the manufactured product by the same road, less for the same service than it charged the factory which makes no such agreement, saying that discrimination was a more dangerous power than high rates, if the latter were charged impartially to all. It will be observed, however, that the facts of this case would permit the allowance of a through wate unrler the milling in transit principle as recognized under the Interstilte Commerce Act. See infir, 163 . 
As to other cases on the same general subject, see Fitchburg R. Co. v. Gage, 12 Gray 393; spothord v. B. \& M. R. Co., 12s Mass. 226 ; Avinger v. So. Car. R. Co., 29 S. C. 265 ; Radilroad Co. v. Forsaitb, 5! N. I. 122; Chicago, etc. R. Co. v. Suffern, 129 Ill. 2it; Atwater v. Railroal Co., 48 X. J. Law, 5.5: Cook v. C. R. I. \& Pac. R. Co., 81 Iowa 5.1, 9. R. 1. T6t. In this latter case the court held, that the allowance of a rebate by a carrier to certain of his customers, from the tariff rates charged other customers for precisely the same service, was sulficient of itself to show that the rate charged was unreasonable and unjustly discriminative.

See also Great Western R. Co. v. Sutton, L. R. 4 H. L. 226; Messenger v. Penn Co., 37 N. J. Law, 531.

149. Discrimination in charge hased "pon difference in service not discriminative.-- While therefore there has been a difference of judicial opinion as to what constitutes unjust discrimination, at common law, with a distinct trend towards a clearer recognition of the public duty of the carrier and the public policy of equality of charge, it is eleariy recognized that a discrimination is not unjust when it is based upon a substantiat difference in the mode and kind of service.

Tkus it was held by the Supreme Court of the Lnited States in the case already cited as to the common law in the Federal Courts, Western Union Telegraph Co. v. Call Publishing Co., supia, that common carrier's, whether engaged in interstate commerce or in that wholly within the state, were performing public service. "They are endowed by the state with some of its sorereign power, such as the right of eminent domain, and so by reason of the public service they render. Is a consequence of this all individuals have equal rights both in respect to service and charges. Of course such equality of right does not prevent differences in the moles and kinds of service and different charges based thereon. There is no cast iron rule of uniformity which prevents the charge from being above or below a particular sum, or requires that the service should be exactly along the same lines. But that principle of equality does forbid any difference in charge which is not based upon difference in service, and even when based upon difference in service must have some reasonable relation to the amount of difference and cannot be so great as to produce an unjust discrimination." 
This was a case of alleged discrimination in telegraph rates which are not subject to the Interstate commerce Act.

150. Circumstances and conditions of through traflic and local trafic are dissimilar. - While competition between carriers cannot justify discrimination between individuals, competition may and does have an influence in determining the throngh rates, thus making them moler essentially different circumstances and conditions from the local rates to other points on the sime line. In such cases the rednced rate affected by competition is controlled by circumstances and conditions substantially dissimilar within the meaning of the act. But whether so controlled or not, it must be the same to all shipper's under the same conditions. It has been miformly held both by the Commission and by the comrts, that a local rate to a given point and the fro rata part of a through rate to the same point on the same line are not under similar circumstinces and conditions.

The phrise " under similar circumstances and conditions" is found in sections 2 and 4 . As hereafter seen, competitive conditions may create dissimilar circumstances and conditions between localities under section $t$, but when the rates are thus fixed under dissimilar conditions, section 2 requires that shippers in any given locality must be treated alike for the same, service. But through tratiic is a different "kind of service" from local trafic. This was held in Lnion Pacific Railway Co. v. I nitcd States, 117 L. S. 355,29 L. Ed. 920, in the construction of the act of Congress of July $1,186,2$, relative to the Inion Pacifie Railway company, and applied to the construction of the second section of the Interstate Commerce Act in the Import Rate case, 16.2 U. S. 157,40 L. Ea. 9 40 . It is not only in the presence of competition, but also in the increased cost of service, resulting from stoppages, that the conditions of through and local traflic are substantially dissimilar. Chicago etc. R. R. Co. v. Tompkins, 17 i L. S. 167 , 4 L. Ed. 417 . See silperte.

1:31. Competition of carriers loes not make circumstancendissimilar under section :- - These words as used in section 2 refer to the matter of carriage, and do not include competition, that is, discrimination between individnals is not justified by the fact of competition with other carrices influ- 
encing the lower eharge. Thus, in Wight v. Cnited States, supre, the Court sustained the conriction of a railroal angent for making to a consignee who had a siding eonnection with a competing rairoad, an allowance or rebate for the expense of cartage from its own station. It was urged that the party who did not have this connection would have to go to the expense of eartage by whicherer roal he transported, and that therefore the traffie was not under the same circumstances and conditions within the terms of section 2 . Lut the Court said that the wrong probibited by the section was a discrimination between shippers, and that the serrice in transporting to the station from the point of shipment was precisely the same to each shipper. The court concluded: "It may be that the phrase 'under substantially similar circumstances and conditions, found in seetion $t$ of the act, and where the matter of the long and short haul is considered, may have a broader meaning or wider meaning than the same phrase found in section 2. It will be time enough to determine that question when it is presented. For this ease it is enongh to hold that that phrase, as found in seetion 2, refers to the matter of carriage, and does not inclucle competition." It was determined in other eases before the court construing section $t$ that the term "under substantially similar cireumstances and conditions" in the latter section did have a broader meaning and dic inelude eompetition as ereating dissimilarity of eireumstanees and conditions. See seetion $t$, infra.

The construction of the section in the Wight Case prevents a earrier from making a concession to secure a business, which it could not otherwise seeure, if that concession makes an inquality in rates between shippers for the same service. Competing shippers in this ease were not in fact injured by the concession, as they were compelled to pay for cartage in any event. The only effect was to give the shipper two competing lines at the same rate, and to give the carrier an opportunity to handle traffic from which otherwise it was cut off. While it could have been contended that the circumstances were substantially dissimilar, and that such a diseriminative rate for the purpose of securing business was not within the intent of the seetion, the construction deelared in this case makes such a concession unlawful, although extended to all, "similarly eircumstanced," that is, to all making the same shipment. 
S 15:. The Party Rate case.- It was ruled by the Commission, 1 I. C. C. R. 2015, 1 Int. Com. Rep. 611, that uncler this section redneed land explorer's tickets and settler's tickets, and special rates to inmigrants, 3 I. C. C. R. 6..2, 2 Int. Com. Rep. sut, were illegal as liscriminating under this section. The same ruling was made in the case of party rate tickets, that is, tickets sold at reduced rates and entitling a number of persons to travel together on a single ticket or otherwise, were an unjust discrimination against other passengers and illegal. This ruling however was disapproved by the Circuit Court, 48 Fed. liep. 35 , and also by the Supreme Court in what is known as the I'arty Rate case, $145 \mathrm{~L} . \mathrm{S} .203,36 \mathrm{~L}$. Ed. 703. The latter court salid that party rate tickets which were used principaliy by theatrical and operatic companies for transportation of their tronps, would hatrlly fall within the meaning of mileage or excursion or commutation ticliets within the exception of section -2 , but that did not make the ticliets unlawful. The unlawfulness defined by section 2 consisted in an unjust liscrimination. It wasthe object of section 20 to settle beyond all loubt that the discrimination between certain persons therein named should not be deemed unjust: but it did not follow that there might not be other classes of persons in whose favor such discrimination was made withont such discrimination being unjust, and that the section was illustrative rather than exclusive. The object of such party rate tickets was to induce more people to travel and to secure patronage that would not otherwise be secured. After a review of the English cases construing the English act of $15.5 t$, the court said that the substance of all those decisions was that the railroad companies were only bound to grive the same terms to all persoms alike under the same circumstances and conditions, and that any lact that produced change in contition and different circumstances and conlitions justifies an inequality of charere.

153. Wholesale and retail rates in freight traflic.-In the case of Hoover $r$. Pennsyrania Railroad Co., sepren, the court based its ruling lipon this l'arty Rate decision, and applied the principle to a discrimination in faror of manufacturing industries which would contribute to the business of the railparl. In one of the early cases before the Commission, the Provilence Coal Company tase, I. C. C. I. 10t, 1 Int. Com. 
Rep. 363, decided in 1587 soon after the organization of the Commission, it was held in an opinion by Judge Cooley, that the analogy of wholesale and retilil purchasers of merchandise could not be extended to a discrimination in freight rates based solely upon the amount of shipment. The cases were not analogous, since the naming of the quantity of freight which should be compared to wholesale purchasers must necessarily be altogether arbitrary. In this case a discount of ten per cent was allowed on 30,000 tons, and it seemed there was only one dealer who could make that shipment. Julge Cooley added: "A railroad company if allowed to do so might in this way hand over the whole trade along its road to a single dealer, for it might at law make a discount equal to or greater than the ordinary profit in trade, and competition by those who would not get the discount would then be out of the question." The 30,000 ton limit was unreasonable and unlawful because necessarily resulting in unjust liscrimination. It was said also that the distinction between carload and less than carload lots was readily understool and appreciated, but that discrimination must be based on the distinction in volved in the cost of handling.

This ruling of the Commission, it will be seen, is in harmony with the recent trend of judicial opinion as to the common law right of discrimination; that is, that it must be based upon a difference of the cost of service, and not upon the mere fact of a larger shipment. This was directly ruled in United States v. Tozer, 39 Fed. Rep. 369, eastern district of Missouri, in a case where the defendant, a railroad agent, was indicted for paying rebates in violation of section 2 of the act. The court, Thayer, J., charged the jury that the fact that the defendants received much more traffic from one shipper than from another did not make the circumstances and conditions. under which the two services were rendered substantially dissimilar.

It will be observed however that the discrimination in favor of the larger shipper could in some cases be justified on the ground of a difference in the cost of service, as it is recognized that as a rule the proportionate expense of handling and carriage is reduced with the increase of quantity. Divested of all considerations of public policy, a carrier might 
well aflord to give a special rate in view of the assurance of a certain quantity for shipment. This was reeognized in the Nicholson r. G. W. R. Co. case, supue. The really controlling consideration is that of public policy in this refusal to apply the analogy of wholesale and retail sales to freight rates. It is becaluse the power to discriminate in faror of a larger shipper, whaterer the business inducement, is necessarily injurious to business competitors who cannot make such shipments, and therelore tencls to monopoly.

\section{$\$ 154$. Wholesale rates in freight and passenger trallic} distinguished. - There is another ground however for the clear diflerentiation of discrimination in passenger rates on the basis of the number carried in party rate tickets, from a like discrimination in the case of freight rates. To one is injured or ean be injured by the issue of passenger tickets at a rednced rate, whereas in the case of freight rates based upon the amount of shipment, the effect might be to put out of business all but the favored shipper whose business was large enough to ship the requisite amount. This distinction was commented upon by the Supreme Court in tire Party Rate case, where the court said at pane 280 : "If for example the railroad makes the public generally a certain rate of freight and to a particular individual residing in the same town a reduced rate for the same class of goods, this may operate as an undue preference, since it enables the farored party to sell his goods at a lower price than his competitors, and maly enable him to obtain a complete monopoly of that business. 'Then if the same reduced rate be allowed to everyone loing the same amount of business, such diserimination may if carried too far operate unjustly upon the smaller dealers engaged in the same business, and enable the larger ones to drive them ont of the market. The same result however loes not follow from the sile of ticliets for a number of persons at a less rate than for a single passenger: it does not operate to the prejuclice of the single passenger, who cannot be said to be injured by the fact that another is enabled at a particular instance to travel at a less rate than he. If it operates unjustly toward any one, it is the rival roal which has not adopted corresponding rates; but as before observed, it was not the design of the act to stiflle competition, nor is there any legal injustice in one person's procuring a particular service cheaper than another." 


\section{\$ 155. Discrimination not unjust when based on special} service. - While discrimination based merely on the quantity shipped is not justified, discrimination is proper when it is based on a difference in the cost of handling. In any event however, whatever the basis, the reduced rate must be open to all alike complying with the same conditions, and the rate must be published as provided in section 6 . Thus if any accessorial services are rendered by the carrier, such as cartage, the circumstances and conditions are clearly dissimilar. See Detroit, Grand Ilaven \& Milwaukee Railroad Co. v. Interstate Commerce Commission, supra.

Where a special service is required of the carrier, such as rapid transit and speely delivery, or refrigeration in transit, a higher rate than for ordinary freight is warranted. If the carrier charging a rate for such special service fails to render it, to the damage of the shipper and withont legal excuse, the remedy of the latter is by proper proceeding at law. $5 \mathrm{I}$. C. C. R. 529, 4 Int. Com. Rep. $205 ; 4$ I. C. C. R. 5s, and 3 Int. Com. Rep. 554.

This principle was applied in a recent case, Wilson v. Atlantic Coast Line R. Co., 129 Fed. Rep. $77 t$, where it was held that a railroad company was not required as a common carrier to take a circus train, a part of which is loaded with wild animals, and transport the same over its line, but it may refuse to transport such train except under special contract limiting its liability from that ordinarily assumed by a common carrier. See also Chicago, Milwankee \& St. Paul R. Co. v. Wallace, 66 Fed. Rep. 506, 14 C. C. A. 257 , 7 th Circuit, and 30 L. R. A. 161. In these cases the question was one of the right of the carrier to make special contracts for such special class of freight and to become in effect private carriers thereof. It would follow that the carrier would have a right to malie special charges therefor without unjust discrimination.

$\$$ 156. Carload and less than carload rates. - The phrase "under similar circumstances and conditions" has always been discussed with reference to the proper unit of freight charges, whether carload or less than carload, and of the proper basis for discrimination between carload rates and less than carload rates. It will be seen that on this point the interest of localities is directly involved. Thus the great centres of distribution opposed the differential for the salie of encouraging less 
than carload shipments to other parts of the country, while shippers at interior points, desiring themselves to distribute to their respective territories, strongly favored a liberal differential between the carload and less than carloal rate.

This subject was exhaustively considered in the Thurber case, 3 I. C. C. R. 473, 2 Int. Com. Rep. 7t2. Although it wis contended by the western jobbers that the carload rate was the proper and recognized unit, the Commission said that it was a sound rule for the carricers to adapt their classification to the laws of trade. If an article moves with sufficient volume and the demands of commerce will be better served, it is reasonable to give it a carload classification and rate. The carload is probably the only practicable unit of quantity, and the fact that an antecelent condition, when no such distinction existed and perhaps was not required, furnish no argument for a return to a condition no longer suited to the requirements of business. It was therefore impracticable and would seriously demoralize classification in business to attempt to restore equal rates for carload and less than carload shipments in respect of goods properly so classified. It was saill however that the public was more largely interested in miscellaneous than in carload shipments of any one kind of traffic, and that differences langing from forty to one hundred per cent. between the carloads and less than carloads were unreasonable and unjust especially upon articles of general and necessary use, as so great a difference would be destructive of competition between large and small dealers.

While the circumstances and conditions in respect to the work done by the carrier and the revenue earned are dissimilar in the transportation of freights in carloads and less than carloads, and a lower rate on carloads than on less than carloads is therefore not in contravention of the statute, yet the difference between the two rates must be reasonable. 9 I. C. C. R. 7 S.

See also I I. C. C. R. 318, where the Commission discussed the proper differential between carload and less than carload rates from the middle west to the Pacific coast.

The determination of what commodities are properly allowed carload rates may involve the matter of undue preference agrainst particular kinds of traffic under sec. 3. See 4 I. C. C. IR. 212, 3 Int. Com. Rep. 25i, and infra, \$206. 


\section{\$15\%. Discrimination in application of carload rates.-} In 9 I. C. C. R. 620 , the ('ommission discussed the right of a carrier in according a carload rating to look beyond the transportation itself to the ownerstip of the property transported. The railroad in that case declined to allow a combination of carriages in carload lots at carload rates, and insisted on allowing the carload rate only where the shipment was from one consignor to one consignee, thus denying the right of a forwarding agent shipping the goods of different parties at a carload rate. The Commission ruled that there should be no discrimination between consignor and consignee in the allowance of carload rates, when the conditions of the ownership after the property was delivered to the carrier was the same. But no opinion was expressed on the further question whether the carrier could distinguish between a forwarding agent and the actual owner.

In Lundquist v. Grand Trunk Railway Co., 121 Fed. Rep. 915 , it was held that a carrier could properly distinguish between the forwarding agent and the owner of the property, and could apply the carload rating when the goods were tendered for shipment by the owner and refuse it when the like trafiic was offered by the forwarder. The Court said however that it was "a pioneer case, and little aid could be obtained from anthoritative sources." A different ruling was made in England as to the English statute, Great Western Railroad r. Sutton, L. Rep. 4 II. L. 238 , the court holding that like circumstances referred to the carriage of the property and that the carrier could not impose a higher rate when offered by an agent than when offered by the owner. In the Lundquist case the court said that the English staute was much more explicit in its terms than the Interstate Commerce Act, in that it provided that all toll shonld be charged equally to all persons; but even if it were not so, it was not probable that our courts would be called upon to follow the English courts, as the cases were so different. It would seem, however, doubtful whether the employment of a forwarding agent constitutes a difference in the circumstances and conditions warranting discrimination by the carrier.

The right to make carload and less than carload rates carries with it the right of the carrier to fix the minimum rate 
and charge for the transportation of less than carload shipments on account of the necessary expense and trouble attending the carriage of such shipments, which aside from the actual manual litbor involved are practically the same irrespective of the bulk of the packige. The question in such cases is whether or not the rate is reasonable and not unjustly discriminative. In 111. C. (C. R. 412, it was ruled that the minimum charge upon any single shipment of freight should be for one hundred poimls aml that the class or commodity rate of a certain property was not umpeasonable or unjustly diseriminative in its application to the tratlic in question.

1is. Carmo rates discriminative.-The principle of the carloul as the only practicable unit of quantity was discussed in - I. C. C. I. 218, where it was strongly intimated, though not finally decided, that a lower rate made by the carrier on cerpo luts. being ten thousand bushels of oats and eight thousand bushels of other grains, than on carload lots in export slsipments, or in shipments made to the seaboard for export, violated the rule of equality and constituted an unjust discrimination. It was saicl that this limit of the lower rate woukl require about ten carloads, and that the effect would be to throw the business in to the hands of the large dealers, the margin of profit being very small and the opportunity afforded for the manipulation of prices at seaboard points would be increased.

As to discrimination based on differential in favor of ten cilloads of cattle, see 10 I. C. C. R. 32 t.

Any regulation not justified by the increased cost of service and which tends to discriminate between shippers according to the amount of tralfic is unreasonable. Thus making certain cluares for the transportation of coal shipped in carloads when the coal is loaded by tipple, that is from platforms and chutes. and exacting a higher charge when it was loaded in soine other way, and for that reason was found in 10 I. C. C. R. wes; not to bes justified by a difference in the cost to the carrier and that the higher rate was discriminatory against the small shippers.

15. Diflerent forms of discrimination.- Any special rate. rebate, drawback or other device whereby discrimination is clfecterl, is prohibited. Thus there may be discrimination 
in the service of cars, 9 I. C. C. R. 207 ; in the manufacturer's rate on coal, 5 I. C. C. R. 466,4 Int. Com. Rep. 157 ; in rebates for the use of live stock or private cars, 4 I. C. C. R. 630, 3 Int. Com. Rep. 502; or in the exaction of unreasonable rent for private cars, 4 I. C. C. R. 131, 3 Int. Com. Rep. 162. All forms of secret rates and drawbacks are prohibited, 1 I. C. C. R. 480, 1 Int. Com. Rep. 764. Discrimination may be effected by unjust classification, 4 I. C. C. R. 585, 3 Int. Com. Rep. 460; or by commissions paid to soliciting agents, 2 I. C. C. R. 512, 2 Int. Com. Rep. 340; also combination rates less than turiff rates are illegal, 2 1. C. C. R. 1, 2 Int. Com. Rep. 1. Any form of discriminating preference is in violation of the statute, $2 \mathrm{I}$. C. C. R. 90, 2 Int. Com. Rep. 6 7.

Discrimination violative of this section may be effected through underbilling the weight of freight, or giving it a false classification, whereby less compensation is paid by one person than by another for a like and contemporaneous service. In the report of the Commission upon this subject, supra, in 1885, it was said that this method of discrimination had been extensively employed, and it reviews the evidence taken by the Commission in their in vestigation. Under the recommendation of the Commission, section 10 of the act was amended,imposing penalties upon the shipper who by false classitication, false weighing, or false report of weight, or by other devices, knowingly or wilfully obtain transportation of their property at less than the regular rate. See infra, section 10. As to discrimination in billing at net weight, see \pm I. C. C. R. S7, 3 Int. Com. Rep. 131 ; 9 I. C. C. R. 440.

Another form of discrimination is in the use of private cars as where freight cars are either owned by the shipper or a prirate car line. See spra, section 118. The Commission says in its annual report for 1904 that the private car may be of advantage to the carrier by enabling it to provide equipment for special service during limited periods and the equipment is likely to be more alequate for the public, than for the carrier to undertake to own the cars itself or to secure them from its own connections. Concessions however were made in the use of such charges to particular shippers which amounted to the payment of a rebate, and that when the owner of the car became a dealer in the commodity transported, the fact of ownership gave him an important advantagre over his competitor. 


\section{9). Discrimination through interest in connecting} company.- Another derice for effecting discrimination is through the making of a joint rate with a connecting railroad controlled by the shipper out of proportion to the value of the service and constituting in effect a rebate to the shipper. This was ilinstrated in the llutehinson salt case, 10 I. C. C. R. 1. Where the Commission found that the connecting railroal did not own any equipment or rolling stock and was not in any way engaged as a common carrier, and that the granting of the dirision of the through rate to this connecting company wats a mere subterfuge to give a concession in the rate and was an unlawiul discrimination. In another salt case inrolving the transportation of salt westward from points in Michigan, where a similar charge was made as to the alleged interest of the salt producer in a boat line on Lake Michigan, 10 I. C. C. R. 1t? the Commission found on in restigation of the facts that the share of the through rate allowed to the boat line was not so disproportionate as to amount to a rebate, and therefore that the discrimination was not established. I iscrimination through the derices of a connecting railroad in the dirision of joint rates was further discussed by the Commission in 10 I. C. C. I. 355, in an opinion filed Nor. :, 1904, wherein the Commission reported the results of inrestigation of the divisions allowed the terminal lines in and about the city of (hicago. It was found that certain connecting railroads were practically controlled by certain large shippers and that the amounts allowed as divisions of the through rate were so excessive as to constitute in effect rebates to such shippers. As this was a general investigation in which no specilic chares had been formulated, no order was made. The Commission ruled that to the extent that these dirisions cxceded the reasonable charge for the performance of the service, they were an nnlawful preference and cliscrimination in fir ror of the shipper owning the railroad. On this subject see also the report of the ('ommission for 1964, pages 19 to $2: 3$.

\section{Discrimination by carrier in favor of itself as a ship-} ber. - I carrier can no more discriminate in favor of itself as producer and shipper than in favor of any other shipper, said Judge rooley in 4 I. (. C. T. 29!6, and 3 Int. Com. Rep. 302. there is however no federal statute which forbids interstate 
carriers from becoming dealer's in articles of transport. Interstate Commerce Commission v. Chesapeake \& Ohio Railroad Co., 12S lied. Rep. 5!".

There is a difficulty in determining the fact of discrimination by a railroad in its own favor as a carrier. Thus in a proceeding against the Delaware, Lacliawanna \& Western Railroal

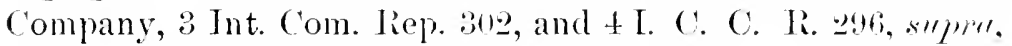
it appeared that the railroad company kept no separate account between itself as a carrier and itself as a shipper of coal. so that there was no means of determining whether it carried for reduced rates as a carrier, or sustained a loss as a dealer. The Commission in that case held that it had no power to order such an account to be kept. It could howerer determine whether the rate charged to the complainant was a reasonable one, and in determining that issue it could determine the price, at which the railroal company sold its coal, and the extent of its own profits upon coal marketed compared with the rates charged other dealers for transportation, or whether it madr. any profit at all, conld be inquired into by any tribmnal authorized to pass upon the reasonableness of rates. The Commission said in the former case, that even if the carrier lept a separate account showing what it charged itself for transportation, and even were such a separate account required, it would not be a sate guide in determining whether the carrier did or did not use its potrer as a carrier oppressively. See also case in S I. C. C. R. 630, another coal case involvin! the rates from Myrick, Missouri, and from Rich Hill, the latter being owned by the Missouri Pacific Railway Company. The court held that the only remedy available to the independent operator was to secure a reasonable rate, as the carrier could so adjust its rates that the moring of the coal could be conducted at a loss, the profit being derived from the carriage, and in that event every mine operating must operate at a loss.

In 7 I. C. C. R. 33 , the railroad company owned the entire stock of a development company, which had been organized for the purpose of holding certain lands of the railroad company, and caused grain to be purchased in the name of the development company and transported over the lines of the railroad company and sold upon the market. The Commission said that eren assuming that the development company was an 
independent entity and that the nominal freight charges were actually paid by it, still it was merely a tool in the hands of the railroad company and the act accomplished was the act of that company. There was no fixed rate and the rate actually receired was less than was, or would have been, charged any other person for the same serrice under the same conditions. Tere it was salil that this was a clear violation of section 2 . The Commission in this case distinguished the coal cases abore cited. saying that in those cases there was a permanent condition which must be met, while this was an unlawful practice which must be stopped.

In the Chesapealie \& Ohio Railroal Company case, supra, there was a contract between the railroad company and another railroal for the sale of coal to be transferred over its line at a price less than the aggregate cost of the expense items and its own published freight rates. The court held that this transaction was not a violation of section 2 unless the transaction was a mere derice to corer an intentional giring of a less rate lor carriage to some than to others, there being no legal ground for assuming that the loss was sustained by it as a carrep rather than as a dealer, and also that if the carrier did not credit on its books its freight accounts with its published rate and did not charge the loss to an account kept with the article dealt in, there would seem to be an apparent violation of the znd and 6th sections of the Aet; but at most only a technical riolation, as it had a right to suffer a loss as a dealer. The court could not find any authority for saying that the loss under such a contract must necessarily be treated as a loss on carriage, there being no evidence in the case affecting the good faith of the contract, and therefore nothing whereon to base an inference that the transaction was a derice to eviule the law.

\section{6:. Discrimination in storage of goods, etc.-A notber} form of discrimination condemned by the Commission was presenterl in the complaint of the American Warehousenen's Association, 7 I. C. C. R. 556, which set forth that a large number of railroals unjustly discriminated in offering free storage of freight in various ways to some shippers and not to other's, in failing to collect demurrage charges on cars detained by farrored shippers, by storing for some concerns large quan- 
tities of freight and making delivery thereof in small lots to purchasers, and by assuming expenses of unloading, loading and cartage for some shippers and not for others. A large volume of testimony was taken in different parts of the country. The Commission held that the system prevailing was open to grave abuses and that the allowance of such privileges as storage and the like was clearly forbidden by section 2 of the statute. The effect of allowing special facilities for storage was to provide a favored shipper with branch business houses in large cities. The investigation resulted in a general order requiring carriers to state in their tariffs what free storage was granted and the terms and conditions under which it would be granted. The Commission said that as this procedure had been recommended by the Supreme Court in the Grand Haven Free Cartage case, it was all the more applicable in the case of storage, which was expressty mentioned in the act. As to right of carrier to contract for storage of through grain in elevators at terminals in transit, see $10 \mathrm{I}$. C. C. R. 309 .

\$ 163. Stoppage in transit privileges.-. The privilege of milling in trinsit, that is of stopping in transit, for the purpose of grinding grain into flour or compressing cotton, or sawing logs into lumber, at some point in transit, and then shipping the manufactured or compressed product forward at the through rate, has been. discussed in several cases by the Commission. See infiet, 194. In S I. C. C. R. 121, the Commission commended the practice in a case of cotton shipment, saying that it benefited both the railroad company and the producer and tended to place non-competitive points upon equality with more distant competitive localities from which lower rates were in force. Such privileges may be granted or withheld by the carrier.

The receiving of cotton from a shipper and having it compressed at a station en route and reshipping to eastern points at the rate equal to the published through rate is not an unlawful discrimination under section 2 when all parties are entitled to the same privilege. Cowen v. Bond, 39 Fed. Rep. 54 (So. Dis. of Miss.). It is immaterial in such case, that the arrangements are made to incluce buyers to believe that the cotton was actually raised in clifferent localities than where it was in 
fact raised, as the deception could not be imputed to the railroad company. But when the privilege is extended, it must be extended to all in the same conditions and "similarly situated." see infru, section 3 .

The mere fact of the payment of a local rate to the manufacturing or compressing point is not material, if there was from the first an agreement that the property should be entitled to the privilege, and it goes forward from the compressing or manufacturing point upon a through bill from the point of origin to the destination.

Another application of the milling in transit privilege was illustrited in 10 I. C. C. R. 193 in the making of a through rate on lumber with allowance of a proportion of a rate for cost of moring the lumber by a "tap line" from the forest to the mill. The Commission held that this allowance could only be made to another common carrier, and could not be granted to a shipper as compensation for cost of moving the lumber to the mill.

In Lemuel Cotton Mills v. Gulf \& S. I. Railroad Co., the supreme Court of Mississippi in June, 1904, 37 So. Rep. $1: 34$, sustained a right of recovery, that is, it held a petition not demurable under a contract by a railroad with a manufacturer about to erect a cotton mill to give it a milling in transit rate not exceeding certain rates to certain competitive points. The court adopted and followed the opinion of the Commission in the lumber tap line case above cited as to the legality of a milling in transit rate.

$\$ 164$. Lnlawful discrimination through abuse of stoplacre in transit privileges. - While the Commission has. recognized and approved the allowance of through rates in cases of stoppage in transit for purpose of milling wheat into flour and compressing cotton, so as to facilitate the movement of the great staples of the country to market, this privilege has been sought to be applied to cases where there was no manufacture or compressing, but where the effort was to secure a through rate when property was stored for a time at an intermediate point on the through line. Thus shipments of grain were carried to Kansas City from points west thereof at local rates, and afterwards shipped and rebilled from Kansas ('ity to ('hicago at the balance of the established through rate 
from the original point of shipment to Chicago. There was no agreement for the through carriage between the shipper and the carrier at the original point of shipment, but the practice was to allow the consignce or other owner of grain at Kansas City to ship from Kansas (ity to Chicago and other points at the balance of the through rate upon presentation of the paid expense bill to Kansas City. The Commission held that such shipment and re-shipment did not constitute a through shipment from the point of origin to the final point of destination, and that the grain so shipped and re-shipped was not entitled to the benefit of the through rate in force and that the shipment from the point of origin to Kansas City was local, resulting in the grain becoming Kansas City grain, and the fact that it had come from a point further west was no reason for applying on shipments of such grain from Kansas City any less or different rate than was in force from Kansas (ity. The Commission held that an indispensible element in erery through shipment was the same-a contract for such through service, and an agreement between the parties at the inception of the carriage from the point of shipment to the destination at the throngh rate. 7 I. C. C. P. 240. The same ruling was made in the case of a cattle shipment. 3 I. C. C. I. $45 \%$, and 2 Int. Com. Rep. 721.

Any devices therefore for securing a through rate where the shipment is not in fact a through shipment, when specifically allowed the milling in transit pririlege on facts not justifying the same, would be an unlawful discrimination and violative of this section. See $\$ 194$, Stoppage in Transit Privileges.

\$165. Unjust discrimination in lassenger service. Unjust discrimination is prohibited in the transportation of passengers, as well as other property. This section however does not prohibit separate cars for the white and colored races, provided cars and accommodations equal in all respects are furnished to both and the same care and protection of passengers observed. 1 I. C. C. R. 428, 1 Int. Com. Rep. 719. See also 1 I. C. C. R. 20s, 1 Int. Com. Rep. 611.

When a railroad company makes a reduction from regular passenger fares which are not found unreasonable, it may lawfully require that a person clesiring to avail himself of such reduction shall purchase a ticket and that all persons not holding 
such reduced rate ticket shall pay the reasonable ordinary fare. 1"I. C. C. R. ‥17. For alleged discrimination in parlor car rates as between through and local passengers not sustained,

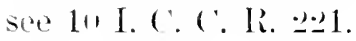

The resulation published on regular tariff sheets that the combluctors shall collect 2.5 cents additional fare on trains from passengers withont tickets was not an unjust discrimination. 3 I. C. C. R. .,12. Int. Com. Rep. 766.

\section{Giring passes to shippers prohibited. - A railroad} official who gives a pass for interstate trinsportation as a matter of personal faror, not within any of the exceptions contained in section 22, violates sections 2 and 3 of the act. ('harge to Crand Jury (X. Dist. of Call.), 66 Fed. Rep. 146. Ine riding on a pass and assuming all risks of accident is bound thereby and cannot recover, and it is immaterial that the pass was issued in riolation of the act. Duncan $r$. Maine ('entral R. R. Co., 11:) Fed. Rep. sos.

It has been muled by the Commission that the giving of free transportation to shippers, TI. C.C. R. 9. or any free transportation other than that allowed by section 22 of the act is illegal. 2 I. C. C. R. 359 and 2 Int. Com. Rep. 243.

The Supreme ( ourt has in recent cases sustained the validity of stipulations in ralway passes against liability for injuries, where parties accept the passes with knowledge of such conditions. See Yorthern Pacific R. Co. v. Arams, 192 U. S. 440 , to L. ed. 513 , and Boering $r$. Chesapealie Beech R. Co., 193 U. $\therefore 4 \%, 4=$ L. Ed. Tt2.

$\$ 16 \%$. Application of the section. - This section only deals with the discrimination, which consists of the charging one person with a different compensation than is charged another for a like and contemporaneons service for the transportation of at like kind of traflic under substantially similar circumstances and conditions. Forms of discrimination which relate to the furnishing of facilities, such as car service and the like, are pwhibited by the more comprehensive langulge of section : inivere.

The mere fact of the payment of a rebate may not constitute "an unjust discrimination" at common law, or under the statutes. at least prior to the ameniment of 190:\%. Thus it was behl in a recent state case, Lemuel Cotton Mills r. Gulf, etc. 
R. Co., 37 So. Rep. 13t, by the Supreme Court of Mississippi, that if there is no unjust discrimination, an agreement by a carrier that they will carry goods at a eertain rate and repay the shipper a part thereof as a rebate after the shipment, is not illegal and the rebate may be recovered by the shipper in a proper ease. But under the publication of rates required under section 6 of the Interstate Commeree Act and especially in view of the provisions of the Elkins Act of February 1!, 1903 (infra), any deviation from the published rate constitutes an offense. If a rebate therefore is paid to one, it must be paid to all under similar eircumstances, and the rebate must be a part of the published tariff.

In the Beef Trust case, Swift v. United States, supra, the bill alleged that the defendants as a part of their unlawful combination for monopolizing the market, were obtaining arrangements with the railroads whereby by means of rebates and other deviees they paid less than the lawful rates for transportation. The Supleme Court said that this did not necessarily eharge unlawful acts, as the defendants might severally lawfully obtain less than the lawful rates for transportation if the eireumstances were not substantially dissimilar for which the regular rates were eharged, as if they furnished their own ears, for instance, and there were other differences in the service. But as the ehitrge was male in connection with the alleged attempt to monopolize the market in violation of the Anti-Trust Aet, the court said that no more powerful instrument of a monopoly could be used than an advantage in the cost of transportation, and that every aet done with the intent to produce an unlawful result is unlawful. The charge was therefore held material in eonnection with the other charges in the bill (See supra, $\$ 68$ ).

This section of the statute has no application where the traffic is of different kinds and elasses not competitive with each other. S I. C. C. R. 531 and 5 I. C. C. R. 198, 3 Int. Com. Rep. 841 . There is no discrimination uncler this section in the case of impartial aetion. It must eonsist in doing for or allowing to one party or place what is denied to the other. 1 I. C. C. R. 401, 1 Int. Com. Rep. 703. A like lind of traffic within the meaning of this seetion does not mean traffic that is identical, but a kincl that is capable of 
a fair and just classification. 4 I. C. C. R. $4+7,3$ Int. Com. Rep. 417 . The section has no application to terminal charges in different cities, 7 I. C. C. R. 513, nor is there any unjust discrimination inrolved in the refusal to pay mileage to a private car company. 1 I. C. C. R. 132, 1 Int. Com. Rep. 329.

Discriminations based solely upon the business motives of the shipper are illegal. 6 I. C. C. R. \$5.

\$ 16s. Retention of orercharge. - The Interstate Commerce let does not recognize indefinite or uncertain transportation charges. The idea of unequal compensation for like service, or discrimination in the treatment of persons similarly situated, is repugnant to every requirement of the law, and a party to an interstate shipment cannot be excluded by the carrier from the privileges afforded to other patrons in the same locality because of his refusal to pay excessive freight charges, even though an agreement to subsequently refund the excess should accompany the demand. 6 I. C. C. R. 34 . The retention of an overcharge has all the effect of extortion and unjust discrimination and when the refund of an excessive charge has been unnecessarily delayed for a considerable period the officials responsible therefor become fairly chargeable with wilful intention to violate the law.

In Ohio Coal Co. v. Whitcomb, 123 Fed. Rep. 359, Circuit Court of Appeals, Tth Circuit, an extra charge of two dollars per car made to one shipper for access to the docks, was held under the facts to be discriminative under the Wisconsin statute, and an agreement by the shipper to pay the discriminating charge in order to obtain the service to which it was legally entitled without such charge did not estop bim from maintaining a suit to recover back the sum so paid.

169. Enforcement of the section.- The section has no application to cases occurring before the Act was passed, $1 \mathrm{I}$. C. C. R. 144,1 Int. Com. Rep. 607, that is, so far as the penalties imposed by the other sections of the Aet for violation of its provisions are concerned. It has been held however that contracts for rebates made before the Act went into effect were thereafter incapable of enforcement. So. Wire Co. v. St. L., etc. R. Co., 38 Мо. Аpp. 191.

In a suit to recover damagres for alleged discrimination, it is sufficient to allege that the defendant had charged plaintiff 
a given rate for transportation, and for like services under substantially the same circumstances and conditions the defendant had charged another a less given rate, or that plaintiff was charged more than the schedule rate. Kinnaver $r$. Terminal Railroal Association, 81 Fed. Rep. so. In this case it was held by Adams, J., of the eastern listrict of Missouri, that it was not necessary for the complainant to set out the facts showing that the conditions were similar, but that it was sufficient to allege the ultimate fact in the language of the statute. The payment of an overeharge in such case is not a voluntary payment precluding recovery. L. A $x$. Consolidated R. Co. v. Wilson, 1:2 Ind. 517 and 1S L. R. A. 10\%. See also Nurray v. Chicago \& Northwestern R. Co., 3.) C. C. A. (i.), 62 Fed. Rep. 24, 92 Fer?. Rep. sis. It was held that an action by a shipper against a earrier for unjost discrimination in the imposition of freight charges paid by plaintiff, lay at common law, regardless of fraul. In Wight $r$. Lnited States, 11 t $\mathrm{U}$. S. 512, 42 L. Ed. 258, the conviction of a railroal agent for violation of this section in granting a relate, was alfirmed.

In Union Pacific Rail way Company v. (roodrich, 149 U.S. 680), 37 L. El. s96, the Supreme Court athimed the julgment rendered in the Circuit ('ourt moler a Coloralo stitute for an unjust discrimination in intrastate traffic, wherein the damages were measured by the amount of the rebate allowed a competitor. The court said that the plaintiff was entitled to the same terms which the farored company received, and damages to the exact extent to which that Company was given the preference.

It constitutes no defense in discrimination between persons that the privilege may be withdrawn at will. Butchers it Drovers Stockyarts Co. v. Railiond (o., 14 C. C. A. 29o, l. c. 297, 67 Fel. Rep. 35.

170. Cnforcement by injunction.-It is now established, especially since the recent Elkins Act, passed liebruary 1:4, 190, infer, 310 , that a comrt of equity has juriseliction at the instance of the fovernment to restrain a railroad from discrimination in rates (see opinion of cirosicup, r., Northern District of Illinois, 122 Fed. Rep. it4, in stits filed by the Government against a number of railroals restraining them from departing from their established tariff rates on the trans- 
portation of grain and grain products, dressed meat and packing house products, and any other interstate traffic in which they might be engagerl.

In this case, Inited States v. Michigan Central Railroad Co. et al, the court said discrimination of the character alleged in the bill was contrary to the plain provisions of the Interstate commerce Act, and that upon it criminal prosecutions could be maintained, and each grain grower could individually maintain a civil suit for snch damages as he might show, and that where the remely at law was inadequate, a remedy in equity must exist. As to the right of the Government to maintain such a suit, see infiut, 520 .

\section{Liflect of rebites upon contracts of afleightment.-} In Merehants Cotton Compress Co. v. Insurance Co., $151 \mathrm{C}$. S. 3ire, it was held, that there was nothing in the Interstate Commerce let which vitiated bills of lading or which by reason of the allowance of rebates actually made would invalidate a contract of afreightment, or exempt the railroal company from liability on its bills of lading. This was a suit of an insurance comprany which bad paid losses claiming to be subrogilted against the railroad company on bills of lading issued to the owners and consignees of cotton. It was not shown that the owners or consignees of the cotton had knowledge of the rebite.

\section{\$171a. Discrimination in allowance to private transfer} companies. - The railroads operating west from st. Louis mi.le the rate on west bound traffic from East St. Louis the salne as from St. Louis, and out of this rate allowed five cents per humdred pounds to transfer companies haning less than carload lots from East st. Louis to t. Louis. The Commission (10) I. C. C. R. 6, fi, without decisling whether the railroads could properly apply the St. Louis rate to the station of a bona fide transfer company in East st. Louis and absorb the cost of transfer to St. Louis, nor whether by proper schedule they conld allow all shippers from East t. Lonis a fixed smm per inundred pomds for transporting their merchandise to the stations in Sit. Lonis, ruled that an allowanee from the rate coukd not be mate to a carrice company which was in effect only a private carrier oreanized and doing the business of one shipper, as such payment would be in eflect a rebate to such

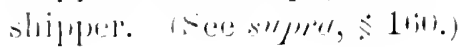




\section{Section 3.}

$\S$ 172. Sec. 3. Undue or unreasonable preference or advantige forbidden.................................... ${ }^{2}{ }^{3}$

173. Origin of the section ...........................

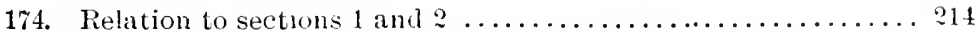

175. Preferences of localities enforced by competition are not urjust....................................

176. Application of the competition rule $\ldots \ldots \ldots \ldots \ldots \ldots \ldots \ldots 216$

17\%. Whether competition is controlling is a question of fact..... 216

178. Discrimination between domestic and foreign traftic in imjort and export rates not unjust preference.............. 217

179. Application of the import rule to intermediate points on the line..................................... 219

180. Competition created by carriers...................2:0

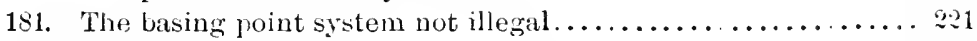

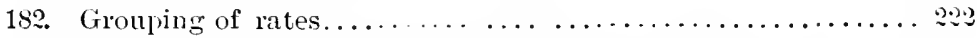

183. Qualifications in the application of the competition rule..... 2?

184. Recognition of natural advantages of localities not an unjust preference............................26

185. Competing cities on opposite banks of rivers ........... 22:

186. Differentials between competitive cities............... 2 88

187. Form of unjust preference immaterial............... 230

188. Unjust discrimination in time of closing freight stations.... . 831

189. Unjust preference in car service...................... 231

190. Discrimination by carrler in its own favor ............ 234

191. Unjust preference in use of private cars............... 234

192. Exclusive use of excursion or sleeping cars of one owner . . . 286;

193. Leasing of cars does not earry right of exclusive use by owner. 236

194. Stoppage in tranit privileges....................... 236

195. Interference by State liailroad Commission with proportional tariff rites. ................................ 293

196. Side tracks and connections. ........................... 238

197. Undue preference in denying shippers the choice of route... . . 240

198. Undue preference in arbitrary division of territory......... $2+1$

199. Rate wars and undue preferences.................... 242

200. Discrimination in kinds of traffic.......................... 4

201. Preferences against traffic, must involve injury.......... 244

202. A reasonable regulation of carload weights not preferential... 245

203. Differentials between grain and grain products..........246

204. The Commission not concluded by ruling of State Commission. 247

205 . Discrimination in mode of shipment................ 24

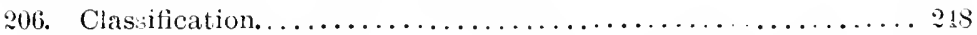

:0\%. Consultation of carriers in classification not illegal combination. : 49

20s. Undue preference in classification................. 249

209. Power of Commission in correctinn classification. . . . . . . . . . 2.51

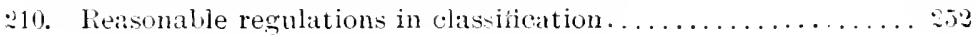


§ 211. Facilities for interchange of traffic... ............. 253

212. Exacting prepayment not unjust c!iscrimination........... 254

213. State control of interchange of interstate trafric.......... 25 1

214. State and municipal control of terminais.............. 25.j

215. The charging of local rates not an unjust discrimination ... . 256

216. The right of exclusive through routing ............. 25:

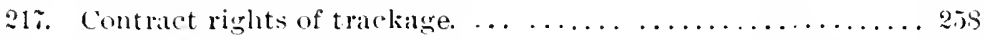

218. Rights of comnecting carriers as to milling in transit privileges. 259

\section{s 1: . Vulue or unreasonable ureference or alvantage} forliddell.-Fire. :. That it shall be unlawful for any common carrier subject to the provisions of this act to make or grive any undue or unreasonable preference or advantage to any paticicular person, company, firm, corporation, or locality, or any piaticular deseription of tratlic, in any pespect whatsoever, or to subject any particular person, company, firm, corporation, or locality. or any particular description of traflic, to any undue or mrealsonable prejudice or disadvantage in any respect whatsoever.

Every common carrier subject to the provisions of this act shall, accorting to their respective power's, afford all reasonable proper, and equal facitities for the interchange of traffic between their respective lines, and for the receiving, forwarding, and delivering of passengers and property to and from their several lines and those connecting therewith, and shall not discriminate in their rates and charees between such connecting lines: but this shall not be construed as requiring any such common carlier to give the use of its tracks or terminal facilities to another carrier engaged in like business.

\section{Oriwin of the section. - It wats said by the Supreme} Court in the Import Rate case, 162 U. S. 1517, 1. c. 222,40 L. Ed. 9 t) that this section wats modeled upon the second section of the linghish act, for the better regulation of tratiie on railways and camals, of July 10, 155t, and the eleventh section of the act of .luty 21, 198: entitled "An Aet to Make Better Provision for Carrying into effect the Railway an l Cinal Act of 1-it, and lor other purposes connected therewith." Section 2 of this English act of $185 \mathrm{t}$ is as follows, 17 and 15 Vic. c. 31 :

“.. Every railway company, canal company, and railway and canal company, shall, accorling to their respective powers, aflord all reasonable facilities for the receiving, and forwarling and delivering of trallic upon and from the several railways and canals belonging to or worked by such companies respectively, and for the return of carriages, trucks, boats, and other vehicles, and no such company shall make or give any undue or un reasonable preference or advantage to or in fivor of any particular person or company, or any particular clescriptom ifl trallice in any respect whatsoever, nor shall any such company subject any particular person or company, or any 
particular deseription of traffic, to any undue or unreasonable prejudice or disadvantage in any respect whatsoever; and every railway company and canal company, and railway and canal company having or working railways or canals which form part of a continuous line of railway or canal, or railway and canal communication, or which have the terminus, station, or wharf of the one near the terminus, station, or whart of the other, shall afford all due and reasonable facilities for receiving and forwarding all the traflic arriving by one of such railways or eanals by the other, without any unreasonable delay, and without any such preference or advintage, or prejuidice or disadvantage, as aforesaid, and so that no obstruetion may be afforded to the public desirous of using such railways or canals, or railways and canals as a continuous line of communication, and so that all reasonable aecommodations may, by means of the railways and canals of the sereral companies, be at all times afforded to the public in that bebalf."

Section 11 of the English act of 1573,36 and 37 Vic. e. 48, re-enacts section 2 of the English act of $14 . j 4$, and provides specifically for the enforcement of the luty of receiving, forwarding and delivering from and to other companies. For history of this second section of the English act of 15.5t, see opinion in the case of L. it T. Railload Co. v. Greenwood, Law Reps. 2 B. 217, 1s. The equality clanse of the Railway Clauses Consolidation Act of 1545 had been construed by the courts to mean equal rates for the carriage of goods over the same portions of the line, and did not apply where the places over which the gools were carried were not the same; and this restricted application led to the more comprehensive provisions of the act of 18.5 .

It will be seen that section 3 of the act of Congress to regulate commerce inserts the word "locality", which does not appaar in the English act, so that any undue or unreasonable preference or arlvantage is prohibited to any particular person. firm, company or cor poration or any locality, or any particular description of trafific.

The effect of the English cases construing the preference branch of the English act were thus summarized by Judge Jackson in his opinion in the Party Rate case in the Circuit Court, 43 Fed. Rep. 37, (affirmed by the supreme Court in 145 U. S. 263,36 L. Ed. 699), qnoting from a report of the English Amalgamation Committee of 1572. page 130, as follows:

"The effect of the decisions seems to be that a compan $r$ is bound to give the same treatment to all prersons equally mider 
the same circumstances, but there is nothing to prevent a company, if acting with a view of its own prolit, from imposing such conditions as may incidentilly have the effect of favoring one class of trade or one town, or one portion of that traffic, providng the conditions are the sime to all persons, and are such as lead to the conclusion that they are really imposed for the benefit of the railwaly company."

It wils silid by the supreme Court in this case, $145 \mathrm{U} . \mathrm{S}$. 26:), as to both sections 2 and 3, p. 276: "It is not all discriminations or preferences that fall within the inhibition of the statutes only such as are unjust and unreasonable. ** Indeed the possibility of just discrimination and reasonable preferences is recognized by those sections in declaring what shall be deemed unjust."

\$it. Relation to sections 1 and :- - The first paragraph of the section in its prohibition of any undue or unreasonable preference or alvantage to any particular person, company, firm or corporation, or the subjection of any particular person, company, firm or corpolation to any undue or unreasonable projulice or disadvantage in any respect whaterer, is comprehensive enough, standing alone, to inclule the prohibition of discrimination contained in section 2 , and such is the judicial construction in England of the term "undue or unreasonable preference or advantage" as used in the English Railway and (anal Traftic det, from which the terms of this section are taken. United States r. D. L. \& W. R. Co., 40 Fed. Rep. 103. Section 3 howerer is broader than section 2, in that it is not limited to a discrimination in rates alone, but includes every form of unjust cliscrimination.

Section 1 prohibits unreasonable rates and the reasonableness of rates can only be determined by the consideration of whether rates are relaticely reasonable. A rate which subjects a person or community or any kind of traffic to any undue or unreasonable prejudice or disadrantage is in that sense an un reasonable rate. Proceedings before the Commission and the courts eontesting the rates established by the carriers have usually included sections 1 and 3 and not infrequently sections 1 , $2: 8$ and t, the latter when the longr and short haul on the same line is involved. Under section :; however, it is only the relative reasonableness of a rate which is considered, and as cases of individual discriminations in rates have been con- 
sidered in connection with section 2 , the cases grouped under this section will be those relating to discriminations between shippers other than in rates and alleged preferences to localities and kinds of traffic.

175. Preferences of localities enforced by competition are not unjust.- Section 3 has been closely related to section 4 in the judicial discussion of the relation of competition to preferential rates. Section 3 contains the general prohibition of undue or unreasonable preference or arlrantage to any locality, while section 4 contains the specific prohibition of any greater rate under substantially similar circumstances and conditions for a shorter than for a longer distance over the same line. After the decision of the Supreme Court in the Social Circle case in 1897 (162 U. S. 184), infra, section 4, it was held by the Commission in a proceeding involving the relative rates to Chat tanoogo and Nashville from the eastern seaboarl, 5 I. C. C. R. 546, and 4 Int. Com. Rep. 213, that while the carrier had the right to judge in the first instance whether it was justified in making the greater charge for the shorter distance under section 4, neverthcless the 3rd section of the act forbiding the making or giving of an undue or unreasonable preference or advantage was still applicable, and that where such unjust preference was created, even as a result of railway competition, compelling a lower charge for a longer haul, the carrier should apply for exemption under the proviso of the 4 th section. This ruling was sustained in the Circuit Court and Circuit Conrt of Appeals, on somewhat different grounds, 39 C. C. A. 413 and 99 Fed. Rep. 52, but was reversed in the Supreme Court, East Tennessee, etc. R. Co. v. Commission, 181 U. S. 1, 45 L. El. 719, 729. The Supreme Court said that the effect of this ruling of the Commission was to blend the 3rd and th sections in such a minner as to necessarily destroy one by the other. The prohibition of the third section was directed against unjust discrimination or undue preferences arising from the voluntary or wrongful act of the carriers complained of, and does not relate to acts the result of conditions wholly beyond the control of such carriers. Where the competition was controlling, the preference was not undue or the discrimination unjust. It appeared in this case that there was a margin of protit in the rates in force to Nashrille and 
Memphis. The court said there might be a case where the carrier conk not be allowed to arail himself of the competitive condition. Thus if he could not meet the competitive rate without transporting the merchandise at less than the cost of transprortation, and therelore bringing about a deficiency which would inerease charges upon other business, the engaring in such competitive tralic wouk both bring about an unjust diserinination and a disregard of the public interest.

The court satil that the question whether the charres were reasonable or otherwise, and whether the certain discriminations were dhe or mulue were questions of fect to be passed upon by the commission in the light of all the facts, and the case was directed to be remanded and the proceedings dismissed withont prejulice to the rights of the Commission to proceed with the further in restigation of the facts.

166. Appication of the competition rule.--The same ruling has been mate in sereral eases in the ('ipcuit Courts and ('ircuit Courts of Appeal. Thus in Commission r. Atlantic Rail-

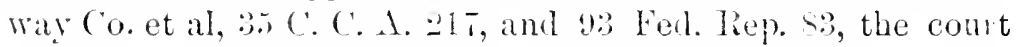
said that under the decisions of the supreme Court compet:tion was a factor to be consitered, and if the competition was real and controlling, it created substantially different circumstances and conditions, and where such lower rate was so indneed, if not so low as to be unreasonable and un remunerative to the carrier, it could not afiord a basis of undue aud unreasonable preferences and adrantiges in falror of the competitive point within the inhibition of the third section, nor be unjust and unreasonable under the first section of the act. It would seem however that uniler the rulings of the Supreme Court that eren if the competion is controlling and thus creates substantially different cireumstance and conditions justifying the lower rate for the entipe haul. and precturling the inference of an unjust preference therefrom, it would still remain for the Commission unler all the facts to determine whether the established rates wope reasonable or not.

18\%. Whetherempetition is controlling is a question of fact. - When competition enters in to a case as an element, whether or not there is an undue preference or allvintage, that is whether the competition is contoling, is a question not of law, but of fact. Commission r. I. d X. Railroal ('o., 7: Fed. Rep. tor. see also lirewer r. Central latilroal of creorgia, ot Fed. Rep. 
257 Commission v. Western Atlantic Railroad Co., ss Fel. Rep. 1S6; Commission v. Cincinnati \& P. R. Co. et al., 12t Fed. Rep. 62t.

In the latter case, the Commission, 9 I. C. C. R. 11, hard found that the rates from western cities to Wilmington, $X$. C., were prejudicial and unduly preferential to Norfolk, lichmond and other Tiroinia cities and it ordered that they shouhl be made upon a basis of 12.5 per cent of the rates contemporaneonsly in force from East St. Louis to Norfolk. The cuurt refused to enforee this order, holding that the conditions at Norfolk and Richmond by reason of the larger number of carrying lines, both rail and water, created a very active competition; and furthermore, the fact that these cities were in what was known as trunk line territory and Wilmington was in what was known as southern territory, where there were fewer transportation lines and less active competition, resuiting in higher rites to Wilmington, although the length of haul was about the same. The Commission had refused to recognize the higher preferential rates based upon location in the southern territory in another case from Wilmington. See 9 I. C. C. R. 17. In the latter case the Commission said it was the first case during their fourteen years experience which showed a through rate charge over connecting roads in excess of the combination charges applying to and from an intermediate point on the through line.

As to the competition rule, see also Commission v. L. \& $\mathrm{N}$. R. Co., t6 C. C. A. 655, and 108 Fed. Rep. 958, altirmed by the Supreme Court in 190 U. S. 273 and 47 L. Ed. 1047.

For application by the Commission of the competition rule to alleged preference, see 10 I. C. C. R. 29 . Where the preference in rate exceels the competitive rate, there is as to such excess a case of undue preference under this section. $10 \mathrm{I}$. C. C. R. 342 .

\$ 175. Discrimination between domestic and foreion trallic in import and export rates not unjust preference.An order was made by the Commission in March, 1589, reyuiring that imported traffic transported to any place in the United States from a port of entry or place of reception, whether in this country or in an adjacent foreign country, should be taken on the inland tariff covering other freights.

Later, in June of the same year, in : I. C. C. R. 137, and 2 Int. 
Com. Rep. 5.s. the Commission ruled that in export rates the proper metho! was to adl to the established inland rates from the interior to the seaboarl, the current ocean rates. The commission held that as ocean mates were not subject to the control of the act, they were not proper for consideration in creating a dissimilarity in eircumstances and conditions within the meaning of the act. The parties to the Export Rate case complied with the order of the Commission, but the import rate ruling was contested by the Texas \& Pacific Railroad Company. The Commission held that the competition of ocean lines or circumstances affecting the morement of foreign commerce before reaching our own country did not constitute a dissimilarity of circumstances and conditions within the meaning of the act. Their ruling was sustained by the Circuit court in a proceding to enforce the order of the Commission, $\therefore 2$ Fed. Rep. 15:, and also by the Circuit Court of A ppeals, $6 \mathrm{C}$. C. A. 65:3 it Fell. Rep. 948. The latter cont thought that some discrimination in rates might be justified nnder the circumstances, but that the rates imposed were unreasonable. The supreme court in 162 U. S. 197 , to L. El. 940 , reversed both courts and directed the dismissal of the bill, (Justices IIarlan, Jrown and Fuller, C. J., dissenting.) The court said that the purpose of Congress was to facilitate and promote commerce, and not to reinforce the provisions of the tariff laws, and that the effort of the Commission to deprive inland consumers of the alrantage of through rates seemed to create the mischief which it was one of the objects of the act to remedy, and that among the circumstances and conditions to be considered, as well in the case of traffic originating in foreign ports as in the case of traffic originating within the limits of the United States, was competition at the seaports, and in deciding whcther rates and chirges, male at a low rate to secure foreign freights which would otherwise go by competitive routes are or are not undue and unjust, the fair interests of the carrier companies and the welfare of the community which is to receive and consume the commolities, are to be considered. The supreme court said that the fact that there was a considerable disparity between other and local rates, dol not warrant the Circuit ('ourt of A ppeals in finding that the disparity constituter an undue discrimination, as no such issue was made 
before the Commission, and the defendant was entitled to have the reasonableness of the rate considered, in the first instance at least, by the Commission upon a full consideration of all the circumstances and conditions upon which a legitimate order conld be based. Espeeially was this true when there was no person, firm or corporation claming that he or they had been aggrieved by the disparity in the rates, the party complaining being the Commission itself.

This lecision was construel as applying to export rates as well as to import rates. The Commission in its report of 1997 said that the aarriers insisted that this decision controlled the rates for inland carriage to the seaboarl of traflic for export, and recommended that Congress amend the act giving the Commission power to control inland rates, both import and export, but no such amendment has been enacted.

It is therefore a question of fact whether rates upon export or import tratfie as well as those npon clomestic traffic are unreasonable and unjustly preferential, but as a matter of law, it is not any violation of the Act for the carrier to make a lower rate to the point of export or from the port of import upon the traflic which is exported or importerl than upon that which is locally consumed. See S I. C. C. R. 214.

8179. Application of the import rule to intermediate points on the line.- It was ruled by the Commission, S I. C. C. R. 214, after the decision in the Import liate case, that in the application of export grain rates the carrier should in no case make the rate from any point to the seaboard less than from any intermediate point on the same line, and that a rate on export flour from Minneapolis which was one and one-half cents less than the domestic rate to the port of export, with no corresponting concessions to intermediate millers, was an unlawful discrimination, and that any line participating in any such lower export rate on flour from Minneapolis must make a corresponding reduction on the same article from all intermediate points. See also S I. C. C. R. 110, 9. I. C. R. ist.

As to the publication of rates on export tratfic, see infir, section 6. See also 8 I. C. C. R. 155 , and S I. C. C. R. 110. The Commission said in the case first cited that the Import Rate decision did not bar the import and export tralfic from the purview of the Commission, althongh it did resuire that 
conditions abroad as well as at home should be considered, and that the interests of classes, and not of a single elass, should be tiken into account. see S I. C. C. R. 304.

S 1s0. Competiton createl by carriers. - In the Nashville and Chattanooma Rilte case, sin'm, the Circuit Court of Appeals in an opinion by Judge Taft, l. c. 424 , commented upon the fact that the competition at Nashville was between railroars unter the same control, the Lonisville \& Nashville railroal owning the majority of the stock of the Nashrille, Chattanooma it st. Louis Railroal Company, and that but for the restriction of normal competition by the southern Traftic Ascociation the situation of Chattanooga would win for her certainly the same rites as Nashville. The Supreme Court in its opinion reversing the ease, held that the Commission and the Circuit court and Circuit Court of Appeals had proceeded upon an erroneous construction of the Act.in holding that a preference enforced by controlling competition could be unjust, and that the assertion that the road from Chattanooga to Nashville, growing ont of the stock ownership, was in effect the Louisvilie 4 Nashrille, was necessarily antagonistic to the express finding of the commission that the carriers through Chattanooga and Nashville were placed in position where they must meet the competition to Nashrille or abanclon all traffic to that point. The court said that it couk not undertake the duty of weighing the eridence and determine the issues of fact which the statute required the Commission in the first instince to pass upon, and the case was therefore directed to be re-committed to the Commission for that purpose.

In Commission v. Sonthern Railway Co., 117 Fed. Rep. $7+1$, the railroad company had acquired the ownership of the only road which had previously competed for the business to a certain point, but it was held that this could not effect the question whether its rates unjustly discriminated against such point in faror of another point where competition existed where it affimatively appeared that the rates to the non-competitive point had not been increased since the purchase of the competingr road.

In the later case of Interstate Commerce Commission v. I. \& X. Railroal Co., 190 L. S. 273. l. c. p. 2-3. 47 L. Ed. 1047, the supreme court said that if by agreement or combination 
among carriers it was found that at a particular point, rates were unduly influence l by a suppression of competition, that fact would be proper to consider in determining the question of undue discrimination and the reasonableness per se of the rates to such possible competitive points. It must be an actual and not possible competition. See also infra, section 4 . It therefore is a question of fact to be determined by the Commission whether the preference is induced by the competition, and wbether competition is forced "pon the carrier or whether the preforence is effected throngh an agreement or combination stifling competition. Iut if the preference is compelled by the competition, then it is not unjust, muler section 3 , though the rates may still be unreasonable per se and on this ground volative of section 1 of the act.

181. The "Basing Point System" not illegal.-The Commission in several cases had condemned what had been called the "Jitsing P'oint System "prevailing in the sonth, 4 I. C. C. R. 686,3 Int. Com. Rep. 452 and 6 I. C. C. R. $342 ; 6$ I. C. C. R. 361; S I. C. C. R. 142. This system consisted in basing local rates according to the relative distance of the local points by the distance of such points from the competitive points, the rate being ascertained in each case by akling to the through rate to the bising point, the local rate from that point back to the local point, the result being that the local points were given an advintige resulting from their proximity to the basing point in proportion to the degree of such proximity. The Interstate Commerce Commission on the complaint of a merchant of La Grange, Alabama, made an order upon the railroad to desist from charging upon this basing rate to La Grange based upon its rate to Atlantal, the basing point. The Circuit Court sustaine I the order of the Commission. 10? Fed. Rep. rog. This julgment was reversed by the Cincuit Court of Appeals, 10s Fed. Rep. 958, and the julgment of the latter court was affirmed by the supreme Court, Commission r. L. \& N. Ratilroud Co., 190 U. S. 273,47 L. Ed. 10t7. The latter court said that as it was conceded that the rate on the through freight from New Orleans to Atlanta wis the result of competition to Atlanta, there was a resulting dissimilarity of circumstinces which prevented any unjust preference in the fact of a higher charge to La Grange and that 
there was no just cause of complaint in giving to the local stations the advantage resulting from their proximity to Atlanta, the competitive point, as the same result would have followed if the rate had been fixed at Montgomery, the competitive point nearer to New Orleans, and the local rate fised from thence on.

\& 1S:. (iromping of rates. - While section 4 of the act prohibits under similar circumstanees and conditions the charging of a greater rate for the shorter distance, there is no prohibition against charging the same aggregate rates on like trallic for the longer clistance orer the same line in the same direction. There is in the act no requirement of mileage apportionment of rates. The Commission in several cases has pissed upon the so called "group" or "blanket" rates, that is, the making of the same rates for different points situated on the same line, or on different lines under the same con trol communicating with a common centre and being the same or approximately the same distance from such centre and possessing substintially the same commercial relations. The prineiple was applied in 2 1. C. C. R. 5t0, and 2 Int. Com. Rep. :31:, to a large number of mines composing a coal mining district extendling across the state of Illinois to points in western Wisconsin, Iowa and Minnesota, the distance by some part of the route being substantially a fair equivalent for the distance from other points and the commercial necessities being substantially the same for all.

In another case the grouping of coal rates at the rate of ninety cents per ton for a distance covering a radius of forty miles around Pittsburoh, Pennsylvinia, was sustained. 2 I. C. C. R. (;1, 2 Int. Com. Rep. 436. The Commission said that actual undue prejulice or damage of which the rate is the cause, must result to more farorably situated producers to render a group), rate unlawful. In this case the Commission cited the practice under the English Railway of Canal Traffic Act of 155t. where it had been held that the grouping of lates was not unlawful, unlexs as a matter of fact the effect was to produre an undue preference, and noted that the new English act of 1 sso had mate speceific provision for grouping of rates in conformity with the ruke which han heen acted on by the Commissioners and the conts. see also + I. C. C. R. 
538 , and 3 Int. Com. Rep. 460 , where grouping of mines in the Lehigh anthracite coal region was held to involve no unreasonable disad vantage.

Thus in + I. C. C. R. 41$\rceil, 3$ Int. Com. Rep. 4 no, it was found that the rates on wheat and whect flour for reasons peculiar to the territory lying west of the Mississippi river and comprising the large portion of Texas, the state of Missouri and a considerable portion of Kansas, were grouped without reference to distance. In 7 I. C. C. R. 92 , the subject of grouping of rates was considered in its application to the rates on mill, which was fixed at a uniform rate from all interstate shipping stations along the lines of the New York, Susquehanni it Western Railroad west of the Hudson river to the points of delivery at Weehawken, Hoboken and Jersey City. The Commission said, reaffirming (5 I. C. C. R. 131, that the practice of maling one rate for the same product over a very large district and thus equalizing the burdens of transportation to the same market was only justified under special ancl exceptional eircumstances. The circumstances in this case were peculiar, in that the furnishing of an extra perishable article like milk in no greater quantity than is required for daily use in a great city was a business which falls naturally to those producers nearest the city who were able to provide the needet supply. The Commission found under the facts that a uniform or blanket rate from all stations of the road was an unreasonable preference to the more listant stations, and said there should be at least four divisions, extending respectively forty miles, fifty-two miles, one hundred miles, one hundred and ninety miles and stations beyond one hundred and ninety miles, with rates adjusted to the respective groups according to distance. On this application of the grouping of rates to milk traflic, see 2 I. C. C. R. 272 , and 2 Int. Com. Rep. 162.

In 5 I. C. C. R. 478 , and 4 Int. Com. Rep. 183, "blanliet" or group class rates applying upon the Northern Pacific road for a distance of orer fire hundred and eighty miles were found relatively unreasonable.

In 7 I. C. C. R. 43 , group rates of seventy per cent. on second class articles and forty-four per cent. on third class applying within a distance of two hundred and serenty-one miles from Pritchard, Alabama, to Verona, Mississippi, on ship- 
ments over an extreme distance of six hundred and forty miles to East St. Louis, and which in the next two hundred miles fall to thirty per cent. on second elass and twenty-two per cent. on the third class, were held prima ficcie unreasonable and unjustly discriminative against points within the group which were nearer to East it. Iouis, and unfair as to shipments from Verona. The ('ommission said howerer that there Were probably cireumstances uncler which a group rate of this kind might be justiliable, and no order was made pending an opportunity for the defendint to readjust its group scale, or justify the apparent discrimination.

s 143. (qualifations in the application of the competition rule.- The julicial construction of the term "unjust preference" by the elimination therefrom of the preferences compulled by railway competition has very materially affected the enforcenent of the third section by the Commission. Thus during the first ten years after the enactment of the law, the Commission proceeded upon a different theory of the law, and the decisions reported in the first six rolumes of the Interstate Commerce Commission Reports, and all of the Interstate Reports, in the construction of this section as well is of section 4 , are based upon the theory that the competition of railways subject to the act was not, although it was conceder that water competition was, a justification of a higher rate for the shorter himl and the resulting preference of localities. In S. C. C. R. 11\%, the Commission said that the greater charge for the shorter than for the longer haul over the same line in the same direction had been made in no case which had been presutel to them, except where the competition existed at the longer distance points and was set up as the sole exeuse lor such weater charge.

But uncler the decisions of the Supreme Court, the application of the competitive rule is subject to the following yualifirations: Firw/ the competition must compel the lower rate. That is, the competition must be controlling. The carrier must either reduce its rates or lose the business. Steroml, the competition must not be created by the carrier; that is, the preference must not be affected throngh an agreement or combination of the carrier with other carriers stifling competition. Thirl, the competitive rate must be at the prelerred point 
remunerative to the carrier. Fonrth, the rates must be reasonable in themselves.

This reasonableness of rates in thenselves must be determined in the light of all the circumstances. The Commission hals held, 9 I. C. C. R. 581, following the decision of (hatirman Cooley in 2 I. C. C. R. 231 and 2 Int. Com. Rep. 137, that no rates can be reasonable in themselves within the contemplation of the Act which are made regardless of proportion; that rates to be reasonable must be under all the facts and circumstances relatively reasonable. In the case cited, the Commission held that although there was a substantial dissimilarity of circumstances and conditions as between Yashville and intermediate points on the Lonisville and Nashville Railroad to Lonisville, so that section $t$ of the Act did not apply, that a difference of one cent in the rates fully offset this difference in circunstances and conditions, and that any greater difierence rendered the rates from the intermediate points relatively unreasonable in violation of sections 1 and :?, although the (ommission said that it did not feel competent to say that the rates from the intermediate points, independent of the Nashville rate, were absolutely unreasonable in and of themselves.

The Commission has considered the clamms of unjust preference in the adjustment of rates as between localities in a great. valiety of cases from all parts of the country. Thus in $8 \mathrm{I}$. C. C. R. 608 , the subject of the transcontinental rates was considered, and it was held that the rates from Denver to San Franeisco should not be higher than the rates from Missouri river points to San Francisco. It was found however that the rate on sugar might be higher to Denver from San Francisco than to the Missouri river on the ground that the circumstances and conditions governing the traffic were different when it was carried to Missouri river points than when it stopped at Denver, but that there was nothing shown justifying higher intermediate rates on any article west bound.

In 10 I. C. C. R. 460, decided January 17, 1905, the differential between Wichita and Kansas City and other Missouri river points of fifteen cents against Wichita was held excessive. In a former case, 6 I. C. C. R. 5s6, such a differential was held violative of the long and short haul clause, but that decision was rendered before the construction of the clause 
by the Supreme Court. As railroad competition existed at Kinsas City, a higher cbarge to Wichita was justified, but the amount of the differential, fiftecn cents per one hundred pounds, on sugar in carloads, was held unduly preferential under section :3. The rate from New Orleans to Wichita, forty cents per one hundred pounds, was also held to be unreasonable fer se.

In S I. C. C. R. .io:, the rates from St. Louis, Nashrille and Chattanooga, to Ilampton and Palatka, in Florida, were held prejudicial to the IIampton merchants. That while the competition at Palatka justified a lower rate, the differenceshould not be greater than the local rate from Palatia to Ilampton. In 9 I. C. C. R. 160, rates on sugar from New (Brleans to Tifton, Creorgia, were held unduly prejudicial as compared with rates to other Georgia points. Sce also on general subject of undue preference to localities, S I. C. C. R.31ı, and S I. C. C. li. 2901.

Where an existing relation of rates is found to be unduly preferential as between localities, the discrimination may be corrected by raising one rate or reducing the other, prorided of course, the rate when adjusted is reasonable in itself. See 10 I. C. C. R. 4., In this case it was ruled that the existence of water competition between Buffalo and New York did not justify any wider difference in the rates from Saginaw and buffalo to points on the New York and Long Branch Railroal than existed in the rates from those shipping points to New Jork.

These and other cases cited under the different topies of this section will illustrate the almost infinite variety of circumstances bearing upon the complex question of the adjustment of rates between localities.

\section{\$ 1S4. Recognition of natural adrantages of localities not} an mujust preference.- The Commission has repeatedly held that a town farorably situated for trade, possessing natural adrantages therefor, is entitled to the benefits in rates naturally arising from such location. See 5 I. C. C. R. 5r1, + Int. ('om. Rep. 290; 10 I. C. C. R. 1ts (the Michigan Salt Case). The law requires the regulation of railroad charges according to the ascertained rights of persons and places, and it is not an atgency for the regulation of trade by enabling shippers or communities to do business by putting them on even terms 
with rivals more remote from competitive territory. 6 I. C. C. R. 458 , 8 I. C. C. R. 409. The equal light of a competing locality is neither increased nor diminished by municipal subscriptions advanced for the building of a road. 2 I. C. C. R. $1+\tau$ and 2 Int. Com. Rep. 9.5.

The refusal to give a through rate is not an unjust disarimination to a locality when the same pule is applied to all towns and the privilege accorded to none, althongh the refusal may operate prejudicially to one.town and favorably to another, as the discrimination must consist in doing for or allowing to one party or place what is denied to another. 1 I. C.C. R. 401 and 1 Int. Com. Rep. T0:3.

Neither can a railroad be held to discriminate against a town which it does not reach and in whose carrying trade it loes not participate. 5 I. C. C. R. 米, and + Int. Com. Rep. 6...

While the Commission has conceded that the recognition of natural advantages of localities is not unjustly preferential, yet it his also ruled that the mere fact that one point is larger than another with more business does not justify a diserimination in its filvor, 9 I. C. C. R. 42, and that one of the underlying principles of the Act was equality between great and small. See also 2 I. C. C. R. 25 and 2 Int. Com. Rep. 32.

\$ 185. Competing cities on opposite banks of rivers. - The principle that a city is entitled to the benefits arising from its location, and that when it enjoys exceptional advantages in one respect it should not therefore be subjected to discrimination in other respects, has been applied in the case of cities situated on the banks of rivers, which railroads must cross by expensive bridges for which an arbitrary toll is charged, or which must be allowed for in an apportionment of through rates. Several such instances have been presented to the Commission. Thus the cases of Omaha and Council Bluffs, st. Louis and East st. Louis, Cincinnati and Louisville were presented, though in the latter case the cities are situated on the opposite banks of the Ohio river some distance apart, but are competitors for the business of the same territory.

In the case of Cincinnati, - I. C. C. R. 180 , complaint was made by the Freight Burean of the Chamber of Commerce against the higher rates charged from Cincinnati than I.ouisville to southern points. The Commission said that the loca- 
tion of Cincinnati upon the north bank of the ()hio river and the fact that the railroads leading sonth must cross that river ly expensive bridge charges justified a higher differential from (incinnati orer rates from Louisville on the south bank of the river. Is the Commission had nothing before it except the fact of distance, it did not pass any opinion as to whether the existing diflerentials were just or excessive.

In the case of Omaha and Council Bluffs, 7 I. C. C. R. 3sti, it was held that there was no unjust diserimination against (Mmaha in the fact that rates to points in Iowa were higher for "'maka than for Council Bluffs by the amount of the bridge toll on an expensive bridge over the Missouri river. It was sand in the opinion that all like or group rates were frequently applied to cities considerably further apart than Omaha and Council Blutls, but that the usage in this regard was not so uniform and well established as to make their application to those cities eren prime fucie unjust.

In .; I. C. C. R. 57 and 3 Int. Com. Rep. 701, an East St. Lonis miller was held entitled to the advantage of his location on the east side of the river as against his competitors on the other side of the river in St. Louis, and that a railroad terminating in East st. Louis which allowed st. Louis millers a rehate for the cost of their tcams across the bridge to the railroar station was an unjust discrimination against the East $\mathrm{St}$. Louis miller, and the latter was therefore entitled to a reduction of six cents a barrel as to flour handled by him to the station on the rates in force, as long as the railroads bore that amount of the eost of earriage for the St. Louis shippers.

$\$ 1>6$. Differentials between competitire cities.- The intense competition of modern commerce is illustrated in the complaints made to the Commission by the Boards of Tracle or other commercial organizations of different cities against alleged discriminations in the relative railroad rates to competing localities. The differentials allowed by the trunk line associations, particularly on the grain traflic from the west to the scaboard, as between the different seaboard eities, have been very exhanstively investigated. Thus in the case of the alleged discriminations against Boston, 1 I. C. C. R. 436 and 1 Int. Com. Rep. Tof, the Commission held in 1888 that the then existing differentials between Boston and New York, being ten eents per hundred pounds on the first and second 
classes, and fire cents per hundred on the four other classes, on trafiic from west of Iuffalo, were not unreasonable. The conclusion was based upon the greater cost of transportation to Boston, the greater volume of business to and from New York, the competition by water and through lakes and caual and IIudson river to New York, and the geographical and commercial advantages of New Iork.

Later however in 1592 , the Commission re-examined the subject and concluded that the differential was excessive and should be made, not by alding an arbitrary sum to the New York rate, but by adding a percentage, ten per cent, to the New York rate. In this case the Commission held that the dcetrine of estoppel was not applicable, as the Commission was not a court, and that the whole spirit and scope of the Act made the report and order of the Commission in no sense final, except in the sense that the parties may be impressed with the justice of the order and acquiesce therein. 5 I. C. C. R. 166, 3 Int. Com. Rep. 830 .

In 1898 the Commission, on the complaint of the New York Produce exchange, investigated the differentials allowed by the railroads of two cents to Philadelphia and three cents to Baltimore below the New Tork rate on grain, flour and provisions. 7 I C. C. R. 612. The Commission matle an exhaustive investigation of the commerce of the three ports, and concluded that the differentials were legitimately based upon the competitive relations of the carriers, and did not result in any unlawful preferences or advantage to Philadelphia or Baltimore over the city of New York. It was contended in this case that the rates were really made by the trunk line associations, but the Commission held that, so far as the alleged violation of the third section was concerned, this was immaterial.

Gases of alleged discrimination in relative rates between competing cities have been investigated in different sections of the country. As in the case of alleged unreasonable rates, the conclusions of the Commission are not adjudications, and as the Commission observed in the case of the Boston differential, they do not preclude the Commission itself from reinces. tigation. A rate which is relatively reasonable at one time, may become through changed conditions, relatively un reasonable.'

1 Another hearing, involving the (1904) progressing before the Comreasonableness of the existing differentials allowed eastern cities is now mission. 
\$15\%. Form of unjust preference immateriai.-The third section is broader than the second, in that it is not limited to discrimination in rates, but includes any form of unjust discrimination whereby a person, a class of persons, a locality or lind of traflic is unjustly prejudiced.

This undue preference between competing cities may be shown in the allowance of femurere: that is, in allowing time unreasonably small in one place and unreasonably long in another. S I. C. C. R. 531. Sce also 7 I. C. C. R. 591.

It may be stated generally that any form of discrimination between persons or localities in the performance of any of the dutics of a carriel, whether such duties are imposed by the common law, or by statute, or by contract, would be violative of this section. 'Tlums the failure to publish through rates to a particular town while such through rates are established and published to other points on the road, operates as an unlawful cliscrimination against that town. 9 I. C. C. R. 221.

In any of the so called "accessorial services" which may be rendered by the carrier, there must be no unjust preference of localities or indiriduals in providing such services. Any injustice resulting from the allowance and non-allowance by the carriers of such privileges and facilities is violative of section three. als well as of section two. See 7 I. C. C. R. 556.

The differential between carload and less than carload rates may be unjustly prejulicial to localities, as well as unjustly discriminative as between individuals. See 9 I. C. C. R. 318, and section 2. supro.

Where the circumstances and conclitions of the localities are dissimilar, there can be no unjust preference under section 3 , as there can be unjust discrimination under section 2 . See Granel IIaven Cartage case, supre. Thus it is not an unjust discrimination against a town situated on a branch line to charge it a ligher rate than an intermediate point on the through line, even though such intermediate point enjoys the same rate as the terminal point. 5 I. C. C. R. $4 t$ and 3 Int. Com. liep. Fur.

In + I. C. C. R. 131 and ? Int. Com. Rep. 162, the Commission ruled that the acquisition and consolidation by a carrier under one system or arrangement of different competing lines of road serving the same territory in the carriage of competi- 
tive traflic to the same markets did not allow it to take arl rantage of the privilege to deprive the public of the benefits of fair competition nor afford warrant for oppressive discrimination for its own interests, such as equalizing profits of the several dirisions; but that its duty to the public required that its service must be alike to all who were situated alike.

It was held in Foster v. C., C., C. \& St. L. R. Co., jo Fed. Rep. 454, that the action of a railroal passenger arent guaranteeing that a theatrical troupe to whom he sold a party rate ticket should arrive at its destination in a given time, was not a giving of an undue or unreasonable preference, and the guarantee was held valid and enforcible.

185. Wujust discrimination in time of closing freight stations.-The Commission ruled in a recent case (10 I. C. C. R. 378), that its jurisdiction under this section extended to a case of allegerl unlawful prejudice and disadvantage to shippers in Cincinnati of outbonnd package freight, through the enforcement by carriers of a regulation providing for the earlier closing of the stations used for the reeption of such freight. The closing hour, 4::30 p. m., was earlier than that in competing cities, and the Commission said that this was a disadrantage to Cincinnati shippers, but that it was for the time justified by the exceptional congestion of traftie then prevailing. The complaint was therefore dismissed withont prejudice to any further necessary proceeding.

S 189. Lnjust preference in car service.-The providing of reasonable car facilities for its patrons is a common law duty of the carrier, and this service must be rendered without unreasonable discrimination either in charges or in the facilities afforded. This common law duty, which is enforced in the different states under state statutes and at common law, is emphasized by and may be enforced under the prorisions of this section as to interstate traffic. Localities as woll as shippers may be prejudiced by the unjust discriminations in the supply of cars. This right is further enforced by the amendment of 1ss:, specifically authorizing the issue of a writ of mandamus (infia section 23 ), for the furnishing of cars and other facilities. In United States v. West Virginia \& Northern Railroad Co., 125 Fed. Rep. 252, the United States Circuit Court of West Virginia granted a mandamus to compel the 
carrier to cease preferences in the supply of cars to certain coal mines. The court said it was the legal duty of the railroal company in furnishing cars to coal mines along its line to distribute the same impartially without unjust discrimination or faroritism, and that such distribution should be based on a disinterested and intelligent examination of the mines, by experts, and upon a consideration of all the factors which wo to make up the capacity of the mines, the production, the equipment for the use for handling and loading of the product bing secondary beause it could quickly and easily be increased to meet the requirements. The distribution of cars was found to have been moluly preferential to certain companies, this conclusion being based upon an estimate of the capacity of the mines and the percentage of cars allotted to each. ${ }^{1}$ See also to same eflect Inited states r. Torfolk \& Western R. Co., 109 leal. Rep. S:31, intia section 23.

It was ruled by the Commission, 1 I. C. C. R. 594 and 1 Int. ('om. liep. Ts, that it was not a valid excuse for refusal to furnish a fair allotment of cars of a certain class that they could be more prolitably employed and could supply the wants of a laror number of shippers on another portion of the line. It also ruled that undue preference of a locality or of a shipper in the car serrice is established by showing that there is a considerable delay in furnishing cars, while other localities or shippers are furnished with comparative promptness. 9 I. C. C. R. 20\%. For other cases of discrimination before the Commission in providing cars for coal, see 10 I. C. C. R. 226 ; 10 I. C. C. R. 47. The Commission in several cases has awarled reparation in lamages for discrimination in car service.

In Harp r. Clooctaw of (i. R. Co., 61 C. C. A. 40.5, and 125 lied. Rep. 445 (eighth circuit) in 1908 , it was held in a case where discrimination in car service was claimed in violation of the Arliansas statute, that a carrer transporting large quantities of coal is entitled to make regulations in respect to the nanner of receiving and transporting it so that it may be handled safely, expeclitiously and economically without interference with the carrier's other business, and regulations which are all resigned to promote such business cannot be complained of on the ground that they operate to give a preference to

1 Affirmed in Cir. ('t. of Appeals (4th Circuit) (Nov. 1901). 134 Fed. Rep. 198. 
one who complies with them or in a discrimination against one who does not. The furnishing therefore of ears to certain mine owners, who, through agreements with the company, had constructed private spur tracks to their mines, while refusing to furnish cars for loading on the station track to owners who had constructed no spur track, did not constitute an undue preference either under the common law or the Arkansis statute, which prohibited the giving of any prelerences in the furnishing of cars. The court found that the volume of business was such that to permit the use of the station tracks for loading cars in that manner would not only interfere with the operation of the trains, but also cause serious loss and inconvenience to other shippers and the public. It was held by the state court under the same statute that there was no undue preference between localities when there were not enough cars to supply all. The court cited as the learling case, Oxlaiil v. Northeastern Ii. Co., 15 Common Bench, N. S. 6so, construing the English Canal and Traffic Act of 185t, upon whieb the Interstate Commerce Act was based. Little Rock it St. L. R. Co. v. Oppenheimer, 44 L. R. A. 353, 64 Ark. 271.

The Commission has ruled that it is not the duty of a carrier to notify the shipper when he can obtain cars for the removal of freight, if by reasonable inquiry he can obtain such information himself. 1 I. C. C. R. Gos and 1 Int. Com. Rep. 7.S.

It was said by the commission in another case, 1 I. C. C. R. $37 t$ and 1 Int. Com. Rep. 68s, where damages were claimed for alleged riolation of the Act in the failure to furnish cars for coal shipments, that the inability of a carrier to furnish cars as fast as clemanded by shippers was not a riolation of the Act, where the company had an adequate freight equipment for ordinary conditions, but owing to an extraordinary demand for coal cars due to exceptional conjunction of circumstances, was unable to supply them as fiast as the shippers demanded. Under such circumstances, the company performed its duty when it furnished the cars ratably and fairly at the mines along its line in proportion of their freights until the emergency had passed. Neither was a carrier responsible for the detention of cars by shippers longer than was necessary, when it appeared that the company did all in its power to enforce the prompt unloading of the cars. See also as to car- 
riers' duty in the matter of car equipment, 2 I. C. C. R. 9u and 2 Int. Com. Rep. tiT.

190. Discrimination by carrier in its own faror.-As. the carrier may discriminate in faror of itself in violation of section :- when it is both a carrier and a shipper, so it may discriminite by an unjust preference against certain localities by the same means. See snl'

Thus in ('ommission v. Chesapeake d Ohio R. Co., supra, the contract by the carrier with another carrier for the delivcly of the coal belonging to the first at a fixed price, was held to operate to give the purchaser an undue preference, in violation of section 3 , and that the contract was therefore illegal amd uninforcible and its further performance was enjoined. see.$" 1 \mu^{2} u$, section 2.

1:11. Tujust preference in prirate cars.-The same principle was applied by the Commission to the use of pricate cers. Thus in : I. C. C. R. 1, the Commission said that the carrier conld refuse to haul private cars at all, or to only haul those of a certain class and refuse to hant others of a wholly or substantially different class. In either case however there shonld be no avoidable partiality. The railroad should therefore exclude from its roal all such cars, or else prescribe in its tariffs the rates and rules under which they would be transported. In this case the private car was that of a commercial silesman and was stocked with his samples of men's clothing and furnishings. The commissions aid that in comparison with the private car service rendered for pleasure journeys and theatrical companies, the service was so very different and unnsual as to justify a greater compensation, and would justify the carrier in refusing the car altogether.

As to truli aers see + I. C. C. R. $1: 31$ and 3 Int. C'om. Rep. liv. Where the Commission said that it was the carrier's duty to erpuip its road with the instrumentalities of carriage suitable to the traffic and furnish them alike to all, and its duty to furnish equipment could not be transferred to nor required of shippers. Where it accepted and used cars owned by shippers or others, in legal contemplation, it adopted them as its own for the purpose of rates and carriage. The carrier could not hy any levice, such as the payment of unreasonable rent, evale the duty of equal charges for equal service. See also- 
1 I. C. C. R. 510, 1 Int. Com. Rep. T20, 6 I. C. C. R. 295; 2 I. C. C. R. 9 ', 2 Int. Com. Rep. 67.

It was said by .Julge Cooley in an early case, 1 I. C. C. I. 50:3 and 1 Int. Com. Rep. 722 , that it is properly the business of a carrier to supply the rolling stock for the freights he offers or proposes to carry, and if the diversities and peculiarities of traffic are such that this is not always pricticable, and consignors must supply it themselves, the earrier must not. allow its own deficiencies in this particular to be the means of putting to a particular disadrantage those who make use in the trallic of the facilities it supplies, citing Railroal Co. v. Pratt, 2.2. Wallace 12:3, 22 L. Eil. 527 .

In 9 I. C. C. R. 182, the California Fruit case, the Commission said that while it must be conceded that the leasing of equipment, by carriers, as refrigerator cars, afforded opportunities for unfair advantage, that carriers are left by the law to procure equipment for business by lease as well as by purchase, and they are not prohibited from leasing from a shipper, nor are they compelled to lease from all shippers because they do from one.

The subject of private cars has been considered in connection with section 1 of the act (see s"lme, $\$ 118$ ), as to the charroing in excess of reasonable rates for refrigeration in consequence of the use of such cars, and the matter of unjust diserimination between shippers has been considered in connection with section 2 of the act $\left(\sup ^{2}(\mathbf{1 5 9})\right.$. See also the extended discussion of this subject by the commission in its annual report for 1904 , page 11 . In this report the Commission says that the use of private cars may be divided into two general classes, those in which the property of the owner of the car is transported and those in which the owner is not interested in the.contents of the car. In the first class the shipper owns the car, and it is ordinarily only used for the carriage of the property of the owner, and in the second class the cars are usually owned by some private car company which constructs the car, keeps it in repair and leases it to the railroad company. The Commission recommends legislation requiring parties furnishing such cars to be subject to the Act, and that all the charges therefor paid subject to the control of the Commission, and that the compensation for the use of the 
cars should also be subject to the juristiction of the Commission.

19:3. Exclusice nse of exeursion or sleeping cars of one owner.- The same principle applies in cases of special clisses of ears, such as excursion and sleeping cars for passengers. A railroal company may aequire cars of any class, by construction, by purchase, or by contract for their use, and no one can compel a railroad company to select among these sereral modes or to contract with all carriers. This principle was applied by the Commission in 3 I. C. C. R. 575 and 2 Int. Com. Rep. 7!:- in ruling that it was not unjustly preferential for a railroal company to refuse to baul the excursion cars of one car company, when it had a sufficient supply of excursion cars for its business from another company with whom it had contracted.

\section{$\$ 193$. Leasing of ears does not cary right of exclusive} use by owner.- It is the duty of a carrier to equip its road with the means of transportation, and in the alsence of exceptional conditions those means must be open impartially to all shippers of like traffic.

The Commission said in one of the numerous tank line cases, $\therefore$ I. C. C. R. $415,+$ Int. Com. Rep. 16ะ, that ownership of a car rented to a carrier for a full consideration did not of itself entitle the owner to the exclusive use of such car, and if he could stipulate for such use, it must be upon such terms as shall not constitute an unjust discrimination against shippers of like traffic excluded from use of the car. Where a carrier pays mileage for a car which it employs in the service of the shipper, it is the carrier, and not the party or company from whom the car is rented who furnished the car to the shipper, and in such case there is no privity of contract between the car owner and the shipper. 6 I. C. C. R. 295.

S 194. Stoppage in transit privileges.- The privilege of stoppage in transit, including the right of milling grain in transit or of compressing cotton, which the Commission sustained as a legitimate privilege extended by carriers, must not be so extended as to operate as an undue preference to localities or unjust diserimination between individuals. See supu, section 2 .

The commission said in 9 I. C. C. R. 373 , that if stop-over privileges are granted for any purpose, all the facts and cir- 
cumstances connected therewith should be clearly stated in the published tariff so that the public generally may enjoy the benefits. In this case the grain was shipped through st. Louis with stop-over privilege in East St. Louis for cleaning, sacking, or any other purpose, the shipment afterwards carrying the proportional or balance of through rate from East st. Lonis. The Commission in this case, however, condemned the practice of shipping to East st. Louis on a local rate for the purpose of "trying the market," and then shipping on a reduced proportional rate to a sonthern point. See also 7 . C. C. R. 240, where a similar practice was condemned.

In the lumber "Tap-line" case, 10 I. C. C. R. 19? (s"p'ce, 16:3), the Commission said that it might be urged with force that practices of this kind were not sanctioned by the act, and that it had intimated that view in 1 I. C. C. R. 4)1, 1 Int. Com. Rep. 703. The practice had become so general that vast amounts had been invested in inciustrial plants upon the faith of the continuance of these privileges; and no doubt their allowance had cheapened the cost of transportation and probably of manufacture. The Commission concluded that when once the principle of milling in transit was arlmitted it could be applied to the manufacture of logs into lumber.

In 1 I. C. C. R. 401 and 1 Int. Com. Rep. 70:, the Commission ruled that the privilege of stoppage in transit should not be extended so as to give to the merchants of a town the privilege of shipping their goosts from the point of purchase to their own locality, and thence to the place where the groods may be sold by them at the sime rate at which they would have been charged if there had been but one shipment from the point of purchase to the point of final delivery.

\section{\$195. Interference by State Railroal Commission with} proportional tariff rates.-The term "proportional tariffs" has been given to freight rates applying upon shipments with stoppage in transit privileges, that is, where the commodities shipped originate beyond the place of shipment, when their ultimate destination is beyond the point to which the proportional rates apply. In a recent Texas case, it appeared that the State Railroad Commission had issued an order that the Chicago, Rock Island d Texas raihroal company should cancel all its so-called proportional tariffs on grain products from and 
to points reached by its railway, whether local or in connection with any other lines of railroal. A bill was filed by the owner of a grain elevaltor at Fort Worth engaged in the purchase of grain from the comntry north of Texas for the purpose of shipping by export from the (inlf ports, alleging that these prop:ortional tarifls hal been filed with the Interstate ('ommerce Commission and relate wholly to interstate trattic. The court held that the orler of the state Raihroad Commission was illegal and roid, that it had no jurisdiction or control over the froporrional tariff rates in question: and a temporary injunction was issued against the enforcement of the order so far as the Commission was concerned; the Court declining to grant any injunction against the railroad company, on the ground that it Nits fully able to respond in damages for any failure to carry out its contract. Rosenbaum Grain Co. v. C. R. \& T. R. Co., $1: 30$ Fed. liep. t6. The order granting the temporary injunction was affirmed in Circuit Court of Appeals, 130 Fed. Rep. 1111.

196. Sidetracks and connections.-Another form of alleged preference has grown out of the practice of building sidings and spurs for connecting the main track of a railroad with inilustrial enterprises, such as mills, furnaces and elevators.

some states, as South Dakota, (R. s. So. Dakota, 1s99, section 2.5, , and Nebraskil, Laws of 1857 , Ch. 69, have made a statutory provision for such connections. The statute of the latter state was construed as authorizing the State Railroad Commission to reyuire the railroad company to grant the right to erect an elevator upon the right of way at a specified point on the same ter'ms and conditions which it had already granted to other persons the right to erect elevators thereat. The Supreme ('ourt ruled in Missouri Pacific Riailway C'o. v. Yebraska. lit L. . . 41:?, 41 L. Ed. to!n, that this Nebraska statute so construed as requiring a railroad company to grant to the petitionr.s a right to build and maintain a permanent structure on their right of wiy was a taking by the state of the private property without the omner's consent for private use, and was violative of due process of law and the Fourteenth Amendment. The court howerer limited its decision to this point, and sall that the question of the power of the legislature to compel the railroal company to erect and maintain an elevator for 
the use of the public, or to compel it to permit all persons to enjoy eqial facilities of access from their own lands to its tracks for the purpose of shipping or receiving grain or other freight was not involved, as the order of the Commission was not limited to the temporary use of the tracks nor to the conduct of the business of the railway company.

In Illinois, railroads were required by the State constitution, article $1:$, section 5 , to permit connections to be male to their tracks so that any consignee of grain in bulliand any public warehouse, coal bank or coal yard ma be reached hy the carts on the railroal. In Clicago, ete., R. ('o. r. Sutlern, 12! Ill. $27 t$, it was held that a railroad company was not justified in refusing to ship coal over its own railroal off of a switch roarl to the shipper's mine simply because the shipper also shipper on another carrier's line.

The question was considered in one of the Louisville toekyar cases, Butchers \& I Irovers Stockyarl Co. r. Railroad Co., $1 t$ C. C. A. 290, l. c. p. 297,67 Fed. Rep. 3.; whether it was a discrimination which could be controlled or restrained by the courts for a railroad company to refuse to furnish a sidetrack or not to its customers and furnish such accomolations to another similarly situated. The Court sail in an opinion by Justice Taft that this question was very difficult, both at common law and under the statute. It was held however not to be involved in the case before the Court, as there wis such a difference between the business of the complainant and that of the other abutters upon the spur track as to make the refusal of the company to grant the sidetrack to the complainant entirely reasonable, this difference consisting of the fact that the complainants' traffic was live stock and that of the other abutters dead freight, making the conditions of deliveries aml shipments entirely distinct.

In Ilarp r. C. O. \& G. R. Co., (Ark.) 11s Fed. Rep. 16it, the court held that a railroad was under no obligation to build a spur track to coal mines for private benefit of the owner, nor was it liable for damages for unlawful discrimination because of refusal to build such track, although it had assisted and permitted other spurs to be built. The judgment was aftirmed in the Circuit Court of Appeals, but on inother ground. 61 C. C. A. $40.5,125$ Fed. Rep. 445. 
This decision was approved and followed in Robinson v. B. it 0 . Railroal Co., 129 Fed. Rep. 75\%, where it was held that the carrier in his right to make reasonable regulations for the delivery of freight was not compelled to receive coal at a siding where merchandise other than coal was received, merely because the place was more acceptable to a shipper, when it had designated the siding for receiving coal and the siding was not an unreasonable place.

In another stockyarls case, that oi the Interstate Stockyards Co. v. Railroal (ompany, 99 Fed. Rep. 473, the Court laid down the general proposition that a "common carrier of interstitte freight cannot lawfully deny switch connection and service to one person, place or locality, or lind of traffic, which it atfords to others similarly situatel." This question however must be construed in connection with the special facts of the case, the alleged discrimination being by a city belt line which was required under the eity ordinance and State statute to grant switch connections to all persons and to render service in respect to all freight upon equal and impartial terms. This road was en joined from discontinuing the receipt of live stock from sidings which had been theretolore constructed and maintained.

Assuming that there can be no unjust preference in the refusil of switch connections unless the circumstances and conditions atre similar, it is difficult to sce how in any case the Court can compel a carrier to construct and maintain such a siling for private use in its own right of way at itsown expense. Nebraska v. Missouri Pacific Ry. Co., supra. There seems to be no case where either the Commission or the Court has enforced the construction and maintenance of such switch connections. see i I. C. C. R. 194, where such an application was unsuceessfully male. The carrier is not bound in every instance to furnish under legal compulsion the same terminal facilities for ail descriptions of traflic. It is sufficient if reasonable provision is malle in this regard, and what is reasonable in a given instance depends largety upon the conditions and surroundings of a particular locality. See 9 I. C. C. R. 61.

\section{s 197. Indue preference in denying shippers the choice} of route.- Another form of undue preference condemned by the Commission is the practice of initial carriers in joint con- 
tinuous routes of reserving to themselves the exclusive control of the ronting of freight, and denying to shippers any choice or control in the selection as between different established routes, the route being determined by the carrier's agents according as they may desire to distribute the shippers business amon one another from time to time or for any reason whatever. The Commission ruled in the California Fruit case, ? I. C. C. R. 1S\%, that this practice was in violation of the statute, subjecting the shippers to undue and unreasonable prejulice and giving the carriers undue and unreasonable preference and adrantige. See also 3 I. C. C. R. 658, 3 Int. Com. Rep. 33.

This subject was brought before the Lnited States Circuit Court for the southern district of California in Commission $r$. Southern Pacific Company et al, 128 Fed. Rep. 597, in a suit to enforce the order of the Commission requiring the railroals to desist from the enforcement of the rule reserring to the initial carrier the unqualified right of ronting beyond its own terminal all shipments made under an established through rate. The Court said that as the Commission found that the rule and the practice therennder worked an undue and unreasonable prejudice to certain shippers of citrus fruits, it followed that the orders of the Commission forbidding the enforcement and maintenance of the rule were lawful orders. The Court in this case cited and applied the decision of the supreme Court construing this section in the Chattanooga Rate case, $181 \mathrm{U} . \mathrm{S}$. 1 , supre. On final hearing of this case, 192 Fed. Rep. 829 (Sept. 1901), the arrangement between the initial and connecting carriers was held to constitute a "trallic pool" violative of section 5. See infra, section 5 .

$\$ 195$. Undue preference in arbitrary division of terri. tory.-Another practice condemned by the Commission as violative of the rights of shippers in creating undue preference was the arbitrary division of territory under the agreement of the Southern Railway and Steamship Association, 6 I. C. C. R. 195, whereunder the Commission found that the rates on traffic of certain classes were made higher from Chicago and Cincinnati to southern territory than they otherwise would be, for the purpose of securing to the lines from the northeastern cities, transportation of that traffic from the territory set apart 
to them under the agreement, and that this raised the presumption of the unreasonableness of the rates in such territory. The Commission found that this dirision of territory was without warrant in law and to have been marle for the benefit of carricrs without regard to the interests of shippers in the ter- . ritory, to whom it was in effect a denial of the privilege of shipping their gools to market by the line or ronte they may prefer. See also S I. C. C. R. 1S., wherein the Commission made a report on the export rates from points east and west of the Mississippi river, and said that it was neither sound in principle or equitable in practice for railroad lines to create artificial differential in the rates, whereby the product of one section is assigned to one market and the product of another section assigned to another market.

199. Rate wars and undue preferences. - The relation of rate wars to the reasonableness of rates was considered under section 1, supra, $\$ 141,2$ I. C. C. R. 231 and 2 Int. Com. Rep. 13i. In the rate war prevailing in the southern freight traffic in June and July, 1s94, great disparities in rates were suddenly produced at intermediate points by the large reduction in rates to Knoxville at the commencement of this war. See 6 I. C. C. R. 682. The Commission made an inguiry of its own motion. T I. C. C. R. 17T; see also Eighth Annual Report of the Commission, 1594 , pp. 20 to 24 . The Commission held that the maintenance of the usual rates to interrening points during the period of such reduced rates to the terminal points was an unwarranted discrimination and entitled the shippers from intermediate points to reparation for the excess paid by them luring such rate war. On the subject of passenger rates and rate wars, see also 2 I. C. C. R. 543 and 2 Int. Com. Rep. 340.

These decisions of the Commission were rendered especially in view of the long and short haul requirement of section 4, and prior to the ruling of the supreme Court that railroad competition created a dissimilarity of conditions within the meaning of the section. The ruling however of the supreme Court that the competitive rate must be remunerative (see supra, $\$ 175)$, would of itself prevent the extreme reductions condemned by the Commission.

As to unlue preference and discrmination in passenger rates, see supra, section 2. 
As to applications for injunctions in rate wars by carriers and shippers, see annual report of 1696, pacre $4: 3$.

For account of "rate war" injunctions tiled by a competing" carrier, a trust company representing security holders of the carrier, and a complaining shipper during rate war between Seaboard Air Line and the Southern Rialway ('ompany in 1596, see annual report of Commission for 1896, page $4: \%$.

:00. Discrimination in kinds of traflic.- The first paragratph of section 3 also prohibits any undue or unreasonable preference or advantage of any particular description of traflic in any respect whatever. It was held in the Oregon short Line \& U. N. R. Co. v. Northern I'acitic Railway Co., ninth circuit, 9 C. C. A. $40 ! 9,61$ Fed. Rep. 15, that this first paragraph of the third section forbidaling discriminations against any locality or description of trattic is for the protection of the locality or traffic itself, and cannot be invoked by a carrier against a connecting carrier for allegerl discriminations in the matter of requiring prepayment of freight and car mileage. The Court said that it was not competent for a railroad company to appropriate the grievances of a citizen or locality under section 3 and complain on account of it.

Goods offered for shipment from a given point must be carried for the established rate from such point, in the absence of a through ronting, regardless of the point where the goods originated. Bigbee Packet Co. v. M. \&O. R. Co., (So. Dist. of Ala.) 60 Fed. Rep. 545; 4 I. C. C. R. 611, 3 Int. Com. Rep. 515.

Discriminations against kinds of traffic are sometimes involved with discriminations against localities where the industries discriminated against are established. This is illustrated in the litigation between the packing houses of Chicago and those which have been established in the stock raising sections of the west, where the industries located at Chicugo are thus directly concerned in keeping down the rates on live stock to that point as compared with the rates on packing house products. See 4 I. C. C. R. 15s, 3 Int. Com. Rep. 2933 where the differential between rates on live stock and packing house products from the Missouri river to the city of Chicago, was held discriminated against the packing house industries located in Chicago. The same discrimination as to the same kinds of traffic was thoroughly considered in the case of the 
Chicago Live stock Exchange in 10 I. C. C. R. 42S. See also 4 I. C. C. R. 611, 3 Int. Com. Rep. 515, as to the rates on live hogrs and dressed products to and from Ijoston. The same alleged discrimination between kinds of trafric and localities wherein the competing inclustries were located were shown in the complaint of the Missouri and Kansas millers against the differential between wheat and flour, where the discrimination operated in favor of the Texas mills as against the mills of Missouri and Kansas. See infire, $20:$ :

Guestions of undue preferences of kinds of traffic have been raised by manufacturers in respect to raw material and manuficturel product for the protection of their local industries against competition, and also by the mannfacturers of and dealers in commolities, which were commercially competitive, as anthracite and bituminous coal, 4 I. C. C. R. 535, 3 Int. Com. Rep. 460, and live hogs and cattle and the dressed prolucts of each, + I. C. C. R. 611, 3 Int. Com. Rep. 515. This question of undue preference to particular kinds of trattic was also involved with the subject of carload and less than carloal rates, supu, \$15\%. See 3 I. C. C. R. 473, 2 Int. Com. Rep. 7t2; 5 I. C. C. R. 638, \& Int. Com. Rep. 29.

\section{:01. Preferences against traffic-Must involve injury.} Endue preference against traffic must ordinarily be such that inju'y is caused thereby to some party of locality. The Commission said in 10 I. C. C. R. 17:, , one of the Louisville Stockyards cases, with reference to a claim that a refusal to receive carlouds of live stock from a connecting carrier, when carloads of dear freight were received, that this involved an undue rreference of the dead freight, that this refusal to receive live stock did not in any respect benefit dead freight. If an undue discrimination was found, the carrier might comply with the order by ceasing to deliver dead freight, and if this latter alternative was adopted, complainant would not be benefited and other shippers would be greatly injured. See also Butchers it Drovers Stockyards Co. v. L. \& N. R. Co., 14 C. C. A. 290,67 Fed. Rep. 35, supro.

When manufacturing industries are established in localities it often happens that a slight change in the adjustment of transportation charges as to the raw material and manufac- 
tured product or article may be sufficient to close manufacturing plants at some points and increase the output at others located elsewhere. It was held by the Commission in at recent case, January 1905 (the Chicago Live Hogs Exchange case, supra), that the very fact that large live stock markets anct packing centres had been built up and maintained under a former relation of rates necessilrily qualified the right of the carrier to change his rate on packing house products for the purpose of increasing his business, when that change would operate to destroy industries that had been built up in reliance on the former relation of rates. In this case it was found that the discrimination between live stock products in the territory west of Chicago was not justified by a difference in the cost of transportation or otherwise.

In the same case it was said that improvements made during recent years in roalbed and equipment of carriers had rendered the item of risk in many cases of little consequence in determining the relation of rates between two articles. The value of the articles is of course material, and the relation between the articles transported is also important.

\$20\%. A reasonable regulation of carload weights not preferential. - It was ruled in 7 I. C. C. R. 2.55, that a rule made by a carrier which had not provicled track scales at stations, forbidding shippers to load cars above a specified weight of marked capacity of the car under the so-called penalty of an increased rate on the excess weight, was not unlawful, provided the increase in charges for the excess weight was not unreasonable, and the margin between such maximum and the carriers' minimum of carloads of grain was so wide that shippers could readily comply with both rules. Such rules however must be shown upon the carriers' posted schedule. See infra, section 6 . In this case it was also ruled that rules for minimum carload weights for corn or other grain which varies with the size of cars furnished by the carrier are unreasonable, in that they would inevitably confuse and puzzle shippers and consignees, and subject them to excessive charges resulting from arbitrary weights, and increase the number of overcharge claims and afford many opportunities for discrimination in rates between competing shippers. The Commission said therefore that the carrier should enforce a fixed and rea- 
sonable minimum carload rate for corn and other grain irrespective of the capacity of the ears furnished by it to shippers.

In another case, 3 I. C. C. R. $2+1$ and 2 Int. Com. Rep. 5:19, the Commission held that a rule was reasonable which prescribed the minimum weight of a earload of eattle at a certain rate, and then charged by the hundred pounds for any excess of weight over the minimum. The Commission said that such a rule was more just and reasonable than the practice of making a carload rate irrespectire of weight, leaving the shipper to load into the car as many cattle as he pleased and was able to put in to it, and the fact that some difficulties were found to exist in the prompt and accurate weighing of the cattle was not a reason for abolishing the new rule, but rather for improving and perfecting it.

s:0:3. Difrerentials between grain and grain products.This question has been extensively liscussed before the Commission. The millers located in wheat producing territory strongly insisted, that flour being more easily handled, was entitled to at least an equal rate with wheat. On the other hand, the millers located in Texas out of the wheat producing territory were directly interested in a high differential between wheat and flour, so as to at once seeure an adequate supply of wheat and exclude competing flour. It appeared from the testimony in the proceeding instituted before the commission by the millers of Missouri and Kansas that the Texas railroats were in the habit of increasing this differential during harvest time for the benefit of the Texas flour mills. The (ommission ruled, 4 I. C. C. R. 417, and 3 Int. Com. Rep. 400, that a differential of five eents per hundred pounds, that is, five cents per hundred pounds higher on flour, was warranted by the peculiar conditions, hut that a larger differential, such as had been maintained for considerable periods, worked an unjust discrimination and was unlawful.

In $>$ I. C. C. R. 804, decided some nine years later, the Commission reaflirmed this decision saying that the advantages were not sufficient to warrant interference with the established differential; and in the same opinion, the differential between corn and corn meal in the same territory was made not to exceed three cents per hundred pounds. This ruling was again reatfirmed in January 1904. 10 I. C. C. R. 35. 
In cases from other sections of the country it was held that grin and grain products were presumptively entitled to equal rates. See 8 I. C. C. R. 214, where the Commission ruled that an equal rate on wheat and flour in the export trade was presumptively proper, but that in view of all the conditions shown in the investigation, the differential rate for export should not exceed two cents per hundred pounds.

204. The Commission not concluded by ruling of State Commission. - In the case last cited it was shown that by the State law or by the rulings of State Commissions a shipper in Kansas or Missouri of cattle consigned to a point in the State was entitled to load the car at discretion without the charge being increased thereby. But the Commission said that while such action of the State authorities had always been treated with respect, it was in no wise conclusive upon the Interstate Commerce Commission in the regulation of interstate commerce, as the Commission thought that the action of the carriers in prescribing rates for the transportation of cattle by weight instead of by carload was not in itself illegal and was in accord with the general practice as to the regulation of carrier's charges. The State action therefore could not be allowed to control the matter which was within the Federal jurisdiction.

\$ 205. Discrimination in mode of shipment.-- Undue preference may consist not only in a differential riate, that is, a difference in rate not warranted by the character of the commodity or any consideration relating to the cost of service, but also in any discrimination in the performance of any of the duties of the carrier, or any accessorial services rendered. This is illustrated in the rulings of the Commission upon the subject of the alleged discriminations in the shipment of oil in tanlis as against the shipment in barrels. Thus it was held in 1 I. C. C. R. 503 and 1 Int. Com. Iiep. 720, that when oil is transported in tanks permanently affixed to car bodies, the tank is to be considered as part of the car, and for oil transported therein the charge for transportation should be the same by the hundred pounds, that the carrier charges for transportation between the same points, of barrels filled with like oil and taken in carload lots, and that the carrier was guilty of unjust discrimination if the shipper in barrels was charged a higher rate. See also 2 I. C. C. R. 90, 2 Int. Com. Rep. 67. 
In the case last cited, on account of the difference in expense of service a higher rate for the oil in barrels in less than carload lots as compared with oil in carload lots was sustained.

The allowance by a carrier to a shipper of oil in tanks of forty-two gallons or any number of gallons for alleged leakage and waste in the transportation, in the absence of a corresponding allowance to shippers in barrels, was an unjust discrimination and unlawful. 4 I. C. C. R. 1:1, 3 Int. Com. Rep. 11:2. There was no objection however to the use of estimated or constructive weights, provided the method of estimating works no inequality in its practical application to competing modes of conveyance.

It is the duty of the earrier to equip its road with the means of transportation, and in the absence of exceptional conditions, those means nust be open impartially to all shippers of like traftic. If the carrier transports freight in cars owned by the shipper. it must be upon such terms as shall not constitute an unjust discrimination against shippers of like traftic, who are excluderl from the use of such private cars. Where the use of a class of privite cars, such as tank cars, is not opened to shippers impartially, but is practically limited to one class of shippers, and the charge for a barrel package in barrel shipments in the absence of a corresponcling charge on the tank shipments results in a greater cost for the transportation, it is unılue preference and discrimination. 5 I. C. C. R. 415,4 Int. ('om. Rep. 162.

: 206. Classification.- The subject of undue preference against linds of traftic necessarily involved the question of clessitication. The strict apportionment of a cost of service on all classes of commodities equally would be impracticable, for the reason that articles which are bulky and cheap would be unable to bear the burden of transportation, as their value would be conliscated by the cost of transportation for any considerable distance. It is universally recognized therefore that in order that such articles as grain and its products, fuel, lumber and ore ean be transported at low rates which they can stand, it is necessary for the carrier to charge upon the other classes of groors, which comprise greater value in smaller compass, a greater proportionate rate. I pon this necessity 
are based the principle and practice of classification of freight traffic, which have been exhaustively discussed in the reports of the Interstate Commerce Commission, see report of 15ss, page 34 . The Commission has also repeatedly urged upon the railroads the adoption of a uniform classification. See report of 1891 , page 23 , and report of 1894 , page 34 .

Commodities not classified, are given what is known as commodity rates. Thus salt requires and receives a commodity rate lower than class rates. The Commission said in 5 I. C.C. R. 299, 4 Int. Com. Rep. 33, that the carriers should only be limited as to such low rating by the rule that a commodity. should not be carried at such unremunerative rates, as will impose burdens upon other articles transported to reconp losses in carrying that commodity.

\section{$\S 20 \%$. Consultation of carriers in classification not ille-} gal combination.-In the report of 1899, pp. 12 to 20 , the Commission discussed the question of the advance in freight rates by the carriers using what is known as the official classification, covering the territory lying east of the Mississippi and north of the Ohio and Potomac rivers, and in that connection gires the opinion of the Attorney-General of December :31, 1s99, to the effect that consultation by the representative railroad men in the committee respecting suggested changes in classification, and subsequent independent action by the respective railroud companies by the adoption of the new classification recommended, in the absence of any testimony of compulsion or combination in adopting a classification, was not in violation of the Anti-Trust law.

\$ 908. Undue preference in classification.- Undue preference may be effected by discrimination in classification between commodities which are in fact competitive, where such classification is not based on a difference in the cost of service. The English statute of 15.54 was construed as imposing upon the carrier the burden of justifying such discrimination by consiclerations relating to the cost of carriage. Oxlade r. X. E. Ry. Co., 1 Ry. \& Canal Traffic Cases, 73; Thompson r. London $\&$ N. W. Ry. Co., 2 Ry. \& Canal Traffic Cases, 115. This general principle has been applied by the Commission in a varirety of cases. Thus, the advance of hay and straw from the 6 th te the 5th class on the official classification of January 1, 
1:00i (see 9 I. C. C. R. 264), was held unreasonable and unjust as resulting in unlawful diserimination and prejudice against the locilities where such commodities are produced, and against producers, dealers and consumers. As to the governingr principles of freight classitication, see 6 I. C. C. R. 14 s and 4 Int. (om. Rep. i2i: 9 I. C. C. R. Ts. See also 3 I. C. C. R. ti: 2 Int com. liep. 7t9.

In + I. C. C. R. 212. 8 Int. Com. Rep. $25 \%$, it was said that where questions of elassification and rates are involved as to one particular article of lreight, it is often necessary to examine and eonsider the classilications and rates upon other articles in which the same calculations in respect to value, bulk and expense of hambling and carriage would to a considerable extent enter. For the purpose of such comparison it is not indispensably necessary that the articles should be competitive, thongh if they are competitive, then this feature is held partly to be considered. The proper method of determining the justice of classitication by comparison, is with classification created by the carrier for analogous articles. 5 I. C. C. R. 635, + Int. Com. Rep. …. The fact that different rates and classifications are in force in different sections of the country would not of itself warrant an extention of the lower rate of classification to the higher rate and classification as applied. There must be proof of unlawful discrimination or disadvantage or unreasonably higher rates to procure an order directing different rates and classitication. if I. C. C. R. 61.

In (I. C. ( . R. S., a commodity (i. e. not classified) rate published for intending settlers only, but in fact given to shippers indiscriminately, was condemned by the Commission as calculating to mislead the public and afford an opportunity for faroritism.

For illustrations of the rulings of the Commission in cases in chassification, see 2 I. C. C. R. 1, 2 Int. Com. Rep. 1, where classification of dried fruit and raisins in two different classes was beld unreasonable.

thab blocks were classed with lumber, instead of with unfinished wagon materials. 2 I. C. C. R. 122, 2 Int. Com. Jiep. -1 .

In 1 I. C. C. R. 39:3, 1 Int. Com. Rep. 685, railroad ties. were classed wh other rough lumber. 
In 2 I. C. C. R. 578,2 Int. Com. Rep. 40:, Iostetter's Stomach Bitters were held not properly classified in the first class with other liquids similar in character. In 4 I C. C. T. .,2, 3 Int. Com. Rep. 7t, patent medicines were held properly classed at a higher rate than ale, beer and mineral water.

In 4 I. C. C. R. 41, 3 Int. Com. liep. 75 , toilet soap was held properly classed higher than launtry soap, the Commission holding that manufacturer's (lescription of his production for commercial purposes warranted a classification accordingly. See aiso 4 I. C. C. R. T39, 3 Int. Com. Rep. 564.

5 I. C. C. R. $60 \%,+$ Int. Com. Rep. 318 , held that celery was properly classified with regetables rather than with fruits. In 6 I. C. C.R. 148 , in view of the great reluction in value of window shades, the classification as first class was held unreasonable. The United States Circuit Court, in 64 Fed. Rep. 724 declined to enforce this order on the ground that it applied to shades having a very high value as well as to the cheaper varieties, and the order was amended accordingly. 6 I. C. C. R. $5 \neq 8$.

In 7 I. C. C. R. 40, open-end envelopes were held properly classed with merchandise envelopes.

In S I. C. C. R. 368, iron pipe and fittings packed in cases were held properly classed higher than iron pipe and fittings packed in barrels. \& I. C. C. R. 61 , held that there were conditions compelling a low rate mpon flour which did not apply in the transportation of cerial products.

In 4 I. C. C. R. 212,3 Int. Com. Rep. 257, the principles of classification were discussed, and applied in the case of surgical chairs. In 10 I. C. C. R. 281 , cow-peas were held properly classed with grain, and not with fertilizurs.

\section{:09. Power of the Commission in correcting classifica-} tion.- The Commission has in a number of cases exercised the power to order a change in the classification, as in the cases before cited; also in 1 I. C. C. R. 398, 1 Int. Com. Rep. 6s5; 2 I. C. C. R. 122, 2 Int. Com. Rep. 81; 4 I. C. C. R. 312, 3 Int. Com. Rep. 257 ; 6 I. C. C. R. 148,4 Int. Com. Rep. 525.

Assurance made by a carrier that if one will locate in business on the line of his road his property shall be taken for transportation as belonging to as pecified class, it was ruled by the Commission in 2 I. C. C. R. 122, 2 Int. Com. Rep. s1, could not bind the carrier so as to compel a classification ac- 
cordingly. There can be no contract right to a special classifieation, as the law requires miformity and impartiality in the dealings of the carrier with all persons.

It will be seen that the power to change classification 'would indirectly involve the power to determine rates. The Commission ruled in 9 I. C. C. R. Ts, l. c. sti, that as it had the power to determine the relation in the rates which should exist between localities, that the same principle should apply in the relation between two commodities. It admitted however that the authority was not clear, but as it was of opinion that there was a plain distinction between fixing a rate and determining the the relation of rates, the Commission would continue to exercise that power until it was judicially cletermined otherwise. In a recent case, January 1905, the L'nited States Circuit Court for the northern aistrict of Ohio, Commission $\checkmark$ Lake Shore Railroad Co., et al., it was held that while the commission bad the power to order certain freight taken from the fifth class, it did not have the power to order it placed in the sixth class. In other words, the Commission did not have the power to order the classification changed which would fix a definite rate for the future.

?.10. Reasonable regulations in classifications.--The Commission has ruled. \& I. C. C. R. 61 , that the fact that different rates and classifications are in force in different sections of the country would not itself warrant an extension of the lower rate and classification to the section where a higher rate and classification were applied. There must be proof of unlawful discrimination or clisadrantage or of unreasonable higher rates to justify directing an order for changes in the classification. In this case it was ruled that a mixed carload rate for cereal products or for cereal products and flonr, that would have the effect of throwing out of the trade many competitors of complainant, or the manufacture only of certain kinds of cereal productsand of centralizing the business in the hands of one or more of the dealer's, should not be curtailed, when without it no wrong is done to any one and the market is open to all competitors. The Commission said therefore that to obtain the abrogation of a rule in classification lenying a mixed carload rate upon specified articles, the rule should be shown to be unreasonable, unfair or unjustly discriminative. 
\$ 211. Facilities for interchange of trallic.-The second paragraph of the third section, though based in part upon the English statute, is materially different therefrom, and the difference has been construed as substantial. Thus the English statute was eonstrued as empowering the court to compel througil routing of passengers or freight. The commission held in an early case, 1 I. C. C. R. St, 1 Int. Com. Rep. 3.i, that this seetion of the act did not compel one railway company to sell through passenger tickets over the roal of another company. In the Kentucky and Indiana Bridge case, decided in 1590 , which was really the pioneer case in the construction. of the act, 37 Fed. Rep. $56 \pi$, Jackson J. said that the Commission was not vested with authority to establish through routes nor to fix through rates between connecting lines.

It has since been definitely determined by the repeated decisions of the Conrts that there is no authority in the Commission or in the Courts under the act to eompel either the routing of passengers or freight, and that the requirement of this section for the afforting of all reasonable and proper fatilities for the interehange of traffic and the reeeiving, forwarting and delivery of passengers and property does not mean the receipt and delivery of cars or their through routing of any kind, but only the receipt and delivery of freight and passengers at connecting points without discrimination. This had been the construction given by the Supreme court to the constitution and statute of Coloraclo prior to the enactment of the Interstate Commerce Act. A. T. \& S.F. L. Co. v. Denver \& N. O. R. Co., 110 U. S. 657, 25 L. Ed. 291 ; and such has been the construction given to the Interstate Commerce Act in a number of eases in the Circuit courts and Cireuit Courts of Appeal, cited approvingly by the supreme Court in the Central Stock Yards case, supru, 192 U.S. 565, tS L. Ed. 565. See also Little Rock \& M. R. Co. r. St. Louis Iron Mountain \& So. R. Co., 41 Fed. Rep. 5.59 and 59 Fed. Rep. 400; (Hegon Short Line \& Utah Northern R. Co. v. Northern Pacific R. Co., dil Fed. Rep. 15s, 9 C. C. 1. to9; Allen v. Oregon Railroad \& Navigation Co., 9s Fed. Rep. 615. It was held in all of these cases that through routing of passengers or freight depends upon contract voluntarily made between the earriers, and there is no power in the Commission or Courts to- 
ensorce the making of such a contract. Prescott \& Arizona Central R. R. Co. v. A. T. \& S. F. R. Co., is Fed. Rep. 438, wherein the court comments on apparently different ruling in X. Y. N Northern R. R. Co. v. X. Y. S. E. R. R. Co., s0 Fed. Rep. sei. For discrimination by carrier between competing local transfer companies, see St. Louis Lrayage Co. v. L. it N. R. R. Co., 65 Fed. Rep. 39. The Commission said that in the Act to Regulate Commerce, Congress intended to effect the same results as the English statute, but omitted the machinery necessary to accomplish it, and it was therefore recommended that the Act be amended in this particular. The Commission has in its annual reports recommended to Congress to give the necessary authority by new legislation.

A rail carrier may make a throngh rate with one line of connecting steamboats, and refuse to make such rates with other steamboats. 4 I. C. C. R. 265 , 3 Int. Com. Rep. 279 . The words "track and terminal facilities" in this section refer to all rail carrier, or a carrier part rail and part water, but not to an independent water line.

s. 21\%. Discrimination in exacting prepayment from connecting carriers not mujust discrimination.- - It follows from the principle, that through routing is a matter of contract, that while the carrier is obliged to receive passengers and freight from other roads at connecting points, it is not obliged to waive the requirement of prepayment, and it therefore follows that the requirement of prepayment on freight on all property received from one carrier and not exacting such prepayment from a competing carrier is not an unjust discrimination. See Little Rock d II. R. Co. v. St. Louis it Southwestern R. Co., 11 C. C. A. 416, and Gulf, Colorado \& Santa Fe R. Co. v. Miami Steamship Co., 30 C. C. A. 142, S6 Fed. Rep. 407; Itwaco Ry. \& Navigation Co. v. Oregon Ry. \& Navigation Co., 4; ( C. A. 495, 57 Fed. Rep 67:3. Little Rock \& M. R. R. Co.

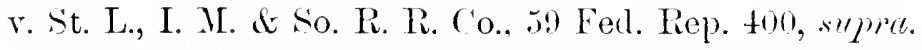

213. State control of interchange of interstate traffic.-Quesions have arisen out of the anomalous control of commerce by gorernmental authority of the States and the United States, as the same carriers are controlled by the State with reference to their intrastate traftic, and by the Federal Government as to in- 
terstate traffic. A belt or switching railroal is subject to the State authority when it charges local rates for its traflic and makes no interstate routing, while it becomes subject to the Federal law when it joins with other carriers in making through shipments of interstate tratfic. In the louisville stockyarls litigation, under the provisions of the State Constitution of Kentucky it was claimed that the defendant company was lequired to receive and deliver freight in the carloals to any point that was in physical connection with the tracks of another company. It was said by the Enited States Coart of Appeals for the sixth circuit, 55 C. C. A. 6:), 118 Fed. Rep. 11:, that assuming, withont deciling, that the Kentucky Constitution and legislation made such requirement, that the state could not regulate interstate connerce, using the term in the sense of intereourse and interchange of tratlic between the states. The power of the State to require connecting trackis between two railroal companies at an intersection for the transfer of cars used in the loeal business of snch line of railroad was eonceded. In the case before the conrt, it was not the means of making a physieal connection with other railroads that was ained at, but it was sought to eompel the ears and freight received from one state to be delivered to another at a particular place and in a particular way. If the Kentucky Constitution could be given any such construction, it would follow that it could regulate interstate commerce. The judgment in this case was affirmed by the supreme Court, in 192 U. S. stos. The latter Court did not decicle this question of the power of the state with reference to interstate traffic, as it construed the Kentucky Constitution as referring only te eases where freight was destined to some further point by transportition over a connecting line. It will be seen that in this case there was no authoritative construction of the State Constitution and statute by the judiciary of the state.

At the time this suit of the Central Stockyarls was filed a proceeding was also instituted before the Interstate Commeree Commission by the Railroad Commission of Kentucky, and the decision of the Supreme Court was followed by the Commission, dismissing the complaint. 10 I. C. C. R. 173.

$\$$ 214. State and municipal control of terminals.- The last clause of the section, providing that the directing of facili- 
ties for interchange of traffic should not be construed as requiring the carrier to give use of its tracks or other terminal facilities to another carrier engaged in like business, was construed by the Lnited states ('ircuit Court of Iowa, in State of Iowa r. ('hicago, Milwalukee d st. Paul Railroal Co., 33 Fed. liep. 291, in 1s-7, soon after the aloption of the Act. The state of Iowa liled a hill in the state court against the defendant carrier to enforce an order of the state Boarl of Railroad commissioners reyuiring the defendant to pass cars of other companies orer its siding in the city of Dubuque at reasonable rates fixed by the board, the sidings having been laid under the permission of the eity on condition that they shonld be open to all. The defendant carrier moved the case to the Inited States Court, there being no liverse citizenship, on the sround that a federal question was involved, to-wit, its right in interstate traffic unler section 3 of the Act. The Court sustained motion to remand the ease, saying that the provision in the section as to the terminal facilities simply declared that the preceling provision of the section should not be deemed to gire the right to one carrier to use the tracks or terminal facilities to another carrier in like business, ant had reference to the effect of the Act of Congress, and to nothing else saying: "If the defendant company by a contract with the city of 1) abume has bound itself to allow other companies to use part of its tracks or terminal facilities, this clause of the Act of Congress does not affect such a contract or the enforcement thereof. so also if the State of Iowa has provided by proper statute that different companies may have a joint or common use of certain terminal facilities, the rights of the several companies to such joint use are not affected by the prorisions of the Interstate Commerce Act, but the same must be determined by the stitutes of the state." See also Interstate Stockyards Co. v. Indianapolis U. R. Co., 99 Fed. Rep. 472, where there was a similar state and municipal regulation for the use of the terminal tracks.

?.j. 'The charging of local rates not an unjust disrimination.- $A$ s through rates and through billing are a matter of agreement between the carriers in interstate commerce, it follows that when a carrier with whom connecting carriers decline to make through rates delivers freight, it only 
has the right to demand that other carriers receive from and deliver freight for transportation at their published local tariff rates. See + I. C. C. R. 265,3 Int. ('om. Rep. $278 ; 3$ I. C. C. R. 450,2 Int. Com. Rep. 721 . As to the distunction between local and through rates, sce supre, section :2.

It was ruled by the Commission in 7 I. (. C. R. 32:), that in the absence of some agreement or urderstanding with a connecting line by which the joint tariff rates was authorized, a given carrier cannot law fully apply any other rates than those which it fixed for the transportation between the points fixed by its railroald; and the rates so fixed are the only lawful rates which the carrier may charge for any transportation service which it may perform. The only rates authorized by the Act are the rates established by a single carrier upon its ronte and the joint rates over continuous lines or routes operated by more than one carrier.

But while a carrier is not bound to make through routing, and in the absence of such agreements for through ronting may charge its regular tariff rates, those charges must be recasonalle for the sarvice.

In Augusta Southern Ry. Co. v. Wrightsville \& T. R. Co., it Fed. Rep. 5.2, the court held that in the absence of through routing the carrier was not entitled to charge the full local rate permitted by the state law on freight which was not in reality local, but through freight. The decision in this case however cannot be reconeiled with the authorities cited above unless upon the ground that the rate was unreasonable per se for the service.

sib. The right of exchsive through routing. - As through routing rests upon contract, it follows that a carrier may lawfully make a contract with one connecting carrier for through ronting to the exclusion of another'. This subject has been extensively litigated in exclusive contracts in what are known as the Live Stock cases. While it is the duty of a railroad company to provide suitable facilities for receiving and delivering live stoek at its stations without adlitional compensation other than the regular transportation charge, it may provide these facilities by making an exclusive contract with one stockyards company, and as long as this company injposes no charge for delivering livestock when that stock is taken by 
the consignee within a reasonable time, such contract is not obnoxious to haw. Covington r. Keith, 1:3! L. S. 128, 35 L. Ed. 7:3 Butehers it Drovers Stockyards (o. v. L. \& $\mathrm{X}$. R. Co., 14 C. C. A. 2!n; Central Stockyards Co. r. L. \& X. R. Co., 50 C. C. A. 63,115 Fed. liep. 113,192 [. S. 565,48 L. Ed. 565.

In the case of the Interstate Stockyards Co. v. Indianapolis U. R. Co., 99 Fed. Rep. t:- the Indiana Cireuit Court held that a belt line connecting with the different carriers and making agreements for continmous shipments of interstate commerce hat no right to. discriminate against different stockyards by refinsing to deliver stock at one of the yards, though consigned to the owner for care, and the court granted a temporary injunction arainst the discrimination. In this case howwer the terminal road was expressly required by the State statute and its city franchise to render such services without discrimination, and it seems that the track connection had been male and the injunction was against the interruption of the service theretofore rendered.

s:17. Contract rights of trackinge. - In the absence of statute the rights of a railroar company under a lawful agreement for the specified use of the tracks of another railroad company are measured in respect to the direct use in the terms of the contract, and the provisions of the Act to Regulate Commerce apply to the situation created by the contract, and add no authority for a different use of the track. 3 I. C. C. R. 519, 2 Int. Com. Rep. $7 i 1$. In this case it was ruled by the Commission that the Rock Island Railway Company which operated the Union Pacific tracks between Kansas City and Topeka upon condition that no intermediate business should be done by the Rock Island Company on any part of the line used under the agreement, the Union Pacific Company retaining the control of the road and supplying accommodations between the intermediate points and Kansas City. The majority of the Commission said that such running arrangements existed in many parts of the country and were of great service in transportation. Chairman Cooley doubted the validity of the contract, but agreed that the commission had no jurisdiction to interfere with the arrangement.

In Inion Pacific Railroal ('o. v. Chicago. etc., R. Co., 163 L. S. sit, +1 L. El. 265,207 , the supreme Court held that a 
later contract made between the same parties for trackare rights by the Rock Island Company orer the Lnion Pacitic tracks from Council Bluffs to South Omaha, and giving the Union Pacific Company the right to operate the liock Island tracks between South Omaha and Lincoln, was valicl, and the Court said that such business arrangements were in accord with the policy in firvor of continuous lines declared by ('ongress in the act of 1860 (supree, it), and that a railroal could contract to give another running rights over its tracks without express statutory authority, and the decree of the court below specifically enforeing the contract was allirmed. The contract in this case provided that the Union Pacific Company should do no intermediate business on the liock Istand's tracks.

\$215. Rights of cometting carriers as to milling in transit privileges. - As through routing is based upon contract and the relation is not created by any application of the common law or requirement of statute, it follows that any railroad company may decline to become a party to any agreement for through routing unless the terms and conditions are satisfactory to it. This principle has been applied by the Commission, 9 I. C. C. R. :311, to the privilege of milling in transit granted by some roads. As before shown the Commis. sion has approved of this practice as promotive of commeree but no authority is given by the Act, to the Commission, to regulate the granting of such privileges. The Commission ruled howerer that the Boston of Maine Railroad, receiving traffic from the west, was not compelled to apply that rate on shipments of feel, ground in transit; and that it was not bound by a private arrangement existing between the shipper and the carrier from whom he received the privilege, to grind his corn in transit. It was ruled in the same case however, that while the connecting carrier was not bound by the arrangement for milling in transit, it could impose an arbitrary charge in addition so the regular through rate on the milled product.

As to right of carriers to juclicial protection in the interchange of traflic, see infra, section $S$, and as to unlawful combinations interfering with such interchanges, see infiru, section 10 . 


\section{Sretion 4.}

Page.

§ 219. Long and short haul provisions... . . . . . . . . . . . 260

290 . History of the section. . . . . . . . . . . . . . . . . . 260

2:1. " Under similar circumstances and conditions."........... 261

2.?. Competition unler section 4 and unler section $2 \ldots \ldots \ldots \ldots .262$

2:3. "Over the same line." ......................... 26:3

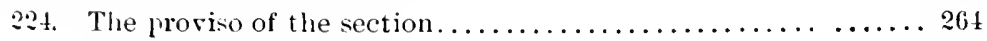

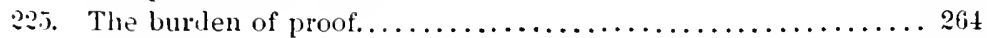

S 21!. Lone and short haul provisions.-Sre. 4. That it shall be unlawful for any common carrier subject to the provisions of this act to charge or receive any greater compensation in the aggregate for the transportition of passengers or of like kind of property, under substantially similar circumstances and conditions, for a shorter than for a longer distance over the same line, in the same direction, the shorter being inclured within the longer distance; but this shall not be construed as anthorizing any common carrier within the terms of this act to charge and receive as great compensation for a shorter as for a longer distance: Provided, fim, That upon application to the ('ommission appointed uncler the provisions of this act, such common carrier may, in special cases, after investigation by the Commission, be authorized to charge less lor longer than for shorter distances for the transportation of passengers or property : and the Commission may from time to time preseribe the extent to which such designated common carrier may be relieved from the operation of this section of this act.

: $:$ o. History of the section. - This section was not based upon any provision in the English statute, and it was more thoroughy discussed in Congress and was the subject of more divergent opinions than any other. The Ilouse bill, known as the heagin Bili, contained an absolute prohibition against charging more for a shorter than for a longer distance, even where the longer distance included the shorter; while the Senate bill, known as the (ullom Bill, contained a similar prolibition yualifiel by the allowance of the granting of exceptions by the Commission in special cases. The section in its present form was reported by the Conference Committee of the two houses, and contined the words "under substantially similar circumstances and conditions," then introduced in to the fourth section for the first time, having theretofore been incorporated into the second section. See 1 I. C. C. R. 6, 1 Int. Com.

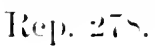




\section{\$ ?21. "Cuder similar circumstances and conditions." -}

The judicial discussion of the section has turned upon the meaning of the words"under similar circumstances and conditions" and upon the effect of competition in determining dissimilarity of circumstances and conditions. In one of the earliest cases decided by the Commission, June 15th 15st, on an application of the Lonisville of Nash ville Railroad Company for relief under the discretionary power given by the Commission, it was held in an opinion by Chairman Cooley, 1 I. C. (. R. 6, 1 Int. Com. Rep. 27s, that the existence of actual and controlling competition in respect of traffic important in amount might make out "dissimilur" circumstances and conditions," in the following cases:

(1) When the competition was with carriers by water which are not subject to the provisions of the statute; (2) when the competition was with foreign or other railroads which were not subject to the provisions of the statute; and (3) in rare and peculiar cases of competition between railroads which are subject to the statute, when a strict application of the general rule of the statute would be destructive of actual competition.

This in effect left with the railroads to determine in the first instance the existence of these rare and peculiar cases of competition. Subsequently, in 1892 , the Commission orerruled this earlier decision so far as it prohibited carriers from judging for themselves in the first instance as to railroad competition, and held that in no such case could a carrier judge for itself, but it should apply to the Commission under its power to grant relief, when, after in vestigation, the Commission, if satisfied that that the interests of commerce and common fairness of the carriers so required, could direct that an exception should be made. 5 I. C. C. R. 324 , 4 Int. Com. Rep. 121; 5 I. C. C. R. 596, 4 Int. Com. Rep. 267.

These rulings were contested in the courts, and fire years later, in 1897, the Supreme Court overruled the Commission, and established the rule which has been adhered to in a series of decisions, that competition of any lind, that is, whether from railroals subject to the act or not, was one of the most obvious and effective circumstances that made the conclitions which its long and short haul would provide substantially dissimilar, and as such must have been in the contemplation of Congress in the passage of the Aet to Regulate Commerce, and 
that such competition when controlling, justified the earrier in making a lower rate for the longer haul, not as a matter of grace or faror from the Commission, but as a matter of right. Import Rilte case, 162 U. S. 197 , t0 L. Ed. 940; Commission v. Alabama Midland Railroald Co., 165 C. S. 14t, 4 L. Ed. 414 ; L. \& X. Railroad Co. v. Behhmer, 175 U. S. 6ts, tt L. Ed. 309; East Tennessee, Virginia \& Georgia Railroad Co. r. Commission, 1 \& L. S. 1, t5 L. Ed. 719, 729; Commission v. L. \& $\mathrm{N}$.

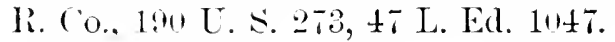

As to the relation of this ruling to the prohibition of undue preferences under section three, and as to the porrer of the commission to determine the reasonableness of rates, see section three. suprel, 183 . In 9 I. C. C. R. 534 , the eity of Wichita complained of rates on grain from Wichita to Galveston. The commission followed the ruling of the Supreme Court of the Inited States and held that the third and fourth sections of the act prohibited disparity of rates between the longer and shorter distance points provided the longer distance competitive point rate is remunerative and the shorter distance point rate is reasonable, and also that its order therefor could be directed against the un reasonableness of the Wichita rate and not against the adjustment of rates. See also 9 I. C. C. li. 5 .

In another Wichita case the Commission had ruled before the construetion of the section by the Supreme Court that any higher charge to Wichita from Kansas City on shipments from Galreston was violative of seetion four. But in 10 I. C: C. R. 460, deciled in January 1905, the Commission said that this ruling was no longer applicable since the deeision of the Supreme (onrt, and that the carriers are not prohibited from charging the higher rate from New Orleans to Wiehita and Kansas City, but that the existing differential was excessive and unduly preferential. See supra, $\leqslant 183$.

The rule is based on distance and relates to actual transportation charges, and not to demurrage eharges, which are in the nature of charges for storige in the cars of the carrier. $S$ I. C. C. R. .; 1.

ב. Competition under section 4 and under sertion 2. It was held in Wight v. Enited States, supra, that the phrase "under similar circumstances and conditions" as used in the 
second section, refers to the matter of carriage, and does not include competition between rival rontes. This was in a case where the discrimination was between two shippers in the same town. It was said by the Supreme Court in the Alabama Midland case, supre, that competition under section 4 was not open to the criticism that different meanings were attributable to different words under different sections of the Act; that as the purposes of the several sections were different, the phrase must be read in the second section as restricted to the case of shippers of the same road, thus learing no room for the operation of competition; but in section 4 , which covers the entire track of interstate commerce, a meaning must be given to the phrase wide enough to include all the facts which have a legitimate bearing on the situation, among which is the fact of competition, when it effects rates. See section 2, supret.

293. "Over the same line."- The view was expressed in the opinion in the United States Court of Appeals, Osborne v. R. R. Co., 3 C. C. A. 347,52 Fed. Rep. 912, that when two railroad companies owning connecting lines of road unitc in a joint through traflic with the view of making the connecting roads a new and independent line, the through tariff on the joint line is not a standard by which the separate tariff of other companies is to be measured in determining whether the fourth section was riolated. In the Social Circle case, $16: 2$ U.S. 184, supre, 40 L. El. 985, a Georgia railway company whose road lay wholly within the state of Georgia and exacted and receired its regular local rite for the transportation on its line, on a through bill of lading, the rate of which was fixed by alding that local rate to the through rate from ('incinnati to Atlanta, was held subject as to the through bill from Cincinnati to Social Circle to the Federal Act and to the control of the Interstate Commerce Commission. The Court distinguished the Osborne case, supe, upon its special filcts, and said that when goods shipped under a through bill of lacling from a point in one state to a point in another are received in transit by a state common carrier on a conventional division of the charges, such carrier ninst be deemed to have subjected the road to an arrangement for a continuous carriage or shipment within the meaning of 
the Act to Regulate Commerce. IIaring elected to enter into the carriage of interstate freights and thus subjected itself to the control of the Commission, the carrier could not withdraw that control with respect to foreign traflic to certain points on its roal and exclule other points. The court added: "When we speak of a through bill of laling, we are referring to the usual methods in use by comnecting companies, and must not be understood to imply that the common control, management or arrangement might not be otherwise manifested."

s.: The proviso of the section.- It is obrious that since the authoritative ruling of the supreme Court as to the right of the carrier to judge for itself in the first instance of the controlling effect of competition in determining rates, the necessity for a resort to the diseretionary powers of the Commission under the proviso has been very materially changed. such applications were comparatively numerous, as will be seen from the Interstate commerce Reports during the period when a different rule prevailed. It is unnecessary therefore to refer to the rulings of the ('ommission upon the specific applications for weh relief made under a theory of the law afterwardsdeclared erroneous. For a summary of the C'ommission's rulines, see annual report of 15.2, pp. 1 is to 21 ; 1893 , p. 22; 1:54, p. 13: 15!\%. p. .24.

Petitions for relief were asked on other grounds than that of controlling competition. Thus the World's Fair at Chicago was hell in 4i I. C. C. R. :32:) and 6 I. C. C. R. 328. to be a case of an exceptional and special nature justifying relief from the operation of thesection. The same ruling wi.: made in the case of an application on account of crop failure and the necessity of reduced rates for the transportation of food for the people and their animals. These cases however were exceptional and nearly all the applications for relief were on the gromel of controlling competition. It was said by the commission in its report of 1-45 that the effect of the decisions of the supreme ('ourt was to eliminate the fourth section from the Act.

9.9.5. The burlen of proof.- Although this judicial construction of the term "under similar circumstances and conditions" has had a very profound effect ppon the alministration of the Act, it is not strictly correct to say that its effect 
was to eliminate the fourth section. It does put upon the carrier the burden of proving the existence of dissimilar circumstances and conditions for its justification when the fact of the greater charge for the shorter haul orer the sime line appears. In other cases of alleged unrlue preference or discrimination, the burden is obviously upon the party complaining. For illustrations of the Commission's application of the Supreme Court's construction of the section to special facts, see 7 I. C. C. R. 431 , 4.it, 458; S I. C. C. R. 98 , 110, 290, 346 , $531 ; 9$ I. C. C. R. $42,534,551$. 


\section{SECTIOX 5.}

ร 296 . Pooling of freights and division of earning forbidilen....... 266

$2:$ Construction of section....................... 266

32: Controlling through routing to connections by initial carrier. . . . . ........................... 20.

: $: 9$. Agreements not within the prohihition................. 208

$2: 30$. The relation of the section to the Anti-Trust Law of $1930 \ldots . .299$

231. Pooling as a defense to action of the carrier............ 270

S: Pooling of freights and division of earnings forhidden.- SEC. 5. That it shall be unlawful for any common carrior subject to the provisions of this act to enter into any contrat, agreement. or combination with any other common earpice or tirlusers for the pooling of freights of clifferent and competing railpouls, or to divide between them the agraregate or net proceets of the earuings of such railroads, or any portion thereol: and in any case of an anpeement for the pooling of freights as alforesalid, each day of its continuance shall be deemed a separate offense.

:28. Construction of section.- This section was more thoroughly discussel in Congress and in the public press before the enactment of the statute than any other, except the long and short haul provision of section t, yet in view of its importance and it declaration of public policy, it has received comparatirely little discussion in the conts or before the Commission. In 11.5 Fed Rep. 5as, this section was construed by the conrt, Hammonl, J., in the western district of Tennessee, in a charge to the grand jury. He said that the statute contemplated two methods of pooling, both of which were prohibited. First a flysimel pooling, which means a distribution by the carriers of property offered for transportation on different and competing railroals in the proportions and on the percentages previously atereed upon; and secondly. a money pooling. which is described best in the language of the statute, "to divile between them (different and competing railroals) the agcregate or net proceeds of the eilrnings of such railroads, or any portion thereof." The court in its charge adopted the definition of the word "pool" from the century Lictionary, as:

"It is a combination intended by concert of action to make or control changes in the market of rates: . a combination of the interests of several otherwise competing parties, 
such as rival transportation lines, in which all take common gromnds as regards the public, and distribute the profits of the business among themselves equally or aceording to speeial agreement. In this sense pooling is a srstem of reconeiling conflieting interests and obviating competition by which the several competing parties or companies throw their revenues into one common fund, which is then divided or distributed among the members of the pool on a basis, percentage or proportion previously agreed upon or determined by arbitration."

The agreement of the southern Rialway and steamship Association provicled for a division of territory between eastern and western lines, and also a system of fines and penalties among the nembers for violation of the assoeiation rules. The Commission said in 6 I. C. C. I. 195, that these fines and penalties are available as substitutes for the penalties which would be exacted uncler a regular pooling system, and that the arrangement was tantamount to a combination forbidden by the section, and that the law had regard to the substance rather than to the form, and that whatever it prohibited from being done directly could not legally be done indireetly.

$\$$ :28. Controlling through routing to connections by initial carrier. - In the Southern ('alifornia Fruit case, 9 I. C. C. R. 182, the Commission found that there was a tonnage pool of traffic as between the conneeting earriers, and that the through routing was controlled so as to give specific percentages of traflic to their several connections, thereby lulfilling and giving effect to this unlawful arrangement, and that the suppression of the practice of allowing rebates was only an incidental result of and was not the primary and principal object of the defendant carriers in taking over to themselves the routing beyond their respective roals, but that the object was to give effect to this tonnage division. Suit was brought in the southern district of California to enforce the Commission's order to desist from this practice. Interstate Commerce Conmission v. Southern Pacific Company et al, 123 Fed. Rep. 597. The Court held that the order was pime facie valid and enforeible, and the demurrer thereto was overpuler.

On final hearing in the same ease this ruling was affirmed. 132 Fed. Rep. 829. The Court said that the worl "freights" in the section meant the commolities carried, and not the compensation paid for the carriage. and that the praetice of conditioning the through rate upon the reservation to the in- 
itial carrier of the absolute power to route the shipments beyond its own lines for the declared purpose of enabling the initial carrier to control and maintain the rate so fixed by prerenting competition, either direct or inclirect, between their connecting carriers, created in effect a traffic pool within the meaning of section 5 of the Interstate Commerce Act. Pooling and rebates were both within the prohibition of the Act and that one could not be lawfully employed as preventive of the other. It was held also that an order of the C'ommission requiring the railroals joining in the agreement to desist from enforcing the rule and practice was not legislative in character. hecanse the rule was embolied in the joint through tariff published by the other carriers, where it is also promulgated to the public and enforced against all shippers.

s.e?. Agrements not within the prohibition.- An agreement for the dirision of through freiglits between the members of a trunk line is not within the prohibition of this section. Neither is an agreement for consultation for the promotion of reasonable rates. 6 I. C. C. R. S.. In this case the Commission held that the agreement of the transeontinental association was not within the prohibition of the section, as there was no provision for the actual pooling of freights or division of earnings between the parties, and it was not shown by the agreement itself or other evidence that the measures providel therein for fixing and maintaining rates constituted a contract, agreement or combination in violation of section 5 , or that those measures if carried ont in good faith for the purpose named, would lear inclirectly to the same result as the actuil pooling of freights and division of earnings prohibited by the Act.

The operation and conduct of the Immigrant Bureau of the Western I'assenger Association, whereunder the immigrant traflie was divided between the carriers in the agreed proportion based upon the proportion of the domestic passenger traffic lone by each line, was not within the prohibition of the section. 10 I. C. ('. R. 1\%. The ('ommission sail that the section forbacle a division of the agregregate or net proceeds of the carnings of such competing railroals, whether such earnings arise from freight or passenger business, but for some reason it did not provide specifically against a division of passengers 
between competing roads. The amount of the immigrant traffic was insignilicant compared with the general tratlic of the railroads, and there was no discriminations against individuals, as the immigrants were forwarled at the domestic published rates and that the arrangements had eventually prompted the protection and greatly improved the comfort and treatment of immigrants. The Commission declined therefore to take any action in the premises.

It would therefore follow that the prohibition of this section must be limited to an actual pooling of freights of competing railroals or the division of earnings, and would not include agreements between carriers looking to the convenient and expeditious handling of their business at terminal points which are not for revenue and therefore not subject to the specific prohibition of this section or of the Anti-Trust Act. See infia, $\$ 324$.

\$:39. The relation of the section to the Anti-Trust Law of 1890 . - The prohibition of pooling contained in this section has been considered in connection with the judicial discussion of the prohibition of all forms of combination whether of trusts or otherwise in restraint of interstate commerce contained in the Anti-Trust Law of 1590.

This section prohibits only the specific form of combination which comes under the definition of pooling, and it is limited to such agreements made by a common carrier subject to the pravisions of the Act "with any other common carrier or carriers." Thus it was ruled in the case of a complaint alleging an agreement for the pooling of freight between certain railroads and the Standard Oil Company, b I. C. C. I. 415,4 Int. Com. Rep. 16:, that such an agreement for the pooling of traffic between a carrier by rail and a carrier by pipe line did not fall within the description of contracts prohibited by section 5 . In the opinion as to the relation of express companies to the act, holding that they were not included therein (see section 1, sepre , the Commission said that the prohibition of section 5 did not include express companies, who were therefore at liberty to pool their earnings. 1 I. C. C. R. 349, 1 Int. Com. Rep. 677.

In United States v. Trans-Missouri Freight Association, 14if U. S. 29 !, 41 L. Ed. 1007, it was urged that as the Commerce 
Act related solely to railroads and their proper regulation and management, the act of 1890 should be construed as applying to all contracts of the nature therein described, entered into by any other than competing common carriers by railroads for the purpose of establishing rates of traffic and transportation. But the Court said that the fifth section of the Interstate Commerce Act prohibited what was termed "pooling." because prior to the passage of the Act railroad companies had sometimes endearored to regulate competition and maintain rates by pooling arrangements, and in the Act that kind of arrangement was forbidlen, and while the Act did not prohibit such. an agreement as that of the Trans- Nissouri Freight Association, it did not authorize it, and both statutes stand, as neither was inconsistent with the other. The conrt sail that the amendment of the Interstate Commerce let would not have been an appropriate methor of dealing with other derices to suppress competition for the reason that the later act included other parties than common carricrs. (See Act of 1590 , infia).

3:31. Pooling as a defense to action of the carrier.-In 1). I. \& W. R. Co. r. Frank et al, 110 Fed. Tep. 689, the United States ('ircuit Court for the western district of New Tork, denied an injunction agrainst certain ticket brokers as to special excursion tickets issued for the Pan-American Exposition at Buffalo on the ground that the complicinant with other railroals lad made an unlawful combination for the fixing of rates and pooling earnings.

A contrary ruling howerer has been made in the United States Circuit Court for the eastern district of Missouri, unreporterl, and in Kinner v. Lake Shore \& Michigan So. Ry Co., 69 ()hio St. Rep. 39:9, on the ground that the alleged unlawful combination did not relate to the specific business sought to be enjoined. 


\section{SECTION 6 .}

§ 232. Printing and posting of schelule of rates, fares and charges

Page etc. . ................................ $2 \tau_{1}$

233. Amendments ................................. 2\%3

234. Effect of publication ......................... 2it

235. Enforcibility of uupublished rate against the carrier ....... 25.5

235. What is included in schedules................... 2:

23\%. What is sufficient publication and filing.............. 278

238. Joint tarifts and through rates.................... 279

239. Published joint rates must be duly authorized.......... $20_{0}$

240. Application to export and import rates ............... s 81

\section{\$ 232. Printing and posting of schedules of rates, fares}

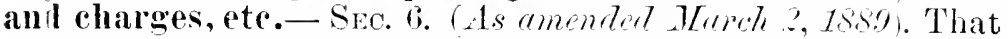
every common carrier subject to the provisions of this act shall print and keep open to public inspection schedules showing the rates and fares and charges for the transportation of passengers and property which any sueh common carrier has established and which are in force at the time upon its route. The schedules printed as aforesaid by any such common carrier shall plainly state the places upon its railroad between which property and passengers will be carried, and shall contain the classification of freight in force, and shall also state separately the terminal charges and any rules or regulations which in any wise change, affect, or determine any part or the aggregate of such aforesaid rates and fares and charges. Such sc , edules shall be plainly printed in large type, and copjes for the use of the public shall be posted in two public and conspicuous places, in every depot, station, or office of such carrier where passengers or freight, respectively, are received for transportation, in such form that they shall be accessible to the public and can bu conveniently inspected.

Any common carrier subject to the provisions of this act receiving freight in the Lnited states to be carried through a foreign country to any place in the United States shall also in like manner print and keep open to the public inspection, at every depot or office where such freight is received for shipment, schedules showing the through rates established and charged by such common carrier to all points in the United States beyond the foreign country to which it accepts freight for shipment; and any freight shipped from the United States through a foreign country into the United states, the through rate on which shall not have been made public as required by this act, shall, before it is admitted in to the Lnited states from said foreign country, be subject to customs luties as if said freight were of foreign production; and any law in conflict with this section is hereby repeated. 
No adrance shall be made in the rates, fares and charges which have been established and published as aforesaid by any common carrier in compliance with the requirements of this section. except after ten dars" public notice, which shall plainly state the chinges proposed to be made in the schedule then in force. and the time when the increased rates, fares, or charges will go into effect; and the proposed changes shall be shown by printing new schedules or shall be plainly indieated upon the scherlutes in force at the time and kept open to public inspection. Reductions in such published rates, fares or charges shatl only be mate after three days previons public notice, to be given in the same manner that notice of an advance in rates must be given.

Anl when any such common carrier shall have established and published its rates, fires, and charges in complance with the provisions of this section, it shall be unlaw ful for such common carrier to charge, demand, collect, or receive from any person or persons a greater or less compensation for the transportation of passengers or property, or for any services in connection therewith, than is specified in such published sehedule of rates. firres, and charges as may at the time be in force.

Ever common carpier subject to the provisions of this act shall tile with the ('ommission hereinafter provided lor copies of its schedules of rates, fares, and charges which have been established and published in compliance with the requirements of this section, and shall promptly notify said ('ommission of all changes male in the same. Every such common carrier shall also file with sald ('ommission copies of all contracts, anpecments, or arringements with other common carriers in relation to any traflic alfected by the provisions of this act to which it may be a party. And in cases where passengers and freight pass orer continuous lines or routes operated by more than one common carrier, and the several common carriers operating such lines or rontes establish joint tarilfs of rates or farres or charges for such continuous lines or routes, copies of such joint tallifs shall also, in like mamner, be filed with said commission. Such joint rates, fares, and eharges on such continuoms lines so filed as a foresail shall be made public by such common carrieps when directed by saill Commission, in so far as may, in the jullnment of the commission, be deemed prateticalle: and said commission shall from time to time prescribe the meatsure of pubicity which shall be given to such rates, lares and charges. or to surh part of them as it may deem it practicable for such common carriers to publish, and the places in which they shall be published.

No advance shall be male in joint rates, fares, and charges, shown upon joint tarills, except alter ten days notice to the fommission, which shall plamly state the changes proposed to be made in the sehedule then in force, and the time when the 
increased rates, fares, or charges will gro into effect. No reduction shall be made in joint rates, fares, and charges, except after three days' notice, to be given to the Commission as is above provided in the case of an alvance of joint rates. The Commission may malie public such proposed alvances, or sucir refluctions, in such manner as may, in its julgment, be deemed practicalile, and may prescribe from time to time the measure of publicity which common carriers shall give to advances or reductions in joint tarills.

It shail be unlaw joint tariff, to charge, demand, collect, or receive from any person or persons a greater or less compensation for the transportation of persons or property, or for any services in connection therewith, between any points as to which a joint rate, fare, or eharge is named thereon than is specilied in the schecule filed with the Commission in force at the time.

The Commission may determine ancl prescribe the form in which the scheduies required by this section to be liept open to public inspection shall be prepared and arranged, and may change the form from time to time as shall be found expedient.

If any such common carrier shall neglect or refuse to file of publish"its schedules or tarif's of rates, fares, and charges as provided in this section, or any part of the same, such common carrier shall, in addition to other penalties herein prescribed, be subject to a writ mandamus, to be issued by any (ircuit Court of the Cnited states in the judicial district wherein the principle office of said common carrier is situated, or wherein such offense may be committed, and if such common carrier be a foreign corporation in the judicial circuit wherein such common carrier accepts tratiric and has an agent to perform such service, to compel compliance with the aforesaicl provisions or this section; and such writ shall issue in the name of the people of the United States, at the relation of the Commissioners appointed under the provisions of this act; and the failure to comply with its requirements shall be punishable as and for a contempt; and the saul Commissioners, as complainants, may also apply, in any such Circuit ('unt of the ['nited states, for a writ of injunction against such common carrier, to restrain such common carrier from receiving or transporting property anong the sereral states and territories of the United States, or between the United States and adjacent foreign countries, or between ports of transshipment and of entry and the several states and territories of the Cnited States, as mentioned in the first section of this act until such common carrier shall have complied with the aforesaid provisions of this section of this act.

9:3:. A mendments. - This section was amended hy act of March $2 n d, 1859$, in the first series of amendments made to the Act. The amendment provided in the tirst paragraph lor 
the printing of the schelule in two public and conspicuous places, prohibitel reluction of rates without three days notice, and made a more specific provision as to the power ol the Commission in prescribing forms of schedules, rates, fires and challives.

This section was also amended by the so-called Elkins law of February 19, 1013, infire, 310 , in the requirement of the publication and the inviriable application of the tariff rates, and the wilful failure of the carrier to file and publish the lates or to strictly observe them until changed accorling to law wis made a misdemeanor pmishable by heary fine. The rates tiked or participated in by the carrier are also declared, as anitinst the carrier. to be the legal rate, and any departure or offer to depart from the same is made an otfense. The Commission in its report for $1: 10$ !, page 10 . recommends that these prorisions as to application and observanee shoukl be made somewhat more definite and extended to appiy to other agencies connected with transportation, such as the use of private calrs, which may now be used as a means of making concessions to shippers.

S:34. Eflect of pullication.-In Gulf, Colorado \& Santa Fe Railroad (o. r. Helley, 158 U. S. 98,39 L. Ed. 910, the supreme Court deciled that all railroarls carring interstate freight were subject to the provisions of the act to regulite commerce, and that the only rule of compensation which can be followed in regard to interstate shipments is the rate expressed in tariffs published at stations and filed with the Commission in accordance with the requirements of the Act. In this case there wasconflict between the Texas law contining a provision for recorery of a penalty in the case of a violation, while the Federal Statute prohibits carriers from devitating from tariff rates published and on file, and providing penalties for any departure therefrom. The Court beld that these two statutes prescribing a different rule on the subject-matter, exposerl a party to a conflict of duties, and that in the case of an interstate shipment, the State law must yield.

As to the effect of the published rates upon the standard of reasonableness in an action at law for alleged unreasonable chareres, see stym, section 1 .

fontracts and tallifs filed with the (ommission muler this 
section may be considered in any proceeding before the Commission, although not specilically introduced in evidence on the hearing. + I. C. C. R. isit, 3 Int. Com. Rep. 4.:?. The reduction of passenger rates without consunt of connecting lines, over which tickets are sold, and without filing schedules with the Commission was helel in violation of this section. 2 I. C. C. R. $51:, 2$ Int. Com. Rep. : +4$).$

The filing of schedules of rates with the Commission as required by statute raises no presumption as to the legality of such rates, and no omission or failure to cballenge or disapprove the schedules of rates so filed can have the effect of making rates lawful which are unreasonable. 4 I. C. C. R. 114, 3 Int. Com. Rep. 135.

When a schedule is filed announcing an adrance of general application, for which no apparent reason exists, such action is a proper subject of inrestigation, and if it thereupon appears that the adrance is unwarranted, the Commission will proceed to correct the in justice. 9 I. C. C. R. 35\%. It is the duty of the carrier to apply the rate as published, and where it appears in the complaint before the Commission that a contract was male for a lower charge than published, the contract is not binding and its violation furnishes no ground for redress under the Act. See 9 I. C. C. R. 216. The Commission said that that question had been decided by the Supreme Court in the Helfley case, supra. See amenlatory act of February 19, 1903, infra, 45 , making the failure to publish the tarifi, or to strictly abserve the tariff, until changed, a misdemeanor, and also declaring the published rate conclusively deemed to be the legal rate.

It was held in Cnited States v. De Coursey, 82 Fed. Rep. 30 , that a receiver is not criminally liable under this section for violation of a joint tariff previously established by a railroad company of which he is receiver and another company which he has not ratified, adopted or recognized in any way.

\$ 93.5. Enforcibiity of unmblished rate against the carrier. - This section provides that it shall be unlawful for the carrier to deviate from the published rates, and the recent amendment of 1903 declared that the published rate should be conclusively deemed to be the legal rate. It was held by the Circuit court of Appeals for the tifth circuit in Pondecker 
Lumber Co. v. Spencer, 30 C. C. A. 430 , s6 Fed. Rep. $\$ 46$ (decided in 1595 ), reversing 81 Fed. Rep. 277 , that where the agent of a connecting carrier by mistake has given a shipper an unusually low rate on a shipment of a special and unusual character, and the initial carrier without knowledge of such rate breaks its contract of carriage by sending the goods over a different road from that preseribed in the bill of lading, so that the shipper is compeled to pay a much higher rate of freight, the initial carrier cannot escape liability for the damages on the ground that the rate given was in violation of the Interstite Commerce let. The court said in its opinion that the Interstate Commerce Act nowhere intimates by any express languace that contracts made by carriers within the scope of their general powers are to be declared null and void in any collateral proceeding which may arise, by reason of some alleged or supposed departure from the requirements of that let with reference to fares and charges. It was not expected that each shipper should be an expert rate sheet reader, or that he should have to visit the local offices of each of the connecting lines to inspect the rate sheets that were to be posted at certain points accorling to the requirements of the Interstate Commeree Act, in order to advise himself as to what are the local rates on the connecting carriers between the points at which the connecting carriers connected, nor was it recinired of him before maling a contract that he shonld make inyury at the offices of the Commission in Washington eity to learn if a through joint rite over the route his goods were to be earried were on file there and if so, its terms. The Court sitid that any such rule would put on shippers a burden $t$, grievons to be borne and opened the doors for the practice of fratud and oppression by the agents of corporation carriers. see also opinion of Commission in 6 I. C. C. R. 655, and as to the general rule, see Mobile ot Ohio R. Co. v. Dismukes, 94 Mla. 1:;1, 17 L. R. A. 11:3; Tricy v. Tamalge, 14 N. I. 162. Isut see contra, Crepber v. Wabash Ry. Co., 63: .To. App. 1t5. In laurel cotton Mills v. (iulf \& S. I. R. Co., 37 So. Rep. 184, the fupreme Court of Mississippi held that it was not necessilly in a suit to recover a rebate under a contract of carriatge, to show that the rates had been filed with a National or State commission, and that the law would not presume illegal 
conduct, and although the contract might be unreasonable because of an unauthorized deviation from established rates, yet this was a question of fact, and the petition was therefore held good on demurrer.

\$ :36. What is included in schedules.--The section provides for the publication not only of the charges for carriage, but for a separate statement of terminal charges, and it is made unlawful for the carrier to charge a greater or less compensation for the transportation of passengers or property, or for any services in connection therewith. In the Grand IIaven Cartage case, supru, the Supreme Court said, quoting the opinion of the Commission, that cartage was not in general a terminal expense and was not in general assumed by the carrier. It said further that as it was informed from an extract from the report of the Commission for 18.99 that there were many railroul companies throughout the country which furnished cartage at their stations, but that in no instance had the rate sheets or schelules contained anything to that effect. The court suggested in a matter of that kind, that much should be left to the judgment of the Commission, and intimated that it would be proper for the Commission to include cartage when furnished as one of the terminal charges, and include it as such in their published schedules. The Commission acted upon this suggestion, see 7 I. C. C. R. 592, S I. C. C. R. 560, and made a general order February S, 1898 , directing that all carriers subjeci to the Act should plainly indicate upon the schedules published and fited with the Commission under the provisions of the sixth section . . what storige room in stations, warehouses or cars will be permitted, stating the length of time and character of the storage, the service rendered in connection therewith, and all the terms and conditions upon which the same will be granted. As to the forms and contents of rate schedules and the authority for making joint tariffs and the published rules of the Commission, see 6 I. C. C. R. 267, 4 Int. Com. Rep. 698. Storage rates and regulations must therefore be published at the stations, and filed with the Commission. 10 I. C. C. R. 352.

In 7 I. C. C. R. 559, the Commission said the object of the sixth section is to secure to the public an opportunity of knowing the rates charged by the carriers for the service rendered; 
but it is of no possible avail to state the amonnt of the rate, unless the thing or things covered by that rate is also known. Whenever any service is rendered or any privilege allowed berond the ordinary receiving, trinsporting and delivering the thing, any service often performed, as in the moving of private cars. should be open to the public and made known by the proper announcement. 9. I. C. C. R. 1. In this case the commission said that the carrier should exchule from its road all private cars, or else preseribe in its tariffs the rules and rates under which they would be transported.

Any rules or regulations which in any wise change, effect or letermine any part of the aggregate of the carrier's rates, fares or charges must be slown separately upon the carrier's posted schedules or charges, and any such rule promulgated by the carrier in circuars independent of its published rates or schelules is unlawful. TI. C. C. R. 25.5. This principle was applied in the case of circulars issued by a railroal company prescribing maximum and minimum carlond rates for grain. The Commission sail that the shipper had only to consult the schedwe showing defendant's rates and charges, and that he was entitled to recover charges collected on a shipment in excess of those set lorth in the schedule.

It was held by Cniterl states Circuit Court of Appeals for the serenth circuit, in Walker 5 . Keenan, 19 C. C. A. fos, 7:) Fed. Rep. 755, reversing 64 Fed. Rep. 992, that a railroad company could by posting schelules make a charge for freight over its own line, and a separate teminal charge of a fixed sum per car for delivery at the stockyards, which were located off its own lines, and to corer the cost of transportation to such stocliyards over the line belonging to the stockyards company.

\section{8;. What is sullicient publication and filing.- Sched-} ules of joint tariffs required to be filed with the Commission need not be duplicated by each company which unite in making them. 1 I. C. C. R. 225, 1 Int. Com. Rep. 595. The receipt of a written statement from each company acknowledring the authority for filing the tariff on its behalf is sufficient. The posting of notices in a railroal station, that all rates are on file in the office of the station agent and may be examined on application to the agrent, is not sufficient. $T$ I. C. C. R. 43.9 I. C. C. IR. 221. 
Shippers and consignees cannot depend for the lawful rate and charge upon statements, as they must be guided by the published rates themselves, and the schedules must therefore be sufficient to give the necessary information. 7 I. C. C. R. 225.

The only satisfactory method of publishing rates, 6 I. C. C. R. $4 S S$, is to definitely state the charges fixed between points ' clearly specified, without burdening and confusing the public with the need of making of involved calculations or with analyzing a series of statements to determine whether a particular rate has been changed since the particular tariff was issued. Thus published tariffs specifying rates upon standard articles, as regetables shipped from Florida, should state plainly the weight or dimensions of the erate to which the rate should apply. S I. C. C. R. 5 S5.

Rules or regulations which, if enforced, would result in changing or affecting rates or charges shown on published schedules, must be notified to the public for the time required by law for other rate changes. The notice should set forth the changes proposed to be made in the schedules then in effect, and such changes must be shown by printing new schedules or be plainly indicated upon the schelules in force at the time. 7 I. C. C. R. 255 . As to publication and filing of rate schedules, see annual report of Commission of 1904 , p. 64 .

\& 39s. Joint tariffs and through rates.- As to both classes of rates, that is, whether orer the line of a single carrier or over a continuous line operated by more than one carrier, the provision is uniform that established rates should not be increased except after ten days notice, or reduced after three days notice, and as to these two classes of rates the provisions of the law differ in no respect except one, and that is that the Commission may prescribe a measure of publicity which the carrier should be required to give of their rates and fares on such continuous route, while on the other class the requirements are specifiel in the law itself. Such exception does not go to the form, substance or application of the rates in any degree whatsoever; and the Commission has by order of March 2:, 18s?, prescribed that carriers by such continuous lines or rates should publish their joint rates as separate and 
individual roads are required by law to do. See 9 I. C. C. R. 152.

Where freight passes orer a continuous line or route operatel by more than one company, on which no joint tariff of rates or charges have been established, the tariff of rates or charges is the same as the established local rates or charges by the several companies operating such continuous line. 5 I. C. C. R. 4t, 3 Int. Com. Rep. 766.

When the rates established applying between the points within a single state are applied as part of combination rates in transportation between lifferent states, such state rates, as well as the interstate rates with which they are combinerl, must be published and filed as provided by section 6 . See also as to application of the section, S I. C. C. R. 316.

So passenger excursion rates are required to be published and tiled. 3 I. C. C. R. thi., 2 Int. Com. Rep. 729.

s:?3:. Published joint rates must be duly anthorized.The only rates, which a carrier is authorized to publish, are its own local rates, that is, to points on its own ine, and such. through rates, as it is anthorized by agreement with any connecting carrier to combine with the rates of such carrier to points on its line. It cannot lawfully adl to the duly established rates of another carrier any amount it pleases less than its own local rates, and publish and use them the same as a through rate to points on the line of another carrier without its consent. Such a through rate is not a joint rate, for joint rates can be made only by concurrence or assent, nor is it a combination rate, for one of its component parts has no legal existence or sanction as a through rate or throngh charge. There must be lawful rates upon each of the roads before there can be a lawful combination of rates. This was ruled in a case, 7 I. C. C. R. 32:?, where the receivers of a roal connecting with the New York, New IIaven \& Hartford railroad, published what purported to be a joint tariff of coal rates from from the point on its roal to a number of destinations reached by the New lork it New Ilaven roal, whereby the complainant company receired its full local charges to said destinations from the junction points with defenlantis roal, and the defendant accepterl the remainler, which was in ach instance less than the established local rate from the place of 
shipment to the point of connection. The New York \& New Haven road which carried coal to the same destinations by a longer route over its own rails thereby securing greater compensation than was afforded to it by coal coming to it from defendant's road, refused to unite in these rates published by the connecting carriers so unathorized and its complaint was sustained. Commissioner Clements dissented, holding that a carrier could make and publish through rates to points on a connecting line less than its regular locals, provided the rates on its own line were duly filed and published and are them: selves just and reasonable and are not in themselves unjustly discriminative against local shippers.

\$ 240. Application to export and import rates.--The most serions question in the practical enforcement of section 6 has been in relation to export and import rates; that is, upon through rates, including an inland rate subject to the juriscliction of the Commission, and the ocean rate to a foreign port not subject to such jurisdiction. The practical difficulty arose from the fact that the ocean rates from the ports are not under the control of the Commission and are constantly varying.

In the language of the Commission in a recent decision, 10 I. C. C. R. 55, the rate varies from day to day and sometimes from hour to hour. The same kind of merchandise may be carried in the same vessel, often for the same person, at different charges for the transportation.

The Commission had held in several cases that the export and import rates should be published. 3 I. C. C. R. 1:37, 2 Int. Com. Rep. 553; 4 I. C. C. R. 694, 3 Int. Com. Rep. 529.

Previous to the decision of the Import Rate case, supre, 16? U. S. 197, the Commission required the publication of the inland portion received by the rail carrier. Since then it has held that where a through rate was named and a through bill of lading was issued, the inland carrier might publish either its total or through rate, or its inland portion which it received. 8 I. C. C. R. 110, S I. C. C. R. 214 . In other words, the Commission rules that the rate for the inland carrier on an export shipment from a point in the interior must either be a joint rate to a foreign destination, or a local rate to the point of export, and that in either event the law requires the carrier 
to publish the rate, leaving him to determine whether its rate is a joint or an inland rate, and to publish either as it may elect. The Commission concluded its recent exhaustive investigation upon this subject, (10 I. C. C. R. 55); by holding. first, thilt the act now requires the publication of the export and import tarills in the same manner as the domestic tariffs, and under the lilkin's Act of February 19, 1903, the enforcement of the $p$ ib ication is made mandatory upon the Commission. Sucomel, that public policy urgently required that the inland transportation of export and import commerce should be subject to the act, and that the publishing and maintaining of tariffs in most instances would impose no hardships upon the cilrrer, but that where it dicl, the only remedy was by amendment to the act, as the Commission had no power to modify the requirements of the act. And thiod, that the carriers should in all cases file with the Commission the rates actually made, and should give thereafter notice to the public of variations in the rate as far as possible. The Commission intimated that the proper remedy was to apply to Congress for an amendment of the act in regard to the publication of through export and import rates, and that if the act was not amended within a reasonable time, it would be their duty to enforce it.

See also discussion of this subject in the report of the Comulission for 19ut, page 49 . 


\section{SECTION T.}

$\$ 241$. Continuous carriage of freights from place of shipment to place of destination.

242. Judicial application of section.

\$ $\$ 1$. Continuous carriage of freights from place of shipment to place of destination.-SEC. 7 . That it shall be: unlawful for any common carrier subject to the provisions of thrs act to enter into any combination, contract or agreement, expresser or implied, to prevent. by change of time scherlute, carriage in different car's, or by otber means or derices, the carriage of freights from being continuous from the place of shipment to the place of destination: and no break of bulk, stoppage, or interruption made by such common carrier shall prevent the carriage of freights from being and being treated as one continuous carriage from the place of shipment to the place of destination, unless such break, stoppage, or interruption was made in grood faith for some necessiry purpose, and without any intent to avoid or unnecessarily interrupt such continuous carriage or to evale any of the provisions of this act.

\$ 24. Judicial application of section.- This section, prohibiting any combination for preventing the continuity of traffic and providing for the continuous carriage of freights from the place of shipment to the place of lestination, is to be considered in connection with the provision of section :3 concerning the interchange of traflic. (snfme, $\$ 11$, which has been construed as leaving the carriers free to make arangements for through trattic among themselves, there being no power in the Commission or courts to compel one railroad company to deliver cars to another. It was said by the Commission in a recent case, 10 I. C. C. R. 1ss, that in view of this construction of section 3 of the act, it was not clear what the seventh section was intended to accomplish, and that possibly Congress had in mind that railways might attempt to interrupt traffic at state lines, thereby depriving the traffic of the character of interstite business, and that the serenth section may have been intended to prevent this. The Commission was clear that it added nothing to the third section in support of the claim made requiring the defendant carrier to deliver its cars to another carrier.

This section has also been cited in the cases wherein the courts have been asked to protect interstate carriers against interference by unlawful combinations. See chapter IV, suph 


\section{S I:CTION $S$.}

Page.

\$243. Liability of common carrier for damages...............254

244. Action batsel on the statute........................284

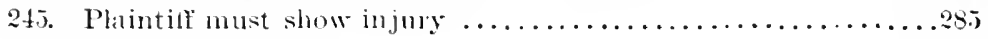

246. Limitation of actrons. . . . . . . . . . . . . . . . . .

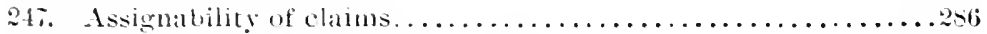

2ts. The juriadiction of Federal courts. $\ldots \ldots \ldots \ldots \ldots \ldots \ldots \ldots 260$

24:) Jurisliction of the Federal conts in equity under the act . . .25:

250. Jurisdiction in equity for protection of interstate commerce. .290

\section{s:t3. Liability of commerce carpiers for damages. - SEo.}

- Thit in cise any common carrier subjeet to the provisions of this act shall do, caluse to be done, or permit to be done any act, matter, or thing in this act prohibited or declared to be unlawtul, or shall omit to do any act, matter, or thing in this aet required to be done, such common carrier shall be liable to the person or persons injured thereby for the full alloment of damages sustained in consequence of any such riolation of the provisions of this act, together with the reasonahle comusel or attorney"s fee, to be lixed by the court in every case of recovery, which attorney's fee shall be taxed and collected as part of the costs in the case.

S4t. Action based on thestatute.- Section eight, and the succeeding section nine, provide for private atetions at law for dimages by persons injured from the violations of the provisions of the act, and atre the only prorisions of the act directly relating to such private actions. These sections are construed in P'alsons r. C. \& N. W. R. Co., 167 U. S. 447,42 L. Ed. 231 , alliming 11 C. C. 1. 459, 633 Fed. Rep. 903, an action for alleged discrimination in shipping grain from Iowa to Chicago on account of differential rates granted to shippers from Tebraska. The court said that the cause of action was basel entirely on the statute, and to enforce what was in its nature a penalty imposed on account of the wrongful conduct of the defendant. One who is seeking to recover a penalty is bound by the rules of strict law, as no violation of the statute was to be presumed and he must make out a ease showing not by way of inference, but clearly and directly, such viojations. Such a suit was dis. tinguished from the ease of a party who had been charged and compelled to pay an unreasonable rate. The right of a shipper, who pays reasmable rates, to recover from such company the exess of such payment over the rates charged to shippers 
of similar goods to the same destination from another place of shipment for the same or greater distance from it, is a right growing out of the Interstate Commerce Act, and being in the nature of a penalty, can be enforeed only by strict proof showing clearly and directly the violations complained of.

\$4.). Plaintiff must show injury.- - Lnder this section the common carrier is liable only to the person or persons injured thereby for the full amount of damages sustained in consequence of the violation of the Act. The Supreme Court suid in the case cited that as the only right of recovery given by the Act was to the individual for the amount of dimages sustained, the party, before he can recover under the Act, must show not merely the wrong of the carrier, but that the wrong has operated to his injury. Thus it is not sufficient to show the failure to publish the tariff rates, as provided by section six, but it must be further shown that this non-publication operated to his injury. Penalties are not recorerable on mere possibilities.

The discriminating rate must be actually charged to make an offense or cause of action uniler the act. Merely making or offering an illegal rate when it is not shown that an actual shipment was made, constitutes no legal injury to a shipper who was charged a higher rate. Lehigh Valley R. Co. v. Rainey, 112 Fep. Rep. 157, E. Dist. of Penn.

It was held in Junod v. C. \& W. R. Co., 47 Fed. Rep. 290 , that where plaintifl is entitled to the same rate for the shorter as is afforded other shippers for the longer hanl, the measure of damages is the difference betreen the amounts paid by each for like services, and that it is for the jury to determine whether they will allow interest on the damage; but if it is awarded, it should be estimated from the date of the last shipment.

$\$ \$ 4$. Limitation of actions.- The Interstate Commeree Act prescribes no limitation of time within which actions based thereon shall be instituted, and therefore, under $R . S$. U. S. T21, the statute of limitations of the State in which the action is brought must apply and control. Michigan Insurance Bank v. Eldred, 130 U. S. 698, 92 L. Ed. 1050. This was directly ruled in Ratticin v. Terminal Railroad Association, $11+$ Fed. Rep. 666 (E. Dist. of No.), and in Copp r. Lonisrille et Nashrille R. Co., 5o Fedl. Rep. 164, Dist. of Ky.; Murray r. Rail- 
roal Co., 35 C. C. A. 12,92 Fed. Rep. Sris. In both cases the state stitutes of limitations were held to apply. Where uncler the statute of a stite the defense of the statute of limitations can be inroked by the defendant by demurrer, the sime procedure will apply in the Federal court. It was ruled in the Missonri case, thit an action to recover damages for a discrimination in violation of section 2 was one to recover money in the nature of a penalty, and therefore must be browght within the time allowed by the state statutes for such action. In this case the Court betd, that the allegations of the petition were not sulficient to prevent the running of the statute. as there wats no allegation that plaintiff believed and relied on defentant's announcement, that it made no discrimination in the rates, or that he exercised liligence to ascertain the facts. In action at common law, not founded on the statute, to recover unreasonable chimpres, the unreasonableness being established by the payment of rebates, it has been held that the statute of limitation did not begin to run agrainst the shipper as long as he had no knowledge of his rights owing to the ficult of the carrier in concealing the facts. See Cook v. C., R. I. d P. R. Co., S1 Iowa 5.51, 9 L. R. A. Tbt.

As to the limitations governing proceedings for reparation before the Commission, see infire, section 11 .

\$. $4 \%$. Issignability of claims. - Claims for lamages under sections $>$ and constitute property rights, which may be assigned, so as to convey the beneficial interests to the assignee; and suits brought in the Cnited States Circuit Court under these sections are maintainable in the name of the assignee uncler provisions of the law of the state, requiring all suits to be brought in the name of the real party in interest. Edmunds v. Illinois Central R. Co., SO Fed. Rep. To.

$\$ 44$. The jurisdiction of Federal Courts.- It is specifically provided in section 9 that a person claiming to be damageet by any common carrier subject to the provisions of the aet may at his election malie complaint to the Commission, or may bring suit in any l)istrict or ('ircuit ('ourt of the Cnited states of competent jurisliction. It lollows that the juriseliction of the federal Court when involied is not hased upon diverse citizenship, but on a canse of action anising under the laws of the Inited States. I)irerse citizenship therefore is not necessiry to jurisliction of the leeleral c'ourt. 
In Van Patten v. C., M. \& St. P. R. R. Co., Tt Ferl. Rep. 9s1, it was decided by shiras, J., of the northern district of Iowa, that the limitation as to the district in which suit may be bronght in the United States Cireuit Conrt contained in the Judiciary Act of 1587 and 1585 , did not appiy to suits brought uncler sections $S$ and 9 of the Interstate Commerce Act, but that such suits maly be brought in any district in which the defendant may be found, as the limitations containerl in those acts are applicable only to the cases whereof the State and Federal Courts have concurrent jurisliction, citing $I_{h}$ Horhorst, 150 U. S. 653,97 L. Ed. 1211. It was said in the same case that the jurisdiction under these sections was exclusive in the courts of the United States, as the use of the words in section 9 concerning certain conrts in the United states indicated that in the view of Congress there were courts in the Inited States who were competent to take jurisdiction orer such cases as arise under the prorisions of the Act, and courts not competent to take juristiction. But see Connor v. V. A M. P. Co., 36 Fed. Rep. 273, lecided in 1sss; Lowry v. C., B. \& Q. R. R. Co., 46 Fed. Rep. 83.

In Swift v. Railroal Co., 58 Fed. Rep. 8.58 , it was held that a court had no jurisliction orer a suit under the Act, remored from a state court, where the state court had none. This did not apply where a state court had jurisdiction of the cause of action stated in the petition, but a federal question was raised in the answer, which set up an alleged discrimination violative of the act. See also Sheldon v. Wabash Railroad Co., 105 Fed. Tep. 75.

The exclusiveness of the jurisliction over suits brought under these remedial sections of the act to enforce its prorisions must be distinguished from the concurrent jurisdietion of the state court orer questions in interstate commerce, not arising from or based upon the act. Murray v. Railroad Co., $62 \mathrm{Fed}$. Rep. 2t. See supra, st.

$\$$ 249. Jurisliction of the Felleral Conts in equity under the Act.- The general ehancery jurisdiction of the Circuit Courts of the United States in cases arising under the Interstate Commerce Act was sustained by the supreme Court in the Lennon case, 166 U. S. 5ts, 41 L. El. 1119. The court beld that a bill brought solely to enforce compliance with the Interstate Commerce Act, and to compel railroad 
companies to comply with such Act, and to offer proper and reasonable facilities for the interchange with the complainant and enjoining them from refusing to receive from complainant for transportation over their lines any cars which might be tendered, made a case arising under the Constitution and liaws of the L'nited states, of which the Circuit Courts harl jurisliction. A case arises under the Constitution and laws of the Lnited States whenever the plaintiff sets up a right which the parties had denied to him and the correct decision of the case depends upon the construction of such laws.

In Central Stockyards Co. v. L. \& N. R. Co., 112 Fed. Rep. s.2:, which was a proceeding to enforce by injunction rights claimed under section 3 of the act, the court, thongh deciding aganst the plaintiff on the merits, was of the opinion that the remedies provided in section 9 were exclusive for remedies at law where the parties did not apply in the first instance to the Interstate Commerce Commission. The Supreme Court howerer in affirming the judgment, assumed, without deciding, that snch rights as plaintiff had, could be enforced by bill in equity. see 1!) U. S. 568, to L. Ed. 515.5.

In Interstate Stockyards Co. v. Indianupolis U. R. Co., 99 Fed. liep. 472, the Circuit Court of Indiana sustained the jurisliction in equity, saying that where a wrong was continuing in chilracter and not susceptible of accurate pecuniary estimation and resorts to actions at law would involve a maltiplicity of suits. none of which would end the litigation, a resort to equity was proper.

The general chancery jurisdiction has been sustained in several cases in the Federial Cireuit ('ourts, where it has been involed by both railroals and shippers for the enforcement of rights under the Act. Thus see Toledo, Ann Arbor R. (o. r. Ratilroal Co., ot Fed. Rep. 730, 19) L. R. A. 35i, jt leal. Rep. Ttti. In Little liock t Memphis R. Co. r. E. Tenn. etc. Li. ('o., ti Fed. Rep. Til, the Circuit Court for the western district of Temnessee in a suit by a carrier clatiming an unjust prelerence violative of section $:$, sail that the court had jurisdiction to entertain all controversies whether at law or in efuity, arising under the Act and that the remedies provided in the Aet were merely supplemented to the ordinary remedies which were rested in the court als to all cases and controver- 
sies arising under an act of Congress. See also Kentucky ir

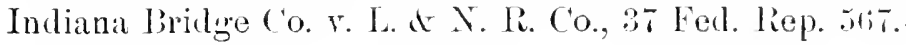

The juriscliction in equity was also successfully invoked in a suit brought by a shipper seeking to enjoin unreasonable rates in Tift v. Southern Railway (So. Dist. of Ga.) 123 Fed. Rep. 790. The suit in this case was brought by a large number of parties engaged in the manufacture of Georgia pine lumber against the Southeaster'n Freight Issociation and a number of railroats, and sought to enjoin the defendants from enforcing an increase of two cents per hundred pounds in the freight rate on lumber from Georgia to (1hio river points. The Court said that Congress, in simpiy re-enacting the common law requirements that the rates should be reasonable, created no new right in the shipper; but by embodying this common law right in a law of the United States, Congress enabled him in the case of controversy to apply for relief to a court having juriscliction of controversies arising under the Constitution and laws of the United States, and that it had long been the practice of courts of equity to grant injunctions against extortionate charges and unjust discriminations. The court held that it had jurisdietion in order to aroid a multiplicity of suits. While thus sustaining the jurisuliction, the Court dissolved the injunction, pending application to the Interstate Commerce Commission for redress.

In United States $\nabla$. Michigan Central Railroal Co., X. Dist. Ill., 122 Fed. Rep. 5t4, it was said by .Juge Growscup that a court of equity under its general chancery jurisdiction could romedy wrongs caused by the discriminations of carriers, that actions at law for such injuries were plainly inadequate, and nothing short of the prohibitive arm of the court of chancery conkl give the grain growers and other producers the free competitive field for the sale of their products to which they were entitled under the Interstate Commerce Act. The decision in this case was given after the passage of the Elkins Act, but in a suit filed before its passage, this act specifically directing that the writ of injunction could be issued in suits filed by the United States at the instance of the Commission. See infia, 310 . The Court seemed clear'y of the opinion in the case cited that the only necessity for the statute was to give the right to the government, irrespective of the investigation of the Commis- 
sion, and that under its chaneery jurisdiction the power could be in roked to remedy the wrong at the instance of private shippers, whenever the remedy at law was not arailable.

In the case of Missouri Pacifie Railway Co. v. Lnited States, 159 L. S. $27 t, 47$ L. El. s11, the Supreme Court overruled the (ircuit Court for the so. D)ist. of Kansas, 6.5 Fed. Rep. 908, and held that prior to the passage of the act of February 19.1903, infre, 310 , known as the Elkins law, the distriet attorney of the [nited States, under direction of the attorney general in pursuance of a request male by the Commission, was without power to commence a proeeeding in equity against a railroad corporation to restrain it from (liscriminating in its rates between different loealities, (Justices Brewer and IIarlan dissenting.) This amenlatory act provides for equity jurisdiction in such cases where proceedings are instituted at the instance of the Interstate Commerce Commission, but makes no change in the law so far as the remedies open to individuals are concerned. The Court in its opinion in this case laid stress upon the fact that prior to the request of the Commission, upon which the suit was brought, no hearing was had before the Commission coneerning the matters of fact complained of and there was therefore no finding of fact or orler to the carrier to desist. In view of the passage of the Elkins Act, authorizing the remedy in pencling cases, the cause was remanded for further proceedings under the law as modified by that act.

In the opinion of Crosscup, J., rendered after this decision, in the Missouri Pacific case, the Court said that this decision lid not apply to a case where there had been a preliminary hearing and finding by the Commission. The Court therefore was inclined to the opinion that it had jurisdiction irrespective of the Elkins Act, where there was such hearing and finding, though since that enactment the question had become an acidemic one.

5.50. Jurisdiction in equity for protection of interstate commerce.- In another class of cases, jurisdiction in equity has been successfully inroked not only by the Lnited States, as in the Debs case, 1.is U. S. 56t, but by railroad companies for the protection of interstate commerce against unlawful combinations preventing the performance by such railroad companies of the duties imposed upon them by the statute. 
Thus in Toledo, A. A. \& N. W. R. Co. v. Pennsylvania Company, 5+ Fed. Rep. 730, Jurge Tift in the northern district of Ohio, sustained the equitable jurisdiction in a suit filed against several railroad companies conneeting with complainant company at Toledo, and asking an order enjoining the companies from refusing to receive and deliver complainant's freight, such refusal being threatened on the ground that the locomotive engineers of the defendants refused to handle tritins containing such freight because the complainant emploged on its line engineers who were not members of their brotherhood. The Court sustained the jurisdiction irrespective of citizenship, saying it was immaterial what rights the complainant would have had before the passage of the Interstate Commerce Act. "It was sufficient that Congress in the exercise of constitutional power had given a positive sanetion of the Federal law to the rights secured in the statute, and any action involving the enforcement of those rights was a case arising under the laws of the United States." See also Ere parte Lennon, 1666 U. S. $5+8,41$ L. Ed. 1110 (1597).

The Court also held that a mandatory injunction was a proper remedy to restore the passage of freight backwarls and forward, as each carrier had the right to enjoy this without interruption. 


\section{SeCrion 9.}

\$ 851. Persors claiming to be damaged may elect whether to complain to the Conmission or bring suit in a United States court.

25?. Judicial application of section.

\section{s.) 1 . Persons claiming to be damaged may elect whether} to complain to the commission or bring suit in a luited states conrt.-SEc. 9. That any person or persons claiming to be damaged by any common carrier subject to the provisions of this act may either make complaint to the Commission as hereinafter provided for, or may bring suit in his or their own behalf for the recorery of the damages for which such common carrier may be liable under the provisions of this act, in any district or cirenit court of the United States of competent jurisuliction: but such person or persons shall not have the right to pursue both of saicl remedies, and must in each case elect which one of the two methods of procedure herein provided for he or they will adopt. In any such action brought for the recovery of damages the court before which the same shall be pending may compel any director, officer, receiver, trustee, or algent of the corporation or company defendant in such suit to attend, appear, and testify in such case, and may compel the production of the books and papers of such corporation or company party to any such suit: the claim that any such testimony or evidence may tend to crminate the person giving such evilence shall not excuse such witness from testifying, but such eviclence or testimony shall not be used against such person on the trial of any criminal proceeding.

?:5. Judicial application of section.- See notes on section 8 , supra. The provisions in this section for the compelling of testimony and the production of books and papers was in effect held unconstitutional by the decision of the Supreme (ourt in the case of Hitchcock v. Counselman, infra, section 12, in that the protection giren to the witness forced to give selfincriminating testimony was not sufficient under the Fifth Amendment of the Constitution. The act of 1893 , infra, section 12 , only related to testimony given before the Commission and did not apply to this section. This, however, was remedied by the act of 1903 . See infra, 310 .

A final judgment in the suit or proceeding before the Interstate Commerce Commission and remaining of record in full force and effect is a bar in the Lnited States Circuit Court to 
a suit brought',for the recovery of damages alleged to be sustained by plaintiff from the same aets complained of in the statement before the Commission. See Riddle v. New York, Lake Erie \& Western Railroad Co., U. S. Circuit Court W. Dist. of Penn., 3 Int. Com. Rep. 230.

A party is not barred from prosecuting an action in court for an individual claim because of proceedings instituted before the Commission by an association of which he is a member, where it does not appear that the association presented a claim for the plaintiff to the Commission. Junod v. C. \& N. W. R. Co., 47 Fed. Rep. 290.

It appears from the discussion in Congress that the purpose of this provision of the section, that a party must elect whether to proceed before the Commission or in the Court, was intended to prevent a party from using the Commission merely as a means of procuring evidence for a suit in court.

Under this section suit may be brought in any Circuit Court or District Court of the United States. Cnder the Anti-Trust Act of 1890 the jurisoliction is limited to the Circuit Court. In New Mexico v. Balier, 25 Sup. Ct. Rep. 375 (1905), the question was suggested, though not decided, whether either under the Interstate Commeree Act or the Anti-Trust Act of 1590 a suit could be brought in a Territorial I)istrict Court, or whether Congress intended that only courts of the Cnited States invested by the Third Article of the Constitution with the judicial power of the Lnited States should have original jurisdiction in such suits. 


\section{Síction 10.}

Page.

\$ 253. Penalties for violations of act by carriers............. 294

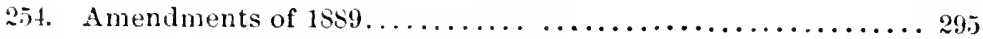

35. Summary of amendments of $1903 \ldots \ldots \ldots \ldots \ldots \ldots \ldots \ldots \ldots \ldots$

256. Illegal combinations under section $10 \ldots \ldots \ldots \ldots \ldots \ldots \ldots \ldots$ agt;

3i. A peaceable strike not a violation of the section........... $29 \pi$

2.). Construction of the statute..................... 298

259. Remoral of indicted persons to other jurisdictıons for trial ... 299

359 (. Limitation of criminal prosecution under the Act...........

\section{:.5.3. Penalties for violations of act by carriers, etc.-} i.e. 10. (As amended March O, 1S89, as prior to amentment of $1 '$ (t). infirel.) That any common carrier subject to the provisions of this act, or, whenever such common carrier is a corporation, any director or officer thereof, or any receiver, trustee, lessee, agent, or person, acting for or employed by such corporation, who, alone or with any other corporation, company, person, or party, shall wilfully do or cause to be done, or shall willingly suffer or permit to be done, any act, matter or thing in this act prohibited or declared to be unlawful, or who shall aid or abet therein, or shall wilfully omit or fail to do any act, matter, or thing in this act required to be clone, or shall cause or willingly sutfer or permit any aet, matter, or thing so direeted or requireil by this act to be done not to be so done, or shall aid or abet any such omission or failure, or shall be guilty of any infraction of this act, or shall aid or abet therein, shall be deemed guilty of a misdemeanor, and shall, upon conviction thereof in any district court of the United States within the jurisdiction of which such oflense was committed, be subject to a fine of not to exceed five thousand dollars for each offense: Provided, That if the offense for which any person shall be convicted as aforesaid shall be an unlawful discrimination in rates, fares, or charges, for the transportation of passengers or property, such person shall, in aldition to the fine hereinbefore provided for, he liahle to imprisomment in the penitentiary for a term of not exceeding two years, or both such fine and imprisonment, in the discretion of the court.

Any common carrier subject to the provisions of this act, or, whenever such common carrier is a corporation, any officer or agent thereof, or any person acting for or employed by such corporation, who, by means of false billing, false classification, false weighing. or false report of weight, or by any other derice or means, shall knowingly and wilfully assist, or shall willingly sutfer or permit, any person or persons to obtain transportation for property at less than the regular rates then established and in force on the line of transportation of such common carrier, shall be decmed guilty of a misdemeanor, 
and shall, upon conriction thereof in any court of the United States of competent jurisliction within the district in which such offense was committed, be subject to a fine of not exceeding five thousind dollars, or imprisonment in the penitentiary for a term of not exceeding two years, or both, in the discretion of the court, for each offense.

Any person and any officer or agent of any corporation or company who shall deliver property for transportation to any common carrier, subject to the provisions of this act, or for whom as consignor or consignee any such carrier shall transport property, who shall knowingly and wilfully, by false billing, false classification, false weigling, false representation of the contents of the package, or false report of weight, or by any other device or means, whether with or without the consent or connivance of the carrier, its agent or agrents, obtain transportation for such property at less than the regular rates then established and in force on the line of transportation shall be deemed guilty of fraud, which is hereby declared to be a misdemeanor, and shall, upon conviction thereof in any court of the United States of competent jursdiction within the district in which such offense was committed, be subject for each offense to a fine of not exceeding five thousand dollars or imprisonment in the penitentiary for a term of not exceeding two years, or both, in the discretion of the court.

If any such person, or any officer or agent of any such corporation or company, shall, by payment of money or other thing of value, solicitation, or otherwise, induce any common carrier subject to the provisions of this act, or any of its oflicers or agents, to discriminate unjustly in his, its, or their favor as against any other consignor or consignee in the transportation of property, or shall aid or abet any common earrier in any such unjust discrimination, such person or such olficer or agent of such corporation or company shall be deemed guilty of a misdemeanor, and shall, upon conviction thereof in any court of the United States of competent jurisliction within the district in which such offense was committed, be subject to a tine of not excceding five thousand dollars, or imprisonment in the penitentiary for a term of not exceeding, two years, or both, in the discretion of the court, for each offense; and such person, corporation, or company shall also. together with said common carrier, be liable, jointly or severally, in an action on the case to be brought by any consignor or consignee discriminated against in any court of the United States of competent jurrsdiction for all damages caused by or resulting therefrom.

$\S$ 254. Amendments of 1859.- This section as originally enacted contained only the general penalty clause in the first paragraph. By the amendment of Narch 2, 1889 all the remainder of the section as above set forth was adder, includ- 
ing the specific penalties for false billing, classification, weighing, etc., recommended by the Commission. Tery important amendments were male by the act of February 19, 1903 (infra, $\$ 310$ ), a summary whereof for convenience is here given.

25.5. Summary of amendments of 1903. - Fist, a railroad corporiation itself shall be liable for prosecution in all cases where the oflicers and agents were liable under the former law, such oflicers and agents continuing to be liable as heretofore. Secomel, the penilty by imprisonment is abolished, and the only punishment proviled for offenses, whether committed before or after the passage of the amenclatory Act, is the imposition of fines, which were limited from a minimum of $\$ 1,000$ to a maximum of $\$ 20,000$. Third, the published tariff is made the standard of lawfulness as to effects of criminal misconduct, and any departure therefrom is declared to be a misclemeanor. Fourth, jurisdiction of the prosecution of offenses against the Act is given to any court of the United states having juriseliction of crime within the district within which the violation was committed, or through which the transportation may have been conducted. In the law before the amendment, the jurisdiction was limited to the district wherein the oflense was committed. It is specifically provided also that in construing and enforcing the provisions of the Act, the omission or failure of any person acting for or in the employ of any carrier acting within the scope of his employment, should in every instance be decmed to be the act of omission or failure of such carrier.

956. Illegal combinations under section 10. - The most important application of section 10 has been made in connection with labor combinations, and attempted boycotts of interstate railroad traflic by employees of other interstate railroads on account of strikes among classes of employees of such railroats. The law of conspiracy has been inroked under section it4" R. S. U. S., which provides that if two or more persons conspire to commit an offense against the United States, and one or more of such parties do any act to effect that object for the conspiracy, all parties to the conspiracy shall be liable to the penalty preseribed. (Supre, chapter IV.) See United states r. Stephens, $4+$ led. Rep. 132 where the statute was 
applied to the case of a conspiracy to commit acts made misdemeanors by section 13 of the Census Act.

In the case of Toledo, A. A. \& N. Ir. R. Co. v. Pennsylvania Co., 54 Fed. Rep. 730, the court, Taft, J., held that Rule No. 12 of the Brotherhood of Locomotive Engineers, then in force, declaring that the bandling of the property of a railroad, when the Brotherhood was at issue with such eompany, was in violation of the obligation of the Brotherhood, constituted a combination to induce the violation of section 3 of the Interstate Commerce Act, providing for the interchange of facilities by railroads engaged in interstate commerce, and made criminal by section 10, and that the Chief of the Brotherhood and all members engaged in enforcing that rule were equally guilty with him as principals, and all guilty of conspiring to commit an offense against the United States subject to the penalties of section 5440, R. S. U.S. The Court granted a mandatory injunction to compel the interchange of facilities. It was said however that the defendants could a void obedience to the injunetion by actually ceasing to be employees of the company, although if they left the service of the company under rule 12 of their order so as to compel the defendant company to injure the complainant company, they were doing. an unlawful act and rendering themselves liable in damages for any injuries which are thereby inflicted, and might be liable to a criminal penalty. The arm of a Court of equity could not be extended by mandatory injunction to compel the performance of personal services. See $5+$ Fed. Rep. Tt6, where one of the engineers was adjudged guilty of contempt. See also C., B. \& Q. R. Co. v. B. C. R. \& N. R. Co., 34 Fed. Rep. 481. See also Arthur v. Oakes, 11 C. C. A. 209, 63 Fed. Rep. 310.

In Beers v. Wabash, St. Louis \& Pacific Railroad Co., $3 t$ Fed. Rep. 244, the court made the same holding as to rule 12 of the Brotherhood, and as the railroad was operated by a receiver, the court said the receiver could not refuse to receive from and deliver to a connecting road, although by doing so his own road may be involved in a strike with its employees.

$\S 25 \%$. The incidental interference with comnerce by a peacable strike not a violation of the section.- While the employees of a railroad corporation cannot lawfully combine 
to compel their employer to discriminate against the traffic of a comnecting railroal for any reason, the incidentul interference with interstate traffic resulting from a combined cessation of employment by railroal employees for the purpose of bettering their own conditions of service does not eonstitute a criminal conspiracy or an ollense under section ten of the Interstate Commerce Act. See Arthur v. Oakes, 11 C. C. A. 209, ri3 Fed. Rep. 310. The point wis directly ruled by Judge Adams in the case of the Wabash Railroal Co. v. Hannahan et al. 121 Fil. liop. ins. where the court dissolved a temporary injunction erantel withont notice against the officers of the brotherhools of trainmen and tiremen restraining them from ordering a strilie on the Wabash Railroad. The Conrt said that while the employees, the members of the brotherhoods, hal the right to combine in leaving their employment, the court would retain jurisiliction of the case so that in the event of any molestation of or interference with interstate commerce by them after learing employment, the lawful powers of the court could be invoked to restrain such interference.

See also Lopkins r. United States, 171 U. S. 575, 43 L. Ed. 290. 2!mi: Taft, J. in Thomas v. Cincinnati, N. O.\&,T. O. Ratlroal, re Fed. Rep. sur. This subject of what constitutes a conspiracy in restraint of trade has been more extensively discussed in connection with the more comprehensive provisions of the so-calied Inti-Trust Law of $1 \$ 90$, infia, $\$ 31+$ et seq, see also charge to grand jury by Judge Grosscup as to what constituted a criminal conspiracy in interstate commerce, 62 Fed. liep. s.ss; chare to grand jury in California by Ross, J., 62 Feel. Rep. S8t; by Morrow, J., 62 Fed. Rep. St0. See supra, ch. II.

S.j. Construction of the statute.- Under the statute before its recent amendment, it was held that a corporation could not be indicted thereunder, as the only parties punishable were individuals. United States v. Michigan Central Railroad Co., 1:; Fed. Rep. 26. (liut see act of Feb. 19, 1903 infra, $\$ 310$ ). The arent who was a party to the carrying of freight or passengers at a rate less than the published tariff was subject to indictment. Under that provision of the section making it unlawful for carriers to receive greater or less compensation from one shipper than from another for an equal service, an indictment stating tirat a carrier gave a rebate to one shipper 
without stating any instance in which he refused a like rebate to another shipper, is defective in not showing discrimination. United States v. I Ianley, 71 Fed. Rep.672. It was held in the same case that an indictment for paying or receiving rebates would not lie under the clause making it unlawful for the earrier by means of fals device knowingly to assist or suffer any person to obtain transportation at less than the regular tariff rates.

In agent of a railroad who merely collects freight and has nothing to do with fixing the rates is not indictable under the act for collecting a greater rate for a shorter than for a longer haul. United States v. Mellin, D. of Kan., 53 Fed. Rep. 229. As to essentials of indietments under the Aet, see also United States r. De Coursey, 82 Fed. Rep. $3(12$; United States v. Henley, 71 Fed. Rep. 672.

This offense of obtaining transportation of property at less than regular rates by means of false billing, etc., is not one that requires the transportation of the property to its destination to make it complete, but the offense is complete when the contract for the illegal rate was secured, and could only be prosecuted in that district. Davis $\mathrm{v}$. United States, $10 t$ Fed. Rep. 136,43 C. C. A. 448 .

In United States v. Howell, 56 Fed. Rep. 21, West. Dist. of Ark., it was held that shippers of lumber could be convicted of conspiracy to violate the Interstate Commerce Act upon showing that their servants procured unlaw ful diserimination in rates by false weights, provided they knew of the unlawful acts and permitted them to continue. United States v. De Coursey, 22 Fed. Rep. 302.

859. Removal of indicted persons to other districts for trial.-In Davis v. Uniterl States, 43 C. C. A. 448,104 Fed. Rep. 13!, the appellant was indicted in the northern district of Texas for trial under an indictment alleging violation of seetion ten, paragraph three, of the Act to Regulate Commeree. The United States District Court at Cineinnati made an order directing the removal of the appellant for trial to the northern district of Texas. It was claimed that the offense was committed in Texas, although the shipment was made from Cincinnati to Texas, under the provision of section 781, R. S. U. S., providing that when any offense against the United States was begrun in one juclicial circuit and completed in another, it 
should be deemed to have been committed in either and may be dealt with, inquired of and tried or punished in either district, in the same manner as if it had been actually and wholly committed therein. The Court held that this section was intencled to provide for that class of cases where the crime was not completed in one district, but where a separate and essential act of commission constituting the erime is committed in another district, and that this section therefore had no application to the case of a shipper who obtains lower rates by means of filse classification, billing, ete. The offense in that case is complete when the shipment is made. The Court therefore held that the Distriet Court erred in ordering a removal of the defendant to Texas, and he was ordered discharged.

As to removal of United States prisoners from one district to another under 101t, R. S, see Green r. Henkel, 183 U. S. 249, 46 I. Ed. 17 s.2.

959a. Limitation of criminal prosecution under the Act. While there is nolimitation of criminal prosecution fixed in the Act, sec. $104 t$, R. S. U. S. provides limitation of three year's, in case of all offenses "other than capital." "Suits and prosecutions for penalties and forfeitures "are subject under sec. $10+i$, R. S. U. S. to limitation of five years. 


\section{SECTION 11.}

§ 260. Interstate Commerce Commission - How appointed.

\$260. Interstate Commerce Commissioners- How appointed.-SEc. 11. That a Commission is hereby created anil established to be known as the Interstate Commerce Commission, which shall be composed of five Commissioners, who shall be appointed by the President, by and with the advice and consent of the Senate. The Commissioners first appointerl nnder this act shall continue in ollice for the term of two, three, four, five, and six years, respectively, from the first day of January, anno Domini eighteen hundred and eighty-seven, the term of each to be designater by the President; but their suceessors shall be appointed for terms of six years, except that any person chosen to fill a racaney shall be appointed only for the unexpired time of the Commissioner whom he shall sneceed. Any Commissioner ma be removed by the President for inefficiency, neglect of duty, or malfeasance in office. Not more than three of the Commissioners shall be appointed from the same political party. No person in the employ of or holding any official relation to any common carrier subject to the provisions of this act, or owning stock or bonds thereof, or who is in any manner pecuniarily interested therein, shall enter upon the duties of or hold such office. Said r'ommissioners shall not engage in any other business, vocation, or emplorment. No vatancy in the Commission shall impair the right of the renaining Commissioners to exercise all the powers of the Commission.

The Commission was organized in $1 \varsigma \varsigma 7$ by the appointment by President Cieveland and confirmation by the Senate of the following members:

Hon. Thomas M. Cooley, of Michigan,

Hon. William R. Morrison, of Illinois,

Hon. Walter L. Braggg, of Mlabama,

Hon. Aldace F. Walker, of Vermont,

IIon. Augustus Schoonmaker, of New Tork.

Judge Cooley served as Chairman until his retirement in 1891. Ile was succeeded by Mr. Morrison, who served as Chairman until Dec. :31, 1897, when he was succeeded by Mr. Martin A. Knapl, who had succeeded Mr. Seboonmaker, of New York, on the Commission. Mr. Knapp is now Chairman (1905). Mr. E. A. Mosley has served as Secretary of the Commission since its organization. 
Vacancies in the Commission have been filled from time to time in accordance with the directions of the act that not more than two shall be members of the same political party. The (ommission is now (Matrch, 1905) composed of the following nembers:

Ilonorable Martin 1. Kńpap, of New York, Chairman; term expiring December 31, 190 s.

Ilonorable Julson C. Clements, of Georgia, term expiring December 20,1906 .

Honorable Charles A. Prouty, of Vermont, term expiring l lecember $31,1907$.

IIonorable Joseph W. Fifer, of Illinois, term expiring March 9, 1910 .

IIonorable Francis M. Cockrell, of Missouri, term expiring Jarch 19, 1911. 


\section{SECTION 12.}

$\S 261$. Power and duty of Commission to inquire into business of car-

riers and keep itself informed in regard thereto.......... 30:3

262. Amendments . . . . . . . . . . . . . . . . . . . . 30.;

263. The compelling of self-incriminating testimony..... . . . 3 3.j

26t. The immunity of corporations from self-incriminating testi-

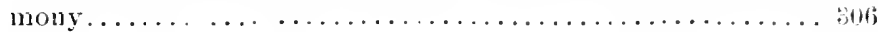

26.j. Probative effect of enforcel self-incriminating testinony .... . 3iv!

266. Immunity is limited to the subject of testimony . . . . . . . . 30.)

267. Power of the court to enforce testimony before the Commis-

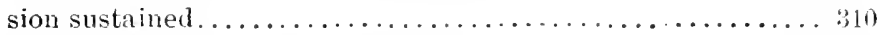

268. Relerancy of testimony before the Commission .......... 310

269. General powers of the Commission.....................311

\$ 261. Power and duty of Commission to inquire into business of carriers and keep itself informed in reand

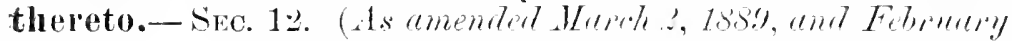
10, 1891.) That the Commission hereby created shall have authority to inquire into the management of the business of all common carriers subject to the provisions of this act, and shall keep itself informed as to the manner and method in which the same is conducted, and shall have the right to obtain from such common carriers full and complete information necessary to enable the Commission to perform the duties and carry out the objects for which it was created: and the Commission is hereby authorized and required to execute and enforce the provisions of this act; and, upon the request of the Commission, it shall be the duty of any district attorney of the United states to whom the Commission may apply to institute in the proper court and to prosecute under the direction of the Attorney-(reneral of the United states all necessary proceedings for the entorcement of the prorisions of this act and for the punishment of all violations thereof, and the costs and expenses of such prosecution shall be patid out of the appropriation for the expenses of the courts of the Cnited States; and for the purposes of this act the Commission shall have power to require, by subpoena, the attendance and testimony of witnesses and the production of all books, papers, tariffis, contracts, agreements, and documents relating to iny matter under investigation.

such attendance of witnesses, and the production of such documentary evidence, may be required from any place in the United states, at any designated place of hearing. And in case of disobedience to a subpena, the Commission, or any party to a proceeding before the Commission, may involie the aid of any court of the United States in requiring the attendance and testimony of witnesses and the proluction of books, papers, and documents under the provisions of this section. 
And any of the cirenit courts of the United States within the juriscliction of which sneh incuiry is carried on may, in ease of contumacy or relusal to obey a subpoena issued to any common citrier smbject to the provisions of this act, or other person, issue an order reguring such common carrier or other person to appear before said ('ommission (and produce boolis and papers if so ordered) and give evidence touching the matter in yuestion: and any failure to obey such oriler of the court may be punished by such eourt as a contempt thereof. The claini that any such testimony or evidence may tend to (riminate the person wiving sueh evildence shall not excuse such witness from testifying; but such evidence or testimony shall not be used against such person on the trial of any criminal proceeding.

The testmony of any witness may be taken, at the instance of a party in any proceeding or investigation depending before the commission, by deposition, at any time after a canse or proceeding is at issue on petition and answer. The Commission may also order testimony to be taken by deposition in any procecting or investigation penting before it, at any stage of such proceeding or investigation. Such depositions ina be talien before any jurge of any court of the United States, or any commissioner of a circuit, or any clerk of a district or cirenit court. or any chancellor, justice, or julge of a supreme or superior contr, milyor or chief magistrate of a city, judge of a comnty court, or court of common pleas of any of the Cunited stites, or any notary public, not being of eounsel or attorney to either of the parties, nor interested in the event of the proceeding or investiuation. Reasonable notice must first be given in Writing by the party or his attorney proposing to take slich deposition to the opposite party or his attorney of record, as either may be nearest, which notiee shall state the name of the witness and the time and place of the taking of his deposition. Iny person may be compelled to appear and depose, and to produce documentiry evidence, in the same manner as witnesses may be compelled to appear and testify and produce documentary evidence before the Commission as hereinbefore provided.

Every person deposing as herein provided shall be cautioned and sworn (or aftirm, if he so request) to testify the whole truth, and shall be carefully examined. Il is testimony shall be reduced to writing by the magistrate taking the deposition, or under his direction, and shall after it has been relueed to writing, be subseribed by the deponent.

If a witness whose testimony may be desired to be taken ly deposition be in a foreign comntry, the deposition may be taken before an officer or person designated by the Commission, or agreed upon by the parties by stipulation in writing to be liled with the commission. All clepositions must be promptly filed with the ('ommission. 
Witnesses whose depositions are taken pursuant to this act, and the magistrate or other officer taking the same, shall severally be entitled to the same fees as are paid for like services in the courts of the United States.

$\$: 6:$ Amendments. - Section 12 was amended March 2 , 1889, again on February 10, 18!1, again February 11, 1১9:?, and finally also amended by sections 2 and 3 of the act of February 19, 1903. See infira, \&310.

The first amendment, that of 1 ss?, was in the first paragraph, empowering the Commission to exact and enforce the provisions of the Act, making it the duty of the district attorney to prosecute under the direction of the Attorney-(ieneral of the United States, and also more specifically provilling for the summoning of witnesses, which last provision as to the summoning of witnesses was again made more specific and comprehensive in the act of 1891. As to the amendments of $189 \%$, see infich, $₫ 26 \%$, Self-incriminating testimony.

sob: The compelling of self-incriminating testimony. The most important julicial discussion under this section has been in relation to the power of enforcing self-incriminating testimony. The provision of the third paragraph of the section, that a party could be compelled to give self-incriminating testimony, but providing that the evidence given by him should not be used against him, was held in counselman $\mathrm{r}$. Hitehcock, $1 \pm 2$ U. S. jti, 35 L. Ed. 1110 (reversing $4 t$ Fed. Rep. 271 ), to be unconstitutional as violative of the Fifth Amendment to the Constitution, which declares that no person shall be compelled in any criminal case to be a witness against himself. The court lisapproved the decision of the New York Court of Appeals in Pcople v. Kielley, 24 N. I. 7t, which held the immunity in a similar statute sufficient, and ruled that the statutory enactment to be valid must afford absolute immunity against further prosecutions. The petitioner who had deelined to answer, whether he had received a rebate or not, on the ground that it would incriminite him, was discharged on habeas corpus. After this decision, the stitnte was amended by the passage of the act of February 11, 189:?, as follows:

That no person shall be excused fro $n$ attending and testifying or from producing books, paper's, tariffs, contracts, agree- 
ments and documents before the Interstate Commerce Commission, or in obedience to the subpo'na of the Commission. whether such subpona be signed or issued by one or more ('ommissioners, or in any cause or proceeling, criminal or otherwise, based upon or growing out of any alleged violation of the act of ( oneress, entitied "In act to regulate commerce," approved February fourth, eighteen hundred and eighty-seren, or of any amendment thereof on the ground or for the reason that the testimony or eridence, documentary or otherwise, reyuiled of him, may tend to criminate him or subject him to a penalty or forfeiture. But no person shall be proserneter or sub-

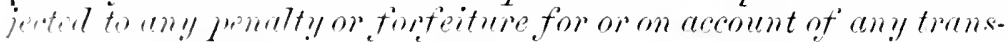
ation, mattre or thing. conceming which he may testify, or produce evilence, docmmentary or othelwise, before said Commission, or in obedience to its subpona, or the subpoena of either of them, or in any such case or proceeding: Provider, That no person so testilying shall be exempt from prosecution and punishment for perjury committed in so testifying.

Any person who shall neglect or refuse to attend and testify, or to answer any law inl inquiry, or to produce books, papers, tarills, contracts, agreements and documents, if in his power to do so, in obedince to the sulppena or lawful requirement of the Commission shall be guilty of an offense and upon conviction thereof by a court of competent jurisdiction shall be punished by tine not less than one hundred clollars nor more than five thousand dollars, or by imprisonment for not more than one year or by both such fine and imprisonilient.

\section{Immunity of corporations from self-incrimina-} tion.-In a prosecution under section 10, before the amendments of 1919, it was held that corporations could not be indicted, as the only parties punishable thereunder were indiriduals; an official could not therefore excuse himself from testifying on the ground that his testimony would implicate the corporation, his employer. In re Peasley, $4+$ Fed. Rep. 271. In a prosecution under section 5 of the Act, whereunder pooling between carriers is made unlawful, and each day of its continuance made a separate offense, indictments agrainst carrier corporations were returned by the grand jury in western district of Tennessee under charge of Hammond, J. $115 \mathrm{led}$. Rep. 5\$S. In this charge the opinion was expressed not only that corporations were indictable under section 5, but that unler the act of $18.9 \%$ there was no ricarions immunity and that there was no immunity to the corporation from the enforcen testimony of the olficers, or productions of its loorolis and papers. 
The Elkins Act of February 19, 19013 (infra, 5.810 ), has distinctly changed the relations of corporations to the act, first, in making (sec. 1) the corporation liable for conviction for mistemeanor and fine on account of any act dome or omitted in riolation of the statute by any officer acting in its behalf, and, secoml, in expressly authorizing (sec. :3) the enforced production of the colporate books and papers; and it then grants immunity in the following language:

"The claim that such testimony or evidence may tend to criminate the person giving such evidence shall not excuse such person from testifying, or such corporation from prochein. its books and papers, but no person shall be prosecuted or subjected to any penalty or forfeiture, for or on account of any transaction, matter, or thing concerning which he may testify, or produce evidence documentary or other wise in such proceeding."

While the immunity is thus extended to the "person" testifying or producing evidence and there is no express inchusion of corporations in "person" in the Interstate Commerce Act, as there is in section 8 , of the Anti-Trust Act, the terms "person" and "citizen" havebeen construed in statutes as including corporations, when necessary to effect the legislative intent, that is when within the reason of the Act. Ramsay v. Lacomil Land Co., 19, C. S. 3641. Corporations are "persons" entitlerl under the fourteenth Amendment to "due process of law," and the "equal protection of the laws." The rule of equity, that the protuction of hooks anil papers will not be enforced when the production would expose a party to a penalty or forfeiture, has been applied to corporations. Kirkpatrick v. Pope Mant. Co., 61 Fed. Rep. 46; U. S. v. National Lead Co. (Dist. of N. J.), 75 Fed. Rep. 94; Newgold v. Am. Elec. It Nav. Co., 108 Fed. Rep. 341, construing sec. $72+$ R. S. In the Southern Pacific R. R. Tax cases, 13 Fed. Rep. 722, 18 Fed. Rep. 385 , the enforcel production of corporate books was heldto violate the property rights of the corporators and stockholders.

The act of $189 \%$ was sustained in lirown v. Waller, 1 ti 1 U. S. 591, 40 L. Ed. s1!, the supreme Court holding that it atforded absolute immunity against prosecutions, federal or state, for the offense to which the question related, and therefore deprived the witness of his constitutional right to decline to answer. (Justices Shiras, Gray, White and Field dissenting on the ground that the state courts would not be com- 
pelled to accept the saving clause of the federal statute in respect to crimes against the state.) This amendment of 1893 only refers to testimony before the Interstate Commerce Commission, and does not refer to testimony given before a court in a suit brought under the provisions of sections $s$ and 9 of the act. The decision in the counselman case would clearly apply to the provision of section 9, providing that self-incriminating testimony foreed from a witness should not be used against him. The latter act however, February 19, 1903, infir, $\$: 10$, extends the same provision of immunity to all witnesses, whether before the Commission or before a court, compelled to give self-incriminating testimony.

While immunity under the legislative amnesty is directed especially against criminal punishment of individual witnesses, and a corporation camot testify except throngh the production of its books and papers, it woukl seem that as far as it call be indicted or punished by fine or loss of franchise, that it should be protected by the lergislative amnesty against conviction by self-crimination through the enforced production of its books and papers. In State v. Simmons IIardware Co., 109 Mo. 11s. a corporation was held protected by the State Constitution atainst self-incrimination. See also People v. Butler Street Founcry, 2011 111. 23:3i; Logan v. Penn. R. R. Co., 182 Pa. St. to8. A corporation may be guilty of a crime when the only intention reguired is an intention to do the prohibited thing. A corporaltion was held indectible and subject to fine for violating an eight hour law: U. S. v. John Kelso ('o., (C'al.), si Fel. Rep. :30t.

'This statutoly immunity is personal to the witness testifying. lirown v. Walker, s"pre. There is therefore no immunity to the corporition by reason of the testimony of its oflicers, nor can an ollicial or employee (in absence of a statutory amnesty) refuse to proluce hooks of an employer copporation on the groun l that it would implicate the corporation employer. Gardner v. Early, b9 lowa, tz. ('ases are to be distinguished bowever, where the witness is himself implicated and the entries in the corporite books are also his own.

The immunity to a corporation, as to an individual, from the enforced probluction of books and papers, extends only to those whichare rrevate; that is, those which can only be enforeed by rirtue of the statutory immunity. It does not include books, 
papers or records, whether corporate or individual, which are mide public by law. Thus the railroad rates and regulations concerning rates are required by law to be pa!lic. A tariff sheet of a railroad which is required by law to be publicly posted is not a private paper, and its enforced production in a prosecution against a railroad company is not compelling it in a legal sense to give evidence against itself. L. \& N. R. Co. v. Commonwealth (Ky. 1899), 51 S. W. Rep. 167; as to applications of same principle, see People v. Coombs, 155 N. I. 532 (1899); State v. Donovan, 10 N. Dak. 203; State v. Smith, $7+$ Iowa, 580 .

\section{\$ 265. Probative effect of enforcel selfincriminating} testimony. - It was held in Burrell v. Montana, 194 U. S. 579 $(1904), 48$ L. Ed. 1122 , that testimony given in an examination in bankruptcy, which was used without objection on the trial of the bankrupt on indictment in the state court did not violate any federal right. Section 7 of the Bankrupt Act providing that the testimony should not be offered, did not deprive the evidence of probative force when admitted withont objection in the State court.

$\S 266$. Immunity is limited to the subject of testimony.In United States v. Price, 96 Fed.Rep. 960, parties were indicted for conspiring to obstruct justice by taking from a witness subpœenoed to appear before a United States Grand Jury, certain papers which he had been directed to produce as furnishing testimony concerning a charge of violation of the Act to Regulate Commerce then before the Grand Jury. Two of the indicted persons testified that they had been called before and had testified before the Grand Jury concerning the violation of the Act to Regulate Commerce, and had also testified concerning the taking of the papers from the witness. The Court overruled the pleas, saving it was not the intention of Congress to grant to a witness amnesty as to other crimes merely because he had testified to the violation of the Interstate Commerce Act. The amnesty was only co-extensive with the requirement to testify. The first clause of the act of 1593 made necessary the second clause; otherwise neither would have been effective. The latter supplemented the former and was limited by it, and referred to nothing except to matter's that witnesses should not be excused from testimony by virtue of the 
Act. The Court said that this was not the proper construetion of the act of 1593. The least collusion with a friendly grand jury might enable the worst violator of the laws of the Cnited States to entitle himself to testily by prosuring himself to be smmmoned as a witness nominally to testify, or to be asked abont a riolation of the Interstate Commeree Law.

s: Power of the court to enforce testimony before the Cominission sustained. - In Brimson r. Interstate Commence Conmission, $15+$ U. S. $4+7$, 3S L. Ed. 10ti, the supreme Cialt, reversing it Fed. Rep. tio, sustained the anthority of the Circuit ( ourt under this section of the Interstate Commeree Act to enfore the giving of testimony and the proluction of books and papers. It was strongly urged that the provision Wils in conflict with the Constitution, in that it imposed on judicial tribmals duties that were not judicial in their character. Bat the Court ruled that the proceding under the twelfth section of the Act was not merely ancillary and adrisory, nor was its object merely to obtain an opinion of the Circuit Court. which would be without operation upon the rights of the parties. Any julginent would be a final and indisputable bissis of action as between the. Commission and the defendiant, and furnish a precedent for similar cases. The judgment was none the less one of a jullicial tribunal, dealing with fuestions julicial in their nature, and presented in the customal'y forms of judicial proceeding.s, because its effect may be to aid an ahministrative or executive boly in the performance of duties legally imposed upon it by Congress in the case of a power granted by the Constitution. The issue made in such a ease wis not one for the determination of a jury, nor could any question of eontempt arise until the issue of law in the Circuit court was determined adversely to the defendants and he hat refused to obey, not the order of the Commission, but the final order of the court. Sueh a power to adjuclge for contempt could not, under our system of government and consistently with due process of law be vested in a subordinate and administrative or executive tribunal for final determination. There was a dissenting opinion by Justice Brewer, in which Chief fustice luller and Justice Jackson eoncurred. 15.; U. S. 1.

: as. Relerancy of testimony before the commission.In a recent decision, Interstate Commerce Commission v. Baird, 
194 U. S. 25 (1904) 4S L. El. 860 the Supreme Court sustained an application of the Commission, reversing the Circuit Court, for the production of papers and the griving of testimony in an investigation pending before the Commission concerning an alleged pooling agreement in the transportation of coal. The complaint filed before the Commission alleged that the railroad companies were natural competitors and had made an 1 agreement or combination in coal rates which were unreasonable and unjust. The witness refused to proluce contracts for purchasing coal by the railroads from operators in Pennsylvania and to answer certain questions as to the sale and price of coal, and it was claimed that the enforced production of these papers and the compelling of this testimony would be violative of the Fourth and Fifth Amendments to the Consti. tution. The Supreme Court said that while the contracts might not establish the pooling arrangement, they would liave a legitimate bearing upon the inquiry, and that the testimony should not be so limited as to uneasonably lamper the Commission by narrowing its field of inquiry beyond the reasonable recuirements of the rights of citizens, as such a course would serionsly impair its usefulness and prevent a realization of the salutary purposes of Congress. The court held also that as under the act of 1903 the witnesses were given inmunity, there was no valid objections under the Fourth and Fifth Amendments to the Constitution. It was also ruled in this cise that the contracts, under which the railroad companies engaged in interstate carriage of anthracite coal had acquired certain collieries, whose proprietor's were about to build competing lines and guaranteed the stock and bonds issued in payment thereof by a corporation whose charter they had purchased for that purpose, conld properly be produced, although they had been made with third persons not parties to the proceeding.

\section{\& 269. General powers of the Commission.- The limita-} tions upon the power of the Commission in the matter of fixing rates, or in ordering through routing, hare been already considered. The Commission has no power to compel carriers to provide cars of any special kind or with any special equipment. (5 I. C. C. R. 193, 3 Int. Com. Rep. 841). Nor to order the granting of special privileges, such as stoppage in transit and milling in transit (1 I. C.C. R. 17, 1 Int. Com. 
Rep. 60.5; 1 I. C. C. R. 20, 1 Int. Com. Rep. 22): nor to compel extra allowance to passengers for baggage. 1 I. C. C. R. 122, 1 Int. Com. Rep. 370 . Neither has t any power to allow counsel or attorney fees, such as are provided under section 8 . 1 I. C. C. R. $: 99,1$ Int. Com. Rep. 639. Neither has it any power to enter judgments or decrees. (5 I. C. C. R. 16r, 3 Int. Com. Lep. \$:30): nor to impose penalties. Nor has it any power to malie any orler over persons not made parties to a proceeding before the Commisssion. 4 I. C. C. R. 195, 3 Int. ('om. Rep. 2ta.

On the other hand. the Commission is expressly given the greneral power to enforce the Act, to institute investigations ani summon witnesses on its own motion. 3 I. C. C. R. 59, $\because$ Int. Com. Rep. 496. It has a continuing juristiction over carriage notwithstanding the refusal of the Circuit Court to cnforce its opler. i I. C. C. R. its. While it cannot fix rates for the future, it has exercised the power of determining the just relation of rates as between localities and linds of traffic ( I. C. C. R. 481), and may fincl a demmrage charge or any existing rate umreasonable and unfair. As neither complainant nor complaint is necessary to confer jurisdiction on the Commission, the repeal of a State law creating a Railroad Commission does not operate as a withdrawal or lismissal of a complaint which has been filed by such State Commission, as the State Commission was only an instrument for the transmission of the complaint, and the Interstate Commerce Commission was fully empowered to proceed thereafter on its own motion. 5. I. C. C. I. 13, 3 Int. Com. Rep. 68s. See infira, section 12.

The eomprehensive and inquisitorial power of the Commission is illustrated by investigations from time to time as to freight rates in difrerent sections of the country and proposed increase of freight rates, as in the uniform bill of lading ${ }^{1}$ investigation made in lecember, 1904 in the city of Chicago at the instance of the American Shippers Association. The

${ }^{1}$ In the annual appropriation act of 1902,32 Stat. p. $110 \%$, there was included $\$ 25,000$ for special counsel for the Commission, $\$ 10,000$ arbitra. tion of railroad differences with em- ployees (infra: $\$ 3 \% 2)$, and \$3.5,000 for securing information as to use of railroad safety appliances under the Safety Act (infre, $\$ 3352-369)$. 
administrative duties of the Commission are also extensive under the safety appliance laws. See infra, $\$ 354$. The services of the Commission have also been invoked in adjusting controversies between shippers and carriers, as in the investigation of the differentials recognized by the carriers in their rates to the different cities of the eastern seaboard. See Report for 1904, p. 23.

The Commission in taking testimony before itself, whether in original investigations or in the hearing of complaints, is empowered to summon witnesses or to produce documentary evidence from any place in the United States to any designated place of hearing. The power of the Commission in this respect is greater than the power of the courts of the United States, as witnesses living out of the district are not required to attend court at a greater distance than a hundred miles, nor to attend the taking of depositions under a Commission at any place out of the county, nor more than forty miles from the place of their residence. Section 570 R. S. U. S. This power however has been rarely used, as the Commission has arranged its hearings as authorized by the Act (section 19) in different parts of the county convenient for the witnesses. 
SECTION 13.

5 270. Complaints to Commission-How and by whom made-How servel upon carriers........................ 314

2i1. Procedure before Commission--Parties ............... 314

$27:$ Pleadings ind proofs. ............................... 315

273. Burden of proof................................... 316

27. Production of books and papers . ..................... 317

275. The rulings of the Commission as precedents.......... 318

\section{:io. Complaints to Commission - How and by whom} made - How served upon carriers. - SEc. 13. That any person. firm, corporation, or association, or any mercantile, agricultural, or manufacturing society, or any boly politic or municipal organization complaining of anything done or omitted to be done by any common carrier subject to the provisions of this act in contravention of the provisions thereof, may apply to satil commission by petition, which shall briefly state the filcts: whereupon a statement of the charges thus made shall be forwarded by the Commission to such common carrier, who shall be called upon to satisfy the complaint or to answer the same in writing within a reasonable time, to be specified by the Commission. If such common carrier, within the time specified, shall make repalration for the injury alleged to have been done, said carrier shall be relieved of liability to the complainant only for the particular violation of law thus complained of. If such carrer shall not satisfy the complaint within the time specified, or there shall appear to be any reasonable ground for in restigating said complaint, it shall be the duty of the Commission to investigate the matters eomplained of in such manner and by such means as it shall deem proper.

said ('ommission shall in like manner investigate any complaint forwarded by the railroad commissioner or railroad commission of any state or territory, at the request of such commissioner or commission, and may institute any injury on its own motion in the same minner and to the same effect as though complaint hal been marle.

No complaint shall at any time be dismissed because of the absence of direct lamage to the complainant.

\$? Pr. Procedure before Commission - Parties. - This section regulating procedure before the Commission has been liberally construed by the Commission in furtherance of the obvious purpose of securing a summary investigation and with only so much formality as was essential to justice. I)ilatory proceedings are considered ohjectionable and a single speedy hearing is desired in every case. 1 I. O. C. R. 2.2:3, 1 Int. Com. liep. +10. 
Any person or association is entitled to complain either for himself or for any community in which he is interested. Many complaints have been made before the Commission by local trade organizations interested in the locality or in specific industries. Thus the Boston Fruit \& I'roduce Exchange was held a mereantile society within the meaning of the section and coukl maintain a proceeding without showing special dimage to itsulf as a society. 4 I. C. C. R. 6ri4, 3 Int. Com. Rep. 4!93. The Chicago Live Stock Exchange, whose members were engaged in the sale of live stock on commission in Chicago, was held entitled to maintain a proceeding to correct an unreasonable freight rate upon live stock from varions points to Chicago, notwithstanding certain by-laws and proceedings of the association were claimed to be in violation of the AntiTrust law. 7 I. C. C. R. 513. It is immaterial that such. trade organizations are unineorporated. See also 10 I. C. C. R. $42 \mathrm{~S}$.

The prior leare of court is not necessary to entitle a shipper to proceed against a railroad in the hands of a receiver. $B \mathrm{I}$. C. C. R. 520. When one malies a complaint under the Aet to Regulate Commerce anu sets up a personal grievance which he fails to prove before the Commission, if a violation of law by the defendant appear's, the Commission can take the necessary steps to bring the violation of the law to an end. 1 I. C. C. R. 209, 1 Int. Com. Rep. cil1.

As to parties defendant, it was held by the Supreme Court in Texas Pacific R. Co. v. Interstate Commerce Commission, supre, that the owner of the portion of line over which through freight is carried is a proper but not a necessary party in a proceeding concerning the alleged discrimination between inland and import rates. The Commission however has exercised the right to bring in all parties interested in a case. 4 I. C. C. R. 276,3 Int. Com. Rep. 2s2, 5 1. C. C. R. 571, 4 Int. Com. Rep. 230 .

$\$ 2 \%$. Plealings and proofs. - A complaint concerning classification of rates should not be made against the (lassiliciltion Committee or Rate Committee, but against the carriers who were represented by such committees, and the complaint should point them out by name. + I. C. C. R. 27i;: Int. Com. Rep. 282. The Commission has early announced and it has al- 
ways insisted that it would not express opi nions on abstract questions, nor on questions presented on exparte statements of facts, nor on questions of the statute presented for its advice, but without any controversy pending before it on complaint of riolation of law. 1 I. C. C. R. S, 1 Int. Com. Rep. 1s. The Commission will not consider the claim of a party for injury to grools resulting from delay, detention, etc., or from any cause not attributable to any violation of the provision of the act to reurulate commerce. 6 I. C. C. R. S.5. Where reparation is askel to the extent of alleged excessive charges, reasonable time is allowed for making proof of the amounts paid when the evidence adduced shows excessive charges without disclosing the amount of the excess. 6 I. C. C. R. 335. The procelure is in the simplest form consistent with reasonable crtalinty. To peplication is required. When the facts are not agreel upon, deposition may be taken upon notice or the hearing entered upon immediately after answer. Assignments of hearing are marie upon the request of either party and parties are heard orally or on briefs, as they may prefer. See 1 I. C. C. R. ㄹ:2: 1 Int. Com. Rep. 40 s.

When a carrier fails to answer the complaint filed, the Commission takes such proof of the facts as may be deemed proper and reasonible, and makes order therein accordingly. 5 I. C. C. R. 6if:, + Int. Com. Rep. 318.

\$ ?3:3. Burden of proof.- The question of burden of proof has been construed in the matter of reasonableness of rates, section 1, discriminations, section 2, and unjust preferences, section 3 . In general terms it may be said that the Commission arlopts the rules in regard to the burden of proof and the shifting of the weight of testimony in accordance with the establisher rules of courts of justice liberally and not technically administered. Thus the burien is upon the part y making the complaint, S I. C. C. R. 5(i1, and relief will not be granted without proof. 1 I. C. C.R. 15., 1 Int. Com. Rep. 627. But when the fact of a greater aggregate charge for a short or long haul on the same line is established, the burden is upon the carrier to justify such excess. 4 I. C. C. R. 10t. But where the carrier makes application for relief under the fourth section, he assumes the burden in the first instance. So where there is a departure from equal rates on several branches of 
a road, the carrier is called upon to justify. 2 I C. C. R. 60t, 2 Int. Com. Rep. 431. 8 I. C. C. R. 93 ruled that the burden is upon the carrier in all cases, where the departure from the rule of the law is made, to show clearly that his departure is justified, eiting Missouri Pacific Ry. Co. v. Texas \& Pacifie Ry. Co., 31 Fed. Rep. $\$ 62$. When the facts justifying an apparent disparity in rates a re peculiarly within the knowledgre of the earrier ( 6 I. C. C. R. 1), the burden is on him; thus the carrier must justify the disparity between rates on gran and grain products. 3 I. C. C. R. 25, 2 Int. Com. Rep. 60t. The informal charaeter of the procedure before the Commission is illustrated by the case (9 I. C. C. R. 602) where the general freight agent of the Texas \& Pacific Railroad Company referred to the Commission a claim of a shipper for carload rating on a mixed carload of lemons and pineapples, it appearing that the tariff provided for a mixed carload of lemons and bananas and pineapples and bananas, but not for a mixed carload of lemons and pineapples, the general freight agent expressing his belief that the claim was equitable. The Commission said that a matter submitted in this way should be treated as a complaint and answer; the railroad company should make answer and make reparation to the complainant for the rate above the carload rate.

When an important question is raised by the pleadings in a case, the determination of which will affect others quite as much as the parties before the Commission, but the parties give their attention almost exclusirely to other questions, and neither by the evidence nor in argument supply the Commission with the information to enable it to be understandingly determined, the Commission will decline to decide it, and leave the parties to bring it forward again as they maty be advised. 1 I. C. C. R. 50:3, 1 Int. Com. Rep. 72:.

\&: 4 . Proluction of books and papers. - In 3 I. C. C. R. 1s6, 2 Int. Com. Rep. 5st, the Commission suggested the morles of procedure by which the inconvenience to defendant carriers of producing books where many entries were involved, might be avoided by petitioner, as by requiring statements of specific charges and facilities during specified period, or taking depositions by consent in advance of hearing.

As to proceedings for taking testimony and the production of books and papers, see this case, in which the Commission 
said that there was a rery manifest difference between ordering the production of books and papers of carriers directly interested and those of other parties, strangers to the proceeding. It was said in this case that the books of defendant carrier as to the rates charged, the facilities furnished and the greneral morements of freight were in the nature of semi-public records, and statements shonkl be made therefrom on rejnest as promptly as pricticable. (See this case for what is required for an order for the production of books and papers.)

s.7. The ruliums of the Commission as precedents. The rulings of the Commission are based so distinetly upon the special facts of the cases submitted that the doctrine of jullicial precedent has only a limited application. Thus in decilling a case against one or more carriers charged with making rates which are unjustly discriminating in a certain line of traflic, the decision may not apply at all to the rates in other sections where facts may be altogether different. 2 I. C. C. R. $36.5,2$ Int. Com. Rep. 24.5 . One case can seldom be an exact precedent for another, for each traftic situation presents points of differenee, and each complaint must be judged upon its own peculial facts. S I. C. C. R. $\frac{1}{4} 19$.

A rate may be unreasonable at one time, and through changed conditions may become reasonable at another time, even before the conclusion of the litigation as to the reasonability of the rate. See conclusion of opinion in Nebraska Rilte case, 169 U. S. 1. c. p. 550. 


\section{Slection 14.}

$\S 2 \pi 6$. Commission must make report of investigations............ 319

27\%. The report of findings of fact made primu facie evidence... . 319

278. The Commission as a general referee . . . . . . . . . . . $3: 0$

2:9. Claims for rep uration before the Commission.............

280. Reports of decisions . ........................

\section{\$ 2j6. Commission must make report of investication.}

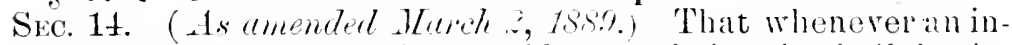
vestigation shall be made by said ('ommission, it shall be its duty to make a report in writing in respect thereto, which shall include the findings of fact upon which the conclusions of the Commission are based, together with its recommendation as to what reparation, if any, shonkl be made by the common carrier to any party or parties who miay be found to have been injured: and such findings so made shall thereafter, in all judicial proceedings, be deemed prime fincie evidence as to each and every fact fomnd.

All reports of investigations male by the Commission shall be entered of record, and a copy thereof shall be furnished to the party who may have complained, and to any common carrier that may have been complainerl of.

The Commission may provide for the publication of its reports and decisions in such form and manner as may be best adapted for public information and use, and such authorized publications shall be competent evidence of the reports and decisions of the Commission therein contained, in all courts of the Uniterl States, and of the several States, without any further proof or anthentication thereof. The ('ommission may also cause to be printed for carly distribution its annual reports.

\section{\$ 27\%. The report of findings of fact male prima facie} evillence.-It was said by Justice Jackson in the Kentucky and Indiana Bridge case, sume, 37 Fed. Rep. 567, the first important decision under the Act, that in respect to interstate commerce matters covered by the Act, the Commission may be regarded as the general referee of each and every Circuit Court of the United States upon which the jurisdiction is conferred of enforcing the rights, duties and obligations recognized and enforced by the Act. The functions of the Commission are those of referees or special commissioners appointed to make preliminary in restigations of and report upon matters for subsequent judicial examination and determina- 
tion. The supreme Court has silil in several cases that the proper course of procedure is for all the facts to be submitted to the Commission, and it has refused to assume to exert its original judgment on the facts, as under the statute the courts are entitled. before approaching the facts, to the aid that must necessarily be allorded by the previous enlightened judgment of the Commission upon such subjects. See East Tennessee ete. liy. (o. v. Interstate Commerce Commission, 1s1 U. S. 1, 1 c. 27 . 45 L. Ed. 719, 729, and cases cited. In L. \& $T$. R. Co. v. Behlmer, 175 U. s. 1its, $4+$ L. Ed. 3019, the Court said that the let attributes mima facie effect to findings of fact made by the commission, and that boly from the nature of its function and the duties imposed upon it by the statute is peculiarly competent to pass upon questions of fact of the character here arising. The comt therefore in several cases, where it adjulged that the Commission had erred in the mistaken view of the law, lirected the dismissal of the proceedlings in court without prejulice to the right of the Commission to further investigate the facts. See supro, and cases cited.

s.s. The Commission as a general referee. - While the Commission is thus a general referee, its position is somewhat anomalons in the law, in that it not only acts in a quasi jurlicial capacity as a referee, but it may also institute proceedings in its name in the courts and thus be a prosecutor in the same cases wherein it has acterl as jurge.

While there is no requirement in the Act that carriers complained of shall produce all of their evidence before the Commission, and in numerous cases parties have reserved such evidence until hearing wits hal in the courts on proceedings instituter by the commission to enforce their orders, the Supreme ("ompt has said that this was not the proper procedure

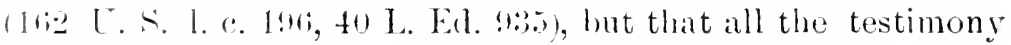
should be submitted to the Commission for their determination of the yuestions of fact. The ('ommission hats rulerl that it is not recpuired to report the letails of evidence, but only its finlings of fact. Siec 1 I. C. C. R. 490,1 Int. Com. Rep. 7T: fi-:, where it said that the report and findings of the Commission upon evidence related only to the ascertainment and pres.ntation of all the material facts necessary to clearly and justly present the merits of the controversy, and the Commis- 
sion therefore does not report evidence which is only eumulative, or which is immaterial or irrelevant, or show details of evidence all embraced in the substantial facts stated upon which the findings and conclusions of the Commission are made. As to the effect of the Commission's finclings upon the questions of reparation in view of the constitutional guaranty of trial by jury, see infra, sections 15 and 16.

898. Claims for reparation before the Conmission.While the Commission cannot determine rates for the future, in order to determine a claim of reparation for the charge of an unreasonable rate, it must decide what l'ate should have been charged, that is, what is a reasonable rate, in orier to determine the amount of damage to which the party is entitled. As to the procelure of the Commission in claims of reparation, it was held that the complainant must make proof of his damage (5 I. C. C. R. 158); that all the carriers on the route need not be before the Commission (6 I. C. C. R. 358), and that speculative damages will not be allowed, is I. C. C. R. 97, 3 Int. Com. Rep. ito. Nor will the Commission eonsider claims not arising out of the duties imposed by the Act. 4 I. C. C. R. 265, 3 Int. Com. Rep. 2-5. It is sufficient for the complainant to consult the published sehedule of charges, and he is entitled to recorer thereon the exeess over such schedules charged him. TI. C. C. R. 2.i. See also as to conclusions of Commission as to its juriselictions in matter of awarding reparation. 5 I. C. C. R. 84,3 Int. Com. Rep. 711 .

The subject of reparation was discnssed by the Commission in the case of the Independent Refiner's Association, 6 I. C. C. R. 375, 7 I. C. C. R. 513 . In this case claims of reparation were allowed to be filed in the same proceeding by the individnal shippers who were members of the complaining association. The Circuit Court however for the western district of Pennsylvania, 82 Fed. Rep. 192, refused to enforce this order, holding that each complainant had a plain, adequate and complete remedy at law. Thereafter in the case of the Cattle Raisers Association of Texas, 10 I. C. C. R. 83, the Commission held that in view of the unsettled state of the law as to the recovery of claims of reparation, the members of the complaining association should file intervening petitions, each for 
his own demand. The suits brought in the Circuit Court (W. Dist. of Penn.) for recovery of the amounts allowed the Commission on the claims of members of the Independent Refiners Association are still (1!04) pending undetermined.

soo. Reports of decisions. - The provision for the publication of the reports of the Commission was alded to the section by the amendment of 1889 . There were originally two series of reports containing the opinions of the Interstate Commeree Commission. The Interstate Commerce Reports, cited as "Int. Com. Rep." were publis!ed by the Lawyer's Co-()peritive Publishing Company of Rochester, New York, and included not only the reports of the Commission but also the proceedings of the Commission, and the reports of decisions of the conrt on Interstate Commerce questions. The Interstate Commerce Commission Reports, cited as "I. C. C. R.." were tirst published by L. K. Strouse \& Co. of New York. The Lawyer's' Co-Operative Publishing Company purchased the other series, and now the official and only edition is that published by the Lawyers' Co-Operative Publishing Company, reporting only the deeisions of the Interstate Commerce Commission, with an occasional appendix of reports of other interstate commerce cases. Advance numbers of volume 10 are now (1905) in the course of publication. The reports now published are eited as I. C. C. R. The five rolumes of the discontinued (Strouse) series contain the same cases included in volumes 1 to 4 of the Co-Onerative series. 


\section{SECTION 15.}

\$ 281. Notice to common carrier to cease from violation of act.

28?. Notice to the carrier jurisdictiona!.

\$ :81. Sotice to common carrier to ceass from violation of act. - Sec. 15. That if in any case in which an inrestigation shall be mate by said Commission it shall be manle to appear to the satisfaction of the Commission, either by the testimony of witnesses or other evidence, that anything has been done or omitted to be done in violation of the provisions of this act, or of any law cognizable by said Commission, by any common carrier, or that any injury or clamage has been sustained by the party or parties complaining, or by other parties aggrieved in consequence of anr such violation, it shall be the duty of the Commission to forthwith canse a copy of its report in respect thereto to be delivered to such common carrier, togrether with a notice to said common carrier to cease and desist from such violation, or to make reparation for the injury so found to have been done, or both, within a reasonable time, to be specified by the Commission; and if, within the time specified, it shall be made to appear to the Commission that such common carrier had ceased from such violation of law, and has made reparation for the injury found to hare been done, in compliance with the report and notice of the Commission, or to the satisfaction of the party complaining, a statement to that effect shall be entered of record by the Commission, and the sail common carrier shall thereupon be relieved from the further liability or penalty for such particular violation of law.

\$2:. Notice to the carrier juristictional.-This section is really supplementary to the preceding, in that it provides for notification to the carrier of the finding of the Commission, when such finding is against the carrier. As seen before, it is provided by section 9 that a party complaining has the election of proceeding under sections 8 and 9 directly in court, or of proceeding before the Commission. If the tind-. ing of the Commission is against the shipper, the complaint is dismissed, and in such case the party is barred from proceeding in eourt on the same complaint. The Commission has no power to enforce its findings and the succeeding section provides for the requisite legal procedure for such enforcement. Notification to the carrier is therefore a jurisdictional step in such procedure. See 7 I. C. C. R. 286. 


\section{Siction 16.}

s. 28. Petition to United States courts in cases of disobedience to order of Commission............................ 324

24. The saving of the right of trial by jury ................ 896

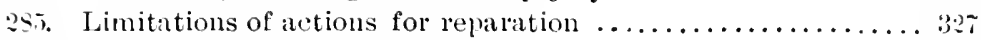

?2: Jurisliction of the Circuit Court. ................. 328

$2:$. Proper and necessary parties to procedure............. 328

: Pas. Parties defendant ............................ 829

3:9. Prima facie effect of the report..................... $3 \geqslant 9$

$: 90$. The revisory power of the court $\ldots \ldots \ldots \ldots \ldots \ldots \ldots \ldots \ldots \ldots$

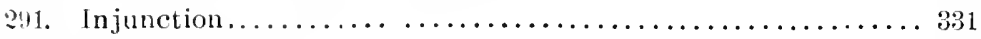

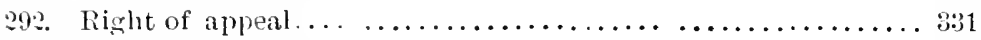

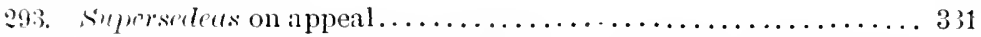

:94. The provision as to supersedects applies only to appeals from

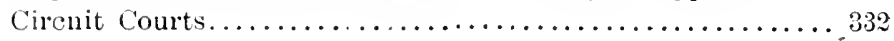

\section{24:3. Petition to Inited States comrts in cases of diso-} bedirnce to order of C'ommission.- SEC. 16. (As amended. Mard . 15s\%.) That whenerer any common carrier, as defined in and subject to the provisions of this act, shall violate, or refuse or neglect to obey or perform any lawful order or reyuirement of the Commission cleated by this act, not founded upon a controversy requiring a trial by jury, as provided by the serenth amendment to the Constitution of the United states, it shall be lawful for the Commission or for any company or person interested in such order or requirement, to apply in a summary way, by petition, to the circuit court of the Inited States sitting in equity in the judicial district in which the common carrier complained of has its principal office, or in which the violation or disobedience of such order or requirement shall happen, alleging such violation or disobedience, as the case may be: and the said court shall have power to hear and determine the matter, on such short notice to the common carrier complained of as the court shall deem reasonable: and such notice may be served on such common carrier, his or its officers, agents, or servants in such manner as the court shall lirect: and said court shall proceed to hear and determine the matter speedily as a court of equity, and without the formal plearlings and proceedings applicable to ordinary suits in equity, but in such manner as to do justice in the premises; and to this end such court shall have power, if it think fit, to direct and prosecute in such mode and by such persons as it may appoint, all such inquiries as the court may think needful to enable it to form a just judgment in the matter of such petition; and on such hearing the findings of fact in the rejort of said Commission shall be prima fercie evidence of the 
matters therein stated; and if it be made to appear to such court, on such hearing or on report of any such person or persons, that the lawful order or requirement of said Commission drawn in question has been violated or disobeyed, it shall be lawful for such court to issue a writ of injunction or other proper process, mandatory or otherwise, to restrain such common carrier from further continuing such violation or lisobedienee of such order or requirement of satil Commission, and enjoining obedience to the same; and in case of any disobedience of any such writ of injunction or other proper process, manda tory or otherwise, it shall be lawlul for such court to issue writs of attachment, or any other process of said court incident or alpplicable to writs of injunction or other proper process, mandiltory or otherwise, against such common carrier, and if a eorporation, against one or more of the directors, officers, or agrents of the same, or against any owner, lessee, trustee, receiver, or other person failing to obey such writ of injunction, or other proper process, inandatory or otherwise; and said court may, if it shall think fit, make an order directing sueh eommon earrier or other person so disobeying such writ of injunction or other proper proeess, mandatory or otherwise, to pay such sum of moner, not exceeding for each earrier or person in defialt the sum of five hundred dollars for every day, after a day to be named in the order, that such carrier or other person shall fail to obey such injunction or other proper process, manditory or otherwise; and such moneys shall be payable as the court shall direct, either to the party eomplaining or into court to abide the ultimate decision of the court, or into the treasury; and payment thereof may, without prejudice to any other mode of recorering the sime, be enforced by attachment or order in the nature of a writ of execution, in like manner as if the same hat been recovered by a finat decree in personam in such court. When the subject in dispute shall be of the value of two thousand dollars or more, either party to such proceeding before said eourt may appeal to the Supreme Court of the Tnited States, uncler the same regulations now provided by law in respect of security for such appeal; but such appeal shall not operate to stay or supersede the order of the court or the execution of any writ or process thereon; and such court may, in every such matter, order the payment of such costs and counsel fees as shall be deemed reasonable. Whenever any such petition shall be filed or presented by the Commission it shall be the duty of the district attorney, under the direetion of the Attorney-General of the United States, to prosecute the same; and the costs and expenses of such.prosecution shall be paid ont of the appropriation for the expenses of the courts of the United States.

If the matters involved in any such order or requirement of said Commission are founded upon a controversy requiring a 
trial by jury, as provided by the seventh amendment to the Constitution of the Cnited States, and any such common car. rier shall violate or refuse or neglect to obey or perform the same, after notice giren by said Commission as provided in the tifteenth section of this act, it shall be law ful for any company or person interested in such order or requirement to apply in is summary way by petition to the circuit court of the United states sitting as a court of law in the judicial district in which the carriel complained of has its principal olfice, or in which the violation or disobedience of such order or requirement shill happen, alleging such riolation or disobedience as the case nuy be; and said court shall by its order then lix a time and plice for the trial of said cause, which shall not be less than twenty nor more than forty days from the time said order is made, and it shall be the duty of the marshal of the district in which said proceeding is pending to forthwith serve a copy of said petition, and of said order, upon each of the defend. ants, and it shall be the duty of the defendants to file their answers to said petition within ten days after the service of the sime upon them as aforesaid. At the trial the findings of fact of said C'ommission as set forth in its report shall be prima facie evidence of the matters therein stated, and if either party shall demand a jury or shall omit to waive a jury the court shall, br its order, direct the marshal forthwith to summon a jury to try the cause; but if all the partics shall waive a jury in writing then the court shall try the issues in said cause and render its judgment thereon. If the subject in dispute shall be of the value of two thousand dollars or more either party may appeal to the supreme Court of the United States under the same regulations now provided by law in respect to security for such appeal: but such appeal must be taken within tiventy days from the day of rendition of the judgment of said circuit conit. If the jucloment of the circuit court shall be in faror of the party complaining he or they shall be entitled to recorer a reasonable counsel or attorney's fee, to be fixed by the court, which shall be collected as part of the costs in the case. For the purposes of this act, excepting its penal provisions, the circuit courts of the United states shall be deemed to be always in session.

sot. 'The saving of the right of trial by jury.- The Amendment of March 2, 1s,9, excepted in the first paragraph from the equity juriseliction of the court the orders not founded upon a controversy requiring trial by jury, as provided by the Serenth Anendinent to the Constitution of the United States, and also provided in the last paragraph for the trial by jury of such controversies. The sieventh Amendment to the Constitution provides that in suits at common law where 
the value in controversy shall exceed twenty clollars, the right of trial by jury shall be preserved and no fact tried by a jury shall be otherwise re-examined in any court of the United States than according to the ruling of the common law. This Amendment of 1859 was made in view of the express requirement in section 14 that the Commission shonld make recommendation as to what reparation, if any, should be made by the common carrier to any party or parties who may have been found to have been injured.

In Interstate Commerce Commission v. W., N. Y. \& P. R. R. S2 Fed. Rep. 192 (W. Dist. of Penn.), the complaint of the Commission contained a requirement that the railroad companies should make reparation to the eomplaining shippers, and included a finding and an order to the amount each complainant was entitled to recover as reparation for defendant's alleged unlawful charges. The Cireuit Court sustained a demurrer to so much of the petition as related to reparation claims, holding that the Court had no power to enforee such orders. The Court said that the distinction between legal and equitable rights and remedies was sharply defined in the Lct, and that each claimant had a plain, adequate and complete remedy at law. The railroals could not be deprived of their rights of trial by jury, by reason of the fact that claimants had seen fit, in the first instance, to apply to the Commission. The jurisdietion of the Court was auxiliary and limited, and the principle in equity to have taken jurisdiction to go through with the case was not applicable. It would follow therefore that the right of each shipper to reparation and damages is a separate legal controversy, which is entitled to a jury trial when in excess of twenty dollars. The Commission proceeded upon this view in a late case, that of the Texas Cattle Raisers (10 I. C. C. R. S8), and direeted each of the individuai members of the complaining association seeking damages, to file a claim in the nature of an intervening petition with a specification giving as definitely as possible, the dates and amounts paid. The Commission said however that the law as to the procedure in the enforcement of such claims was unsettled.

\$ 255. Limitations of actions for reparation.- - In the case last cited, the Commission discussed the question of limitations, 
and inclined to the opinion that the beginning of proceedings before the Commission should be treated as the beginning of the suit by the tiling of the original petition before the Commission. This question however of the application of the statute of limitations to such claims has not been judicially determined. It would seem from analogy to the applieation of the statute in suits brouglat by shipper's under sections $S$ and :", (see sup're), that the limitation statute as to such rights of action, in the states where the claim is sought to bo enforced, should control, and the beginning of the suit to enforce the individual clammants rights to reparation should be the beginning of the action within the meaning of such statute.

Soti. Jurisliction of the Circuit conrt.- The petition of the Commission is to be filed in the Cireuit Court of the United States in the julicial district where the common carrier complatined of has his principal office, or in which the violation or disobelience of this order shall happen. In Interstate Commerce Commission v. W., X. T. \& I'. R. R., s2 Fed. Rep. 192, the court silid that the riolation within the judicial district of the order of the Commission by any one of the defendints who were parties to the common arrangement for interstate shipments, was riolation or disobedience of all the defendants who were parties to and acting under the common arrangement, and that all of them were subject to the jurisdiction of the court in the district wherein the offense was committed.

See also Commission r. Sonthern Pacific Ry., 74 Fed. Rep. 42: C'ommission r. So. Pa. R. R. Co. et al., 123 Fed. Rep. 597.

בs. Proper and necessary parties to procedure.- Proceedings in the circuit Court to enforee the orders of the Commission may be filed by any company or person interested in the order of the Commission, or by the Commission itself, as a party complainant. In Texas \& Paeifie R. R. v. Interstate ('ommerce ('ommission, 16:2 L. S. 197, to L. Eal. Sti', the supreme Court said that the Interstate Commerce Commission was a body corporate, with legal capacity to be a party plaintill or defendant in the ferleral courts. When the petition is filed or presented by the Commission, it is the duty of the district attorney under direction of the Attorney General of the I'nited States to prosecute. Suit may also be frought by the Lnited States at the expense of the Commission without any preliminary proceeding before the Commission. 
It seems that it is not necessary that the Commission should have a preliminary investigation before filing suit for the en. forcement of its own orders; on the contrary, it was said by the Supreme Court in Texas \& P'acific case, supra:

"We do not, of course, mean to imply that the Commission may not directly institute proceedings in a Circuit Court of the United States charging a common carrier with dispegard of the provisions of the Act and that thus it may becone the daty of the court to try the case in the first instance."

:ss. Parties defendant.- All the parties to the rate complained of are proper parties, but they are not all necessary parties. See Texas \& Pacific Ry. case, supra.

The successors of railroad companies who are made parties to proceedings before the Commission, are not strangers to the order, but are bound by the judgment or decree in the suit, on the principle that they are purchasers of the litigation, jendente lite.

See Interstate Commerce Commission v. W., N. Y. \& P. R. R., 82 Fed. Rep. 192. Commission v. So. Pa. Co. et al., 123 Ied. 597 .

\$89. Prima facie effect of the report.- The supreme Court said in C., N. (). \& T. P. RY. v. Commission, 162 U. S. 1St, 40 L. Ed. 985, that the testimony in the Circuit Court is not limited to that taken before the Commission; that is to say, either party may introduce other testimony. The supreme Court in this case, expressed disapproval of such a method of procedure on the part of the railroad companies as wonld lead them to withhold the larger part of their evidence from the Commission and first adduce it in the circuit court, saying:

"The Commission is an administrative board and the courts are only to be resorted to when the Commission prefers to enforce the provisions of the statute by a direct proceding in the court, or when the orders of the Commission have been disregarded. The theory of the act evidently is, as shown by the provision, that the findings of the Commission should be regarded as prima facie evidence that the facts of the case are to be disclosed before the Commission. We do not mean, of course, that either party, in a trial in a conrt. is to be restricted to the evidence that was before the Commission, but that the purpose of the act called for a full inquiry by the Commission into all the circumstances and conditions pertinent to the questions involved."

It follows that in a suit to enforce the orders of the Commission, the burden rests upon the defendant company to show 
them to be erroneous. Commission r. L. \& N. Ry., 102 Fed. liep. row, 11s Fed. Rep. 613. See also Commission r. C. B. \& Q. R. R. Co. $9+$ Fed. Rep. 272.

In Commission $r$. Southem Pacific Company et al, 12s. Fed. Rep. $89 \pi$, in a suit brought to enforce the order of the Commission, that the railroad company should desist from the practice of controlling through routing, the Court held that the fimling of the Commission that this practice subjected shippers to an undue prejudice was one of fuct, and the order based thereon requiring the company to desist was prima facie a law ful order such as the court was required to enforce in a suit bronght under section 16, and the finding of the Commission that such a practice was made in violation of section 5 . of the Act supported the lawfulness of the order requiring the companies to lesist from enforcing such rule. The demurrer to the petition was therefore orerruled. See final decree in this case in 1920 led. Tep. 829.

\section{smo. The revisory power of the Court.- The Circuit} Court has no revisory power over the orders of the Commission; that is, the court can only enforce or refuse to enforce the orlers of the Commission. Thus it was said in Commission v. 1)., L. \& IV. Riy., lit Fed. Rep. ros, that the Court could not substitute for an order actually made, one which the Commission might or should have made, or which it intended, but failed to make. In the Alabama \& Midland Ry. case, $16 \mathrm{~s} \mathrm{U}$. $\therefore 17.2$ L. Ed. 41 t, the supreme Court said, that where the Circuit court of Appeals was of opinion that the Commission in making its order has misconeeived the extent of its powers, and the Circuit Court had erred in affirming the validity of an order mate under such misconception, it was the duty of the Circuit Comrt of Appeals to reverse the decree, set aside the order, and remand the case to the Commission, in order that it might, if it saw tit. proceed therein according to law. The defendant wis entitled to have its defense considered in the first instance at least. by the Commission, upon a full consideration of all all the circumstances and conditions upon which a legitimate order conkl be found, and it did not comport with the true schene of the statute that the Circuit Court of A ppeals undertake of its own motion to find and pass upon the questions of facts. The Supreme court in the several cases heretofore cited, wherein it held that the Commission had proceeded 
upon a misconception of the law as to the controlling effect of competition, directed the dismissal of the proceedings without prejudice to the right of the Commission to re-investigate the facts.

\$991. Injunction.-The section authorizes writ of injunction or process against the earriers in cases of disobedience. A writ of preliminary injunetion however to restrain a carrier from disobeying an order of the C'ommission must be established according to due course of equity procedure. Where the facts set out in the petition of the Commission are denied by the answer of the defendant, such findings are not taken as established on an application for preliminary injunction. Commission v. Lehigh Valley Ry., 49 Fed. Rep. 177; Kentucky, etc. Bridge Co. v. L. \& N. Ry. Co., 37 Fed. Rep. 567.

\$? Right of appeal. - The section provides for an appeal from the Circuit Court to the Supreme Court. After the act of 1891 establishing the Cireuit Court of Appeals went in to effect, appeals thereafter taken from decrees of the Circuit Court enforeing orlers of the Interstate Commerce Commission were taken directly from the Circuit Court to the Cireuit Court of Appeals. Commission v. A., T. \& S. F. R. Co., 149 U. S. 264,37 L. Ed. 727; Little Rock, etc. R. Co. v. E. Tenn. etc. R. Co., 159 U. S. 698,40 L. Ed. 311. Appeal or errorlies from such judgments of the Circuit Court of Appeals to the Supreme Court under the act of 1591 , section 11 . In controversies of this kind arising under the Interstate Commeree Act, where the jurisliction of the Circuit Court is not dependent upon diverse citizenship, the judgment of the Court of Appeals is not final. L. \& N. R. Co. v. Behmer, 169 U. S. $64 t, 42 \mathrm{~L}$. Ed. S59. But see Expedition Act of February 11, 1903, whereunder suits in equity under this act, and the Anti-Trust Act, wherein the United States is complainant, are appealable directly to the Supreme Court. See infira, $\$ 34 \%$

29:3. Superserleas on appeal. - The section provides that such appeal "shall not operate to stay or supersede the order of a court, or the execution of any writ or process thereon." It was held in Commission v. L. \& N. Ry., 101 Fed. Rep. 146, that this provision related only to the effect of an appeal, and did not deprive the Circuit Courts of their rights of control over their own decrees. A decree granting an injunction is not superseded by an appeal from the decree even though all the 
recuisites for a supersededs be complied with. Ilovey v. McDonald, 109 U. S. 161, 27 L. Ed. S91; Leonard v. Land Co., 115 U. S. 468, 29 I. El. 4t5; Knox Co. v. Harshman, 132 U. S. 14, 8:) L. Ed. 249. The Circuit Court has power to order a continnance of the status quo, and to keep the injunction in force pending the appeal, and as long as the appeal remained unperfected it continued under the power of the Court during the term. Is the defendants might be subject to irreparable injury and to multiplicity of suits, if the injunction should be enforced pending the appeal, it wars ordered that the defendant keep an accurate account of their shipments, to make reports to the Comrt quarterly, and to give bond, and thereupon the Court orderer the injunction suspended pending the appeal.

\section{$5: 94$. The provision as to supersedeas applies only to ap-} peals from Cirenit Courts. - It was held in Louisville \& Nashville R. Co. v. Pehlmer, 169 U. S. 644,42 L. Ed. sso, that the provision in this section as to supersodects relates only to appeals from the trial court. In this case the Circuit Court entered a decree dismissing the bill filed for the enforcement of the order of the Commission. 71 Fed. liep. 885 . Beblmer appealed to the Cirenit Court of Appeals for the fourth circuit, and that court reversed the decree of the Circuit Court and directed that the order of the Interstate Commerce Commission be enforced. 25 C. C. A. 2.29, 5 Fed. Rep. s!s. An appeal was then allowed and perfected to the supreme Court. The supreme Court held that this latter appeal operated as a supersrdeces, and denied the motion of Behlmer to vacate the supersedver resulting from the allowance of the appeal and the approval of the bond tendered. The court said that the appeal treated of in section 16 was the appeal from the tricl court, and dirl not apply to appeals from the Cirenit Courts of Appeals, and the scope of the provision was not enlarged by the act of 1591 creating the Circuit Court ol 1 ppeals so as to make this provision apply to the appeals from the Circuit Court of Appeals. The court sairl that when the case was brought to the Supreme Court from the Circuit Court of Appeals, their mandate went to the court of the first instance, and was there carried into effect, although the court of Appeals may have sent its own manclate down before the case was brought to the supreme Court. 


\section{SECTION 17.}

§ 295. Interstate Commerce Commission-Form of procelure.

\$ 295. Interstate Commerce Commission-Form of procedure.-Sec. 17. (As amended Marde .), 1s89.) That the Commission may conduct its proceedings in such manner as will best conduce to the proper dispateh of business and to the: ends of justice. A majority of the Commission shall constitute a quorum for the transaction of business, but no Commissioner shall participate in any hoaring or proceeding in which he has any pecuniary interest. Said Commission may, from time to time, make or amend such general rules or orders as may be requisite for the order and pegulation of proceedings before it, including forms of notices and the service thereof, which shall conform, as nearly as may be, to those in use in the courts of the United States. Any party may appear before said Commission and be heard, in person or by attorney. Every vote and official act of the Commission shall be entered of reeord, and its proceedings shall be public upon the request of either party interested. Said Commission shall have an official seal, which shall be judicially noticed. Either of the members of the Commission may administer oaths and affirmagions and sign subponas. 


\section{Siection 18.}

รุ 396. Salaries of Commissioners, secretary, etc.

29\%. Expenses of the Commission.

596. Salaries of Commissioners, secretary, etc.-SEc. 1s. (As amended.) That each Commissioner shall receive an annual salary of seven thousand five hundred dollars, payable in the same manner as the julges of the courts of the United states. 'The Commission shall appoint a secretary, who shall leceire an annual salary of three thousand fire hundred dollars, payable in like manner. The Commission shall have authority to employ and fix the compensation of such other emplorees as it may find necessary to the proper performance of its duties. Tntil otherwise provided by law, the Commission mar hire suitable oflices for its use, and shall have authority to procure all necessary office supplies. Witnesses summoned betore the Commission shall be paid the same fees and mileage that are paid witnesses in the courts of the linited states.

All of the expenses of the Commission, including all necessary expenses for transportation incurred by the Commissioners, or by their employees under their orders, in making any investigation, or upon oflicial business in any other places than in the city of $W^{\top}$ ashington, shall be allowed and paid on the presentation of itemized vouchers therefor approved by the chairman of the Commission.

89\%. Expenses of the Commission. - The secretary of the Interstate Commerce Commission is entitled to be reimbursed for telegrams sent by him in pursuance of directions of the Commission, approved by the chairman of the Commission, and accompanied by the request of the chairman that the rules of the comptroller as to the production of copies of telesrams for which credit is aslied be disregarded on account of the confidential character of the messages, the secretary haring also offered to submit the books of the Commission to the comptroller and auditing officers of the Treasury. United Sitates v. Moseley, 157 U. S. 322, 47 L. Ed. 195, affirming the judgment of the C'ourt of Claims. 


\section{Section 19.}

§ 298. Principal office of the Commission, etc.

299. Practice of Commission in hearing.

898. Principal office of the Commission, etc.- SEC 19. That the principal office of the Commission shail be in the city of Washington, where its general sessions shall be held; but whenever the convenience of the public or the parties may be promoted or delay or expense prevented thereby, the Comimission may hold special sessions in any part of the United states. It may, by one or more of the Commissioners, prosecute any inquiry necessary to its cluties, in any part of the United states, into any matter or question of fact pertaining to the business of any common carrier subject to the provisions of this act.

\$ 299. Practice of Commission in héaring.- The Commission has from its first organization followed the pratice of deciding cases involving local rates to be heard before one or more members of the Commission at a central point in the territory immediately affected bv the rates. 2 I. C. C. R. 309, 2 Int. Com. Rep. 799. 


\section{Section 20.}

$\$ 300$. Carriers subject to the Act must render full annual reports to Commission.

\$300. Carriers subject to the Act must render full annilal reports to Commission. - Sec. 20. That the Commission is hereby authorized to require annual reports from all common carrier's subject to the provisions of this act, to fix the time and prescribe the manner in which such reports shall be made, and to refuire from such carriers specific answers to all questions upon which the Commission may need information. Such annual reports shall show in cletail the amount of capital stock issued, the amounts paid therefor, and the manner of payment for the same; the dividends paid, the surplus fund, if anv, and the number of stockholders; the funded and floating debts and the interest paid thereon; the cost and value of the carrier"s property, franchises, and equipments; the number of emplorees and the salaries paid each class: the amounts expended for in provements each year, how expended, and the character of such improvements; the earnings and receipts from each branch of business and from all sources; the operating and other expenses; the balances of profit and loss; and a complete exhibit of the financial operations of the carrier each year, including an annual balance-sheet. Such reports shall also contain such information in relation to rates or regulations concerning fares or freights, or agreements, arrangements, or contracts with other common carriers, as the Commission mat require; and the said Commission may, within its discretion, for the purpose of enabling it the better to carry ont the purposes of this act, prescribe if in the opinion of the Commission it is practicable to prescribe such uniformity and methods of keeping accounts) a period of time within which all common earriers subject to the provisions of this act shall have, as near as may be, a uniform svistem of accounts, and the manner in which such accounts shail be kept.

\section{Railroads which are not sulyject to section 20 of} the Act.- A railroad lying wholly within a state which transports freight, whether coming from within or without the state, solely on local bills of lading, under a special contract limited to its own line, and without dividing charges with any other carriers or assuming any other obligations to or for them, does not come within the provisions of the Interstate commerce Act and is not bound to make any report of its business to the Interstate Commerce Commission. United 
States ex. rel. Com. v. K. \& S. R. Co., 81 Fell. Rep. 78., W. Dist. of Mich. See also Commission v. Bellaire C. \& Z. R. Co., 7t Fed. Rep. 942.

The Commission has held that a carrier operating a railroad wholly within astate, but engaged in interstate transportation, is required under the Act to report to the Commission, (see report for 1897, p. 100). Interstate Commerce Commission v. Seaboard Railway (o., $\$ 2$ Fed. Rep. 56:). A suit is now (190.) pending in the Supreme Court of the United States brought by the Commission against the Jake Shore \& M. S. R. ro.by mandamus to compel compliance with an orter of the Commission to file an annual report under this section, the Circuit Court haring denied the writ on the ground that it had no jurisdiction to issue an original writ. Similar suits are pending in other circuits waiting the decision of the Supreme ('ourt in this case. In L. S. ex rel Com. v. C. K. S. R. R. Co., 81 Fed. Rep. 7 s. $(1896)$, and U. S. ex rel v. Seaboard liy. Co., S.) Fed. Rep. 955 (159s), the jurisliction to enforce reports by mandamus seems to have been assumed. While question seems to have been raised as to the extent of the power of the Commission in the reyuircments of reports from the carriers, there seems to have been no judicial determination.

This case was alfirmed by the Supreme Court 1 prii 10, 1905, the Court holding that the Circuit Court had no jurisdiction under this section to enforce reports by writ of mamdamus, such power to issue original writs of mundum only existing. in the circuit courts when specifically conferred by statute. 


\section{SECrION 21.}

302 . Annual reports of the Commission to Congress on or before December 1st each year.

30:. Ammual reports of the Commission to Congress on or before December 1st each year. - SEc. 21 . 1.1. "imended March $\therefore$. 1859). That the Commission shall, on or before the first lay of December in each year, make a report, which shall be trinsmitted to Congress, and copies of which shall be distributed as are the other reports transmitted to Congress. This report shall contain such information and data collected by the Commission as may be considered of value in the determination of questions connected with the regulation of commerce, together with such recommendations as to additional legislation relating thereto as the Commission may deem necessary: and the names and compensation of the persons emplored by said Commission. 
Section 22.

$\S 303$. Persons and property that may be carried free or at reduced

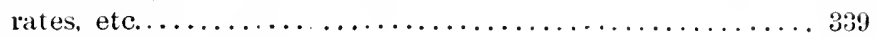

304. Amendments to section......................... 340

30. The section illustrative and not exclusive ............. 340

306. The section permissive only ................... 341

$30 \%$ Withdrawal of commutation tickets .............. 341

8303. Persons and property that may be carried free or

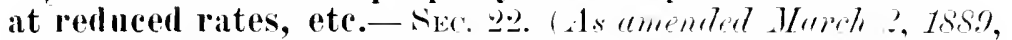
and Februray 8,1895 .) That nothing in this act shall prevent the carriage, storage, or hanlling of property free or at reduced rates for the United States, State, or municipal governments, or for charitable purposes, or to or from fairs and expositions for exhibition thereat, or the free carriage of destitute and homeless persons transported by charitable societies, and the necessary agents enployed in such transportition, or the issuance of mileage, excursion, or commutation passenger tickets; nothing in this act shall be construed to prohibit any common carrier from giving reluced rates to ministers of religion, or to municipal governments for the transportation of indigent persons, or to inmates of the National Ilomes or state IIomes for Disabled Tolunteer Soldiers, and of Soldiers' and sililors' Orphan Homes, including those about to enter and those returning home after distharge, under arrangements with the boards of managers of said homes; nothing in this act shall be construed to prevent railroads from giving free carriage to their own officers and employees, or to prevent the principal officers of any railroad company or companies from exchanging passes or tickets with other raitroad companies for their officers and employees; and nothing in this act contained shall in any way abridge or alter the remedies now existing at common law or by statute, but the provisions of this act are in addition to such remedies: Procided, That no pending litigation shall in any way be affected by this act: Provided f'urther, That nothing in this act shall prevent the issuance of joint interchangeable five-thousand mile tickets, with special privileges as to the amount of free baggage that may be carried nnder mileage tickets of one thousand or more miles. But before any common carrier, subject to the provisions of this act, shatl issue any such joint interchangeable mileage tickets with special privileges, as aforesaid, it shall file with the Interstate Commerce Commission copies of the joint tariffs of rates, fares, or charges on which such joint interchangeable mileage tickets are to be based, together with specifications of the amount of free baggage permitted to be carried under such tickets, in the same manner as common carriers are required to do with regard to other joint rates by section six of this act: and all 
the prorisions of said section six relating to joint rates, fares. and charges shall be observed by said common carriers and enforcel by the Interstate Commerce Commission as fully with regall to such joint interchangeable mileage tickets as with regard to other joint rates, fares, and charges referred to in said section sis. It shall be unlawful for any common carrier that has issued or anthorized to be issued any such joint interchangeable mileage tickets to demand, collect, or receive from any person or persons a greater or less compensation for transportation of persons or baggage under such joint inter('hangeable mileage tickets than that required by the rate, fare, ol charge specified in the copies of the joint tariff of rates, fares. or charges filed with the Commission in force at the time. The lurovisions of section ten of this Act shall apply to any violation of the requirements of this proviso.

304. I mendments to section. - The amendment of March 2. 1589, incorporated in the Act to Regulate Commerce, a prorision as follows:

"Nothing in this act contained shall in any way abridge or" alter the remedies now existing at common law, or by statute. but the provisions of this act are in addition to such remedies."

Notwithstanding the collocation of this provision in the twenty-second section, it clearly is to be construed with all of these sections, and relates to ail the remedies provided by the Act and has been so construed by the courts. See section $S$ of Act, supree.

The amendment of 1895 incorporated a second proviso concerning the issuance of joint interchangeable fire thousand mile tickets.

8 30.). The section illustrative and not exclusive. - This section wals construed in the Party Rate case, 145 U. S.( $* 1, \ldots+$, where the Court said, that the provision that the discriminations in faror of certain persons therein named shall not be deemed unjust, did not forbid discriminations in favor of others under circumstances and conditions so substantially alike as to justify the same treatment. The object of section -2 was to settle beyond all doubt that discriminations in faror of certain persons therein named should not be deemed unjust, and the section was rather illustrative than exclusive. The (ourt said that many, if not all, of the excepted classes named in section 22 , are those which in the absence of the section would not necessarily be held the subjects of an unjust discrimination, if more favorable terms were extended to them than to ordinary passengers. 
In Ex parte Koehler, 31 Fed. Rep., 315 , it was ruled by the Circuit Court under this section, that the exception allowed for the issuance of passes in favor of officers and employees, did not include the families of such persons, such preferences being forbidden by section 2 of the Act.

In U. S. v. Chicago \& X. W. Ry., 127 Fed. Rep. 785, it was ruled by the Circuit Court of Appeals of the Sercnth Circuit, that the government of the United States in buying transportation of a railroad for its soldiers in lots of ten or more, was not entitled to the benefit of the reduced ten party rate given by the company's schedule to theatrical, operatic or concert companies, hunting and fishing parties, glee clubs, brass or string bands, and other parties of like character. The Court said that the refusal to give the same rates did not constitute an unjust discrimination. These rates were for tickets closely limited in time and paid for in cash in adrance, while those furnished the government were furnished on requisitions and paid after a delayed auditing; that the tickets of other classes increased the company's business, while the carryiug of soldiers for the government did not. So that the conditions were essentially different under section 2 .

\$306. The section permissive only.-This section is permissive only and imposes no restriction upon the carrier as to the issuance of such tickets. Congress intended by this provision to leave the issuance of such tickets free from restriction. There is no discrimination therefore in issuing them on one occasion and not issuing them on another. 6 I. C. C. R. 113. When they are issued however whatever the occasion, they must be offered impartially to all who accept the conditions on which they are issuel, and the rates at which they are sold must be published. The general requirements of the act to regulate commerce are as applicable to these classes of tickets as to any others. 2 I. C. C. R. 649,2 Int. Com. Rep. 340. In the latter case the Commission recommended the amendment of the Act so as to define what should be considered excursion and commutation tickets and restrict their issue in interstate commerce so as to prevent the abuses pointed out in the opinion.

\$30\%. Withdrawal of commutation tickets.- - Under this section carriers are allowed to issue mileage and commutation as well as excursion tickets, but they cannot be compelled to do so. As it is their discretion when they shall issue such 
tickets, it is equally within their discretion when to withdraw them. It was suggested in S I. C. C. R. 443 , whether the allowance of commutation rates at stations on fone line of a railroad system and the denial of such rates on another line of the same system, such stations being respectively of the same character. would be an undue preference or not, but the question was not inrolred in the case for lecision. The Com. mission in this case cited the opinion of the Supreme Court in Lake shore \& M. S. R. Co. v. Smith, 173 U. S. 6st, t3 I. El. -is. where the supreme Court held that the power of the levisliture to enact general laws regarding the company and its affairs did not include the power to compel it to make an exception in faror of some particular chass or community and to carry the nembers of that class at a less sum than it has the right to charge those who were not fortunate enough to be nembers thereof. The Commission saicl in this case that commutation tickets are extensively used and have become at recognized featmre of suburban transportation, and that they were far from sayng that a carrier who has established commutation rates for suburban service, especially when residenees have been fixed and business interests adjusted in reliance upon their continuance, could suddenly or otherwise withdraw those rates and exact from its patrons the full rates charged to the occasional traveler. It was helel in the calse however that the action of the railroads in withorawing the 1so-trip quarterly tickets between Baltimore and Washington was within the limits of their discretion and did not constitute a violation of the det.

Is to thousand mile tickets, see 1 I. C. C. R. 156, 1 Int. (om. Rep. 39:. As to mileage tickets, see 1 I. C. C. R 147, 1 Int. Com. Rep. 3 is:?.

lmdinn sinplies. - When under the statute the Government contracts for the delivery of the supplies needed for the Indian serrice, at New York and other points designated, and then alvertises for bids for the transportation of the supplies from the points of delivery to the points where they are to be marle use of, this transportation at the eost of the Government is "for the United stites " within the meaning of section 22 of the Act to Regulate ('ommerce, and is not required to be made at the regular published rates. See 1 I. C. C. R. 15, 1 Int. ('om. Rep. $2 \cdot 2$. 


\section{Section 23.}

\$ 308. Jurisdiction of United States courts to issue writs. 309. Application of section to car shortage.

$\$$ 30S. Jurisdiction of United states conrts to issue writs. SEc. 23. (Alded. Mareh 2. 1889). That the (ircuit and I) istrict Courts of the United States shall have jurisdiction upon the relation of any person or persons, firm, or corporation, alleging such violation by a common carrier, of any of the prorisions of the act to which this is a supplement and all acts amendatory thereof, as prevents the relator from having intelstate trattic moved by said common carrier at the same rates as are charoed, or upon terms or conditions as farorable as those given by said common carrier for like traftic under sim. ilar conditions to any other shipper, to issue a writ or writs of mandamus against said common carrier commanding such common carrier to move and transport the traflic, or to furnish cars or other facilities for transportation for the party applying for the writ: I'rovided, That if any question of fact as to the proper compensation to the common carrier for the service to be enforced by the writ is raised by the pleadings, the writ of peremptory mandamus may issue, notwithstanding such question of fact is undetermined, upon such terms as to security, payment of money into the court, or otherwise, as the court may think proper, pending the determination of the question of fact: Provided, That the remedy bereby given by writ of mandamus shall be cumulative, and shall not be held to exclude or interfere with other remedies provided by this act or the act to which it is a suplement.

\$309. Application of section to car shortage.- This section was not a part of the original Act, but was first enacted in the amendatory act of March 2,1559 . It deals wholly with the remedial process of mandamus. This remedy was unsuccessfully invoked in a number of cases in the litigation in which the effort was made to enforce through routing. See "Interchange of Facilities," sup" The difficulty in these cases was not in the remedy, but with the right. It has been successfully involied however in cases involving the alleged discrimination in the supply of cars. Thus in United States v. Norfolk it Western R. Co., 109 Fed. Rep. 831 (Circuit Court of West Virginia), the writ was granted compelling the railroad company, the supply of cars being short, to pro-rate 
the cars on hand without unjust discrimination among all the operators. The court said that this duty of the railroad to so allot the ears could not be evaded by furnishing special ears for one shipper to be used exclusirely in the tranportation of coal for that shipper. It could not rent its tracks or permit them to be appropriated by one to the detriment of other shippers, and in the stress of unusual business special cars would be applied to the aceomodation of all shippers alike. See also Lnited States v. West Virginia \& Northern R. Co., 12.5 Fed. liep. 2.2. Inited states v. I)elaware, L. \& W. R. Co., to Fed.

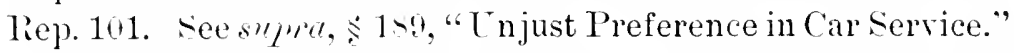

In Wrst Virinia Northern Ry. Co. r. United States, $13 \pm$ Fed. liep. 1!1s, the (ircuit Court of Appeals (th Cir.), November 194t, in allirming the judgment of the Cireuit Court for Corthern I)istrict of West Virginia, 125 Fed. Rep. 252 (opinion ly fuller. ( . J.), said that a mandamus proceeding against a carrier under this section properly included the President of the road, and there was no error in addressing the mandate to the Company and the President and each of them according to their several and respective power's, while the judgment for costs went against the company alone. The court held also that the strict rule of the common law in respect of amendments in mandamus was not applicable to eases where the writ was ordinary process under a statute and not prerogative. Xo reason existed, said the court, why proceedings in mandamus under the judgment should not be governed by the rules obtaining in the existence of ordinary legal remedies.

In this case, as there was no stipulation in writing wairing a jury, the only question of law reviewable on error was the sufficiency of the alternative writ, or of the findings to support the julgment. The Cireuit Court was not required to make specific findings of facts. The court held also that the Cireuit fourt had the power in a proceeding of this character to fix the percentage of cars a relator should have and to command that such percentage of ears should be furnished to the relator. Congress did not intencl to confine the scope of the aret to admonition merely or to general command to desist from discrimination, and the court therefore had the power to frint out the particular aetion on which the diserimination ronsisted and to determine from the facts the percentage of the supply of ears to which the relator was entitled. 


\title{
INTERSTATE COMMERCE ACT AMENDMENT.
}

\author{
Amendatory Act of February 19, 1903.
}

An Act to further regulate commerce with foreign nations and among the States.

310. Carrier corporation as well as officer or agent liable to conviction for misilemeanor. - Be it enacted by the? Senate and IIouse of Representutives of the United States of Ameriea in Congress assembled: Sec. 1. That anything done or omitted to be done by a corporation common carrier, subject to the Act to regulate commerce and the Acts amendatory thereof which, if done or omittel to be done by any director or officer thereof, or any receiver, trustee, lessce, agent, or person acting for or employed by such corporation, would constitute a misdemeanor under said Acts or under this Act shall also be held to be a misclemeanor committel by such corporation, and upon conriction thereof it shall be subject to like penaities as are prescribed in said Aets or by this Act with reference to such persons except as such penalties are herein changed. The willul failure upon the part of any carrier subject to said Aets to file and publish the tariff's or rates and charges as recpuired by said Acts or strictly to observe such tariffs mutil changed according to law, shall be a misdemeanor, and upon conviction thereof the corporation offending shall be subject to a fine of not less than one thousand dollars nor more than twenty thonsand dollars for each oftense: and it shall be unlawful for any person, persons, or corporation to offer, grant, or give or to solicit, accept, or receive any rebate, concession, or diserimination in respect of the transportation of any property in interstate or foreign commerce by any common carriep subject to said Act to regulate commerce and the Acts amenlatory thereto whereby any such property shall by any device whaterer be transported at a less rate than that named in the tariffs published and filed by such earrier, as is reguired by said Act to regulate commerce and the Acts amendatory thereto, or whereby any other advantage is given or cliscimination is practicel. Every person or corporation who shall offer, grant, or give or solicit, aceept or receive any such rebates, concession, or discrimination shall be deemed guilty of a misdemeanor, and on conviction thereof shall be punished by a fine of not less than one thousand dollars nor more than twenty thousand dollars. In all convictions occurring after the passage of this Act for offenses under said Acts to regulate 
commeree, whether committed before or after the passage of this let. or for offenses under this section, no penalty shall be imposed on the eonvicted party other than the fine prescribed by law. imprisonment wherever now prescribed as part of the penalty being hereby abolished. Every riolation of this section shall be prosecrited in any eourt of the Lnited States having juriseliction of erimes within the district in which such violation was committed or through which the transportation maly have been conducted: and whenever the offense is begun in one jurisliction and tompleted in another it may be dealt with, incuired of, tried, determined, and punished in either juristiction in the same manner as if the offense had been actuilly and wholly committed therein.

In comstruing and enforeing the provisions of this section the act. omission, or fialure of any officer, agent or other person actinn for or employed by any eommon carrier acting within the scope of his employment shall in every ease be also deemed to be the act, omission, or failure of such earrier as well as that of the person. Whenever any carrier files with the Interstate ('ommerce C'ommission or publishes a particular rate under the provisions of the Act to regulate eommerce or Lets amendatory thereto, or participates in any rates so filed or published. that rate as against such carrier, its officers, or anents in any prosecution begun under this Act shall be conclusirely deemed to be the legal rate, and any departure from such rite. or any offer to depart therefrom, shall be deemed to be an offense under this section of this Aet.

This section materially amends section 10 of the Act. See s"f"n, s.is. In its provision that the published rate is conchusively deemed the legal rate and any departure or offer to depart therefrom mate an offense, it has an important bearing unon the construction of section $2, s^{\prime \prime} p r^{2} a$, $\$ 14 \%$, in that it makes unlawful all rebates from published rates. See supra, $514 i$.

\section{:311. Parties interested subject to orders or decrees.-} $\therefore i . \%$ That in any proceeding for the enforcement of the frovisions of the statutes relating to interstate commerce, whether such proceedings be instituter hefore the Interstate fommeree (ommission or be begm originally in any Circuit (orrt of the lnited states, it shall be lawful to include as parties, in addition to the carrier, all persons interested in or alfected by the rate, regulation, or pratctice under consideration, and inguiries, investigations. orders, and decrees mar be made with reference to and against such additional parties in the same inanner, to the same extent, and subject to the same frovisions as are or shall be authorized by law with respect to carriers. The party receiving the rebate is included in the ponalty of the lirst section. 
See $\$ 106$, "Parties Subject to the Act," sup" of this amendment as to who are includer in the "persons interested in or affected by the rate, regulation or practice under consideration," has not been judicially determined. The owners of equipment leased by the carrier, and who are directly interested in the rates charged by the carrier for the use of such equipment, would seem to be "interested in or affected by the rate" within the meaning of the section. The party receiving the rebate is inchuled in the penalty of the first section.

\section{1\%. Proceedings to enjoin or restrain lepartures from} published rates._- SEc. 3. That whenever the Interstate ('ommerce ('ommission shall have reasonable wround for belief that any common carrier is engaged in the carriage of passengers or freight traffic between given points at less than the published rates on tile, or is committing any discriminations forbidden by law, a petition may be presented alleging such facts to the ('ircuit Court of the Inited states sitting in equity having jurisoliction; and when the act complained of is alleged to have been committed or as being committed in part in more than one judicial district or stite, it may be dealt with, incuired of, tried, and determined in either such judicial district or state, whereupon it shall be the duty of the court smmmarily to inquire into the circumstances, upon such notice and in such manner as the court shall direct and without the formal pleadings and proceedings applicable to orlinary suits in equity, and to make such other persons or corporations parties thereto as the court may deen necessary, and upon being satisfied of the truth of the allegations of said petition said conrt shall enforce an observance of the published tarifts or direct and require a discontinuance of such discrimination by proper order's, writs, and process, which said orders, writs, and process may be enforceable as well against the parties interested in the traftic as against the carrier, subject to the right of appeal as now provided by law. It shall be the duty of the several district attorneys of the L'nited states, whenerer the AttorneyGeneral shall direct, either of his own motion or upon the request of the Interstate C'ommerce ('ommission, to institute and prosecute such proceedings, and the proceedings provided for by this Act shall not preclude the bringing of suit for the recovery of damages by any party injured, or any other action provided by said Act approved February fourth, eighteen humdred and eighty-seven, entitled An Ict to regulate commerce and the Acts amendatory thereof. And in proceedings under this Act and the Acts to regulate commerce the said courts shall have the power to compel the attendance of witnesses, both upon the part of the carrier and the shipper, who shail be required to answer on all subjects relating directly or indirectly to the matter in controversy, and to compel the produc- 
tion of all books and papers, both of the carrier and the shipper. which relate directly or indirectly to such transaction; the claim that such testimony or evidence may tend to crimiinate the person giving such evidence shall not excuse such person from testifying or such corporation producing its books and papers, but no person shall be prosecuted or subjected to any penalty or forfeiture for or on account of any transaction, mitter, or thing concerning which he may testify or produce cridence documentary or otherwise in such proceeding: P'orifiel. That the provisions of an Act entitled "An Act to expedite the hearing and determination of suits in eguity pending or herealter bronght under the Act of July second, eimteen hundred and ninety, entitled 'An Act to protect tride and commerce against unlawful restraints and monopolies, 'In . Ict to regulate commerce,' approved February fourth, eighteen hundred and eighty-seven, or any other Acts having a like purpose that may be hereafter enacted, approved lebruary eleventh, nineteen hundred and three," shall apply to any case prosecuted under the direction of the Attorneycieneral in the name of the Interstate Commerce Commission.

As to the authorization of injunction to restrain violations of the act. see supre, section $s$ of Interstate Commerce Act. As to extension of immunity to self-incrininating witnesses, and as to immunity of corporations, see 868 , section 12 of Interstate Commerce Act.

\$13. Conflicting laws repealed.-SEC. 4. That all acts and parts of acts in conflict with the provisions of this Act are hereby repealed, but such repeal shall not affect causes now pending nor rights which have already accrued, but such causes shall be prosecuted to a conclusion and such rights enforced in a manner heretofore provided by law and as modified by the provisions of this Act.

As to effect of this section upon pending cases, see supra, $2 \pm 0$, section $S$ of Interstate Commerce Act. 


\section{THE ANTI-TRUST ACT OF 1890.}

SECTION 1.

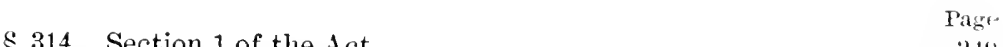

315. Constitutionality and scope of the 1 et ..................

316. Interstate transportation is subject to the Act............

31\%. Unlawful combinations in commerce other than transporta-

tion. The Addyston Pipe Trust case................... 351

318. The California Tile Trust case........................ 35

319. The Tennessee, California and Ohio Coal cases............

320. The Chicago Meat Trust case. . . . . . . . . . . . . . . 35:3

321. The Washington Shingle Trust case................. 354

32. Incidental restraint of trade not violative of the Act... . . . 3.54

323. The Kansas City Lire Stock Exchange cases. . . . . . . . . . . . 35;

324. Agreements not within the Act ... . . . . . . . . . 356

325. Certain agreements not to enter into competition not within the Act....................................

3?6. Labor combinations...........................

An Act to protect trade and commerce against unlawful restraints an l monopolies.

314. Contracts, combinations, conspiracies, in restraint of trade. - Be it enarted by the Senate and IIonse of Repressntatives of the United States of A merica in Congmis assembled: SEc. 1. Every contract, combination in the form of trust or otherwise, or conspiracy, in restraint of trade or commerce among the several states, or with foreign nations, is hereby declared to be illegal. Every person who shall make any such contract or engage in any such combination or conspiracy, shall be deemed gruilty of a mistemeanor, and, on conviction thereof, shall be punished by tine not exceeding five thousand clollars, or by imprisonment not exceeling one year, or by both said punishments, in the discretion of the court.

\$315. Constitutionality and scope of the Act.- As to the circumstances of the passage of this Act, its constitutionality and its general construction and relation to business and labor combinations in interstate commerce, see supre, chap. IV.

The most important case decidel under the Act was the socalled Sugar Trust case, United States v. Knight Company, 156 U. S. 1, 39 L. Ed. 32 , decided January 18, 1595, as it de- 
termined not only the construction and application of this Act, but the limitations of the power of Congress in clealing with basiness combinations or so-called monopolies.

The American Retinery Company had acquired by purchase of stock of other refining companies through shares of its own stoek nearly complete control of the manufacture of refined sagar in the Inited States. The bill filed by the Lnited states eharged that the eontracts uncler which these purchases were mate constitnted combinations in restraint of trale, an $]$ the relief sought was the eancellation of the awreements under which the stock was trinsferred, the redelivery of the stock to the rendors and an injunction against the further performance of the agreement. The supreme Court atfirmed the decree of the Circuit Court, 60 Fed. Ris. :306, and of the Cirenit Court of Apl als, (5) Fed. Rep. 9:4, dismissing the bill (IIarlan, J., (Issuting). The Court said the monopoly and restraint de. nounced by the Act were the monopoly and restraint of interstate trale and commerce. Manuficture was not commeree. (ommeree succeeded to manufacture and was not a part of it, and sale as an incilent of manufacture therefore was distinyuished from commeree. See snpra, $\$ 68$.

\$316. Interstate transportation is subject to the Act.Transportation is commerce, and the provisions of the fict are subject to and cover common carriers by railroads. This application of the Act was first made in the Freight Association vase, $16 f$ U. S. $290,+1$ L. Ed. 1007 , decided in 1597 , where the court held (.Justices White, Shiras, Field and Gray dissenting'), that the agreement of the Trans-Missouri Freight Association for the purpose of mutual protection by establishing and maintaining reasonable rates on all freight traflic, both through and local. between competing carriers, was an unlawful combination within the meaning of the Act. It was strongly urged in this case that the Act did not apply to railroads, that the llouse of liepresentatives in ('ongress had roted down an amendment making it so applicable, and the Aet was passed finally withont this amendment. But the Court said that the lebates in Congress were not the proper source of information to discover the meaning of a statute, and that als all combinations. in the form of trusts or otherwise were prohibited, the 
limitation was not confined to any specific form of combination restraining competition.

This ruling was reatfirmed at the following term with the same division of the court (Justice Field having retired and his successor Justice Mckenna not sitting), in the Joint Traffic Association case, 171 U. S. 50.5, 4: L. Ed. 2.5. This case was sought to be distinguished from the Trans-Missouri lireight Association case, on the ground that the latter conferred an unlimited power to lix rates in the first instance, while in the Joint Traffic Association ease the agreenent started ont with the rates fixed by each company itself and filed with the Interstate Commerce Commission. The conrt howerer sail that the distinction was unimportant, as the intent and direct effect of each agreement was the same, that is, to maintain through the elimination of competition, higher rates than wouk otherwise prevail, and this agreement also was declared riolative of the Act.

These rulings as to the applicability of the Act to interstate milroads were again reaftirmed in the Northern Securities case, 193 U. S. 197, ts L. El. 679, where the Court, four judges dissenting, held that the organization of a New Jersey corporation as a "holding corporation" for the shares of competing" interstate railroads was an illegal combination and in restraint of interstate commerce.

\$31\%. Cnlawful combinations in commerce other than transportation - The Alyston Pipe Trust case.-.The leading case as to the application of the statute to unlawful combinations other than railroals, is Arldyston Pipe d steel Co. v. United States, 17.5 L. s. 211 , 4 I. Ed. 136, wherein the Court unanimonsly affirmed the julgment of the Circuit Court of Appeals. 29 C. C. A. $1+1$, 8.5 Ferl. Rep. 271 . In this case the Court held the agreement of certain pipe manufacturers void under the Act, on the ground that the purpose of the combination directly and by means thereof was to increase the price at which pipe should be sold within the territory and to abolish all competition between the parties. The Court found that the output and price were regulated so as to deprive the public in a large territory of the advantages accruing from proximity of pipe factories, and that the prices were kept just low 
enough to prevent competition by eastern manufacturers, the parties agreeing to sell only at prices fixed by their committee, and the highest bidder at a secret auction became the lowest bidler at a public letting.

The Court laid down the rule in this case that when the direct immediate and intended effect of a contract and combination among the deaters in a commorlity was the enhancement of the price and the suppression of competition, it amounted (1) a restraint of trade in the.commolity, even though contracts at the enhanced price were made and it was not a complete monopoly.

31s. The California 'Tile Trust case.-The prineiple laid down in the Addyston case was applied by the supreme court in Montague r. Jowry, 193 U. S. 39, 48 L. Ed. 608, where an association formed in California by the manufacturers of and dealers in tiles, mantels and grates was held obnoxious to the Act. Nembership in the association was prescribed by rules and dependent on conditions, one of which was the carrying of at least three thousand dollars worth of stock, and whether applieants were admitted or not was a matter of arbitrary decision. The dealers in the association agreed not to purchase materials from manufacturers who were not members and not to sell unset tiles to anyone other than members for less than list prices, which were fifty per cent higher than the prices to members; and the manufacturers who were residents of states other than California agreed not to sell to any one other than members, violations of the agreement rentering the members subject to forfeiture of membership. The Court ruled without dissent, that although the sales of unset tiles were within the state of California and although such sales constituted a very small portion of the trade inrolvel, the agreement of the manufacturers without the state not to sell to anyone but members was part of a scheme which inclucled the entancement of the prices of unset tiles by dealers within the state, and that the whole thing was so bound togrether that the transactions within the state were inseparable, and became a part of the purpose which when carried out anounted to and was a combination in restraint of trade and commerce. The agreement therefore was brought within the 
rule declared in the Addyston case and distinguished from the Hopkins and Anderson cases, infir

319. The 'Tenmessee, California and Ohio Coal cases.The same construction and application of the Act has been made by the Federal Circuit Courts. In United States r. Telico Mountain Coal \& Coke Co., 46; Fed. Rep. 432, the United States Circuit Court for Tennessee held void an agreement between coal mining companies operating chiefly in one state and the deliveries of the coal in another state, creating a coal exchange and fixing the price for the coal at the mines, and the margin of profit to the dealer, and enforcing the same by fines.

In United States v. Coal Deaters Association of Cal., 85 Fed Rep. 252 (N. D. of Cal. 1895), an unincorporated association of coal dealers, regulating distribution and prices in interstate coal traffic, was adjudged illegial.

In United States v. Chesapeake \& Ohio Fuel Co., 105 Fed. Rep. 93, the Circnit Court for the sonthern district of Ohio followed the Adrlyston Pipe \& Steel Co. case in annulling a contract male by a corporition to take the entire product of a number of producing firms and corporations engaged in the mining of coal, intending to sell the same at not less than a price to be fixed by an executire committee, and to account and pay over to the parties the entire proceels above a fixed sum to be retained as a compensation, the stated purpose bein ${ }^{\circ}$ to enlarge the western market. The Court said that the agreement whereunder shipments were to be made in that and other states was one that affected interstate commerce and subject to the provisions of the Anti-Trust Act. and that it was no defense that the agreement had not in fact been productive of injury to the public, or even that it har been beneficial, enab. ling the combination to compete for the business of a wider field.

$\$ 300$. The Chicago leat Trust case. - The Act was applied in the United States Circuit Court for the northern district of Illinois in the so-called Meat Trust case, Inited States v. Swift, 122 Fed. Rep. 529, decided in April, 1909. The bill in this case set out that the defendants controlled sixty per cent. of the trade and commerce in fresh meats in 
the Inited States, buying the live stock from different parts "it the Lnited states, converting it into fresh meats and then shipping the meats to their agents to be sold to consumers in diflerent parts of the Inited ritates. The Court said that the purchases, shipments and transportation were commercially interdependent, and that it was immaterial that the fresh meats in the liands of the acents of the defendiunts were sub. ject to orlinary state tisation. The Court also said that the allegations of the bill of an unlawful eombination to the effect that the purchasing agents were required to refrain from bidding anainst each other, and in bidding up at times so as to induce large shipments and agrecing upon prices to be adopted and restrictions upon the quantities of meats to be shipped, and the making of andements between transportation companies for rebates and diseriminating rates, was suffieient to show a violation of the law. The demurer was overuled and the motion for an injunetion was sustained. This judgment was allimed by the supreme Conrt (no dissent), January 30, 190.5,

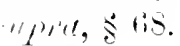

s:?1. The Wawhington Slingle Trust case.- In Gibbs ․ Me Neeley et al., 55 C. C. A. 70, 118 Fed. Rep. 120, 60 L. R. 1. 152 ininth cirevit. 192 . resersing 107 Fed. Rep. 210 and 102 Fed. liep. .94), it was held that an assoeiation of mannfacturers ind dealers in red cerlar shingles in the state of Washington formed for the purpose of controlling the production and sale of such shingles, which are male only in the state, but are prineipally sold and used in other states, and by its action in elosing the mills of its members, has reluced the production and has also arbitrally inereased the prices at which the proluet is sold, is a combination in restraint of commerce, in violation of the let of 18.90 . The Court applied the rule of the lanight anıl dhlyston cases, and said that it was not essential for a contract to refor expressly to interstate commeree, if its purpose and ellect were necessarily to restrain such commorce.

:2:30. Indental restraint of trade not violative of the let.- The contract condemned hy the statute is one whose lirect and immediate effect is a restrint upon that lind of trarle or commerce which is interstate. It cloes not inelnde renulations which are nothing more than a charge for a local 
facility provided for the transaction of commerce, nor does it include an agreement among business men for the better conduct of their own business which incidentally effects interstate commerce. The leading cases on this subject are those decided in relation to the Kansas City Live Stock Exchange, Ilopkins v. United States, 171 L. S. 57 , 4:3 L. Ed. 2!lo, s!ni, and the Traders Live Stock Exchange of Kansas City, 171 L.S. fout, 4:? L. Ed. 300, wherein the Supreme Court reversed the julgment of the Circuit Court in 52 Fed. Rep. 529 .

39:3. The Kansas City Live Stock Exchange ases.- In the first of these cases the Court held that the Kansas City Live Stock Exchange, an unineorporated roluntary association of men doing business at the stock yards situated partly in Kansas City, Missonri, and partly across the state line in Kansas City, liansas, doing business as commission merchants, receiving consignments of cattle under rules which prohibited the employment of agents to solicit consignments exeept upon a stipulated salary, and forbidling the sending of prepaid telegrams or telephone messages as to the conditions of the market, and providing that no member should transact business with any commission merchant of Kansas City not a member of the Exchange, or that any person riolating the rules or regulations or with any expelled or suspended member after notice of such violation, was not in violation of the Act. The court said that the situation of the yards partly in Kansas and partly in Missonri was a fact without any weight, and that such business was not in fact interstate business or commerce. The Association merely provided facilities for the transaction of commerce. There must be some direct and immediate effect upon interstate commerce to come within the Act. The Court in this case cited a number of agreements incidentally affecting commerce which would not be included, as agreements among land owners, enhancing the cost of transporting cattle, or that of railroad employees to cease from work unless paid a certain compensation, saying that these agreements would enbance the cost of interstate commerce, but only inclirectly and incidentally.

In Auderson v. L'nited States, s"fm, the defendants were not commission men, but were themsel ves purchasers of cattle on the market. The members bore the sime relation to the 
Association and they had carried on the same business as they carried on in the llopkins case. The court said it was not called upon to decide whether the defendants were or were not engaged in interstate commerce, because the agreement was not one in restraint of trade, nor was there any combination to monopolize or attempt to monopolize such trade within the neiming of the Act.

The Court in this latter case laid down the general rule that where the subject-matter of the agreement does not directly relate to and act upon and embrace interstate commerce, and where the anticipated facts clearly show that the purpose of the agrecment was not to regulate, obstruct or restrain that commeree. but that it was entered into with the object to properly and fairly regulate the transaction of the business in which the parties to the agreement were engaged, such agreement will be upheld as not within the statute, where it can be seen that the character and terms of the agreement are all calculated to attain the purposes for which it was formed and where the effect of its formation and enforcenent upon interstato trate and commerce is in any event indirect and incidental, and not its purpose or object. 'These cases were decided with only one dissent, that of Mr. Justice IIarlan.

See also Field v. Barber Asphalt Co., 194 U. S. 61S, $48 \mathrm{~L}$. Ed. 114.2. where the Court held that the specification in an ordinance, that a particular kind of asphalt produced only in a foreign country should be used in a city pavement, was valid under the laws of the state and did not violate the Act of 1890, or any federat right.

:3:4. Amperments not within the Act.- Agreements of manufacturers or lealers with their customers for the preven. tion: of dealing with competitors by such customers through the payment of rebates to them conditioned on their not so dealing (Whitwell v. (ontinental Tobacco Co., 60 C. C. A. 290, 12. Fed. liep. 4.5t), and agreements with customers restrieting sales to certain territory (P'hillips v. Iola Portland fement ('o., 61 C. A. A. 19, 25) Fed. Rep. 513), nor the incidental restraint of trade resulting from the purehase of competitor's (In re (ireene, 5e led. Rep. 104), are not within the Act. See also In re Corning, United States v. Greenhutt, 51 fed. Rep. 205, and In re Tymeh, 51 Fed. Rep. 213.

An agreement between all the lumber dealers of a city to 
raise and maintain the price of lumber to local customers and to refuse to sell to consumers who purchased supplies from outside mills, some of such mills supplying the local market being situater in another state, was held in Ellis v. Inman, $12+$ Fed. Rep. 956 , not to be in violation of the Anti-Trust Act, as the effect upon interstate commerce was indirect and incidental only.

In Dueber Watch Case Manufacturing Company v. Howard Watch \& Clock Co., 55 Fed. Rep. 851 (S. Dist. of N. Y.), affirmed, though on different grounds and with dissent, by the Circuit Court of Appeals in 66 Fed. Rep. 637, an agreement by a number of manufacturers and dealers in watch cases to fix an arbitrary price on their gools, and not to sell the same to any one buying watches of the plaintiff, was held not violative of the statute, there being no a verment of absorbtion, or intention to absorb or control the entire market or any large part thereof.

This case it will be observed was decided prior to the definite construction of the Act by the supreme Court.

§ $3: 5$. Certain agreements not to enter into competition not within the Act.-- In Booth v. Davis, 127 Fed. Rep. 575 , the Circuit Court for the eastern district of Michigan held that the act of July 2, 1590 had no application to a contract by which the stockholders of a corporation engaged in dealing in fish at different places in consideration of the business and good will of the company agreed not to enter into competition in such business for a term of ten year's. The Court said the contract was based upon a good consicleration and was lawful, and the right of the purchaser to enforce it could not be effected by the question whether he had conducted such business lawfully or not since its purchase. The purchaser therefore, the court ruled, had the right to enforce this covenant by injunction although the co-defendant had hired the defendant in ignorance of the contract and would suffer damages if deprived of his services.

\$326. Labor combinations. - The act prohibits any combination or conspiracy in restraint of interstate commerce. It was held In re Debs, 64 Fed. Rep. 724, U. S. Cir. Ct. X. Dist. of Ill, in an exhaustive opinion, that the original design in the Act was to suppress trusts and monopolies in the form of trusts, which of course would be of a contractual character, 
but that it was equally clear that a fmrther and a more comprehensire purpose came to be entertained and was embodied in the final form of the enactment. Combinations were condemmel not only when they took the form of trusts, but in whatever form found, if they be in restraint of trade, and that was the effect of the words "or other wise."

The lebs case was tilien to the supreme court, where the julyment of the Circuit Court was alfirmed, 15 U. S. 56it, 39) L. El. 1192, on the broater gromul of the general power of tise liederal ciovernment in respect to interstate commerce. The conrt saill howerer that this wis not because it differed from the Circuit court in its construction of the statute of $1-90$.

In Lnited states r. Worlingmen's Amalgamated Council of New Orieans, it Fed. Rep. 994, the Lnited States Circuit Cuurt of Louisiana helel that combinations of laborers as well as of calpitilists in restrilint of interstate commerce was violative of the Act, and that it was no defense that the origrin and general purpose of a strike were innocent and lawful, if they had been turned into an unlawful purpose for the restraint of interstate and foreign commerce, and that a general strike for the discontinuance of labor in all departments of business, including interstate and foreign commerce, enforeed by violence and intimidation for the sake of enforcing the employment of none but union men, was unlawful and properly enjoined. See also Waterhouse v. Comer, ..5 Fed. Riep. 1 t!! C Cniterl States r. Elliott, it Fed. Rep. 27, Phillips, J. in Western district of Missouri; United States v. Agler, 62 Fed. Rep. s26, Baker, J., in District of Indiana; Thomas $v$. Railroad ('o., 6:2 Fed. Rep. S03, Taft, .J., in southern district of ()hio; Toledo, etc. R. Co. v. Pennsylvania Co., et al, it Fed. liep. 780, Taft, J., in northern distriet of (Mhio; Samer. Same, it Fed. Rep. Ttli, Ricks, J. Charge to (imand Jury by (irosseup, J., 6.2 Fed. liep. ses and by Ross .J., 6.2 Fed. Rep. $\therefore:$ t. See s'l $^{\prime \prime \prime \prime}$, chapter $I V$; also sections sand 10 Interstate commerce lct.

The contrary view was taken in Lnited States r. Patterson, $\therefore$ Fed. Rep. tir.s: but with the exception of this decision the ruling in the lobs case was followed by the other ('ircuit Courts. 


\section{SECTION 2.}

\$32\%. Section 2 of the Act.

328. Criminal procedure under the Act.

§ 32\%. Persons engagins in mouopolies guilty of misdemeanor.-SEc. 2. Every person who shall monopolize, or attempt to monopolize, or eombine or conspire with any other person or persons, to monopolize any part of the trade ol commerce among the several States, or with foreign Nations, shall be deemed guilty of a misdemeanor, and, on conviction thereof, shall be punished by fine not exeeding five thousand dollars, or by imprisonment not exceeding one year, or by both said punishments, in the discretion of the court.

\$3:8. Criminal procednre under the Act.-The first section of the Act condemned two distinct thing's, a contract in restraint of trade and a combination or conspiracy in restraint of trade, and it was held in Rice v. Stamdard Oil Co., 134 Fed. Rep. $46 t$, Dist. N. J., January 1905, that these distinct offenses should not be confused either in indietments or in civil suits, eiting United States v. Cadwallader, 59 Fed. Rep. 67\%. The second section makes a distinct offense, that of monopolizing or attempting to monopolize any part of trade or commeree among the States.

As to what constitutes a monopoly under this section and the distinction between monopoly in law and in fact, see supra, chapter IV, $\$ \$ 9,70$.

The Aet does not define what is a monopoly any more than it does what is a conspiraey in restraint of trade, and resort must therefore be had to common law for a definition of these greneral terms. In re Green, 22 Fel. Rep. 10t. It is insulficient in an indictment to simply follow the language of the Act, for the reason that the words of the statute do not of themselves fully, directly and clearly set forth the elements necessary to constitute the offense intended to be punished.

For the essentials of indictment for violation of the Aet, see In re Corning and United States v. Greenhutt et al, 51 Fed. Rep. 205, northern district of Ohio, 1592, and In re Tyrrell, 51 Fed. Rep. 213, Cireuit Court southern distriet of New York, 159\%. In re Greene, Circuit Court southern district of Ohio, 5.2 Fed. Rep. 104, 1892: Lnited States v. Nelson, 52 Fed. Rep. 
646 , District Court district of Minnesota, 1892; and charge to the Grand Jury by Grosscup, J., 62 Fed. Rep. $\$ 2 \$$ (1894), and by Ross, J., 6.2 Fel. Rep. S34, in southern district of California, 15 !.

It was held in these cases that it was not sufficient to simply follow the language of the statute, but that the indictment must contain a certain description of the offense and a statement of the facts constituting the same. 


\section{SECTION 3.}

$\S 229$. Section 3 of the Act.

330. Territories and District of Columbia includerl.

\$329. Section 3 of the Act.- Swe. 3. Every contract, eombination in form of trust or otherwise, or conspiralcy. in restraint of trade or commerce in any Territory of the l'nited States or of the l)istrict of ('olumbia, or in restraint of trade or commerce between any such T'erritory and another, or between any such Territory or Territories and any state or States or the Jistrict of Columbia, or with foreign nations, or between the District of Cohmbia and any State or States and foreign nations, is hereby declared illegal. Every person who shall make any such contract or engage in any such combination or conspiracy shall be deemed guilty of a misclemeanor, and on conviction thereof, shall be punished by fine not exeeeding five thousand dollars, or by imprisonment not exeeeding one year, or by both said punishments, in the discretion of the court.

\section{\$ 330. Territories and District of Columbia included.-} This section, it will be seen, differs from section 1 only in the fact that it includes in the contracts in restraint of trade declared illegal and criminal not only those male in commerce among the several States and with foreign nations, but also those made in any Territory of the United States or of the District of Columbia, or between any such Territory and another, or between any such Territory or Territories and any State or States, and also between the District of Columbia and any State or foreign States. This inelusion of contracts in a Territory or in the District of Columbia is not under the authority of the commeree clause of the Constitution, but uncler the general governmental power vested in Congress over the Territories of the United States and over the District of Columbia. Congress in the exereise of its power to organize and govern its territories combine the Federal and state authority, Mormon Chureh v. United States, 139 U. S. 1. Congress is also vested by the Constitution with the exclusive legislative authority over the District of Columbia. Constitution of $\mathrm{U}$. S., Art. IV, Sec. 3, Par. 2 ; Art. I, See. 8. This authority was not specifically exereised in the Interstate Commeree Act. See supra, $\$ 106$. 


\section{SECTION $t$.}

Page

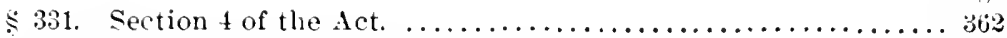

33:. Frocedure in equity umler the Act ................ 362

33:3. Right to statutory injunction limited to the government..... 363

:334. A state cinnot enjoin under the Act................. 36:3

:3:31. Courts may prevent and restrain violations. - SEe. t. The several circuit eourts of the I'nited States are hereby invested with jurisdiction to prevent and restrain violations of this act: and it shall be the duty of the several distriet attorners of the I"nited states, in their respective districts, under the direction of the Attorney-(ieneral, to institute proceedings in eyuity to prevent and restrain such violations. Such proeeeding mal he by way of petition setting forth the ease and praving that such violation shall be enjoined or otherwise prohibited. If hen the parties complained of shall have been cluly notitied of such petition the eourt shall proceed, as soon as may be, to the healring and determination of the ease; and pending. such petition and before final decree the coart mat any tome malie such temporiry restraining order or prohibition as shall be deened just in the premises.

3:3:. Proceslure in eyuity under the Act.--The right of the Lnited states to proceed by injunction against illegal combinations under this Act has been uniformly sustained. Thus in the Trans-Missouri Freight Association case the Court said that the (iovernment had the power to bring the suit to enjoin the association from proceeding, although the association had been dissolved pending the suit before the lecree was entered. This ruling was followed in the other cases cited, the Joint Traffic Association case and the Northern Securities case. In the batter case the court enjoined the corporation organized under state laws from exercising. the powers acquired by virtue of the acquisition of the stock of the subsidiary companies.

In such a suit filed by the I'nited states, a restrainıng order may be issued without notice, and where the unlawful combination acts as an unincorporated association, it is sufficient that the assuciation with a number of its ollicers and members are made parties: it is not necessary that all of its numerons nembership should be male parties. Inited States v. Coal lealers Assoc. of Cal., 8., Fed. Rep. 2.52 (X. Dist. of Cal., 1898). 
333. Right to statutory injunction limited to the Government.- - Ender this Aet a court of equity is not authorized to entertain a bill by a private party to enforee its provisions, the remedy being limited to the (iovernment of the United States. See Gulf, Colorado \& Santa Fe R. Co. v. Miami Steamslip Co., 30 C. C. A. 14., s6 Fed. Rep. to7; Southern Indiana Express ('o. v. Inited States Express Co., et al., 35 C. C. A. 172, 92 Fel. Rej. 1022; Pillock v. Harrington, 64 Fed. Rep. 821; Bloek v. Standard I)ist. Co., 95 Fed. Rep. 978.

The eourt said in the first eited ease however that it did not doubt the general jurisdiction of the Supreme Courtas a court of equity to aflord preventive relief in a proper ease against threatened injury about to result to an individual from any unlawful agreement, eombination or eonspiracy in restraint of trade. The distinction is between the statutory remedy conferred by the Aet and the general jurisdiction of the court of equity to grant equitable relief, where irreparable injury or other conditione for the exercise of equity jurisdiction exists.

In this latter elass of eases where the general jurisliction of a court of equity is in volied, and no rights under the constitution and laws of the United states are in question, the juristiction of the Federal Court must be based upon the diverse eitizenship of the parties. See Hagan v. Blindell, 6 C. C. A. 86,56 Fed. Rep. 696, affirming 5t lied. Rep. 40.

Where however the equity jurisdiction of a Cirenit Court of the United States is incoked on the ground of a property right under the Constitution or laws of the United states, for protection against any illegal combination threatening such property right, the Court would have jurislieiion irrespeetive of diverse eitizenship. See seetion s, Interstate Commerce Aet.

$\$ 334$. A State camnot enjoin under the Act.- Neither can a State proeed under the Aet by injunction. Thus in the State of Minnesota v. Northern recurities Co., 194 U. S. 48 , 4. I. Ed. Soo, the sinpreme Court held that the State of Minnesota could not maintain a suit in its political eharacter to enforce the Anti-Trust Act of Congress, as the statute eonlines the action to suits by the several distriet attorneys of the United States in their several distriets under the direction of the Attorney-General. The Court said that the purpose was 
to secure the uniformity of the enforcement of the Act so far as direct procedure in equity was concerned, according to the uniform plan applicable throughout the entire country. This case had been brought in the state court and removed by the defendiant to the Circuit Court of the Cnited States on the ground that it was one arising under the Constitution and laws of the Cnited States. The (irenit Court sustained the jurisdiction and dismissed the bill upon the merits. 12? Fed. Rep. 1:2. Sut the supreme Court reversed the decree, with directions to remand the case to the State court on the ground that the Circuit ('oult of the United States could not acquire jurisdiction of such proceeling, although both parties urged the conrt to take jurisoliction, as the State of Minnesota was not a citizen within the meaning of the Constitution, and there was no diverse citizenship to sustain the jurisdiction of the federal court. 


\section{Section 5.}

\& 335. Section 5 of the Act.

\$ 33.5. Additional parties may be summoned.-SEC. 5 . Whenever it shall appear to the court before which any proceeding under section four of this act may be pending that the ends of justice require that other parties should be brought before the court, the court may cause them to be summonerl, whether they reside in the district in which the court is held or not; and subpoenas to that end may be served in any district by the marshal thereof.

The comprehensive jurisdiction vested in the court under this section is enforced by the provisions of the Act of February 11, 1903, known as the Expedition Act, infira, \$37 whereunder suits in equity brought by the United States may be given precedence over others on the certificate of the Attorney General as to the general public importance of the suit. 


\section{SECTION 6.}

\$33. Section 6 of the Act.

33\%. Enforcement of seizure of goods under section 6.

ş336. Seizure and condemuation of property.-SEC. 6. Any property owned moler any contract or by any combination. or pursuant to any conspiracy and being the subject thereof) mentioned in section one of this act, and being in the course of transportation from one state to another, or to a foreign country, shall be forfeited to the Inited states, and ma! be seized and condenned by like proceedings as those provided by law for the forfeiture. seizure, and condrmnation of property imported into the L'nited states contrary to law.

s:3:3. Fnforcement of seizure of goods under section 6 The seizure of groods authorized under section 6 can be enforcel only by the procedure like to that provided by sections $8909-$ :?::91 R. S. U. S. for the forfeiture of goods uncler the customs laws, and with trial by jury. There is no reported case of such proceeding under this section. The seizure cannot be enforced in an equity suit by the Cnited States under section $t$. Mdirston l'ipe \& Steel'Co. v. United States, 29 C. C. A. 1t1, $\therefore$ Ferl. Rep. $2 \tau 1$.

It was said in this case by Taft, J., that the only remedy which can be afforded under section $t$ is a decree of injunction. 


\section{SECTION $\tau$.}

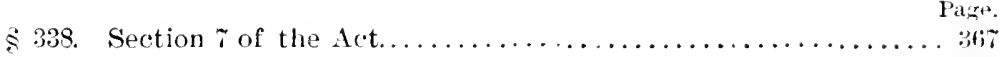

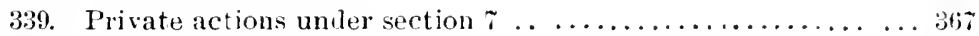

340. Plaintiff must show in jury ..................... 364

341. A State is not a "person or corporation " under section $7 . \ldots$. . 3;9

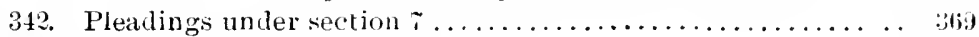

343. Measure of damages uuder section $\tau \ldots \ldots \ldots \ldots \ldots \ldots \ldots \ldots$. 36 !)

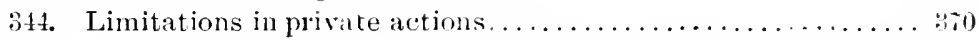

345. The Act as a defense in suits by alleged illegal combinations. 330)

346. The Act as a delense in patent litigation . . . . . . . . . .

34\%. Self-ineriminating testimony $\ldots \ldots \ldots \ldots \ldots \ldots \ldots \ldots \ldots \ldots \ldots \ldots \ldots \ldots$

\$333. Persons injured may recover threefold damages and attorney"s fee.-Ser. 7 . Any person who shall be injured in his business or property by any other person or corporation by reason of anything forbidden or declared to be unla wful by this act, may sue therefor in any circuit court of the [nited States in the district in which the defendint resicles or is found, without respect to the amomnt in controversy, and shall recover threefold the damages by him sustained, and the costs of suit, including a reasonable ittorney's fee.

\$ 3:39. Private actions muler section $\boldsymbol{\mathfrak { x }}$.- This section was construed by the supreme Court in Montagne v. Lowry, s"yper, aftirming the judgment of the Circuit court of Appeals for the Ninth Circuit, 11; Fed. Tep. 27 , and of the Circuit Court (N. Dist. of Cal.) 166: Fed. 38, for treble damages and attorney's fees in favor of a firm which had entearored to procure tiles for the purposes of their husiness from the tile manufacturers, nembers of the association, who refused to deal with them because they, the plaintiffs, were not members of the association. Plain tiff's were not eligible to membership in the association, because they did not always carry stock worth $\$: 0,00$, which was male a condition of eligibility to membership. It was claimed that this provision had not been enforced. But the Court said there was nothing to prevent its enforcement at any time, if an application was made by any one who did not fill the conclition. The proof showed that by reason of the formation of the association plaintiffs had been injured in their business, because they were unable to procure tiles from the manufacturers at any price or from the dealers at san Francisco at less than the list price which was more than fifty per 
cent abore the price at which members of the association could purchase the same.

In this case the jury found a rerdict for $\$ 5110$ and judgment was rendered for treble this amount, and in aldition thereto the conrt allowed $\$ 50$ for attorney's fees. The trial lasted five diars. The court sail that the amount of the attorney's fees wils within the discretion of the trial court reasonibly exercised, and that the discretion was not abused.

This section was also construed by the Cirenit Conrt of Appals for the sixth Circuit, 127 Fed liep. 25, in City of Atlantar. Chattanooga Fommly of Pipe (o. In this case the recosery by a municipal copporation engaged in operating water, steam and lighting plant, from which revenue was derived. Was sustained on the ground that it was a business corporation and able to maintain an action for relief under tiis section for injury to its business by combination or conspiracy.

In the case last cited the Court held that every menber of an allegal combination in violation of the Act was liable for damages to the party injured, and it was immaterial that there was no direct contract between plaintifl and defendant. It was alio immaterial that the business of the plaintiff was not int:pitate, proviled the transaction by which the purchase was mule wits interstalte.

It was held in lishop r. American Preservers Co., $105 \mathrm{Fed}$ Rop. -45, that the Anti-Trust law dis not anthorize an action aguinst an alleged trust corporation by one who was a party to its organization, and a stockholder thereof, to recover damates resulting from the enforcement by it of the rights given it by the alleged unlaw ful agreement, and that the bringing of a suit in replevin by the company against the plaintifi was but the exereise of its lawfui right. See also $\therefore 1$ Fed. Tiel. 그.

:3fo. Plaintiff must show injury. The fact of an illegall combination in an industry loes not establish a right of private action for lamages. unless plaintiff shows injury directly accruing to himself by reason of the illegal combinatirn: lut an allowation that plaintiff is in the husiness affected ly the combination, and by reason thereof is unable to make 
purchases and suffers loss thereby, is sufficient. Cibbs v. McNeeley, 102 Fed. Rep. 594, reversed in 55 C. C. A. 70, 115 Fed. Rep. 120, 60 L. R. A. 152.

$\$ 3 \$ 1$. A state is not a "person or corporation" muler section 7.- In Lowenstein v. Evans, 69 Fed. Rep. 90S (169.), a demurrer was sustained to a suit filed by a liyuor dealer in South Carolina under the serenth section of the Act against the members of the State Board of Control of the liquor tratfic, under the State Dispensary law, alleging that the State monopoly of the liquor business was in violation of the Act. The court said that a State is not a "person "or "corporation" within the meaning of the section.

\$34\%. Pleadings unler section \%.-A declaration in a suit under section 7 was held bad for indefiniteness and uncertainty in Rice $v$. Standard Oil ( o., $13 \pm$ Fed. Rep. 464 , l)istrict of New Jersey (Januilry, 190.), which alleged in a single count that defenclant entered into a "contract, combination and conspiracy," in restraint of trade. The court said that in a declaration under this section, plaintiff must aver, not only facts showing such a contract, combination or conspiracy as is declared by the Act to be mlawful, but also facts showing that by reason of such unlawful thing he had been injured in his business or property. The court also held that the Act made a distinction between a contract and a combination or conspiracy, and the two could not be confused either in a declaration in a civil proceeding any more than in an inclictment in a criminal proceeding. That is they could not be declared upon as synonymous terms and charged in a single count.

543 . Measnre of damages under section 7.- The measure of damages which a party is entitled to recover in such an action is the difference between the price paid and the reasonable price under natural and competitive conditions. Seo also Montague v. Lowry, supere.

The Court said in the City of Atlanta case that the plain intent was to compensate the person injured and that the enlargement of compensation by the provision for trebling the amount of damages did not constitute the action a penal action within the meaning of section $10 t i$ R. S., L.S. The 
other sections of the Act were penal, but the 7th section was distinctly compensitory.

\$34. Limitations in private actions. - The action in this case was brought in Tennessee, and it was held subject to the Tennessee statute of limitations prescribing the limitation of ten years for eertitin actions and in all other cases not expressly provided for. The court ruled that it did not fall within the provision of the Tennessee statute prescribing a limitation of three rears for injuries to personal or real property. As to limitations, see section $\mathrm{S}$ of Interstate Commerce Act, NI1"

\section{4.). The let as a defense in suits by alleged illegal} combinations. - While it is a general rule that any one sued upon a contract may set up a defense that it is a violation of an Act of Congress, bement r. Xational IIarrow Co., 186 [. S. 71,46 I. Ed. 1058, it is a]so true that a party will not be permittel to confiscate the property or property right of another on the grouml that that other has violated the AntiTrust Act. See Soda Fountain Co. v Green, 69 Fed. Rep. 393: Columbia Wire Co. v. Freeman Wire Co., 71 Fed. Rep. $\therefore 10$.

There is is no provision in the Anti-Trust Act, such as is contiined in some of the State Anti-Trust statutes, making the fact of membership of a rendor in an illegal combination a defense by a rendee in suit for gools purchised. Connolly v. Inion Sewer Pipe Co., $18+$ U. S. 540 and 46 L. Ed. 679.

See also In re Wisewall, it Fed. Rep. s12, where it was held that one who requests and accepts services of a tug for towage purposes, cannot escape paring the reasonable value of the services rendered on ground that the tug owners are members of an association which is illegal under the Act.

It is no objection to the enforcement of a contract, in the consilleration of which nothing illegal inheres, that it may incirlentally aid one of the parties in exacting and riolating the Anti-Trust statute. This was held in Ingrabam v. Nat'l silt Co., 13 ' Fed. Rep. firi, Circuit ('t. of App., und Cir. reversing. 12: Fed. Rep. to, where the action was to recover the amount of certificates created by defendant, in payment of stock of another company, the certificates in payment of the 
stock purchased being held to have been lawfully issued in exercise of the defendant's implied power to incur indebtedness.

$\$ 346$. The act as a defense in patent litigation.- - It was held in General Electric Co. v. Wise, 119 Fed. Rep. :12.2, that the fact that a complainant in a pitent suit is a member of a combination in violation of the Anti-Trust Act, does not give third persons the right to infringe a patent of which the defendant is the owner, nor does it preclude the complainant from maintaining a suit to enjoin such infringement. The court in this case refused to follow the case of National Jarrow Co. v. Quick, 67 Fed. Rep. 130, decided in 159., which held that the company authorized to receive assignments of letters patent and grant back to the assignors licenses, and to regulate and control prices, was against public policy and roid. This ruling however was not made under the Anti-Trust Act.

In Bement v. National Harrow Co., 196 U. S. 70 , to I. Ed. 1058, in a suit brought by the same complainant, the Court said that the object of the patent laws was monopoly, and that the rule was, with few exceptions, that any conditions, which were not in their nature illegal with regard to the kind of property, imposed by the patentee and agreed to by the licensee for the right to manufacture or use or sell the article, will be upheld by the courts, and the fact that the conditions in the contract keep up a monopoly does not render them illegal.

See also Edison Electric Light Co. v. Sawyer Mfg. Elec. Co. (2nd Circ.), 3 (. C. A. 695, .13 Fed. Rep. 592 ; Ponsack Machine Co. et al v. Smith et al, (C. C., W. D. of N. C.), io Fe(l. Rep. 383 ; National Folding Box Co. v. Robertson et al C. C., E. D. of Conn.), 99 Fed. Rep. 95.5.

\$34. Self incriminating testimony. - It was held in Foote v. Buchanan, 113 Fed. Rep. 15i, that the act of Congress of February 11, 189: does not apply to prosecutions uncler the Anti-Trust Act, and that the Fifth Amendment applies thereto so that self incriminating testimony could not be enforcel. The Court held in this case that where the witness claims that the answer would incriminate him, it is not for the witness 
but for the judge to deeide whether under the circumstances such might be the effect This lecision however was prior to passige of the act of Feb. 25,1903 , which provides both as to this Act and the Interstate Commerce Act, that no "person shall be subjected to any penalty or forfeiture for or on account of any transaction, matter or thing, concerning which he may testify or produce evidence, documentary or otherwise, in any suit, proceeding or prosecution under said Acts; and provided further that no person so testifying shall be exempt from prosecution or punishment for perjury committed in so testifying." 


\section{SECTION 8.}

348. Section 8 of the Act.

\$345. "Person" or "persons", defined.-SEC. 8. That the word "person," or "persons," whererer used in this act shall be deemed to include corporations and associations existing under or authorized by the laws of either the Cnited states, the laws of any of the Territories, the laws of any State, or the laws of any foreign country.

This statutory inclusion of the corporations and associations in the term "person" is not contained in the Interstate Commerce Act. The general rule however is well established that the term "person" as well as the term "citizen" is to be construed as including corporations unless there be something beyond the mere use of the word to indicate the intent on the part of Congress to include them. United States v. Amedy, 11 Wheat. 329, 6 L. Ed. 502 ; Ramsey v. Tacoma Land Co., 196 U. S. 360 . See also supra, $\$ 264$. 


\section{THE EXPEDITION ACT.}

\$349. Expedition of cases $\ldots \ldots \ldots \ldots \ldots \ldots \ldots \ldots \ldots \ldots \ldots \ldots \ldots \ldots \ldots$

350. Judicial application of Act...................... 375

An Act to expedite the hearing and determination of suits in equity pendinc or hereafter brought under the Act of July second. eighteen hundred and ninetr, entitled "An Act to protect trade and commerce against unlawful restraints and monopolies." . An Act to regulate commerce." approved February fourth, eighteen hundred and eighty-seven, or any other Acts having a like purpose that may be hereafter enacted.

349. Expedition of cases.- Be it enucted by the Senate unil Ilouse of Representutives of th. C'nited Stutes of' America in Compress ressmbled: SEc. 1. That in any suit in equity pending or herealter brought in any circuit court of the Tnited states under the act entitled " $\mathrm{An}$ Act to protect trade and commeree against unlawlul restraints and monopolies," approved luly second, eigliteen hundred and ninety, "An I.t to regulate commerce," approved lebruary fourth, eighteen hundred and eighty-seren, or any other acts having a like purpose that herealter may be enacted, wherein the Inited rtates is complainant, the Attorney-General may file with the clerk of such court a certificate that, in his opinion, the rase is of reneral public importance, a copy of which shall be immediately furnished by such clerk to each of the circuit julges of the cireuit in which the case is pending. Thereupon such case shall be given precellence over others and in every way expedited, and be assigned for hearing at the earliest practicable day, before not less than three of the circuit judges of said circuit, if there be three or more; and if there be not more than two circuit juclges, then before them and such district judge as they may select. In the event the judges sitting in such case shall be divided in opinion, the case shall be certified to the Supreme Court for review in like manner as if taken there by appeal as hereinafter provided.

S.F. .2. 'That in every suit in equity pending or hereafter brought in any circuit court of the United States under any of said acts, wherein the United States is complainant, including cases submitted but not yet decided, an appeal from the final decree of the circuit court will lie only to the supreme ('ourt and must be taken within sixty days from the entry thereof: P'rovidral, That in any case where an appeal may have been taken from the final decree of a circuit court to the circuit court of appeals before this act takes effect, the case shall proceed to a final decree therein, and an appeal may be taken from such decree to the Supreme Court in the manner now provided by law. 
This Act, known as the "Expedition Act," was approved February 11, 1903, prior to the act amendatory of the Interstate Commerce Act, which was approved February 19, 1903, supra, $\$ 310$, and is therefore referred to in the third section of that act, where it is provided that the prorisions of this Act shall be applicable to any suit prosecuted under the direction of the Attorney General in the name of the Interstate 1 Commerce Commission.

$\$ 350$. Jullicial application of Act.- The summary procedure provided by this Act was illustrated and enloreed in the Northern Securities case, which was argued in the Circuit Court at St. Lonis before the four judges of the court in April, 1903, lecided in May, 1903, appealed to the Supreme Court, advanced on the docket and finally decided on the fourth day of April, 1904.

In Interstate Commission r. Baird, 194 U. S. 25, decided April 4, 1904, which was appealed directly to the Supreme Court from the Circuit Court in a proceeding instituted by Mr. Hearst before the Commission, the Supreme Court beld that the appeal was properly made to the Supreme Court from the Circuit Court, and the right of direct appeal was also applicable to proceedings to enforce the production of books and papers or the giving of testimoney before the Commission. The Court said it was the purpose of this Act of $190: 3$ to eliminate the necessity of any appeal in the Circuit Court of Appeals and permit the litigation to be shortened by direct appeal to the Supreme Conrt.

In Missouri Pacific Railroar Co. v. United States, 189 U. S. $27 t, 47$ L. Ed. S11, decided March :, 1903, the Supreme Court while holding that the Circuit Court had erred in refusing to sustain a demurrer of a railroad company to a bill filed by the district attorney of the United states under the direction of the Attorney-General, at the instance of the Interstate Commerce Commission, also said that the Act of February 190? expressly conferred this power to invoke the remedy of injunction, which laad not heretofore existed, and as that let specificilly provided that the new remedies which it created should be applicable to all cases then pending, the court therefore decided that the case would not be finally be disposed of, but would be remanded for further proceedings in accordance with the provisions of this Act of Feb. 19, 1903. 


\section{THE DEPARTMENT OF COMIIERCE AND LABOR.}

$\$ 351$. The Department of Commerce and Labor............... 356

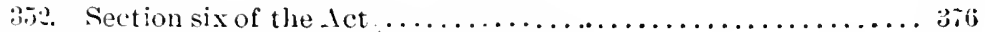

353. The remaining sections of the Act.................... $3 \pi 8$

351 . The Department of Commerce and Labor.- The l)epartment of Labor was established by the Act of June 1:; 1s8s. That Jepartment was placed under the jurisdiction and made part of the Department of Commerce and Labor established hy Act of February 1t, 160:, sup. to Comp. Stat., page +1.

Section 1 proviles for the establishment of the executire department and the secretary of Commerce and Labor; section 2 for an Assistant Secretary of Commerce and Labor, and other clerks; section 3 declares in general terms the province and duties of the department to foster, promote and develop the foreign an! domestic commeree, the manufacture, mining, shipping and fishery industries, the labor interests and the transportation facilities of the Inited states, and certain appropriations are made applicable therefor; section 4 provides for the transfer of certain existing offices, etc., from the Treasury and Interior Departments to this Department, including the Lighthouse Establishment, Steamboat Inspection Service, Inrean of Navigation, the liureau of Immigration, the Bureau of Statistics from the Treasury, and the Census Otlice from the Department of the Interior; section 5 establishes a Bureau of Manufactures making it the province and duty of the Bureau to foster and develop the various manufacturing interests of the Lnited states and markets for the same at home and abroad, domestic and foreign, by gathering, compiling and supplying all useful information concerning such markets. Consular reports are provided for. Section 6 of the Act providing for a lineatu of corporations is set out in full:

53,5. Burean of Corporations-- ('ommissioner, Deputy, retr.-. Sisc. 6. That there shall be in the Department of Commeree and Labor a bureau to be called the Bureau of Corpo. rations, and a Commissioner of C'orporations, who shall be the 
head of said burean, to be appointed by the President, who shall receive a salary of five thousand dollars per annum. There shall also be in said burean a deputy commissioner, who shall receive a salary of three thousand five hundred dollars per annum, and who shall, in the absence of the Commissioner, act as and perform the duties of the Commissioner of corporations, and who shall perform such other duties as may be assigned to him by the Secretary of Commerce and Lahor or by the said Commissioner. There shall also be in the saill bureau a chief clerk and such special agents, clerks, and other employees as may be authorized by law.

The said Commissioner shall have power and authority to make, under the direction and control of the Secretary of Commerce and Labor, diligent investigation into the organization, conduct, and management of the business of any corporation, joint stock company, or corporate combination engaged in the commerce among the several States and with foreign nations, excepting common carriers subject to " $\Lambda \mathrm{n} A$ ct to regulate commerce," approved February fourth, eighteen hunilred and eighty-seven, and to gather such information and data as will enable the l'resident of the Lnited states to make recommendations to Concress for legislation lor the regulation of such commerce, and to report such data to the President from time to time as he shall require: and the information so obtained or as much thereof as the President may direct, shall be made public.

In order to accomplish the purposes declared in the foregoing part of this section, the said Commissioner shall have and exercise the same power and anthority in respect to corporations, joint stocls companies, and combinations subject to the provisions hereof, as is conferred on the Interstate Commerce Commission in said "Act to regulate commerce" and the amendments thereto, in respect to common carriers so far as the same may be applicable. including the right to subpoena and compel the attendance and testimony of witnesses ant the production of documentary evidence and to administer oaths. All the requirements, obligations, liabilities, and immunities imposed or conferred by said "Act to reguiate commerce " and by "An Act in relation to testimony before the Interstate Commerce Commission," and so forth, approved February eleventh, eighteen hundred and ninety-three, supplemental to said "Act to regulate commerce," shall also apply to all persons who may be subponaed to testify as witnesses or to produce documentary evidence in pursuance of the authority conferred by this section.

It shall also be the province and duty of said Burean, under the direction of the secretary of Commerce and Labor, to gather, compile, publish, and supply useful information concerning corporations doing busmess within the limits of the 
United States and shall engare in interstate commerce or in commerce between the Lnited states and any foreign country, including corporations engaged in insurance, and to attend to such other duties as may be hereafter provided by law.

353. The remaining sections of the Act. Section 7 deals with the control of the fur-seal and other Alaskan fisheries, the immigration of aliens: section s with the annual reports to congress and special investigations and reports: section s with the custody of the department buildings, property, records, etc. Section 11 with the transler of duties and powers of heads of exeentive departments, and their duties, powers, etc., for the secretary of the Treasury, seamen, shipping, etc. Section 11 provicles for the co-operation of the State Department in the matter of consular reports. Section 12 provides for the transfer to this department of offices, bureaus, ete., engaged in scientific work to this department. The remaining sections of the Act dealt with the time of taking effect of the transfer's provided for and for the administrative details in the matter of appropriations, transfer of officers, clerlis, etc., and the occupation of buildings. See supre, $₫$ it. 


\section{THE SAFETY ACT OF 1893, AMENDED 1896.}

\section{SECTION 1.}

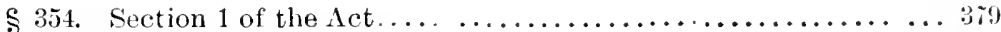

355. Railroads subject to the Act ........................ 379

356. The common law duty of the carrier in relation to safety ap-

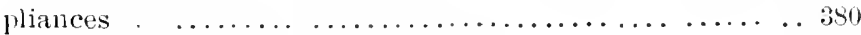

357. Petition and procedure under the Act................. 381

3.58. Federal question in suits under the Act..................... 381

An Act to promote the safety of employees and travelers upon railroals by compelling common carriers engaged in interstate commerce to equip their cars with automatic couplers and continuous brakes and their locomotives with driving-wheel brakes, and for other purposes.

\$3.) D. Diving-wheel and twain hrakes.- B, it macted by the Senate and Ilouse of liejusentaties of the Crited sitates of Americe in Congress dsembler. SEc. 1. That from and alter the first day of January, eighteen hundred and ninety-eight, it shall be unlawful for anv common carrier engaged in interstate commerce by railpoal to use on its line any locomotive engine in moving interstate tratfic not equipped with a power driving-wheel bralie and appliances for operating the trainbrake system, or to run any train in such tratfic alter said date that has not a sufficient number of cars in it so equipped with power or train brakes that the engineer on the locomotive drawing such train can control its speed withont requiring brakemen to use the common band brake for that purpose.

\$3.5.). Railroals subject to the Act.-This Act, as also the Accident law, is made applicable to any common carrier engaged in interstate commerce by railroad, while the Interstate Commerce Act applies only to the interstate traffic of railroal carriers, except in the requirement of annual reports under section 20 of that Act. In Lnited states r. Gedles, 1:31 Fed. Rep. 45\%, C. C. A., sixth Circuit, which was a suit on behalf of the United States for the recovery of penalties under this Act, the Court held that a narrow gauge railroad wholly in Ohio which connected at one of its termini with an interstate road but neither shipped nor received any trattic under a through bill of lading, or any other arrangement, and 
charged local freight tariffs on its own line, assuming payment of the Baltimore \& Ohio adrance charges with weekly settlements, was not engaged in interstate commerce within the meaning of this Ict, and was therefore not subject to penalties for non-compliance. The Court said that under the rulings of the supreme Court, express and sleeping car and railroal companies were limited to the nature of their business, making it local or interstate or both as they pleased, and that assuming the payment of the charges of the delivering road dicl not constitute a continuous carriage necessary to malie the businuss of interstate commerce.

\section{3:54. The common law duty of the carrier in relation to} safoty appliances.- - It was held by the Supreme Court of North Carolina that the action of the Interstate Commerce commission in extending the date at which the Act should go into force could not set aside the principle of law that failure to proricle the appliances was negligence per se, and that such postponement could not have any other effect than to postpone the late at which the ase would impose the penalty for failure to do so. In other words, that the Court would take notice of the act as establishing by legislative recognition a measure of legal duty of the railroal company in providing safe appliances, that is, morlern self-coupling devices, for its empioyees. Troxler v. Southern Ry. Co., 122 N. C. 902, 44 1. R. A. :13. See also Greenlee v. Southern Railway Co., 122 X. C. 982,41 L. R. A. 99.

In Schleman v. Railroad Co., 207 Pa. St. 19s, the Court intimated that it was dombtful whether the Act had any applicability to actions for negligence in Pennsylvania, butdid not decile this point as the plaintiff was non-suited for contributory negligence.

In New England Railroal Co. v. Conroy, 1 \%5 U. S. 328,44 I. El. 1s1, (1 19!!), a case not arising uncler the Act, but in rolving the question of the responsibility of the engineer, the Court said that as railroals are now operated, the engineer is a much more important functionary in the actual movements of the train than the confuctor, ancl particularly has this become the case since the introduction of the air brake train system, and the Court referred to the first section of this Act of March 2 1 $14: 3$, providing for air brakes under the control of the en- 
gineer, saying: "We do not refer to this statute as direct'y applicable to the case in hand, but as a legislative recognition of the dominant position of the engineer." See also Northern Pacific Railroal Co. v. Tynan, 5ti C. C. A. 192, 119 Fed. Rep. 2Ss, where the Courtsays that prior to the passage of this Aet there had been numerous decisions rendered by the courts of this country where it was held that the railroad companies were guilty of negligence in using the Miller coupler in connection with the ordinary link draw bars. See also Texas w Pacific R. Co. v. Archibald. 170 U. S. 665.5, 42 L. El. 11 ss.

\$3.5\%. Petition and procedure under the Act.-Feld in Voeiker v. Railroal Co., 116 Fed. Rep. s67, and affirmed on this point by the Court of A ppeals, that it is not necessary for the petition for personal injuries suffered under violation of the Act to refer to the Act, although the burden is on the plaintiff to show that the car on which he was injured was engaged in interstate commerce, Winkler v. Pennsylvania R. Co. (Dela.), 58 Atl. Rep. 90; and it is a question for the jury whether railroad companies comply with the act. Craw ford $r$. Railroad Co., $10 \mathrm{Am}$. Negligence Reps. 160.

3.5s. Federal question in suits under the Act.-The instruction by a court to a jury that railroals are required to keep their appliances in good and suitable order, raised no question under the Act so as to make a claim of a federal right under section $609 \mathrm{R}$. S., which can be the basis of a writ of error from the Supreme Court to the highest cont of the state. Southern Ry. Co. v. Carson, 194 U. S. 13ti, to L. Ed. 907. It was objected in this case that the instructions in the State Conrt assumed that if the antomatic coupling was out of order the company failed to comply with the act of Congress, and the Supreme C'ourt of the State held that there was no error in this, as Congress must have in tended that the couplers should have been kept in proper repair for use, and moreover as such was the law of the State, even if the act of Congress had not specifically imposed this duty. The Court said that in this ruling no right was specifically set up or claimed under the act of Congress, and the writ of error was dismissed. 


\section{SECTION 2.}

Page.

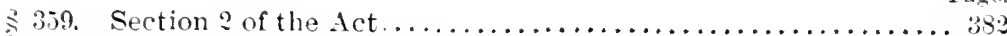

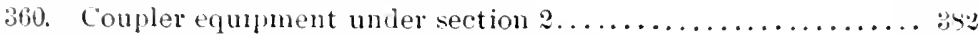

361. Antomatic couplers of different makes ... . . . . . . . . . . 3४3

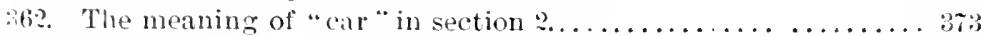

$3 t: 3$. When cars are in interstate commerce................. 384

S3.). Intomatic rouplers.-S1:- 2. That on and after the first day of Jinualy. eighteen hundred and ninety-eight, it shall be unlaw ful for any such common carrier to haul or permit to be hauled or used on its line any cal used in moring interstate traflic not equipper with complers coupling automatically hy impact, and which can be uncoupled without the necessity of men going between the ends of cars.

है: :60. Coupler equipment under section:- The requirement of automatic couplers in section 2 has been construed by the Circuit Court of Appeals for the eighth Circuit in a recent taise. Chieigo, Milwaluee d St. Paul R. Co. v. Toelker,

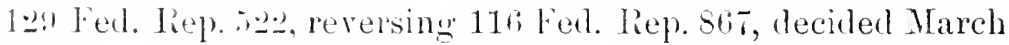
1:14. The Court said that the Act of Congress forbade the use of a compler which required the operator to go between the cnds of the cars to prepare the compler for the impact. The frepraration of the compler for the impact in not distinct from the act of compling. Botle are connected with the indispensabe parts of the larrer act. Which is regulated by the statute and the pertormance of which is intencted to be released from unnecessary risk and danger. The court ruled that when an antomatic car coupler had been permitted to become worn and defectireso the lever would not lift the pin from the socket, and the knuckie could not be drawn open by leaning towar the coupler and using one hand, but repuired the presence of the operator's antire bodr between the ends of the ears and the draw balrs and the use of both his hands, it failed to meet the requirements of the Act and constituted actionable negliwence.

It was hell in birigers r. ('. X. o $W^{+}$. R. Co., 12. Fed. Rep. Ft.; that whan aribrand company in order to comply with section 2 of tho act remored the lone piot from in front of the en gine and subitituted a shorter one in order to put the antomatic coupler in front of the engine, an accident which could hare 
been prevented by a long pilot does not make the eompany liable.

\$361. Antomatic couplers of different makes.- The amendment of 1903 provicles that the Act shall apply in all cases whether or not the couplers brought together are the same kind, make or title, and the provisions and requirements relating to train brakes, automatic couplers, grab irons and the height of draw bars apply to all trains, locomotive tenders and cars, and similar vehicles used on any railroad in interstate commeree and saving those excepted by the Act.

Prior to this amendment of 1903 it had been held by the Circuit Court of Appeals of the eighth Circuit, in Johnson v. Southern P'acific Ry. Co., 5+ C. C. A. 508,117 Fod. Rep. 462 , that the equipment with automatic couplers which would couple antomatically with those of the same make, was a compliance with the statute, and it did not require cars used in interstite commerce to be equipped with couplers which would couple automatically with cars equipped with automatic conplers of other malies. This ruling was applied to a case where a freight engine was equipped with a Janney coupler and a car whieh was provided with Miller hook or Miller coupler which would not couple automatically with the Janney coupler. The plaintiff, a brakeman on defendant's road, undertook to make a coupling by means of a link and pin and was injured in so doing. The Circuit Court instructed the jury to return a verdict for the defendant, but this julgment was reversed by the Supreme Court, December 19, 1!)t, which held that the couplers reyuired must be of such a nature and character, that they must couple antomatically and save the employees from going between the ears, and that the use of automatic couplers whieh did not couple automatically on the same train, whether of the same make or not, violated the Act.

As stated above howerer this requirement is now enforced by the amended statute of 1908 .

\$30. 'The meaning of "car" in section 2.- In the same case the term "ear" as used in section 2 , which was held by a majority of the Court of Appeals, Thayer, J., dissenting, not to include locomotives, and that there was no language in the act which would make it unlawful to use in interstate com- 
merce locomotive engines which were not equipped with automatic couplers. This ruling was reversed by the supreme Conrt, which held that the law must be construed with reference to the danger to employees which it sought to remedy, and that for the purposes of safety appliances, locomotives were cars within the meaning of the $A$ ct and are required to be exuipled with automatic complers, and that it was even more necessary that locomotives should be so equipped than It was that freight, dining and passenger cars should be, since locomotives had occasion to make couplings more frequently. The word car was therefore used in a generic sense as inclucling both the locomotive and its tender.

363. When cars are in interstate commerce.-Another important ruling was made in the same case. The injury in this case was caused in compling a freight engine with a dining ear which had been detached from a throngh train, turned on the turn-table and was to be drawn by a freight engine to the turn-table, turned, and then moved to a side track to wait another through train moving in the opposite direction. As the car was standing empty on the side track when the phaintiff was injured, the majority of the Court held that it wis not engaged in interstate commerce, and therefore at the time of the accilent the locomotive and dining car were not being used in moring interstate tratfic within the meaning of the Aet. The supreme Court in the case eited, and in the same opinion, reversed this decision, and held that the dining car, though empty and on a side track, was engaged in interstate commeree within the meaning of the Act. 


\section{SEeTION 3. \\ § 364. Section 3 of the Act.}

\$364. When carriers may refuse to receive cars. - SEc. : That when any person, firm, comprany, or corporation engaged in interstate commerce by railroad shall have efuipped a sufficient number of its cars so as to comply with the provisions of section one of this act, it may lawfully refuse to receive from connecting lines of road or shippers any cars not equipped sufficiently, in accorlance with the first section of this act, with such power or train brakes as will work and readily interchange with the brakes in use on its own cars, as required by this act. 


\author{
Sicrion 4. \\ \$36.5. Section 4 of the Act. \\ 366. The use of defective cars forbidden.
}

86.5. Grab irons and handholds. - SEc. 4. That from and after the first day of July, eighteen hundred and ninety-fire, until otherwise ordered by the Interstate Commerce Commission, it shall be unlawful for any railroad company to use any car in interstate commerce that is not provided with secure grab irons or handholds in the ends and sides of each car for greater security to men in eoupling and uncoupling cars.

\$: :66. The use of defective cars forbillen.- The prohibition of the statute is against the use, and not against the ownership of a car, defective in its required equipment. There is no right of recovery by a terminal railroad, which has been mulcted in damages in a suit by an employee for injuries sustained in handling a car, wanting in equipment, from the carrier company owning the car; as it was its duty to refuse to receive the defective car; and therefore it was so far a wrong (Joer that it could not recover orer from the owning company. Enion Stockyards of Omaha v. C., B. \& Q. R. R. Co.,- U. S. Jan. 1905. 


\section{SECTION 5.}

S 36\%. Section 5 of the Act.

\section{\$367. Standard height of drawhars for freisht cars.-} SEc. 5. That within ninety days from the passage of this act the American Railway Association is authorized hereby to designate to the Interstate Commerce Commission the stanlard height of drawbars for freight cars, measured perpendicular from the level of the tops of the rails to the centers of the drawbars, for each of the several galuges of railloats in. use in the United states, and shall fix a maximum variation from such standard height to be allowed between the drawbars of empty and loaded cars. Upon their determination being certified to the Interstate Commerce Commission, said Commission shall at once give notice of the standard lixed upon to all common carriers, owners, or lessees engraged in interstate commerce in the Lnited States by such means as the Commission may deem proper. But should said association fail to determine a standard as above provided, it shall be the duty of the Interstate Commerce Commission to do so, before July first, eighteen hundred and ninety-four, and immediately to give notice thereof as aforesaid. And after July first, eighteen hundred and ninety-fire, no cars, either loadeil or unloaded, shall be used in interstate traftic which do not comply with the standard above provided for.

Note.-Prescribed standard height of drawbars: Stanlard-gauge roads, $34 \frac{1}{2}$ inches; narrow-gauge roads, 26 inches; maximum variation between loaded and empty cars, 3 inches. 


\section{Section 6.}

s38. Section 6 of the Act.

369. Enforcement of Act by prosecution.

\section{36s. Penalty for the violation of the provisions of this}

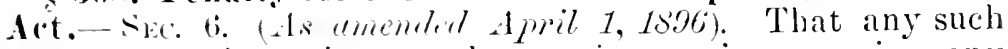
common carrier using any locomotive engine, running any train, or hauling or permitting to be hauled or used on its line any car in violation of any of the provisions of this act, shall he liable to a penalty of one hundred dollars for each and every such violation, to be recorered in a suit or suits to be brought by the Lnited States district attorney in the District Court of the Cnited States having jurisdiction in the locality where such violation shall have been committed; and it shall be the duty of such district attorney to bring stich suits upon duly veritied information being lodged with him of such violation has ving occurred; and it shall also be the duty of the Interstate commerce Commission to lodge with the proper district attorners information of any such violations as may come to its knowledge: I'rurided. That nothing in this act contained shall apply to trains composed of four-wheel cars or to trains comfrosed of eight-wheel standard logging cars where the height of such car from top of rail to center of coupling does not exceed twenty-tive inches, or to locomotives used in hauling such trains when such cars or locomotives are exclusively used for the transportation of logs.

3(69). Enforcement of Act hy prosecntion.- In U. S. v. (ieddes, (6th Circ.), 131 Fed. Rep. 452 (1904), the prosecution under this section failed, as the defendant carrier was held not to be included in the Act, $m \mu^{\prime \prime}(, 5353$. In the U. S. Dist. Ct. $\therefore$ Wist. of Ill. (Warch 190.5), several interstate railroad companies were convicted and fined for failure to keep in order the automatic couplers with which their cars were supplied. 


\section{SECTION 7.}

§3\%0. Section 7 of the Act.

371. Discretion of the Commission in delaying enforcement of the Act.

830. Power to extend time.- SEc. 7. That the Interstate Commerce Commission may from time to time upon full hearing and for good cause extend the period within which any common carrier shall comply with the provisions of this Act.

\&37. Discretion of the Commission in delaying the enforcement of the Act.- This statute, which as amended is the only enactment for the safety of railroad employees in the ferleral regulation of railroad transportation, has been construed by the Commission from time to time in connection with the discretionary power lorlged with the Commission under section 7 of the Act for the extension of the period of time in which the railiroads are required to comply with the Act. The Commission has ruled that this cliscretionary power was designed to afford relief in cases which would otherwise inflict special hardships upon the public and the carriers and should only be exercised under such circumstances and for such short lengths of time as are contemplated by the framers of the statute and are plainly inferable from its terms. 9 I. C. C. R. $222 ; 8$ I. C. C. R. 643,$662 ; 6$ I. C. C. R. 332 . 


\section{SECTION S.}

372. Section 8 of the Act.

3\%3. Contributory negligence under the Act.

\section{\$37:. Employees not lleemed to assume risk of employ-} ment.- SEc. S. 'That any employee of any such common carrier who may be injurel by any locomotive, citr, or train in use contrary to the provision of this act shall not be deemed thereby to have assumed the risk thereby occasioned, although continuing in the emplorment of such carrier after the unlawful use of such locomotive, car, or train had been brought to his knowledge.

\$373. Contributory negligence muler the Act.-It is provided in section $S$ of the original Act that the continuance in the employment of the carrier by an employee after knowing of the riolation of the Act shall not be deemed an assumption of the risk. It has been held in some of the State courts that this provision clearly indicates the morlification of the terms and limiting the applications theretofore announced by the courts with reference to the assumption of the risk by the employee. Sec Texas, etc. R. Co. r. Swearingen, 122 Fed. Rep. 19\%. See also Narramore v. Railroarl Co., $96 \mathrm{Fed}$. Rep. 298 , construing the Ohio statute to the same effect.

But it was held by the Cnited States Circuit Court of Appeals for the eighth Circuit in Gilbert v. Burlington C. R. \& $N$. R. ('o., 128 Fed. Rep. 529, affirming 123 Fed. Rep. 832 , that the devolution of the duty upon the common carriers to so equip their cars, that they could be uncoupled withont requiring their servants to go between the ends of the cars, necessarily imposed upon their servants the railroad's duty of using the equipment thus used upon them, and refraining from going between the ends of the cars to couple or uncouple them unless compelled to do so by necessity. Under this legislation the breach of either of these duties constituted a want of ordinary care and constituted actionable negligence. The Court also said the principle was applicable, that where there is a comparatively safe and a more dangerous way of discharging the duty known to the servants, it was negligence for him to select the more dangerous method, and if his negligence 
contributed to his injury, his negligence is fatal to recovery therefore. See also Northern Pacific Ry. Co. v. Tynan, 119 Fed. Rep. $28 S$, and 56 C. C. A. 192, ninth Circuit, 1902, where the court left the issue of contributory negligence to the jury. See also Railway Co. v. Palier, 33 C. C. A. 468, 91 Fed. Tep. 224 , in the seventh Circuit, where plaintiff was held guilty of contributory negligence for failing to exercise reasonable care for his own safety in the absence of grab irons or liand holds; and Denver \& Rio Grande R. Co. v. Arrighi, 129 Fed. Rep. $3 \pm 7$ (C. C. A., eighth Circuit.) In this case the Court said that the defense of contributory negligence was as available to the railroad company after as before the passage of the Act of Congress, although it had not complied with its requirements. In this case the plaintiff rester his case entirely on the failure of the defendant to comply with the Act. The Court said that the rationale of the doctrine of assumption of risk was not that which supported the rule of contributory negligence.

It was held in the Toelier case, supre, that a switchman does not assume the risk where the car requiring complers is not so equipped, and is not marked or isolated as one in bad repair, and its morement at the time is not with the view to its isolation or repair, though he continues in the employment with knowledge of the unlawful use of the car. 


\section{AMEXDMENT OF 1903 TO SAFETY ACT.}

An Act to amendan Act entitled "An act to promote the safety of employees and travelers upon railroals by compelling common carriers engaged in interstate commerce to equip their cars with automatic couplers and continuous brakes and their locomotives with driving-wheel brakes, and 1 or other purposes." approver March second, eighteen hundred and ninety-tliree, and amended April first, eighteen hun Jred and ninety-six.

\section{S:3t. Amendment of 1903.-Be it enacted by the Senate and} Ilome of lispresentatives of the I nited states of 1 merira in Con!ress asemblilert, That the provisions and requirements of the Act entitled "In Act to promote the sa fety of employees and trarelers upon railroals by eompeling eommon earpiers engaged in interstate commerce to equip theil cars with a tomatic couplers and continuous brakes, and their locomotives with driving-wheel bralies, and for other purposes." approved March seeond, cighteen hundred and ninety-three, and amended April first, eighteen hundred and ninety-six, shall be held to apply to common earriers by railroads in the Territories and the Distriet of Columbia and shall apply in all eases. whether or not the complers brought torether are of the same lind, make, or type: and the provisions and requirements hereof and of said acts relating to train blakes, automatic couplers, grab irons, and the height of clrawbars shall be held to apply to all trains, locomotives, tenders, cars, and similar vehicles used on any railroad enoared in interstate commeree, and in the Territories and the District of Columbia, and to all other locomotives, tenders, ears, and smilar vehieles used in eonnection therewith, excepting those trains, cars, and loeomotives exempted by the provisions of section six of said act of March seeond, eiditeen hundred and ninetr-three, as amended by the at of April first, eighteen hundred and ninety-six, or which are used upon street railways.

Sic. 2. That whenever, as provilled in said act, any train is operated with power or train brakes, not less than tifty per centum of the cars in such train shall have their braties used and operated by the engineer of the locomotive drawing such train; and all power-brake ears in such train which are associated together with sail lifty per centum shall have their brakes so used and operated; and, to more fully carry into effect the objects of said aet, the Interstate Commerce Commission may, from time to time, after full hearing, increase the minmmum percentage of ears in any train reyuired to be operated 
with power or train brakes which must have their brakes used and operated as aforesaid; and failure to comply with any such requirement of the said Interstate Commerce Commission shall be subject to the like penalty as failure to comply with any requirement of this section.

$S_{\text {EC. }} 3$. That the prorisions of this act shall not take effect until September first, nineteen hundred and three. Nothing. in this act shall be held or construed to relieve any common carrier, the Interstate Commerce Commission, or any Inited States distriet attorney from any of the provisions, power's, duties liabilities, or requirements of said act of March second, eighteen hundred and ninety-three, as amended by the act of April first, eighteen hundred and ninety-six; and all of the provisions, powers, duties, requirements and liabilities of sald act of March second, eighteen hundired and ninetr-three, as amended by the act of April first, eighteen hundred and ninety-six, shall, except as specifically amended by this act, apply to this act. 


\section{THE ACCLDENT LAW OF MARCH 3, 1901.}

An Act refuirin $20 m m o n$ carriers engaged in interstate commerce to make full reports of all accidents to the Interstate Commerce Commission

3.5. Mouthly reports of railway accidents. - Be it

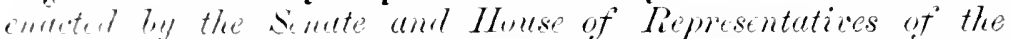
Crited vitutes of America in commess assmbled: SEC. 1. It shall be the dity of the general manager, superintendent, or other proper ollicer of every common carrier engaged in interstate commerce by railroad to make to the Interstate Commerce Commission, at its office in Washington, District of columbial a monthly report, under oath, of all collisions of trains. or where any train or part of a train accidentally leaves the track, and of all aecidents which may occur to its passengers or emplovees while in the service of such common carrier and actualiy on duty, which report shall state the nature and causes thipeof, and the circumstances connected therewith.

SE. 2. That any common carrier failing to make such report within thirty days after the end of any month shall be deemed guilty of a misclemeanor and, upon conviction thereof by a court of competent jurisliction, shall be punished by a tine of not more than a hundred dollars for each and every offense and for every day during which it shall fail to make such report after the time herein specitied for making the simle.

SEC :3. That neither said report nor any part thereof shall be admitted as evidence or used for any purpose against such railroad so making such report in any suit or action for damages growing out of any matter mentioned in said report.

sie. t. That the Interstate Commerce Commission is authorized to prescribe for such common carriers a method and form for milling the reports in the foregoing section providerl.

This Act by the terms requires the report of all accidents by railroad carriers engaged in interstate commerce. A carrier whose line lies wholly within one state may engage in interstate commerce when it is a party to through interstate routing, and the accidents required to be reported, may have no relation to the interstate traffic. 


\section{FEDERAL LABOR STATUTES.}

\section{\$ 3r6. The National Trade Enion Incorioration Act.-}

The Act of June 29, 1856, legalizes the incorporation of $\mathrm{Na}$ tional Trades Unions, 3 Compiled Statutes 3204 :

"National Trade Cuious" defined.-Be it enarted, etr: SEc. 1. Thit the term "National Trade Union," in the meaning of this act, shall signify an association of working people having two or more branches in the states or Territories of the United States for the purpose of aiding its members to become more skillful and efficient workers, the promotion of their general intelligence, the elevation of their character, the regulation of their wages and their hours and conditions of labor, the protection of their individual rights in the prosecution of their trade or trades, the raising of funds for the benefit of sick, disabled, or unemployed members, or the families of deceased members, or for such other object or objects for which working people may lawfully combine, having in view their mutual protection or benetit.

Incorporation.- Sre. 2. That National Trale Cnions shall, upon filing their articles of incorporation in the office of the recorder of the District of Columbia, become a corporation under the technical name by which said National Trade Union desires to be known to the trade; and shall have the right to sue and be sued, to implead and be impleaded, to grant and receive, in its corporate or technical name, property, real, personal, and mixed, and to use said property and the proceeds and income thereof, for the objects of said corporation as in its charter defined: Provided, That each Union shatl hold only so much real estate as may be required for the immediate purposes of its incorporation.

Constitution, rules, and hy-laws.- Sec. 3. That an incorporated National Trade Union shall have power to malse and establish such constitution, rules, and by-laws as it may deem proper to carry out its lawful objects, and the same to alter, amend, add to, or repeal at pleasure.

Duties of officers. - SEc. 4 . That an incorporated National Trade Union shall have power to define the duties and power's of all its officers, and prescribe their mode of election and term of. oflice, to establish branches and sub-unions in any territory of the United States.

Healquarters.--SEc. 5. That the headquarters of an incorporated National Trade Union shall be located in the District of Columbia. See supre, p.-- 


\section{NATIONAL ARBITRATION ACT.}

Act of June 1, 1898, 3 Compiled Statutes, 3205.

In Act concerning carriers engaged in interstate commerce and their employees.

S3ri. De it enatod by the Senate and Tonse of Representaties at the Initad states of Imerian in Congress assembled: sic. 1. That the provisions of this act shall apply to any common earrier or carriers and their officers, agents, and emploves, except masters of ressels and seamen, as defined in section forty-six humdred and twelve, Rerised Statutes of the I nited states. engaged in the transportation of passengers or property wholly by railroad, or partly by railroad and partly hy water, for a continuous carriage or shipment, from one siate or Territory of the Lnited States. or the District of columbia. to any other state or Territory of the United States or the District of Columbia, or from any place in the Inited sitates to an adjacent foreign country, or from any plice in the Eniteil states through a foreign country to any other place in the United sitates.

The term "railroad" as used in this act shall include all bridges and ferries used or operated in connection with any railroad, and also all the road in use by any corporation operating a railroad, whether owned or operated under a contract, "grecment, or lease; and the term "transportation" shall inelucle all instrumentalities of shipment or carriage.

The term "employees" as used in this Act shall include all persons actually engaged in any capacity in train operation or train service of any discription, and notwithstanding that the cars mpon or in which they are employed may be held and operated by the carrier under lease or other contract; l'rovided, horever. That this act shall not be held to apply to employees of street railroads and shall apply only to employees encraged in railroal train service. In every such case the carrier shall be responsible for the acts and defaults of such employees in the same manner and to the same extent as if said cars were owned by it and said employees directly employed by it, and any provisions to the contrary of any such lease or other contract shall be binding only as between the parties thereto and shall not affect the obligations of said carrier either to the public or to the private parties concerned.

Siz. 2. That whenever a controversy concerning wages, hours of labor, or conditions of employment shall arise between a carrier subject to this act and the employees of such 
carrier, seriously interrupting or threatening to interrupt the business of said carrier, the chaiman of the Interstate Commerce Commission and the Commissioner of Labor shall, upon the request of either party to the controversy, with all practicable expedition, put themselves in communication with all parties to the controversy, and shall use their best efforts, by mediation and conciliation, to amicably settle the same; and if such efforts shall be unsuccessful, shall at once endeavor to bring about an arbitration of said controversy in accordance with the provisions of this act.

SEc. 3. That whenever a controrersy shall arise between a carrier subject to this act and the employees of such carrier which cannot be settled by mediation and conciliation in the manner provided in the preceding section, silil controversy may be submitted to the arbitration of a board of three persons, who shall be chosen in the manner following: One shall be named by the carrier or employer directly interested: the other shall be numed by the labur reguniartion to which the employees directly interested belong, or, if they belong to more than one. by that one of them which specially represents employees of the same grate and class and encraged in services of the same nature as said employees so directly interested: I'rovided, lowower, That when a controversy involves and effects the interests of two or more classes and grades of employees belonging to different labor oranizations, such arbitrator shall be agreed upon and designated by the concurrent action of all such labor oroanizations; and in cases where the majority of such employees are not members of any labor organization, said emplorees may by a majority rote select a committee of their own number, which committeo shall have the right to select the arbitrator on behalf of satid employees. The two thus chosen shall select the third commissioner of arbitration; bat, in the event of their failure to name such arbitritor within five davs after their first meeting, the third arbitrator sball be named by the commissioners named in the preceding section. A majority of said arbitrators sball be competent to make a valid and hinding award under the provisions hereof. The submission shall be in writing, shall be signed by the employer and by the labor organization representing the employees, shall specify the time and place of meeting of said board of arbitration, shall state the questions to be decided, and shall contain appropliate provis. ions by which the respective parties shall-stipulate, is follows:

First. That the board of arbitration shall commence their hearings within ten days from the date of the appointment of the third anbitrator, and shall find and file their award, as provided in this section, within thirty days from the date of the appointment of the third arbitator; and that penting the arbitration the status existing immediately prior to the dis- 
pute shall not be changed: Provider, That no employee shall be compelled to renler personal service without his consent.

second. That the awird and the papers and proceedings, including the testimony relating thereto certified uncler the hands of the albitrator's and which shall have the force and eflect of a bill of exceptions, shall be filen in the elerk's office of the circuit court of the United States for the district wherein the controversy arises or the arbitration is entered into, and shall be tinal and conclusive upon both parties, unless set aside for error of law apparent on the record.

Thiml. That the respective parties to the award will each faithfully execute the same, and that the same may be specitically entorcel in equity so fiar as the powers of a court of expity perunt: I'mided. That no injunction or other legal proces shall be issued which shall compel the performance by any laborer against his will, of a contract for personal labor or service.

Fourth. That employees dissatisfied with the award shall not by reason of such dissatisfiation quit the service of the empiover before the expiration of three months from and after the making of stleh awad withont giving thirty days notice in writing of their intention so to quit. Nor shall the employep dissatistied with such award clismiss any employee or employees on atecount of such dissatistaction before the expiration of three months from and after the making of such a wial without griving thirty day's notice in writing of his intention so to discharge.

Fifth. That said award shall continue in force as between the parties thereto for the period of one year after the same shall wo into practical operation, and no new arbitration upon the same subject between the same employer and the same class of employees shall be had until the expiration of said one vear if the award is not set aside as provided in section four. That as to individual employees not belonging to the labor ormanization or or manizations which shall enter into the arbitration, the said arbitration and the award made therein shall not le binding, unless the said molivilual emplorees shall give assent in writing to become parties to said arbitration.

sic. t. That the award being filed in the clerk's olfice of a circuit court of the Lnited states, as hereinbefore provided, shall go in to practical operation, and judgment shall be en tered thereon accoldingly at the expirition of ten days from such filing, unless within such ten day's either party shall file exceptions thereto for matter of law apparent upon the record, in Which case said award slatl go into practical operation and judgruent be entered accordingly when such exceptions shall have been finally disposed of either by said circuit court or on appeal therefrom.

At the expiration of ten days from the decision of the cir- 
cuit court upon the exceptions taken to said a ward, as aforesaid, judgment shall be entered in accordance with silil decision mnless during said ten days either party shall appeal therefrom to the circuit court of appeals. In such case only such portion of the record shall be transmitted to the Appellate Court as is necessary to the proper understanding and consideration of the questions of law presented by said exceptions and to be decided.

The determination of said circuit court of appeals upon said questions shall be final, and being certified by the clerk thereof to said cireuit court, julgment jursuant thereto shall thereupon be entered by said circuit court.

If exceptions to an award are finally sustained, julgment shall be entered setting aside the award. But in snch case the parties may agree upon a judgment to be entered clisposing of the subject-matter of the controversy. which judgment when entered shall have the same force and effect as julgment entered upon an awarl.

SEc. 5. That for the purposes of this act the arbitrators herein provided for, or either of them, shall have power to administer oaths and allirmations, sign subponas, recuire the attendance and testimony of witnesses, and the production of such books, papers, contricts, acreements, and documents material to a just determination of the matters under investigation as may be ordered by the court: and may involie the aid of the United States courts to compel witnesses to attend and testify and to produce such books, papers, contracts, agreements and documents to the same extent and under the same conditions and penalties as is provided for in the act to regulate commerce, approved February fourth, eighteen bundred and eighty-seren, and the amendments thereto.

SEc. 6. That every agreement of arbitration under this act shall be acknowledged by the parties before a notary public or clerk of a district or circuit court of the Lnited states, and when so acknowledged a copy of the same shall be transmitted to the chairman of the Interstate Commerce Commission, who shall file the salme in the olfice of sail Commission.

Any agreement of arbitration which shall be entered into conforming to this act, except that it shall be executed by employees inclividually instead of by a labor organization as their representative, shall, when duly acknowledged as herein provided, be transmitted to the chairman of the Interstate Commerce Commission, who shall cause a notice in writing to be served upon the arbitritors, fixing a time and place for a meeting of said board, which shall be within fifteen days from the execution of said agreement of arbitration: Provided, however, That the said chairman of the Interstate Commerce Commission shall decline to call a meetihg of arbitrators under such agreement unless it be shown to his satisfaction that the 
employees signing the submission represent or include a majority of all employees in the service of the same employer and of the same grade and class, and that an award pursuant to said submission ean justly be regarded as binding upon all such emplorees.

sac. $T$. That during the pendency of arbitration under this act it shall not be lawful for the employer, party to such arbitration, to discharge the eniployees, parties thereto, except for inefliciency, violation of law, or neglect of duty: nor for the oranization representing such employees to order, nor for employees to unite in, airl, or abet, strilies against said emplover: nor, during a period of three months after an award milersuch an arbitration. for such employer to discharge any such employees, except for the causes aforesaid. without giving thirty days written notice of an intent so to discharge: nor for any of such employees, during a like period, to quit the service of said emplorer without just cause, without giving to saicl employer thirty days' written notice of an intent so to do: nor for such organization representing such employees to order, counsel, or alvise otherwise. Any violation of this section shall subject the offending party to liability for damages: I'ruiled, That nothing herein containerl shall be construed to prevent any employer, party to such arbitration. from reducing the number of its or his employees whenever in its or his julgment business necessities require such reduction.

sEc. 8 . That in every incorporation under the provisions of chapter five hundred and sixty-seven of the L'nited States Statutes of eighteen hundred and eighty-five and eighteen hundred and eighty-six it must be provided in the articles of incorporation and in the constitution, rules, and by-laws that a member shall cease to be such by participating in or by instigating force or violence against persons or property during strikes, lockouts, or boycotts, or by seeking to prevent others from working through violence, threats, or intimidations. Members of such incorporations shall not be personally liable for the acts. detets, or obligations of the corporations, nor shall such corporations be liable lor the acts of members or others in vinlation of law; and such corporations may appear by designated representatives before the boarl created by this act, or in any suits or proceedines for or against such corporations or their members in any of the federal courts.

sEc. !. That whenever receivers appointed by federal courts are in the pussession and control of ritroads, the employees mpon such railroads shall have the right to be heard in such courts upon all questions affiecting the terms and conditions of their employment, through the ollicers and representatives of their associations, whether incorporated or unincorporated, and no reduction of wages siall be marle by such receivers without the anthority of the court therefor upion notice to such employees, satil notice to be not less than twenty days before 
the hearing upon the receivers' petition or application, and to be posted upon all customary bulletin boards along or upon the railway operated by such receiver or receivers.

Sec. 10. That any employer subject to the provisions of this act and any officer, agent, or receiver of such employer who shall require any employee, or any person seeking employment, as a condition of such employment, to enter into an agreement, either written or verbal, not to become or remain a member of an y labor corporation, association, or organization: or shall threaten any employee with loss of employment, or shall unjustly discriminate against any employee because of his membership in such a corporation, association, or organization; or who shall require any employee or any person seek. ing employment, as a condition of such employment, to enter into a contract whereby such employee or applicant for employment shall agree to contribute to any fund for charitable, social, or beneficial purposes; to release such employer from legal liability for any personal injury by reason of any benefit received from such fund beyond the proportiton of the benefit arising from the employer's contribution to such fund; or who shall, after having discharged an employee, attempt or conspire to prevent such employee from obtaining employment, or who shall, after the quitting of an employee, attempt or conspire to prevent such employee from obtaining employment, is hereby declared to be guilty of a mislemeanor, and, upon conriction thereof in any court of the [nitel states of competent jurisdiction in the district in which such offense was committed, shall be punished for each offense by a fine of not less than one hundred dollars and not more than one thousand dollars.

SEc. 11. That each member of said board of arbitration shall receive a compensation of ten dollars per day for the time he is actually employed, and his traveling and other necessary expenses; and a sum of money sufficient to pay the same, together with the traveling and other necessary and proper expenses of any conciliation or arbitration had hereunder, not to exceed ten thousand dollars in any one year, to be approverl by the chairman of the Interstate Commerce Commission and auditer by the proper accounting officers of the Treasury, is hereby appropriated for the fiscal years ending June thirticth, eighteen hundred and ninety-eight and June thirtieth eighteen hundred and ninety-nine, out of any money in the Treasury not otherwise appropriaterl.

SEc. 12. That the Act to create boarls of arbitration or commission for settling controversies and differences between railroad corporations and other common carriers engaged in interstate or territorial transportation of property or persons and their employees, approved i)ctober first, eighteen hundred and eighty-eight, is hereby repealed.

As to this Act, see supere, p. 119. 
PROCEDURE BEFORE INTERSTATE COMMERCE COMMISSION.

\title{
$\$ 2$ S. Rules of Practice Before the Commission in Cases and Proceedings Cuder the Act to Regulate Commerce.
}

\author{
I. \\ PUBLIC SESSIONS
}

The general sessions of the Commission for hearing contested cases will be held at its oflice in the Sun Building, No. $1317 \mathrm{~F}$ street $\mathrm{NW}$., Washington, D. C., on such days and at such hour as the Commission may designate.

When special scssions are held at other places, such regulations as may be necessary will be made by the Commission.

Sessions for receiving, considering, and acting upon petitions, applications, and other communications, and also for considering and acting upon any business of the Commission other than the hearing of contested cases, will be held at its salid office at $110^{\circ}$ clock a. m. (laily when the Commission is in Washington.

II.

PARTIES TO CASES.

Any person, firm, company, corporation, or association, mercantile, agricultural, or manufacturing society, body politic or municipal organization, or the railroad commissioner or commission of any State or Territory, may complain to the Commission by petition, of any thing done, or omitted to be clone, in violation of the provisions of the Act to Regulate Commerce by any common carricr or carriers subject to the provisions of said Act. Where a complaint relates to the rates or practices of a single carrier, no other carrier need be made a party, but if it relates to matters in which two or more carriers, engaged in transportation by continuous carriage or shipment, are interested, the several carriers participating in such carriage or shipment are proper parties defenclant.

Where a complaint relates to rates or practices of carriers operating different lines, and the object of the proceeding is to secure correction of such rates or practices on each of said 
lines, all the carriers operating such lines must be made defendants.

When the line of a carrier is operated by a receiver or trustee, both the carrier and its receiver or trustee should be made defendants in cases inrolving transportation over such line.

Persons or carriers not parties may petition in any proceeding for leave to intervene and be heard therein. Such petition shall set forth the petitioner's interest in the proceeding. Leave granted on such application shall entitle the intervener to appear and be treated as a party to the proceeding, but no person, not a carrier, who intervenes in behalf of the defense, shall have the right to file an answer or otherwise become a party, except to hare notice of and appear at the taking of testimony, produce and cross-examine witnesses, and be heard in person or by counsel on the argument of the case.

\section{III.}

\section{COMLLAINTS.}

Complaints of unlawful acts or practices by any common carrier, made in pursuance of section 13 of the Act to Regulate Commerce, must be by petition, setting forth briefly the facts claimed to constitute a violation of the law. The name of the carrier or carriers complained against must be stated in full, and the address of the petitioner, with the name and address of his attorney or counsel, if any, must appear upon the petition. The complainant must furnish as many copies of the petition as there may be parties complained against to be served.

The Commission will cause a copy of the petition, with notice to satisfy or answer the same within a specified time, to be served, personally or by mail in its discretion, upon each carrier complained against.

IV.

ANSWERS.

A carrier complained against must answer within twenty days from the date of the notice above provided for, but the Commission may, in a particular case, require the answer to be filed within a shorter time. The time prescribed in any case may be extended, upon good cause shown, by special order of the Commission. The original answer must be filed, 
with the Secretary of the Commission at its office in Washington, and a copy thereof at the same time served, personally or by mail, upon the complainant, who must forthwith notify the secretary of its receipt. The answer must specifically admit or deny the material allegations of the petition, and also set forth the facts which will be relied upon to support any such denial. If a carrier complained against shall make satisfaction before answering, a written acknowledg ment thereof, showing the character and extent of the satisfaction given, must be filed by the complainant, and in that case the fact and manner of satisfaction, without other matter, may be set forth in the answer. If satisfaction be made after the filing and service of an answer, such written acknowledgment must also be filed by the complainant, and a supplemental answer setting forth the fact and manner of satisfaction must be filed by the carrier.

\section{V.}

SOTICE IN NATURE OF DEMURRER.

A carrier complained against who deems the petition insufficient to show a breach of legal duty, may, instead of answering, or formally demurring, serve on the complainant notice of hearing on the petition; and in such case the facts stated in the petitition will be deemed admitted. A copy of the notice must at the same time be filed with the Secretary of the Commission. The filing of an answer, however, will not be deemed an admission of the sufficiency of the petition, but a motion to dismiss for insufficiency may be made at the hearing.

\section{VI.}

\section{SERVICE OF PAPERS.}

Copies of notices or other papers must be served upon the adverse party or parties, personally or by mail; and when any party has appeared by attorney, service upon such attorney shall be deemed proper service upon the party.

\section{VII.}

AFHII A VITS.

Afficlavits to any pleading or application may be made before any officer of the United States, or of any State or Territory, authorized to administer oiths. 


\section{VIII.}

AMENDMENTS.

Upon application of any party, amendments to any petition or answer, in any proceeding or investigation, may be allowed by the Commission in its discretion.

\section{IX.}

ADJOLRNMENTS AND EXTENSIONS OF TIME.

Adjournments and extensions of time may be granted upon the application of any party in the discretion of the Commission.

\section{$\mathrm{X}$.}

\section{STIPULATIONS.}

The parties to any proceeding or inrestigation before the Commission may, by stipulation in writing filed with the Secretary, agree upon the facts, or any portion thereof involved in the controversy, which stipulation shall be regarded and used as evidence on the hearing. It is clesired that the facts be thus agreed upon whenerer practicable.

\section{XI.}

\section{HEARINGS.}

Upon issue being joined by the service of an answer or notice of hearing on the petition, the Commission will assign a time and place for hearing the case, which will be at its office in Washington, unless otherwise ordered. Witnesses will be examined orally before the Commission, unless their testimony be taken or the facts be agreed upon as provided for in these rules. The complainant must in all cases establish the facts alleged to constitute a violation of the law, unless the carrier complained against admits the same or fails to answer the petition. The carrier must also prove facts alleged in the answer, unless admitted by the petitioner, and fully disclose its defense at the hearing.

In case of failure to answer, the Commission will take such proof of the facts as may be deemed proper and reasonable, and make such order thereon as the circumstances of the case appear to require. 
Cases may be argued orally upon submission of the testimony, unless a different time shall be agreed upon by the parties or directed by the Commission, but oral argument may be omitted in the discretion of the Commission.

XII.

DEPOSITIONS.

The testimony of any witness may be taken by deposition. at the instance of a party, in any proceeding or investigation before the Commission, and at any time after the same is at issue. The Commission may also order testimony to be taken by deposition, in any proceeding or investigation pending before it, at any stage of such proceeding or investigation. such depositions may be taken before any juclge of any court of the Cnited states, or any commissioner of a circuit, or any clerk of a district or circuit court, or any chancellor, justice, or julge of a supreme or superior court, mayor or chief magistrate of a city, judge of a county court, or court of common pleas of any of the United States, or any notary public, not being of counsel or attorney to either of the parties, or otherwise interested in the proceeding or investigation. Reasonable notice must be given in writing by the party or his attorney proposing to take such deposition to the opposite party or his attorney of record, which notice shall state the name of the witness and the time and place of the taking of his deposition, and a copy of such notice shall be filed with the secretary.

When testimony is to be taken on bebalf of a common carrier in any proceeding instituted by the Commission on its own motion, reasonable notice thereof in writing must be given by such carrier to the Commission itself, or to such person as may hare been previously designated by the Commission to be served with such notice.

Every person whose deposition is taken shall be cautioned and sworn (or may affirm, if he so request) to testify the whole truth, and shall be carefully examined. His testimony shall be redueed to writing, which may be typewriting, by the magistrate taking the deposition, or under his direction, and shall, after it has been reduced to writing, be subscribed by the witness. 
If a witness whose testimony may be desired to be taken by deposition be in a foreign country, the deposition may be taken before an officer or person designated by the Commission, or agreed upon by the parties by stipulation in writing to be fiłed with the secretary. All clepositions must be promptly filed with the secretary.

\section{XIII.}

WITNESSES AND SUPPGNAS.

Subponas requiring the attendance of witnesses from any place in the United States to any designated place of hearing, for the purpose of taking the testimony of such witnesses orally before one or more members of the Commission, or by deposition before a magistrate authorized to take the same, will, upon the application of either party, or upon the order of the Commission directing the taking of such testimony, be issued by any member of the Commission.

Subpenas for the production of books, paper's or documents (unless directed to issue by the Commission upon its own motion) will only be issued upon application in writing; and when it is sought to compel witnesses, not parties to the proceeding, to produce such documentary evidence, the application must be sworn to and must specify, as nearly as may be, the books, papers, or documents desired; that the same are in the possession of the witness or under his control; and also, by facts stated, show that they contain material evidence necessary to to the applicant. Applications to compel a party to the proceeding to produce books, papers, or documents need only set forth in a general way the books, papers, or documents desired to be produced, and that the applicant believes they will be of service in the determination of the case.

Witnesses whose testimony is taken orally or by deposition, and the magistrate or other officer taking such depositions, are severally entitled to the same fees as are paid for like services in the courts of the United States, such fees to be paid by the party at whose instance the testimony is taken.*

* Fees of witnesses are fixed by law at $\$ 1.50$ for each day's attendance at the place of hearing or of taking depositions, and 5 cents per mile for going to said place from his place of residence and 5 cents per mile for returning therefrom. 


\section{XIS.}

\section{PROPOSED FINDINGS AND BRIFFS.}

Proposed finclings embracing the material facts claimed to be established by the evidence, and referring to the particular part of the record relied upon to support each finding proposed, shail be filed by eacli party. Printed or written arguments or briefs may be filed by any party. A copy of the proposed findings, brief, or argument tiled on behalf of any farty, must at the same time be served upon the adverse party or parties, personally or by mail, and notice of such service thereupon filed with the Secretary of the Commission. The time within which proposed findings and printed or written arguments or briefs shall be filed in any case will be determined by the Commission upon submission of the testimony.

\section{Xr.}

\section{REHEARINGS.}

Applications for reopening a case after final submission, or for rehearing after decision made by the Commission, must be by petition, and must state specifically the grounds upon which the application is based. If such application be to reopen the case for further evidence, the nature and purpose of such evillence must be brielly statel, and the same must not be merely cumulative. If the application be for a rehearing, the petition nust specify the findings of the fact and conclusions of law claimed to be erroneous, with a brief statement of the grounds of error: and when any recommendation, decision, or order of the Commission is sought to be reversed, changed, or modified on account of facts and circumstances arising subsequent to the hearing, or of consequences resulting from compliance with such recommendation, decision, or order which are claimed to justify a reconsileration of the case, the matters relied upon by the applicant must be fully set forth. Such petition must be duly verified, and a copy thereof, with notice of the time and place when the application will be made, must be served upon the adverse party at least ten days before the time named in such notice. 


\section{XVI.}

PRINTING OF PLEADINGS, ETC.

Pleadings, depositions, briefs, and other papers of importance, shall be printed or in typewriting, and when not printed only one side of the paper shall be used.

\section{XVII.}

COPIES OF PAPELS OR TESTIMONY.

Copies of any petition, complaint, or answer in any matter or proceeding before the Commission, or of any order, decision, or opinion by the Commission, will be furnished without charge, upon application to the secretary by any person or carrier party to the proceeding.

One copy of the testimony will be furnished by the Commission for the use of the complainant, and one copy for the use of the defendant, without charge; and when two or more complainants or defendants have appeared at the hearing, such complainants or defendants must designate to whom the copy for their use shall be delivered.

\section{XVIII.}

\section{COMPLIANCE WITH ORDERS AGAINST CARRIERS.}

Upon the issuance of an order against any carrier or carriers, after hearing, investigation, and report by the Commission, such carrier or carriers must promptly, upon compliance with its requirements, notify the secretary that action has been taken in conformity with the order; and when a change in rates is required, such notice must be given in addition to the filing of a schedule or tariff showing such change in rates.

\section{XIX.}

\section{APPLICATIONS BY CARRIERS CNDER PROVISO CLAUSE OF FOURTH}

\section{SECTION.}

Any common carrier may apply to the Commission, under the proviso clause of the fourth section, for authority to charge for the transportation of like kind of property less for a longer than for a shorter distance over the same line, in the same direction, the shorter being included within the longer distance. Such application shall be by verified petition, which 
shall specify the places and traffic in rolved, the rates charged on steh tratfic for the shorter and longer distances, the carriers other than the petitioner which may be interested in the traffic, the character of the harelship claimed to exist, and the extent of the relief sought by the petitioner. Upon the filing of such a petition, the Commission will take such action as the eireminstances of the ease seem to require.

\section{XX.}

INFORMATION TO PARTIES.

The Secretary of the Commission will, upon request, alvise any party as to the form of petition, answer, or other paper necessary to be filed in any case, and furnish such information from the files of the Commission as will conduce to a full presentation of facts material to the controversy.

\section{XXI.}

ADDIRSS OF TIIE COMIISSION.

All complaints concerning anything lone or omitted to be done by any common carrier, and all petitions or answers in any proceeding, or applications in relation thereto, and all letters and telegrams for the Commission, must be addressed to Washington, D. C., unless otherwise specially directed. 


\section{FORMS OF PROCEDURE BEFORE COMIMISSION.}

These forms may be used in cases to which they are applicable, with such alterations as the circumstances may render necessary.

\section{No. 1.}

\section{Complaint Against a Single Carrier.}

INTERSTATE COMMERCE COMMISSION.

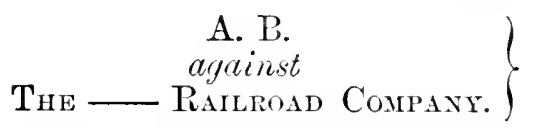

The petition of the above-named complainant respectfully shows:

I. That [here let complainant state his sceupation and place of business.]

II. That the defendant above named is a common carrier engaged in the transportation of passengers and property by railroad between points in the State of __ and points in the State of - and as such common carrier is subject to the provisions of the Act to regulate commerce, approved February 4,1857 , and Acts amendatory thereof or supplementary thereto.

III. That [ here state concisely the matters intended to be complaines of. Continue numbering each succeding paragraph as in Vos. 1, II, and 111.]

Wherefore the petitioner prays that the defendant may be required to answer the charges herein, and that after due hearing and inrestigation an order be made commanding the defendant to cease and desist from said violations of the Act to regulate commerce, and for such other and further order as the Commission may deem necessary in the premises. [The prayer may be varied so as to ask also for the ascertuinment of lawful rates or proctices and an order requiring the 
currier to conform thereto. If reparation for any wrong or iniury be desired, the petitioner should state the nature and extent of the reparation he deens proper.]

Dated at —, - - $190-$.

$$
\begin{gathered}
\text { A. B. } \\
\text { (Complainant's signature.) }
\end{gathered}
$$$$
\text { No. } 2 .
$$

Complaint against two or more Carriers.

INTERSTATE COMMERCE COMMISSION.

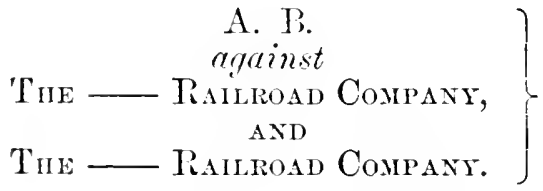

The petition of the abore-named complainant respectfully shows:

I. That [here let complainant state lis occupation and place of l,usiness.]

II. That the defendants abore named are common carriers engaged in the transportation of passengers and property, by continuous carriage or shipment, wholly by railroad [or partly ly raitroat and partly by water, as the case may be ], between points in the state of - and points in the State of and as such common carriers are subject to the provisions of the $A$ ct to regulate commerce, approved February 4, 1857, and Acts amendatory thereof or supplementary thereto.

[Then proceed as in Form 1.]

No. 3.

Answer.

INTERSTATE COMMERCE COMMISSION.

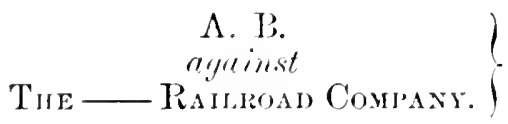

The above-named defendant, for answer to the complaint in this proceeding, respectfully states-

I. That [here follow the usual almissions, denials, and averments. Contime numbering earlh succeding paragraph]. 
Wherefore the defendant prays that the complaint in this proceeding be dismissed.

The- Railroad Conpant.

By E. F.

(Title of officer.)

\section{No. 4.}

\section{Notice by Carrier under Rule V.}

INTERSTATE COMMERCE COMMISSION.

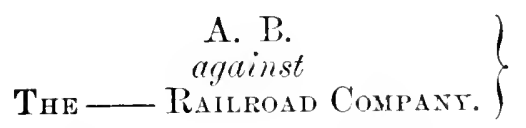

Notice is hereby given under Rule $V$ of the Rules of Practice in proceedings before the Commission that a hearing is desired in this proceeding upon the facts as stated in the complaint.

The Rimiroad Company.

By E. F.,

(Title of officer.)

No. 5.

Subpœna.

INTERSTATE COMMERCE OOMMISSION.

To

You are hereby required to appear before in the matter of a complaint of —__ against —_ as a witness on the part of ——, on the - day of — $-190-$, at—o'clock-m. at - and bring with you then ancl there

Dated

(Seal.)

\section{Commissioner.}
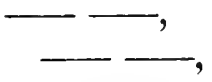

Attorney for —.

(Notick. - Witness fees for attendance under this subpcena are to be paid by the party at whose instance the witness is summoned, and every copy of this summons for the witne.ss must contain a copy of this notice.) 
No. 6.

Notice of taking Depositions under Rule XII.

INTERSTATE CUMMERCE COMMISSION.

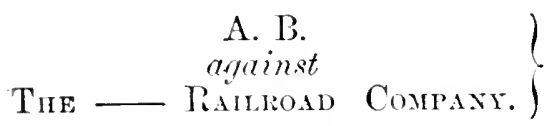

You are hereby notified that G. II. will be examined before C. D., a - [title of officer or magistrates], at - on the — day of — 190_, at _ o'clock in the — noon, as a witness for the abore named complainant [or defendant as the ase may be], according to act of Congress in such case made and provided, and the rules of practice of the Interstate Commerce Commission; at which time and place you are notified to be present and take part in the examination of the said witness.

Dated ——, 190-.

\section{$\mathrm{J} \mathrm{I}$.}

(Signature of complainant or d. fendunt, or of counsel.)

To A. B., the above named compiainant [or The _ Railroad Company, the above-named defendunt; or to $K$. L., counsel for the above-named complainant or defendant]. 


\section{TABLE OF CASES.}

References are to pages.

Adams v. Ohio (165 U. S. 194, 41 L. Atchison, T. \& S. F. R. Co. v. MatEd. 683), 29.

Adams v. Scott (104 Mass. 164), 46.

Adams Express Co. v. Kentucliy (166 U. S. 171, 41 L. Ed. 960), 29.

Aikens v. Wisconsin (25 Sup. Ct. Rep. 3), 140.

Addyston Pipe \& Steel Co. v. United States (175 U. S. 211, 44 L. Ed. 136,29 C. C. A. $141, \$ 5$ Fedi. Rep. 271), 91, 92, 93, 95, 100, 115, $351,366$.

Allen v. Flood ( 67 L. J. Rep. H. of L. -) , 98, 114.

Allen v. Oregon Ry. \& Nar. Co. (98 Fed. Rep. 616), 253.

Allis-Chalmers Co. v. Reliable Lodge (111 Fed. Rep. 264), 106.

Almy v. California (24 How. 169, 16 L. Ed. 644), 13.

American Refrigerator Transit Co. v. Hall (174 U. S. 70,43 L. Ed. 899), 29.

American Steamship Co. v. Louisiana (118 U. S. 455,30 L. Ed. 237), $6,33,41$.

American Steel \& Wire Co. v. Speed (192 U. S. 500, 48 L. Ed. $538), 25$.

American Steel \& Wire Co. v. Wire Drawers, etc. (90 Fed. Rep. 608), 106.

Ames v. Union Pac. R. Co. (64 Fed. Rep. 165), 129.

Anderson v. United States (171 U. S. 604,43 L. Ed. 300,82 Fed. Rep. 529), 92, 355 .

Arbuckel v. Blackburn (51 C. C. A. 122, 113 Fed. Rep. 616, 65 L. R. A. 864), 17.

Arnold v. Yanders (Ohio, 47 N. E. Rep. 50), 47.

Arthur v. Oakes (11 C. C. A. 209, 63 Fed. Rep. 310), 106, 117, 118, 297, 298.

Asher v. Texas (12S U. S. 129, 32 L. Ed. 368 ), 28 .

Atchison, T. \& S. F. R. Co. v. Denver \& N. O. R. Co. (110 U. S. 667, 28 L. Ed. 281), 139, 253. thews (174 U. S. 96,43 L. Ed. 909), 142.

Atlanta v. Chattanooga Foundry \& Pipe Co. (127 Fed. Rep. 25), 368.

Atlantic Coast Line Co. v. Commonwealth (46 S. E. Rep. 910), 48.

Atlantic, etc. Tel. Co. v. Philadelphia (190 U. S. 160,47 L. Ed. $995), 29$.

Atwater v. Railroad Co. (48 N. J. Law, 65), 189.

Augusta Southern R. Co. v. Wrightsville \& S. R. Co. (it Fed. Rep. 522), 167, 257.

Austin v. Tennessee (179 U. S. 343, 45 L. Ed, 2:11, 17, 26.

Avinger v. South Car. R. Co. (29 S. C. 265), 189 .

Baldwin v. Great Northern R. Co. ( 81 Minn. 247), 46.

Ball, The Daniel (10 Wall. 557, 19 L. Ed. 999), 21.

Bannon v. United States (156 U. S. 464, 39 L. Ed. 491), 111.

Baxendale v. Railway Co. (4 C. B. N. S., 63) . 185.

Beavers v. Henkel (194 U. S. 73, 48 L. Ed. 882), 300.

Beers v. Wabash, St. Louis \& Pacific R. Co. (34 Fed. Rep. 244), 297.

Behlmer v. Louisville \& Nashville Railroad Company (175 U. S. 648, 44 L. Ed. 309), 149, 171, 262, 320 .

Bement v. National Harrow Co. (186 U. S. 70, 46 L. Ed. 1058), $370,371$.

Benedict v. Construction Co. (49 N. J. Eq. 429), 19.

Berkowitz v. United States (C. C. A., 93 Fed. Rep. 452), 111.

Eessette v. Conkey Co. (194 U. S. 324), 123, 126.

Bigbee Packet Co. v. M. \& O. R. Co. i6, Fed. Rep. 545), 243.

Bishop v. American Preservers Co. (105 Fed. Rep. \$45), 368. 
References are to pages.

Boehring v. Chesapeake Beach R. California v. Pacific R. Co. (127 U. Co. (193 U. S. 442,48 L. Ed. 742),

Bogardus v. Insurance Co. (101 N. 1. $326,24$.

Booth r. Daris (127 Fed. Rep. S75), 357.

Bonsack Machine Co. v. Smitli ( 70 Fed. Rep. :3st), 371.

Block r. Standard Dist. Co. $(95$ Fed. Rep. 478), 363.

Lowman v. Railway Co. (125 U. S. 465.31 L. E(l. $\div 00), 25,45,50$, 51.

Boyer $r$. Western Union Telegraph Company (124 Fed. Rep. 246), 113.

Brass v. North Daliota (153 U. S. $341,3 \mathrm{~s} \mathrm{L.} \mathrm{Ed.} 757$ ), 53.

Brennan $v$. Titusrille (153 U. S. 24.9. 3S L. Ed. 719), 28.

Brewer v. Central R. Co. of Georgia (34 Fed. Rep. 256), 216.

Briggs v. C., N. \& Wi. R. Co. (125 Fe(l. Rep. 745$), 382$.

Briges v. Railway Co. $(109$ N. C. $279), 382$.

Brimmer v. Rebman (13S U. S. 7S, 31 L. Ed. 862$), 40$.

Brimson v. Interstate Commerce Commission (15t C. S. 4ti, $3 \mathrm{~S}$ L. Eil. 1047, 54 Fed. Rep. 476), it, 310.

Brown v. Houston (114 U. S. 622, 29) L. E(. 257), 25.

Brown v. Maryland (12 Wheaton, 419,6 L. E(1. 175), 25, 26, 25, i6.

Brown v. Spillman (155 U. S. 665, ;y L. E(l. :304), 19.

Brown r. Walker (161 U. S. 591, 40 L. Erl. 819), 307.

Burld $r$. New York (143 U. S. 517, 3) L. E(. 247), 59.

Burlick v. lllinois (149 Ill, 600), 14.

Burlington C. R. \& N. R. Co. v. Dey (8) Jowa, 31:), 65, 160.

Burlineton $\mathrm{C}$. R. \& $\mathrm{N}$. R. Co. v. corthwestern Fuel Co. (21 Fed. Piep. 652 ), 186 .

Burrell v. Montana $(194$ U. S. $5 \% 2$, t8 L. E(l. 11\%2), 309.

Butchers' \& Drovers' Stocliyards v. L. \& N. R. Co. $(1+$ C. C. A. 290,31 L. S. App. 252, tir Foul liep. 15.0. 2019, 29.4. 214, 258.

I3uffeld v. Stranahan (192 U. S 471,48 I. E(l. 525), 72.

Caldwell v. North Carolina (187 I. S. 6;2, 17 L. E(l. 326), 28.

S. 1,32 L. Ed. 150$), 66,81$.

Callan v. Wilson (127 U. S. 540 , 32 L. Ed. 2:3), 111.

Canal v. Loclies Co. (6 Oregon, $219),-$.

Capital City Dairy Co. v. Ohio (1S? U. S. 2:38, 46 L. Ed. 171), 16.

Carew v. Rutherford (106 Mass. 1), 115.

Cardwell v. American Bridge Co. (113 U. S. 205,28 L. Ed. 959 ), 34.

Case of Monopolies (11 Colie Rep. S4b), 9!, 101.

Central Stockyards Co. v. L. \& N. R. Co. $(192$ U. S. 568,49 L. Ed. 565,55 C. C. A. 63,112 Fed. Rep. S23, 118 Fed. Rep. 113), 155, 253. $25 \%, 258,288$.

Casey v. Central Typo Union (4j Fed. Rep. 185), 115.

Central Union Tel. Co. v. State (11s Ind. 194), 12.

Central of Georgia R. R. Co. v. Hurphy (25 Sup. Ct. Rep. 218), 44.

Charge to Grand Jiry (6: Fed. Rep. S.4, S28, s:4, 66 Fed. Rep. 146, 115 Fed. Rer. 588), 107, 111, 119. $206,298,258,360$.

Charles v. Missouri Pacific Ry. Co. 168 Mo. 652, 58.

Chattanooga Rate Case (181 U. S. 1. 45 1. Fir. 719$), 241$.

Cheroliee Nation v. Georgia (5 Peters, 1, \& L. Ed. 25), 5.

Chesapealie \& O. R. Co. v. Kentucliy (179 U. S. $38 s, 45$ L. Ed. 244), 37.

Chicago, Burlington \& Q. R. Co. V. B. C. R. \& N. Co. $(34$ Fed. Rep. $481), 297$.

C. C. C. \& I. R. Co. v. Closser (126 Ind. 345,9 L. R. A. 754), $1 S 6$.

C. C. \& A. R. Co. v. Gebbes (142 C. S. 386,35 L. Ed. 1051), 130.

Chirago \& Grand Trunk R. Co. Wellman ( 143 U. S. 339,36 L. Ed. $17(i), 1: 34$.

Chicago, etc. R. Co. v. Minnesota (1:31 U. S. 118,39 L. Ed. 970), 122,134 .

Chicago, etc. R. Co. v. Suffern (129, lil. 274), $189,239$.

Chicago, etc. R. Co. v. Solan (169 U. S. 133,42 L. E(l. 685$), 35,39$, 43.

Chirago, etc. R. Co. v. Jones (149 I11. :361), fis.

Chicago, M. \& St. P. R. Co. v. Becker (3) Ferl. Pep. 849), 150. 
References are to pages.

Chicago, M. \& St. P. R. Co. v. Becliel ( 35 Fed. Rep. S\$3), 131.

Chicago, M. \& St. P. R. Co. v. Tomplins $(176$ U. S. 167, 44 L. Ed. 417, 110 Fed. Rep. 473), 132, 133, 134, 190.

Chicago, MI. \& St. P. R. Co. v. Voelker (129 Fed. Rep. 522, 116 Fed. Rep. 867), 381, 382.

Chicago, M. \& St. P. R. Co. v. Wallace $(66$ Fed. Rep. 506,14 C. C. A. 257,30 I. R. A. 261), 195.

Chicago \& N. W. R. Co. v. Dey 135 Fed. Rep. S66), 129.

Chinese Exclusion Acts $(130$ U. S. 5\$1. 32 L. Fd. 106\$, 149 U. S. 698, 37 L. Ed. 905), S.

Cherokee Nation v. Kansas Ry. Co. (135 U. S. 641, 34 L. Ed. 295), 5.

Chy Lung v. Freeman (92 U. S. 275,23 L. Ed. 550), 15.

Cincinnati Freight Bureau Case 167 U. S. 479,42 L. E(l. 243), 162.

Cincinnati, N. O. \& T. P. vs. Commission (162 U. S. 184,40 L. Ed. $935), 147,148,329$.

Claflin v. Houseman (93 U. S. 130 , 23 L. Ed. 839$), 56$.

Cleveland, C., C. \& St. L. R. Co. v. Backus ( 154 U. S. 439 , is L. Ed. 1041), 29.

Cleveland, C., C. \& St. L. R. Co. v. Jilinois (177 U. S. 514, 44 L. Ed. 868), 38.

Clune v. United States (159 U. S. $590,40$ L. Ed. 69$), 111,112$.

Coe v. Errol (116 U. S. 517,29 L. Ed. 715), 26, 158.

Coem $d^{*}$ Alene C. Mfo. Co. v. Miners' Union (51 Fed. Rep. 260), 106.

Cohens r. Virginia (6) Wheaton. 264,5 L. Ed. 257 ), 87.

Collins v. New Hampshire (147 U. S. 31,43 L. E(l. 60), 16.

Columbia Wire Co. v. Freeman Wire Co. (71 Fed. Rep. 302), 370.

Commonwealth v. Carter (96 Va. 791), 124.

Commonwealth v. Hunt (4 Metcalf, 111), 111 .

Commonwea!th v. Railway Co. (Ky., 40 S. W. Rep). 5201). 48.

Commonwealth v. Wilson (14 Phila. $354), 4 S$.

Connery V. Q. O. \& K. C. R. Co. 91 Minn.—, 64 L. R. A. 625), 46.

Connolly v. Union Sewer Pipe Co. (194 U. S. 540,46 L. Ed. 679), 141,370 .
Consolidated Steel \& IV. Co. v. Murray ( 80 Fed. Rep. S11), 106.

Conway v. Taylor's Executors (1 Black, 603, 17 L. Ed. 191), 67.

Connol v. V. \& M. R. Co. $(36$ Fed. Rep. 273), 287.

Cook v. Railway Co. ( S1 Iowa. 5.51, 9 L. R. A. 764$), 160,189,286$.

Cook v. County of Marshall (190.) -Sup. Ct. Rep. -), 25, 26, 143.

Cooley v. Board of TVarlens 112 Howal', 299, 13 L. Ed. 996), 32, 33.

Copp r. I. \& N. R. Co. $(50$ Fed. Rep. $164), 58,285$.

Cotting r. Kansas City Stockyards Co. et al. 1153 U. S. 79,46 L. Erl. $92), 148,165$.

Council Blufis v. Railway Co. ( 45 lowa, $3: 38), 47$.

Conncilman v. Hitcheocli (142 U. S. 547,35 L. Ea. 1110,44 Fed. Rep. 271), 305 .

County of Mobile v. Kimball (10? L. S. 691, 26 L. Erl. 2381, 34.

Covington, etc. Bridge Co. v. Kentucky (154 U. S. 204, is L. Ed. $962), 11,33,43,66$.

Covington \& Lexingion Turnpilie. Co. v. Sandford $(164$ U. S. 578,41 L. Ed. 560), 132, 163.

Covington Stockyards Co. v. Keith (1:39 U. S. 128,35 L. Ed. 73), 155. 258.

Cowden v. Pacific Coast S. S. Co. (94 Cal. 470, 1S L. R. A. 221), 185.

Cowen v. Bond (39 Fed Rep. 59), 203.

Crawiord $r$. Railroad Co. (10 Am. Neg. Repts. 166), 381.

Crossman v. Lurman (192 U. S. 189, ts L. Ed. 101), 11 .

Crutcher r. Kentucky (141 U. S. 47, 35 L. Ed. 649), 22, $\$ 6$.

Clump v. Commonwealth (\$4 Va. $927,114$.

Crandall v. Nevada (6 Wall. 35, is L. Ed. 745), 30.

Davis v. United States (104 Fed. Rep. 136,43 C. C. A. 448), 299.

Decker v. Railroad Co. (30 Fer. Rep. 723), 81.

Delaware, The (161 U. S. 471, 40 L. Ed. 776$), 39$.

Delaware L. \& IV. R. Co. V. Frank et al. (110 Fed. Rep. 689), 270.

Denaby Main Colliery Co. v. MF. S. \& L. R. Co. (6 Ry. \& Canal Cas. 141), $1 S 1$. 
Referpmes are to pages.

Denver \& Rio Grande R. Co. v. 'Farmers' Loan \& Trust Co. v. Arrighi (12:9 Fell. Rep. 347), 391.

Diamond Glue Co. $r$. United States Glue Co. (113 Fed. Rep. A:3 1. 13.

Dooley $v$. Lnited States (1s: L. S. 151,46 l. Ea. 128, 6.

Doremus $r$. Hennesey $\left(\begin{array}{lll}176 & 11 !\end{array}\right.$ (i心). 115.

Dow r. Bitelman (125 T. S. 680. 31 L. E(l. $\$ 41) .1: 38$.

Dueher Watch \& Mfg. Co. v. How ard Wateh \& C. Co. $(55$ Fed. Rep. 51. 6h Fed. Rel. fit), 35 .

Duncan v. Naine Central R. Co. 111: Fed. Rep. rits). 206 .

East Temn. ete. R. Co. $v$. Commis sion is I C. S. 1. 1. e. 27.45 L. Ed 719, 729, 39 C. C. A. 419, 99 Ferl. Rep. 52), 215, 262, 320.

Easton v. lowa (18s U. S. 220, tT L. E(l. 452) s. 4.

Edison E. L. Co. V. Sawyer M. Elec. Co. (3 C. C. A. 695, $5:$ Fed. Rep). $592), 371$.

Eamunds v. Ill. Cent. R. Co. (s0) Fed. Rep. Ts), 5s, 286.

Elder $x$. Whiteside (72 Fed. Rep. 7:4), 106 .

Ellis r. Inman (124 Fed. Rep. 9561. 3.7.

Equitable Ass. Soc. v. Clements (140 [. S. 2206, :35 J. Ed. 497), 24.

Erb y. Morasch (17T C. S. ist, 44 L. E(1. 8:17), 36. 151.

Erie R. Co. r. Pennsylvania 1158 [. S. 43]. 39 L. Ell 144:3), 28.

Esranaba Co. r. Chicago (107 C. S. tiTs. 27 J. E(l. $142,21,34$.

Evershed $\checkmark$. London \& $N$. IV. R. Co. (L. R. :3 Q. B. D. 135, 1ns.

Ex parte benson (1S S. C. :3, 1S.

Ex larte Koehler (:31 Fed. Rep. :315, :311.

Ex larte Lemon refiti L. S. 548. 41 L. Erl. 11101, 12t.

Ex prarto Rolsinson cl9 Wallace, 5ns,

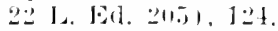

Express Company Casrs 1117 L. S. Gilman v. Philadelphia (:) Wall. 1. 2:! L. Ed $7: 11,11 \times$.

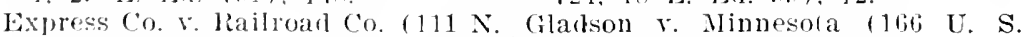
C. $46,93,4 ; 5$.

Fairlanks $v$. Cuited States as L. Gloncester Ferry Co. v. PennsylS. 28:; 45 l. Erl. size) $1: 3$.

Fanning re Gegorie it; Howard, 524, 14 1. Bil. 104:31. 1;.

Fargo $\because$ Hart (19:; T. S'. 490, 48 L. Ed. T61), 29 .

Faris v. Henderson (4 Olila. 384 ), 47.

Northern Pac. R. Co. ( 83 Fed. Rep. 249), 163.

Farmers', etc. National Bank v. Deering (91 U. S. 29, 23 L. El. $196)$. 81.

Field r. Barber Asphalt Co. (194 U. S. 618. is I.. Hel. 114\%1. 356 .

Field r. Clark (143 U. S. 649, 36 L. Ed. 291). 72.

Fitch v. Liringston $(6$ N. Y. Super. Ct. 4921,48 .

Fitchburg R. Co. v. Gage (12 Gray, 39:3), 189.

Foote r. Buchanan (113 FerI. Rep. $15(\%), 371$.

Foster y. C. C. \& I. P. Co. (56 Fed. liep. 4:34, $2: 31$.

Fowle v. Park (1:31 U. S. 88, 97, 33 L. E(l. 74), 160.

Fretz $v$. Bull (12 Howard, 466, 13 L. E(. 1068), 21.

Gardner v. Early (69 Iowa, 40), sos.

Garrison r. Tillinghast (1s Cal. $404), 47$.

Geel v. Connecticut (101 U. S. 519 , 411 L. Ed. 79:3, 18.

General Electric Co. v. Wise (119 Fed. Rep. 922), 370.

Genesee Chief, The (12 Howard, 443, 13 L. Ed. 1458), 21.

Georgia, etc. R. Co. $r$. Smith (70 Ga. 694$), 65$.

Gerber v. Wabash R. Co. (63 Mo. App. 145), 276.

Gibbes v. Consolidated Gas Co. (130 L. S. :897, 32 L. Ed. 979), 100.

Gubes $\mathrm{r}$. Ar Neeley (55 C. C. A. 70 . 118 Fed. Rei. 120, 107 Fed. Rep. 211, 102 Fe(l. Rep. 694). 96, 354, 369.

Giblons r. Ogden (9 Wheaton, 1, 6 L. Ed. 23). 9.

Gilbert r. Burlington, C. R. \& N. R. Co. (128 Fed. Rep. 529, 123 Fed. Rep s::2), :390.

Giman r. Philadelphia (.) Nan. 427,41 L. Ed. 1ont1, 38. rania 1114 U. S. 196,29 L. Ed. $158), 34,60$.

Grand Rapids \& Ind. R. Co. v. Osborne (19:' U. S. 17. is L. Ed. (is) 110.

Granger Cases (94 U. S. 113, 24 L. E(l. 77), 159 . 
References are to pages.

Great Western R. Co. v. Sutton (L. R. 4 H. I. 226, 238), 185, 189, 197. Green v. Henliel (1S3 U. S. 249, 46 L. Ed. 177), 300 .

Green V. Statler ( 77 Fed. Rep. 1$)$. Greenlee v. Sonthern Ry. Co. (122 S. C. 982.41 L. R. A. 99$), 380$.

Groves v. Slaughter (15 Peters, 449, 505, 10 L. Ed. S00. 821), 6 .

Gulf. Colo. \& S. F. R. Co. V. Heffley (158 U. S. $9 S, 39$ L. Ed. 910$), 86$ 274.

Gulf, Colo. \& S. F. R. Co. v. Miami S. S. Co. $(30$ C. C. A. 142,86 Fed. Rep. 407), 90, 254, 362.

Gulf, Colo. \& S. F. R. Co. v. Moore (Tex.-8.3 S. W. Rep. 362), 58.

Hague v. Wheeler (157 Pa. St. 324), 19.

Hall v. Decner $(95$ U. S. $485,24 \mathrm{~L}$. Ed. 547), $37,76$.

Iall v. Railroad Co. (25 S. C. 264), $4 S$.

Handy v. C. \& N. R. Co. (31 Fed. Rep. 683), 186.

Hanley $v$. Kansas City S. R. Co. 187 U. S. 617,47 L. Ed. 390$), 12$. 150 .

Harman v. Chicago (147 U. S. 396 , 37 L. Ed. 216), 34.

Harp v. Choctaw O. \& G. R. R. Co. (61 C. C. A. 405, 125 Fed. Rep. 445. $11 \mathrm{~s}$ Fed. Rep. 109), 232, 239.

Hayes v. Pennsylania Co. (12 Fed. Rep. 309), 187.

Head Money Cases (112 U. S. 580 , 28 L. Ed. 798$), 80$.

Helms $r$. Mortgage Co. $(92$ Ala. 157), 13.

Henderson Bridge Co. v. Kentucky (166 U. S. 150,11 L. Ed. 958), $12,29$.

Henderson Bridge Co. v. Henderson (173 U. S. 592, 43 L. Ed. 893 ), 12.

Henderson v. Mayor $(92$ U. S. 1. c. 273,23 L. Ed. 556), 32.

Henderson v. New York (92 U. S. 259, 23 L. Ed. 543), 15.

Hennington v. Georgia (163 U. S. 299, 41 L. Ed. 166), 36, 52.

Higgins v. Casks of Lime (180 Mlass. 1$), 47$.

Hilton Lumber Co. v. Railroad Co. ( N. C. -60 C. L. J. 301), $18 s$.

Hitcheock v. Counselman $(142 \mathrm{U}$. S. 457,35 L. Ed. 1110), 292.

Hagan v. Blendell (6 C. C. A. 86 , 56 Ferl. Rep. 696, 54 Fed. Rep. $40), 363$.
Hooper v. California (155 U. S. 647, 39 L. Ed. 297 ), 14.

Hoover v. Pennsylvania (156 Pa. St. 220.28 L. R. A. 23), 187.

Hoplins v. Oxley Stave Co. (28 C. (. A. 99, 83 Fed. Rep. 99), 106, 114.

Hopkins v. Tnited States (171 U. S. 578 . 1. c. 593,43 L. Ed. 290 , $296), 92,1118,298,355$.

Houston \& Texas C. P. Co. v. Mlayes (s3 S. WV. Rep. $531,48$.

Hovey r. MeDonald (109 U. S. 161, 27 L. E(l. 891), 332.

Huse v. Glover (119 U. S. 543, 30 L. Ed. 487), 34 .

Illinois Cen. R. Co. v. lllinois (163 T. S. 142, 41 L. Ed. 107), 38.

Ilwaco v. Or. Ry. \& Nar. Co. $16 \mathrm{C}$. C. A. 495, 57 Fed. Rep. (378), 254.

Import Rate Case (162 U. S. 197, 40 L. EAl. 940, 6 C. C. A. 653,52 Fed. Rep. 185), 69, 151, 212, 262.

Import Tax Cases 1158 U. S. 601, 39 L. E(. 1108), 190.

Income Tax Cases (158 U. S. 601, 3! L. Ea. 108). so.

Independent Refiners' Ass'n v. Railroad Co. ( 82 Fed. Re1), S4, 192), 221.

Indiana Consumers' \& T. R. Co. v. Horlass (1:31 lnd. 446), 19.

Ingraham r. National Salt Co. (130 Fed. Rep. 676, 120 Fed. Rep. 40), 370 .

In re Bessette (111 Fed. Rep. 417), 112. 120.

In re Davenport (102 Fed. Rep. $540), 18$.

In re Corning (51 Fed. Rep. 205), $356,859$.

In re Christensen Engineering Co. (194 U. S. 458,48 L. Ea. 1072), 126.

in re Debs ( 158 U. S. 564,29 L. Ea. 1092, 64 Fed. Rep. 724), 4, 8, 90, $107,111,112,120,122,124,128$. $290,357,358$.

In re Deininger (10s Fed. Rep. $623), 18$.

ln re Doolittle ( 23 Fed. Rep. 54t), 124.

In re Garnett (141 U. S. 1, $85 \mathrm{~L}$. E(1. 631), 21, 22.

In re Grice (79 Fed. Rep. 627), 141, 142.

In le Green (52 Fed. Rep. 104), 98 , $356,359$.

In re Higgins (27 Fed. Rep. 443), 124 . 
References are to pages.

In re Horhorst $(150$ U. S. 653, 37 L. Ed. 1211), 257 .

In re Jackison (9ti U. S. 727$)$, $7 \mathrm{~s}$.

In re lenuon ( $166 t^{U}$ U. S. 548,41 L. E(l. 1110), 57, 118, 122, 2S7, 291.

ln re Vevitt 155 C. C. A. 622, 117 Fed. Rep. 44s), 126.

In re l'easley (4t Ferl. Rep. 271), $301 \%$.

In ro Nagle (185 U. S. 1, 34 L. Ed. ii) $s$

In re I'enn Tel. Co. (48 N. J. Eq. $191+1: 2$

In re Reese (9S Fed. Rep. 9S4, 47 C. C. A. ST, 107 Fed. Rep. 942), 122. 124i.

Insurame Co. v. Stathan (93 U. S. $21), 24$

In re Rahrer (140) U. S. $545,35 \mathrm{~L}$. Ed. $5721,27,70$.

In re Rapier (143 U. S. $110,36 \mathrm{~L}$. Ed. 93), 79.

In re Robiuson (19 Wallace, 505, 22 L. Ed. 205) . 124.

In re Savin (131 U. S. 267,33 L. E(I. 150$), 12.1$.

In re Tyrrell (51 Fed. Rep. 213), $351 \%$

In re Wiswall (74 Fed. Rep. \$02), 370.

In re Wung Yung Quy (6 Sawyer, 412) 15.

Interstate Commerce Commission

v. Alabama Mid. Ry. Co. (16is C. S. 144, 42 L. Ed. 414), $262,263,330$.

v. Atchison, 'T. \& S. F. R. Co. (149 U. S. 264,37 L. Ed. 727) 831

v. Atlantic R. Co. $(35$ C. C. A. 217, 93 Fed. Rep. 8:3), 216.

v. Bairl (194 U. S. 25, 48 L. Ed. (6, 01$), 74,311,375$.

v. Baltimore \& O. R. Co. (4:3 Ferk. Rep. 47), 61.

v. Baltimore \& O. R. Co. (145 U. S. $26 \%, 1$, c. 276,36 L. El. 1,94, 709) 192.

v. Brllaire C. \& Z. R. Co. (17 Ferl. Rep. 942, 147.

v. Brimson (154 U. S. 447, 38 L. Erl. 1047, 155 U. S. 1, :9 L. Er. 49, 53 Fed. Rep. $47(;), 74$.

v. B. Z. \& C. R. Co. $(77$ Fed. Rep. 942), 3.3.

v. Chesapealie v. Ohio R. Co., (128 Ferl. Rep. 59), 201, $202,234$.
Interstate Commerce Commission v. Chicago, B. \& Q. R. Co. (94 Fed. Rep. 272), 330.

v. Chicago, B. \& Q. R. Co. (186 U. S. 320,46 L. Ed. 1182 . 43 C. C. A. 209, 103 Ferl. Rep. 249), 155.

v. Cincinnati, N. O. \& T. P. R. Co. $(167$ U. S. $479,494,42$ L. Ed. 243, 251), 77.

v. Cincinnati P. \& V. R. Co. (124 Fed. Rep. 624), 217.

v. Delaware, L. \& W. R. Co. (64 Fed. Rep. 723), 171, 330.

v. Detroit, G. H. \& M. R. Co. $(167$ U. S. 633,42 L. Ed. 306,21 C. C. A. 103,74 Fed. Rep. 803), 154, 195.

v. Lalie Shore R. Co. et al. (unreported January, 1905), 252.

v. Lehigh V. R. Co. (49 Fed. Rep. 177), 391.

v. Lehigh V. R. Co. $(74$ Fed. Rep. 784), 171.

$\mathrm{v}$. Louisville \& N. R. Co. $(78$ Ferl. Rep. 409), 216.

v. Louisville \& N. R. Co. (101 Fell. Rep. 146), 331.

v. Louisville \& N. R. Co. $(190$ U. S. 273,47 L. Ed. 1047, 112 Fed. Rep. 9S), 220, 221, 262.

v. Louisville \& N. R. Co. (102 Fed. Rep. 709), 330.

v. Louisville \& N. R. Co. 190 U. S. 273.47 L. Ed. 1047. (46 C. C. A. 685, 108 Fed. Rep. $9 S 8), 217$.

v. Louisville \& N. R. Co. (118 Fed. Rep. 613), 17 (\%.

v. N. C. \& St. L. R. Co. $(120$ Fed. Rep. 934), 170

v. Seaboard R. Co. (82 Fed. Rep. 563), 387.

v. Southern Pac. R. Co. (117 Fell. Rep. 741), $170,220$.

v. Southern Pac. R. Co. (74 Fed. Rep. 42), 328.

v. Southern Pac. R. Co. (12? Fed. Rep. 597, 132 Fed. Rep. 829), 241, 267, 328, $329,330$.

v. Texas \& Pacific R. Co. (167 U. S. 197, 40 L. Ed, 52 Fed. Rep. 187, 6 C. C. 940, A. $653), 186,218$

v. Western Atl. R. Co. (sS Fed. Rep. 186), 217. 
Refirences are to pages.

Interstate Commerce Commission v. IV. N. Y. \& P. R. Co. (182 Fed. Rep. $1921,151,329,337,338$.

Interstate Stockyards Co. v. Indianapolis U. R. Co. (99 Fed. Rep. $473), 240,256,258,288$.

James v. Union Paeific R. Co. (62 Fed. Rep. 714), 298.

Jamison v. Indiana Gas \& Fuel Co. (128 Ind. 555,12 L. R. A. 652), 19.

Jefferson, The Thomas (10 Wheaton, 428, 6 L. Ecl. 35S), 20.

Johnson v. Pensacola, etc. Co. (16 Fla. 628), 155.

Johnson v. Southern Pae. R. Co. (117 Fed. Rep. 462,54 C. C. A. $508), 383,384$.

Joint Traffic Assoeiation Case (171 U. S. 505,43 L. Ed. 259), 91, 92, $94,104,351$.

Joy v. St. Lonis (13S U. S. 1, $34 \mathrm{~L}$. Ed. 843), 127.

Junod v. C. \& WI. R. Co. (47 Fed. Rep. 290), 285, 293.

Kelley r. Fhodes (1S8 U. S. 1, 47 L. Ed. 359 ), 26 .

Kentucky Railroad Tax Cases (115 U. S. 321, 29 L. Ed. 414), 29.

Kentucky \& Indiana Bridge Co. r. L. \& N. R. Co. ( 37 Fed. Rep. 587, $638), 51,153,253,289,219,3: 31$.

Fidd v. Pierson $112 \mathrm{~S}$ U. S. $1,32 \mathrm{~L}$. E(l. 346), 13, 82.

Kimmish v. Ball (129 U. S. 217. 32 L. Ed. 695), 40 .

Finnavey $v$. Terminal Association ( 81 Fed. Rep. so2), 55, 161. 209.

Kinsey v. Buffalo, N. Y. \& P. F. Co. $\left(37^{\circ}\right.$ Fed. Rep. 181), 187.

Kirkpatrick v. Pope Mig. Co. (61 Fed. Rep. 46). 307.

Knowlton v. Noore (17s U. S. 41, 44 L. Ed. 969), so.

Fnox v. Harshman (132 U. S. 14 , 33 L. Ed. 249), 332.

Inudson v. Benn (123 Fed. Rep. 686) 116,117

Kohl v. United States (91 U. S. 367 , 23 L. Ed. 449), S.

La Fariel v. Railway Co. ( 84 Mle. $28(6), 47$.

Lalie Shore \& M. S. R. Co. v. Smith 173 U. S. 684,43 L. Ed. 858$), 138$, 342.

Landa v. Holck (129 Mo. 6is3). 46.

L. \& Y. R. Co. v. Greenwood (Law Rep. 21 Q. B. Div. 217, 218), 181, 212.
Lanrel Cotton Mills v. Gulf etc. R. Co. (37 So. Rep. 134), 204, 206, 276.

Legal Tender Cases (110 U. S. 42, 28 L. Ed. 64), 7, 8 .

Lehigh Valley Railroad Co. v. Dupont (128 Fed. Rep. St0), 170.

Lehigh V. R. Co. v. Pemnsylvania $(145$ U. S. 192,36 L. Ed. 672), 150 .

Lehigh V. R. Co. v. Rainey (112 Fed. Rep. 407), 2S5.

Leisy v. Hardin (1:5 U. S. 100, 34 L. Ed. 128), 25, $: 23$.

Leloup $v$. Port of Nobile (127 U. s. 640,32 L. Ed. 311$), 4$.

Leonard $v$. Land Co. (115 U. S. 468,29 L. Ed. 445), 332.

License Cases (5 Howard, 504, 12 L. E(t. 256$), 25.31,32$.

Little Rock \& N. R. Co. $\vee$ E. Tenn. fli. R. Co. (47 Fedl. Rey. T71, 1.:4 (I. S. 698,40 L. El. 311), 2\$s, 331.

Little Rock \& N. R. Co. v. St. L., lion Mit. \& S. R. Co. $(41$ Feit. Rep. 559, 59 Fed. Rep. 4001, 258, 254.

Little Rock \& N. R. Co. v. St. L. \& S. 17. R. Co. $(11$ C. C. A. $416,5 i$ Fed Rep. 775), 251.

Little Rock \& St. L. R. Co. v. Oppenheimer (64 Arli. 471, 44 L. R. A. 353), 233.

Livingston $v$. Van Ingle (9 Johns. $5(17), 9$.

Logan Y. Penn. K. Co. (152 Pa. 403), 398.

Lombard v. West Chicago Park Commes (181 U. S. 38,45 L. Ed. 731), 171.

Lottery Cases (18s U. S. 321, 47 L. E(l. 492$), 12$.

Lomisville \& Nashville R. R. Co. r. Drown (123 Ferl. Rep. 94i), 171.

Lomisville \& Nasluville R. Co. v. Behlmer (169 U.S. (44. I2 L. E!. $889), 331,332$

Louistille \& Nashville R. Co. v. Commonwealth (51 S. IV. Pep). 167), 809 .

Louisville \& Nashville R. Co. V. Eubank (1St U. S. 2- 4 , ti L. Ed. 416), 130.

Louisville \& Nashrille R. Co. v. Kentucliy (183 U. S. $508,40 \mathrm{~L}$. Ed. 298,161 U. S. tiт t0 L. Ed. S.19), 130. 139 . 
References are to pages.

Lonisville \& Nashrille R. Co. v. Messenger v. Pennsylvania Co. (37 Mississippi (133 L'. S. 587, 33 L. N. J. L. 407), 189. E(l. TSt), 37 .

Louisville \& Nashrille Consolidated R. Co. v. Wilson (13: lnd. $51 \%, 1 \mathrm{~s}$ L. R. A. 105), 1ST, 209.

Lowe v. Railroal Co. (63 S. C. 24 S), 47 .

Lowenstein v. Erans (69 Fed. Rep. (4) , :34.

Lowry v. C., B. \& Q. R. Co. $(46$ Fed. Rej s.3., 25.

Luclie $v$. Clothing Cutters' \& Trim. mers Assembly (77 . Md. 396), 115.

Lumlquist $r$. Grand Trunk R. Co. (121 Fed. Rep. 915). 197.

Luxton $r$ North River Bridge Co. (153 U. S. 525, 88 L. Ed. 808), titi. $s 1$

IICCall v. California ( 136 U. S. 134 (1s!!(3), 34 L. E(l. 391$)$, 30.

IIchord r. L. \& $\therefore$. R, Co. (183 U. S. 483,46 L. Ed. 289$), 64$.

JuCrealy virginia (94 U. S. 391, 24 L. Ed. 248), 18.

Ml.Culloch $r$ Maryland ( 4 Wheat. 316,4 l. Ed. 579), 7, 8, 9, 28.

McGrew v. Missomri Pac. R. Co. (114 N1o. 210), 160.

Maclin v. Cnited States (117 U. S. :its, 29 L. Ed. $9 y 9), 111$.

II. S. \& L. R. Co. v. Denaby Main Colliery Co. ( 4 Ry. \& C. Tr. Cases, 4521 . Is 1

Maenolia. The $(29$ How. $296,15 \mathrm{~L}$. E(l. 9119$), 21$.

Maine v. Grand Trink R. Co. (142 C. S. 217,85 L. Ed. 994), 29.

Maliall r. Latchiford ( $8:$ Ferl. Rep. 41). 1166 .

Manarlio $\therefore$ Warl (27 Fed. Rep. $5291,185$.

Munclirstor v. Massachusetts (139 C. S. 211. 8. L. Ed. 159), 18 .

Manufarturers" (Gas Co. v. Indiana Nat. G. de I. Co. (155 Ind. 545), 19.

Nartin $r$ Solithwark (191 U. S. 1 , is L. E I. fi.) , 156 .

Marye $v$ Ballimore \& Olio R. Co.

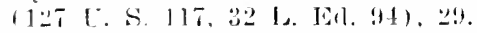

Massarhusfits v. Telegraph Co. (14I E. S. 40, 35 L. E(1. 628), 29 .

Maximnm Rate Case (1tit U. S. 1 , 4: L. E(1. 251), 128, 159, $16 \%$.

May $\checkmark$. New Orleans (17s U. S. 496 , 4t L. 106. 1165$), 26$.

H.rehants' Cotton Comp. Co. v. Insuranre Co. (151 U. S. 368, 38 1. (il. 195), 219.
Iletropolitan Trust Co. v. Railroad Co. et al. (90 Fed. Rep. 683), 136, 165.

Michigan Central R. Co. v. C., M. \& L. S. R. Co. (1 IlI. App. 399), 46.

Michigan Insurance Bank $\mathrm{V}$ Eldred $(130$ U. S. 69:3, 32 L. Ed. $1080), 255$.

Miller v. The Mayor (109 U. S. 385. 27 L. Ed. 971), 21.

Minneapolis \& St. L. R. Co. v. Minnesota $(186$ U. S. 257,46 L. Ed. 1151 ), 134. 139.

Minneapolis \& St. L. R. Co. v. Minnesota (193 U. S. 53, 48 L. El. (614), 140 .

Minnesota v. Barber (136 U. S. 313, it L. E(l. 455), 17, 40.

Mimnesota r. Northern Securities Co. (194 U. S. 48 , ts L. Ed. 870 , 123 Fed. Rep. 692), 363.

Minnesota Rate Case (186 U. S. 257, 46 L. Ed. 1151), 58, 16t, 166 .

Missouri, Kan. \& Tex. R. Co. v. Haber (169 U. S. 613, 42 L. Ed. $878), 41,52$.

Missouri, Kan, \& Tex. R. Co. v. Nay (194 U. S. 267 , tS L. Ed. $971), 143$.

Missouri Pac. R. Co. v. Nebraslia (164 U. S. 408,41 L. Ed. 489), $238,230$.

Mlissouri Pac. R. Co. v. United States ( 189 U. S. 274,47 L. Ed. 811, 65 Fed. Rep. 903), 290, 375.

Missouri lac. R. Co. v. Texas Pac. R. Co. (31 Fed. Rep. S62), 317.

Mobile \& Ohio R. Co. v. Dismukes (94 Ala. 131,17 L. R. A. 113 ), 276.

Mognl Steamship Co. v. McGregor (App. Cases, Part 1, p. 25, 23 Q. B. Div. 598), 90, 98.

Montaglio v. Lowry (193 U. S. 88. 18 L. Ed. 608, 115 Fed. Rep. 25, 75. 106 Fed. Rep. 38), 92, 96, 352, 367.

Montello, The (20 Wall. 430, $22 \mathrm{~L}$. E(l. 891), 21.

Moores v. Mricklayers' Union (23 Weekly L. Bul. 48), 114.

Morgan v. Louisiana (118 U. S. 455 , 30 L. Erl. 237), 41, 633.

Mormon Church v. United States (1:3; U. S. 1, 34 L. Ell. 481 ), 14S, 361.

1lugler v. Kansas (123 U. S. 623, 31 L. E(l. 205), 17. 
Ruferences are to pages.

Munn v. Illinois (94 U. S. 113,24 L. Ed. 77), 52.

Murray v. C. \& N. IV. R. Co. (62 Fed. Rep. 24, 43, 35 C. C. A. 62, 92 Fed. Rep. 868$), 55,56,58,209$, $286,287$.

Murray v. G. \& S. W. R. Co. (4 Ry. \& C. Tr. Cases, 460), 181.

Nashville, etc. R. Co. v. Alabama (128 U. S. 96,32 L. Ed. 352 ), 36.

Nathan v. Lonisiana (s How. 73, 12 L. Ed. 992), 13.

Narramore v. Railroad Co. (96 Fed. Rep. 298), 390.

National Folder Box Co. v. Robertson et al. (99 Fed. Rep. 985), 371.

National Harrow Co. v. Quicti $(67$ Fe(i. Rep. 180), 3ī.

Nebraska Rate Case (169 U. S. 550 ), 318.

New England R. Co. v. Conroy (175 U. S. 323,44 L. Ed. 181), 380.

Newgold v. Am. Elee. \& Nav. Co. (10) Fed. Rep. 341), 307.

New York v. Miln (11 Pet. 102, 9 L. Ed. 64S , $31,32$.

New York Life Ins. Co. v. Cravens (17s U. S. 389, t4 L. Eil. 1116), $15,24$.

New York, etc. R. Co. v. New York (16.5 U. S. 628, 41 L. Ed. 853$)$, 20.

New York \& $\therefore$. R. Co. v. N. Y. \& N. E. R. Co. (50 Fed. Rep. 867), 254.

Niagara Fire lus. Co. $\vee$. Cornell (110 Fed. Rep. 816), 142.

Nicholson v. G. W. R. Co. $(4$ C. B. (N. S.) 366 ), 187, 194.

Nicol v. Ames 1173 U. S. 509,43 L. Ed. 786$), 80$.

Northern Pac. R. Co. Y. Tynan (56 C. C. A. 192, 119 Fed. Rep. 2ss), $391,391$.

Norther'n Penn. R. Co. v. Commelcial Nat. Bank of Chicago (123 U. S. 727,31 L. E(1. 287), 155.

N. \& IV. R. Co. v. Sims $(191$ U. S. 41, 48 L. Ed. 254), 28.

Nortlern Par. R. Co. v. Arlams (192 U. S. 440,48 L. Edl. 742$), 206$.

Oates v. National Bank (100 U. S. 239, 25 L. Ed. 5811$), 55$.

Ohio Coal Co. v. Whitcomb (123 Fed. Rep. 359), 208.

Ohio Oil Co. v. Indiana (177 U. S. 190,44 L. Ed. 729). 19.

Old Dominion Steamsilip Co. v. MeKenna (30 Fed. Rep. 49), 115.

Oliver v. Gilmore (52 Fed. Rep. $563), 100$.
Opinion of Justices (14 Gray, 615), 9.

Ordway v. Central Nat. Bank (47 11(2. 245), 58.

Oregon Short Line \& U. N. R. Co. v. Northem Pac. R. Co. $(9$ C. C. A. $469), 243,253$.

Orient Ins. Co. v. Daggs (172 U. S. 557. 43 L. Ed. 5521, 24.

Osborne v. Railroad Co. (3 C. C. A. 347,52 Fed. Rep. 912), 263.

Otis Steel Co. v. Local Union No. 18 (110 Fed. Rep. 698), 106.

Oxtale v. N. E. R. Co. (1 Nev. \& MeN. Ry. Cases, 73), 249.

Oxlaid v. Northeastern R. Co. (15 Com. Bench (N. S.), 680), 233.

Pacific Railroad Remoral Cases (115 U. S. 2, 29 L. Ed. 319$), 81$.

Packet Co. v. Aiken (121 U. S. 444, 30 L. Ed. 976$), 34$.

Parsons, The Robert $W$. (191 U. S. 17. 48 L. E(. 7i), 22.

Parsons v. C. \& N. W. R. Co. (167 U. S. 447,42 L. Ed. 231,11 C. C. A. 489, 6:3 Fed. Rep. 903), 22, 284.

Party Rate Cases 1145 U. S. 263, 275,36 L. Ed. 703), 184, 18s, 192, 19-. 21:, 21t, 340.

Passaic Print Goods Co. v. Ely Walker Dry Goods Co., is.

Passenger Cases (7 How. 283, 12 L. E(1. 702), 10, 30, 31, 32.

Patapsco Guano Co. v. North Carolina Board of Agr. (171 U. S. 345 , 43 L. E(3. 191), 17.

Paul v. Virsinia (S Wall. 168, 19 L. Ed. 357$), 14$.

Peik v. Railroad Co. (9+ U. S. 164, 24 L. Ed. 57), 52, 59.

Pennsylvania $v$ Wheeling, ete. Bridge Co. (1s How. 421, $15 \mathrm{~L}$. Ed. 435$), 65$.

Pemnsylvania R. Co. v. Hughes $(191$ U. S. 477,48 L. Ed. 268$), 38$. $43,78$.

Pennsylvania R. Co. v. Jones (155 U. S. 333,39 L. Ed. 176$), 170$.

Pensacola Tel. Co. v. W. U. Tel. Co. $(96$ U. S. 1, 12, 24 L. Ed. 708, 711), 11, 12, 33, 34, 68.

People v. Butler Street Foundry $(201111.236), 308$.

v. Coler $(166$ N. Y. 144$), 48$.

v. Cook (148 U. S. $397,37 \mathrm{~L}$. Ed. 498$), 140$.

v. Coombs (158 N. Y. 582), 309.

v. Hawkens (157 N. Y. 1), 47.

v. Jenkins (1 Hill (N. Y.) $469), 48$. 
Firferemess are to pages.

People r. Kelley (24 \. Y. 71). $30 \pi$. r. Shelilon (1:29 X. Y. 251$)$ 101.

Petibone r. Cnited States (148 U. S. 197.37 L. F(t. $\$ 191,110$.

Philadelphia Fire Assn. v. New York 1119 L. S. 111. 30 J. Ed. $34: 1.24$.

lhillips r. Iola l'. Cement Co. (125 Fril. Rep. 5!? 81 C. C. A. 191). ati. :3ti.

Pircock v. Harrington (64 Fed. Repr. $8211,830$.

Piersall $r$ Great Northeru R. Co. $(10.1$ T. S. (4ti. 40 I. E1]. S:S), $1: 3$.

Pitslutroh. etc. Coal Co. v. Bates

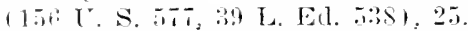

Pittsinugh. etc, R. Co. v. Backus (154 C. S. 421. :S L. Jit. 10:31), 29.

Plessy v. Ferouson (16i: U. S. 537. $41 \mathrm{I}$. E(k, 256i), :3.

Plumley v. Massachusetts (15.5 U. S. 4bi. 39 1. Ell. 229$), 16$.

Pondecker Lamber Co. v. Spencer $1: \because 1$ C. C. A. $4: 30$. sti Fed. Rep. slf. S1 Fed. Rep. 277$), 276$.

powell v. Vennsyrania (127 L. S.

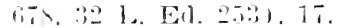

Prescott \& A. Con. H. Co. r. A. T. \& S. F. R. Co. (7: Fet. Rep. 43S). 251.

Pullman Palare Car Co. v. Pennsrlvania (141 L. S. 1S. 2,-) L. Ed. (i):3). 2.4 .

Ragan v. Alien (? Lea, fing). 185.

Railroad Co. v. Alabama (12,S T. S. sti, :?2 I. Frl. :32, $: 26$.

v. IBalior (::2) C. C. A. lits, 91 Fol. Rop. 22t1, 391.

y. Baush ( 149 1. S. Bis. :7 L. E(1. 772). 54.

v. rarien ITex. :It S. MV. Rep. $15,15$.

․ ?)wyer (75 Tex, 572). 19.

r. Ellis (16:- I. S. 1. H1 1. El. titit, 1:3. 14:.

․ Fullog (17 Vall. 56, 2] $\mathrm{L}$. Erl. 710, :3, 5id.

v. Forsatil ise ‥ 11. 122, 189.

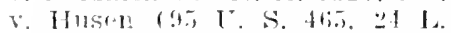
Er. 5271. 411.

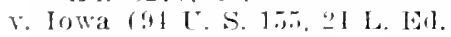
94, 52.

v. National Banli ( to2 [E. S. 11 ,

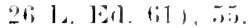

ง. Wolrott (1+1 Int. 26it), As.

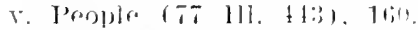

v. Pratt (2) Wall. 12:3, "2, L. Wil. $8: 7,2 .: \div$.

v. Rirhmond (19, Wall, 594, 22 1. Fi, 17:3, :I.
Railroad Commission Cases (116 I. S. 307,29 L. E(l. 636), 65, 128, 129.

Rasmussen v. Idaho (1S1 C. S. 198, 45 L. E(l. $82(1), 41$.

Ramsey v. Taroma Land Co. (196 T. S. :360) , :37:

Rattican v. Terminal R. R. Assn. (114 Fer?. Rep. 666) , 285.

Reagan y. Farmers' Loan \& T. Co. (154 U. S. $362,391,38$ L. Ed. 1014 , $1021), 129.121 .182,123.134$.

Reagan $\checkmark$. Norrantile Trust Co. (154 U. S. 413, 38 I. Ed. 1028), S3. 129 .

Regina v. Bauld (13 Cox. C. C. $252), 113$.

Reid v. Colorado (1ST L'. S. 1:7, 47 J. Erl. 1(is) 41, 72, $7 \mathrm{~s}$.

Rex $v$. Waddington (1 Fast, 167), 1112.

Rholes $r$ Iowa $(170$ L. S. 412, 42 L. El. 10SS), 26, 27, $71,115$.

Rice r. Standard Oil Co. (134 Fed. Rep. 16t). 259. 9:5?.

Richmond r. Southern Bell Tel. Co. $(174$ T.S. $7611,11.69$.

Richmond. ete. R. Co. r. Tohaceo ('o. $(169$ L. S. 311,42 I. Wil. 759$)$, :i). 44 .

Rindle v. N. Y. L. E. \& V. R. Co. (:89 Fed. Firl). 2901$)$. $29: i$

Roblins v. Shelby County Taxins District (:2010 L. S. $45 \%$, \$0 L. Ed. $(994), 28,42,50$.

Robertson v. Babrwin (1fi.j L. S. 1, 2)7. 41 L. E(L. 719). $11 \%$.

Robinsoll v. P. \& O. R. Co. (129 Feal. Rep. 75:3), 240.

Roseribaum Grain Co. v. C. R. \& T. R. Co. (1:01 Fed. Rep. 4ti). 2:3S.

St. Clair Co. v. lnterstate Sand \& car Tr. Co. (192 L. S. 454, 48 L. Til. $5181,24,66$.

St Louis Drayage Co. v. L. \& N. R.

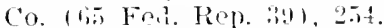

Si. Louis r. Western U. Tel. Co. 148 [. S. 92, 37 I. Er? :280) , 6.8.

St. L. \& S. F. R. CO. v. Gill (150; U.

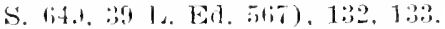

Sants r. Nanistee River Imp. oC. 12:) Y. S. 2.St, :31 L. E(l. 149), 3t.

Santa Clara County v. So. Pac. R. ('o. (118 L. S. 394, 20 I. Ed. 118), $1: 31$.

Soliloman v. Railroal Co. (207 Pa. $1 !+8$, , :3(1).

Sclimicit v. People (1s Colo. $7 s), 47$.

Sibofirld $\therefore$. I. S. \& M. S. R. Co. 11:) Ohio St. 57, 3 N. E. 907), 158. 
References are to pages.

Schollenberger v. Pennsylvania State v. Omaha R. Co. (Iowa. St N. (171 U. S. 1, 43 L. Ed. 49), 16, 26.

Scott v. Donald (165 U. S. 58,41 L. Fd. $6: 32), 43$.

Sheldon v. Wabash R. Co. (105 Fed. Rep. 785), 55, 58, 287.

Sherlock v. Alling (92 U. S. 99, $103,23$ L. Ed. 819$), 35$.

Similey v. Kansas (U. S. Sup. Ct. Feb., 1905), 140.

Smith v. Alabama (124 U. S. 465 , 31 L. Ed. 508$), 35,36,54$.

Smith v. Railroad Co. (63 N. H. $25), 48$.

Smyth v. Ames (i69 C. S. 466, 42 L. F( 1.819$), 83,129,132,159$.

Sorial Circle Case-(162 U. S. $1 S 4$, 40 1. E(l. 935), 162, 215, 263.

Soda Fonntain Co. V. Green (69 Fed. Rep. 333), 379.

South Carolina v. Georgia (93 U. S. 4, $23 \mathrm{~L}$. Ed. 782), 12.

Sorell v. Railroad Co. (75 Ga. $50 !)$. 160.

Southern Cal. R. Co. v. Rutherford (62 Fed. Rep. 791;), 117, 1:7.

Southern ludiana Ex. Co. $\checkmark$. L. S. Exp. Co. 135 C. C. A. 172.92 Ferl. Pep. 1022, ss Fed. Ren. 659), $148,363$.

South Dikota Rate Caso (176 U. S. 167, 44 L. Eo. 417), 166.

Southem Pac. R. Co. v. Colo. F. \& 1. Co. $(42$ C. C. A. 12, 101 Fed. Rep. 779), 160, 162.

Southern Pac. R. Tax Cases (1.) Fed. Rep. 722, 18 Fed. Rep. 3851. 307.

Sorthorn Ry. Co. v. Carson (19t U. S. 136,48 L. EA. 907$), 381$.

Southern Ry. Co. $r$. Greenboro Ice \& Coal Co. (134 Fed. Rep. S2). 131.

Southern Ry. Co. v. Machinists" Local Union (11t Feri. Rey. 49), 106.

So. Nite Co. v. St. L., etc. R. Co. (:8 Mo. App. 191 , 208.

Spofford v. B. \& M. R. Co. (12) Mass. 326$), 189$.

State v. Corbett (57 Minn. 345$), 4 \mathrm{~S}$.

v. Donaldson (32 N.J. L. 151), 114.

v. Donovan (10 N. D. 243), 309

v. Fry (63 Ind. 552), 48.

v. Glidden (55 Conn. 46), 114.

r. Indiana Ry. Co. (138 Ind. 69). 48.

7. Morgan (2 S. D. 32), 48.

v. Railroad Cos. (47 Ohio St. 130), $18 \mathrm{~S}$

v. Sanders (19 Kan. 127), 18.

v. Scott (39 Minn. 1), 47.

v. Smith (7t lowa, 580), 309.

v. Smith ( 83 Me. 458), 47, 48 .

․ Stewart (59) Vt. 273), 114 .

State ex rel. v. Associated Press (159 Mlo. 410), 53.

v. Ind. \& O. Gas \& Mining Co. (120 Ind. 575), 19.

v. Simmons Hardware Co. (109 No. 118), 308.

State Freight Tax Case (15 Wall. 232,21 L. Ed. 146), 29, 32. 42.

State of Jowa v. Chicago, M. \& St. P. R. Co. (33 Fed. Rep. 391), 256.

State Railroad Tax Cases (92 U. S. 575,23 L. Ed. 669), 29.

Storkard v. Mlorgan. (1S5 U. S. 27, $4(i$ L. E(?. 785), 28.

Stockton v. Baltimore, etc., (32 Fed. Rep. 9), S.

Stone v. Mississippi (101 U. S. \$14\$18: 25 L. Ed. 1079), 87.

Swift v. Railroad Co. (5S Fed. Rep. S5S), $55,58,287$.

Swift v. Trson (16 Peters 1, 18, 10 L. Ed. S65, $871,55$.

Swift v. Enited States (25 Sup). Ct. Rep. 2761,93, 121, 207.

Steamship Co. r. Lonisiana (118 U. S. 455,30 L. Ed. 237$), 6,33$, 11.

Telegraph Co. v. Philadelphia 0190 U. S. 190, 47 L. E(l. 995), 34 .

Telegraph Co. v. Texas $(105$ U. S. 4(i), 26, L. Ell. 10167), 34.

Territory v. Evans (2 I laho, 634), 18.

Texas Pacific R. Co. r. Archibald (170 U. S. 665, 42 L. Ed. 118s), 381.

Texas Paeific R. Co. v. Int. Com. Com. (16.2 I. S. 19T, 40 L. Ed. $940), 181,398,339$.

Texas, etc. R. Co. r. Swearinger (122 Texas, 193), 390.

Thomas v. C. N. O. \& T. P. R. Co. (62 Fed. Rep. S119), 107, 108. 109, 119. 124, 298, 3.5.

Thompson v. London \& $\mathrm{N}$. II. R. Co. ( 2 Ner. \& Hct. Ry. Cases $115), 249$.

Tift v. Southern Ry. Co. (123 Fed. Rep. 790), 289 . 
References are to pages.

Toledo A. A. R. C. r. Pennsylrania R. Co.. 5t Fed. Rep. l. c. 7:9;

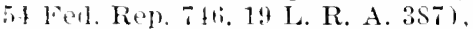
$1117.114,122,127,285,291,247$, $3 \pi \mathrm{s}$.

Townsend r. State (147 Ind. 524). $1 ! !$

Tracy r. Talmadge (1t Y. Y. 162), $\because 36$.

Tlade llark Cases $(100$ U. S. S2. $2 \therefore$ L. El. sinl) 14.

Traders Live Stock Exchange (171

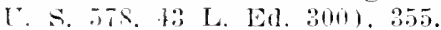

Trans-llissonti Freight Association Case (1tili L. S. 331, 41 L. Ed. $101)$. $121,137,350$.

Troxler r. Southern Ry. Co. (N. C. - . $4+$ L. R. A. 313$), 380$. Inion Pac. R. Co. v. Chicago \& C. R. Co. (16.) U. S. $54 i \frac{1}{4}, 589,11$ I. E1]. 2015. 271$), 51,25 \mathrm{~s}$.

Enion I'ac. IR. Co. r. Goodrich (14?) L. S. (is0, 37 L. EU. 896$), 182$, 209.

Union Par. R. Co. v. Ruff (120 Fed. Rep. 10: ) $11 \%$.

Enion Par. R. Co. v. Tuited States (1114 [. S. 662, 26 L. E.l. 8st), 166.

Luion Jar. R. ('o. v. Cnited States $(117 \%$. S. 3.5. 29 L. El. 9201), $16,1,10$.

Lnion Refricerator Transit Co. v. L.rinll (17\% C. S. 149, 44 L. Ed. (1) . 20.

Enion Stokliveruts Co. of Omaha $r$. ( I. \& Q. R. Co. (Sul). Ct. Rep. Jantuly. 1:4051. 984.

Lnited Siates r. Agler (ti2 led. Rep. $8211,107.358$.

r. Analgamated Ass'n (5t Fed. IRep. .94$), 112$.

v. Amrely $(11$ llieaton 3:9, 6

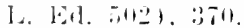

v. lios? (sis Ferl. Rep. 125), 41.

v. Lirantino lilliam (2 Halls Am. I. .1. 25, 5.

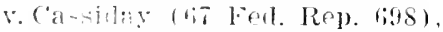
$111 \%, 1 ! 1$

v. Calwallader (.5) Fed. Rel. .

r. Chreapralir \& O. Fural Co.

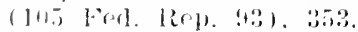

v. Chiragen \& N. IV. R. Co. (127

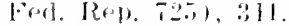

v. Conl Jonalers Ass'n of ral.

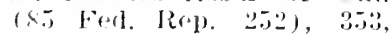
$2,12$.

v. lowromersy (82 Fed. Rep.

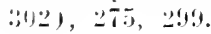

United States v. Delaware, L. \& W R. Co. (40 Rep. 101-103). $185,214,344$.

v. Elliott ( it Fed. Rep. 27, 62 Fed. Rep. 801), 107, 358 .

$v$ Forty-three Gallons of Whisliey $(93 \mathrm{U}$. S. $188,23 \mathrm{~L}$. Ed. 846$), 5$.

v. Geddes (131 Fed. Rep. 452), $147,379,38 S$.

v. Greenhutt et al ( 51 Fed. Rep. $205,469), 359$.

v. Hanley (71 Fed. Rep. 672). 299.

v. Howell (56 Fed. Rep. 21), 299.

v. Interstate Commerce Com. ( 81 Fed. Rep. 783), 337.

v. Jelico Mt. Coal \& Coke Co. (46 Fed. Rep. 32), 352.

v. Joint Traffic Association (171 U. S. 505, 43 L. Ed. 259), 91 , $92,94,104,121,351$.

$\checkmark$ John Kelso (St; Fed. Rep. $304), 30 \mathrm{~s}$.

v. Kagama (118 U. S. 375,30 L. Ed. 228$), 5$.

v. Kane ( 23 Fed. Rep. 748 ), 124.

v. Knight Co. (156 U. S. 1.39 L. Ed. 325,60 Fed. Rep. $306,934), 13,82,91,349$. 350 .

v. Lehigh Valley R. Co. Fed. Rep. 372), 150.

$(115$

Mellin (53 Fed. Rep. 229). $29 ?$.

v. Michigan Cen. R. Co. (43 Fed. Rep. 26), 298, 300.

v. Nlichigan Cen. R. Co. (122 Fed. Rep. 544), 210, 289.

v. Mor'sman (42 Fed. Rep. 448 ), 148.

v. Mosley (187 U. S. 322, 47 L. E(1. 198), 334.

v. National Lead Co. $(75 \mathrm{Fed}$. Rep. 94). 307.

v. Nelson (52 Fed. Rep. 646), 359.

v. Norfolk \& TV. R. Co. (109) Fed. Rep. 831), 232, 343.

v. Northern Pac. R. R. Co. (120 Fedl. Rep. 546 ), 69.

v. Northern Secmities Co. (193 U. S. 197, 48 I. Ed. 679, 120 Fed. Rep. 721), 92, 103, $121,351$.

v. Patterson (55 Fed. Rep. 605), 358.

v. Price (96 Fed. Rep. 960), 309.

v. Railroad Co. ( 81 Fed. Rep. $783), 147$. 
References are to pages.

United States v. Sancher 7 Fed. Rep. Weher v. Virginia (103 U. S. 344, $715), 110,111$.

v. Seaboard R. Co. ( $\$ 2$ Fed. Rep. $563), 149$.

v. Stephens (44 Fed. Rep. 132), 297.

v. Swift (122 Fed. R?1). 529), 93 . $103,115,209,853$

v. Tozer (39 Fed. Rep. 269), 193.

v. Trans-Missouri Freight Ass'n $(166$ U. S. 290.41 L. Ed. $1007), 92.121,137,350$.

v. Union Pacific R. Co. (160 U. S. 1,40 L. Ed. 319 : 8 C. C. A. 2s: 59 Fed. Rep. 813, 50 Fed. Rep. 2S), 69. v. Weber (11' Fed. Rep. 950), 100 .

v. West Va. \& N. R. Co. (12.j Fed. Rep. "s2), 231, 344.

v. Workingmen Amalgamated Ass'n (54 Fed. Rep. 994), $107,116,117,358$.

ex rel Com. v. K. S. R. R. Co. (81 Fed. Rep. 783), 337.

ex rel Com. v. Saloen Ry. Co. (85 Fed. Rep. 955), 337.

Vance v. Vandercook (17) U. S. 438, 42 L. Ed. 1100). 12.

Van Patten v. C. M. \& St. P. R. R. Co. (\$1 Ferl. Rep. 545, 74 Fed. Rep. 981), 5\&. 160, 287.

Veazie Banli v. Fenno ( 8 Tall. 533, 19 L. E(l. 482), 80.

Vegalhahn v. Hunter (167 Mass. $62), 114$.

Voelker v. Railroad Co. (11; Fed. Rep. 867$), 381,38 \%$.

Wabash Ry. Case (118 U. S. 557, 30 L. Ed. 244), 42.

Wabash R. Co. v. Hannahan et al (121 Fed. Rep. 563), 106, 119, 298.

Wabash, St. L. \& Pac. R. Co. v. Illinois $(10+$ Lll, 476$), 50,58$.

Walker v. Cronin (107 Mass. 555), 115.

Walker v. Keenan (19 C. C. A. 668. 73 Fed. Rep. 755, it Fed. Rep. 992), 156, 278 .

Wall v. Norfolk \& W. R. Co. $(52$ W. Va. 485,64 L. R. A. 501), 45.

Waterhouse v. Comer (55 Fed. Rep. $149), 358$.

Waters Pierce Oil Co. v. Texas, (177 U. S. 28,44 L. Ed. 657), 24. 26 L. Ed. 5 t5) , 40.

Welton v. Missouri (91 U. S. l. c. 280.23 L. Ed. 349$), 32,76$.

Western Union Tel. Co. v. Call Pub. Co. $(181$ U. S. 92,45 L. Ed. $765), 55,67,185$.

v. Ann Arbor R. Co. 1178 U. S. $239,4+1$. Eil. 1053). 68.

v. Gottlieb $(190$ U. S. 412, 4i L. Ed. 1116), 29.

v. James $(162$ U. S. 650,40 L. $\mathrm{E}(1.1105), 35$.

v. Massachusetts $(125$ U. S. 580 , 31 L. Ed. 791) ), 29, 68.

v. Pendleton (122 U. S. 347,30 L. Ed. 11s7, 11. 35.

v. Penn. R. R. Co. (25 Sup. Ct. Rep. 151), 69.

v. Taggard (163 U. S. 1, 41 L. Ed. 491, 29.

Westmoreland \& Cambria Nat. Gas. Co. v. Dewitt (130 Pa. St. 235), 19.

Wheaton v. Donaldson ( 8 Peters l. c. 658. S L. Ed. 1079), 54.

Whitwell v. Continental Tobacco Co. $(125$ Fed. Rep. 454, 63 C. C. A. $2901,96,99,356$.

Wight $v$. Uniter States 1167 U. S. 512,12 L. Ed. 258), 18., 191, 209. 262.

Willimette Bridge Co. r. Hatch (125 U. S. 1, 31 L. E(l. 6;29), 64 .

Wilmington \& W. R. Co. V. R. R. Commissioners, 90 Fed. Rep. 33 ), 138.

Wilson v. Atlantic Coast Line R. Co. (129 Fed. Rep. 77t), 195.

Wilson v. Black Bird Creek Marsh Co. (2 Peters 245,7 L. Ed. 412), 31.

Windsor Coal Co. v. C. \& A. R. Co. 152 Fed. Rep. 716), 160.

Winkler v. Pennsylvania R. Co. (58 Atl. Rep. 90), 381.

Wisconsin \& C. R. Co. v. Jacobson (179 U. S. 287,45 L. Ed. 194), 139.

Wisconsin \& M. R. So. V. Powers (191 U. S. 379, t\& L. Ed. 229), 29.

Woodruff v. Parbam (8 Wall. 123, 19 L. Ed. 3s2). (i, 13, 25.

Worcester v. Georgia (6 Pet. 515, 8 L. Ed. 483), 5.

Young v. Kansas City, St. J. \& Co. B. R. Co. (33 No. App. 509 ), 169. 
TABLE OF COMMISSIUN CASES.

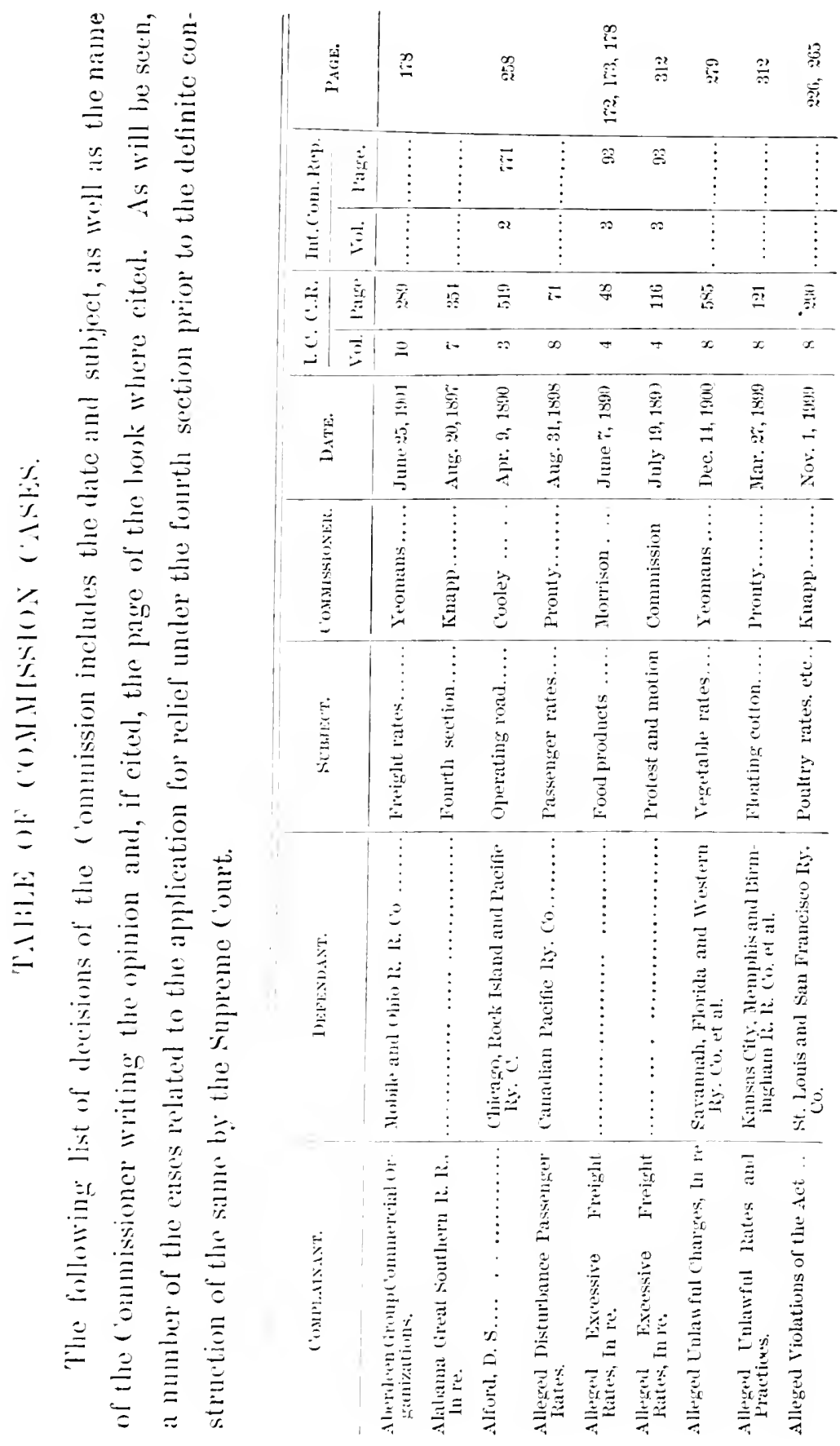




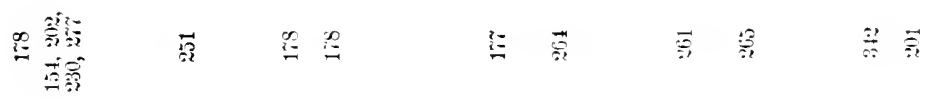

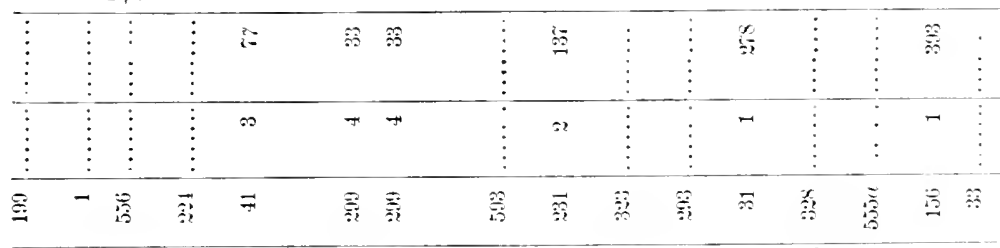

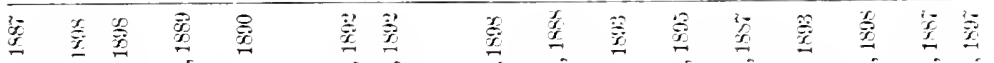

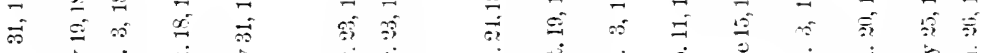

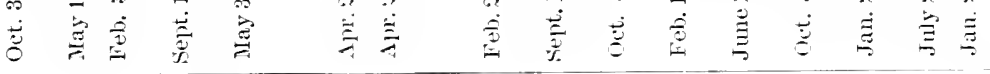

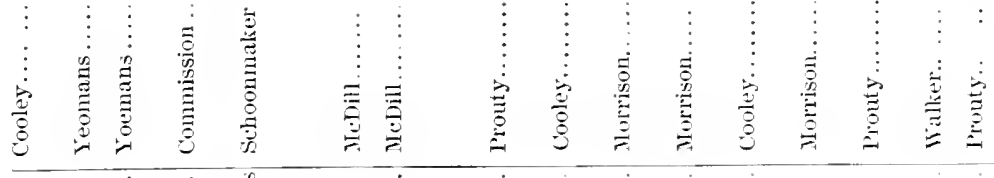

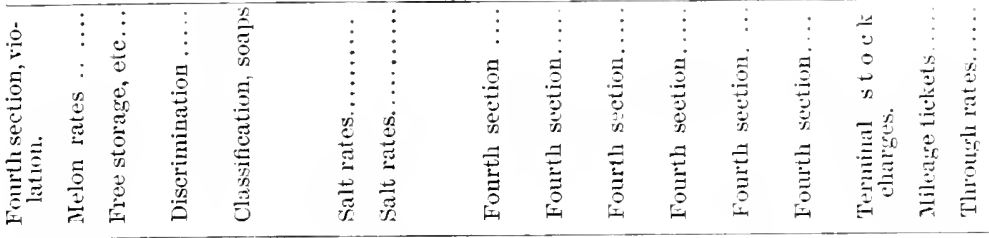

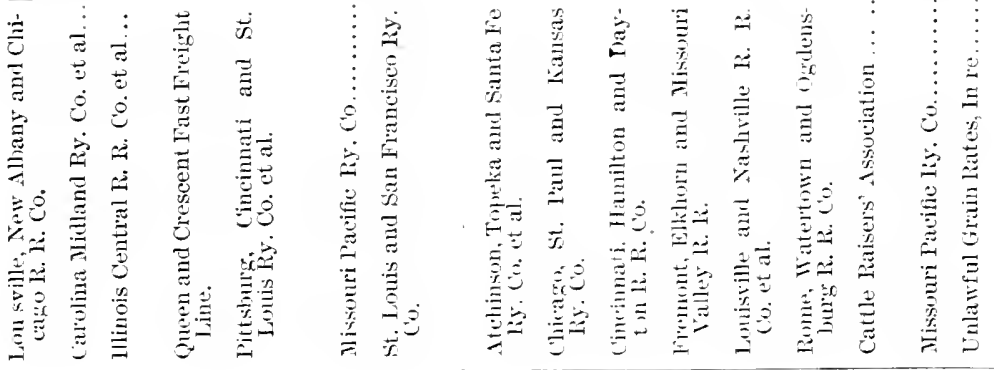

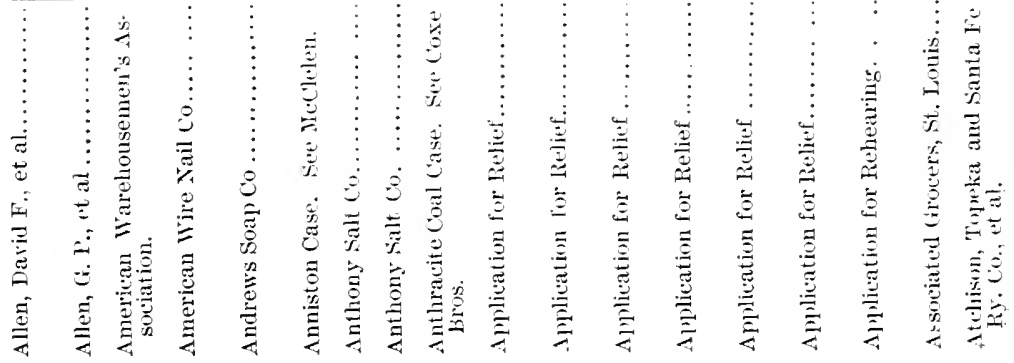




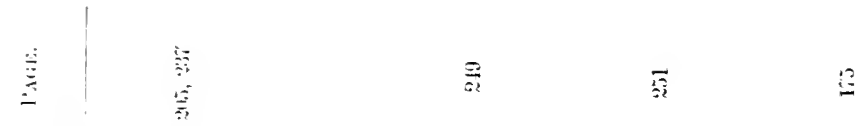

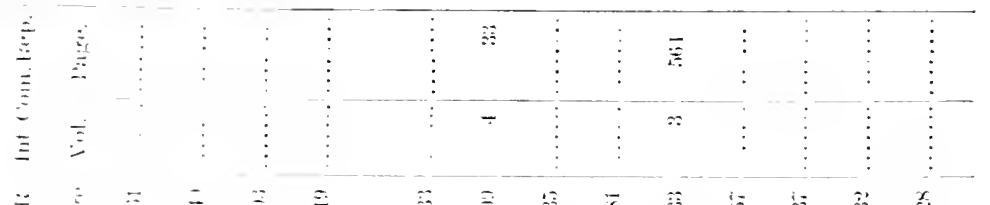

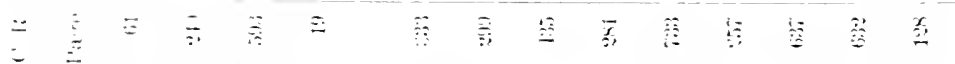

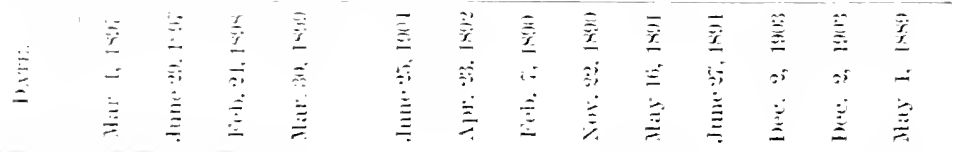

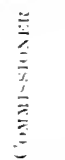

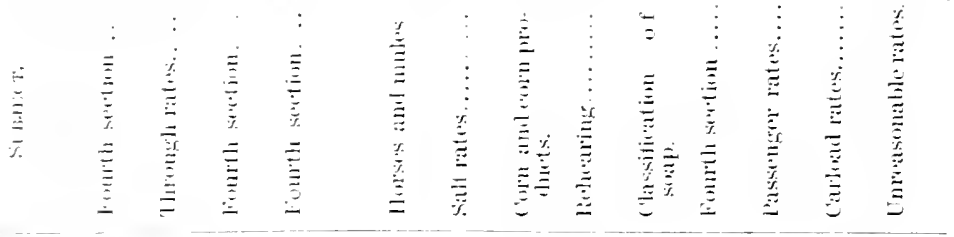

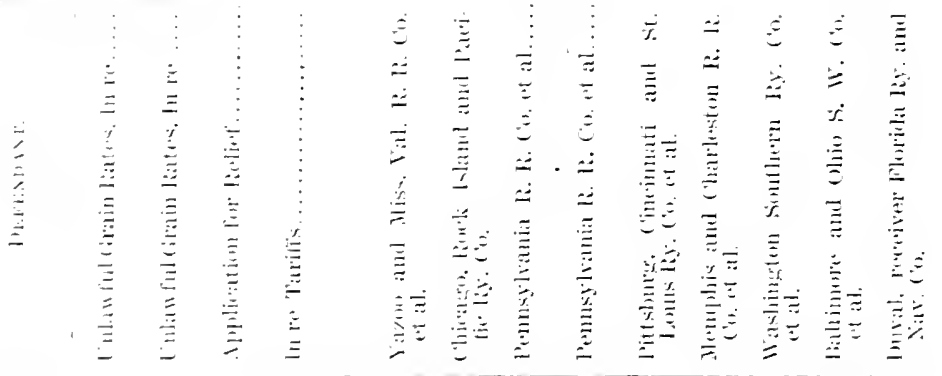

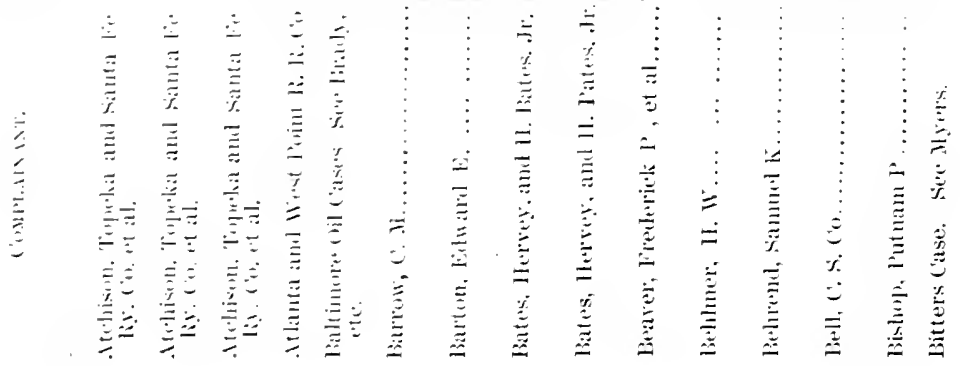




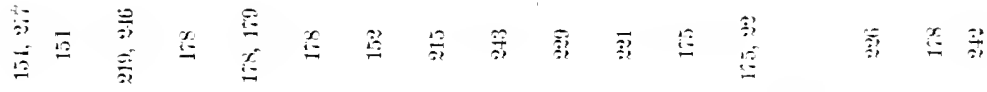

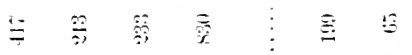

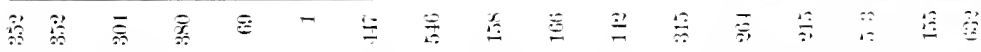

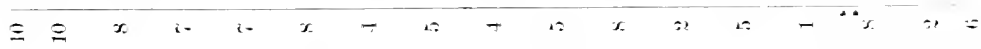

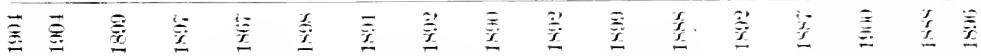

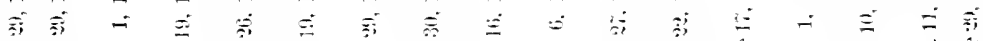

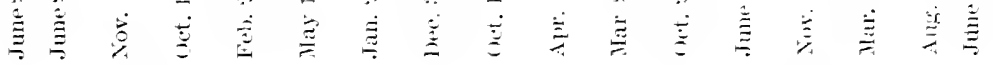

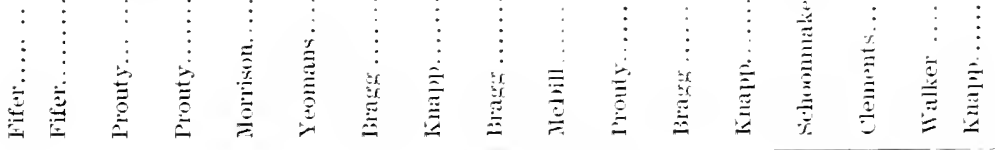

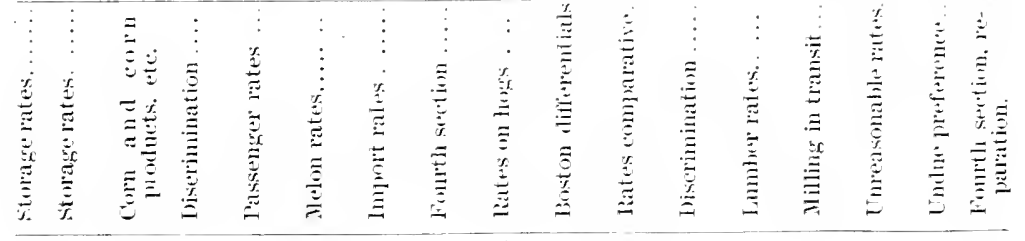

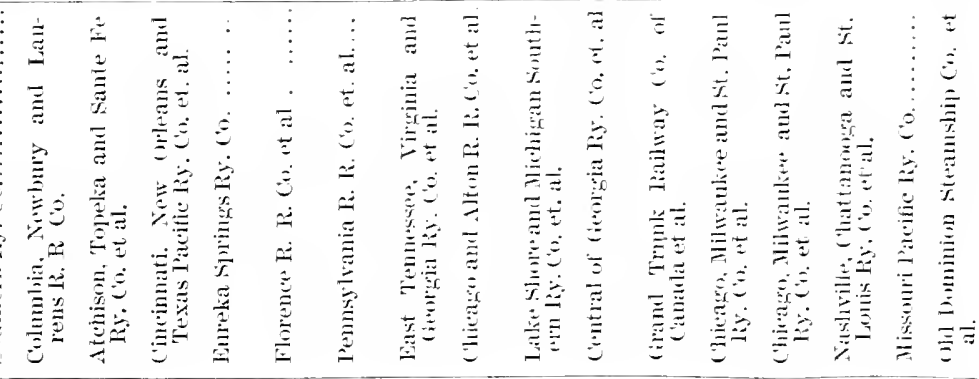

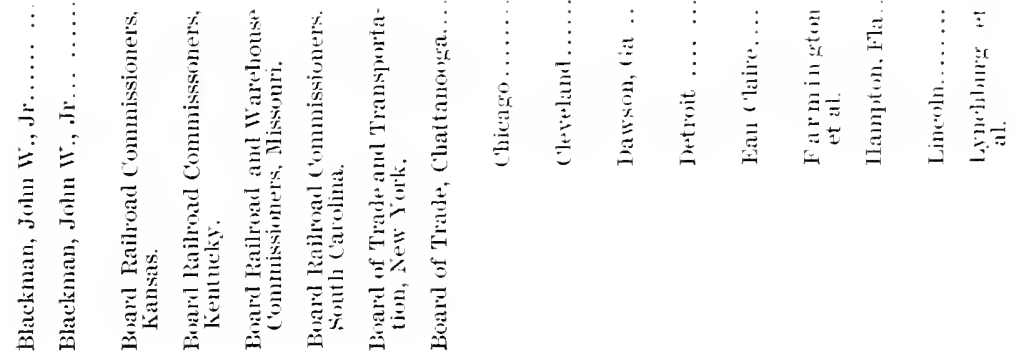




\begin{tabular}{|c|c|c|c|c|c|c|c|c|c|c|c|c|c|c|c|}
\hline 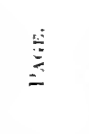 & 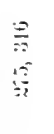 & & 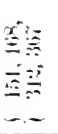 & & & $\stackrel{2}{3}$ & 黑 & 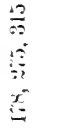 & & & & $\frac{2}{8}$ & & & \\
\hline $\begin{array}{l}\dot{\bar{E}} \\
\vdots \\
\vdots\end{array}$ & $\mathscr{\sim}$ & & $\vdots$ & $\vdots$ & $\vdots$ & $\vec{a}$ & $\vec{i}$ & 呂 & $\vdots$ & & & $?=$ & $\vdots$ & & \\
\hline$\doteq \equiv$ & $\because$ & $\vdots$ & $\vdots$ & : & & - & $\pi$ & $\Leftrightarrow$ & $\vdots$ & & $\vdots$ & $\because 2$ & $\vdots$ & & \\
\hline $\begin{array}{l}\because= \\
\because \quad \\
=\end{array}$ & $\equiv$ & $\vec{\Xi}$ & - & 秀 & 8 & 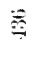 & 芧 & $\vec{\Xi}$ & - & & : & $\vec{\ddots}$ & 盗 & $\overrightarrow{\hat{\tilde{3}}}$ & \\
\hline$\because \equiv$ & - & $\therefore$ & $=$ & - & $\therefore$ & - & - & - & $\therefore$ & & $i-$ & $\therefore$ & $\therefore$ & in & \\
\hline 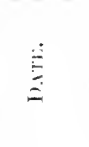 & 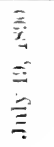 & $\begin{array}{l}\vec{x} \\
\stackrel{x}{J} \\
x^{n} \\
\stackrel{\dot{\Xi}}{\Xi}\end{array}$ & 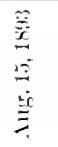 & 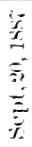 & 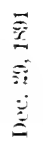 & 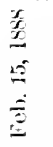 & 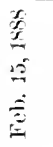 & $\begin{array}{l}\overline{\tilde{z}} \\
\vec{\Xi} \\
\ddot{\Xi} \\
\ddot{\ddot{z}}\end{array}$ & 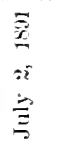 & & 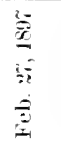 & 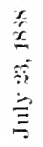 & 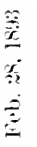 & 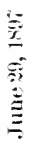 & \\
\hline 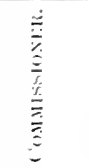 & 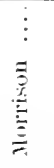 & 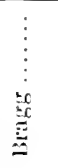 & 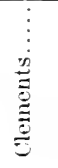 & 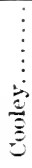 & 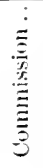 & 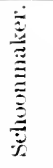 & 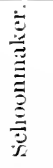 & 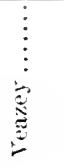 & 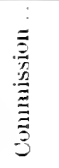 & & 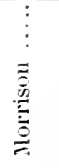 & 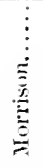 & 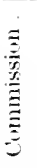 & $\begin{array}{c}\vdots \\
\vdots \\
\vdots \\
\vdots \\
\vdots \\
\vdots \\
\vdots\end{array}$ & \\
\hline 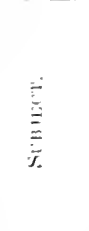 & 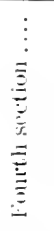 & 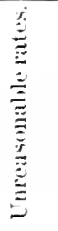 & 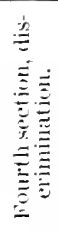 & 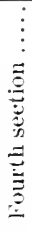 & 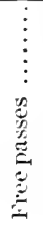 & 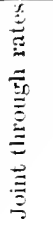 & 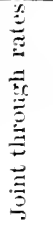 & 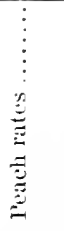 & 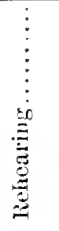 & & 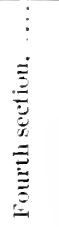 & 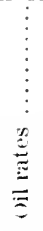 & 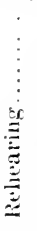 & 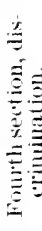 & \\
\hline 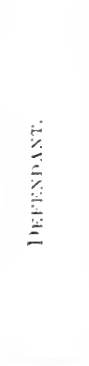 & 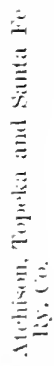 & 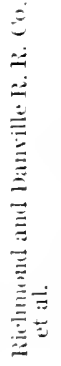 & 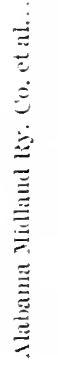 & 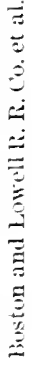 & 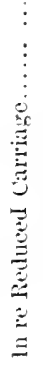 & 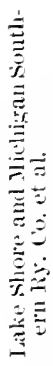 & 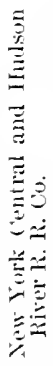 & 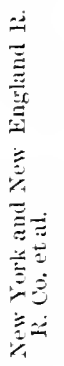 & 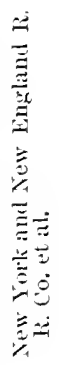 & & 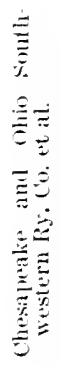 & 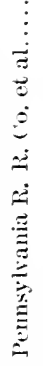 & 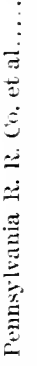 & 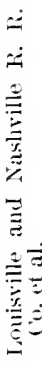 & \\
\hline 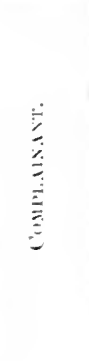 & 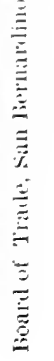 & 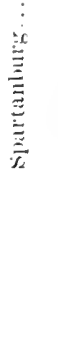 & 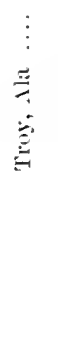 & 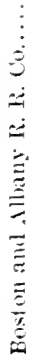 & 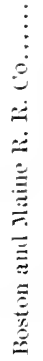 & 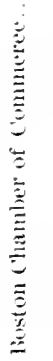 & 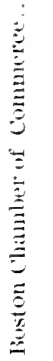 & 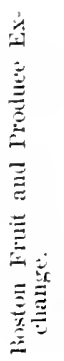 & 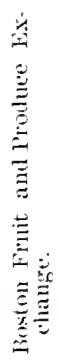 & 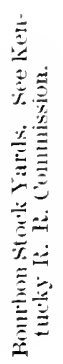 & $\begin{array}{c}\vdots \\
\vdots \\
\vdots \\
\vdots \\
0 \\
0 \\
\vdots \\
\vdots \\
\vdots \\
\vdots \\
\vdots \\
0 \\
0\end{array}$ & 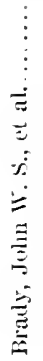 & 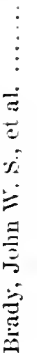 & 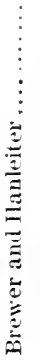 & 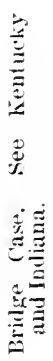 \\
\hline
\end{tabular}




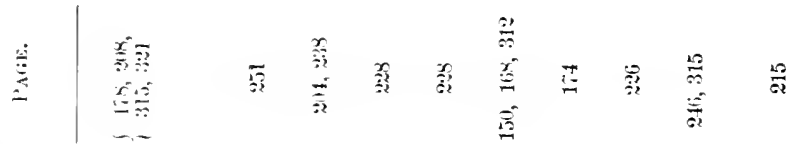

\begin{tabular}{c|c|ccccccccccccc}
\hline \\
\hline
\end{tabular}

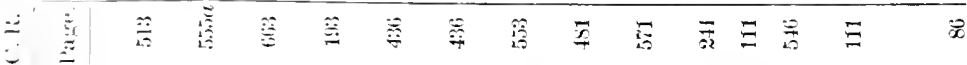

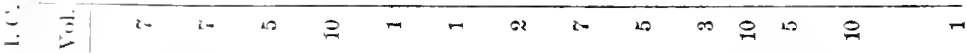

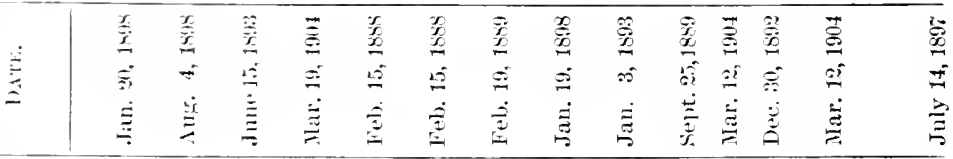

\begin{tabular}{|c|c|c|c|c|c|c|c|c|c|c|c|c|c|c|}
\hline$\because$ & $\hat{\bar{E}}$ & $\stackrel{\Xi}{\Xi}$ & 䒿 & 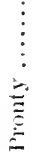 & & 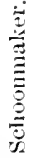 & : & 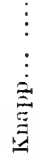 & $\begin{array}{c}\vdots \\
\vdots \\
\vdots \\
\vdots \\
0 \\
0\end{array}$ & $\begin{array}{c}\vdots \\
\vdots \\
\vdots \\
\frac{2}{5}\end{array}$ & $\underset{\Xi}{\stackrel{\Xi}{\Xi}}$ & 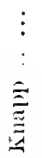 & 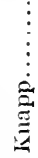 & 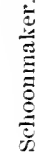 \\
\hline
\end{tabular}

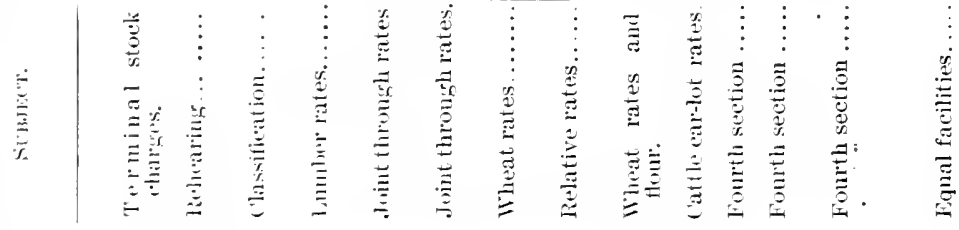

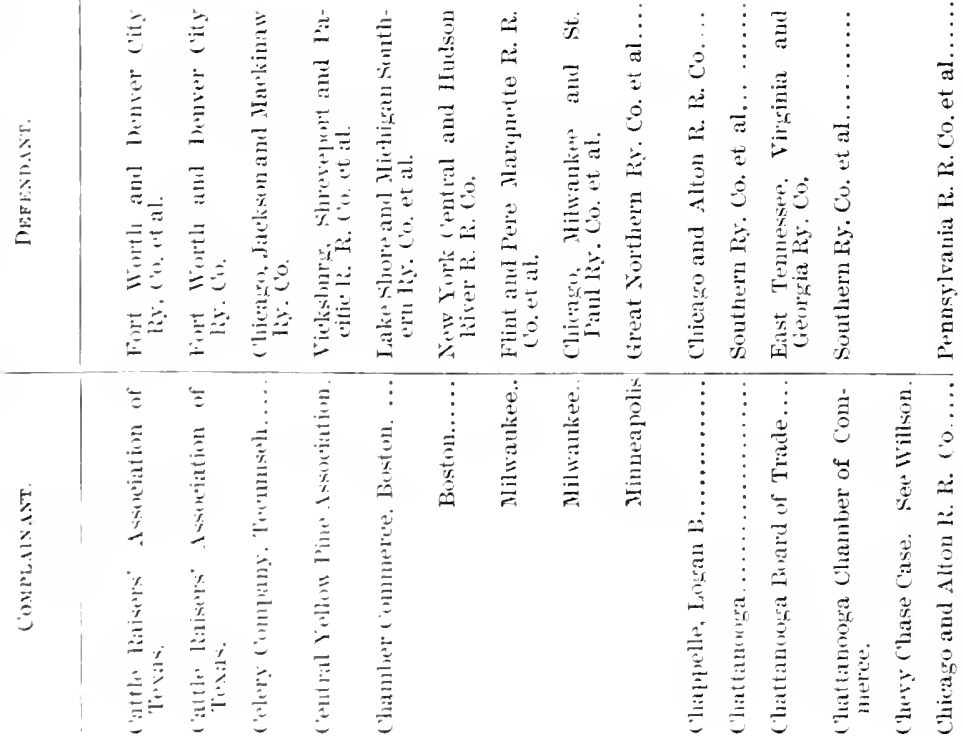




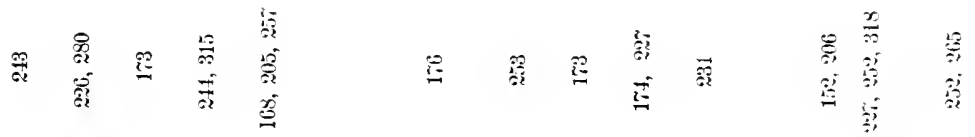

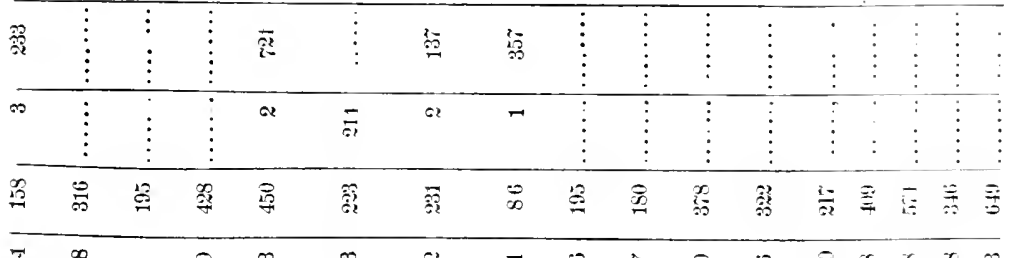

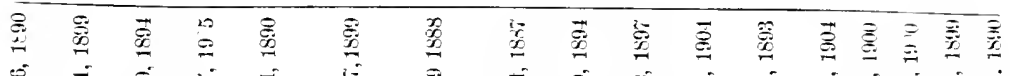

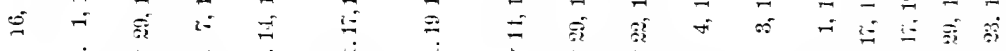

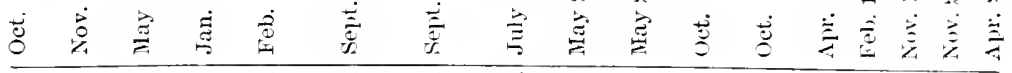

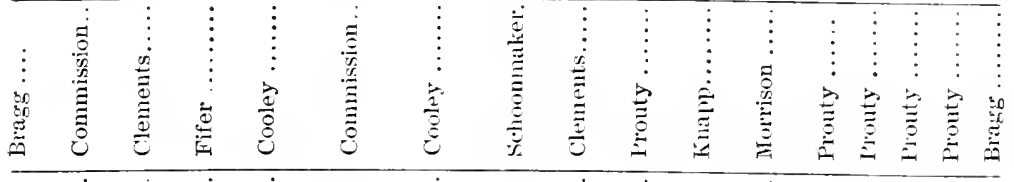

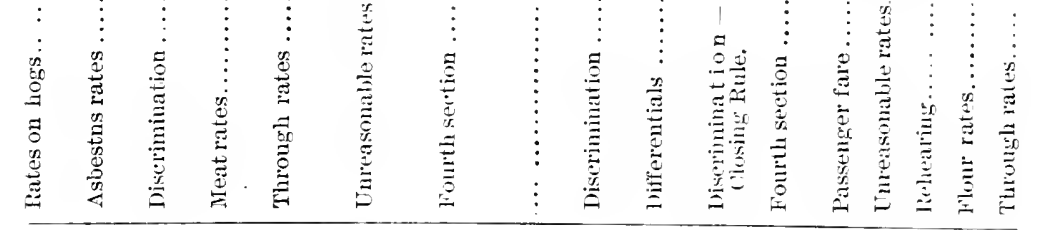

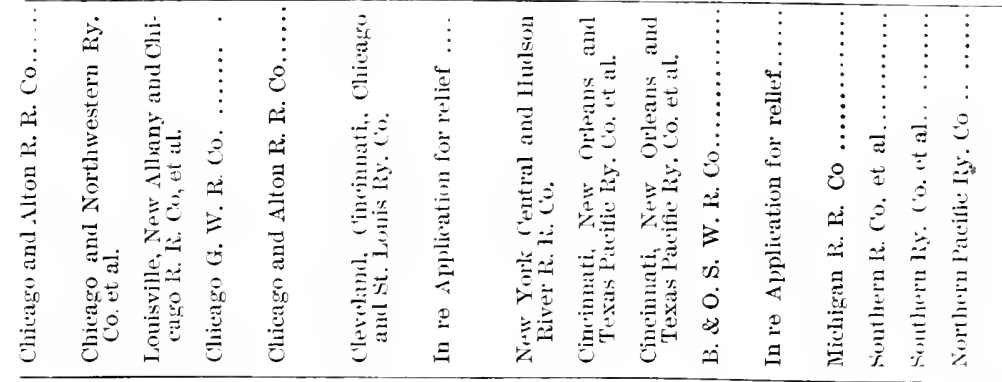

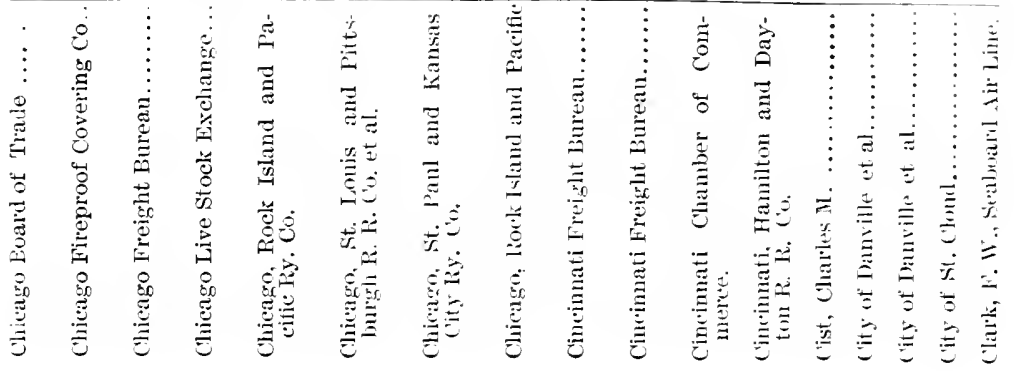




\begin{tabular}{|c|c|c|c|c|c|c|c|c|c|c|c|c|c|c|}
\hline 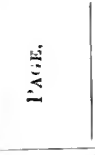 & & 露 & & & 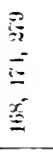 & & & 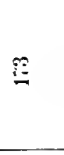 & 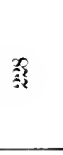 & & $\stackrel{\oplus}{c}$ & & 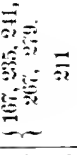 & \\
\hline $\begin{array}{ll}\dot{\bar{E}} & \vdots \\
& \vdots\end{array}$ & & $\overline{\tilde{\tilde{x}}}$ & & & $\vdots$ & & $\vdots$ & $\begin{array}{l}\vdots \\
\vdots \\
\vdots\end{array}$ & $\begin{array}{l}\vdots \\
\vdots \\
\vdots\end{array}$ & & $\stackrel{\infty}{\rightarrow}$ & $\begin{array}{l}\vdots \\
\vdots\end{array}$ & & \\
\hline $\begin{array}{l}\vdots \\
\equiv\end{array}$ & & 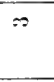 & & & $\begin{array}{l}\vdots \\
\vdots\end{array}$ & & $\begin{array}{l}\vdots \\
\vdots \\
\vdots\end{array}$ & $\vdots$ & $\begin{array}{l}\vdots \\
\vdots \\
\vdots\end{array}$ & & - & $\begin{array}{l}\vdots \\
\vdots \\
\end{array}$ & & \\
\hline$\because \quad \stackrel{\vdots}{=}$ & & 点 & & & st & & 落 & $\frac{1}{0}$ & $\vec{x}$ & & $\infty$ & $\vec{B}$ & 尊 & \\
\hline$\because \equiv$ & & $\therefore$ & & & $\therefore$ & & - & $=$ & i- & & - & $3 x$ & $0=$ & \\
\hline 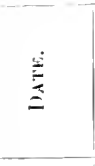 & & $\begin{array}{l}3 \\
\dot{3} \\
\dot{\vdots} \\
\dot{\vdots}\end{array}$ & & & 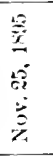 & & 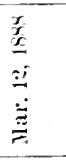 & 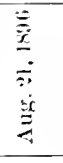 & 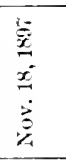 & & 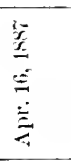 & 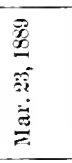 & 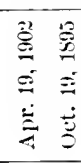 & 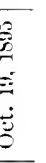 \\
\hline 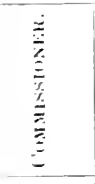 & & 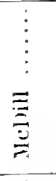 & & & 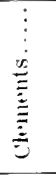 & & 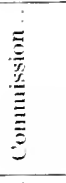 & 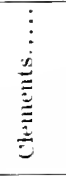 & 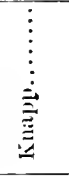 & & $\begin{array}{c}\vdots \\
\vdots \\
\vdots \\
\overline{3} \\
\bar{E} \\
= \\
=\end{array}$ & 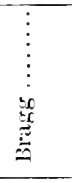 & 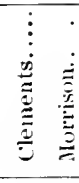 & 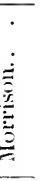 \\
\hline$\frac{\dot{s}}{\bar{x}}$ & & 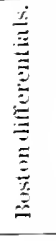 & & & 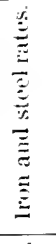 & & $\begin{array}{c}\vdots \\
\vdots \\
\vdots \\
\vdots \\
\vdots \\
\vdots \\
\vdots \\
\stackrel{5}{\vdots} \\
=\end{array}$ & 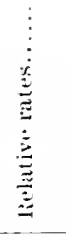 & 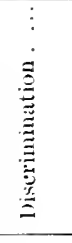 & & 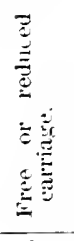 & 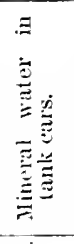 & 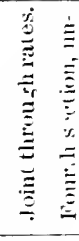 & 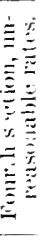 \\
\hline 童 & & 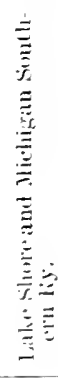 & & & 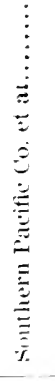 & & $\begin{array}{l}\vdots \\
\vdots \\
\vdots \\
\vdots \\
\vdots \\
\vdots\end{array}$ & 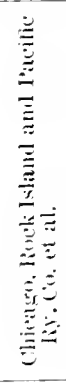 & 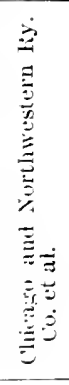 & & $\begin{array}{l}\vdots \\
\vdots \\
\vdots \\
\vdots \\
\vdots \\
\vdots \\
\vdots \\
\vdots \\
\end{array}$ & 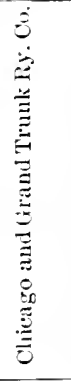 & 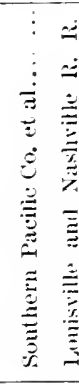 & 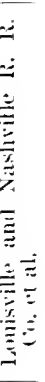 \\
\hline 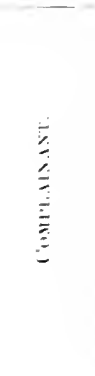 & 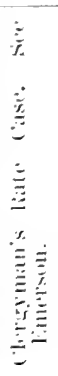 & 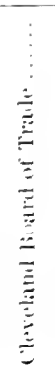 & 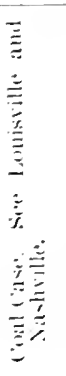 & 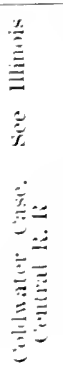 & 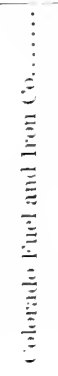 & 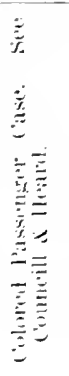 & 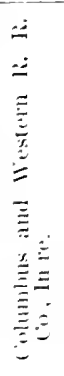 & 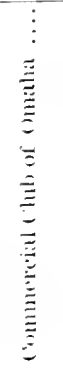 & 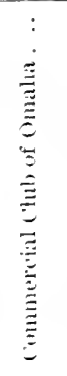 & $\begin{array}{ll} & \\
\end{array}$ & 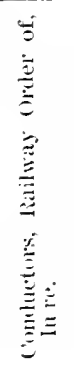 & 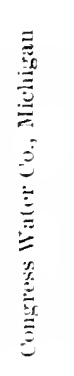 & 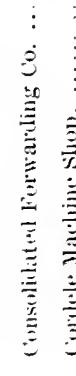 & 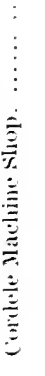 \\
\hline
\end{tabular}




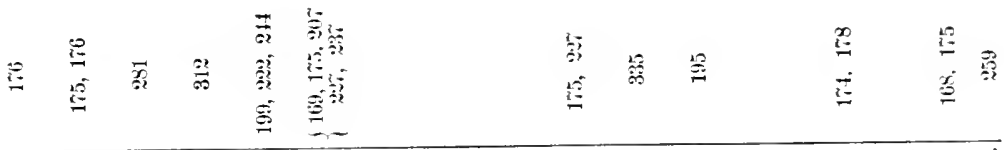

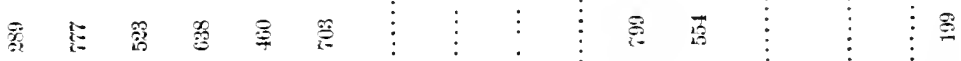

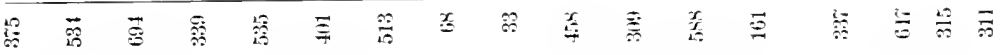

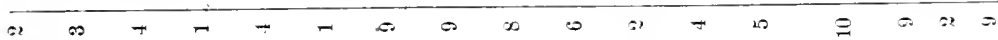

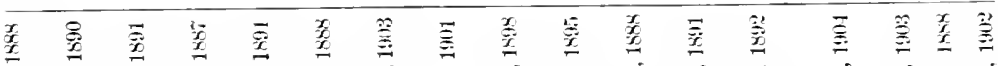

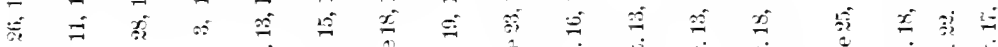

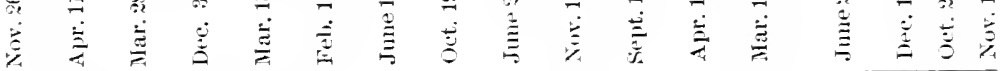

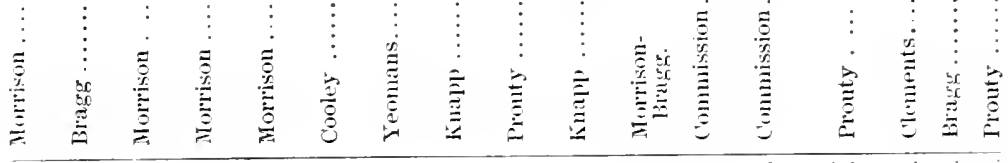

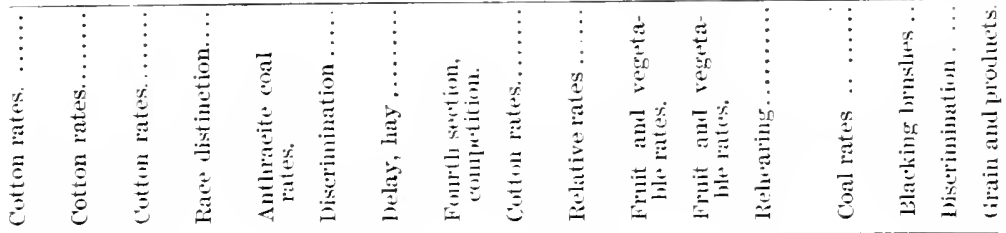

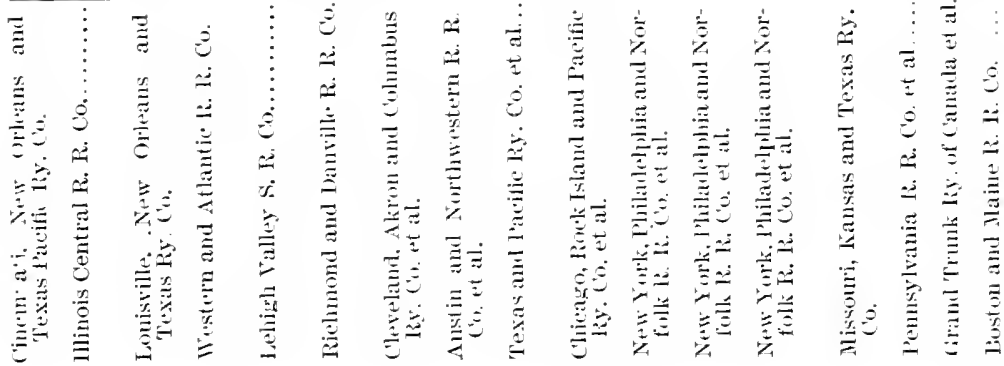

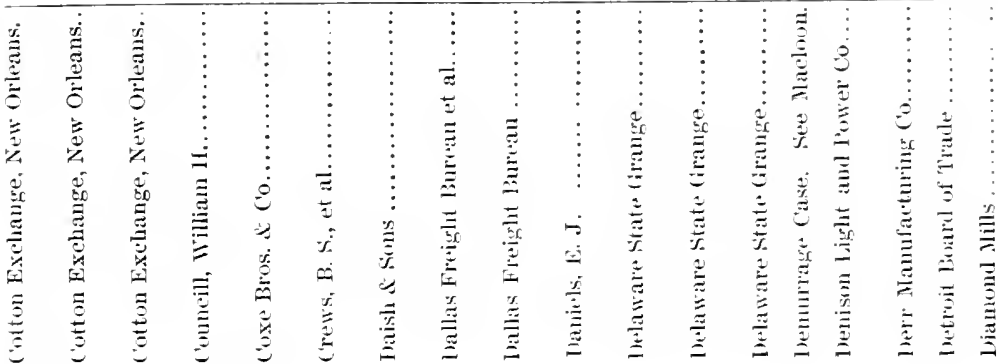




\begin{tabular}{|c|c|c|c|c|c|c|c|c|c|c|c|c|c|}
\hline 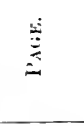 & & 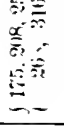 & 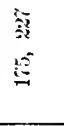 & & & $\hat{\Theta}$ & & & 里 & $\frac{10}{m}$ & $\overrightarrow{c_{0}}$ & 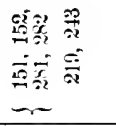 & \\
\hline $\begin{array}{l}\overline{\bar{\Xi}} \\
\dot{\Xi}\end{array}$ & & $\vdots$ & 3 & & & $\overline{\overline{\bar{x}}}$ & $\vdots$ & & $=$ & & 骂 & $\vdots$ & \\
\hline$\equiv$ & & $\vdots$ & $\nabla$ & & $\vdots$ & 02 & $\vdots$ & & $r$ & $\vdots$ & $\alpha$ & $\begin{array}{l} \\
\vdots\end{array}$ & \\
\hline $\begin{array}{l}\dot{y} \\
\because\end{array}$ & & $\hat{\alpha}$ & $\overrightarrow{\sigma_{C}}$ & & $\stackrel{8}{\circ}$ & 瓷 & $\overrightarrow{z_{k}}$ & & 茧 & 蕗 & 产 & $\stackrel{18}{18}$ & $\vec{x}$ \\
\hline$\because \equiv$ & & $=$ & 10 & & $\Xi$ & $\infty$ & $=$ & & $r$ & 0 & $\infty$ & $\subsetneq \infty$ & $\neg$ \\
\hline$\stackrel{E}{E}$ & & 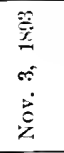 & 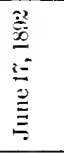 & & 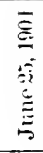 & 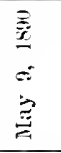 & 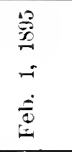 & & 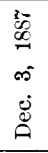 & $\begin{array}{l}\mathscr{8} \\
\stackrel{8}{0} \\
\infty \\
\infty \\
0 \\
0 \\
0\end{array}$ & 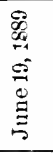 & 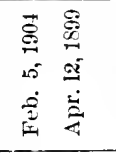 & 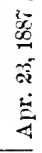 \\
\hline 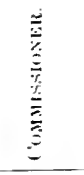 & & 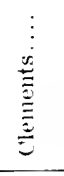 & 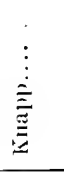 & & $\begin{array}{c}\vdots \\
\vdots \\
\vdots \\
\overline{\hat{\Xi}} \\
\vdots\end{array}$ & 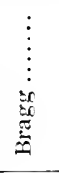 & 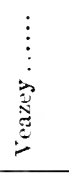 & & 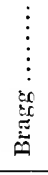 & 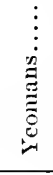 & 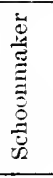 & 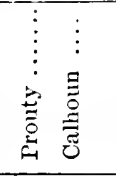 & $\begin{array}{c}\vdots \\
\vdots \\
\vdots \\
\frac{2}{8} \\
0 \\
0\end{array}$ \\
\hline 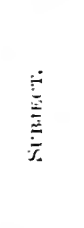 & & 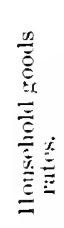 & 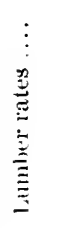 & & 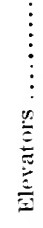 & 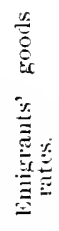 & 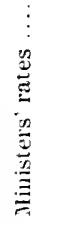 & & 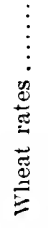 & 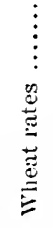 & 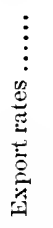 & 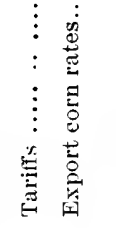 & 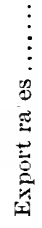 \\
\hline 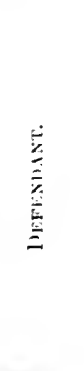 & & 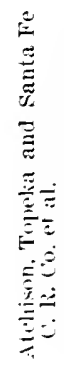 & 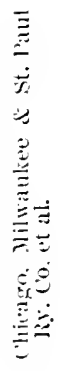 & & 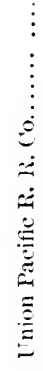 & 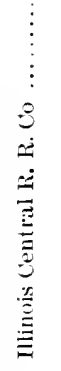 & 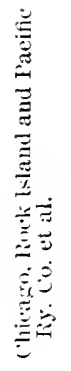 & & 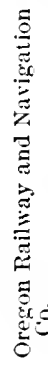 & 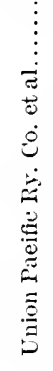 & 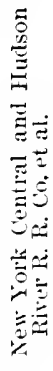 & 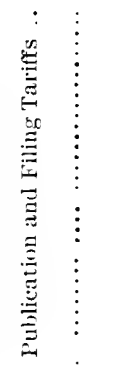 & $\begin{array}{l}\vdots \\
\vdots \\
\vdots \\
\vdots \\
\vdots \\
\vdots \\
\vdots \\
\vdots \\
\vdots\end{array}$ \\
\hline 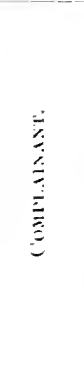 & 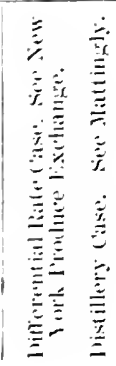 & 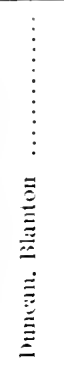 & 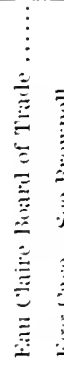 & 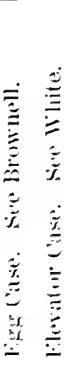 & 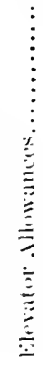 & 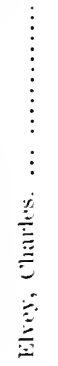 & 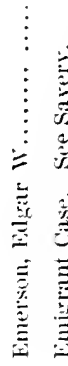 & 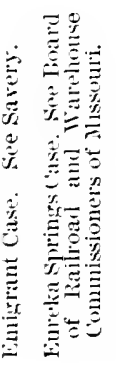 & 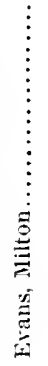 & $\begin{array}{c}\vdots \\
\vdots \\
\vdots \\
\vdots \\
\vdots \\
\vdots \\
\vdots \\
\vdots \\
\vdots \\
\vdots \\
\vdots \\
\vdots\end{array}$ & 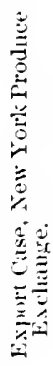 & 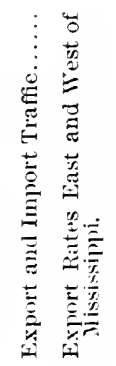 & 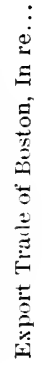 \\
\hline
\end{tabular}


TABLE OF COMMISSION CASES.

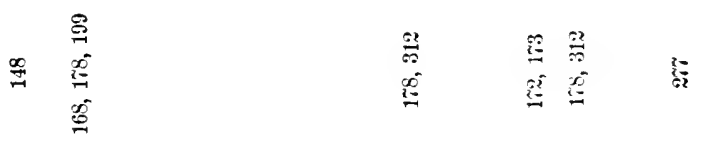

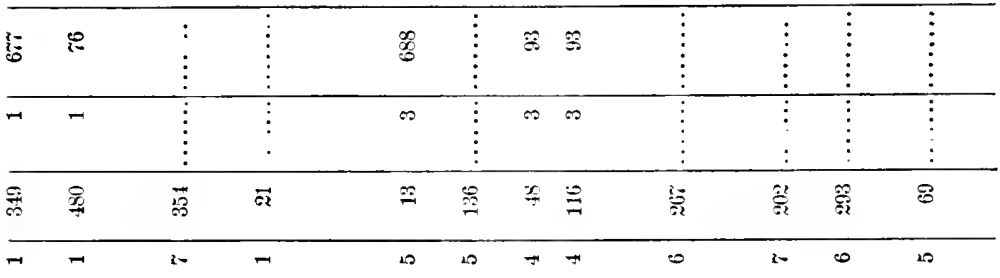

\begin{tabular}{|c|c|c|c|c|c|c|c|c|c|}
\hline 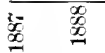 & 悹 & 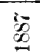 & $\underline{\bar{E}}$ & 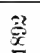 & 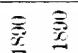 & $\vec{x}$ & 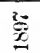 & 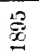 & 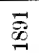 \\
\hline s. & : & $\Xi$ & $\tilde{\tilde{g}}$ & $\therefore$ & $\therefore \approx$ & $\infty$ & $\tilde{g}$ & $=$ & ธิ \\
\hline$\dot{\vec{D}}$ & $\stackrel{d e}{z}$ & 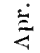 & 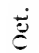 & $\dot{\overrightarrow{\hat{\theta}}}$ & $\stackrel{\Xi}{\underline{\Xi}}$ & 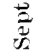 & $\stackrel{\Xi}{\vec{z}}$ & 恿 & $\dot{\mathscr{\varpi}}$ \\
\hline
\end{tabular}

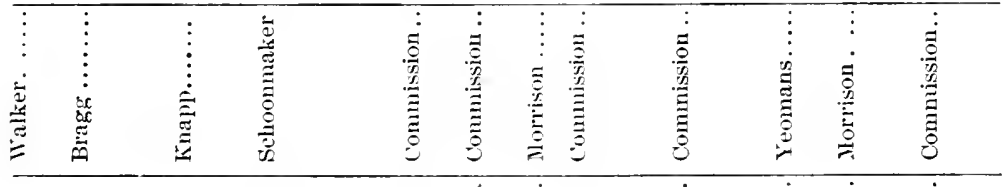

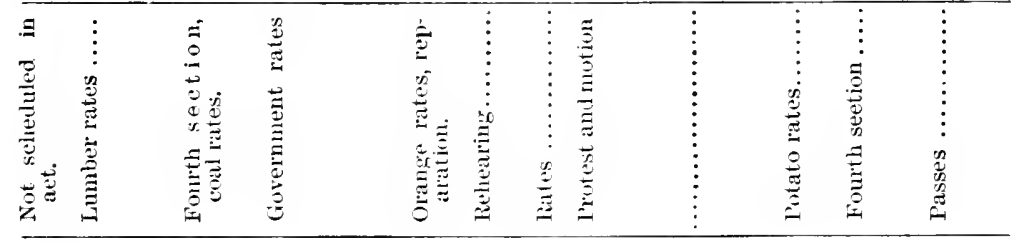

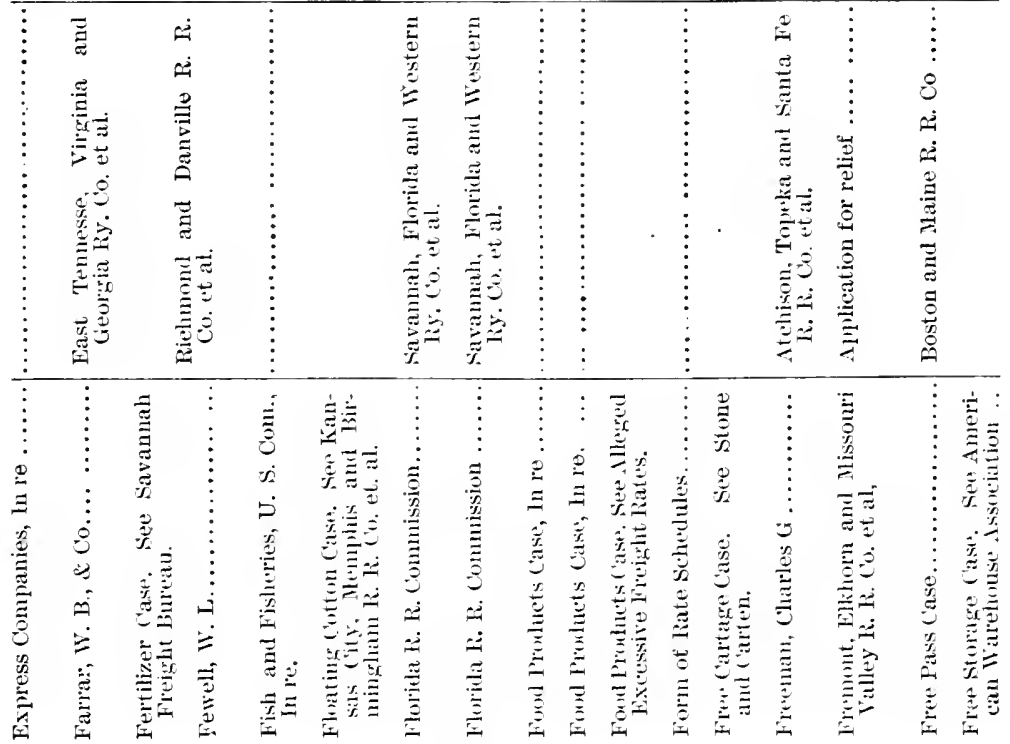




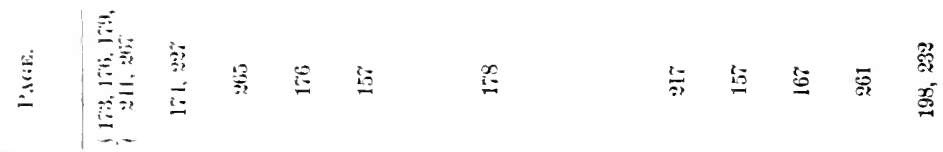

\begin{tabular}{|c|c|c|c|c|c|c|c|c|c|c|c|c|c|c|}
\hline 㝘 & & & & $\vdots$ & $\vdots$ & & 笋 & $\vdots$ & $\vdots$ & $\vdots$ & & 糫 & 黛 & \\
\hline $\bar{\Sigma}$ & $\vdots$ & & & $\vdots$ & $\vdots$ & : & $\approx$ & $\vdots$ & & $\vdots$ & $\vdots$ & $T$ & $\vec{\sigma}$ & \\
\hline 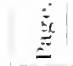 & 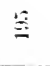 & $\overline{\bar{z}}$ & 至 & $\bar{\Xi}$ & $\overline{\mathrm{E}}$ & $\stackrel{P}{\underline{P}}$ & $\vec{\sigma}$ & - & $\Xi$ & $\stackrel{\vec{\partial}}{\partial}$ & : & $\overrightarrow{3}$ & 总 & 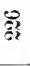 \\
\hline$\dot{\vec{B}}$ & $\therefore$ & iv & iv & is & $\equiv$ & $\because$ & $\rightarrow$ & $\therefore$ & - & $\equiv$ & $\equiv$ & 10 & 10 & 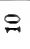 \\
\hline
\end{tabular}

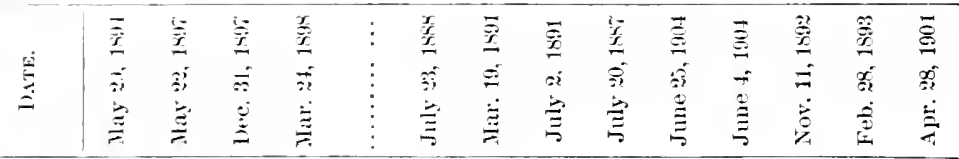

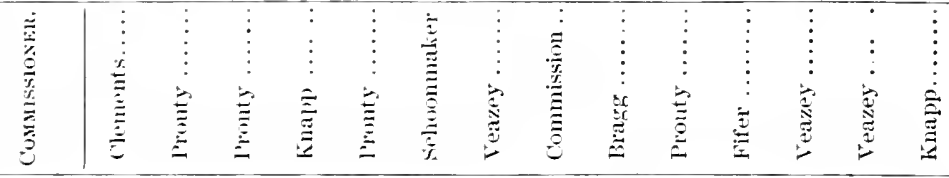

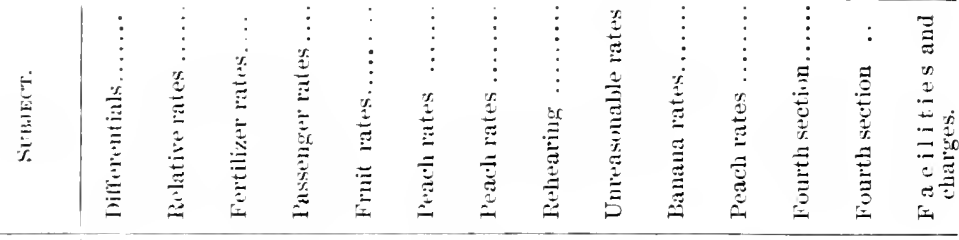

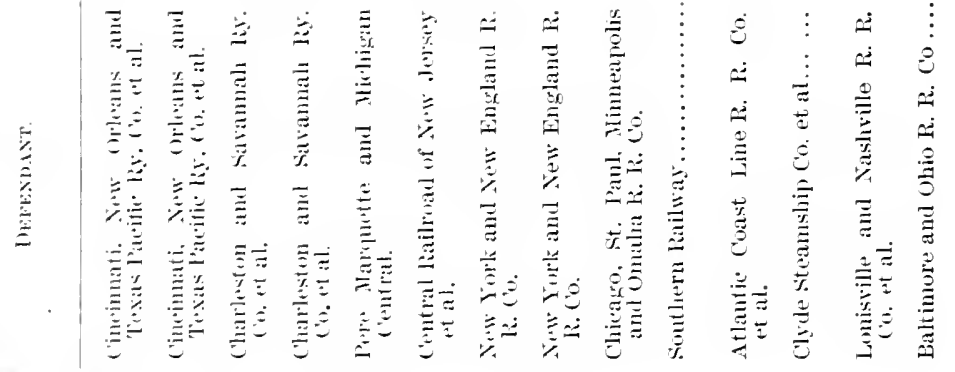

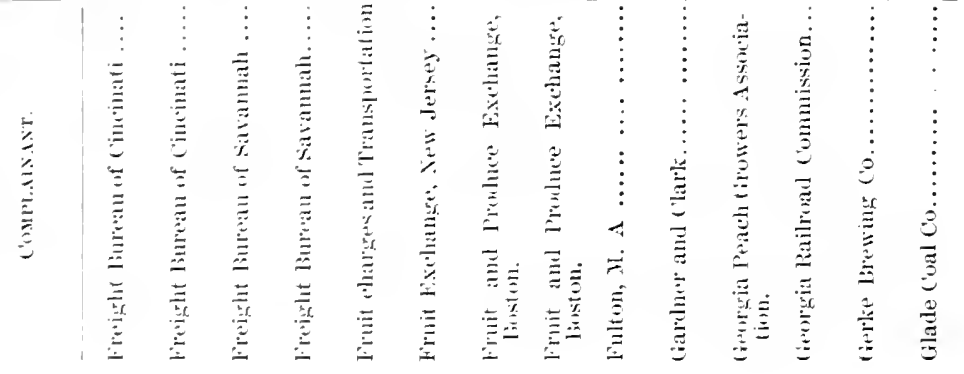


TAHLE OF COMMISSION CASES.

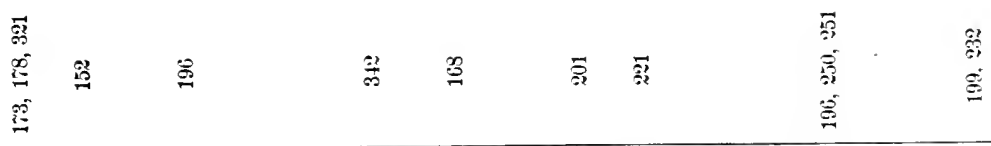

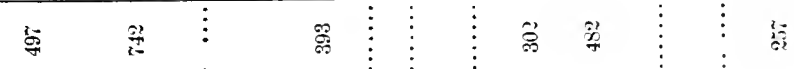

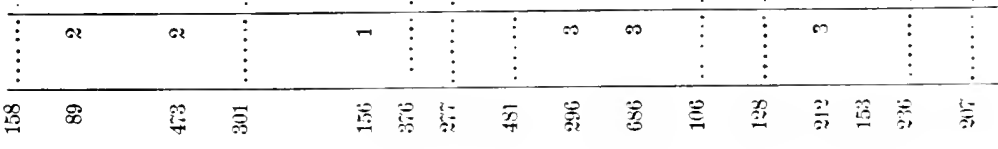

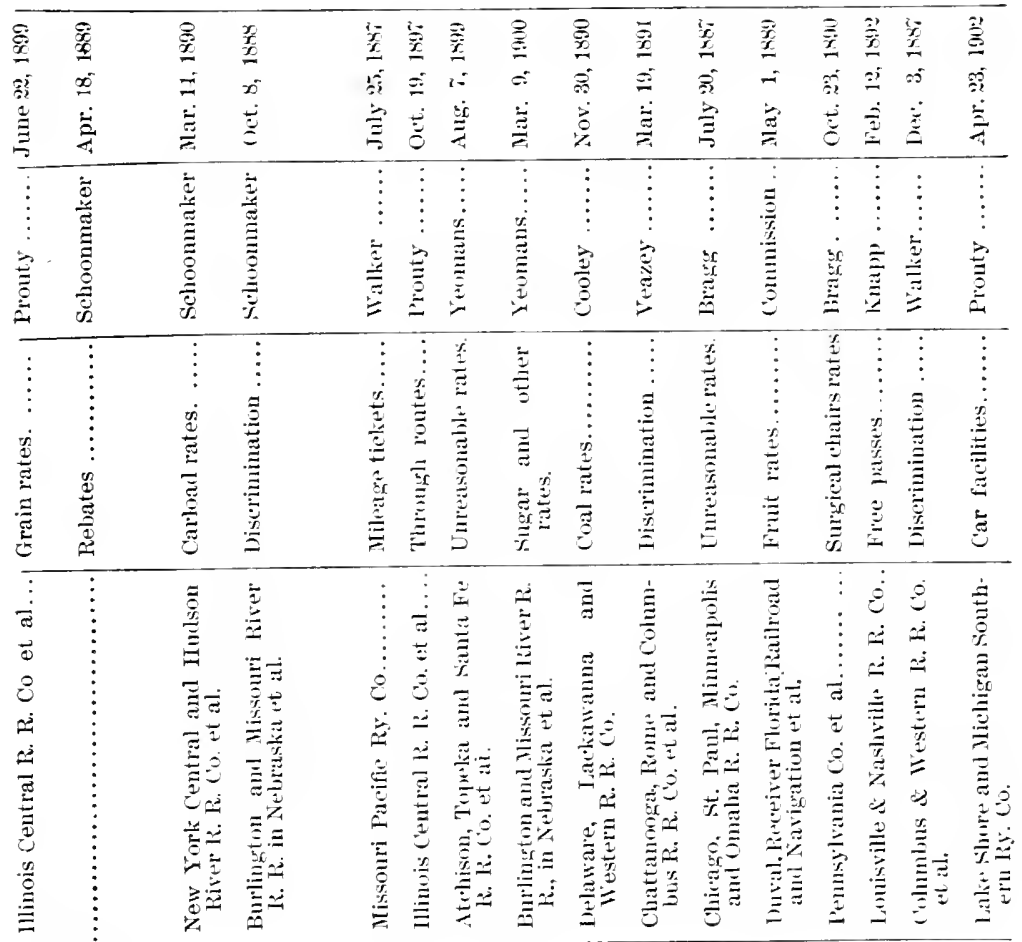

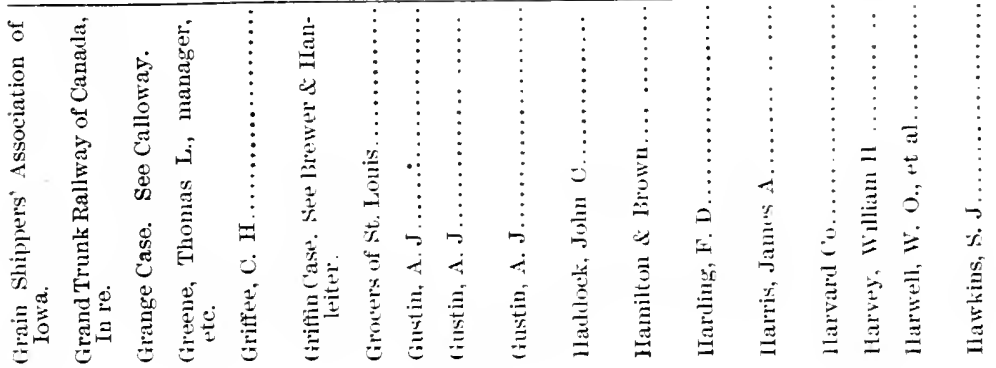




\begin{tabular}{|c|c|c|c|c|c|c|c|c|c|c|c|c|}
\hline 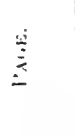 & & 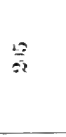 & 该 & 彎 & 爻: & $\overrightarrow{\hat{\hat{\xi}}}$ & 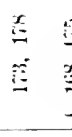 & 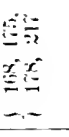 & & 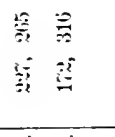 & & 管 \\
\hline & & 栗 & $\vdots \vdots$ & : & $\equiv$ & & & & & & & 管 \\
\hline & $\vdots$ & - & - & & $\therefore$ & & & & - & & & 32 \\
\hline & $\frac{y}{3: 2}$ & $\frac{x}{12}$ & $\equiv \hat{\Xi}$ & $\overline{3}$ & $i$ & 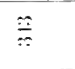 & $\underline{\Xi}$ & 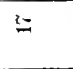 & 䓀 & $2 \overline{3}$ & 8 & 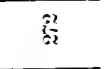 \\
\hline$\equiv$ & $=$ & - & $\therefore-$ & $\equiv$ & $\therefore$ & $=$ & $=$ & $\Rightarrow$ & - & $\infty x$ & $\propto$ & $\Rightarrow 2$ \\
\hline 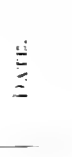 & 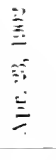 & 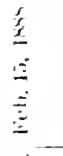 & 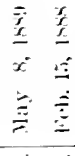 & 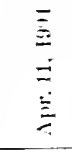 & 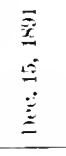 & 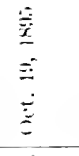 & 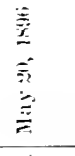 & $\begin{array}{l}\bar{\Xi} \\
\vdots \\
\vdots \\
\vdots \\
\vdots\end{array}$ & 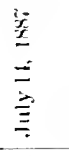 & 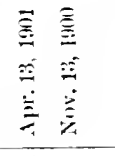 & 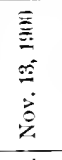 & 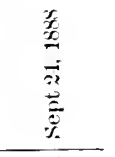 \\
\hline & $\begin{array}{l}\vdots \\
\vdots \\
\vdots \\
=\end{array}$ & 产 & 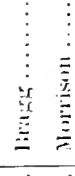 & 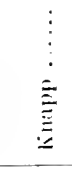 & 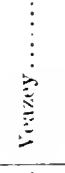 & 高 & 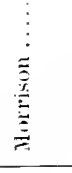 & 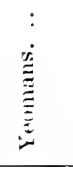 & 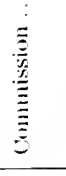 & 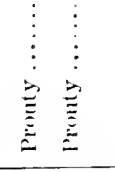 & 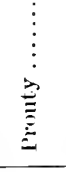 & 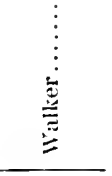 \\
\hline & 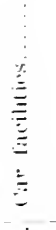 & 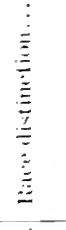 & 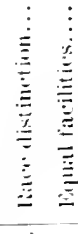 & 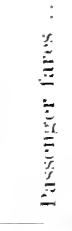 & 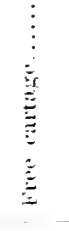 & 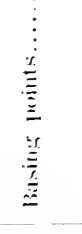 & 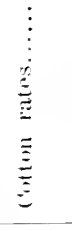 & 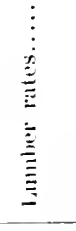 & 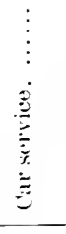 & 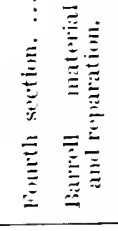 & 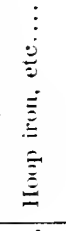 & 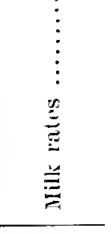 \\
\hline & 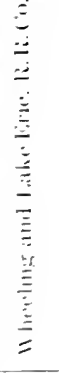 & 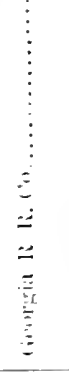 & 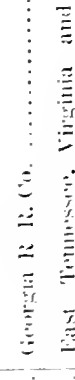 & 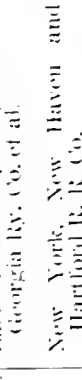 & 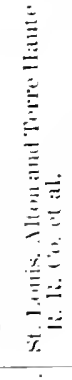 & 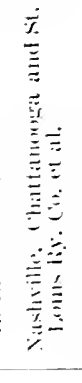 & 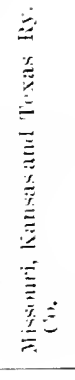 & 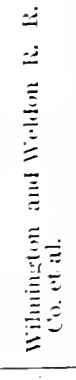 & 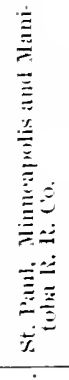 & 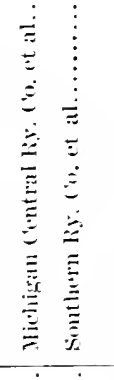 & 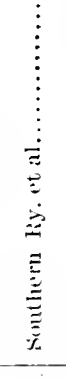 & 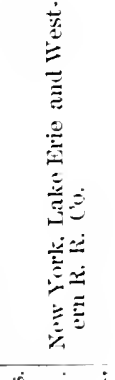 \\
\hline 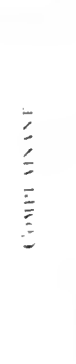 & 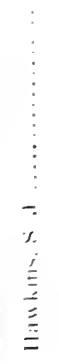 & $\begin{array}{c}\vdots \\
\vdots \\
\vdots \\
= \\
\\
\bar{E} \\
\bar{E} \\
\bar{E} \\
=\end{array}$ & 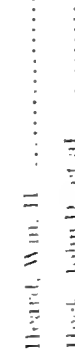 & 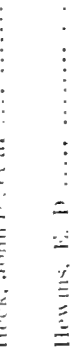 & 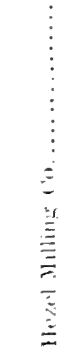 & 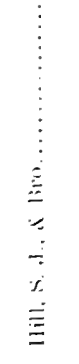 & 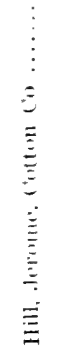 & 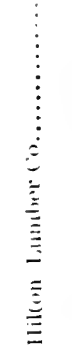 & 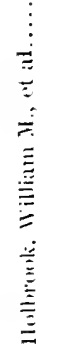 & 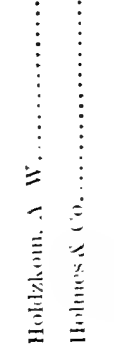 & 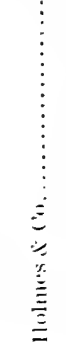 & 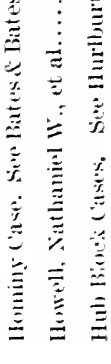 \\
\hline
\end{tabular}




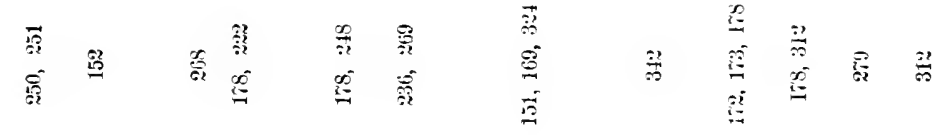

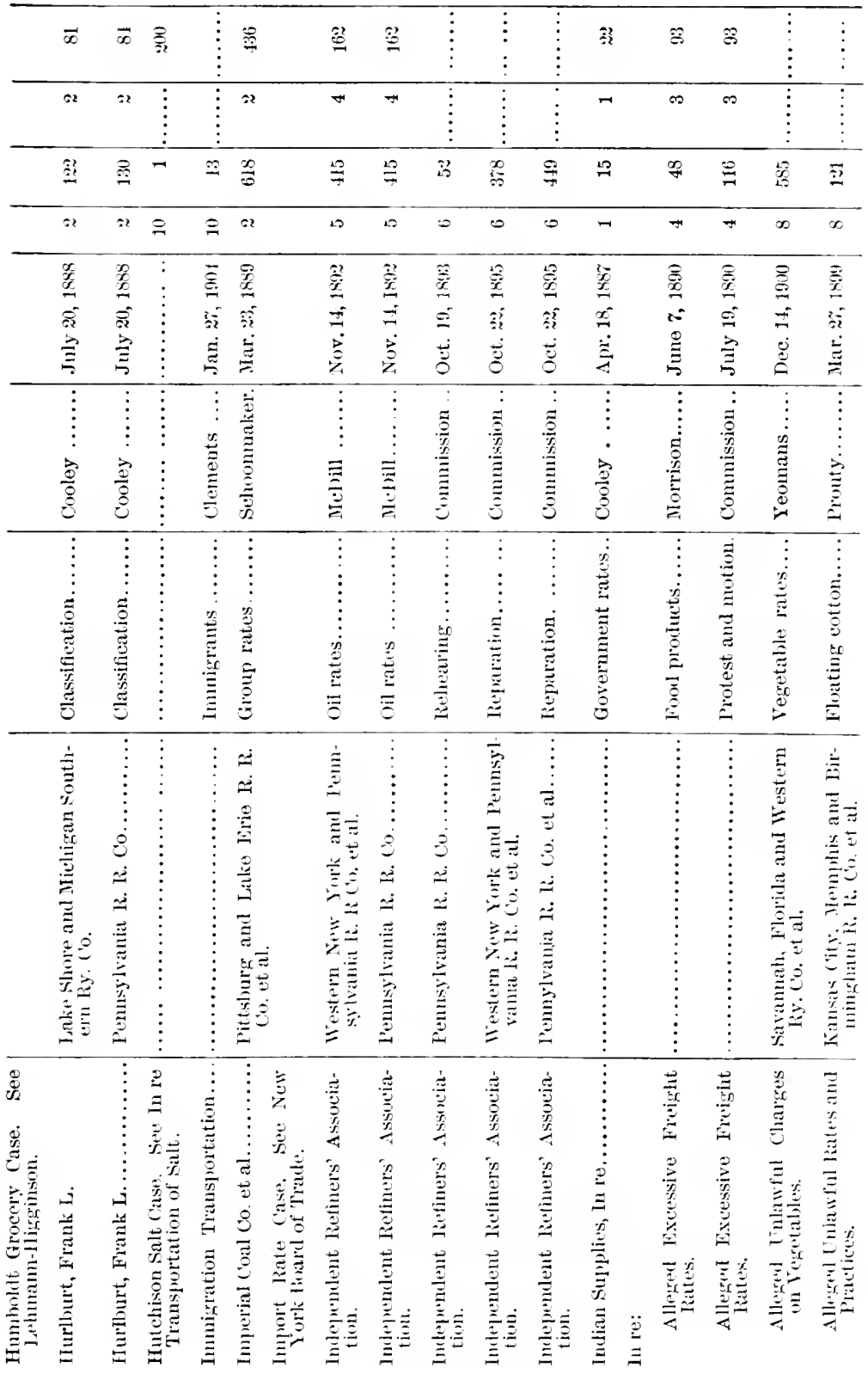




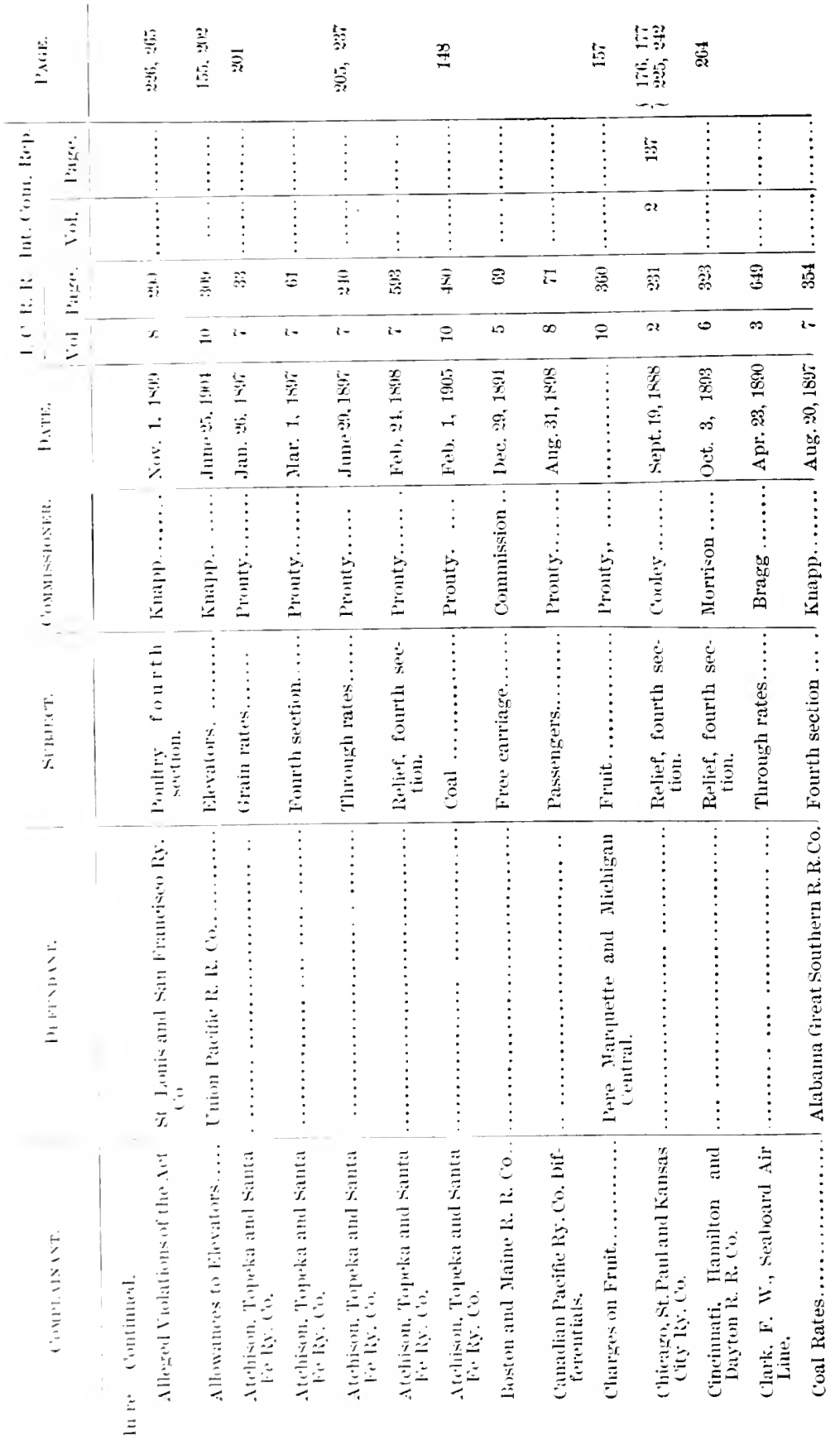




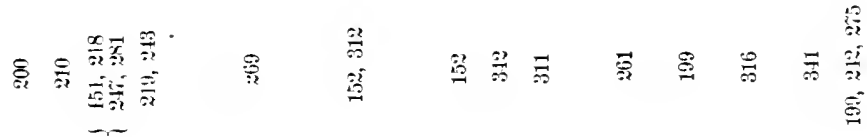

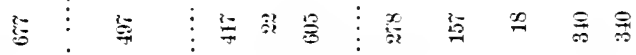

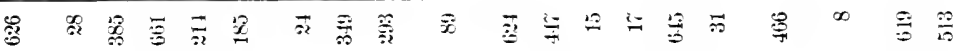

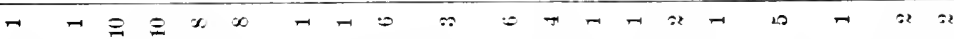

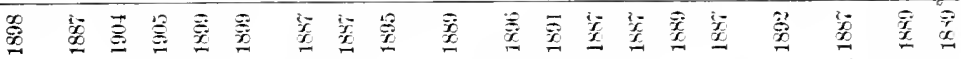

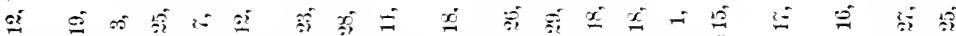

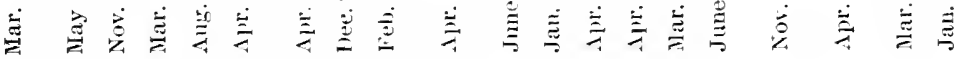

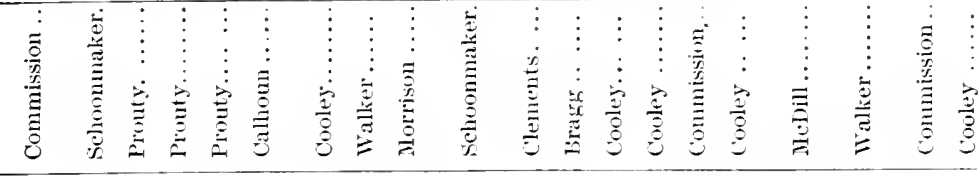

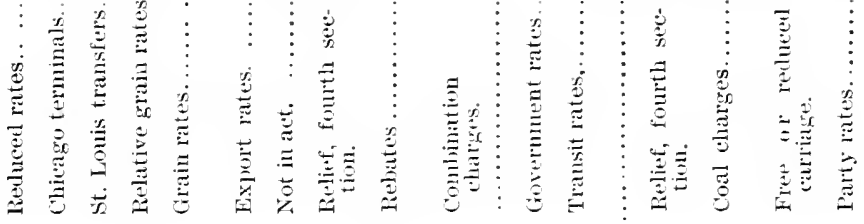

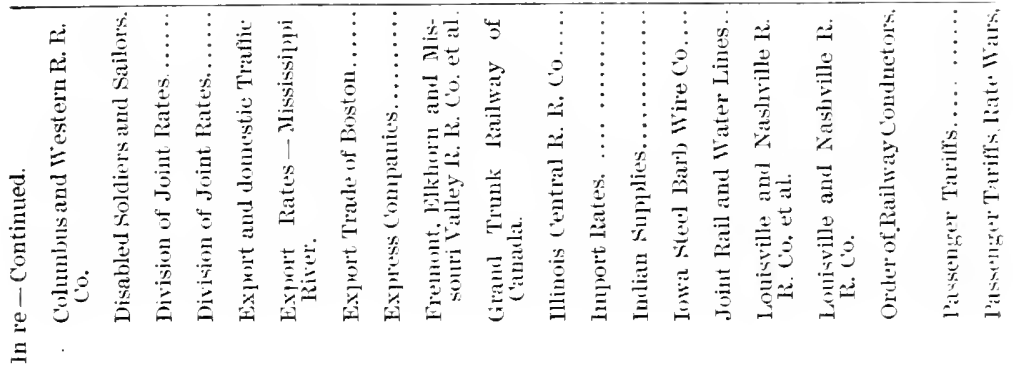


|

\begin{tabular}{l}
\hline \\
\hline
\end{tabular}

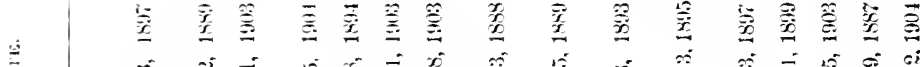

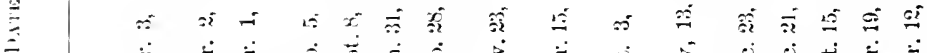

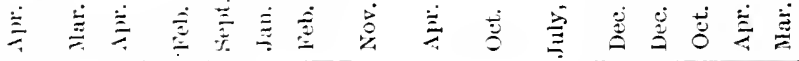

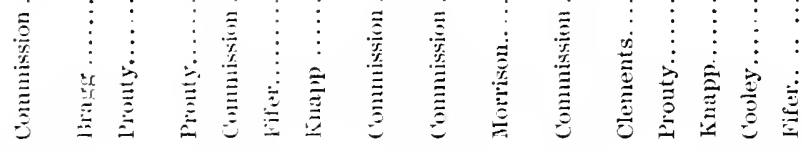

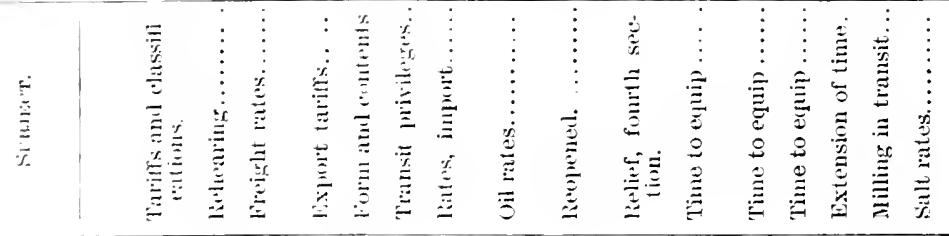

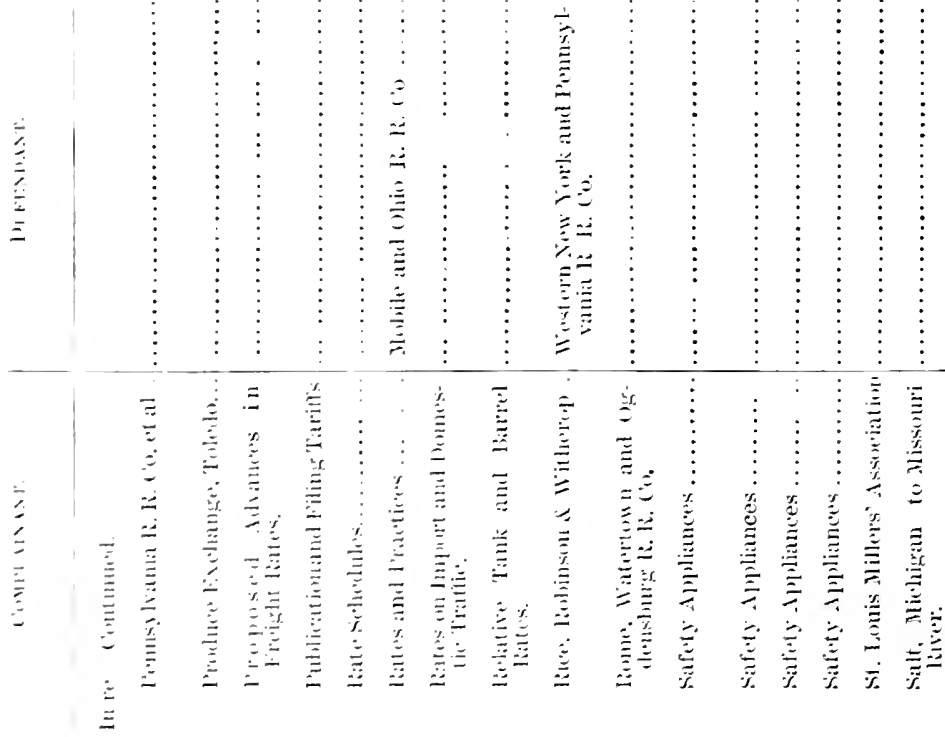




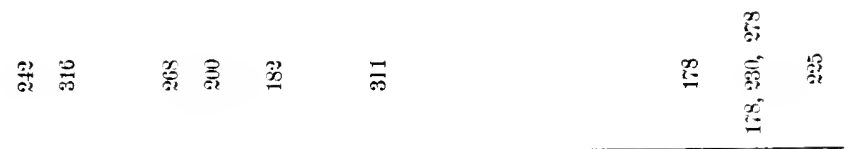

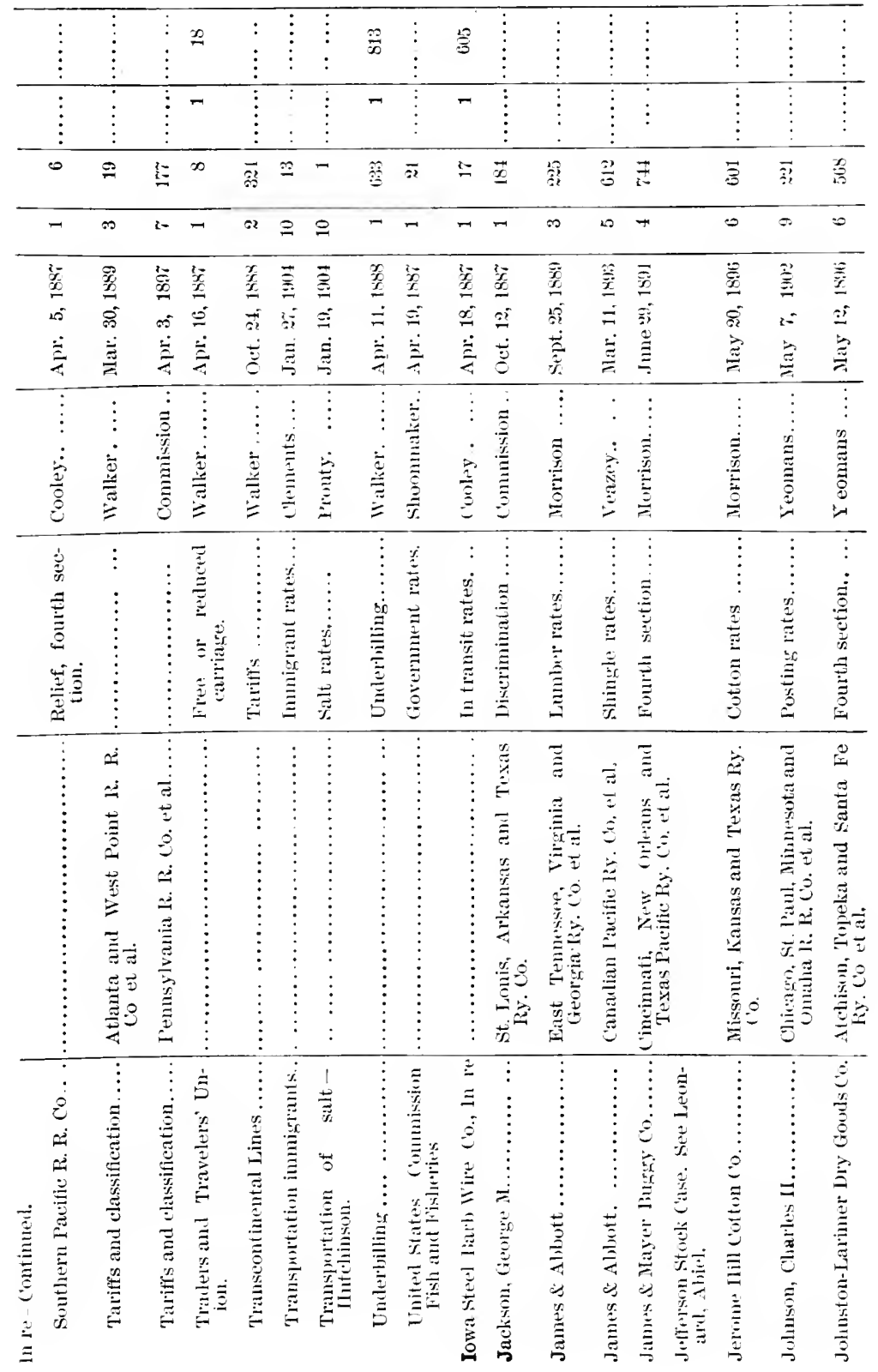




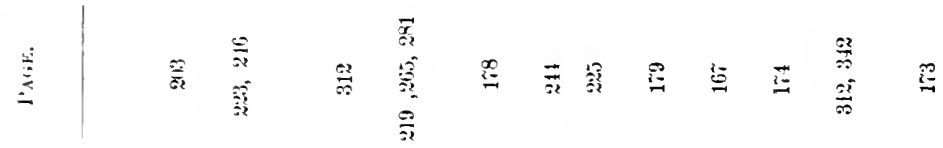

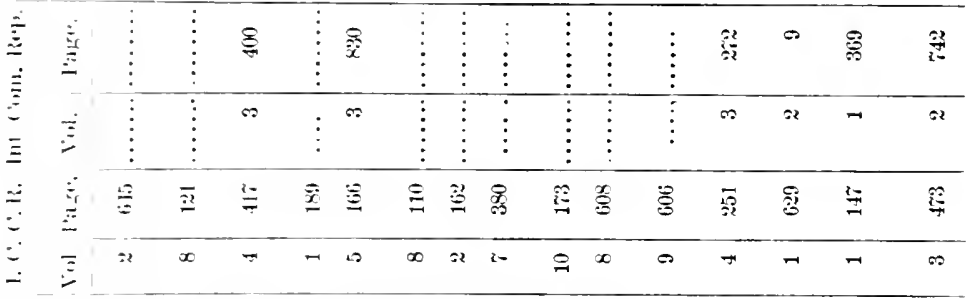

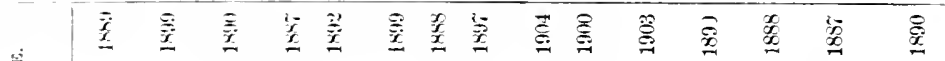

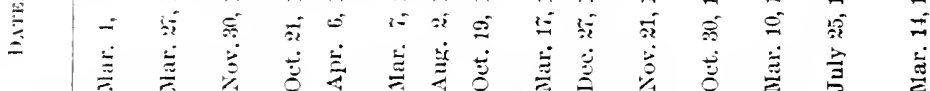

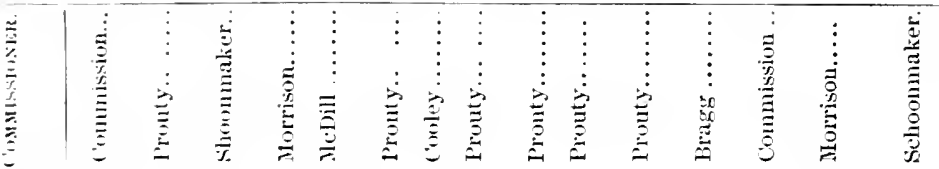

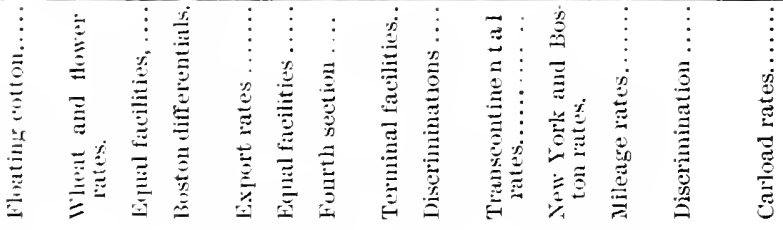

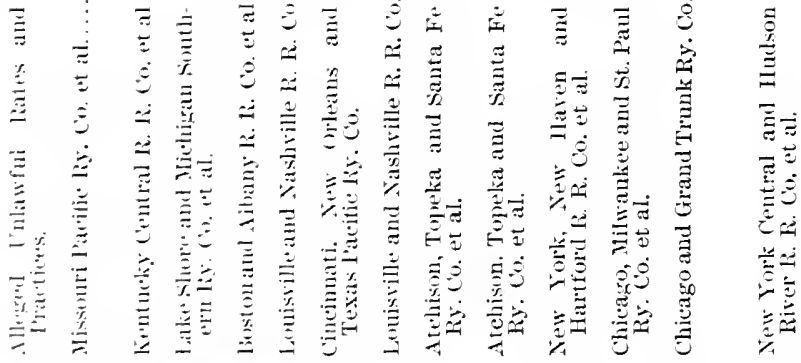

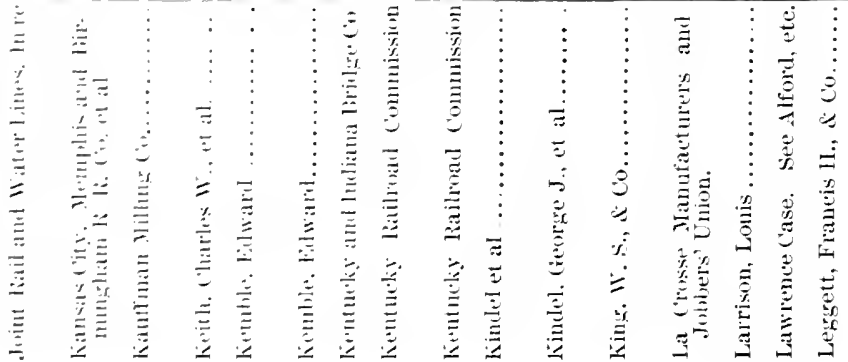




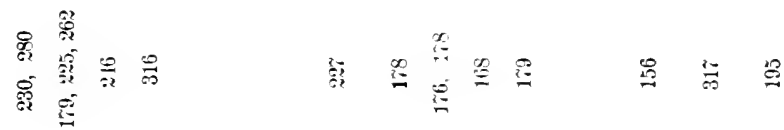

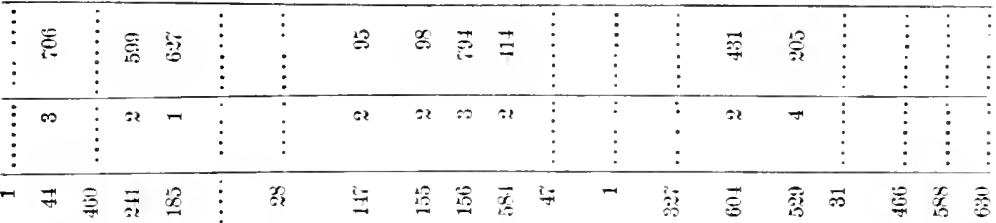

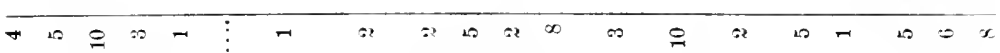

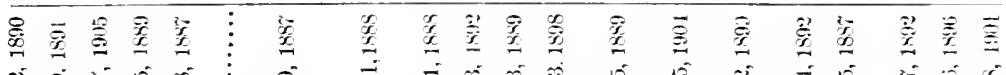

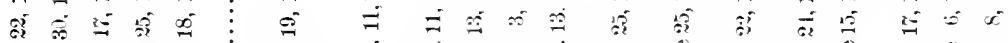

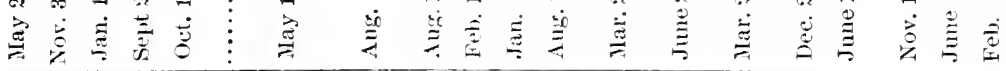

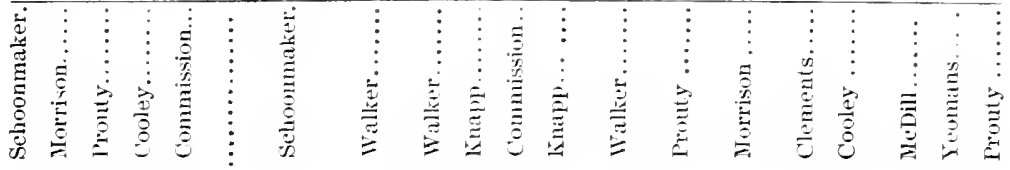

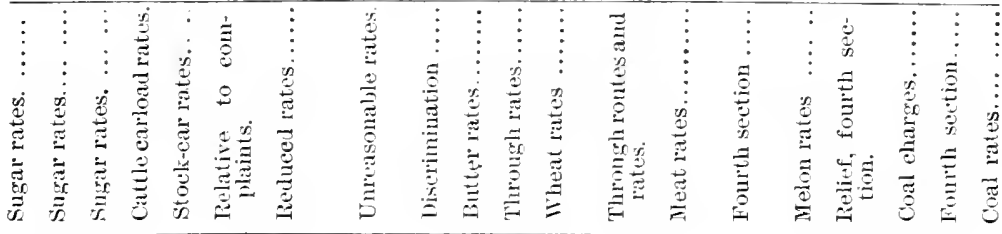

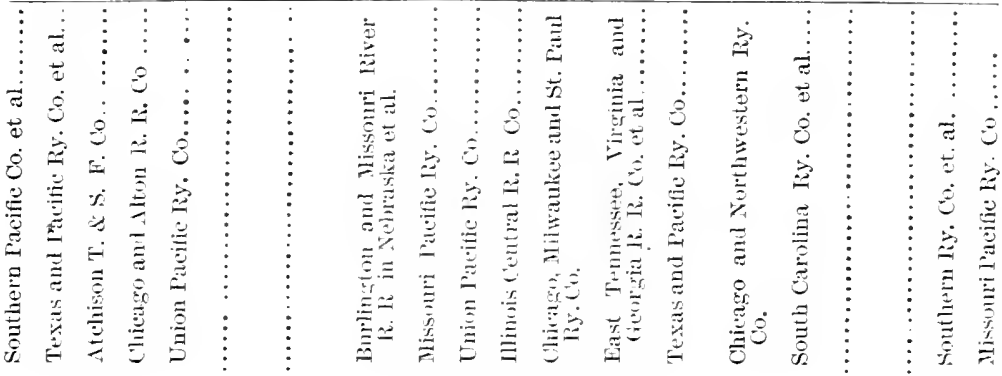

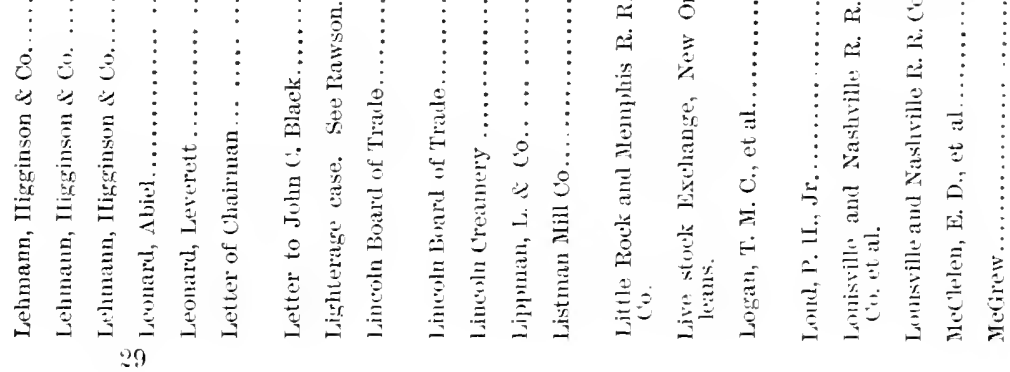




\begin{tabular}{|c|c|c|c|c|c|c|c|c|c|c|c|c|c|c|c|}
\hline 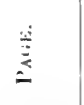 & 芦 & 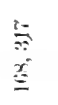 & 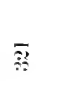 & i? & & 12 & 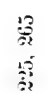 & 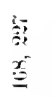 & 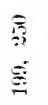 & 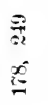 & 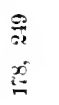 & 员 & $\frac{10}{50}$ & $\begin{array}{l}\text { 蛋 } \\
\hat{R} \\
\hat{R}\end{array}$ & 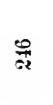 \\
\hline 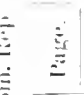 & 莯 & $\overrightarrow{\mathrm{B}}$ & $\vec{i}$ & : & & $\stackrel{2}{=}$ & $\begin{array}{l}\vdots \\
\vdots\end{array}$ & คै & - & $\hat{⿵ 门 丶 ~}$ & 刢 & $\mathscr{\check { \varnothing }}$ & & & \\
\hline$\dot{\bar{\Xi}}$ & $\because$ & $a x$ & $\Leftrightarrow$ & : & & $\therefore$ & $\vdots$ & $a 2$ & $c_{2}$ & $\pi$ & $\pi$ & $a_{2}$ & & & $\begin{array}{l}\bar{\vdots} \\
\vdots \\
\vdots\end{array}$ \\
\hline 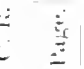 & 恶 & 㺃 & $\bar{x}$ & $\frac{1}{6}$ & 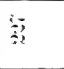 & 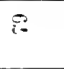 & $\vec{D}$ & 13 & $\rightarrow$ & $\stackrel{8}{3}$ & 袊 & 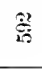 & 屏 & $\stackrel{3}{3}$ & 10 \\
\hline$\equiv$ & - & $\because$ & $\therefore$ & $=$ & - & $=$ & $\theta$ & $\therefore 2$ & $s 2$ & 10 & 10 & $\infty$ & $\Rightarrow$ & $\infty$ & 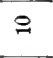 \\
\hline 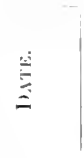 & 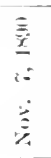 & 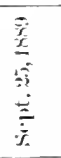 & 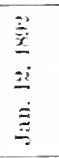 & 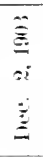 & 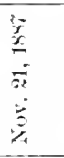 & 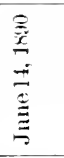 & 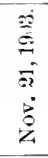 & 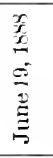 & 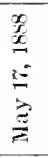 & 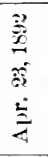 & 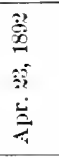 & 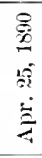 & $\begin{array}{l}\mathscr{8} \\
\sim \\
\infty \\
\dot{0} \\
\dot{3} \\
\dot{y}\end{array}$ & 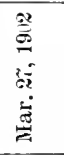 & 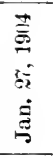 \\
\hline 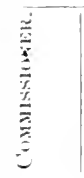 & 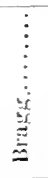 & $\stackrel{\bar{E}}{\stackrel{\bar{E}}{\bar{E}}}$ & $\begin{array}{c}\vdots \\
\vdots \\
\vdots \\
\vdots \\
-1\end{array}$ & 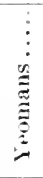 & 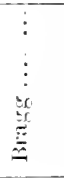 & 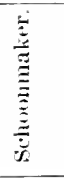 & $\begin{array}{c}\vdots \\
\vdots \\
\vdots \\
\overline{\hat{\Xi}} \\
\Delta\end{array}$ & $\begin{array}{l}\vdots \\
\vdots \\
\frac{2}{2} \\
\frac{2}{2}\end{array}$ & 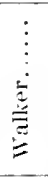 & 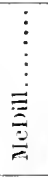 & 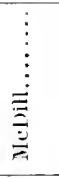 & 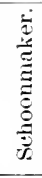 & 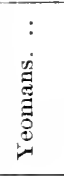 & 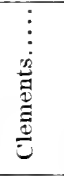 & 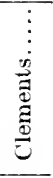 \\
\hline 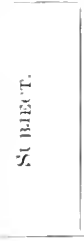 & 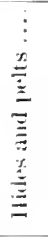 & $\begin{array}{c}\vdots \\
\vdots \\
\vdots \\
\vdots \\
\vdots \\
\vdots \\
\vdots \\
\vdots \\
\vdots \\
\vdots \\
\vdots \\
\vdots \\
\vdots\end{array}$ & 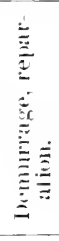 & 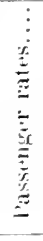 & 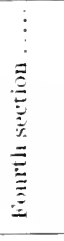 & 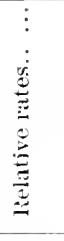 & 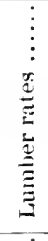 & 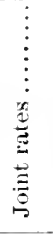 & 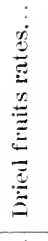 & 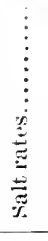 & 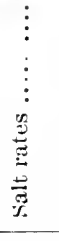 & 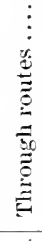 & 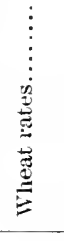 & 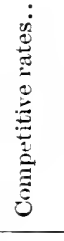 & 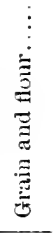 \\
\hline $\begin{array}{l}\vdots \\
\bar{\vdots} \\
\vdots \\
\vdots\end{array}$ & 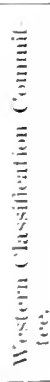 & 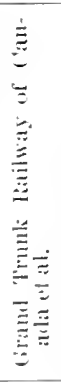 & 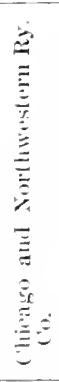 & 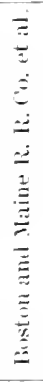 & 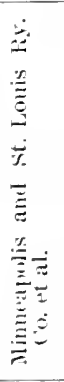 & 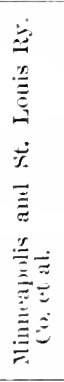 & 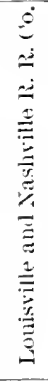 & 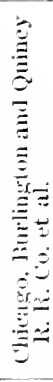 & 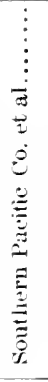 & 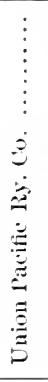 & 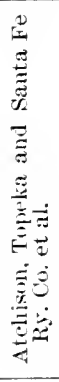 & 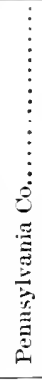 & 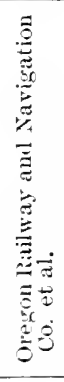 & 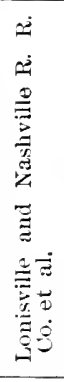 & 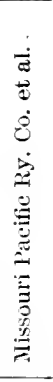 \\
\hline 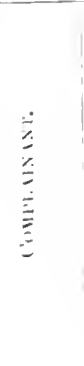 & 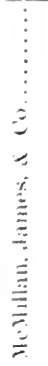 & 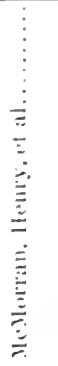 & 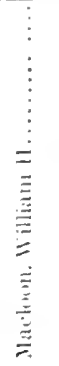 & $\begin{array}{l}\vdots \\
= \\
\vdots \\
\vdots \\
\vdots \\
\dot{E} \\
\vdots \\
\bar{z}\end{array}$ & 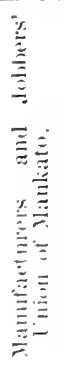 & $\begin{array}{l}0 \\
0 \\
0\end{array}$ & $\begin{array}{c}\vdots \\
\vdots \\
\vdots \\
\vdots \\
\vdots \\
\vdots \\
\bar{\Xi}\end{array}$ & 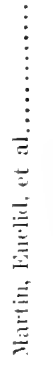 & 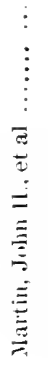 & 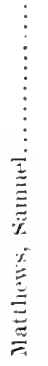 & 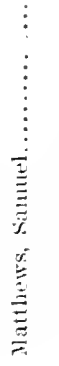 & 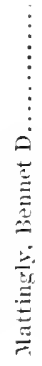 & 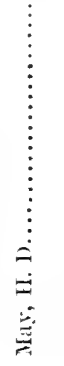 & 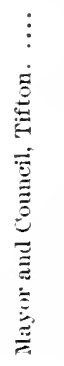 & 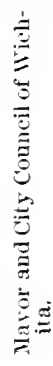 \\
\hline
\end{tabular}




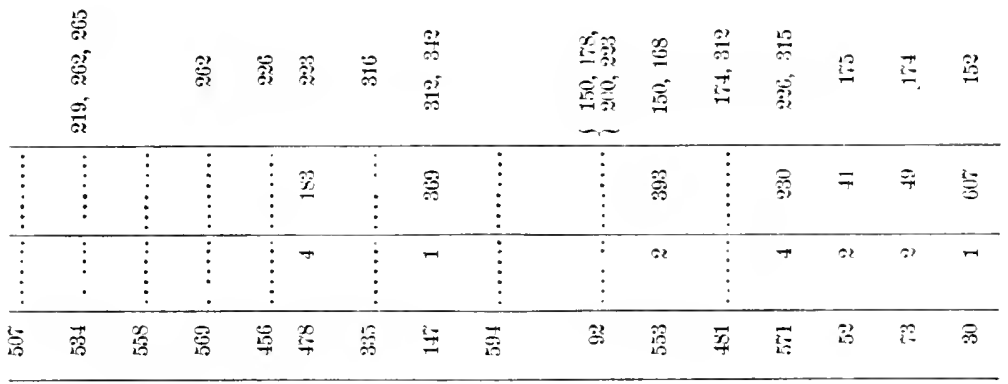

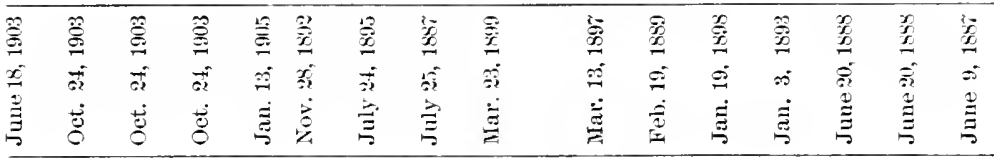

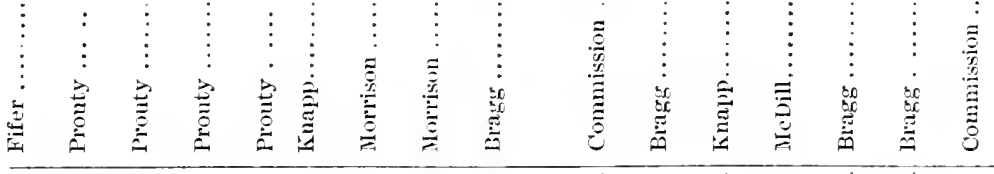

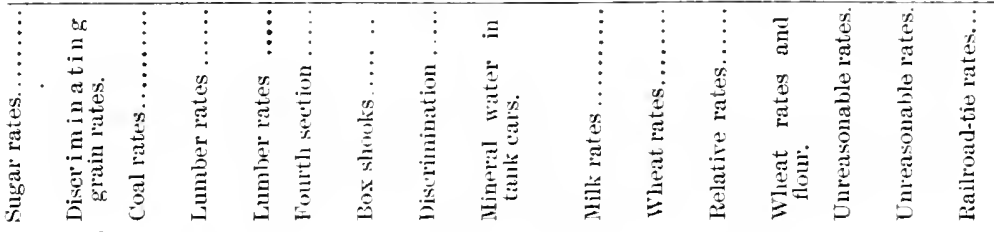

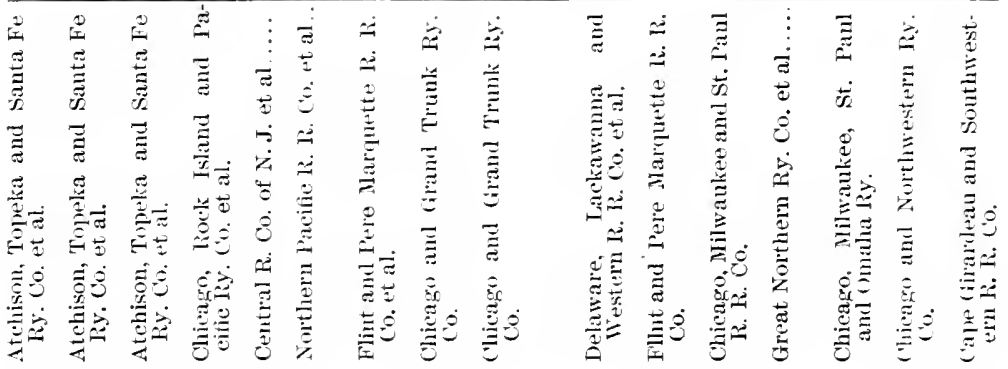

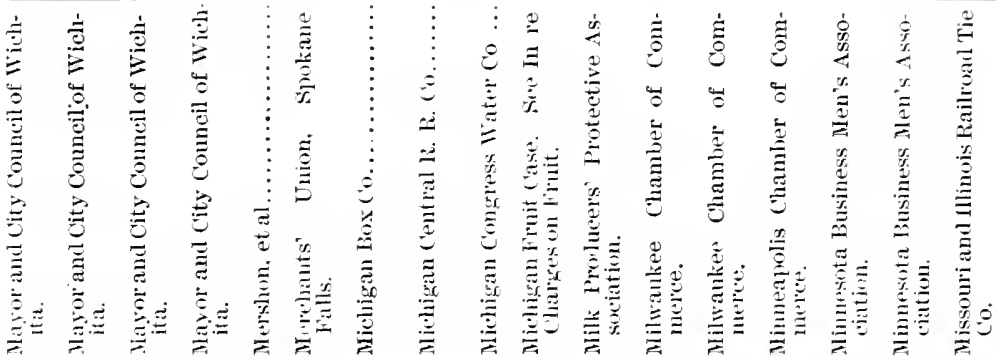




\begin{tabular}{|c|c|c|c|c|c|c|c|c|c|c|c|c|c|c|c|}
\hline 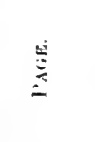 & : & & & $\equiv$ & 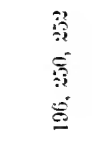 & $\overline{3}$ & & $\frac{9}{32}$ & $i$ & & 芌 & 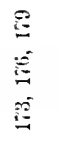 & & $\overrightarrow{3}$ & 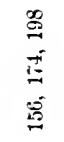 \\
\hline 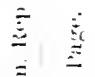 & & & & & & 孚 & & & & & & 蛋 & 标 & 飨 & \\
\hline$\dot{\bar{\Xi}} \bar{\Xi}$ & $\vdots$ & $\vdots$ & & & & 22 & $\vdots$ & & $\begin{array}{l}\vdots \\
\vdots\end{array}$ & & & $=2$ & al & $\infty$ & \\
\hline $\begin{array}{l}\because \quad \\
\because \quad\end{array}$ & 5 & $\stackrel{2}{7}$ & $\overline{3}$ & $\equiv$ & $3 x$ & 绐 & 畨 & $\overline{3}$ & $s_{0}$ & 羿 & $\overline{9}$ & 影 & $\overrightarrow{\text { ⿵乃 }}$ & $\overrightarrow{8}$ & 施 \\
\hline$\because 1 \quad \equiv$ & is & in & $=$ & $i$ & $\therefore=$ & $\because 2$ & $\infty$ & 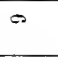 & $\theta$ & $a r$ & $\infty$ & $\theta$ & $\infty$ & $\nabla$ & 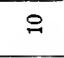 \\
\hline$\stackrel{5}{=}$ & 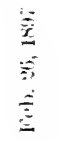 & 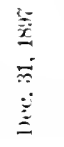 & 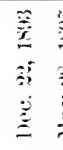 & 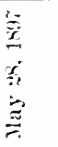 & 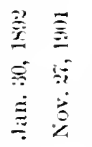 & 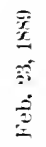 & 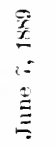 & 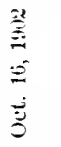 & $\begin{array}{l}\vec{\Xi} \\
\dot{\Xi} \\
\dot{0} \\
\dot{0}\end{array}$ & 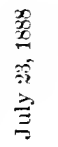 & 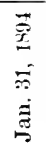 & 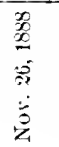 & $\begin{array}{l}\stackrel{8}{3} \\
= \\
= \\
\ddot{3}\end{array}$ & 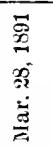 & 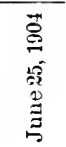 \\
\hline 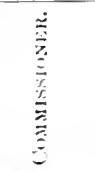 & 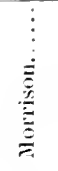 & 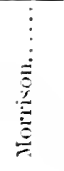 & 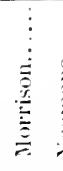 & 离 & 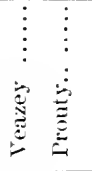 & 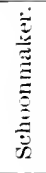 & 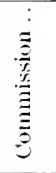 & 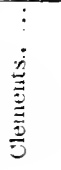 & 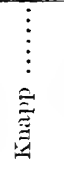 & 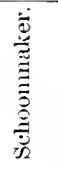 & 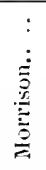 & 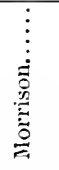 & 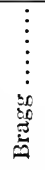 & 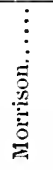 & $\stackrel{\vec{\Xi}}{\leftrightarrows}$ \\
\hline 容 & 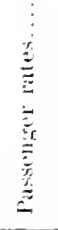 & 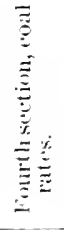 & 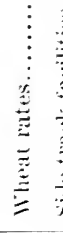 & 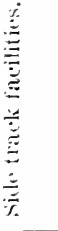 & 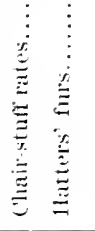 & 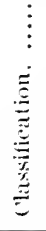 & 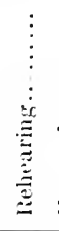 & 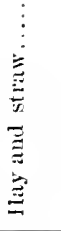 & 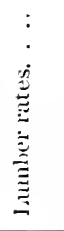 & 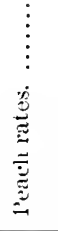 & 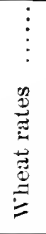 & 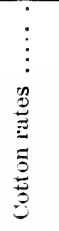 & 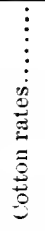 & 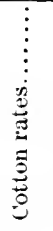 & 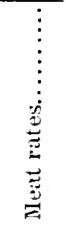 \\
\hline 咅 & 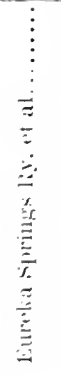 & 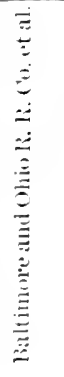 & 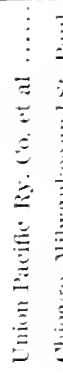 & 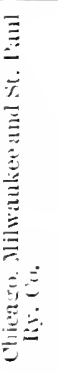 & 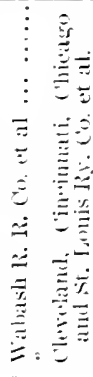 & 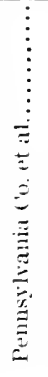 & 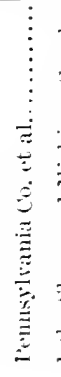 & 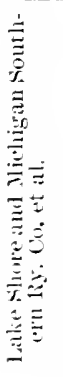 & 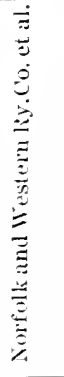 & 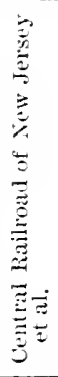 & 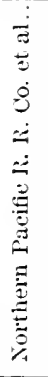 & 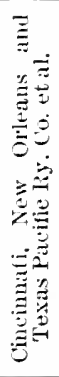 & 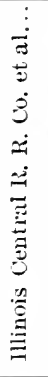 & 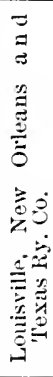 & 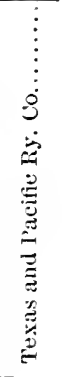 \\
\hline 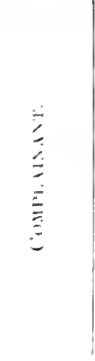 & 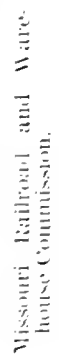 & $\begin{array}{c}\vdots \\
\vdots \\
\vdots \\
\Xi \\
\vdots \\
\vdots \\
\vdots \\
\bar{E} \\
\bar{E} \\
\bar{E}\end{array}$ & 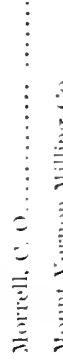 & 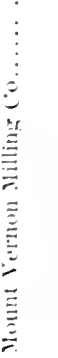 & 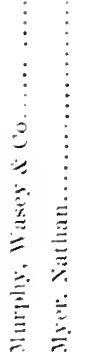 & 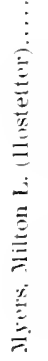 & 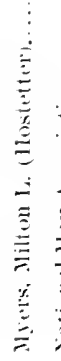 & 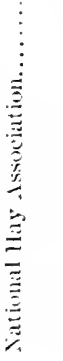 & 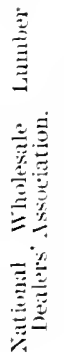 & 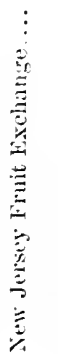 & 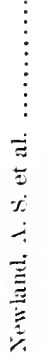 & 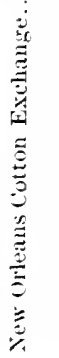 & 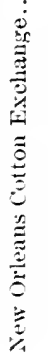 & 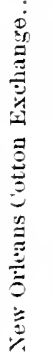 & 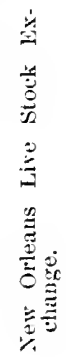 \\
\hline
\end{tabular}




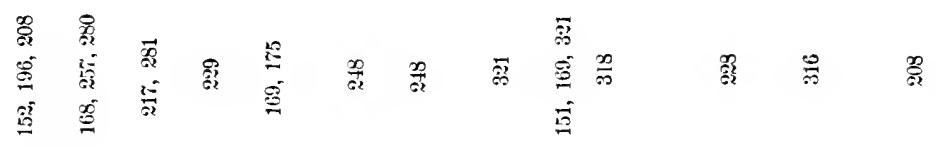

\begin{tabular}{|c|c|c|c|c|c|c|c|c|c|c|c|c|c|c|c|c|}
\hline & 5 & & 箈 & & R & & $\ddot{B g}$ & 롬 & & & & & & & $\stackrel{\infty}{=}$ & \\
\hline & $\infty$ & $\vdots$ & . & $\vdots$ & $\therefore$ & & & $\sigma$ & & & & 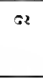 & & & - & \\
\hline & 9 & 筑 & 獣 & $\frac{3}{6}$ & $\overline{\widetilde{P}}$ & 䓃 & $\stackrel{19}{7}$ & $\stackrel{10}{=}$ & $\ddot{B}$ & 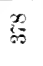 & $\stackrel{8}{9}$ & 瓷 & 活 & $\not 0$ & & $\vec{G} \equiv$ \\
\hline & $\pi$ & $\therefore$ & $m$ & is & $\Leftrightarrow$ & 10 & 2 & 10 & $\theta$ & 0 & $\theta$ & $\therefore$ & 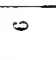 & & - & $\Leftrightarrow-$ \\
\hline & 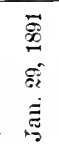 & 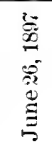 & 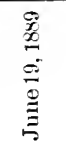 & 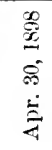 & 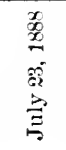 & 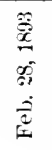 & 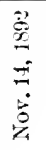 & 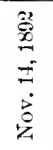 & 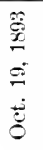 & 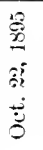 & 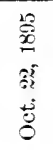 & 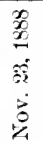 & 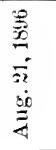 & 言 & 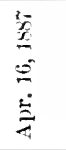 & 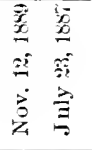 \\
\hline & 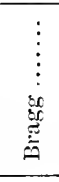 & 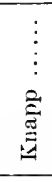 & 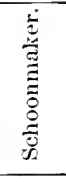 & $\begin{array}{r}\vdots \\
\vdots \\
\vdots \\
\vec{E} \\
\tilde{E} \\
\end{array}$ & 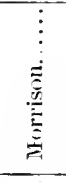 & 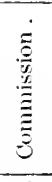 & 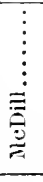 & & 兟 & & 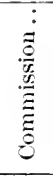 & & 哿 & 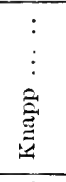 & 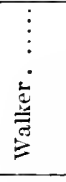 & 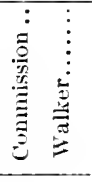 \\
\hline & 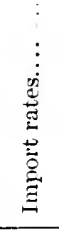 & 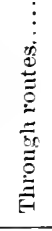 & 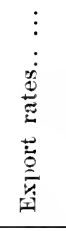 & & 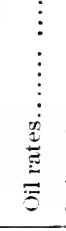 & 总 & 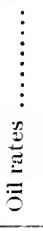 & 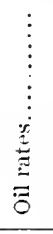 & 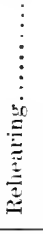 & 离 & 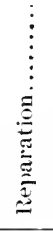 & & 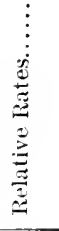 & 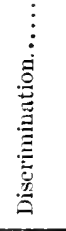 & 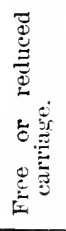 & 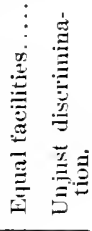 \\
\hline & 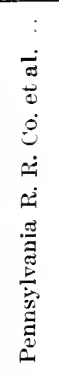 & 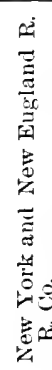 & 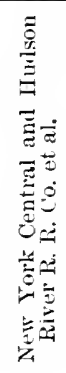 & 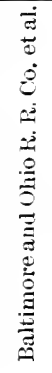 & 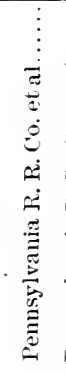 & 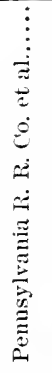 & 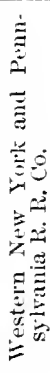 & 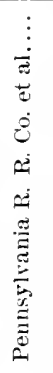 & 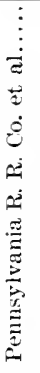 & & 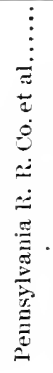 & 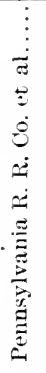 & 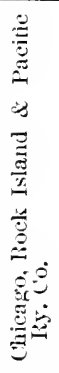 & 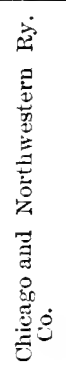 & & 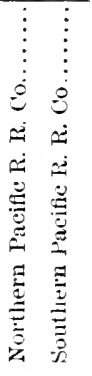 \\
\hline
\end{tabular}

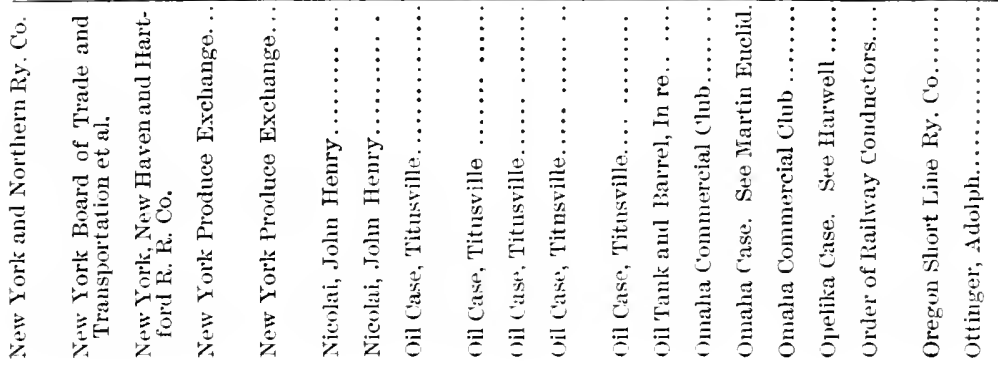




\begin{tabular}{|c|c|c|c|c|c|c|c|c|c|c|c|c|c|c|c|c|}
\hline$\frac{\vdots}{\vdots}$ & $\begin{array}{l}\overline{5} \\
\overline{2} \\
\overline{4}\end{array}$ & $\begin{array}{l}\frac{5}{3} \\
\frac{5}{53}\end{array}$ & $\stackrel{\infty}{\Xi}$ & $\equiv$ & $\bar{\Xi}$ & 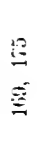 & & 苓 & & & $\overrightarrow{\vec{\theta}}$ & $\begin{array}{l}\frac{i}{i} \\
\frac{i 2}{2} \\
g\end{array}$ & & & 盗 & \\
\hline $\begin{array}{l}\bar{\Xi} \\
\bar{\Xi}\end{array}$ & 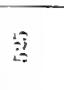 & $\begin{array}{c}\vdots \\
\vdots \\
\vdots\end{array}$ & $\vdots$ & $\vdots$ & $\hat{\xi}$ & 悉 & & : & & $\vdots$ & 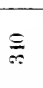 & 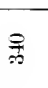 & & & & $\begin{array}{l}\vdots \\
\vdots\end{array}$ \\
\hline $\bar{\equiv}$ & - & $\vdots$ & $\begin{array}{l}\vdots \\
\vdots\end{array}$ & $\vdots$ & $\because$ & 22 & & $\vdots$ & & & $a r$ & $a x$ & & & & $\vdots$ \\
\hline $\begin{array}{l}\because \\
\because\end{array}$ & $\underline{x}$ & $\frac{x}{2}$ & $\frac{x}{62}$ & $E$ & 3 & $\overline{\underline{\underline{S}}}$ & 商 & 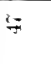 & & 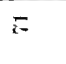 & $\stackrel{5}{5}$ & 管 & & & 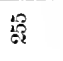 & 䠹 \\
\hline$\because \quad \dot{\Xi}$ & $=$ & $=$ & $i-$ & $\infty$ & $n$ & $\Rightarrow$ & $B$ & $\equiv$ & & $x$ & 02 & ax & & & 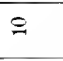 & $\infty$ \\
\hline 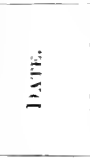 & 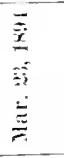 & 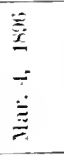 & 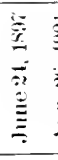 & 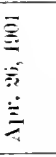 & 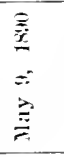 & 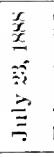 & 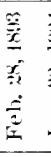 & 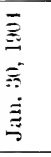 & & 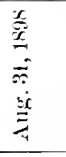 & 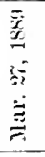 & 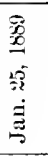 & & & 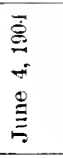 & 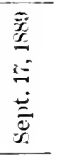 \\
\hline 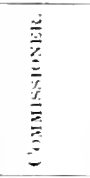 & 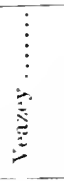 & 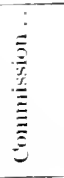 & 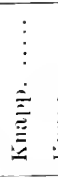 & $\begin{array}{c}\vdots \\
\vdots \\
\vdots \\
\vdots \\
\vdots \\
\vdots \\
\bar{\Xi}\end{array}$ & 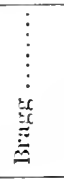 & 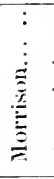 & 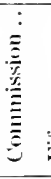 & $\begin{array}{c}\vdots \\
\vdots \\
\vdots \\
\vdots \\
\vdots \\
\vdots \\
\vdots\end{array}$ & & 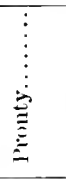 & 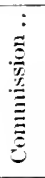 & $\begin{array}{c}\vdots \\
\vdots \\
\vdots \\
3 \\
\frac{3}{3}\end{array}$ & & & $\begin{array}{c}\vdots \\
\vdots \\
\vdots \\
\vdots \\
\text { 离 }\end{array}$ & 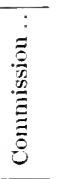 \\
\hline$\frac{5}{\bar{x}}$ & 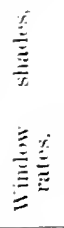 & 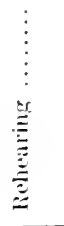 & 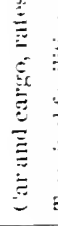 & 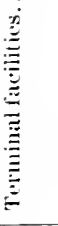 & 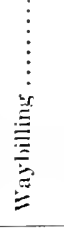 & 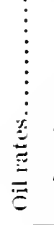 & 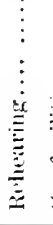 & 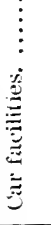 & & 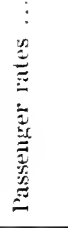 & $\begin{array}{l}\vdots \\
\vdots \\
\vdots \\
\vdots\end{array}$ & $\begin{array}{c}\vdots \\
\vdots \\
\vdots \\
\vdots \\
\vdots \\
\vdots\end{array}$ & & & 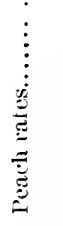 & 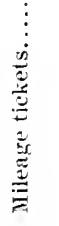 \\
\hline 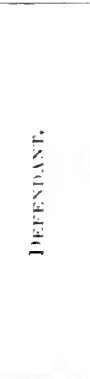 & 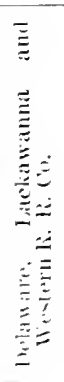 & 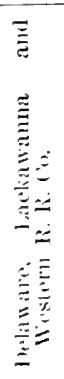 & 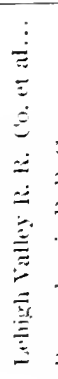 & 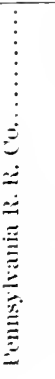 & 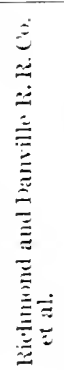 & 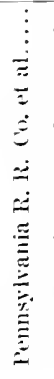 & 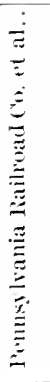 & 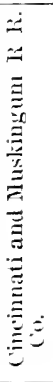 & & 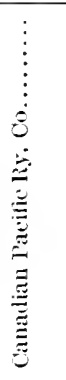 & & $\begin{array}{c} \\
\vdots \\
\vdots \\
\vdots \\
\vdots \\
\vdots \\
\vdots \\
\vdots \\
\vdots \\
\vdots\end{array}$ & & & 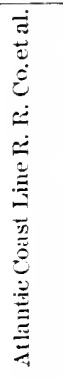 & 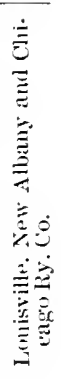 \\
\hline 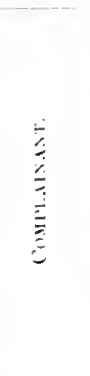 & $\begin{array}{c}\vdots \\
\vdots \\
\vdots \\
\vdots \\
\vdots \\
\vdots \\
\equiv \\
\vdots \\
\vdots \\
\vdots \\
\vdots \\
\vdots \\
\vdots \\
\vdots \\
\vdots\end{array}$ & 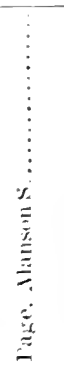 & 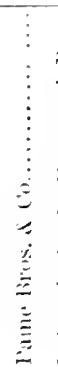 & 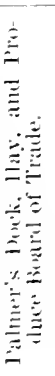 & $\begin{array}{c}\vdots \\
\vdots \\
\vdots \\
\vdots \\
\vdots \\
\vdots \\
\vdots \\
\vdots \\
\vdots \\
\vdots \\
\bar{\Xi}\end{array}$ & 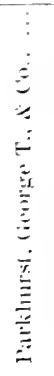 & 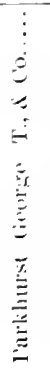 & 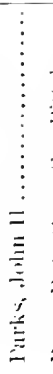 & 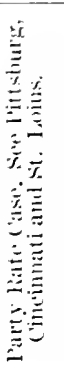 & 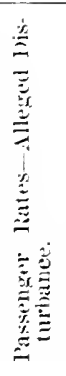 & 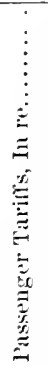 & 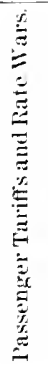 & 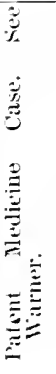 & 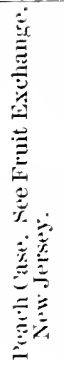 & 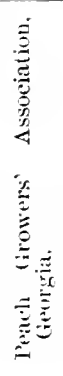 & 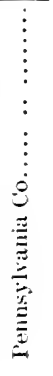 \\
\hline
\end{tabular}




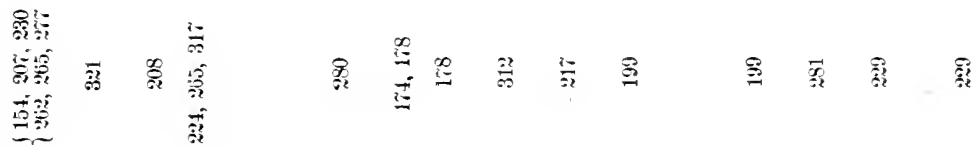

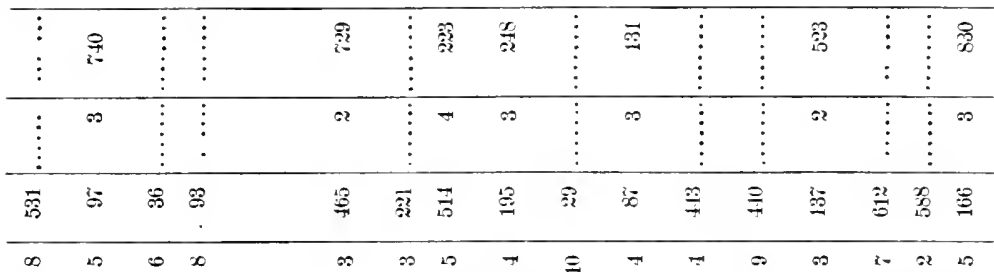

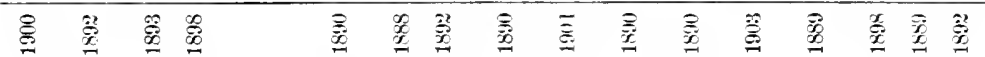

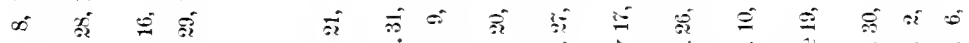

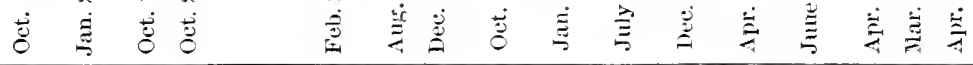

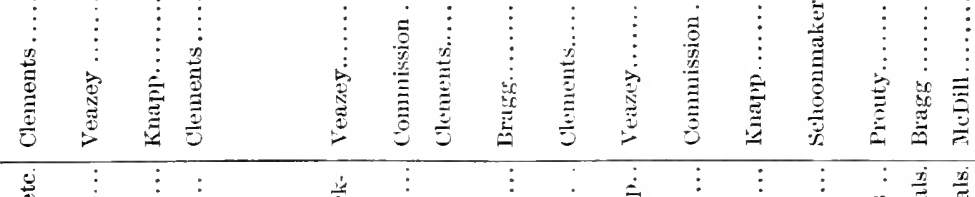

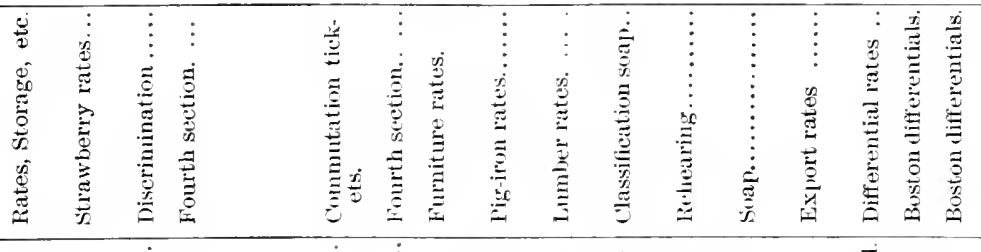

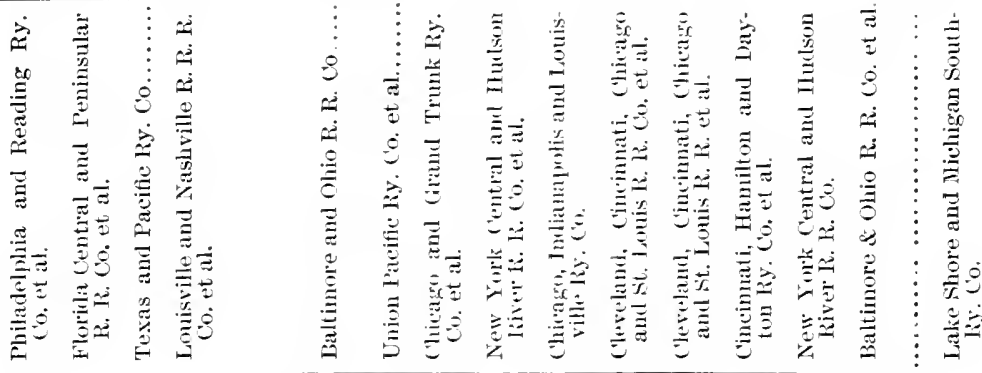

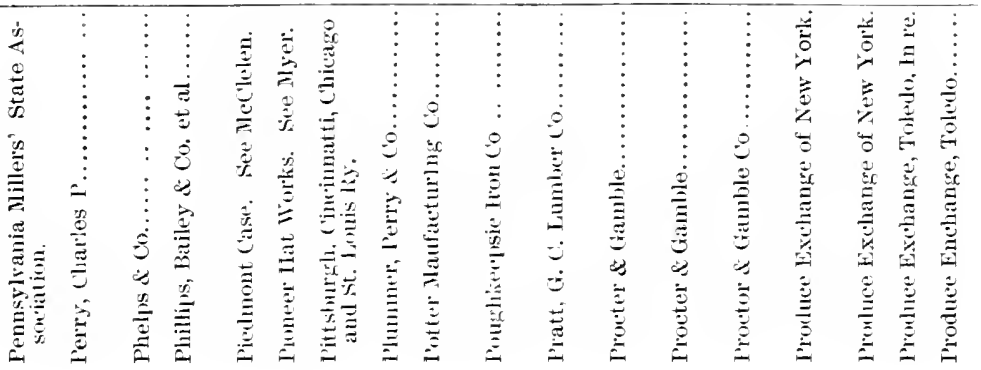




\begin{tabular}{|c|c|c|c|c|c|c|c|c|c|c|c|c|c|c|}
\hline 突 & $\hat{\imath}$ & 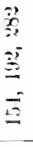 & & & 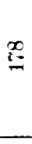 & 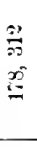 & & $\underline{\underline{t}}$ & ? $=$ & 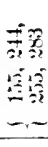 & $\frac{\theta}{m}$ & 5 & & : \\
\hline & $\begin{array}{l}\vdots \\
\vdots\end{array}$ & 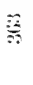 & $\vdots$ & $\begin{array}{l}\vdots \\
\vdots\end{array}$ & $\vdots$ & 羿 & $\vdots$ & 焉 & $\vdots$ & $\vdots$ & $\underline{x}$ & : & & \\
\hline $\begin{array}{l}\Xi \\
\equiv\end{array}$ & $\vdots$ & - & : & : & $\begin{array}{l}\vdots \\
\vdots\end{array}$ & $\infty$ & & $\nabla$ & ( & $\vdots$ & 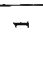 & & & $\vdots$ \\
\hline$\stackrel{\tilde{z}}{\tilde{E}}$ & 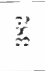 & 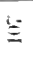 & $\therefore$ & 器 & 3 & $\cong$ & 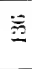 & 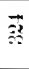 & $\stackrel{\vec{Z}}{\rightarrow}$ & 跑 & $\infty$ & $\frac{5}{5}$ & $\frac{9}{6}$ & 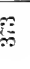 \\
\hline 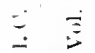 & $\theta$ & - & $\Xi$ & - & is & is & $\Delta$ & 10 & $i=$ & 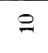 & - & 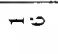 & $\therefore 2$ & os \\
\hline
\end{tabular}

\begin{tabular}{|c|c|c|c|c|c|c|c|c|c|c|c|c|c|}
\hline & 气 & 8 & $\equiv$ & $\frac{x}{x}$ & 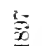 & $\overline{\underline{x}}$ & 蓠 & 籇 & 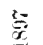 & $\vec{\Xi}$ & 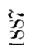 & $\vec{D}$ & 䇾 \\
\hline & $\therefore$ & 3 & $\therefore$ & $\therefore$ & 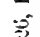 & $\overline{x_{j}}$ & $\dot{\theta}$ & $=$ & 8 & $i=$ & $\cong$ & $x^{-}$ & $\bar{m}=x_{20}^{\infty}$ \\
\hline & $\doteq$ & 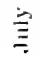 & 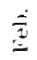 & $\dot{\square}$ & 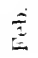 & $\dot{\leftrightarrows}$ & $\dot{\overrightarrow{1}}$ & 安 & نे & 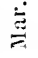 & 泀 & 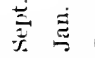 & $\dot{\vec{E}}$ \\
\hline
\end{tabular}

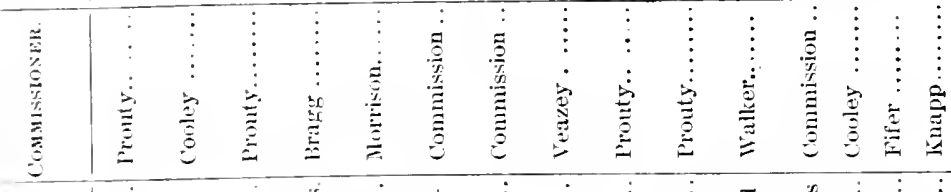

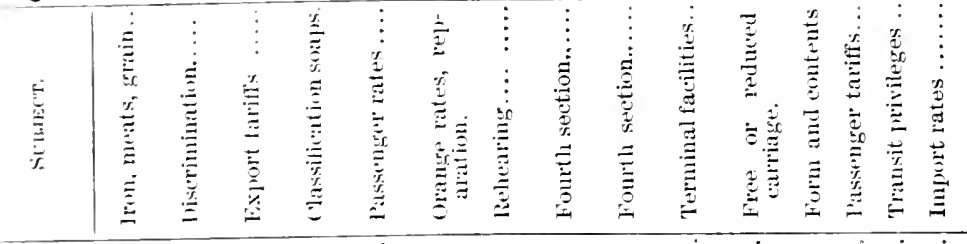

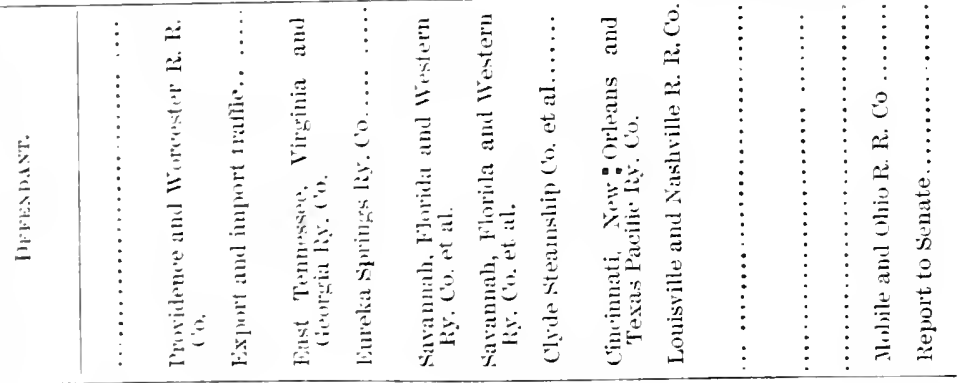

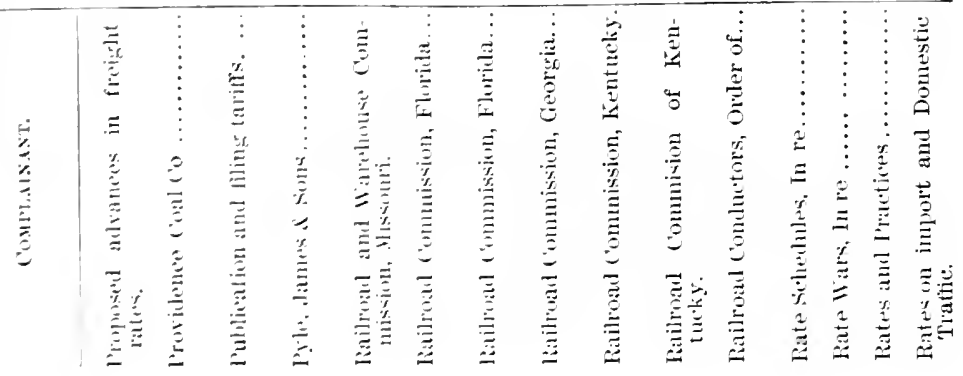




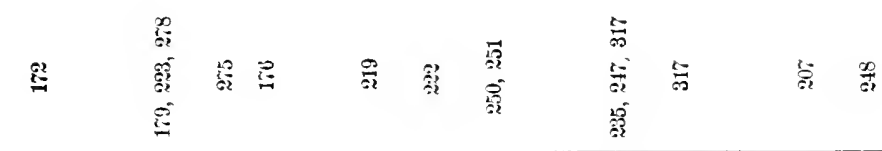

\begin{tabular}{|c|c|c|c|c|c|c|c|c|c|c|c|c|c|c|}
\hline & 8 & & & & Fे & $\vdots$ & $\stackrel{9}{30}$ & 总 & & $\hat{n}$ & 总 & & $\bar{D}$ & $\tilde{*}$ \\
\hline & 7 & $\vdots$ & $\vdots$ & & 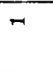 & $\vdots$ & $a z$ & - & $\begin{array}{l}\vdots \\
\vdots\end{array}$ & 7 & $a$ & & $\infty$ & $\rightarrow$ \\
\hline 范 总 & 蛋 & $\overline{3}$ & 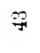 & $\frac{9}{32}$ & 锅 & $\vec{x}$ & 急 & 确 & $\ddot{\theta}$ & 管 & -7 & 芠 & 筂 & 落 \\
\hline
\end{tabular}

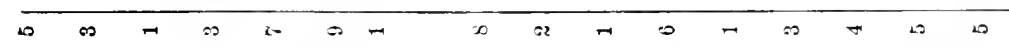

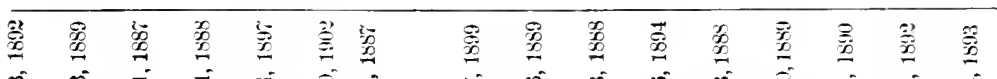

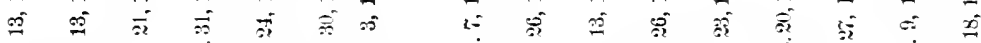

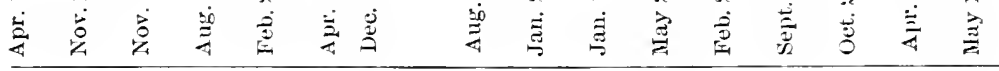

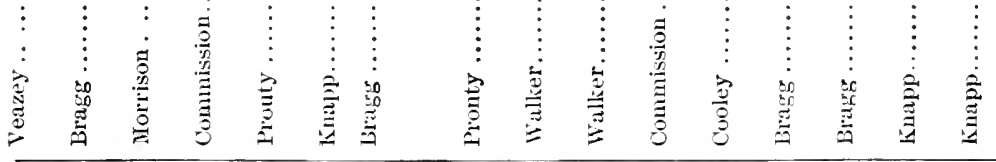

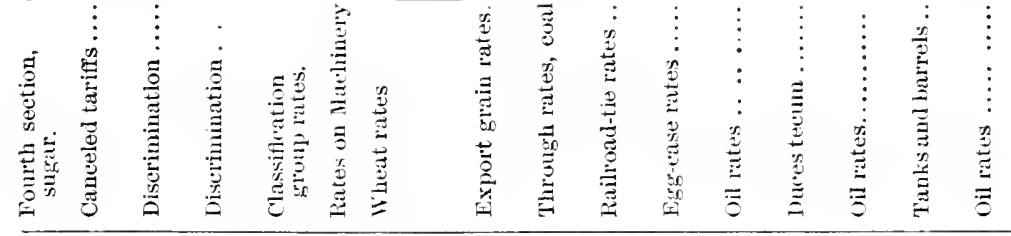

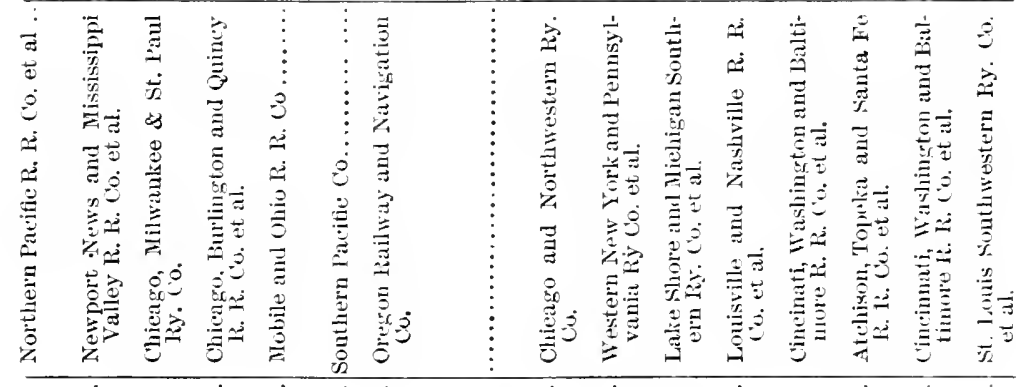

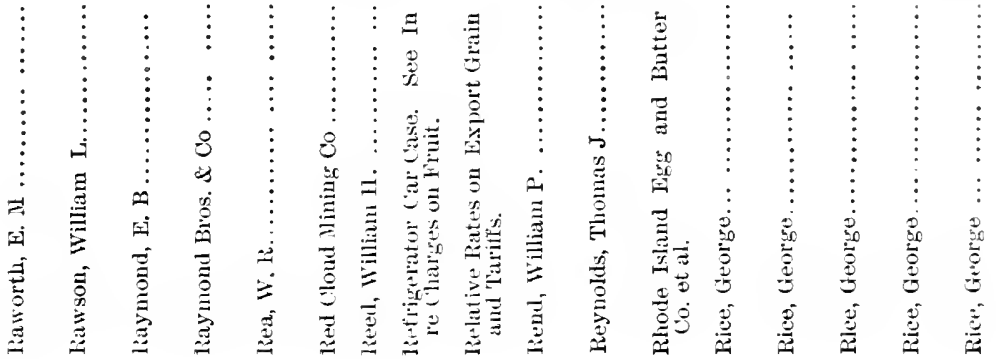




\begin{tabular}{|c|c|c|c|c|c|c|c|c|c|c|c|c|c|c|c|}
\hline 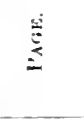 & & & 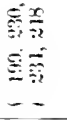 & & & 䇾 & $\stackrel{x}{=}$ & 草 & 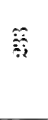 & 克 & & & $\frac{1}{\circ}$ & 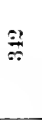 & $\stackrel{\vec{x}}{\ddot{m}}$ \\
\hline $\begin{array}{l}\vdots \\
\equiv\end{array}$ & & & $\ddot{z}$ & & & 在 & $\hat{\imath}$ & $x$ & $\underset{i=}{x}$ & $\vdots$ & $\begin{array}{l} \\
\vdots\end{array}$ & $\vdots$ & $\begin{array}{l}\vdots \\
\vdots\end{array}$ & 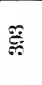 & $\hat{\hat{\sigma}_{2}}$ \\
\hline$\doteq \equiv$ & . & & $\Leftrightarrow$ & & & - & - & - & - & : & $\vdots \vdots$ & : & $\vdots$ & $r$ & - \\
\hline$\because \quad$ & $\overline{\mathrm{B}}$ & $\ddot{i}$ & $\overline{9}$ & 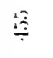 & 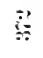 & $\pi$ & 要 & $\overline{8}$ & 总 & $r$ & $\$$ & 类 & 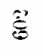 & $\stackrel{0}{\underline{\Xi}}$ & $\widehat{\overline{3}}$ \\
\hline$\because \quad \equiv$ & $\therefore$ & $\approx$ & $\vec{T}$ & $=$ & - & -7 & - & - & - & $\infty$ & $\therefore$ & $\varphi$ & $e$ & - & -0 \\
\hline$\stackrel{5}{E}$ & 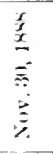 & 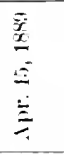 & 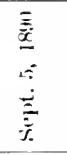 & 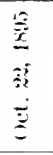 & 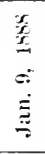 & 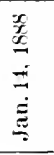 & 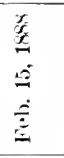 & 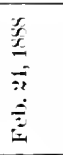 & 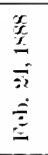 & 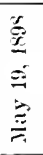 & 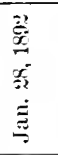 & 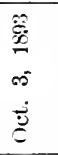 & 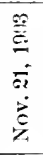 & 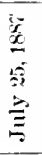 & 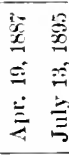 \\
\hline 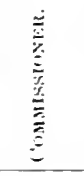 & 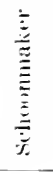 & 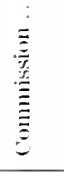 & 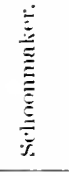 & 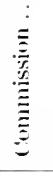 & 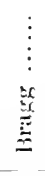 & 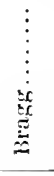 & 泀 & $\begin{array}{c}\vdots \\
\vdots \\
\vdots \\
0 \\
\bar{E} \\
=\end{array}$ & 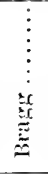 & 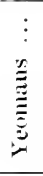 & 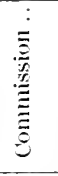 & 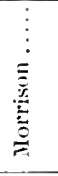 & 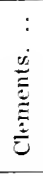 & 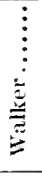 & 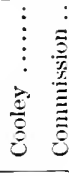 \\
\hline 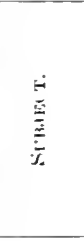 & 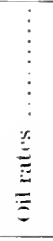 & 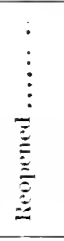 & 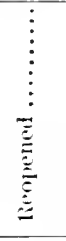 & 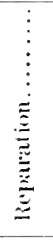 & 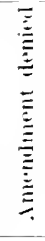 & 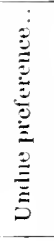 & 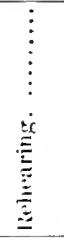 & 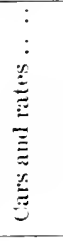 & 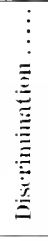 & 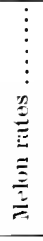 & 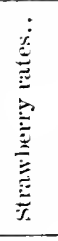 & 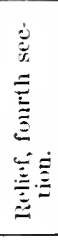 & 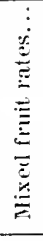 & 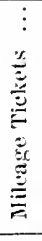 & 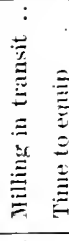 \\
\hline 柆 & 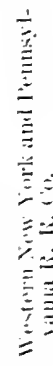 & 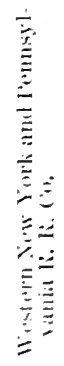 & 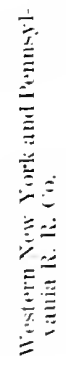 & 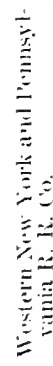 & 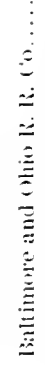 & 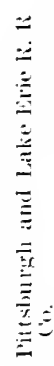 & 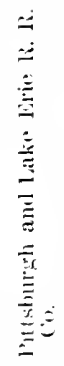 & 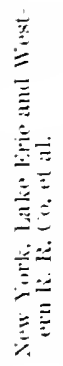 & 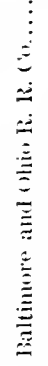 & 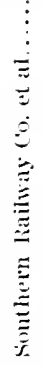 & 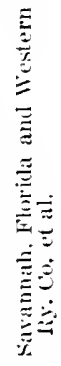 & $\begin{array}{l}\vdots \\
\vdots \\
\vdots \\
\vdots\end{array}$ & 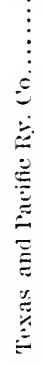 & 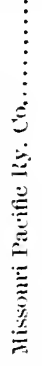 & $\begin{array}{l}\vdots \\
\vdots \\
\vdots\end{array}$ \\
\hline
\end{tabular}

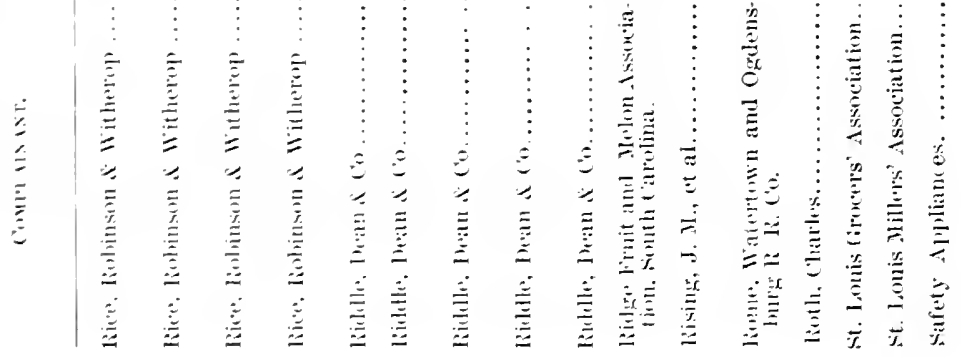




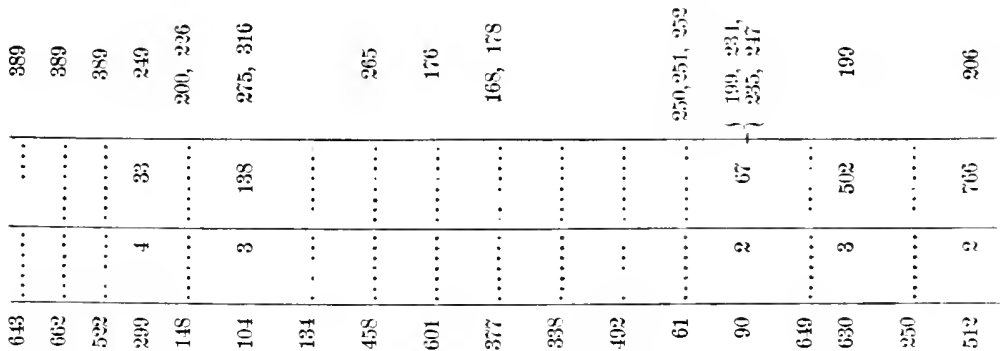

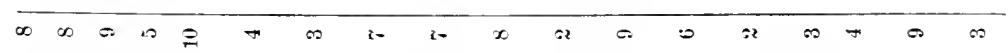

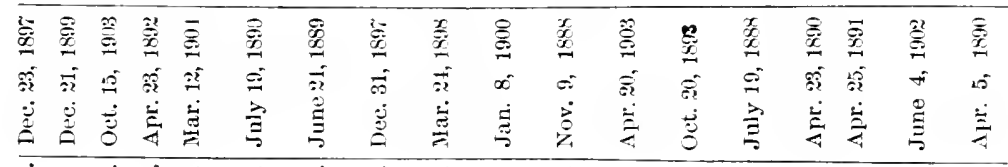

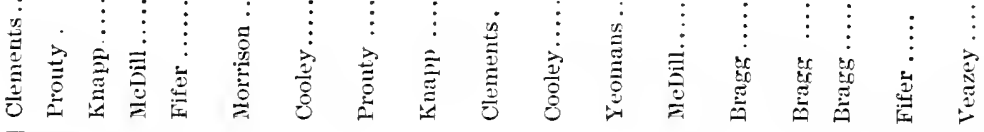

\begin{tabular}{|c|c|c|c|c|c|c|c|c|c|c|c|c|c|}
\hline 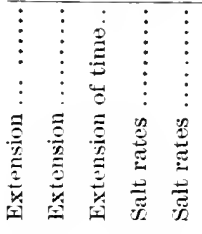 & 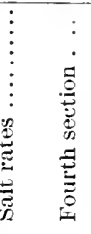 & 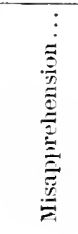 & 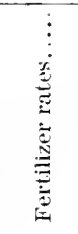 & 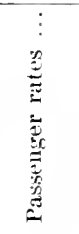 & 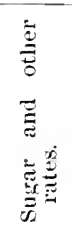 & 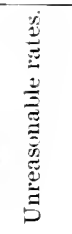 & 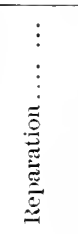 & 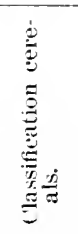 & 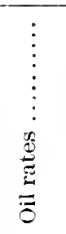 & 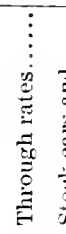 & 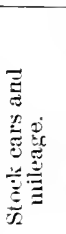 & 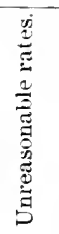 & \\
\hline$\Xi$ & 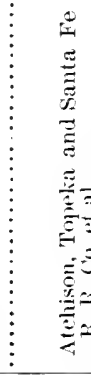 & 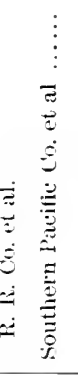 & 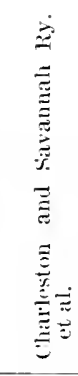 & 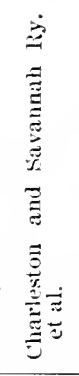 & 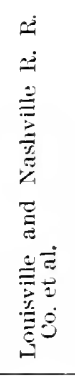 & 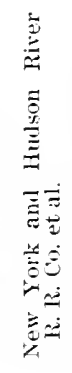 & 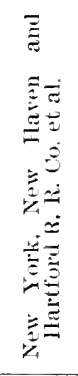 & 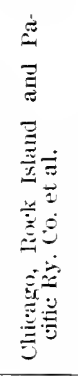 & 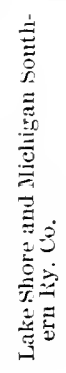 & & 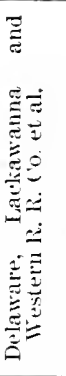 & 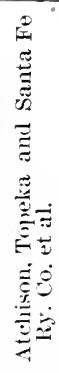 & \\
\hline
\end{tabular}

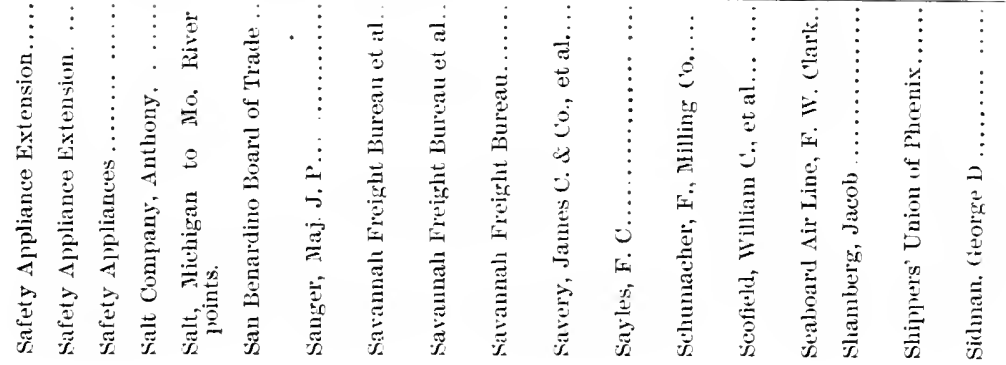




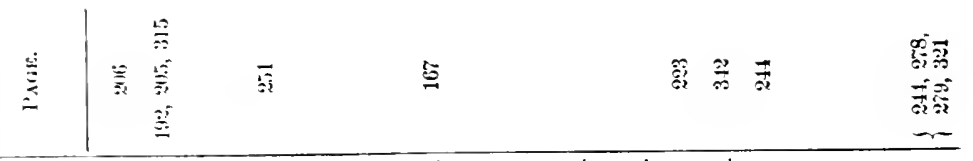

\begin{tabular}{|c|c|c|c|c|c|c|c|c|c|c|c|}
\hline 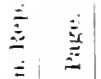 & $\stackrel{\Xi}{*} \Xi$ & 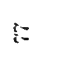 & & & & & $\widetilde{\tilde{X}}$ & $\frac{19}{10}$ & & & \\
\hline \begin{tabular}{ll|l}
$\bar{\Xi}$ & $\dot{\Xi}$ \\
\end{tabular} & $\because-$ & $\infty$ & & & & & $r$ & 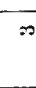 & & & \\
\hline$\because \quad$ & 焉 & $F$ & 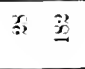 & $=\bar{x}$ & $\vec{\forall}$ & $\vec{\sigma}$ & $\begin{array}{l}x \\
\frac{x}{3}\end{array}$ & $\bar{a}$ & & 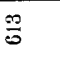 & 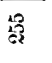 \\
\hline$\therefore \quad \bar{\Xi}$ & $\therefore-$ & - & -0 & $\vec{H} 0$ & $s 2$ & $\infty$ & $\therefore x$ & + & & $\infty$ & $\pi$ \\
\hline 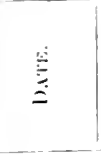 & 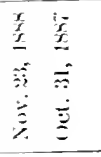 & 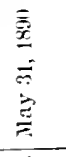 & 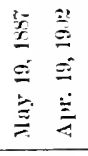 & 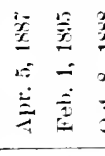 & 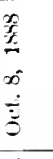 & 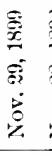 & 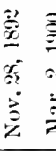 & $\begin{array}{l}3 \\
3 \\
3\end{array}$ & & 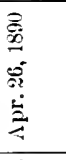 & 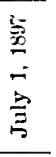 \\
\hline 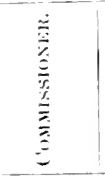 & 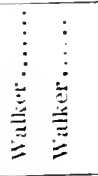 & 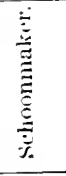 & 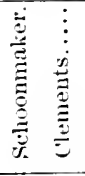 & 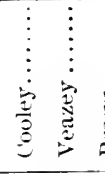 & 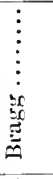 & 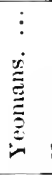 & 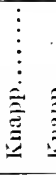 & & & 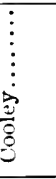 & 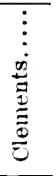 \\
\hline 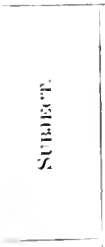 & 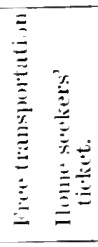 & 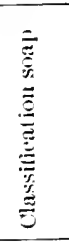 & 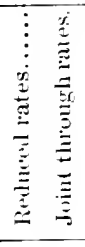 & 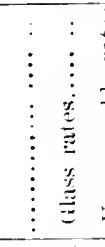 & 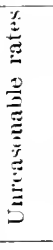 & 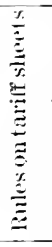 & 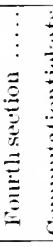 & & $\frac{1}{3}$ & 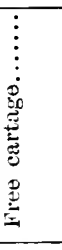 & 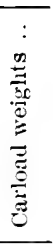 \\
\hline 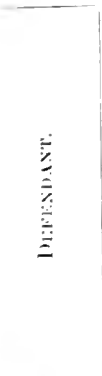 & 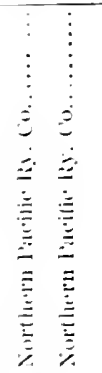 & 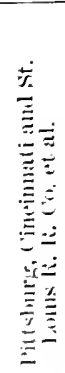 & 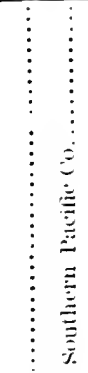 & 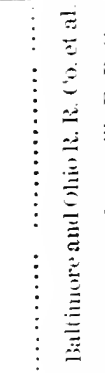 & 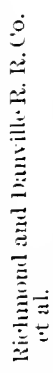 & 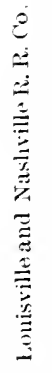 & 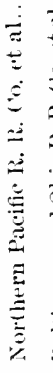 & & 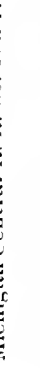 & 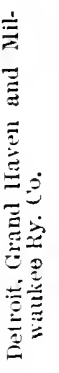 & 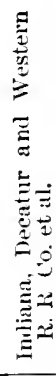 \\
\hline
\end{tabular}

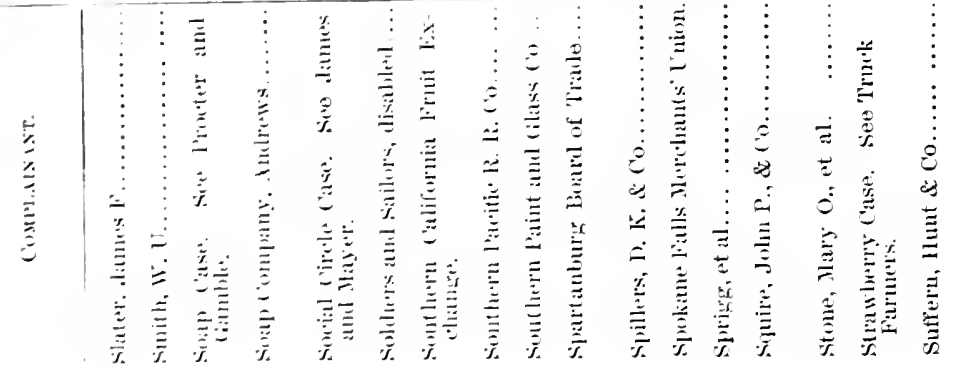




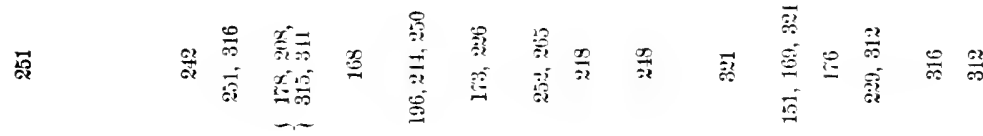

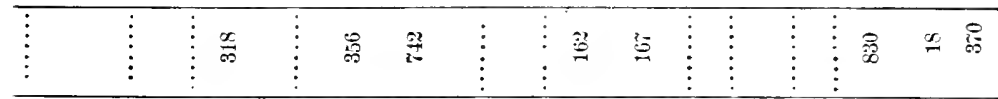

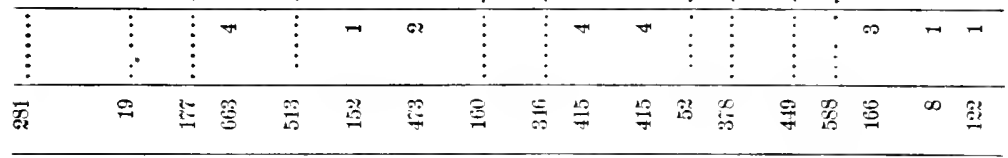

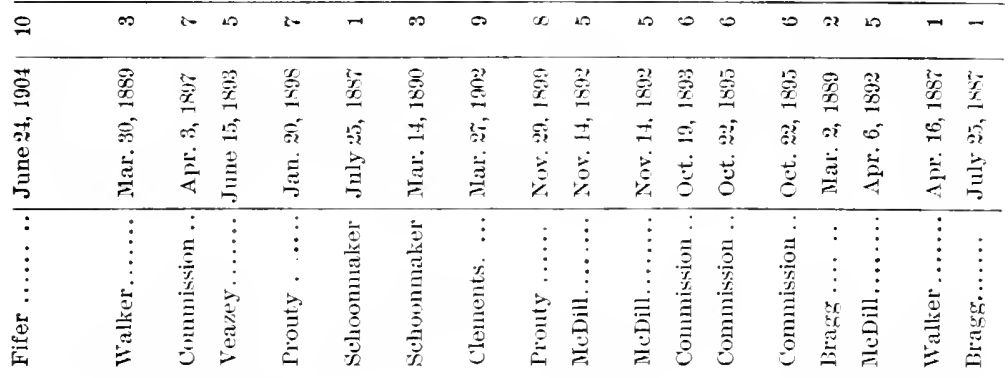

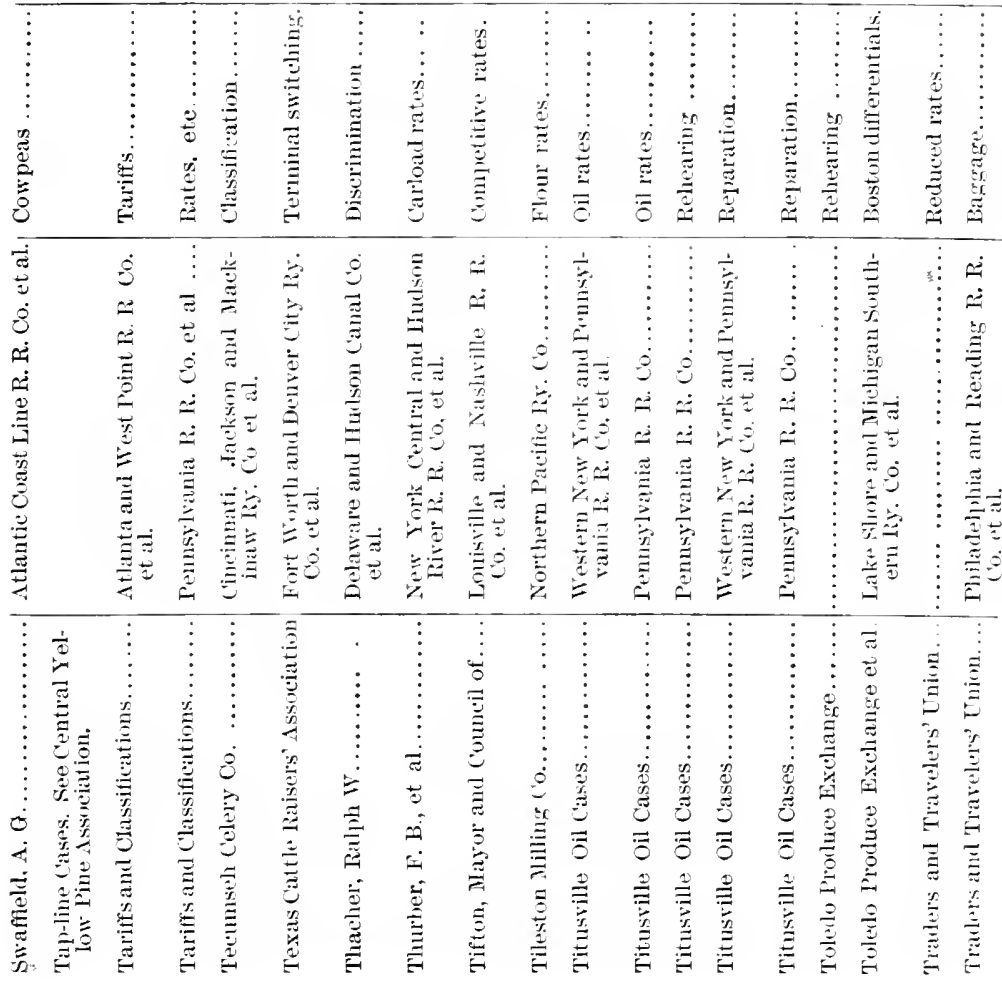




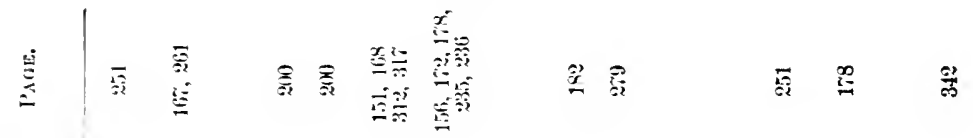

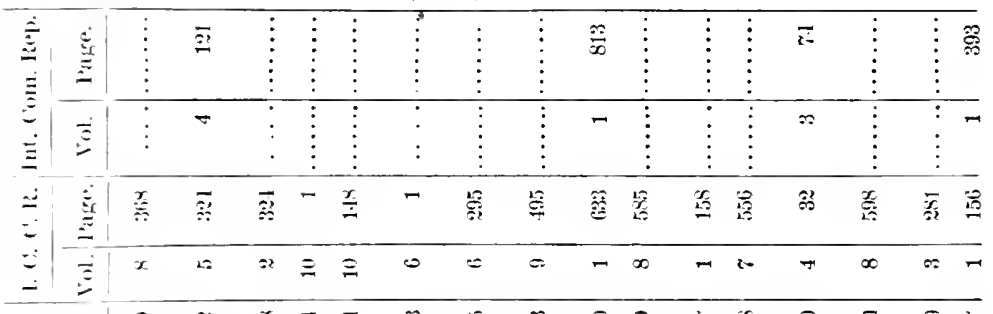

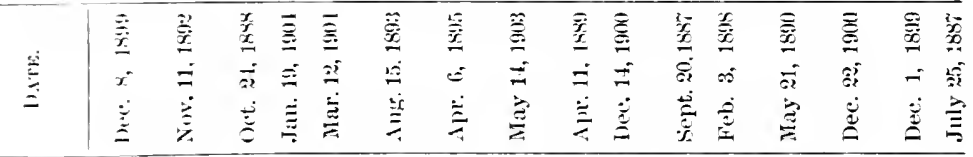

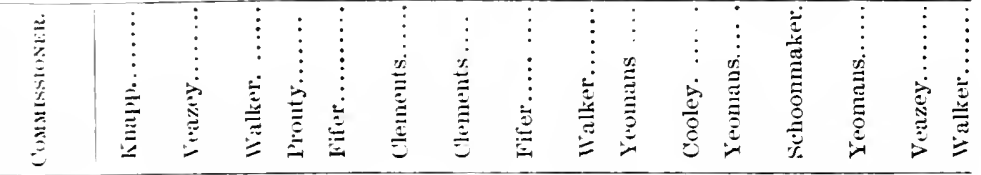

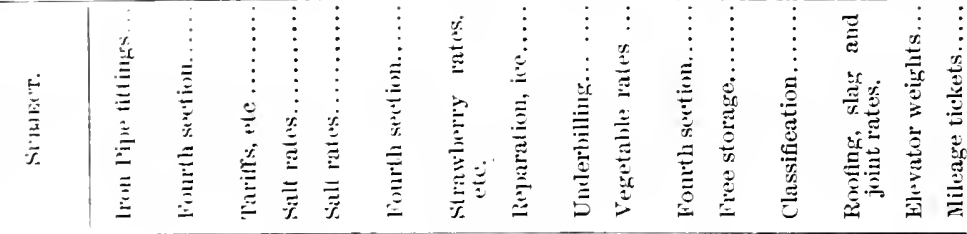

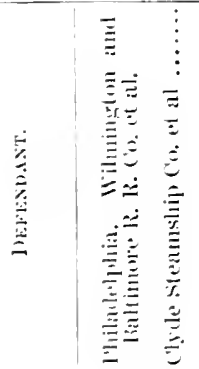

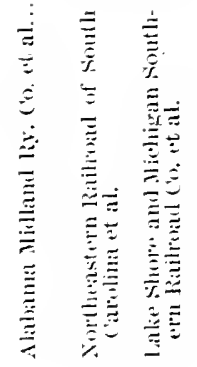

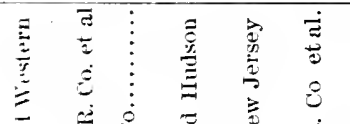

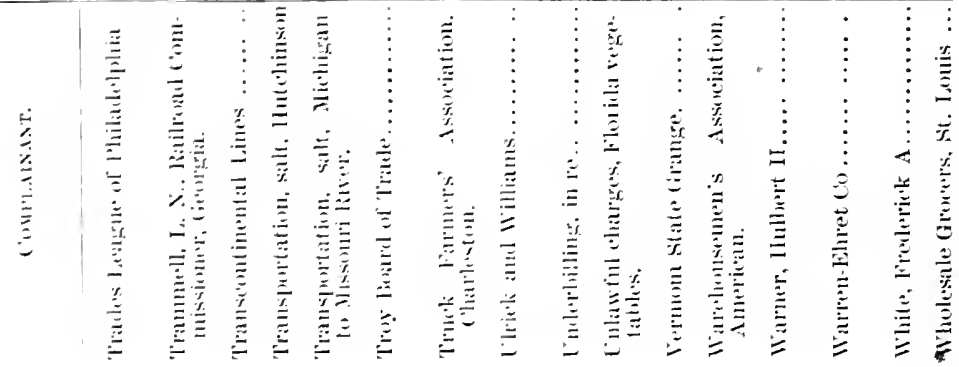




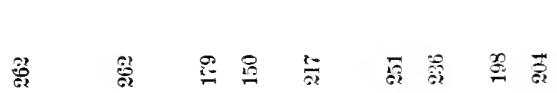

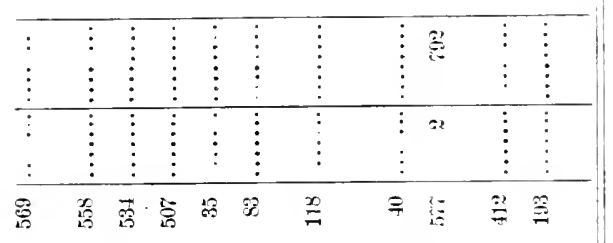

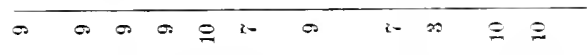

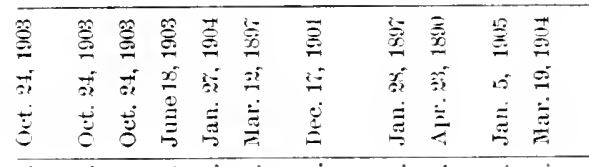

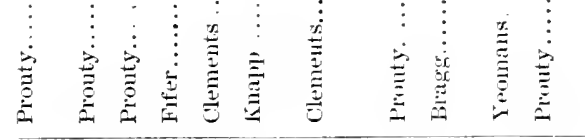

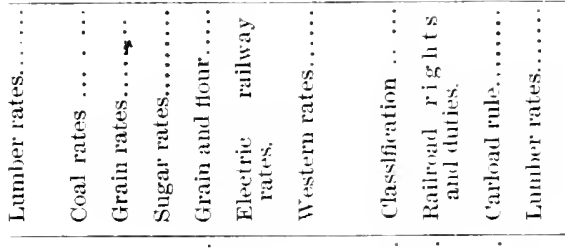

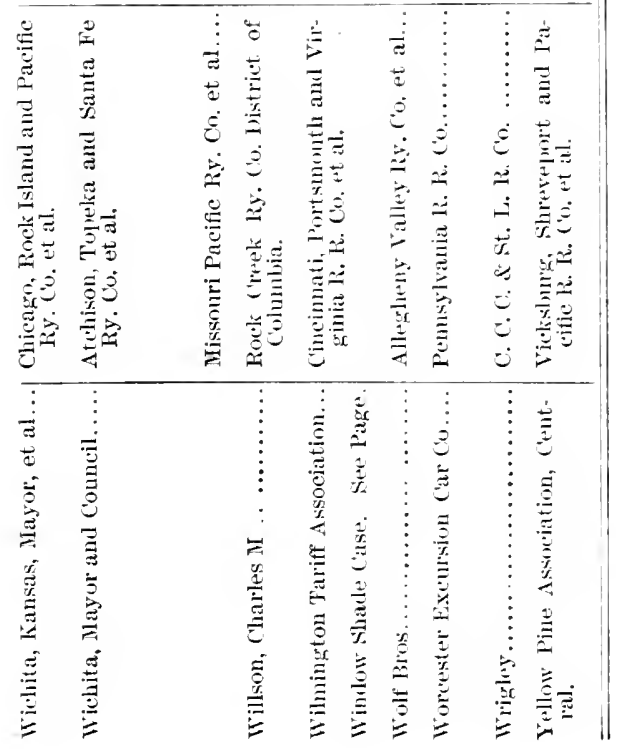


Table showing cases where the Commission found rates unreasonable, and ordered same discontinued, and the subsequent disposition of such cases, either under order of court or voluntary compliance by carrier. (Prepared by Commission and filed with the Senate Committee on Interstate Commerce April 19, 1905.)

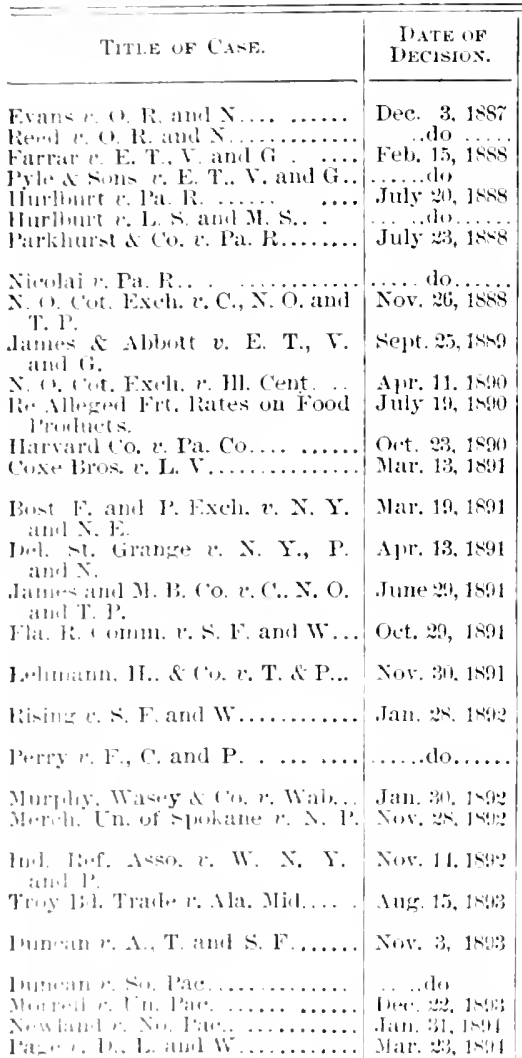

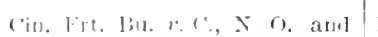
'T. I'.

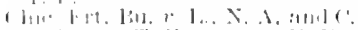

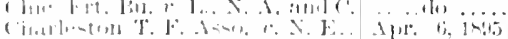

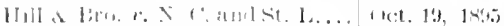

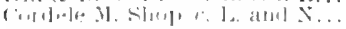

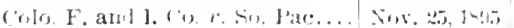

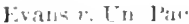

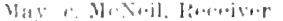

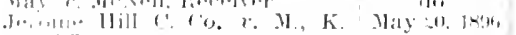
: 11,1 ' $\mathrm{T}$

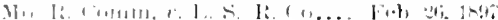

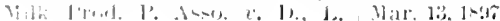
in 111 .
DISPUSITION.

Order complied with.

Iro.

Ino.

Do.

Do.

Order not conplied with: suit for damages adverse to complainant. ho.

Order complied with.

Do.

110.

Order partially complied with; no suit bronght in conit.

Orider eomplied with.

Order not complied with; circuit court refinsed to enforce order.

Order partially complied with; no suit l,renght in crints

Order not commlied with; cirenit court refusd to endince order.

Orlor not compliea 1 ith; supreme court enfore 2 d palt of order.

Order not complied with; Supreme Court. refused to enfurce order:

order partially complical with; no suit

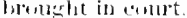

creter int complited with; no retuest for en. forcement if order.

Order fartially complied with; no suit brought iu court. Ino.

mel not romplied with; circuit court refilsed to enforce order.

orrer mot complied with; case pending in cinevil coart.

order mu complied with; Supreme Court rofused torenforce orcler.

medre partially complied with; no sujt linerght in court.

1)o.

Do.
1).
10.

(1) reler not complied with; eireuit court refustel to enforete order. Ansemiled oriter grantel, which was not connglied with ani] ujun whicle no suit was brought.

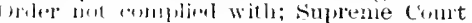

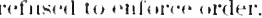
I).

melor not complited with; C. C. and C. C. A.

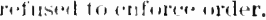

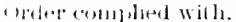

Mrer furtially complied with; no suit homelit in coint.

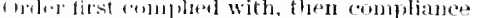
whblawn; C. C. A. refused to enforce arding.

arelor 0 mplien with.

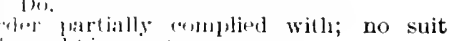
firengets in eniut.

(ribler romplent with.

1). 


\begin{tabular}{|c|c|c|}
\hline TITLE OF CASE. & $\begin{array}{l}\text { WATE (WF } \\
\text { DECISIUN. }\end{array}$ & HIFPOSITION. \\
\hline Suffern, llant \& co. v. I., I. & July 1, 1s:r? & Order complied with. \\
\hline $\begin{array}{l}\text { Cary } v \text { E. S R. ('o } \ldots \ldots \ldots \ldots \ldots \\
\text { Callaway } v . \mathrm{L} \text { and } \mathrm{N} . \ldots \ldots \ldots \ldots\end{array}$ & 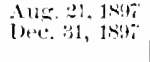 & 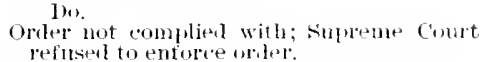 \\
\hline $\begin{array}{l}\text { Milw. Ch. Conn. } \iota . \text { C., Mt. and } \\
\text { st. P. }\end{array}$ & Jan. $19,1 \mathrm{~s} ! \mathrm{K}$ & $\begin{array}{l}\text { Orver partially complitei with; no suit } \\
\text { brumght in court. }\end{array}$ \\
\hline $\begin{array}{l}\text { Cattle Raisers' Asso. } \because . \text { F. W. } \\
\text { and W. C. }\end{array}$ & Jaus. 's), 1s:s's & 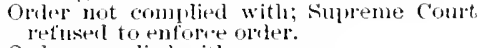 \\
\hline Phillips. B.. \& Co. r. L. and N... & (1).t. $: 9,1894$ & Oritrlenplied with. \\
\hline Grain S. Asso., de., $\imath$. Ill. cent. & Jume $: 2\}, 1899$. & 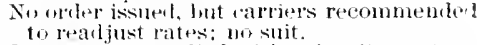 \\
\hline Sarannalı Bu., Sec, v. L. and I. & Jan. $8,1 ! 100$ & 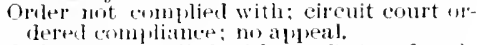 \\
\hline $\begin{array}{l}\text { Ilinipton Bd. Trade r. N. C. and } \\
\text { st. L. }\end{array}$ & Matl: 10,19110 & 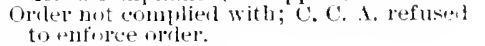 \\
\hline Warren-Ehret ('o. v. C. of X. I. & her. : : , 1940 & Orilel complied with. \\
\hline Mechew ${ }^{2}$ Mo. Pae ............ & Fels. $8,1(n) 1$ & lin. \\
\hline Hilton blus. Co. $\because$. W. and IV & 1]ю. 10,1901 & 1). \\
\hline $\begin{array}{l}\text { Natl. W. L. D. Asso. } r \text {. N. and W. } \\
\text { Wilm. T. Asso. } r . \text { C. P. and V. }\end{array}$ & $\begin{array}{l}\text { Were. 11, 19H1 } \\
\text { leec. 1\%, } 1101\end{array}$ & $\begin{array}{l}\text { Wo. } \\
\text { order not complied with; cirenit compt ro- } \\
\text { fused to anforete orter. }\end{array}$ \\
\hline Johnsoni $v$. C, st. P., II. and & May 7,1902 & Order complied with. \\
\hline $\begin{array}{l}\text { Re Proposecl Idvances in } \\
\text { Freighr Rates. }\end{array}$ & Apr. $1,191 \%$ & 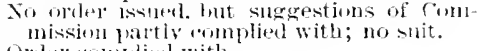 \\
\hline 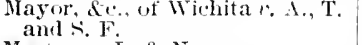 & ()et. $\because 4,190 \%$ & Oriter connplited with. \\
\hline 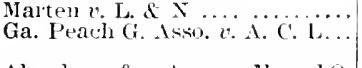 & $\begin{array}{l}\text { Tow. } 21,19 k: 3 \\
\text { June } 4,19,4\end{array}$ & $\begin{array}{l}\text { Tro. } \\
\text { Order partially complits with; no -uit } \\
\text { Ifought in condet. }\end{array}$ \\
\hline 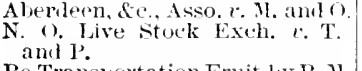 & $\begin{array}{l}\text { Jume } 25,1911 ! \\
\ldots \ldots \text { do. }\end{array}$ & 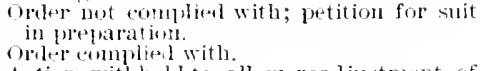 \\
\hline Re Translortation Fruit lyy P. 11. & July : $: 1901$ & $\begin{array}{l}\text { Artion withluelet to allow readjustment of } \\
\text { chaldistas. }\end{array}$ \\
\hline
\end{tabular}





\section{INDEX.}

References are to sections.

ACCIDENT LAW OF MARCH 3,1901-

monthly reports of railway accidents, 875.

failure to malie report penalty, 875 .

report as evidence against the carrier, 375.

form of report, 375.

ACCessorial Services (see Chiture, Storige, Deminery, DenterRAGE) -

must be rendered equally to all alike, 187.

ACCOUNT-

railroar not compelled to lieep separate accounts as shipper and carrier, 161.

ACTS IN THE REGULATION GF COMMERCE (see AnExminexts) July 1, 1862. Gorerment airled Pacifie Railroads, 50.

June 15,1866 ,

scope and purpose of, 40.

does not compel through routing. 40 .

does not interfere with State police laws, 40.

does not interfere with State Sunday laws, 4 .

July 24, 1866,

prohibits state monopolies in interstate telegraph business, 50. permissive only, 50 .

does not grant telegraph company eminent domain over road's property, 50.

does not apply to telephone companies. f, 51.

May 29, 1884. Burean of Animal Industry, 54.

June 29. 1886, authorizing incorporation of national trades unions,

78 .

Aug. 7, 1888, supplementary to Act of $1862,50$.

July 2, 1890 (see Axtr-Trist Act').

Aug. 30, 1890, unconstitutional, 38.

March 2, 1898 (see SArety Appliaxe ).

May 2, 1895. prohibiting interstate carriage of condemned animal carcasses, 54.

Feb. 2, 1897, prohibiting interstate carriage of obscene literature, 54.

June 1, 1898, arbitration between carriers and employees, is.

March 3, 1899, Secretary of War vested with certain power's. 53.

May 25, 1900. prohibiting interstate carriage of game unlawiully lislled, 54 .

March 3, 1901, Accident Law, 54, 373.

May 9, 1902, police power of State extended to oleomargarine, 54.

July 1, 1902. prohibiting interstate carriage of dairy products falsely labeled, 54 .

Feb. 2, 1903, respecting armissions of live stock into state, $5 \frac{1}{4}$

Feb. 25,1903 , immunity to testifying witnesses, 847 .

ACTIONS AT LAW (see CoMmexcenext of ACTIOAS) -

under section 7 , Anti-Trust Act, $3: 9$.

under section 8 , Interstate Commerce Act, 243.

ADDYSTON PIPE TRLST CASE, 68, 71. 75. 317. 
AnJOLRNMENTS AND EATENSIONS OF THIE (see RULES of PRACTle k, rule 9. pase 405.

ARTICLES OF CONFELERATION-

in connection with convention of list, 1.

ANAAOLIS CONFERENCE-

in relation to Constitutional Convention, 1 .

ADMIRALTY AND MARITIME JURISDICTION-

not limited to tide waters. 12.

wemcls to pullic navigable lakes and rivers, 12.

what are navigable waters. 12.

houndidies and limits of matters of judicial cognizance, 14. extrluls to Erie c'anal, 13.

AMANCE OF RATES-

without reason, subjert of investigation, 23t.

AFFIIIVITS-

who qualitied to talie (see Rules of Procruce, rule 7 , nage 404 ).

AFFREIGHTUENT-

effect of rebates, on contract of, 171 .

AIENT-

act of, binds carrier, :310.

ALIEXS-

power to exclude. 2.4.

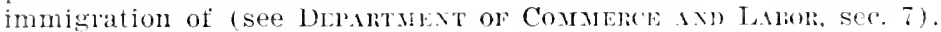

AMENDMENTS TO THE FNTERSTATE COMMERCE ACT-

Iareh 2. 1899 .

mandamus to compel carrier to furnish equal facilities, $48,398$.

F(1). 11, 1․:?;

enforrement of selt-incriminating testimony, 48, 263.

Fol). 11, 1!(1:?,

Experlition Act, 48.: :47.

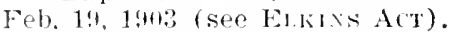

A.HENIIIENTS PROPOSED, is.

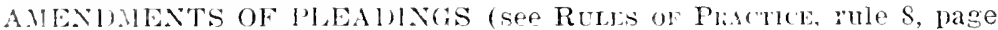
1115.

ANIMAL INUM STRIES AC"T-

s.oper of , : : :

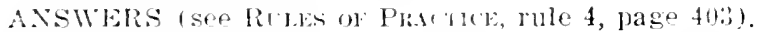

INTI-TRLST ART-

serction $1,: 14$.

siortion $2,: 3:-2$.

siretion : :, : : :

Shortiont t, :3:

sistions $5,: 3: 5$.

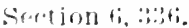

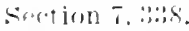

Sintions, $: 346$.

Ilassage of, 194.

moruose of. 6i.

zen"ral provisions, 6.5.

common-law prolertion irrespective of act, o,

ronstitutionality of , rit. :3.5.

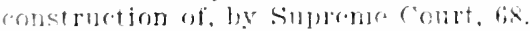

rot inconsistent with Interetate (ommerer Art, f, S. 
References are to sections.

ANTI-TRUST ACT-continued.

what monopolies denounced, 68 .

agreements for charges tor local farilities not inclurler?, fis.

not restraint of trade, illegal, but contract in restraint thereof, cs. no application to commerce within a State. 75.

application to state "holding companies," $76,92$.

application to combinations of labor and capital. S0, 326.

necessities of lite on same footing with other articles, 68, 74 .

combination between interstate railroads for suppression of com petition, $6 S$.

combination to regulate competition and rates by pooling, cs. procedure under the Act, $3: 31$.

interstate transportation is subject to the Act, 816 .

applies to transportation wholly within a territory, 100 .

Addyston Pipe Trust Case, 317.

California Tile Trust Case, :318.

Tennessee, Calitornia and Ohio Coal Cases, :319.

Chicago Neat Trust Case, 320.

Wasbington Shingle Trust Case, 321.

incidental restraint of trade not violative of the Act, 322, 323.

Kansas City Live Stock Exrhange Case, 32:3.

agreements not within the Act, 324 .

prevention of dealing with competitors through payment of rebates not unlawfil, 824 .

restriction of sales to certain territory not unlawful, 324.

incidental restraint of trade through purchase of competitors, 324 . agreement of manufacturers to fix arbitrary price on goods not un-

lawful, 324 .

agreements not to enter into competition, 325 .

criminal provisions of the Art, $314,327,328,329$.

indictment under, essentials of, 329 .

injunction under the Act limiterl to the Government, 382, 333.

State cannot enjoin under the Act. 393.

State not a person or corporation, $3: 34$.

bringing in new parties and service of subponas, 335.

seizure and condemnation of property. 337.

private action at law under section 7.389.

measure of proot, 340 .

petition when sufficient, 340 .

measure of damages, $3+1$.

limitations of private actions, 342 .

the Act as defense in suits by alleged illegal combinations, 343.

the Act as defense in patent litigation. :344.

term "person" or "persons" include what, 346.

self-incriminating testimony, 345 .

commodity may be subject of illegal agreement in restraint of trade, yet subject to State taxing power, $6 \mathrm{~s}$.

does not apply to agreements between business men for better con. duct of their business, though incidentally affecting interstate commerce, 69 .

interstate contract unenforcible at common law violative of the Act, 74 .

APPEAL (see Expebitrox Act of Fer. 11, 1908)-

right of, 292 .

to Supreme Court in equity where United States complainant, 292. time of taking, 283.

no supersedeas on, 293.

provision as to superserleas applies only to appeals from circuit court, 294.

under Fourteenth Amendment, 94. 
ARBItRATION ACT-

passed lune 1, 1s9s, is.

the courts on. 79.

"ARRIYAL"-

meaning of term in Wison's Ovixinal Package Bill, 17, 52.

contrate for, at siven time enforcible, 187.

ASSLIXIENT-

cause of action may be, 247 .

ASSOCIATIONS-

are persons within meaning of Anti-Trust Act, 348 .

AsLIMPTION OF RISK ( see SAFETy APllaxe ACT).

ATT.ICHMENT-

of foreign railroad cars, 37.

for disobedience to injunction, $2 \$ 3$.

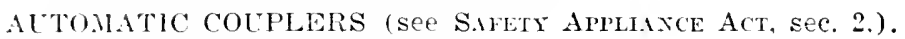

"AVERALiE HABITUAL USE"rule of. 19.

BAGCACRE-

Cor:mision no power to compel extra allowance for, 269.

IANKRLPTCY-

power to establish uniform system. 4.

IALI:O HOINT SISTEII-

mogning of $1 \mathrm{sl}$.

not illinal, $1 \$$ l.

IEELT RALLROAD-

subjet to state control when doing local business, 213.

IBHL OF EXCHANGE-

not intorstatr commerce, 7 .

BILL, OF LADING-

Whon on interstate commerce Slate tax on void, 7 .

when on forein shipment exempt from State or Federal taxation, 7.

HIANKET RATES (see GHOTHA OF RATES).

BOATS-

Siate may regulate speed of, on navigable waters, 38.

Slate may preseribe number of lights for, 38 .

IOOKS AND JAlPRS (see IMMIXITY)-

Annriments of 1 s.9.; only reless to testimony before the Commission, 20.tit.

Swlion 9, compelling protuction of, unconstitutional, 252.

compulsory production of betore Commission, 274 .

compulsory produrtion of under experlition Ac1, 350 .

compulsory proluction not enfored when party or corporation theneloy axpe-ril to penalty or forteiture, 264.

distinction by Comnission between those of carriers and strangers, 27 - 2 .

disimain by Commission between "private" and "public" documants, 2:1.

may ha slummoned lefore commission from any part ot the United Sigtes. 26 it.

JOMTIMARIES ON SEA-

Statr may define, sulject to limitations, 10.

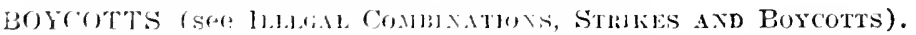

BRAKES-

driving wherl and train brales pepuired (see SAFETY Aprlance Ar $\mathrm{s}, \mathrm{sr} .11)$. 
references are to sections.

BRANCH LINE-

point on may be charged higher rate, 187 .

\section{BRIDGES-}

not common carriers, 6 .

power of Congress to authorize between States, 49.

regulation of over navigable streams, 119.

when included in term "Railroad," sec. 1, 115.

power of Congress to charter between States, 59 .

State regulation of toll, on interstate roid, 6 .

when carrying on interstate commerce, 15.

State cannot regulate tolls on interstate, $6,22,35$.

as affecting unjust discrimination against locality, 185.

BRIEFS (see Rrles of Practice, ruie 14, page 408).

BROKER--

State tax on money or exchange broker not a regulation of commeree, 7.

BROTHERHOOD OF LOCOMOTIVE ENGINEERS-

rule 12 of, violated section 10 of the Act, 256.

BURDEN OF PROOF (see Presuatroxs)-

follows general rules, 273.

on carrier when seeking relief under section 4,273 .

on party complaining, 273.

on complainant shipper beiore the Commissioner, 97.

on carrier to show dissimilar circumstances and conditions under section 4, 225.

on carrier where there is a departure from the rule of the law, 273. on carrier to show unreasonable limitation fixed by state, 125.

on complainant to show carrier has exceeded reasonable standari. 125.

on plaintiff under Satety Appliance Act to show car engaged in interstate commerce, 355 .

in court after finding of Commission, 259.

on complainant to show mieasonableness, $1: 3$. .

on carrier where departure from equal rates on several branches of the road, 273.

on carrier where facts justifying disparity peculiarly within his knowledge, 27:?.

BUREAU OF COMALRCE (see Depsrtinext of Comalere Axi Libon).

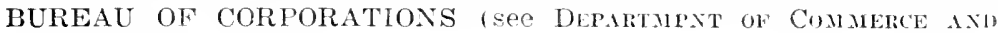
LABOR).

BUREAU OF LABOR-

created under Art of Tume 27, 1S\&4, 7 .

made Denartment of Labor tune $1: 3,1898,77$.

BUREAU OF NANUFACTURE-

estabisherl Feb. 18, 1943, 55.

BUTTER (see OWomananirye)-

rates on from Lincoln to Denver, 142.

CALIFCRNIA COAL, CASE, 319.

CALIFORNIA TILE TRUST CASE, 318.

CANALS (see Erme CAxML).

between points in same State, subject to State control, 22.

CAPITALIZATION OF RAILROAD-

as basis for rate making, 126, 195.

\section{CARCASSES-}

interstate carriage of condemned prohibited, 54.

CAR SERVICE-

meaning of "car" in Safety Appliance Act, 360.

Commissioner's' report for 1944 roncerning, 11s, 191. 
Reperences are to sections.

CAR SERYICE-continued.

when "engaged" in interstate commerce, 361.

common-law duty to furnish, 159.

mndue preference in, $1 \mathrm{~s} 9$.

may be against localities or individuals, 189.

compulsion by way of mandamus. 159.

no drense fol retusal to furnish, that cars can be more profitably

emploved elsewhere, 1 ss.

delay in furnishing cars, when discrimination. 189.

furnishing of cars on spur track not discrimination. 189.

no duty to notify shipper when he can obtain cars, 189.

no duty of carrier to meet extraordinary demand, 189.

State statute valid requiring furnishing within specified time aft?

rencler of treight. :38, n.

discrimination in private cars. 146, 191.

two elasses whether or not owner interested in contents, 191.

rules and rates of carriage must be published. 236 .

tank ears, duly to fumish impartially, 191, 205.

carrier may accullie cars as it pleases, 118.191, 192.

leasing of car does not carry right of exclusive use by owner, 193.

no discrimination against locality where lack of ears, 189.

shortage how dealt with, $308,309$.

(arrier not restonsible for detention of cars. 189.

refusal to receive from connecting line (see SArtri Apriaxce

Ac"r, sece, 3).

may refuse to haul private rars, 191.

State constitution prescribing rules for car service valid, s8.

if rarrier cannot supply cars duty to notify shipper, 191.

commontaw duty requires fumishing of refrigerator cars, 118.

CAligO RATES-

discriminative 158.

CARLOAIS AND LESS THAN CARLOAD RATES-

lecality recomized. 154 .

mins bear reasonable relation, 150 .

discriminations hased on ownership of cargo. $15 \bar{\tau}$.

poper differential between, from Middle West to Parific Coast, 156. reate dissimilar cirrumstances and conditions, 156 .

(lifferential botween may effect unjust discrimination, 156, 187.

minimum rlarge to be for one hundred pounds, $15 \%$.

rARHILR AND SHIPPLR THE SAME-

"arrier may give itself undue prefcrence, 190.

(ARIRERS AND TRANSIORTATION SUBIECT TO THE ACTall rarriors in interstate commerce not included, 10.5.

only those carpiers described in scetion 1, 106.

rexpress companies not included, 107.

transwortation of persons or poperty wholly by raitroad, 1 j.

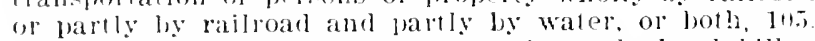

railroad wholly within one state vising only loral bills of lating, not. 111., :301.

lransiortation loy team or wason not included. 10.5.

transportation vholly by water not included. 105.

transportalion wholly within a ferritory, 1llt.

forrign rommorere, whell subject to the Act, 112.

loral switrhing rompany when and when not, 108 .

transportation thoongh a State. 111:, :316.

interstato coerotrie railroads. 1 lo.

railroarl cannot free itself by leasing its road, 111.

ferejuers, when smbject to the Ac1, 111.

lesseres. when subjeret to the Act, 111.

ralmat wholly within one staw hough operated by interstate carrirs. $11 \%$ 
References are to sections.

CARTAge (spe STolige, Dellueir) -

Commission may require publiration of charges for under section 6 , 116,236 .

railroad not hound by custom to pay rharges, 116 .

unjust discrimination and undue preference may be based on, 116 . 187.

not in general a terminal expense, $116,2: 36$.

CATTLE (see Differextals ix Rites, LME STO(K).

CHANCERY (see Equtry Prochengas).

CHANNELS, IMPROVEMENT OF NAVIGABLE (see RGiLATON O:

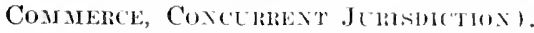

CHARGES REASONABLE AND .JUST (see RiTis)provision of first section affirmance of common law. 119. rule in England, 119.

question of reasonableness one of fact, 49, 120, 175.

in absence of legislation court must decide what is reasonable, 119. practical difficulties in enforcement of rule, 120.

rate unreasonable when paid may become reasonable before trial in court finished, 120 .

\section{CHARTER CORPORATE-}

State may alter, amend or repeal, when, 101.

federal power of slanting, 59.

power to grant not within enumerated powers of Congress, 59.

CHICAGO MEAT TRUST CASE, 320 .

CHOICE OF ROLTE-

undue preference in denying shipper, $19 \pi$.

\section{CIGARETTES-}

State may declare how far to he sold, ?.

State may prohibit sale entirely after leaving original package, 9. cannot prohibit importation in original pachage, 9.

CIRCUIT COURT OF APPEALS (see Feneral Courts) -

jurisdiction on appeal in contempt cases, 89.

CIRCUMSTANCES AND CONDITIONS-

of through and local traffic are dissimilar, 150 .

not mare dissimilar by quantity of treight, $15 . ;$.

rendered different by arcessorial services, $15 \pi$.

employment of forwarding agent as creating dissimilar, 157.

increased cost of service resulting from stoppage create dissimilar, 150.

of carload and less than carload are dissimilar, 150, 156, 157.

ocean transportation creates dissimilar, $17 \delta$.

dissimilarity of, renders preference not undue, 17.5, 176, 180.

under fourtl section. 221.

competition creates dissimilar, 150, 175, 176, 180, 221.

under second section not rendered dissimilar by competition, 151.

distinction in term as used in sections 2 and 4,222 .

\section{CIRCUS TRAIN-}

carrier may refuse to transport except under special contract lim-

iting liability, 155 .

\section{CITY ORDINANCE-}

regarding stone, when void, $38, \mathrm{n}$

regarding street, railroad in interstate commerce, $\$ S, n$. 


\section{CLASSIFICATION-}

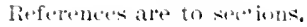

commodity, when not classified. siven commodity mie, ant.

minum preference in. 20 s.

complaint concerning. acainst whom mate. 272 .

consultation of carriers in classification not illegal combination, 217.

j) of of undne preference in, necessary to obtain order of change, ㅂ․ 211 .

in stare railroad legistation, this.

reasonable resulations in classification, 210.

justice of classification letermined by comparison, 208 .

lowe? of ('ommission in correrting. 209.

no rontract right 10 special classification, 209.

lansier from low to high class may be unlawful, 20 s.

coverning principles of freiglut classification, 208.

silerifie rommodities.

Iried fruits and raisins, 208

hul blocks and ]11mber. 2018.

railroarl ties and rounh lumber. 20 s.

Instetter"s Stomach Bitters with other liquids, 208.

patent medicines and ale, beer, mineral water, 208.

iollet soap and laundry soap, 208.

(-olery and regetables, :015.

olen end envelopes and merchandise envelopes, 208.

iron pipe fittings in pipes and in barrels, 208

flour and cereal proslucts. 208.

(ow peas and grain, and tertilizers, 208 .

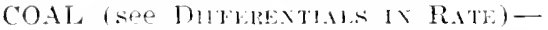

desirable traffic owing to small hazard, 136 .

rates on in Lalie parie district. if:.

rates on trom Ifomphis 10 Lonisville, 14.

rates on from South McAlister to Denison, Texas, 142.

"(

ristaing or, 4 .

COINAGE OF . IONEY-

hower of Coneress ovfr. 4 .

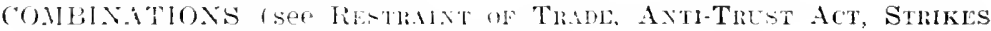

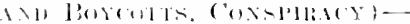

other thatl in tansportaticus. :317.

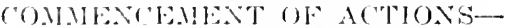

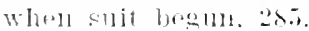

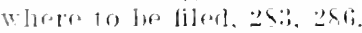

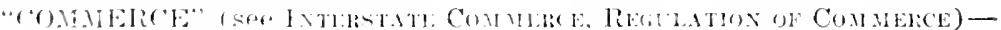
what is. li,

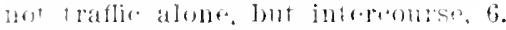

transporlation of bascencerse, i;

ulat is not. 7 .

What ale subjuets or.

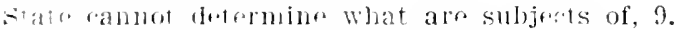

manutarlura nol, :35.

sale as an inciront of manufarture not, :315.

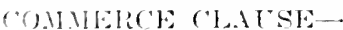

in the consigution discusset], I.

jurlir.ial consilnetion of, is.

rulines of slate roulls oul, :38.

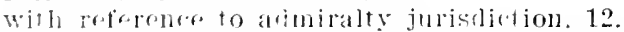

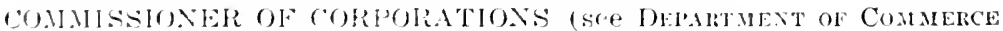
1. II I II:Hli). 
References are to sections.

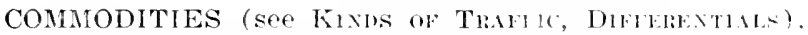

“COMIION CONTROL, MANAGEMENT," ETC.what constitutes, 108 .

test of, is through routing in interstate commeres. 10?. immaterial that one road receive sole benefit, 10 s. express agreement obviated by acquiescence, 108.

\section{COMMON LAW-}

right of discriminations, 147 .

right of discrimination not unlimied, 148 .

no obligation to charge equal rates to all anstomers. 147.

contract governed by, when in interstate commeroe. sti.

contracts in restraint of trade menforcible ar, i), it.

no common law of conspirary. it.

\section{COMPARISON-}

not a basis for determining reasonableness of rates, $139,133$.

\section{COMIPETITION-}

does not render circumstances and conditions dissimilar nuder see tion 2, 151.

as affecting through rates, 150 .

allows givilu of jreference or discrimination. 175.

at the seaport renders circumstances and combitions dissimilar, 17s. railroar competition same as water competition, $18 n$.

creating dissinilar rirmmstances and contitions under scrtion $i$, 221.

when with carriers by waters not subject to the Ad. 221.

when with foreign or other railroads not subject to the $\mathrm{A} t \mathrm{t}, 221$.

in peculiar cases between railroals subject to the Ar.t, 221 .

carrier can judge for itself in first instance undor section $4,221$.

diffelence inmer section 4 and sertion 2,222 .

preferences of localities enforced by, not munue, 17.5 .

question of tact, whether controlling, 17\%, $15 \%$.

application of the rule, $176,177$.

qualification in the application of the rule, 153.

competition createrl by carriers. 184.

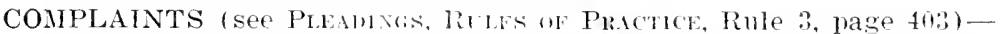
repeal of law reating State ('ommission does not operate as withdrawal of complaint filed loy. 20 .

CONPLIANCE With ORDERs (see Riles of Plin tree, Rule 18, page 409.

CONCURRENT AND EXCLUSIVE POWERSdistinguished (see Rariatm of Commine).

CONGRESS, JURISDICTION OF (see RGirltTUX OF COMALRCE)no jurisdiction over commerce wholly within one State, 75.

labor legislation of, 7 .

the mexercised power of, 56 .

CONSPIRACY-

lefined, 82.

may result from boycott. so.

a misdemeanor, not a felony, sz.

essential of indictment for, 82 .

doctrine of merger inapplicable, 82.

obstruction to United States mail, 82.

each conspirator liable for acts of co-conspirator. 82 .

enforcement of rule of Brotherhood of Engineers as, 82,256 .

conspirators liable for loss to private parties, 82 .

concerted quittiug employment, 81 .

doing a lawful thing in unlawful manner, 82 . 
Fieferences are to sections.

('ONSPlRACl-continmed.

English legislation on, Sis.

conspiracy under the Act distinguished from comnon law cons]piracy, s:3.

malice in conspiracy, 84.

ipplication to contempt rases, 89.

I thited States statute conceming, 82, 256.

unler section 10. 258 .

incidental interference with commerce not, 257.

what constitutes, s.3. $257,259$.

('ombination to compel railroad to break contract for use of cars, 81 . as a plolied to proceedings lor contempt, si?.

uewspaper reports, ete., to show character of, 82.

('ONTAGIOLS I)ISEASES-

state legislation may exclude persons infected with, 9.

CONTEMPT IN INITED STATES COURTS-

proceedings rriminal in naine, s.

Euited states statute concerning, $\$ 9$.

power of Concress over, 89.

jower to punish for, at common law. S?.

interference with receiver appointed by court a contempt, 89 .

not triable by jury, s.t.

rourt may punish for crime, though indictable, 89.

for refusal to testify, 261.

raim that proceeding should not be summary, \$9.

involves no element of personal injury, 89 .

application of law of conspilacy, 89.

liability not limited to party of record, 89.

review of rontempt finding on appeal, s.

only matters of law considered, facts of trial tribunal being conclusive, 8:

power to punish for disobedience of injunction, 83 .

riminal and junitive contenut, 89 .

direct and indilect contempt, $\$ 9$.

fusineer guilty of, 250 ).

('ONTINENTAL TOBACCO CASE, 72, 74.

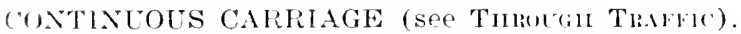

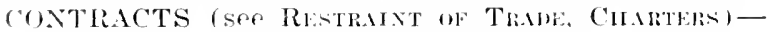

low wen shipper and carrier soverned by law of state where made, :n.

in interstate commerre governed by rules of eommon law, 66 .

in rest raint of tracle not illegal at rommon law, 6ij.

libliting liability valia. 1,is.

110 rontract rieht to sjercial rassificalion, 209.

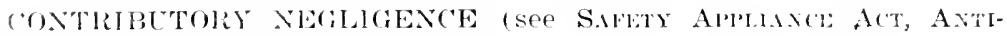
Tiliti A( T).

(

Siate legislation may exrlude, 9.

(')RPORATIONS-

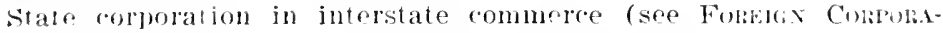

jux).

not a "r.iti\%n" within mraning of Constitution, 15.

a "person" or "riti\%"n" when necessaly to effective legislative intent in slatulfs, ze;

a "person" willin moaning of $14 t \mathrm{l}$ Amendment. 15, 94, 164.

refplifenfent of ferloral franchise, 62.

railroarl oprerating in several states rorporation of what state, 91. ar" jersons within meaning of Anti-Trust Act, $\ddot{4} 4$.

rolation of Staie to peleral corporations, 61. 
Referencers are to steetithis.

CORPORATIONS-continued.

as to self-incriminating testimo:y, 264.

subject to penalties, 204 .

subject to indictment, 264.

visitorial power over, 54 .

nower of Congress to charter, 59.

power of Congress to charter bridge across navigable streams, th

place of, immaterial, 113.

place of, immaterial as to regulating power, 92.

cannot appropriate property without compensation therefor, :"

conviction for mistemeanor", 310.

power of Congress to charter not in enmmerated power, 5y.

\section{CONSTITLTION-}

article I, section 8, par. :3, 1 .

article I, section 8 , prar. 18.1 .

article 1 , section 9 , par. 5,1 .

article IV, section: 2,1 .

article VI, par. 2, 1.

article 1 , section 4 , par. 5, :3.

article IIl, section 2. par. $5,14$.

article $I T$, section :?, 106.

CONSTITUTION, AMENDMENTS TO-

$X, 1,4$.

Xir, 1, 94, 100.

COPIES OF PAPERS OR TESTIMONY (see Rules of Practur, Rule 17 , page ting.

\section{CORPSE-}

not a subject of commerce, 9.

\section{COsTs-}

how levied, 283.

how paid in suits by Commission, 283.

\section{COST OF CARRIAGE-}

in relation to reveipts as regulating charge, 131 .

\section{COTTON-}

rates on, from Florida to Savannal. 14:.

rates on, from Indian Territory to St. Louis, 142

COURTS (see Faner.h Cortats)-

no revisory power after finding by Commission, 2!lt.

power to enforce, testimony betore Commission (see ITrxesisest. prior leave of, mnnecessary to entitie shipper to proceed against railroad in hands of receiver, 27. have no power to fix rates, 124 .

CPIMES-

none at common law in Inited States, titi.

State legislation may prevent spread of, 9.

CROSSINGS ON SURFACE-

State may regulate, 27.

DAIRY PRODUCTS-

interstate carriage of lakely labeled, prohibiterl, 54.

DAMAGES (see Entrin SwTw) -

measure of in unjust discrimination, 169, 24:, 279.

proot of. must be made by complainant, 279.

speculative, not allowed, 279.

jurisdiction of Commission in awarding, 279.

measure of, where rate rharger excesis published rate, 279 
DAMAGES-rontinued.

for discrimination in ear service. 1s?.

remedy for tailure to render special service, 15.5.

measure of, in rate wars, $1 ! ! !$

IECREASE OF RATE-

not until three days notice of, 2::98.

IUEFENSE-

of judsment before commission to action in Federal couit, 252 . individual rlamant not barred by suit of his association, 25:.

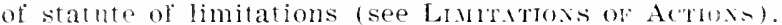
110 drense in discriminations between persons that the priviles? may be withliraw at will, 169 . atoption, minting and posting schedule of rates as, 122.

1)EL.AY-

not of itself gromed for complaint, 272 .

in furnishing ars may effect discrimination, 189.

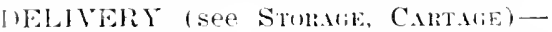
no arklitional duty of imposed by section 1, 11 is. services if rendered must be imprartial and reasonalle, $115,157$. distin.tion hetween American and English customs of, 116 . live stock and perishable property require additional facilities for, 117

extra charge for these additional facilities unlawful, 117. railroar may contrart with stockyards company for delivery of live stock, 117 .

where ronsignees off main line. 117 .

higher charge for quick delivery, 15.5

DEATCRRAGE CHARGESundue preterence shown br, 1 st. nnjust riscrimination in failure to collect, 162.

HENTRRERTnot iee in nature of ( see Rulw of Plis("TItk, inle 5, page 404). siatute of limitations raised by, 246 .

WEPARTMENT OF (OMALRCE AND LABORsertions 1, 2, $\therefore, 4,5,351$

seretion ti. : : sorolons 7, ., 9, 111, 11, 12, \$151.

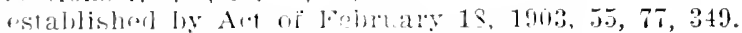

bevartment of libber mate part of, 7 . Serertary of commerere and Lahor. 349. a rabinot member. 5.5 . what corperation subject to, 5.5 . Art neyer judjelally roustruted, 5.5.

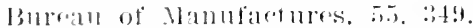

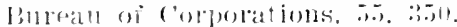

fommissionse of comporations, 350 .

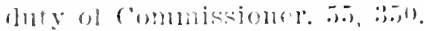

has no judiolal pourse is. power of commissioner, s.5, :350. 1)avmly Commissionsr, ;:50.

rmployose, :ind.

immonity to winreses tostifying before, 350 .

(r)mulation and puldiration of intormation, 350 .

DEFARTMLNT (JF IAABORrestablisherl lumo 1:, 1858, 77, :34. llurias of Commissioner, $77,7 s$ marl" part of the Leparment of Commerce and Labor, .849 . 
lieferences are to siectinns.

DEPOSITIONS (see Roles of Punctur. Rule 12, page 406)-taken by order of Commission, 261.

notice must be given, 261,272 .

testimony by deposition may be compelled, 261 .

manner of talins. 2til.

when witness in foreign country 201.

must be filed with Commission,

before whom taken, 261.

DETENTION-

not of itself ground for complaint, 27z.

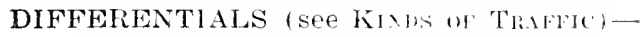

in rates between live hoss and packing house products, 279 . wheat and flour, 200 .

raw materials and manufactured product, $24 \%$.

anthracite and bituminons coal. 22m.

live hogs and cattle and dressed products of each, 200.

grain and grain products, -13 .

competitive cities, 186.

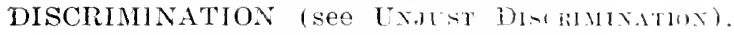

DISEASED CATTLE, EXCLUSION OF ( see Retithitis of Connerce, CONCLRENT JURATITION).

DISPENSARY LAWS OF SOLTH CAROLINA (sep SIRITUCE LIOYOORS).

DISTRICT ATTORNEY (see SIFET APrinur Acr, sec. b) power of, under Elkins A(r. 24:4.

duty to prosecute under section 12, 21i2.

in general, 287.

DISTRICT OF COLEMBIA-

power of Congress to grant charters in. 50.

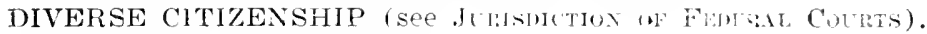

DIVISION OF TERRITORI-

undue preference in. 198 .

DOCKS, Regllation OF (see Rerimtox of Comneree, ConcirREXT J(RISH(TION).

"DOING BUSINESS"-

distinction from "carrying on" interstate commerce, 15.

DRAW BARS (see S.IFT APILAN A('T, sec. 5 ).

DRUMMERS-

may be sent through rarions States, 15.

ECONOMIC CHANGES-

influence of, on construction of Ferleral Constitution, 63.

EIGHTH SECTION-

liability of carriers for damages, 243.

construction of, 244.

plaintiff must show injury, 245.

action at law, 244 .

cause of action under may be assigned, 247.

EIGHTEENTH SECTION-

salaries of Commissioners, Secretary, ete. 20,9 .

expenses of the Commission. 2sti.

employees of the Commission, 29f.

offices and supplies of the Comnission, 290.

ELECTION ( see Nixtu Skctiox)

ELECTRIC RAILROADS-

between States, subject to the Act, 110 .

between States, rates on, 142 . 
ELEVATORS-

References are to sectiuns.

construction of on risit of way, 196.

ELEVENTH AMENDMENT-

suit awinst State Commission not suit against State within mean ing of , 15.

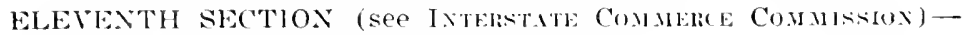
Interstate commerce Commission, 260.

number of 'ommissioners, 260.

how appointed, 260 .

term of, $2(0)$.

requirements of, 260 .

removal, 2liti.

in general, 260.

ELKIXS ACT, :,11, :311.

discussed, 48, $106,146,167,238,240,249,254,255,262$.

EMbARGO-

Congress may plare on foreign commerce, 2.

EMINENT DOMAIN-

jower of, in Congress, 4.

jower of, in telesraph companies under Act of $1866,50$.

does not give telegraph company right of way over railroad propprly, in.

\section{EMPLOYEES-}

interstate rommerce in relation to employees theroin. 84 .

relation of carrier and employee that of free contract. 86 .

richt to leare employment, subject to ertain limits, s1, s6.

distinction between relation of quasi-mublic and private corporatjons to employees, $8: 3$.

abandonment of train, sf.

peareable strike lawful, 257.

State laws establishing qualifications of. valid, 27.

ENGILSH ACTS IN REGULATION OF COAHERCE-

Railway Clauses Consolidated Aut, 42, 44.

Railway and Canal Traffic Act, $42,17,17,182$.

Regulation of Railways Act, 1873,42 .

Conspiracy and Protection of Property Act, 1875, \$3.

ENIMERATED POWERS-

grovernment one of, 4 .

power to rhatrer corporations not within, 59.

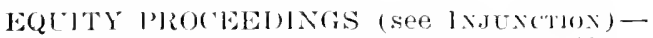

juristirtion of Federal rourt over, 249.

by Act of February $19,190: 3,219$.

for porection of interstate commerce against conbination in violation of the Acr, 2in.

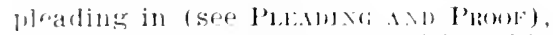

juristielion jurespective of ritizenship, 250.

io flotret against ronbinations in restraint of trade, fit.

WRIE (ANAL-

subjert 10 admilalty and marilime jurisdiction, 13.

ESTOPगI:-

Intrestate commores commission not bound by ruling of State rommission, 201.

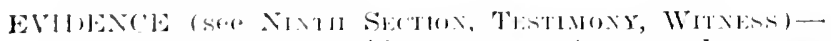

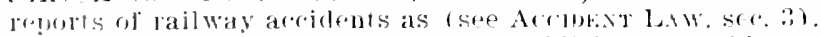
tax roturn of railroal offirials to establish reasonahleness, 131. contrates and tariffis filed and published under sorlion t, $2: 34$. of contrare for llitwien routing, 10 s.

contrarts betwor n thidr persons not party to prorectings, 26s. 
References are to sections.

EVIDENCE-continued.

advanced rate filed with Commission going in effect pending hearing, 131 .

newspaper reports, ete., to show character and purpose oi conspiracy, 82 .

EX PARTE STATEMENTS (see Moot Qristluas).

EXPEDITION ACT FEB, 11, 196\%-

terns, 349 .

judicial application of, 350 .

Expert testimony (see Testmoxy, Witaess, Evinexce).

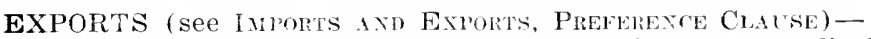

prohibition of tax or duty on, from any state not applicable to interstate traffic, 3.

\section{EXPRESS COMPANIES-}

not subject to the Act, 107 .

railroad not bound to grant eriual facilities to, 107 .

may pool earnings, 230.

EXTENSION OF TIME (see Rules or Prictie, Rule 11, page 405).

FACILITIES FOR INTERCHANGE OF TRAFFIC-

danger of strilie as exruse for refusal, 256 .

injunction to compel, 254 .

construction of term, 211.

State control of, : 13.

does not compel through ronting. 211 .

meaning of "track and terminal facilities," 211.

FEDERAL COURTS, JURISDTCTION OF-

exchsive of State conts nuder the A.t, $41,218$.

concurrent jurisfiction where action bised on common law of interstate commerce, $44,248$.

distinction between cause arising or not arising nuder Act, 248 .

suit, where bronght, 248 .

over equity proceerlins under the Act, 249.

under Elkins Act. 255, 210.

irrespective of citizenship. 96, 248.

prior to auoption of Fourteenth Amentment, 94.

based on canse arising under Constitution and laws of Uniter States, 44, 248.

when such a suit arises, 44, 249.

no jurisdiction on remotal when State cont had none, 43, 248.

power of, cannot be limited by state lesislation, 95.

in admiralty and martine case's, 14.

under Juticiary Act ö̈ $1879,11$.

includes maritime cases wholly within single state, 14.

of Cirenit Court, $283,286$.

of Circuit Court of Appeals in contempt cases, $\delta 9$.

suits by non-resident stockholder's aganst state Commission con-

testing State imposer] rates, 36.

moler Anti-Trust Act, $8: 00.932$.

power of State regulation of intrastate trafic subject to review by, 95.

in cluestions involving reasonalueness of rates, $45,96$.

cannot be limited by state law, 5.

in seneral, 44.

where state statute denies due process or erual protection of the law, 95.

not hound to follow state courts, $4:$.

no revisory power of Conmission's findings, $29 n$. 


\section{FEES-}

References are to sections.

of attorney, how allowed and collected. 243 .

of attorney uniler Anti-Trust Act, :3:3, 3:39.

of witnesses. 261 (see Rurk of Prictict, Rule 13, page 407).

FERRIES (see Rraltatox or Commence.)

when included in term "railroad," section 1,11 b.

regulation of, on navigable streams, 49 .

in interstate commerce. 15.

as instrumentalities of interstate commerce, 49.

free from State rontrol. 49.

\section{FIFTEENTH SECTION-}

notice to common carrier to cease from violation of Act, 281.

notice jurisuictional, 282.

FIFTH SECTION-

nooling of freights and division of earnings forbidden, 226 , construction of, 227 .

acrements controlling through routing and allotting territory, 228 . agreement not within the prohibition, 229 .

agreements for division of through freights between members of trunk line not unlawful, 229 .

agreement for consultation for promotion of reasonable rates, 229 . division of immigrant traffic in proportion to domestic traffic, 229. relation to Anti-Trust Act of $1 \$ 90,230$.

"physical" pooling, 227.

"money" pooling, 227.

pooling as detense to action by carrier, 231.

meaning of term "freights," 2:28.

FILING OF SCHEDULES (see Scitedules).

FINES-

for refusal to obey injunction or other process, 283.

FIRE INSURANCE-

not interstate commerce, 8.

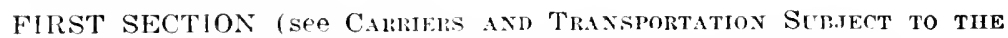
Act, Chabres Reasonable and Just, Rates, Comalerce).

FISHERIES-

how far State may regulate, 10.

Fiofle (see Dhithenthis in Rates).

FOOD PRODUC'TS-

protection against arilterater. 9.

rates on, from Mississippi River to eastern points, 42.

alleged exressive rates on, 134 .

State may protert people against fraud in sale of, 9 .

FORECLOSURE SALE-

purchasers at have no contract right against State legislation subsequent to mortgage, 101.

foreign conmerre (see Commerce, interstate Commerce, ReguDATION OF COMMHE(E) -

when subject to the Act. 112.

Congress may plare embargo on, 2 .

no power in State over, 2.

congressional inaction in foreign and interstate commerce distinguished, 36 .

FOREIGN CORPORATIONS (see CoRpolRAT1ONS) -

State may exclude or impose conditions on, 15.

right to engage in business in local state depenrls on whether corporation is carrying on interstate commerce, 15. 
Rieferences are to sections.

FOREIGN CORPORATIONS-continned.

may depend upon its own rharter, 15.

meaning of term "carrying on interstate commerce." 15.

public carriers are "carrying on interstate commerce," 1 s.

bridge companies are "carrying on interstate commere," 15.

ferry companies are "carrying on interstate commerce," 15.

telegraph companies are "carrying on interstate commerce" 15.

telephone companies are "carrying on interstate commerce," 15.

steamboat companies are "carrying on interstate commerce," 15.

railroad companies are "carrying on interstate commerce," 15.

manufacturer who ships goods to purchaser in another state is manufacturing or trading company is, 15.

may send drummers through other States, 15.

cannot establish office within local State without latter's consent, 15.

may accuire stock of competing State corporation, 68.

\section{FOREIGN COUNTRIES-}

Porto Rico not, 3.

\section{FORNIS-}

page 402 et seq.

FOURTEENTH AIIENDIENT-

adoption of, 94.

applies to corporation as well as individuals, 94 .

protects carvier from unreasonabie State interterence, 100.

FOURTH SECTION (see Loxir axb Silort Hati) -

history of, 220.

proviso of, 224.

burden of proof under, 225 .

"over the same line." meaning of, 22s.

application for relief under proviso (see RuiEs of Practice, rule 19, page 409$)$.

carrier may judge in first instance whether circumstances and conditions dissimilar, 175.

FRANCHISE-

State tax on valid, 20 .

requirement of federal franchise for business corporation in interstate commerce, 62 .

\section{FRAUD-}

cause of action at common law for unjust discrimination irrespective of, 169 .

FREE OR REDUCED RATE TRANSPORTATIONpersons and property entitled to, 303 .

\section{FREIGHT-}

term means commodity carried, not compensation paid, 229.

State may impose penalty for refusal to deliver on payment of charges, $3 \delta, \mathrm{n}$.

State may prohibit charge of higher rate than shown by bill of lading, $38, \mathrm{n}$.

State may prohibit increase of rate after tender of shipment, 38, $\mathbf{n}$.

FREIGHT ASSOCIATION CASE, 73.

FUNCTIONS OF GOVERNIIENT-

blending of legislative, executive and judicial in Interstate Commerce Commission, 49.

\section{FURNITURE-}

rates on from Lansing. Mich., to California, 142.

gas (see Natural Oil and Gas). 
G.ANE-

Reforences are to sections.

unlawfuly killed, interstate carriage prohibiter, jt.

GARXISHART-

railroal not subject to hecause in possession of cars of foreign (arrier. : :

railroal is subject to for debts of shipper, 37.

\section{GIBBONS Y. OGDEN-}

discussed, 5.

GRAB IRON AND HANDhOLDS (see Saffty Applance Act, sec. 4).

GRAIX AN]) GRAIN FRODLCTS (see DHFERExTILS IN RATES)rates on from northwestern fowa to Chicago, 142.

rates on from Chicago to New York, 142.

rates on from Rit\%ille. Wash., to st. Paul, 142.

rates on from kenturky to Newport News. 142.

rates on from East St. Louis to eastern points, 142.

GROIPING OF RATES-

meaning of. 182 .

not mawtul unless undue prelerence results, 182.

illustrative cases on the subject, 182.

GLARLS AND CLARD POSTS-

State law ralid requiring them on bridges and tresiles, 27.

HARBORs, POLJCING OF (see Rearintux of Connencel.

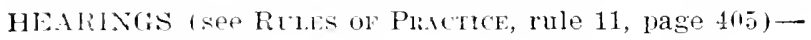
Ilite of, $26 \mathrm{~s}$.

assignments for at request of either party, 272 .

HEATRE OF PASSENGER TRAINS (see ArT of 1866). may be remblated by State law, 27.

HIIIIIATSconstruction of. subjert to State control, "2.?. lower of coneress to althorize national, 59.

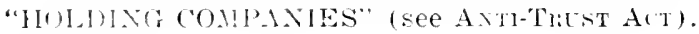

"IClin?-

an injortant bator in refrigerator car service, $11 \mathrm{~s}$.

Ihlerial comblattons (see Texti Section, Axtr-Trust Act, Re-

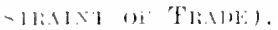

HLIECSALITY OF RATEats drefense in artion against rarrier, 28.

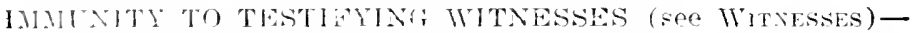
no vications inmmity, 20t.

form te corporation trom enfored testimony of ofluers, 264.

16) anjorations under Ellins Are, z̈rt.

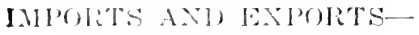

b...el rate on from or to seaport than on domestic traffic, not un

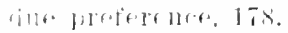

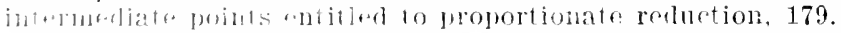

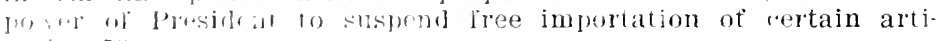

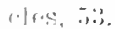

Jmblination and liling of mates muder seetion $6,179,240$.

HIPTISONALXT-

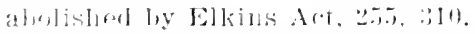

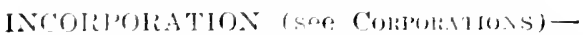
Iww of Congress to marm bridge aross navigable streams, 50. railroarl running thromsh sevral states and holding charter from? rearle a corporation of each, al.

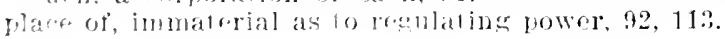


References are to sections.

INCREASE OF RATE-

not until after ten days' notice of, 238.

INDIAN SUPPLIES-

for United States may be transported at less than published rate, 307.

INDIAN TRIBES (see Regulation of Commelit).

INDICTMENT-

defective in not showing discrimination, 258 .

essentials of, 258.

agent of railroad who merely collects freight not indictalsle, 258 .

who in general, 258.

essentials of under Anti-Trust Ac1, 329.

personal to witness, 264 .

extends only to "private" books and papers. 264.

distinction between "private" and "public" doruments, 264.

immunity limited to subject of testimony, 266 .

perjury exrepter, 261.

under amendment of Feb. $25,1903,347$

under amendment of $1893,263$.

information to PARTiEs (see Rules of Prictice, rule 20, page $410)$.

inJUNCTIONS ( see EquTr Procendngs) -

to enjoin interference with interchange of trafice, $s \theta$.

for protections to receivers. 8 .

against labor conbinations interfering with commerce, so.

not defeated because crime involved, 88 .

scope of, in trade disputes. Ss.

distinction where persons are in privity or independent tort-feasors, 88 .

mandatory injun tion in interstate commerce, 90.

cannot enjoin competition, only agrements not to compete, 68 .

value of preliminary injunction, 90.

to enjoin extortionate charges and unjust diserimination, 243 .

to restore passage of freight hackward and torward, 250.

to restrain order of State railroad commission, 195.

against unjust discrimination, 216.

to enforce section 2. 170 .

under section 16, 291.

to compel interchange of facilities, 256 .

not issued to compel performance of personal services, 256 .

in rate wars, $1: 9$.

defense of pooling of earnings, 231.

government only can enjoin moder Anti-Trust Act. 38:.

private party cannot enjoin under Anti-Trust Act, $3: 33$.

State cannot enjoin miler Anti-Trust Act. 394.

order which neither forbids nor commants the doing of a specific act not granterl, 124.

INSPECTION LAWS (see Regulation of CoMnerce) -

absolute prohibition of certain cattle within certain seasons unlawful, 32 .

of State, valid, but must be reasonable, $9,32$.

State cannot require inspection of animals before slanghtering, when, $38, \mathrm{n}$.

Congress has no power of, over State manufacturing business, 33 . 


\section{INSLRANCE-}

not interstate commerce. s

suhject to State lesislation, $s$.

incorporation by Congress in District of Columbia, 59.

\section{INTENTION-}

does not make shipment interstate. 114.

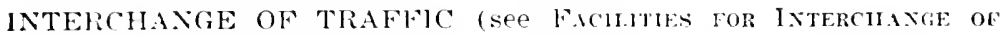

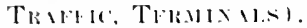

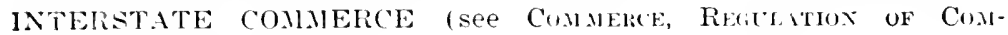

ข1:1:1 1-

roninon law of, $4:$.

free from state control by police ö taxing power, :35.

under iesteral ronstitution. bi.

in relation to employees therein. St.

shipment not made interstate by intemion, 114.

peteral sovereignty in, ::

when carried on ly water sulject to maritime law, 43.

no statutory regulation of prior to Interstate Commerce Act, 43 .

navigalion is, ti.

transperration is. 1i. 15. :16.

telecraph messages. 6. 15.

telephone messages, ti. 15.

Carrying of lotery ticlitts between States. 6.

suiritous liquors. ?.

husiness of "ratrying on," fi:ee from State taxation, 18.

risht to soll of solicit sales tree from State taxation, 18.

immaterial that taxation is without discrimination. 18.

immunity from unlawful interterence not limited to railroads, but extencls to all thagerl in interstate commerre, 83.

carriag, between points in same state passing through another State ti.

Concress alone can act as to admission of goods from one State to another, 16 .

frory rompanies between states, 15.

l,rigere rompanies lwtween states, 15.

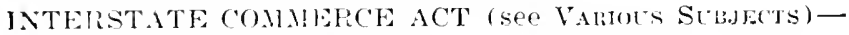

eronesis of the art, 15.

pastage of the art Feb. 4, 1857, 46.

jurpose and seope of the Act. 7 .

junlicial ronstruction of the Act, ti.

power of congress with reference to, 5.

ameneinents of the Ait, is.

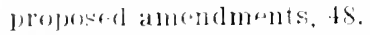

INTERSTATE COMMHERE COMMISSION-

orierinal mombers, 2atio.

unesent members, 26010.

apmointment. term, qualification, vacancies, ete. (see sec. 11).

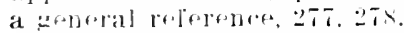

quasi-jullialal borly. 25:5, 275.

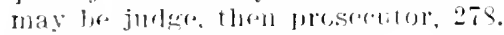

gereral powers of ghit.

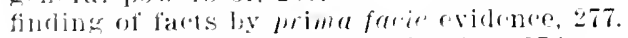

most make reports of investisation, 20ti.

What repere neressary, 2is.

restraining order of not lesiclatise in chararter, 228.

powers of under soretion 1i, 2::3:.

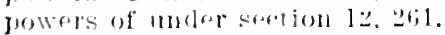

no power as to rar services, 26 .

no jowrer in granting speral privileges, 269.

no Jowere to ronuel exira allowance lor hagsage, 269. 
References are to sections.

INTERSTATE COMMERCE COMMISSION-continued.

no power to allow attorney's fees, 269.

no power of entering judgments, 269.

no power of imposing penalties, 269.

no power to make order over one not party to proceeding, 269 .

power to institute investigation, 269.

to summon witnesses, 269.

to determine relation of rates as between localities and commodities, $269,269$.

to find existing rates unreasonable or unfair. 269.

over foreign commeree extends to what, 112.

over foreign corporation limited to this country, 113.

cannot compel through routing, 11, 211.

no power to entorce finding, 282.

diseretion of under section 7 , Safety Appliance Act, 53.

only violation of the Act considererl, 272, 279.

rulings of the Commission as precedents, $48,275$.

may declare rate unleasonable, but cannot order substitute, 47 .

may determine whether rate is reasonable or unreasonable, 47.132.

no power to fix rates, maximum, minimum or absolute, 47, 123.

no power to raise rate in rate wars, 111 .

no power to compel carrier to deliver cars to another carrier, 242

power to grant relief under section 4. 5: (ses see. 4).

duty of chairman under Aet of June 1. 186s, is.

no jurisdiction except orer cariers and those who invoke its juris-

diction against carriers, 106 .

powers and duties of Commission under Act of $1888,50$.

not bound by ruling of State Commission, 204.

power to correct classification. 209.

prima farie effect of findings, 48 .

address of, Washington, D. C., 298.

form of procedure, 295 .

official seal of 295 .

oaths by members, 295 .

quorum, what constitutes, 295 .

appearance of parties before, 295 .

proper party to complaint, 256 .

subpenaes may be signed by members, 295.

sessions of, 298 .

salaries of conmissionels, 296 .

secretary of, 296.

expenses of, $296,297$.

employees, 296.

offices and supplies, 290 .

INTERVENING PETITIONS-

whell allowed, 279, 2st (see page 402).

INTRASTATE RATES (see RATEs)-

State power in regulating limited by federal authority. 97.

standard of reasonableness considered by cont not same as that considered between carrier and patron, 97.

what is reasonalleness. 98.

what considered in determining. 99.

no definite stanclard of, 98 .

INVESTIGATION-

of complaints by Commission, 270 .

preliminary investigation by Commission not necessary, 287.

"JIM CROW" CARS-

not prohibited by second section, 16.5.

how far State may regulate, $2 .$. 
JOINT RATLS (see THrocgil Raths).

J"DGMENTS, CNTERING OF (see Ixterstate Comanere Commission, Dumins OF).

JUDICIAL PRECEDENTdoctrine of, las limited application, 4S, 186. 275. jurgment hefore Commission bar to action in the court, 252 .

ILIICIARY ACT OF 1ST9jurisdiction of federal courts nuder, 14.

IURY TRIALright to discussed, 284 . may be waived in writing. 2S3.

KANSAS CITY LIVE STOCK EXCHANGE CASES, 126, 323.

FINDS OF TRAFFIC (see DHFELETIAL IN RATES)discrimination in, 200. may also be against locality, 200. second section does not deal with diserimination between, 145 . preterence aginst must invoive injury, 201.

KNIGHT CORPANY CASE, 70, 73.

IABELLING OF GOOIS-

State cannot retulle it, when, 38 , n.

L.ABOR COMBINATIONS (see Axt-THES Act) -

the courts on the relation to interstate commerce, 79 .

L.ABOR LEgislation OF CONGRESS (see Departient of ComMlise AX1, LABOH:).

L.IBOR ORGANIZATHON-

risht of includes right of requecentatime "

L.EASES-

Stite may requile recording of railroad leases, $38, \mathrm{n}$.

LAGAL TENDER NOTESmowro to issue, 4.

LESSETEwhen subject to the Act, 111 .

1.ICFXSE FEErity may exart of interstate telecraph companies, 20. Stite cannot exart for use of navigalle waters, 23.

LAFE INSIRANCEnot interstate unmeree, 8.

HIGITS ON VESSELSState may urescribe number of, $38, \mathrm{n}$.

I.IKE KIXD OF TRAFFICmraning of in section 2,167 .

1.1.11:State cannot recuire inspertion of when imported into State, $38, \mathbf{n}$.

JIMTATION OF ACTIONno provision in Intritare commerce Act, 246.

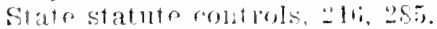
question raisorl hy dembirler, 246. whrn statute broins to run, 246. when suit is logenu, 2sis. private artions under Anti-Trust Art, 344 . in cases of criminal prosecution, $259 a$. 
References are to sections.

\section{LIMITATION OF LIABILITY-}

to stipulated valuation, 30 .

to carrier's own line, 30.

complete exemption, 30 .

complete exenption where pass used, 166.

State statute placing duty on carrier of tracing loss void, 35.

State statute placing duty on carrier of showing loss not on his line valid, 35.

\section{LIS PENDENS-}

purchasers bound by order of Commission, 111.

LIVE HOGS (see DHFFenextils in Rates).

Live STOCK (see Regulation of Comalice, Covirnext JumisnicTIOx) -

transportation from State to State not included in Act of 1s $84,54$. increased hazard in carriage warrants higher rate, 136.

require additional facilities for delivery, 117.

railroad may contract with stock yards company în delivery of, 117.

when commercial transit of ends, 16,68 .

power of Secletary of Agriculture over, 54.

State cannot require inspection of and fee, $38, n$.

\section{LOCAL AND THROUGH RATES-}

charging of local rate not unjust discrimination when no through rate, 215 .

charge of local rate greater than proportionate part of through rate not unlawful, 127.

division of through rates usually less than corresponding local, 128.

distinction between, 127,128 .

the Commission on, 128.

mileage basis not required, 128 .

responsibility for through rates, 129.

manner of making through rate only important as to its legality, 128.

not properly compared, 138.

local rate, inclucling terminal expenses, is prima facie excessive as part of through rate, 128 .

local rate need not correspond with division of joint through rate, 128 .

LOCAL AND THROUGH TRAFFIC-

circumstances and conditions of are dissimilar, 150 .

through traffic different "lind of service" from local traffic, 150.

\section{LOCALITY-}

second section does not deal with preferences in favor of or against, 145.

rates will not be changed to equalize commercial conditions, 134.

adjustment of rates between, 183 .

preference of excused by competition, $175,176$.

competing cities on opposite banks of rivers, 185 .

recognition of natural advantage of situation not unclue preference, 184 .

\section{LOCAL INDUSTRIES-}

Congress no power orer, 75 .

LONG AND SHORT HAUL (see Folntir Secton) application where short haul wholly within one State, 93, 2.3. carrier may judge in first instance whether circumstances and conditions dissimilar, 175. 


\section{LOTTERY TICKETS-}

as subjects of commerce. $s$.

carriage hetween States may be prohibited by Congress, 6. 54 . carriage between states may be punished by Congress, 53. in general, $56, \overline{5}$.

LCMBER-

rates on from southwest Virginia to New York, 142. rates on from Inition to Lynchburg. 142.

MADISON, TAMES-

on feleral resulation of interstate commerce, 1.

MALICE-

as an ingredient of ciril action, 84 .

MANDAMLS-

to compel equal distribution of cars, $189.308,309$.

remedy rmmulative, 308, 309.

to compel carrier to obey the law, is, $30 \mathrm{~s}$.

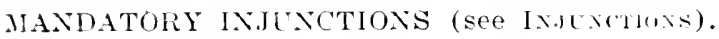

MANTFACTLIRE-

distinguisled from commerce, 315.

MANLFACTERER-

when encaged in interstate commerce, 15.

MANUFACTERING, BLSINESS OFnot interstate rommeree, 7 .

MANTFACTLRING CORPORATIONS (sec Fonkigr Compontoxs).

MARINE INSIRANCEnot interstate comnerce. 8 .

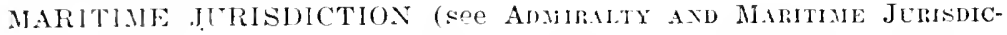
1101.

MEAS(RE OF DAMAGES (sce DAMAGLS).

MEASLRE OF PloOg (see Prone).

MEI,ONSrates on from Sonth carolina to New lork, 142.

MILEACEE PASISrulw as to State laxition, 19.

Commission no power to makr 137 .

no rempirement ior in Art, les.

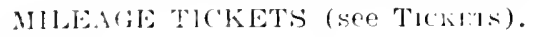

M11K-

Erouping rates basis to New York, 142.

MIJLING; INUTSTRY-

Jiscrimination arainst, 2ous.

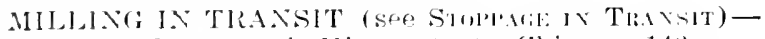

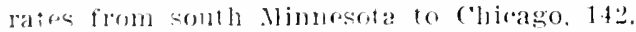

ratres irom Hrorlian and Now Orloans, 142.

rales from chirateo and ('incinnati to solluhern ferritory. 142.

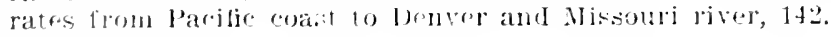

MISIENLAXOR-

failur io publish rate, 319.

as to los latres, :310.

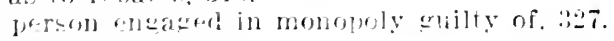


References are to sietions.

MISDEMEANOR-continued.

party to contract or combination, of conspiracy in restraint of trade, guilty of, 328 .

under Anti-Trust Act, 314, :327, 328. 3:29.

conspiracy a misdemeanor not feluny, 82.

MODE OF SHIPNENT-

discrimination in, 205 .

MONEY-

power of coinage, 4.

MONOPOLY-

meaning of term, $i 2$.

in law and in ract distinguished, i3.

persons engaged in guilty of misdemeanor, 327.

MOOT QUESTIONS-

not decided, 272. 273.

MUNICIPAL SUBSCRIPTIONS-

for building road, no effert on competing locality, $18 t$.

NARROW GAUGE RAILROADS (see RAIIRUMA).

NATIONAL BANK-

power to charter, $t$.

NATIONAL HIGHWAYS (see Raritatos on Commerea) power of Congress to authorize, 59.

NATIONAL INCORPORATIONS (see COHPHRTMGS)--

relation of state to lecleral rorporations. til.

State cannot interfere with federal "orporation, 61.

franchise not subjert to State taxation, fil.

requirements for terteral franchise for business corporation in interstate commerce. $1 i_{2}$.

as a means of regnlating rommeree, for.

power of Congress to chartrer rorporations. 59.

removal of case trom State to lesleral court under Act of $1875,59$.

power of Congress to incorporate interstate railroarl companies, 59. power to charter corporation for construction of interstate briase, 59.

NATURAL ADVANTAGES (see Lon M.TTI- ).

NATURAL OIL AND GAS (see OHL)-

as subject of commerce, 11.

not suliject to State legislation. 11.

distinction letween and animals "ferat hatwiar." 11 .

State statute prohibing piping out of siate voir. 11.

State statute prohibiting escape of into air valid. I1.

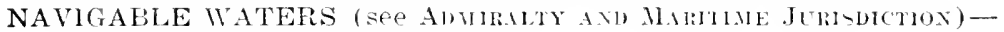
what are, 12 .

navigable in law if so in fact, 12.

immaterial that rapids and falls interrupt the flow, 12.

NAVIGATION-

is interstate commerre: i.

"NECESSARY AND PROPER"-

constriction of term, 4 .

NECESSITIES OF LIFE ( see ANTT-TIRT A(T).

NINETEENTH SECTION-

principle office of the Commission, etc., 298. place of hearing, :29!?.

NINTH SECTION-

testimony clause of unconstitutional. 252 .

suit may be brought either hetore Commission or in United States courts, 251. 
Rirferences are to sections.

NOTICE IN NATLRE OF DenuRRer ( mage $4(1)$.

NOTICE TO THE CARLIER-

of findings ly Commission, 282.

1) RACENE LATERATTRE-

interstate carriage of prohibited, 54.

OCEAN TRANSIORTATION-

reates dissimilar circlumstances and conditions, 178.

OFFlCFR-

act of the act of carrier, : $: 10$.

(1HIO COAL, CASE, : :19.

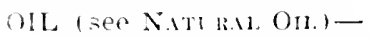

ratrs on from Oil City to New York and Boslon, 142.

liscrinuination in mose of shipment, 215.

higher rate for barrel than tank rar shiments unlawful, 205.

hicher rates for less than car load than for car load of barrels not inlaw ful. 20.5.

allowance for leakage in tanks and not in barrels unlawful, 205.

UIAOMAREARIXE-

subject of commerce, 9 .

subjert to taxation, 9.

siate may prohibit manufarture and sale of, 9.

(annot yrohibit its introdution into state in original package, 9. poline power of state extented to, 54 .

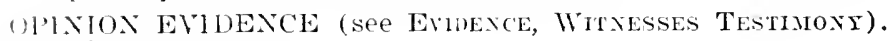

ORINGES-

rate on from Florida to New York, 142.

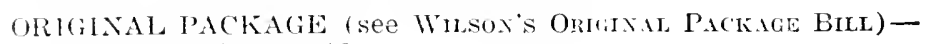
maining of term, 16.

time when taxing power of State begins, 16.

in relation to State taxing power, 16.

in relation to State police power, 16.

meaning of term "arrival," $17,53$.

whell trinsit ends, 16.

oriokCHARTisferbion of a violation of the law, 168 .

“() THR THE SAME LINE"

meaning of term in section 4, $22 \%$.

(MNERSHP.

hiscrimination based on ownership of cargo, 157.

MSTERS-

how far State may rogulate. 10.

WARIC COAST RATL-

to benver ant Alstimi River points, 142.

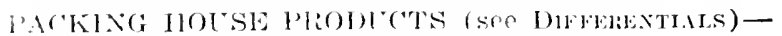
rates on lrom chisago to New York, 14?. rates on from Savamah to Florila, 142.

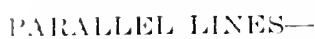

one railroal owning both should provide equal advantages, 138.

PARLOR CAR RATESdiscrimination in between loral and throngh passengers, 165.

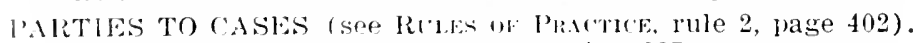
all parties infresterl ale proprer laties, 287.

any person or assoriation may complain either for himself or communily.271. 
References are to sections.

PARTIES TO CASES-continued.

proper and necessary defendants, 287.

under Ellins Act, 310 .

Interstate Commerce Commission as party, $28 \pi$.

all carriers on the route not necessary, $27 \%$.

in suit against unincorporatel assoriation, 391.

in suit by unincorporated association, 271.

owner of portion of through line not necessary, 271.

Commission may bring in all parties interesterl, 271 .

PARTY RATES-

govermment not entitled to, 305.

Party Rate case discussed, 15:.

\section{PASSES-}

issuing of unlawiul unless excused by section 22, 166 .

no recovery for injury, if risk assumed, 16it.

to officers and employees do not include their families, 305.

\section{PASSENGERS-}

unjust discrimination in service to, 165.

State imposed duty on master of vessel to report arrival of valid, 21.

State tax on immigrant roid, 21.

\section{PAUPERS-}

State cannot compel gratuitous removal of by rairoarl, $38, \mathrm{n}$.

State legislation may exclure, 9.

\section{PATENTS-}

power to grant, 4.

subject to State police power, 31.

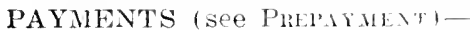

by shipper ignorant of discrimination not roluntary and may be recovered back, 120, 160.

PEACE OF THE UNITED STATES-

meaning oì, 4.

entorcement of by executive. 4.

\section{PEACHES-}

rate on from Delaware district to Boston, 142.

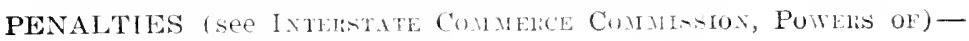
for refusal to testify, 2 til.

corporations suliject to, 264.

for violation of the Ar.t. $85: \%$.

for failure to report areidents, :3:3.

in sertion 10 apply to cmployees refusirg to hanl freight of other roats. 80 .

for fallure to publish rates or observe published rate, :310.

as to rebates, 310 .

for violation of Safety Appliance Act, ses.

under Anti-Trust Act, $314,327,328$.

\section{PERJURY-}

prosecution for, 261.

PERSONAL SERVICES-

equity cannot enjoin performance of, 256.

"PERSON" OR "PERSONS"-

meaning of in Anti-Trust Act, 348 .

corporation a person within meaning of fourteenth amendment, 15. $94,164$.

corporation a person when necessary to effect legislative intent in statutes, 264.

PETITION isee Presmingis). 
"PICKETING" AND "SOLICITING"-

in interstate conmerce, $\$ 5$.

PIERS. REGLLATION OF (see REgintian of CoMmerce).

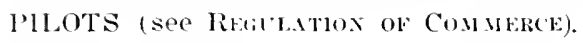

\section{PHOTOGRAPHS-}

State tax on, when void, :88. n.

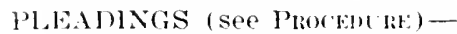

neressary averments for a cause of action in relation to schedules, $12 \cdot 2$.

no replication, $2-2 \cdot 2$.

in equity cases, $28:$ ?

complaint concerning rlassification against whom made, 272.

necessary averments in action for damages under section $2,169$.

petition to state what under section 7 Anti-Trust Act, 342.

petition to recover penalty must show what, 246 .

POLICE POWER ( see State Legislation, Regulation of Commerce) State not deprived of by regulating power of Congress, 9, 40.

distinguished from regulation of commerce, 85.

in relation to sale of United States patents, 31.

Felleral Goverument as such has none, 4.

in relation to inspection of live stock (see Ixspectiox LAws).

extends to reasonable inspection of articles brought from another State, 9.

POOLING (see Fiftil SEctun) -

forbidden, 68 .

cinnot be lawfully employed as preventive of rebates, 228 .

reservation to initial carrier of power to route shipment beyond

its own line unlawtul, 228 .

meaning of term "pool," 227.

express companies may pool earnings, 230 .

as defense in injunction, 291.

aqrerments not within the prohibition, 229.

meaning of tern "freights," $22 s$.

"physical" pooling, 227.

"money" pooling, 2יㅡ.

POST OFFICES AND POST ROADS-

jower to establish, 4.

POWERS OF (GOVERNMENT ( see Finctoxs of Governuext).

PREFERENCE AND ADVANTAGE (see UNAUST Discrinixation) form of inmalerial, 187.

proference of locality excused by rompetition, $175,176$.

betwern domestic and torsign traffo in import and export rates not indue, 178.

where ploference rate exceeds rompetitive rate, 177 .

rannot be alleged by town which railroald does not reach, 184.

shown by "flenurrage," 187.

failure to jullish rate thro!gh to particular town is, 187.

failure to allow equal "areessorial service" is, 187.

in rlifferential betwen rarloarl ani less than carload, 187.

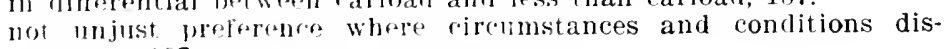
similar, 187.

against traffic must involve injurv, 201.

delay in furnishing rars. 189 (ses ('Al Skruce).

glarantef to party rate purchaser, arrival at certain time not preferential, 187. 
References are to sections.

PREFERANCE AND ADYANTAGE-continued.

in denying shipper choice of route. 197.

in arbitrary division of territory, 198.

in classification, 208 .

PREFERENCE CLAUSE, IN CONSTITUTION-

discussed, $3,56$.

no application to interstate commerce, 3.

transportation from United States to Porto Rico not included, 3.

PRELIMINARY INVESTIGATION-

by Commission before filing suit for enforcement of its orders, unnecessary, 287.

PREPAYMENT (see PAYMENT) requirement of one connecting carrier and not of another not unjust discrimination, 212.

PRESIDENT OF THE UNITED STATESpower to suspend free importation, 53.

PRESUMPTIONS ( ( see Binitex of Pronf) long continuance of rate presumption of reasonableness, 133, 134 . voluntary reduction presumption of unreasonableness, 134.

PRIMA FACIE CASEreports of proceedings before Commission as, 4S, 277, 259. rulings of Commission on unreasonableness as, 132.

PRINTING OF PLEADINGS (see Rules of Prictile, rule 16, page 409).

PRIVATE CARS (see Car Serilce).

\section{PRIVITY OF CONTRACT-}

none between car owner and shipper where carrier pays mileage, 193.

\section{PORTO RICO-}

not a foreign country, 3 .

PROCEDURE (see Plenings axd Ploof) -

before Commission simple, 271,272 .

dilatory proceedings not favored, 271 .

who may complain, 271.

where suit to be filed, 283,286 .

leave of court unnecessary in suits against receivers, 271.

failure of proof, effect of, 271.

hearings, 272.

failure of carrier to answer, Commission will proceed, 272.

no replication required, 272.

hearings orally or on brief, 272.

complaints, how and by whom made, 272.

how served upon carriers, 270.

immaterial that trade organization is unincorporated, 271.

in federal review of State regulation of carriers, 96.

suit by United States under Anti-Trust Act, 331 .

restraining order may issue without notice, 331.

proceedings by Commission to enjoin violations, 312 .

effect on other action, 312 .

PROOF (see Eridexce)-

plaintiff must show injury, 245.

reasonable time allowed for making, 272.

measure of, under Anti-Trust Act, 340 .

newspaper reports, etc., to show conspiracy, 82 . 
Fieferences are to sectinns.

PROOF-continued.

plaintifi must show rate unreasonable, 122.

in ase of unpublished rate, 245.

tiailure of proot, Commission may take charge, 271.

for refovery of penalty, 245 .

relief not given without. 273 .

in rase asling reparation proof necessary, 279 .

PROPOLTION-

as alfecting reasonableness of rates, 140 .

“PROPOR'TIONAL, TARIFFS”-

mraning of term, 195.

State Commission no control over, when, 195.

PRUnUAle hlNUINGS (see Rules of Prictice, Rule 14, page 408).

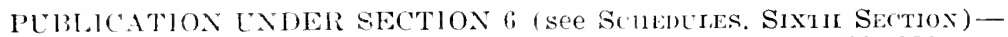
joint rates must be duly authorized before published, 129, 239.

rffect of publication. $122,234$.

what is sufficient, $2: 37$.

contrarts and tarifis filed may be considered before Commission

witlout introduction, 234.

pubished rate conclusively deemed legal, 235, 310.

finforribility of unpublished rate, 235.

sood delense to artion for damages, 121 .

of joint traffic and through rates, $2: 38$.

of State rates in comection with interstate, $2: 38$.

excursion rates must be, 238 .

sillediles need not be duplicated by each company. 2:i7.

postin wotice that all rates are on file in office not sufficient, 237.

terminal rlurges must be, 236 .

storage charges must be, 236 .

rules and rates of carriage of private cars, 236.

andication to import and export rates, $112,240$.

of harges for refrigeration in transit, i1s.

fature to priblish when nudue preferente. $187,255$.

fallur to mblish or olsserve, a mistemeanor, 314.

reduction of rates without filing schedule unlawiul, 238.

increase of rate, $2: 3$.

(ontrart for rate lower than published rate not binding, 234.

PLlill' CHAlire-

state locistaltion may exclude persons likely to become, 9.

PCL1.16:01PINTON-

infinde uf on ("onstruction of Federal constitution, 63.

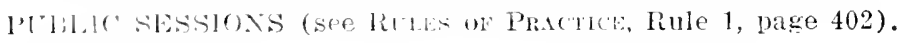

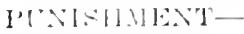

inf frited 10 olpey injunction or other process, 283.

QLARANTIER LAWS-

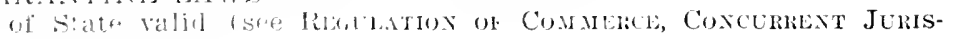

$1+11,110,0),: 1$.

RAllatodH:-

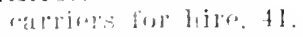

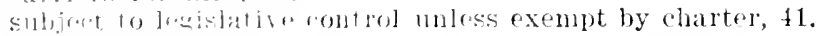

d1119 10 rarry, 11.

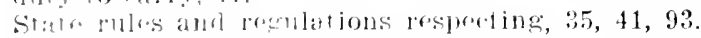

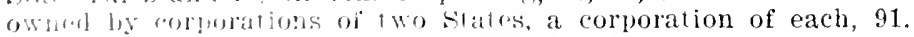

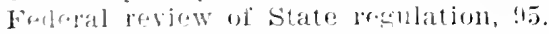

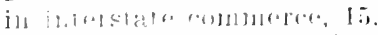

trem "ridtrome" in section 1 includes all bridges and lerries used or operated in comperetion with any malroarl, 115. 
RAILROADS-continued.

Reftren ins are to sections.

but not when operated by the ratroat company. 115.

State power of resulation cannot extenil to interstate trafic, 41.

State power of regulation may fix a limit of charge, 41 .

cannot require exchusive business of shipper, 196.

wholly in one State when not subjert to the Act, 105.

when subject to the Act, 105.

State regulation under State Commissions, 81.

power of regulation independent of incorporation, 92 .

regulations may be nade hy railroars for delivery of freight. 196.

regulations may be made by railroad respecting reduced rate ticket, $11 ; 5$.

governmental regulation of, in Englark. 42.

when not subject to section 20. 3i1.

Govemment Aided isee Ar T J J LY 1, 186:2).

reports of acidents isee Acruext L.W. sp. 11 .

Railroal Commissions established in States, $\$ 1$.

\section{RAPID TRANSIT-}

warrants higher charge, $136,155$.

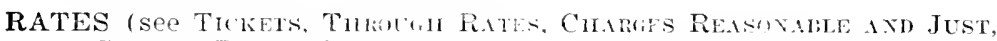

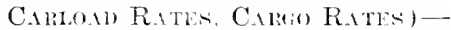

quantity of freight as afferting rates, 14s, 153.

wholesale rates in passprger and freight traffic distinguished, 154. limitation by Federal authority of State power in regulating interstate rates, 97.

what is reasonable in the limitation of State authority, 98.

character of treight as affecting rate, $1: 1$ 1:it.

cost of service and needs of shipter as alfecting rates, 135.

rapid transit as atterting rates. $1: 6$, 15.5.

cost of handling as affecting rates, 136 .

clistance as affecting rates, $1: 3$.

reasonalieness of rates question one of tact, $49,129,175$.

no definite standard of, in railroad rates. 99.

finding of Commission does not extonet to nltimate question of, 49. practical difficulties in the entorement of, 120 .

standard of under State states, 1 -

standard of, moler the Act, 121.

what consideref in detemining. 9s.

presumption of reasonablemess from long continuance, 133, 124.

interests of both the publin and owner of proverty to be consitiered, 125.

in absence of legislation court must decile, 119.

construction ot, by the Federal rounts, 125.

capitalization of railroad as basis of retes, 126 .

reasonableness of, mner section 1 distinguished from prelerences under section 3,130 .

comparison not a basis for determining reasonableness, 13:, 1:8. fixing of tuture rate a legislative, not administrative or judicial. finction. 49, 124.

Interstate Commerce Commission no power to fix rates, 47, 12:3. efrect of Commission's ruling on reasonableness of rates. 132 . question of reasonableness raised by defense in action at law. 96. question of reasonableness raiser by bill in equity, 96.

may he unreasonable because too low as well as too high. 125.

consideration of, in the courts, 138.

immaterial whether railroads combine or act separately, 138.

tax return of railroar officials to establish, 131.

interstate rates bear no comparison to State rates. 139.

reasonableness and proportion. $1411,183$.

in comparison of rates, dissimilar circumstances and conditions are to be considered, $1: 3 \mathrm{~S}$. 
I. TTES-continued.

rates on lines of rival companies or different branches of same "ompany properly consilered, 133.

increase of rates for purpose of securing traffic under agreement, un reasonable, 1:38.

standard of reasonaluleness considered by the courts not the same as between carrier and patron, 97 .

presumption of reasonableness of State imposed rates, 97 .

rate per ton per mile rule, 128.

reduetion of rates without consent of connecting carrier or filing of schedule, 294.

three days' notice required, 23:3, $2: 38$.

frrimption of un reasonahleness, 134 .

oro continuous line where no rate established, 2238.

rates may be reasonable in one part of country and not in another, 13.

no connection between rates in opposite directions, 138.

filed or participated in, deemed legal (see Erisixs ACt).

transfer from rate to another does not determine future rate, 209 . commodity rate for inteniled settlers only, 208 .

rates cannot he apportioned according to milage, 109.

share of through rate not measure of reasonable rate, 138 .

aphortionment of throngh rates to different parts of line as signifiient of reasonablenes. 138.

illustrative rates on different commodities between different points, 142 .

Rebates (see Uxilst Dischumatiox, Premerexce axd Adyantage) given to serure business. unlawful, 151.

contracts for, malle prior to taling effect of Act unenforcible thereafter, 169 .

REGLLATION OF COMHERCE-

exclusive jurisalinion of Congress-

distinction betwern power over interstate and foreign commerce and with Indian tribes, 2, 36 .

all suljocts national in nature or requiring one uniform sys16m, 20, 21.

all interstate shimments, fi.

all interstate brirges, 6, 22.

Ir lease of the Federal regulating power, 52.

regulation by the delegation of power, $5:$.

the leveloping construction of the Federal power, 63.

not the reprise. lust tle existence of the power in Congress lhat invalidates state laws, :36, 89, 45.

rralation in relation to labor. is.

lesinning of Federal regulation, 39.

romerce may be regulated by inaction of Congress, 21, 55, 36, :",

un-xercised Forderal regulating power, 56 .

unexercised ferleral powers in matters of State legislation, $54 ; 57$.

(1ustion for Supremo court to determine whether State laws abrogater liy Aret of Congress, 56.

rogulation ly taxing lower, 5.

prolubition and regulation, 5 .

lerglation of navigation over inland waters. 22.

Forleral and State rourts, juriscliction of, 44.

inartion of concress in toreign and interstate conmerce distingrishorl, :36.

i: rotion of congress mrans intristate commerce must be free, $\because \div$ 
References are to sections.

REGULATION OF COMMERCE-continued.

State regulation under rules of common law in State court, 31.

Supreme Court on the three classes, 22.

by national incorporation, 1,60 .

concurrent jurisdiction includes-

regulation of pilots, 28.

quarintine laws, $2: 34$.

inspection laws, $23,32$.

live stock laws, $32,3: 3$.

policing of harbors, $; 2.93$.

improvement of naviqable waters. 29.

regulation of wharves, $2: ?$.

regulation of bridges over navigable waters, 23.

regulation of piers. 23 .

regulation of dorks. 23 .

construction of bridges across navigable waters of a State, 23, 4.4

establishing of ferries across navigable wateis of a State, 23, 49.

regulation of telegraph poles, wires, etc., 24.

exclusion of diseased cattle, 32 .

in interstate railroad traffic, 25.40.

action of Congress renders State law void, 22, 25, 27.

concurrent and exclusive powers distinguished, 21.

effect of police laws of State on interstate carriers, 25.

effect of Act of Concress on police laws of State, 25.

State laws prohiliting l'unning of freight trains on Sunday, 26.

exclusive State jurisdiction includes-

construction of highways, 22 .

construction of turnpiles, 22.

consuruction of railways between points in the same State, 22. construction of canals between points in the same State, 22 .

operation of briages over navigable streams, 22 (see contra), 1118

resulation of domestic commerce. 101.

State may make reasonable regulations for, 101 .

State may enfore facilities for transportation of freight, 101.

State may alter, amend, or repeal charter, when, 101.

State may prohibit discrimination, 101.

State may prohibit consolidation of parallel or competing lines, 101.

State may requile erection of stations along line of railroad, 101.

REHEARINGS (see Rties of Prictice, Rule 15, page 408.

RELIEF FRON OPERATION OF SECTION 4 (see Fourtil Section, proviso of 1 .

REMOVAL OF CAUSE TO FEDERAL COURT-

national corporation may remove, 59.

no jurisdiction on removal where State court had none, 43, 248.

REMOVAL OF PERSON-

from one district to another for trial, 259.

REPARATION (see DANAGES) -

before investigation relieves carrier from liability, 270 .

REPORTS-

carriers must render annual, to Commission, 300 .

what reports to contain, 300.

Feleral courts no jurisdietion in mamamus to compel, 301.

Commission to render anmial, to Congress, 202.

REPORTS OF ACCIDENTS (see ACClENT LAW, sec. 1). 
References are to sections.

\section{REPORTS OF DECISIONS-}

lnt. com. kinn.. zsol.

1. C. C. R., 280 .

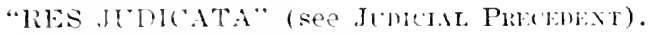

RESTIANINT OF TRADE-

contracts in, at common law and under Anti-Trust Act, 66, 69, 70, $7 \mathrm{i}$.

contlacts in. how construed. in.

rombacts restricting sales by rebates not unlawful, 71 .

combinations between interstate railroads suppressing competiifoil. 71 .

acreements for charees for local facilities not included. bs.

commolity may be subject of unlawful agreement, also of State taxation, 188 .

combinations in restruint of interstate commerce unlawtul, though subject of contract within jurisaliction of a. State, 84 .

combination for emplorment of none but union labo: may be. 84 .

complete monopoly unnecessary, sufficient if prices enhanced and romplition suppressed, 317.

invilental restraint of trade not unlawful, 322 .

REVISORY POWER (see CorrTs).

ROLLING STOCK (see CAr Srmule -

not subject to attachment, when. :it.

RLIES AND REALLATIONS-

respecting reduced rate ticliets. 165 .

collexion of extra fare from lnssonger without ticket, 165.

unreasonahle. may be discriminative, 158.

SAFETY APPIANCE AC'T-

Sertion $1,:, \%$.

Surtion $2 .: 8 \pi$.

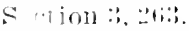

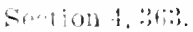

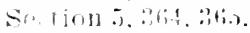

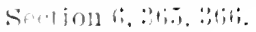

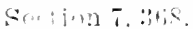

S1+1011 S : :

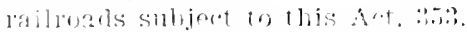

rommon law duly of carrive in relation to safety appliances, 354. petition and proserelure under the Art. 3.5 .5$.

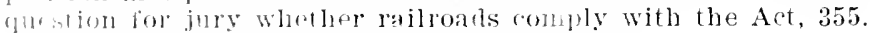

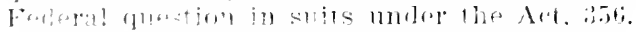

conpler equipmont under sertion 2, 358.

mbomalis: eomplers of nifferent malses. 359.

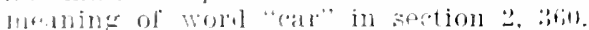

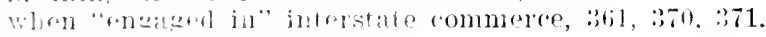

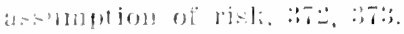

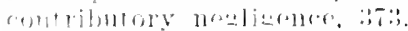

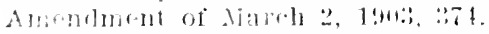

Aiscolion of the commission in delaying entorement of the Act.

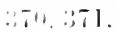

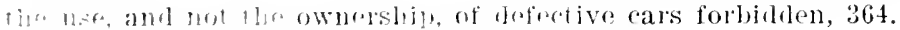

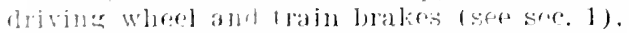

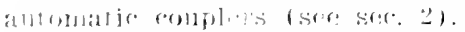

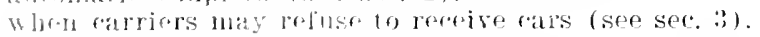

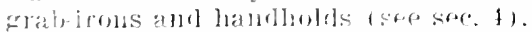

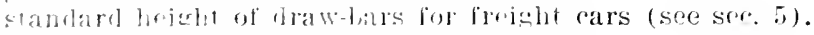

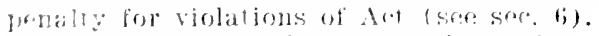

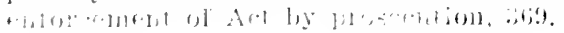


SALE-

References are to sections.

as incident of manufacture, distinguished from commerce, 315.

SALT-

rates on, 142 .

SAVINGS BANIKS IN DISTRICT OF COLUNBIAincorporated by Congress, 59.

SCHEDULE (see Plblication) -

what is included in, 286 .

filing of raises no presumption of legality, $2: 1$.

failure to challenge does not malie unlawitul rate lawful, 284. what is suffirient publication and filing, $2 ; 7$.

SECOND SECTION (see Preretexce axb Amantage, Uajust Dis('MMIINATHOX)-

orisin of the section, 144 .

purpose of the section, 145 .

does not cleal with preferences in favor of or agrinst loralitios, 145.

does not deal with discrimination between linds of trafic, 145 .

effectiveness of the section. 146 .

aiplication of the section. 167 .

no application to cases ormuring hefore Act passed, 169.

meaning of a "like ling of traffic." 167.

enforcement of the section, $11 \%$.

enforcement by injunction, 170 .

What constitutes violation of section, 144 .

SECRETARY OF AGRICULTURE (see LIVE STUCr).

SECRETARY OF WAR-

nowers and duty of in regulation of commerce, 54.

SEIZURE AND CONDEMNATION OF PROPERTY-

how enforced under sertion 6, Anti-Trust Act, 337 .

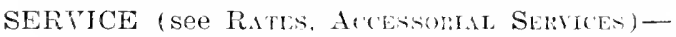

difference in warrants, difference in rates, 149-15j.

remedy where special service charged for but not rendered, 155.

SERVICE OF PAPRlis see Rules of Practur, Fule b, paze 404).

SEVENTEENTH SECTION-

Interstate Commerce Commission-Form of Procedure, 295.

SEVENTH SECTION-

considered in connection with section $2,212$.

judicial application of section. 242.

continuous carriage of treight from place of shipment to place of destination, 241.

\section{SHEEP-}

sheep driven from one State to another subject of interstate commerce, 16 .

SHERMAN ANTI-TRUST ACT (see Axtr-Trest ACT of 1890).

SHIPMENT-

State cannot impose penalty for disoledience of, $3 \$, n$.

SHIPPER AND CARRIER THE SAMEdiscrimination by carrier in favor of himself as shipper, 161.

SHIPPERS' ORDERS-

State cannot impose penalty for disobedience of, : 2 S.

SIDE TRACK AND CONNECTIONS-

State legislation concerning, 196.

railroals under no obligation to huild spur track, 196.

no discrimination to build for one and refuse to another, 196. 
References are to sertiuns.

\section{SIXTEENTH SECTION-}

petition to Lnited States conrts in cases of disobedience to orders of Commission, 283 .

SINTH SECTION (see PInLI(ITHix)-

printing and posting of shethles of rates, fares and charges, 232.

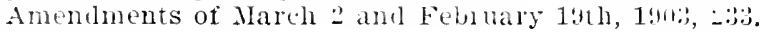

"SOLIClTINC"

in interstate commerce, 85.

SOLTH CAROLINA-

insuretion laws of, invalid, 25.

SPARKS FROAI EXGINE-

State ma impose liability on ratroats for damages done by, $38, n$.

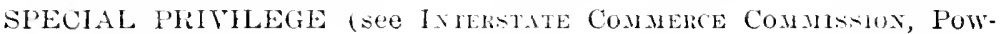
EISS $0: 1$ -

SPECIAL, SERVICE (see Rates, Accessonil Skrtich).

SPEED OF TRAINS WITHLN MUNICIPAL LIAITS-

may be regulated by State laws, $2-$.

SPIRITLOt's Liquors (

siliject 10 commerce, 9.

State may prohibit introluction of, 21.

State cannot prohibit introdurtion and sale in original package, 9.

State may prohibit domestic manufacture and sale of, 9.

Sonth Carolina lispensary laws invaid, 35.

SPlR ON SIDE TRACK (see SIDE Tracks axd Coxiectoxs).

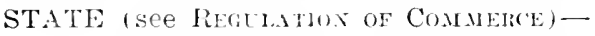

not a prem or corporation within meaning of section $\tau$, AntiTrust Act, $2: 0$.

power to resulate rates by legislature or by State Commission, 91.

STATE ANTI-THUST LAN-

in comnection with 1 th Amendment, 10?.

protertion of carrier against cliscriminative State legislation, 100. discriminations may be prohibited, 101.

facilities for interclange of tiaffic may be enjoined, 101.

reasonableness of contracts liecween carrier and patron or other ("arritil. 1'1.

concolirlation of paralled and competitive lines may be prohibited, 1111.

statmir valid punishing wilful or malicious injury to another's bus iness, 102 .

statum invalid which punishes offense committed by person outside of siatrat $11+2$.

stathtrinalid which exempts certain class of the community, 102 .

STATE OOMIMISSION-

lasulation of railrouls, 91.

subjocl, to terleral reviow, $91,96$.

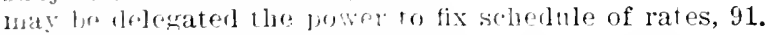

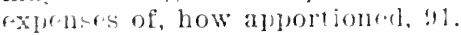

linilation of anthority in domestice commerce, 93.

suit atranst, not against State within maning of Eleventh Amendnimitr, 4.).

no rommol over proportional tarifs, 195.

STATE COLRTS-

on the rommeree relanse, : 28 .

jurisdirtion of, in the recrilation of rommerce, 44.

jurisdiction in common law of interstate commeres. 43. 
Refirences are to seetions.

STATE LEGISLATION-

protection of carrier against discriminating, 100.

STATE RAILROAD LEGISLATION-

classification of, ralid if reasonable, 103.

illustrative cases on, 103.

\section{STATIONS--}

State statute valid requiring erection of, 101.

STIPULATIONS (see Rules or Plintio, Ruie 10, page 405).

STOCKYARDS-

extra charge for delivery to, when off main line, 117.

Stockyards case, 69.

State statute regulating charge of one only, invalid, $10 \%$.

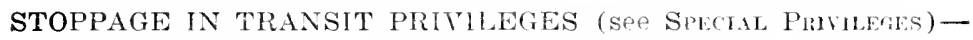
discussed, 163.

unjust discrimination through abuse of. 164 .

inclucles right of milling grain in transit, $168,194$.

right of connecting carrier as to, 21 s.

includes right of compressing cotton, 16 i? 194.

includes right of mannfacture of logs into lumber, 163. 194.

does not include stop between point of purchase and point of sale, 194 .

the "Tap Line" case, $16: 194$.

STOPPAGE OF TRAINS AT CERTAIN STATIONS-

to what extent State may compel, 29.

STORAGE (see Deliner., Chithat)--

no additional duty imposed by section 1,116 .

charges for must be publisher, 236.

services, if rendered, must be impartial and reasonable, 116 .

unjust diserimination and undue preference may be based on, 116, $162,187$.

charge for, in depot may be higher than in warehouse, 116.

of grain in elevator's at stoppage points, 116. 163.

free storage as basis of unjust discrimination, 162 .

right of carrier to contract for storage of through grain, in elevators at terminals in transit, 162.

\section{STRAWBERRIES-}

rates on from Florida to New York, 142.

STREET RAILROAD-

city ordinance prohibiting discrimination, void, ?s, n.

STRIKES AND BOYCOTTS-

distinguished (see Coxisir.ry).

boycott may result in conspiracy, so.

concerted quitting employment may be lawful, 81 .

when concerted quitting inlawtinl, s1.

boycott of any form of interstate commerce, unlawiul, 84.

immaterial that no violence results, 81 .

peaceable strike lawitul, 257.

sympathetic strikes and boycotts, st.

SubPCeNas (see Rules of Practice, Rule 13, page 407 )issued according to practice in Federal coults, $261,269$. how served in bringing in praties. 335.

SUCCESSORS OR RAILROAD-

bound by order of Commission or doctrine of lis pemlens, 298.

SUGAR一

rates on from New Orleans to Wichita, Kan., 142.

SUGAR TRUST CASE, 6.8 . 
Roferences are to sectiens.

SLNHAY JAHS-

State may molnbit rumning of freight trains on Sunday, 26, 40.

in senerall. 2 li.

SLPERSEDEAS (sfe AlPEAL).

SLTRACE CROSSINGS-

state law for protection ol, valia, :-

SITCHING RAILROAD-

subject to state control when doing local business, 21:?.

when not suljeat to the Interstate Commerce Act, 1 its.

simpatheTlC ETRliEs AND BOYCOTTS (see STllies axi Boy(n)tist.

TANK CARS (see OIL) -

dut: of corrier to tomisis, 191, 20.5.

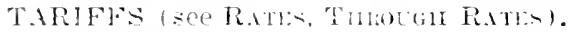

TAXATION-

restulation of eolmmroe throush, 59 .

Srate taxation and intersate commeres 1 s.

State taxing power of corporations crisased in interstate commeree. 21

property in commercial transit free from State taxation, 16.

business of "arring on interstate commerce not taxable, 18, 20, 35. intangible loromen how lorated in state, 19.

the "unit rule," 19 .

the "arrage hahitnal nse" pule. 19.

the "milumer basis" linte. 19.

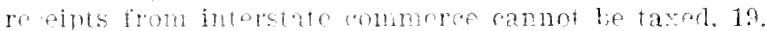

intont to rxport floes not free from State taxation, 6, 114.

franchise laxation. 20.

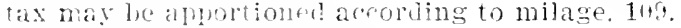

on loroker, when lawill.

State tax on trelogranh inmponies. 24.

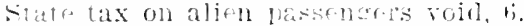

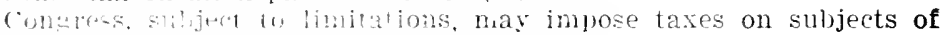
rommine and on riolits to earry on, is.

TEA HS -

transuortation by not sabjoet to the Ant, 105.

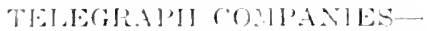

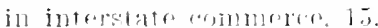

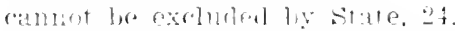

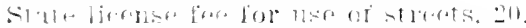

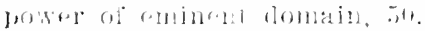

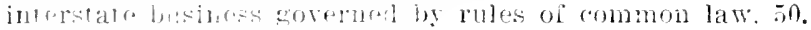

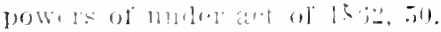

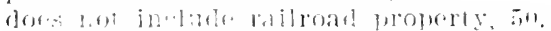

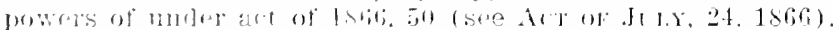

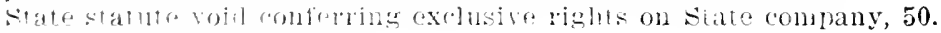

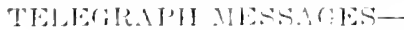

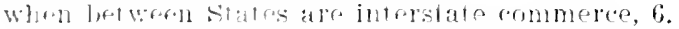

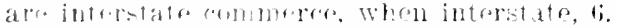

rannot lof taxed lix Stato.

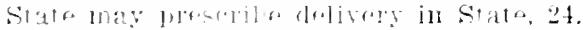

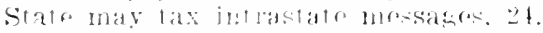

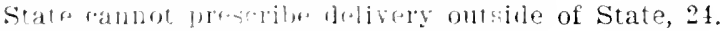

TELEPHONE (OONHANHE-

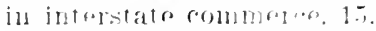

not ineluded in Ace of 1 , int 51 . 
References are to sections.

TELEPHONE MESSAGES-

are interstate commerce, when interstate, 6 .

Act of July 24, 1866, not applicable to, 6 .

TENNESSEE COAL CASE, 319.

TENTH AMENDMENT TO CONSTITUTION, 1, 4.

\section{TENTH SECTION-}

as amender Mareh 2. 1599, 25:2. 254.

amendments of $190 \%, 255$.

illegal combinations under, 256.

construction of section, 258 .

essentials of offense under section 10, 258 .

TERMinals (sea Finhthes fol Ixterchayge of Trafric, Tracks and Termixal Fichlities) -

State and municipal control of, 214 .

no duty to tumish same facilities for all kinds of traffic, 196.

charges must be published, 236 .

extra charge allowed tor delivery off main line, 236.

on live stock at Chicago, 142.

TERRITORIAL COURTS-

jurisdiction of under Interstate Commerce and Anti-Trust Acts, 252.

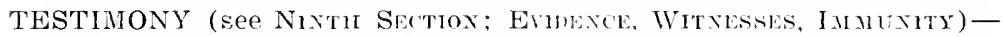
experts to determine difference in cost of moving between local and through ireight. 127.

in determining reasonableness of rates, 131 .

self-incriminating, $263,349$.

section nine compelling, unconstitutional. 252.

in circuit court not limited to that before Commission, 289 .

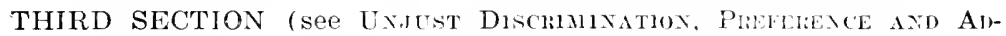

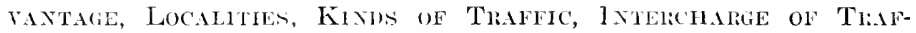
FIC) -

origin of. 173 .

relation to sections 1 and 2,174 .

relation to section $4,17 \%$.

all discrimination not included, 173.

discrimination must be undue or un reasonable, 173.

not limited to discrimination in rates alone, 174.

construction of, as to tacilities for interchange of trainc, 211, 213.

THIRTEenth SeCtion isee Procedure, Pleanixgs axd Proof, Bur:dex of Proon, Plobletion of Eooks axd Paperis, Juniclal PlisCELENT).

\section{THROUGH RATE-}

agreements for division of may be unlawful (see Poolsag. Fiftu SE('IIOx) -

refusal to give, when not unjust discrimination, 184 .

admit of great variety, 128 .

favored becalise cheaper rate result, 128 .

relation of proportion of to the rate over the same distance along same line must be reasonable, 128.

responsibility for through rates, 129.

cannot be relieved from by breaking haul in two, 129 .

not responsible for rate given merely for information, 129.

where lines of several carriers are conducted as one system partnership establishd, 129.

ownership of stock or bouds of another road does not show such partnership. 129. 


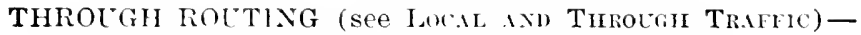

matter of contract, 10s, 12s, 211, 216, 218, 24?.

Commission no power to compel, 108, 211, 242.

not rompelled by section 3, 211 .

risht of to the exclusion of others, 216 .

court no power to compel, 211 .

Act of June 15 . 1stiti. lloes not compel, to.

to establish common control management, etc., 10 s.

agreements controlling unlawful (see Fifril Sectox, Pootrixg).

TICKETS-

State may prohibit sale of by mauthorized persons, $38, \mathrm{n}$.

State may preseribe hours for sale of, $38 . \mathrm{n}$.

Stite cannot make ticliet binding on railroad unreasonable time, 35. $\mathrm{n}$.

State rogulation in general, $11 \%$.

miscellaneous kinds, 303,317 .

mileate, excursion and commutation, issuance not compulsory, 306, 807 .

withelrawal of at will. 307.

sale of. $: 11: 2$.

party rates lawlul. 150.

lant cxplorers' tickets lawful, 152.

srttlers" tirliets lawful, 152.

immierant ticliets lawful, 152 .

returerl tirliets permissive but not compulsory, 306 .

relucel tichets if issued must be done impartially, 306 .

TINH-

allower for making proof, 272 .

of rlosing freisht station may effect mnjust discrimination, 183. contract ior given time of arrival enforible, $18 \mathrm{~s}$.

TOBAC $\mathrm{CO}-$

suljiect of commere. ?.

State ammot prohilit introduction and sale of $j$ n original packace. 9.

State nay prohibit domestic manufacture and sale of. 9 .

State may probibit introduction not in original parkage, 23.

TOLI -

State may exart for use of navigable waters, when, 23.

TONNARE OF VESSELS-

Statr may requin. list of, when, $3 \mathrm{~S}, \mathrm{n}$.

TRACKAC:L-

rolblact rient of, 217 .

Commission no power to interfere with, 217.

TRACKS AND TERMINAL FACILITIES (see FACILITIES For INTER-

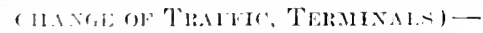

niraning of term in section :2, ㄴ11.

TRAIE MARKS-

when intretate rommeree, 7.

TRAIH: CNIONS-

incorporation of, 78.

Irefinerl, $: 37.1$.

inropursation act, 59. :36.

amenflocl by Act of lune 1, 1ss, is.

no incrorporation under up to dan. I, 1905, 59.

the romets on. 79.

ronstitution, rules and by-laws, :-it.

dutios of offirerse sit.

hearlouartere, : : 
References are to sections.

TRADING CORPORATIONS (see Foreiga Conporations).

TRAFFIC-

is interstate commerce, 6 .

TRAINS-

State law may require posting notice of time of arrival, $38, \mathrm{n}$.

TRANS-CONTINENTAL SHIPMENTS-

rates on from New York and Boston, 142.

TRANSFER CONIPANIES-

discrimination between by carriers. 211.

TRANSFER OF FREIGHT, PASSENGERS, ETC.State cannot require at certain points, is, $n$.

TRANSPORTATION-

court ot. proposed, 4 S.

is commerce, : $11 ;.$

of persons and reight is interstate commerce. 6 .

through a State, when subject to the Act, 6, 109.

TRIAL-

place of, 310 .

removal of United States mrisoners for, 259.

TRUST COMPANIES IN DISTRICT OF COLUMBIAincorporated by Congress, 59.

TURN-PlKES--

construction of, subject to State control, 22.

TWELFTH SECTION (see WITAESSES)-

power and duty of Commission to encuire into business of carriers, 261.

amendments to, 262.

general powers and duties of Interstate Commerce Commission, 269. third paragraph held unconstitutional, 263.

TWENTY-SECOND SECTION-

persons and property that may be carried free or at reduced rates, 303.

illustrative and not exclusive, 345.

permissive only, 306 .

amendment of ilarch 2, 1889,304 .

amendment of 1895,304 .

withdrawal of commutation tickets. $2 n 7$.

TWENTY-FIRST SECTION-

Commission to renter annual reports to Congress, 302.

UNDER BILLING-

a means of unjust discrimination, 159.

"UNDER SIMILAR CIRCUMISTANCES AND CONDITIONS" (see CIRCoMstaxces axp Cuxmtoxis)term found in sections 2 and 4, 150, 221.

UNDUE PREFERENCE (see Prererexie ird ADraxtige).

UNJUST DISCRIMINATION-

UNJUST DISCRIMINATION UNDER SECTION 2-

essential elements of, 144 .

difierent forms of, 159 .

must be based on difference in cost of service, 153.

common law as to discrimination. 147.

common law right of discrimination not unlimited, 148.

in abuse of stoppage in transit privileges, 164.

payment of rebate not necessarily unlawful. 167 .

not unlawful where traffic is of different linds, 167. 
LXJIST DISCRIMINATION-contimed.

meaning of "like limel ol traflic." 16 .

consists in doing for or allowing to one party of place what is denierl to another. 16i.

refusal to pay mileage to private car company not unlawful, 167. discrimination based solely on motive of shipper mlavful, 167. discriminations lased solely on quantity of freiglt manful, 148, 1 i:3.

no diccrimination where service lifferent, 149, 155.

in ear service, 1 ig (see Cak Sinvere).

in car:o rates, lis.

in carloarl and less than earload rates, $150,157$.

in manutacturels rates on coal, 159.

in rebates for nse of livestoek or mivate ars, 159 .

in exaction of unreasonale rent for private cars, 159.

in mujust rassitioation, 159.

in commiscions paid to soliriting agents, 169 .

in combination rates less than tarifi rates, 159.

in under billing. 159.

in billing of net weight, 159 .

thrown interest in comnecting company, 160 .

by calrier in faror of itseli as shipler, 161, 190.

in storage of goods, 162 .

in passenger service, $15 \mathrm{t}, 16.5$.

in retention of orercharge, 168.

in division of joint rates, 160, 161.

in division or rates with terminal companies, 146.

carricr may liscriminate in favor of himself as shipper, 190.

all forms of secret rates and rebates, 159 .

merely making or offering illegal rates, not, 245 .

roisial to give through rate lawful if impartial, 184.

rabuall cannot discriminate asainst tow it does not rearh, 184.

hisher rate to point on branch line not discriminative, $18 \%$.

("NIT RLLE," 19.

$\because$ ILRE GE RAILROAD PROPERTY-

how estimalest, lefi.

YCOFTABLAS-

Jales on from Florida to New York, 142.

Vistmorial polvele (

Srite has exelusire over State morporations, 59.

compress bas over federal corporations, bit.

irarosis-

lansuertation ly not subject to the Act, 365 .

"AsHINGTON SIINGLE TRUST CASE, 70, 321.

UTER TRANSIOARTATON-

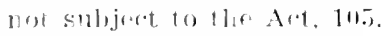

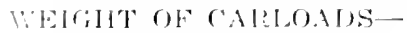

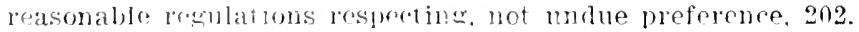

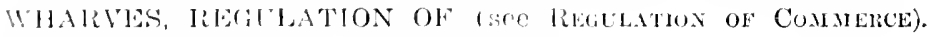

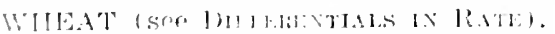

WHOLEGALE ANI) RETAL, RATES-

in freight and lassenger trac distinguished, 15:, 154.

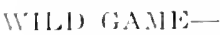

as suldiferet of intrestate commerere. 10.

Sidre may pohibis killing with intent to export, 10.

prasons for the rule, 10. 
References are to sections.

WILSON'S ORIGINAL PACKAGE BILL OF 1590purpose and validity of, 17 .

not a delegation of tederal power, 52.

meaning of term "arrival," 17, 5:.

Witnesses (see linexity, Testinoxy, Rides of Prictice, rule 13, page 407$)-$

summoning of, under section $12,261,263$.

attendance and testimony of, 261 .

production of documentary evidence, 261.

selitincriminating testimony, the compelling of, $263,312$.

penalties for refusing to testify, extends only to witness personally, 264 .

probative effect of, 265 .

power of court to enforce testimony hefore Commission, 267.

relevancy of iestimony before the Commission, 268.

amendment of Feb. 11, 1893, 26:3.

only refers to testimony before the Commission, 264 .

fees of, 296.

cannot refuse to testify on ground of implicating employer, 264 .

may be summoneil before the Commission from any part of the United States, 2irit.

WRIT OF ERROR-

to highest State court where federal right denied, 96. 





UC SOUTHERN REGIONAL LIBRARY FACILIT Y

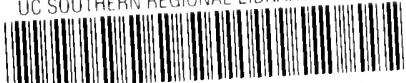

AA $000742943 \quad 4$ 
玨 ma ma ma m (3) m m m m

mm

m m m m m m

s

m.

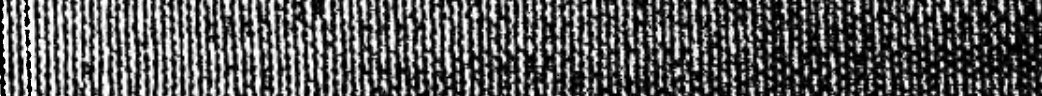

m

H

m)

m.m

m

(3)

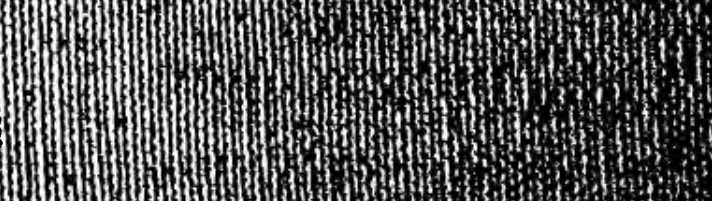

3

I

mam

m.

II

II)

ma

m

排

m

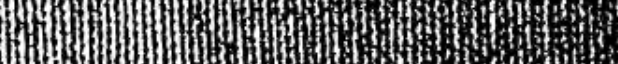

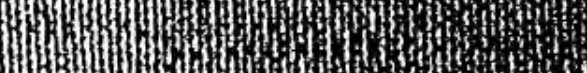

(3)

铜

3

3

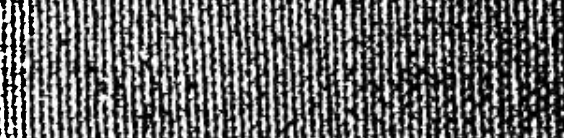

m

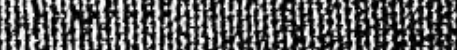

